Stefanie Kron / Sérgio Costa / Marianne Braig (eds.)

\title{
Democracia y reconfiguraciones contemporáneas del derecho en América Latina
}


B I B L I O T H E C A I B E R O-A M E R I C A N A

Publicaciones del Instituto Ibero-Americano

Fundación Patrimonio Cultural Prusiano

Vol. 149

Consejo editorial de la colección

Peter Birle (Instituto Ibero-Americano)

Sandra Carreras (Instituto Ibero-Americano)

Ulrike Mühlschlegel (Instituto Ibero-Americano)

Héctor Pérez Brignoli (Universidad de Costa Rica)

Janett Reinstädler (Universität des Saarlandes)

Friedhelm Schmidt-Welle (Instituto Ibero-Americano)

Liliana Weinberg (Universidad Nacional Autónoma de México)

Nikolaus Werz (Universität Rostock) 
Stefanie Kron / Sérgio Costa /

Marianne Braig

\section{Democracia y reconfiguraciones contemporáneas del derecho en América Latina}

Iberoamericana $\bullet$ Vervuert

2012 
Reservados todos los derechos

(C) Iberoamericana 2012

c/ Amor de Dios, 1

E-28014 Madrid

(C) Vervuert 2012

Elisabethenstr. 3-9

D-60594 Frankfurt am Main

info@iberoamericanalibros.com

www.ibero-americana.net

ISSN 0067-8015

ISBN 978-84-8489-710-1 (Iberoamericana)

ISBN 978-3-86527-761-9 (Vervuert)

Depósito legal: M-39467-2012

Composición: Instituto Ibero-Americana Berlin

Diseño de la cubierta: Carlos Zamora

Foto de la cubierta: (C) Sérgio Luiz Silva: "Sertanejas"

Este libro está impreso íntegramente en papel ecológico blanqueado sin cloro.

Impreso en España 


\section{Índice}

Stefanie Kron/Sérgio Costa/Marianne Braig

Democracia y reconfiguraciones contemporáneas del

derecho en América Latina: una introducción

1. El Estado de derecho: perspectivas políticojurídicas, socioeconómicas y culturales

Kathya Araujo

La relación con las normas en América Latina y el

ordinario trabajo moral del sujeto

Jacint Jordana

El desarrollo del Estado regulador en América Latina

Marianne Braig

Los derechos humanos como autorización para hablar.

Metatexto universal y experiencias particulares

Hans-Jürgen Burchardt

¿Democracia desigual o desigualdad democrática?

Un acercamiento teórico a la realidad socio-política de

América Latina

Ingrid Wehr

On the Problematic Coexistence of Democracy and

Blatant Social Inequality in Latin America

Thamy Pogrebinschi

Participatory Policymaking and Political Experimentalism

in Brazil 


\section{Activismo judicial: eficacia y legitimación}

Martín Aldao

Teorías de la democracia y activismo judicial

José Rodrigo Rodriguez/Marta Rodriguez de Assis

Machado

Law and Public Sphere: Spaces for Interaction and Flow

Directions

Daniel Bonilla

Parejas del mismo sexo en Colombia: tres modelos

para su reconocimiento jurídico y político

Fabiola Fanti

Las políticas de salud ante los tribunales: un estudio sobre la ciudad de São Paulo

\section{Política, derecho y protesta}

Marco Estrada Saavedra

Alteraciones comunicativas: democracia, medios de difusión y la Asamblea Popular de los Pueblos de Oaxaca

Juliana Ströbele-Gregor

Movimientos indígenas: ¿motor de la democratización de las sociedades andinas?

Jonas Wolff

Movimientos sociales y la lucha por la democratización de la democracia: experiencias recientes en América del Sur

Sérgio Costa

¿Unidos e iguales? Anti-racismo y solidaridad en el Brasil contemporáneo 
Carla Gras

Elites rurales contemporáneas: cambio tecnológico,

liderazgo empresarial y acción política en la Argentina

sojera

\section{4. (In-)seguridad y violencia}

María Carolina Agoff

Del sentimiento de injusticia y el rol de las nuevas

legislaciones contra la violencia de género en México

Stefanie Kron

¿Legitimidad política por despolitización de la migración?

Una reflexión crítica del arreglo institucional de un nuevo

régimen regional de migración en Norte y Centroamérica

Markus-Michael Müller

Citizen Participation and Crime Prevention in Latin

America: The Problems Behind the Solution 



\section{Stefanie Kron/Sérgio Costa/Marianne Braig}

\section{Democracia y reconfiguraciones contemporáneas del derecho en América Latina: una introducción}

El presente libro ofrece un amplio espectro de contribuciones teóricas y empíricas que exploran conflictos y transformaciones de las contemporáneas democracias latinoamericanas desde una perspectiva internacional y multidisciplinaria. Los textos ponen énfasis en las múltiples y cambiantes relaciones entre derecho y democracia. El interés principal de este libro es, por ende, describir y analizar procesos de reconfiguración del derecho en el marco de las reformas constitucionales que acompañaron y siguen acompañando los procesos de (re-)democratización en América Latina desde los años $1980 .^{1}$

Así, a partir de esta época y hasta hoy, la mayoría de los Estados latinoamericanos ha modificado su constitución al menos una vez, algunos incluso varias veces. Nuevas constituciones se aprobaron i.e. en Brasil (1988), Colombia (1991), Paraguay (1993), Ecuador (1998, 2008), Venezuela (1999) y Bolivia (2009). En otros países como en Colombia, Nicaragua, Perú y México se discute sobre extensas reformas constitucionales o nuevas Cartas Magnas (Nolte 2009).

Muchas de estas reformas constitucionales se caracterizan por la inclusión de las demandas de movimientos sociales. Entre los movimientos más exitosos al respecto se cuentan los anti-racistas, de derechos humanos, de mujeres o feministas, de indígenas y de afro-descendientes. El ejemplo más reciente lo representa el fortalecimiento de los derechos de las poblaciones indígenas y del carácter "pluri-nacional" del Estado por las nuevas constituciones en Bolivia y Ecuador. $^{2}$

1 Agradecemos a Dennis Arias y a Carla Macdougall su valioso trabajo de apoyo en la coordinación y corrección de las contribuciones.

2 Véase i.e. Palacio/Candioti (2007) y Dagnino/Olvera/Panfichi (2006) para un panorama general de las relaciones entre democratización, movimientos sociales 
Sin embargo, a pesar de una creciente constitucionalización y juridificación de demandas de actores organizados de la sociedad civil, el debate académico aún está dominado por posturas escépticas en cuanto a la eficiencia de las reformas constitucionales y las respectivas legislaciones novedosas.

Ese escepticismo es normalmente justificado con base en el paradigma de los estudios de la transición y consolidación democrática (O’Donnell 1993; 2007; O’Donnell/Schmitter/Whitehead 1986, Schmitter/Karl 1991; Whitehead 1992). De acuerdo con dicho paradigma, la democracia es definida a partir de una idealización de las democracias europeas y norte-americana, tratadas "as the only valid model for democracy. Actors and structures found in other societies are signified as deficits of or obstacles to democratization" (Boatcă/ Costa 2010: 22). Además el análisis se limita a los arreglos institucionales de un régimen político, los cuales deben cumplir con ciertos criterios para ser considerados como democráticos. Entre estos criterios cuentan elecciones libres, derecho de sufragio activo y pasivo, representantes electos, libertad de opinión, de información y organización, predominancia de un gobierno civil y ciertas medidas constitucionales (Dahl 1971; Rüb 1996).

Ante este trasfondo conceptual, el paradigma de transición considera el Estado de derecho latinoamericano -comparado con el ideal (imaginado) del Estado europeo- un Estado de derecho crónicamente deficiente (Méndez/Pinheiro/O'Donnell 1999; O'Donnell 2001). Se le señala al Estado latinoamericano i.e. una brecha estructural entre la ley escrita por un lado, y las prácticas y normas legales y jurídicas por el otro. Según Marcelo Neves (1998), esta brecha se debe al hecho de que, en muchos casos, las constituciones latinoamericanas se perciben más como desiderata colectiva y menos como derecho positivo, lo que habría que implementar.

Esta percepción del defectuoso Estado de derecho latinoamericano refiere a la constatación de que las opciones del imponer nuevas

y derecho; Facio (2002) y Facio/Fries (1999) en cuanto al tema de género y derecho; Costa/Gurza (2006), así como Machado/Puschel/Rodriguez (2009) con respecto a desafíos y problemas de la coexistencia intercultural y de la juridificación de políticas antirracistas; y Sieder (2002) en lo que concierne al impacto de las reivindicaciones de movimientos indígenas en las nuevas constituciones de los países centroamericanos y andinas. 
normas constitucionales así como las respectivas leyes de protección, son sumamente limitadas con respecto a las poblaciones pobres en general y en cuanto a las mujeres y minorías étnicas o sexuales en particular.

Compartimos el análisis de que existen problemas estructurales acerca de la implementación del derecho así como graves desigualdades con respecto al acceso a los sistemas jurídicos en América Latina. También parece evidente que hay problemas para garantizar el pleno ejercicio de la ciudadanía en América Latina. Eso ha sido hartamente demostrado también por autores como Craske/Molyneux (2002) y Jelin/Hershberg (1996) que parten de líneas teóricas muy distintas del paradigma de la transición/consolidación democrática. Esos autores han examinado empíricamente lo que O'Donnell (1993) denomina "low-intensity citizenship", es decir las reducidas opciones de acceder a los sistemas jurídicos y de hacer valer los (nuevos) derechos ciudadanos formales para amplios sectores de las sociedades latinoamericanas, entre ellos mujeres, pobres, indígenas y afrolatinoamericanos (Braig/Huffschmid 2009; Kron/Noack 2008).

Sin embargo, vemos que el paradigma derivado de los clásicos estudios de transición, que consiste en la suposición global del deficiente Estado de derecho latinoamericano en cuanto a la imposición de sus normas constitucionales y sus leyes, muestra graves carencias teóricas y empíricas.

En lo que concierne al nivel teórico, consideramos que los estudios de transición parten de una percepción reduccionista del Estado de derecho ya que subsumen el conflicto entre las distintas formas de aplicación e interpretación del derecho a una estructura binaria de eficiencia/no-eficiencia de este. Lo que aquí queda conceptualmente invisible es el potencial de transformaciones subjetivas, institucionales y estructurales que resulta de las diversas dinámicas de actuación y negociación que se han ido desarrollando entre movimientos sociales e instituciones estatales alrededor de los temas de derechos, leyes y constituciones (Werle et al. 2011).

Esto también tiene consecuencias a nivel empírico, ya que la reducción analítica a un dualismo eficiencia/no-eficiencia del derecho lleva a la incapacidad de aclarar suficientemente la relación entre movimientos sociales y derecho (sea en forma de ley, de deman- 
das o prácticas) que ha ido cambiando fundamentalmente en las últimas tres décadas.

Así, el campo de actuación de los movimientos sociales se ha ido expandiendo evidentemente desde los años 1980. Las luchas de movimientos de mujeres, indígenas, afro-latinoamericanos y gays ya no se limitan al campo de la constitución del derecho sino que se extienden hacia el campo de la interpretación y aplicación del derecho. Al mismo tiempo se puede observar una relativa apertura de los sistemas jurídicos hacia los argumentos y las razones aportados por los movimientos sociales al espacio público. Lo mismo vale para actores internacionales, i.e. organizaciones intergubernamentales como la ONU y corporaciones empresariales u ONGs con trayectoria transnacional (Santos/Rodríguez-Garavito 2005; Sieder 2007). Resulta que estos argumentos y razones se toman en cuenta cada vez más en la interpretación y aplicación del derecho por los sistemas jurídicos nacionales.

Con base en estas observaciones suponemos que existe una relación intrínseca entre derecho y publicidad política, cuando movimientos sociales y otros actores no-estatales fungen de "catalizador" para la tematización pública de nuevas problemáticas. Por consiguiente, en América Latina (como en Europa) la intensidad y calidad de la negociación pública de asuntos y demandas son o podrían ser objetos de reglamentos jurídicos, los cuales influyen decisivamente en la formación y aplicación del derecho. Además asumimos que el Estado nacional ya no es el único actor que diseña, implementa e interpreta el derecho; más bien se puede observar una pluralización de actores involucrados en los campos legislativos y jurídicos.

El objetivo de este libro es, por ende, explorar, esbozar y debatir enfoques teóricos y metodológicos así como casos empíricos, que contribuyan a complementar o corregir el aún predominante marco formalista de análisis en cuanto a la relación entre movimientos sociales $\mathrm{u}$ otros actores no-estatales/internacionales, espacio público y derecho en América Latina.

Un segundo objetivo ha sido poner en diálogo a académicos de América Latina y Europa, así como de distintas disciplinas, con el fin de debatir sobre derecho y democracia en América Latina desde varios trasfondos regionales y culturas académicas. En tal sentido, las contribuciones a este libro son resultado de las discusiones desarro- 
lladas en el marco de un diálogo sistemático entre investigadoras e investigadores del Instituto de Estudios Latinoamericanos (LAI) de la Freie Universität Berlin con colegas e instituciones de distintos países de América Latina. Particularmente relevante para esta publicación han sido las investigaciones y debates ocurridos en el marco de las cooperaciones del LAI con el Instituto de Desarrollo Económico y Social, en Buenos Aires, y en particular con Elizabeth Jelin y Carla Gras. Igualmente importante han sido los trabajos conjuntos del LAI con el Núcleo Derecho y Democracia coordinado por Marcos Nobre y Ricardo Terra y ubicado en el Centro Brasileiro de Análise e Planejamento (CEBRAP), en San Pablo.

El libro, en su primera parte, se dedica a esbozar los principales rasgos político-jurídicos, socioeconómicos y culturales que caracterizan los Estados de derecho en América Latina, como una manera de cuestionar la idea de la deficiencia crónica de esos Estados. Kathya Araujo y Marianne Braig enfocan el ámbito de los sujetos; basándose en un estudio empírico sobre los sectores medios en Chile, Araujo elabora una crítica al eurocentrismo de los trabajos sociológicos clásicos sobre las normas que toman como premisa que la relación de "los latinoamericanos" con "la ley" es conflictiva, y Braig, por su parte, discute si la referencia al texto universal de los derechos humanos puede autorizar a tomar la palabra a los subalternos y permitirles hablar sobre las experiencias de violencia vividas, traspasando las fronteras territoriales, los contextos históricos, las diferencias étnicas y de género, y la polarización entre lo privado y lo público. Jacint Jordana explora el desarrollo y funcionamiento específico del Estado regulador latinoamericano. Las contribuciones de Hans-Jürgen Burchardt y de Ingrid Wehr discuten el fenómeno de la coexistencia de democracia formal y de graves desigualdades sociales. Thamy Pogrebinschi analiza las denominadas "conferencias nacionales sobre políticas públicas" en Brasil respecto a su potencial de incrementar la participación de la sociedad civil en procesos legislativos.

La segunda y tercera parte reúnen trabajos teóricos y empíricos que tratan desafíos, alcances y conflictos en los campos de protestas por derechos y del activismo judicial. Martín Aldao examina varias teorías de la democracia con respecto a como perciben, conceptualizan o problematizan el activismo judicial de movimientos sociales. Marta Machado y José Rodrigo Rodríguez examinan la relación en- 
tre luchas anti-racistas y las instituciones jurídicas brasileñas. Daniel Bonilla nos presenta tres modelos para el reconocimiento jurídico y político de parejas del mismo sexo en Colombia. Fabiola Fanti examina las luchas judiciales en el ámbito de políticas de salud en San Pablo. Marco Estrada analiza la importancia de los medios masivos de comunicación en la articulación o no-articulación pública de demandas y luchas sociales, tomando la "Asamblea Popular de los Pueblos de Oaxaca" (México) como ejemplo. Juliana Ströbele-Gregor y Jonas Wolff ponen énfasis en las prácticas y estrategias de los actuales movimientos indígenas y discuten su potencial de democratizar las democracias de los países andinos ante el trasfondo actual de las nuevas constituciones en Bolivia y Ecuador. La contribución de Sérgio Costa discute las tensiones entre anti-racismo institucionalizado y solidaridad en la sociedad brasileña, y compara las relaciones entre solidaridad y Estado nacional en Brasil con el modelo europeo-occidental. Carla Gras finalmente se dedica a un tema poco explorado: el creciente rol de las nuevas élites sojeras en procesos de decisión política en la Argentina.

Las contribuciones reunidas en la cuarta parte aclaran ciertos aspectos de un tema complejo y contradictorio - y esto no solo con respecto a las democracias latinoamericanas: el de la seguridad/inseguridad y la violencia. Carolina Agoff examina por un lado la tensión entre las nuevas legislaciones contra la violencia de género y la "costumbre" respecto a esta forma de violencia y, por el otro lado la posibilidad de la apropiación subjetiva de derechos por parte de mujeres víctimas de violencia de pareja dentro de este marco. Stefanie Kron por su parte analiza cómo discursos securitarios globales sobre migración despolitizan movimientos de migrantes y cómo estos discursos han ido legitimando políticamente un nuevo régimen regional de control de migración en Norte y Centroamérica, cuyo arreglo institucional es predominado por actores intergubernamentales que no han sido legitimados por procedimientos democráticos de decisión. Markus Müller finalmente presenta un análisis crítico de un programa de seguridad comunitaria participativa, llamado la policía del barrio, en la ciudad de México; el autor explora las graves diferencias entre los democráticos objetivos oficiales y las prácticas cotidianas de la policía del barrio que resultan en nuevas formas de clientelismo, corrupción y apropiación privada de recursos. 


\section{Bibliografía}

Braig, Marianne/Huffschmid, Anne (eds.) (2009): Los poderes de lo público. Debates, espacios y actores en América Latina. Madrid: Iberoamericana/Frankfurt am Main: Vervuert.

Boatcă, Manuela/Costa, Sérgio (2010): "Postcolonial Sociology: A Research Agenda", en: Rodríguez, Encarnación G./Boatcă, Manuela/Costa, Sérgio (eds.): Decolonizing European Sociology. Transdisciplinary Approaches. Farnham: Ashgate, pp. 13-32.

Costa, Sérgio/Gurza Lavalle, Adrián (2006): "Cohesión social y coexistencia intercultural en América Latina". En: Cotler, Julio (ed.): La cohesión social en la agenda de América Latina y de la Unión Europea. Lima: IEP Ediciones, pp. 247-279.

Craske, Nikki/Molyneux, Maxine (eds.) (2002): Gender and the Politics of Rights and Democracy in Latin America. Houndmills: Palgrave McMillan.

Dagnino, Evelina/Olvera, Alberto J./Panfichi, Aldo (eds.) (2006): La disputa por la construcción de la democracia en América Latina. Veracruz: Centro de Investigaciones y Estudios Superiores en Antropología Social/Universidad Veracruzeña/Fondo de Cultura Económica.

Dahl, Robert A. (1971): Polyarchy: Participation and Opposition. New Haven/London: Yale University Press.

Facio, Alda (2002): “Con los lentes del género se ve otra justicia”. En: El Otro Derecho, 28, pp. 85-102.

Facio, Alda/Fries, Lorena (1999): Género y derecho. Santiago de Chile: LOM.

Jelin, Elizabeth/Hershberg, Eric (eds.) (1996): Constructing Democracy. Human Rights, Citizenship and Society. Boulder: Westview Press.

Kron, Stefanie/Noack, Karoline (eds.) (2008): ¿Qué género tiene el derecho? Ciudadanía, historia y globalización. Berlin: Tranvía.

Machado, Marta/Puschel, Flavia/Rodriguez, José Rodrigo (2009): “The Juridification of Social Demands and the Application of Statutes: An Analysis of the Legal Treatment of Antiracism Social Demands in Brazil". En: Fordham Law Review, 77, 4, pp. 1535-1558.

Méndez, Juan/Pinheiro, Sérgio P./O’Donnell, Guillermo (eds.) (1999): The (Un)Rule of Law and the Underprivileged in Latin America. Notre Dame: University of Notre Dame Press.

Neves, Marcelo (1998): Symbolische Konstitutionalisierung. Berlin: Duncker \& Humblot.

Nolte, Detlev (2009): Verfassungspopulismus und Verfassungswandel in Lateinamerika. Hamburg: GIGA (Focus Lateinamerika, 2/2009).

O’Donnell, Guillermo (1993): “On the State, Democratization and Some Conceptual Problems: A Latin American View with Glances at Some Postcommunist Countries". En: World Development, 21, 8, pp. 1355-1369.

- (2001): "Democracy, Law and Comparative Politics". En: Studies in Comparative International Development, 36, 1, pp. 7-36. 
- (2007): Dissonances. Critiques of Democracy in Latin America. Notre Dame: Notre Dame University Press.

O’Donnell, Guillermo/Schmitter, Philippe/Whitehead, Laurence (eds.) (1986): Transitions from Authoritarian Rule. Prospects for Democracy. Baltimore/London: The Johns Hopkins University Press.

Palacio, Juan Manuel/Candioti, Magdalena (eds.) (2007): Justicia, politica y derechos en América Latina. Buenos Aires: Prometeo Libros.

Rüb, Friedbert (1996): "Die Herausbildung politischer Institutionen in Demokratisierungsprozessen“. En: Merkel, Wolfgang (ed.): Systemwechsel 1. Opladen: Leske + Budrich, pp. 111-137.

Santos, Boaventura de Sousa/Rodríguez-Garavito, César (eds.) (2005): Law and Counterhegemonic Globalization: Towards a Subaltern Cosmopolitan Legality. Cambridge: Cambridge University Press.

Schmitter, Philippe/Karl, Terry Lynn (1991): "What Democracy is ... and is not". En: Journal of Democracy 2, 3, pp. 75-88.

Sieder, Rachel (ed.) (2002): Multiculturalism in Latin America. Indigenous Rights, Diversity and Democracy. Basingstoke: Palgrave Macmillan.

- (2007): "Derechos indígenas, reformas multiculturales y globalización". En: Palacio, Juan Manuel/Candioti, Magdalena (eds.): Justicia, Politica y Derechos en América Latina. Buenos Aires: Prometeo Libros, pp. 63-82.

Werle, Denilson et al. (2011): "Más allá de la ineficacia de la ley. Estado de derecho, esfera pública y anti-racismo". En: Gurza, Lavalle Adrián (coord.): El horizonte de la política. Brasil y la agenda contemporánea de investigación en el debate internacional. México, D.F.: CIESAS.

Whitehead, Laurence ([1992] 1995): “The Alternatives to 'Liberal Democracy': a Latin American Perspective". En: Pridham, Geoffrey (ed.): Transitions to Democracy: Comparative Perspectives from Southern Europe, Latin America and Eastern Europe. London: Dartmouth Publishing Group, pp. 307-320. 
1. EI Estado de derecho: perspectivas político-jurídicas, socioeconómicas y culturales 



\section{Kathya Araujo}

\section{La relación con las normas en América Latina y el ordinario trabajo moral del sujeto}

Las ciencias sociales se han interesado desde su nacimiento por el tema de las normas. Ello, por cierto, porque su consolidación como disciplina estuvo inextricablemente ligada a la inquietud moral y política que recorre las sociedades europeas a comienzos del siglo XIX (Nisbet 1973).

Como es posible reconocer, aun cuando no fuera de manera exclusiva, el mainstream de la disciplina se abocó con ahínco a este problema, poniendo el acento en diferentes asuntos: la función de las normas para la integración (Durkheim), la cuestión de la legitimidad de las reglas (Weber, Habermas); el proceso de interiorización normativa (Parsons, Mead); el problema de la desviación y de las sanciones (formales e informales) presentes en todo grupo (Merton, Goffman); la articulación entre el deber moral consciente y las rutinas incorporadas (Bourdieu, Giddens); sin olvidar, por supuesto, la incesante producción de nuevas normas y valores (Joas, Touraine). También se ha constituido en un punto de corte entre autores el peso disímil otorgado a la función que cumplen las normas: a) la de integración social: es decir la función de definir criterios y obligaciones por la cual los individuos son enlazados en un grupo, b) la de orientación: en cuanto definen lo permitido, lo prohibido y en esa medida reducen la complejidad de la elección de metas y medios; o c) la función de coordinación: al permitir la estabilización contrafáctica de las expectativas de acción y con ello asegurar la coordinación de los intercambios entre individuos y subsistemas a largo plazo (Thome 2003).

La presencia de estos debates clásicos en las ciencias sociales en América Latina fue sin embargo relativa, porque el punto de partida fue diferente. No es que se haya desconocido la importancia de la relación con las normas, como lo muestran ya los análisis culturales clásicos. Al contrario, las normas y la relación de los latinoamericanos con las normas han sido una preocupación de base constante en las 
discusiones sobre nuestras sociedades. No obstante, lo que caracteriza a esta discusión es que en el abordaje de esta temática más que de una pregunta se partió de una certeza: nuestra histórica conflictiva relación con la ley. De esta manera, se tomó como premisa que nuestra relación con la ley se caracterizaba por una particular dinámica: una sumisión retórica a esta que no implicaba necesariamente un impacto para nuestras conductas. Al definir esta relación con la ley como rasgo distintivo, ella ha servido para dar cuenta de la cultura, idiosincrasia y funcionamiento de nuestras sociedades. Al mismo tiempo, y por otro lado, como lo discutiremos en detalle más adelante, ha servido de base y fuente para los argumentos a partir de los cuales durante mucho tiempo América Latina, en lo relativo al tema de las normas, ha sido caracterizada a partir de sus deficiencias. El punto de partida adoptado en estas lecturas ha obstaculizado una concepción más rica y compleja de nuestras sociedades y, en la misma medida, ha abonado la retórica del déficit que ha gobernado las lecturas de la región (Araujo 2009a; Martuccelli 2010).

Dicho en breve, si en la discusión europea y estadounidense se puso el acento en el problema de cómo se explica que los individuos sean enlazados al grupo, y se ha partido de la evidencia de la integración para desde allí discutir las posibles desviaciones (Merton), las amenazas a la misma (Durkheim y el concepto de anomia) o, prueba fehaciente del peso de la integración, de sus efectos patógenos (en el modo de la dominación o la sujeción como en el caso de Bourdieu o Foucault); en América Latina el dato de base ha sido precisamente la desviación, la anomia y la desregulación. Lo que constituyó el caso de excepción en otras regiones, fue considerado la media desde la que había que empezar a pensar nuestras sociedades. Y se las pensó en la mayor parte de casos en el modo del déficit y la amenaza, de la condena moral.

Las reflexiones que presentaré en este artículo, al partir del diagnóstico presentado, se nutren de la convicción que requerimos en América Latina de un esfuerzo por ampliar los debates y los estudios empíricos en el ámbito de la sociología de las normas así como por modificar la perspectiva analítica que hemos estado utilizando para abordar a este problema.

Debemos ampliar estos estudios porque la región ha conocido procesos políticos decisivos y contradictorios en las últimas décadas, los 
que obligan a las sociedades civiles latinoamericanas a replantearse de manera profunda sus relaciones con las normas. Ya sea porque las experiencias de violencia política de las últimas décadas empujan a una toma de conciencia colectiva sobre la centralidad del derecho y de los ideales en la producción de una vida civilizada (como en el caso de Chile o el de Argentina, por ejemplo). Ya sea por la aparición de fenómenos inéditos de corrupción, de informalidad, la presencia permanente de actividades ilegales en la vida política y social (tráfico de drogas, etc.) y en muchas ciudades del continente de inquietantes fenómenos de violencia. En cualquier caso, la democracia, pero también la justicia, aparecen ante nosotros, brutalmente, como íntimamente dependientes del funcionamiento de las reglas. La relación con las normas exige ser reconocida como un ítem central para la construcción de sociedades democráticas. Resulta evidente que el éxito de los esfuerzos de democratización de las sociedades no será resultado solamente del desarrollo de estos procesos en clave política, lo será también, siguiendo una intuición temprana de O'Donnell, del grado de "democraticidad" de las relaciones sociales (O’Donnell 1984: 21).

Pero, si la importancia de ampliar los estudios sobre las relaciones con las normas es reforzada por los procesos socio-históricos, no es esta ampliación la única tarea pendiente, como ha sido mencionado. Un argumento central aquí es que se requiere una sociología de las normas que ponga en cuestión la certeza transgresora y deficitaria desde la que ha partido para convertir la relación de los individuos con las normas en una auténtica pregunta de investigación. Es decir, que requerimos de una sociología de las normas que sea exigida a producirse en un marco en el que la comprensión prime sobre la condena moral.

En este artículo me propongo, en primer lugar, un análisis de las maneras en que la premisa del carácter transgresor de la relación con las normas de los latinoamericanos actúa en las producciones contemporáneas sobre el tema así como las consecuencias que tiene una tal pregnancia en nuestros análisis. En segundo lugar, en conversación con lo anterior, presentaré una propuesta de abordaje conceptual para el estudio de la relación con las normas que pone el acento en el rendimiento moral ordinario de los individuos en su relación con estas. Finalmente, presentaré este modelo en obra en el caso de Chile, basándome en resultados de una investigación empírica. 


\section{Los estudios sobre las normas en América latina}

\subsection{Contexto y antecedentes}

Los trabajos que comenzaron a abordar el problema de las normas como un problema fáctico han tendido a desarrollarse muchas veces de manera independiente unos de otros.

Un grupo de estudios se ha centrado en los últimos años en presentar, muchas veces a través de investigaciones empíricas, las cartografías precisas de los actores involucrados en procesos de transgresión, en los mecanismos de la corrupción o en la consolidación de la relación con la justicia (Smulovitz/Urribarri 2007; Schwartzman 2007). Otros, como ciertos trabajos abocados al estudio del sector informal, se interesaron sobre todo en desentrañar las relaciones estructurales de estos fenómenos, poniendo en evidencia, incluso de manera polémica, no tanto las razones de índole propiamente económica, sino los factores que, desde la práctica burocratizada de las reglas, sostienen esta actividad en la región (De Soto 1986). Efectuados desde un abanico sin duda más amplio y complejo de temáticas, y con mayor base empírica que en un pasado aún próximo, estos estudios subrayan sobre todo los efectos perversos o la (in)efectividad de la ley en América latina (Méndez/O’Donnell/Pinheiro 2002).

No obstante, es probablemente el ya clásico y pionero trabajo de Roberto Da Matta (1978), el que abre la vía de manera más clara a los estudios propiamente de las relaciones de los individuos con las normas en las diferentes sociedades nacionales. Tanto el libro de Da Matta como el conocido diálogo que establece con él algunos años más tarde el ensayo de Guillermo O'Donnell (1984), se interesaron en las maneras específicas en que las normas de sociabilidad operaban en distintos contextos nacionales. En estos dos casos, la relación con las normas es discutida en el marco del ejercicio de la autoridad y de los modos en que se estructuran las relaciones de jerarquía en sociedades específicas. El libro de Da Matta, uno de los referentes más importantes en este campo, ofrece un análisis de la sociedad brasilera a partir de diferentes ritos y formas de sociabilidad. El autor discute, de un lado, los ritos integradores en Brasil, entre los cuales destacan las estrategias de expresión controlada de la transgresión, de todos los sectores pero especialmente populares, expresadas plásticamente en el carnaval. Por el otro lado, pone en relieve las formas autoritarias y 
divisionistas de mantener a raya la subversión de las posiciones sociales real o teóricamente diferenciadas, lo que se expresa en la famosa fórmula “¿Usted sabe con quién está hablando?”. Es decir, formas de transgresión de las normas que se apoyan y legitiman por el lugar privilegiado ocupado en las relaciones de poder y jerarquía.

El texto de O'Donnell, defendido como ensayo por el autor pues no se basa en estudios empíricos, se construye en diálogo con el análisis de Da Matta. Comparada con el caso brasilero, la sociedad argentina aparece con mayor "democraticidad" en el trato interclase y en las interacciones sociales, lo que se reflejaría en la pregnancia del tuteo, de la actitud "yo trabajo, no soy sirviente", y en la fórmula que sirve de contrapunto a la del caso de Brasil: "¿Y a mí qué mierda me importa?". No obstante, el autor se guarda de afirmar que se trate de una sociedad democrática o no jerárquica. La fórmula argentina refuerza las jerarquías en la misma medida en que las revela, y al mismo tiempo pone en escena los modos transgresivos y violentos de su enfrentamiento en esta sociedad, bastante lejos de la "cordialidad" brasilera. Ahora bien, el ensayo de O'Donnell consiste propiamente en vincular estas observaciones sobre la sociabilidad con la dimensión más macro, de la política. ${ }^{1}$ En contraposición con este rasgo de la sociabilidad argentina en términos políticos se trata para el autor de una sociedad claramente no democrática. El corporativismo anárquico habría implicado una escena política marcada por la imposición de intereses, en una competencia en la cual el más audaz gana (equivalente a la imagen del tráfico en Buenos Aires, en el que el que "mete la trompa" gana). Una competencia en que toda arma es válida y en la que, por lo tanto, las prácticas transgresivas de las normas (corrupción, desobediencia o uso selectivo de la ley, etc.) son de rigor. A un nivel o a otro, y a pesar de un mayor igualitarismo presente en la sociabilidad argentina, también aquí la lectura subraya el destino transgresivo de la relación con las normas, sea que éste se sostenga como un modo de defensa contra la violencia jerárquica, sea que se presente como efecto de una lógica de intereses desprovista de una ética del bien común.

$1 \mathrm{Y}$ en última instancia con las dictaduras y sus estrategias y políticas represivas, aspecto que dejaremos fuera aquí por no ajustarse a nuestro interés argumentativo. 
Incluso cuando una condena moral era aún implícita en estas posiciones, y el modelo transgresivo opera en estas aproximaciones, ambas tienen el enorme valor de tratar de comprender las formas efectivas de la relación con las reglas presentes en el continente.

\subsection{Los rasgos del campo}

Luego de este debate, el campo de las discusiones sobre la relación de los individuos con las normas en América Latina se ha caracterizado principalmente por dos rasgos: 1) su escaso sustento empírico, 2) compartir un diagnóstico descriptivo común que devela un marco de comprensión compartido.

Primero. A pesar de la potencia explicativa que se le ha adjudicado a esta dimensión, de manera paradójica los estudios empíricos que se han emprendido son extremadamente escasos. El debate se ha dado principalmente a partir de producciones ensayísticas, o sobre lecturas indirectas sostenidas en interpretaciones culturalistas-historicistas (cfr., p.ej., solo para el caso de Chile, Larraín 2001; Garretón 2000; Jocelyn-Holt 1999).

No es posible dar una explicación certera de las razones de esta característica del debate, que por lo demás no se restringe a nuestra región, pero plausiblemente una de las razones es que el abordaje de esta temática requiere acercarse al problema de la moral social, entendida más allá de la mera conjunción de actitudes u opiniones (como, por ejemplo, los acercamientos de tipo cuantitativo vía encuestas de opinión), lo que necesariamente obliga a la producción de perspectivas teórico y metodológicas trans o interdisciplinarias exigentes. Una siguiente razón, se puede vincular con el poco interés por temas ligados al campo de la moral en las ciencias sociales latinoamericanas, especialmente aquellas asociadas con una posición crítica en las últimas cuatro décadas, por lo menos. De un lado, por la convicción de que existían otros temas prioritarios como el desarrollo, la pobreza o la democratización. Del otro, porque la moral apareció considerada como una temática propia al reducto de posiciones conservadoras. El problema de la moral individual y social no consiguió tener el brillo que le permitiera llamar la atención de la investigación social sobre él.

Segundo rasgo del campo, lo diré brevemente porque ya lo he desarrollado: América Latina estaría caracterizada por el carácter tras- 
gresor de los individuos. Es el tono de un texto fundamental en este campo como Carnavales, Malandros y Héroes de Roberto Da Matta, como acabamos de discutirlo, pero también, y a fin de cuentas, sobre sociedades como la chilena, en la cual tras la afirmación del "legalismo" que la caracterizaría se discute la existencia de un permanente "doble discurso" (Shepard 2000). Una relación oblicua con una ley nunca suficientemente eficiente ni legítima es lo que encontramos como piedra de tope en este debate.

Lo que resulta relevante poner en relieve aquí, es que esta interpretación revela la permanencia de un enfoque que pone el acento en la distancia entre las normas y los individuos y sus conductas. Esto se expresa en los diagnósticos culturales, pero también en muchos trabajos que ponen el acento explicativo en la distancia entre prácticas y discursos o representaciones. El problema aquí es que una vez que hemos definido la distancia con la norma, no sabemos exactamente aún qué significa ello en la economía societal e individual. No es posible determinar sin un forzamiento, por ejemplo, si eso que llamo trasgresión en el análisis, es concebido como trasgresor y si tiene un efecto de erosión o no en la sociedad. En contraposición, las lecturas de la transgresión han estado moduladas por un implícito juicio moral o de valor.

\subsection{Claves interpretativas y sus trampas}

La distancia entre los individuos y la norma ha sido interpretada en por lo menos dos grandes claves. En primer lugar, el desajuste entre normas y conductas es considerado principalmente como una amenaza contra las sociedades. Un ejemplo paradigmático en este sentido es el trabajo de Carlos Santiago Nino, para el caso de Argentina (Nino 1992). Nino ha propuesto que lo que caracteriza a esta sociedad es la presencia de lo que denomina una "anomia boba", la que entiende como un estado de inobservancia de normas ya sean jurídicas, sociales o morales que son en todo contraproducentes para la sociedad. Las dificultades en el desarrollo y bienestar argentino estarían correlacionadas con este rasgo constitutivo de la relación con las normas en el país.

Una segunda manera en que la distancia entre conducta individual y norma es interpretada es aquella que entiende que los desajustes no 
solo resultan inevitables sino también positivos. El ejemplo de los trabajos de Nugent $(1996 ; 1998 ; 2003)$ es expresivo en este sentido, pero también una parte de las discusiones de los estudios feministas sobre las transformaciones de género y el valor de la puesta en cuestión normativa. Para Nugent, en el caso peruano la trasgresión debe ser vista como resultado de acomodos y resistencias a relaciones de poder en una sociedad jerárquica y en el contexto del empuje modernizador-modernizante. La inobservancia de las normas es una respuesta activa y positiva de los subordinados en el reacomodo necesario en una sociedad en la que ciertos sectores pierden rápidamente las bases materiales y simbólicas de la legitimidad que había sostenido su poder. La transgresión en el Perú contemporáneo, sería así, una modalidad de resistencia a la jerarquía pero también de agencia modernizante social.

Si bien los estudios que se ubican tanto en una clave de lectura como en la otra han aportado al debate sobre las reglas en nuestra región, lo cierto es que es posible perfilar dos grandes trampas potenciales que se derivan de cada una de estas claves de lectura.

En la trampa normativista los análisis se abocan a definir la distancia entre ideal y actuación del individuo. De esta manera, la pregunta que subyace a estos abordajes es por las razones que explican que los individuos no actúen según los ideales que dicen tener. Formulada de este modo, la noción de déficit juega un papel central y una cierta perplejidad e impotencia acompañan las interpretaciones. Esta perplejidad y lo que es percibido como un aparente muro para el análisis es efecto en buena medida de la suposición de base de estas posiciones: la existencia de una relación inmediata entre las reglas y los individuos. Dicho de otro modo, lo que está en juego es la convicción de que existiría una relación directa entre los ideales y las conductas. La concepción moral es formal y abstracta. Lo que con en este modelo es puesto en exclusión es la actuación de la experiencia social. Obvia que esta es materia prima para el trabajo moral y en consecuencia la extrae del campo de análisis. Esta trampa normativista conduce a que la "insuficiencia" o "inferioridad moral" de latinoamericanos y latinoamericanas resulte de entrada una conclusión.

La trampa pragmativista, por su parte, se vincula con la suposición de una preeminencia de las determinaciones sociales por sobre el individuo. Las conductas de estos son concebidas como resultado del em- 
puje de la estructura económica o de las relaciones sociales, ya sea como acatamiento, ya sea como reacción refleja a ellas. Lo que subyace es la concepción de que existiría una articulación inmediata entre la experiencia social y el sujeto. La experiencia social aparece aquí como el todo explicativo suficiente de la relación con la norma que establecen los individuos y, en muchos casos, es fundamento de la disculpa moral basada en la denuncia social. Así, por ejemplo, una cierta lógica argumentativa de estas posiciones propone que es porque la experiencia social está armada a partir de abusos permanentes que el recurso al ideal sería una actitud imposible. Lo que se excluye o no se considera adecuadamente aquí es la función del ideal en la orientación de las conductas. Como efecto de la exclusión del Ideal, se obvia toda configuración de sujeto moral positiva y ordinaria en los individuos.

Como es visible, en ambas trampas el juicio moral texturiza el análisis social. El juicio moral que recae sobre el individuo en el caso de la trampa normativista. El que recae sobre la sociedad, en el de la pragmativista. En los dos casos una elisión doble se evidencia: del lado del primero, la elisión de la experiencia social; del lado del segundo, la elisión de la función del ideal. En ambos, y esto es un argumento central en este texto, lo que se revela es la omisión del activo y ordinario trabajo moral de los individuos.

Tanto las respuestas que ponen el acento en los efectos modeladores de las normas como aquellas que privilegian una perspectiva más pragmática transportan el presupuesto que los individuos actúan y se orientan sin mediación alguna de su propio trabajo y principalmente moral.

\subsection{Pensar las salidas}

Hecho el breve estado del arte anterior, ¿cómo enfrentar, entonces, el estudio de las relaciones de los individuos con las normas? A nuestro juicio son tres las direcciones centrales que se requiere tomar:

1) Evitar una estructura analítica que se centre en la distancia de los individuos respecto a la norma, la que conduce necesariamente al diagnóstico común de la trasgresión. Por el contrario se trata de atender a los procesos que impactan en los individuos y que producen y sustentan sus formas de relación a las normas y las formas en que éstos responden a ello. La propuesta aquí es poner la aten- 
ción no ya a la distancia de los individuos con la norma sino a la lógica de su relación con ella.

2) Superar la omisión del trabajo de los individuos por producirse como sujetos y sujetos morales. Ello implica integrar al análisis el hecho que la acción individual por más banal o insignificante que sea está orientada por una modalidad de sujeto, un sujeto que funciona como orientación y legitimación de la acción.

3) Complejizar los marcos conceptuales para evitar elisiones que empobrecen y mecanicen los análisis. Resulta indispensable, en este sentido, reconocer conjuntamente la función combinada del Ideal y de la experiencia social.

En breve, respetar la especificidad de la relación de los individuos con la norma implica la creación de un abordaje teórico y conceptual que garantice la aprehensión de la pluralidad de lógicas, marcos y estrategias que componen esta relación. Para decirlo de la manera más precisa posible: el estudio de los individuos en su relación con la norma implica dar cuenta de las lógicas y estrategias a partir de las cuales se orientan y conducen en lo social (si cruzan un semáforo rojo, si rechazan una oferta de corrupción, si movilizan recursos de influencia fuera de la ley, etc.). Dicho de otro modo, aún, cuando alguien pasa por delante de decenas de personas gracias a sus influencias, ello no puede ser entendido como simple ceguera o definido cinismo. Es indispensable dar un paso más. Resulta necesario responder de qué manera una acción tal es integrada por los individuos de una sociedad en la comprensión de sus actos y de dónde extraen su legitimación (o no). En otras palabras, de qué modos y a partir de qué nociones de si y del mundo es posible encadenar el acto de pasar por encima de los derechos de las otras personas a la serie de las acciones o trayectorias individuales. Responder por las modalidades en que los individuos se relacionan con las normas supone integrar la dimensión moral de los actos ordinarios al horizonte de los individuos comunes.

A nuestro juicio, una inteligencia de la acción social que responda a estos requisitos pasará por introducir en nuestro horizonte analítico y de manera simultánea a los ideales y las experiencias sociales propias a una sociedad, pero restituyendo en toda su magnitud el lugar debido al ordinario trabajo moral del sujeto. 


\section{El ordinario trabajo moral: las configuraciones de sujeto}

Los procederes individuales no pueden ser entendidos como respondiendo aisladamente a uno $\mathrm{u}$ otro, a ideal o a experiencia, pero tampoco como una combinación mecánica de ambos elementos. Para evitar una explicación mecanicista se requiere incorporar un tercer término que dé cuenta de la función y el precipitado de la articulación de ambas dimensiones. Este tercer término es el sujeto.

Son las configuraciones de sujeto, las que son fuentes de orientación y legitimación de las acciones individuales y, por lo tanto, están en el lugar de dar cuenta de la inteligencia de los modos de actuación en lo social. Pero ¿cómo entender la configuración de sujeto? Es la tensión entre experiencias sociales e ideales, la que va a participar en la definición de las opciones y modalidades de configuración de sujeto posibles en una sociedad. Pongamos un ejemplo: los principios meritocráticos. Si mi experiencia, ya sea producida por lo vivido directamente o por lo que me ha sido relatado, me dice que las relaciones personales, y las influencias que de ello derivan, tienen un peso significativo en los procesos de selección de personal y contratación, aunque el ideal de sujeto moderno cuyo valor reside en sus méritos individuales pueda estar funcionando como ideal movilizador para mí, me puedo ver inclinado a actuar en función de lo que la primera me muestra. El saber decantado de lo social muestra que mi valor reside en el entramado de relaciones familiares y amicales al que pertenezco y que puedo movilizar. El sujeto que puedo ser se define entonces en este interregno que es constituido por los ideales que me orientan y lo que mi experiencia social me dice sobre las vías posibles, aconsejables y eficientes para presentarme y conducirme en lo social. Por supuesto, las posibilidades de configuración de sujetos son plurales en una sociedad. No hay una sola manera en que esta configuración se defina. Volveremos sobre el punto más adelante cuando presentemos un caso empírico.

Ahora bien, el sujeto no es un producto acabado y permanente. Es el trabajo constante de su configuración, reconocible en los momentos de su actualización. El sujeto es el resultado de un trabajo permanentemente inacabado de conformación en el marco de las expectativas, restricciones y posibilidades sociales. Así, una configuración de sujeto es un producto siempre inconcluso y es, simultáneamente, el trabajo 
mismo de su permanente creación (Araujo 2009a). Un trabajo que se desarrolla en el marco de los desafíos que se presentan de cara a los ideales que funcionan como orientación y del saber decantado de las experiencias sociales.

Es la acción combinada de las experiencias sociales en su encuentro con los horizontes producidos por el Ideal, lo que va a definir las posibilidades y modalidades de cada cual para configurarse como sujeto: el que define las vías abiertas y vedadas, las estrategias apropiadas e inapropiadas para presentarse y habitar lo social. Por otro lado, esta dualidad explica, por un lado, su carácter provisorio -porque siempre estoy obligado por las experiencias sociales a producir y reproducir el trabajo de mi configuración en cuanto sujeto. Por otro lado, permite dar cuenta del "aire de familia" conservado a lo largo del tiempo -en la medida en que los ideales inscritos en el Ideal del Yo individual procuran una relativa estabilidad.

La noción de configuración de sujeto permite así incorporar la dimensión subjetiva pero lejos de una concepción intimista o afectiva (p.ej., Lechner 2002; PNUD 1998), o como mero exceso fantasmático (Žižek 1992; 2001). Al mismo tiempo habilita a incorporar al sujeto sin caer en el modelo que hace de él una figura producto de un entramado puramente discursivo (Foucault 1990; 1998). El sujeto es la actualización que se deduce de un trayecto o un curso de acción, cuyas condiciones de posibilidad están definidas por la acción compleja y combinada de los ideales y de las experiencias sociales.

En este marco interpretativo, es indispensable comprender de manera precisa el rol del ideal. El Ideal no es referencia única, aunque su acción es constante. Por otro lado, y de manera central, el sujeto ideal no es el sujeto encarnado. Primero, porque los ideales sociales no actúan de manera directa y mecánica influyendo los procederes de los individuos (como lo supuso en el fondo el modelo clásico de la socialización), sino que encuentran su camino por un proceso de inscripción individual vía Ideal del Yo. Segundo, porque el sujeto no precede a la experiencia. El sujeto se produce en relación con la experiencia y en cierta medida como su efecto. Suponer que hay un sujeto ideal más allá de la experiencia social, del cual se espera que cumpla con sostener la norma, es, por decir lo menos, un exceso de idealismo en la concepción de sujeto, el que nos conduce a callejones sin salida cuando intentamos dar cuenta de los fenómenos que enfrentamos. 
Las configuraciones de sujeto no son meramente normativas, en el sentido que, aunque funcionan como orientación y soporte, no están constituidas puramente por una dimensión ideal. Una visión que, como lo muestra el célebre trabajo de Robert Bellah y su equipo, conduce a privilegiar un número reducido de modelos de sujeto, fuertemente normativos, que los individuos se limitarían a encarnar en proporciones variables (Bellah et al. 1985). De esta manera, el individuo no está librado a la acción del ideal. Dicho en otros términos, no está en posición de indefensión pasiva o acatamiento necesario frente a la dimensión normativa. Los ideales, los modelos de sujeto y los dispositivos que buscan encarnarlos materialmente no se apropian totalmente de las conciencias y de los cuerpos, porque la experiencia social funciona como barrera y como tope. Visto desde la perspectiva del lazo social y la convivencia social: los ideales en una sociedad son intrínsecamente inestables y frágiles porque estarán siempre a merced de los impactos y requerimientos que emergen de la experiencia social.

Es esta articulación permanente que da cuenta de la maleabilidad de las configuraciones de sujeto, como hemos sostenido, pero también de la imposibilidad de considerar experiencia social e ideal normativo fuera de los efectos de su interacción capturada por el trabajo de su articulación.

Intentemos ahora mostrar en obra esta propuesta en el caso de la relación de los individuos con las normas en la sociedad chilena.

\section{El caso de los sectores medios en Chile}

La investigación desarrollada para el caso de Chile partió de la pregunta por la manera en que el derecho en cuanto ideal normativo participaba o no en la regulación de las relaciones cotidianas entre las personas y entre éstas y las instituciones. Se interrogó así por el conjunto de elementos a partir de los cuales las acciones de los individuos resultaban inteligibles así como cuáles eran las formas de justificación y legitimación para el tipo de relación con las normas que ellos establecían. ${ }^{2}$ En lo que sigue me detendré a dar un ejemplo preciso de la

2 Con la orientación de esta pregunta se aplicó la técnica de Grupos de Conversación Dramatización a hombres y mujeres de generaciones y dos sectores socioeconómicos distintos. Esta investigación fue posible gracias al apoyo de Oxfam Gran Bretaña. Mi agradecimiento a Carolina Ibarra, Claudia Moreno, y María 
manera en que los avatares del ideal y las características de la experiencia social se articulan en determinadas configuraciones de sujeto. La explicación de la relación de los individuos con las normas se nutre de los destinos de la inscripción del ideal, de la reconstrucción del paisaje y las lógicas sociales a partir de las experiencias de los individuos para arribar a ciertos modelos de sujeto que testifican de los tipos de relación con la norma más frecuentes en una sociedad. Tomemos el caso de los sectores medios chilenos.

\subsection{El Ideal}

En estos sectores se aprecia la enorme difusión y extensión en el uso de la noción de derecho en los modos en que se constituyen las expectativas sobre lo social pero también de sí en él. Esta noción aparece como una herramienta a partir de la cual los individuos codifican y producen significaciones en los diferentes ámbitos de la experiencia social. Aún ámbitos que no están sometidos a la regulación por los derechos positivos, como por ejemplo las normas de cortesía, aparecen siendo concebidas como campos regulados por la lógica del derecho. De esta manera, los "derechos" percibidos y su campo de acción exceden en mucho lo que es efectivamente cubierto por los mismos en su vertiente positiva. Junto a los derechos laborales se apela al derecho a ser bien tratado, a que no se le deje esperar o a que otra persona lo escuche. La casi totalidad de los intercambios y las relaciones con otros es codificada haciendo uso de esta noción, estableciendo una modalidad hegemónica, y monocorde, de apelar a los principios plurales de justicia. En breve: el derecho como ideal tiene un lugar definitivo en las expectativas sobre el funcionamiento de lo social y una función clara como orientación ideal en las configuraciones de sujeto.

\subsection{Las experiencias sociales}

No obstante, esta extensión e inscripción del ideal normativo se acompaña paradójicamente con la lectura de su experiencia social como un campo de masiva vulneración de los mismos y, más específicamente, de una vulneración normalizada. La experiencia de vulnera-

Elena Fuentes por su aporte en la realización de la investigación. Una presentación y discusión detallada de la técnica de investigación y de los resultados se puede encontrar en Araujo (2009b). 
ción aparece como parte consustancial del paisaje social y de la experiencia cotidiana. La magnitud de la percepción de vulneración, es decir su masividad y su "normalización" responde, por lo menos parcialmente, a la contradicción entre un muy robusto ideal normativo del que hacen uso los sujetos, y una realidad social que contradice los principios sobre los que este orden debería fundarse.

Lo que su experiencia social les muestra es que son principalmente dos lógicas que ponen en cuestión el orden de derecho y lo que es reconocido como su fundamento por estos sectores: el principio de igualdad. Por un lado, la lógica del privilegio. Por el otro, la lógica de la confrontación de poderes. La percepción de la extensión de recursos de poder que no corresponden al marco de derecho pero que se movilizan y actualizan en campos de relaciones que se suponen reguladas por éste, apoya la deslegitimación de una visión de la vida social como un orden regido por el ideal normativo. Se trata aquí, entonces, de un ideal que ordena la lectura de lo social y que funciona como elemento estructurante de la noción de sujeto misma, por un lado, pero que en el encuentro con la masividad de las experiencias sociales que lo ponen en cuestión no alcanza para orientar los actos e interacciones. $\mathrm{Su}$ falta de legitimidad y poder en las interacciones sociales concretas hace que sean otras las estrategias a las que los individuos apelan. Aunque se lea la situación en términos de derecho ("está vulnerando mi derecho"), se actúa sobre la base de lógicas efectivas distintas (se hace uso del tráfico de influencias o se produce una posición de "sometimiento estratégico" a las arbitrariedades del otro, por ejemplo).

La experiencia social así definida conduce a la entronización de la dinámica ventaja-desventaja. Ella revela la amenaza que constituye para cada cual encontrarse en desventaja, al mismo tiempo que impregna del sentimiento de encontrarse en riesgo de caer en esta situación. La experiencia social muestra, de este modo, que la condición de base para configurarse y sostenerse como sujeto es poder manejar o resguardarse lo mejor posible de los efectos de las lógicas del privilegio y del poder. La paradoja está, por tanto, en el reconocimiento que para sostenerse como sujetos en lo social resulta absolutamente necesario participar en las lógicas sociales que ellos mismos denuncian como atentatorias contra lo que preservan a pesar de todo como ideal. 
¿Cómo, entonces, en este contexto de relación entre ideal y experiencia social se constituyen las posibilidades de configuración de sujeto?

\subsection{Las configuraciones de sujeto}

En función de su pregnancia subrayaremos cuatro principales:

1. La primera modalidad de configuración de sujeto es, como puede suponerse, la figura del pragmático. El pragmático se orienta de manera privilegiada a partir de lo que la experiencia social le muestra como las vías indicadas para habitar lo social. En ambos casos, su actuación está sometida a las indicaciones que provienen de la experiencia social. Pero esta configuración de sujeto pragmática se caracteriza por el hecho que, dada la presencia extendida del ideal, junto al peso otorgado a lo que la experiencia social entrega respecto a los resquicios transitables que hay que instrumentalizar y manejar, convive la crítica más ácida a la sociedad y su funcionamiento. Pragmatismo y denuncia se articulan en una lógica particular. Los intereses propios son reconocidos como motor de la acción pero tamizados por la denuncia. En esta modalidad, se trata de "hacer lo que hay que hacer", pero movilizando al mismo tiempo un discurso ideal y edificante de sí. Se está obligado a hacer lo que se está haciendo, porque no hay salida y es parte de la propia lógica de dominación del "sistema", del que no es posible sustraerse. Se "hace lo que hay que hacer", pero se testimonia, retóricamente, de la insatisfacción, se lo relata en términos de forzamiento. Veámoslo ejemplificado en el siguiente diálogo:

Hombre 2: Si mal no recuerdo en [...] una reunión en mandos medios en la famosa ciudad empresarial que está en Huechuraba. Fueron supervisores, mandos medios. Y los gerentes allá arriba contaron maravillas de la empresa, de su seguridad, de todo, todo positivo, todo bonito. Cada área, los jefes, los supervisores, los subgerentes, tenían que exponer con respecto a lo mismo. Y un supervisor se paró con el micrófono y empezó "si en realidad nosotros tenemos estas metas, tenemos todas estas cosas, pero nosotros para poder llegar a estas metas necesitamos, punto uno: capacitación, punto dos, más sueldos, punto tres". Sabes que terminó el tipo, los gerentes estaban así, se veían así como... Pero terminó el tipo la disertación, todos, todos, todos nos paramos en las sillas y empezamos a aplaudir fuerte, aplaudimos con el alma. A la semana siguiente mi compadre, chao.

Mujer 2: No ganaron ninguna...

Mujer 1: Por ser justo... 
Hombre 2: Y ahí tenías un [...] masivo, o sea, habían subgerentes, habían de todos, pero lo que más aplaudieron fueron los jefes hacia abajo. Pero los subgerentes, gerentes...

Mujer 2: Y espérate que si este tipo quiere buscar de nuevo trabajo, ya está $[\ldots]$.

La retórica argumentativa que desculpabiliza al sujeto y apoya el mantenimiento de una imagen de sí valorada, es un rendimiento central que debe ejercer el pragmático debido a la vigencia de la función del ideal. La desculpabilización se apoya en que esta es una estrategia que es percibida como colectiva, o más bien, y de manera más precisa, masiva. Son, lo que puede llamarse, a pesar del contrasentido a primera vista, pragmáticos-idealistas. O sea trágicos. Se inclinan ante la realidad, pero sin perder el horizonte del ideal desde el cual quisieran poder sostenerse. La configuración de pragmático-idealista es una solución resultado de la fuerza de la experiencia social que debe convivir con un ideal extendido y sólidamente sostenido.

2. La segunda modalidad de configuración de sujeto es la que podríamos llamar la del sujeto crítico. En este caso, lo que aparece como predominante es el juicio crítico respecto a la experiencia social, en muchas ocasiones con un alto nivel de elaboración. Se denuncia profusamente la falta de funcionamiento del ideal normativo. Se es capaz de expresar de manera muy detallada las formas consideradas negativas de la relación con la norma que aportan a la erosión del ideal en la sociedad. Se invoca al ideal de derecho como ordenador de las relaciones y se tiene una alta conciencia de la propia condición de sujeto de derecho como un elemento vertebrador de la lectura de sí. La configuración de sujeto crítico es una modalidad que se presenta en dos versiones. La primera que está más claramente vinculada con una posición crítica orientada hacia lo externo. La segunda, lo que podríamos llamar la versión autocrítica.

En la versión crítica que se centra en elementos exógenos, la crítica y la denuncia se produce como un rechazo a lo que en la experiencia social se revela a sus ojos como causa de la erosión del ideal normativo de derecho. Pero los modos de referir son poco discriminadores y más bien se identifica las causas o responsables en entes generalizados o abstractos: "el sistema", "la justicia" o los "poderosos". El ideal normativo es fuertemente sostenido en su calidad de aspiración, 
y la experiencia social claramente rechazada. Pero es la tendencia a colocar la experiencia social como resultado de factores externos de manera tan acentuada, que termina incidiendo en una cierta desresponsabilización.

En la versión autocrítica, el ideal normativo es marcadamente activo. Es una aspiración y una orientación efectiva para el sujeto. No obstante, y esto es tan relevante que regresaremos sobre ello, otros registros son invocados en la lectura de lo que aporta a regular las relaciones sociales - como la cordialidad, la empatía, la humanidad. En este sentido, el ideal normativo de derecho pierde en algo el carácter de instrumento hermenéutico omnímodo que lo caracteriza en estos sectores. En todo caso, esta es una versión que, a diferencia notoria de la versión precedente, pone el acento fuertemente en el acto individual. El sujeto que se configura, es aquel que cuestiona la propia participación en el "desorden del mundo". Se encuentra como efecto de lo anterior una incorporación constante de la responsabilidad propia y una apelación al peso que le corresponde a la acción individual. Puesto que la relación con la norma es percibida como un asunto individual, el campo privilegiado de construcción de la experiencia social es la vida cotidiana. En este sentido, se trata de una modalidad de configuración de sujeto perfiladamente ética, en la que la vigilancia de los propios actos es continuada.

La configuración del sujeto-critico es, así, dual. Las aguas se parten según los cauces de la acción. El primero, el sujeto crítico exógeno es, y se contenta en ser, un comentador y un juez certero del mundo. La lucidez crítica no se traduce en deseo de acción. El segundo, por el contrario el sujeto auto-crítico, es un actor lúcido del mundo. Dicho en pocas palabras: en el sujeto crítico exógeno la crítica socava la acción; en el sujeto autocrítico la conciencia de la urgencia de la acción individual prima sobre la crítica.

3. La tercera modalidad de configuración de sujeto es la orientada por la amargura. Lo que es el pivote aquí es la evidencia de la distancia al Ideal. La amargura sobreviene en la medida en que se hace presente la constatación que ni las "cosas" ni el propio sujeto es lo que podría o debería llegar a ser. Se produce en el intersticio entre ideal y su denegación por la experiencia social. Es la amargura que resulta de la promesa incumplida. 
En la amargura la rabia es todavía un pequeño motor, un surtidor de algo del orden de la pasión que evita la desesperanza y la apatía. En la amargura resta todavía espacio para la denuncia del engaño, para la figura, aunque debilitada, del franco tirador. El pragmático, en el fondo, y a pesar del halo trágico del que hace gala (y del que sabe hacer gala), se ha acomodado con el orden del mundo. Obtiene ventajas de él, evita otras tantas desventajas. El amargado o no puede o no quiere. La brecha entre el ideal y la experiencia en la cual se inscribe el pragmático, se transforma para él en una distancia insalvable. Pero, como el pragmático-idealista y a diferencia de lo que ocurre en los sectores populares, él tampoco renuncia al horizonte del derecho como ideal regulatorio de las relaciones sociales.

El punto mismo de la distancia al Ideal, funciona aquí, entonces, como la escena en la que se fija la mirada. Aquí, como en todas las modalidades de configuración de sujeto encontradas para este sector, el ideal es sostenido y la experiencia social es considerada negativa, pero a diferencia de las anteriores, la experiencia social se impone en su potencia negativa, pero aunque muestra su potencia corrosiva, el ideal se mantiene.

El amargado es prisionero de un dilema al punto que tiende constantemente a deslizarse hacia las dos configuraciones precedentes. $\mathrm{O}$ se esfuerza en darle un contenido más colectivo a su frustración, transfiriendo al "sistema" la brecha insalvable que él resiente entre lo que su ideal le dicta y la experiencia le enseña, y se aproxima por ende al sujeto crítico exógeno. O se esfuerza en imitar lo que hacen los otros, en aprender de ellos, con el objeto de escaparse de lo que ha terminado por convencerse que no es sino el fruto de un conjunto de discapacidades momentáneas y que debe por ende aprender a superar, con lo cual se aproxima al sujeto pragmático. El amargado se configura entre estos dos horizontes. Él vive en un país donde no se aplican las normas, en la medida en que el ideal lo dictaría. Él no puede hacer algo con eso, ni aprovechar los resquicios, ni exteriorizarlo, ni encontrar espacio para la agencia. La amargura lo invade. Frente al país o frente a sí mismo.

4. La cuarta modalidad de configuración de sujeto es probablemente la más problemática. Por un lado, por sus efectos en lo social. Por otro, por la dificultad para cernirla y capturarla analíticamente en el 
modo de la primera persona. Esta es una modalidad extremadamente presente, pero, al mismo tiempo, siempre colocada en tercera persona. Lo que caracteriza esta modalidad es que en nombre de la ley o del derecho, lo que el sujeto encarna es su exceso.

Es la modalidad del sujeto del exceso, un exceso que se materializa en abuso. Es una modalidad en la que se erosiona el ideal normativo amparado en las atribuciones de la autoridad y aún más, en no pocas ocasiones, en nombre del resguardo del propio ideal. Está fuertemente vinculada a instituciones, funciones: a la idea de un colectivo aunque se encarne en alguien singular. Es, en este sentido, que esta modalidad puede proponerse contenida en una afirmación que sería algo así como - "La ley somos nosotros". Se trata del nosotros del colectivo al que se representa -nosotros los médicos, nosotros los ricos, nosotros los padres de familia, nosotros Carabineros, y una lista extensa de otros nosotros-, y que legitima encarnar la ley o la norma que, a fin de cuentas, se erosiona.

Vale la pena reiterar que en el caso de los sectores medios chilenos, el sujeto del exceso, aquel que erosiona la norma, lo hace en nombre del propio orden normativo. Aparece, entonces, como un exceso normativo. El recurso al Ideal aquí se mantiene: se parte apelando a él desde una posición de legitimidad, institucional o social, y se hace uso de esta legitimidad y en nombre de ella, y por cuenta del exceso, se transgrede la norma. Se trata del uso desmedido de la posición de ventaja. Es la traición al Ideal que se trasviste de fidelidad al mismo.

Esta posición orientada por el uso excesivo de la norma, se revela en las actuaciones de aquellos que se sienten en posición de exigir porque pagan:

En el colegio no hay respeto por los profesores, los profesores somos unos empleados, somos nanas prácticamente, los papás porque están pagando ponte tú, ellos son dueños de echarte un par de garabatos (Mujer, mixto, adulto).

También aparece en los atropellos de las fuerzas policiales, como en el caso de un joven al que detienen por consumo de alcohol sin que lo hubiera consumido, en una constelación en la que lo que se pone en juego y se castiga es más bien no haberse comportado con la debida sumisión a la autoridad. Para dar solo dos ejemplos. 
En todos estos casos, las normas se ponen al servicio de los propios intereses o beneficios. El exceso es el sostén mismo del sujeto. El riesgo: que en un contexto marcado por la confrontación de poderes y la movilidad de los lugares ocupados en la dinámica ventaja-desventaja, ésta es una posición siempre provisoria. La exigencia: ella solo sobrevive a condición del éxito de la careta de resguardo con el ideal normativo que le otorga su legitimación: tal es la fuerza de la acción del Ideal normativo en estos sectores.

Las cuatro modalidades son por cierto modelos presentes en la sociedad chilena. No corresponden a perfiles psicológicos individuales: se trata de modos societales de configuraciones de sujeto que dan cuenta de la orientación y legitimación de la acción en un determinado contexto histórico. En este sentido, los individuos encarnados pueden mostrar una mayor pregnancia de un modelo u otro, pero también, pueden en ocasiones transitar entre configuraciones según la coyuntura o incluso el momento vital.

Como lo muestra lo hasta aquí desarrollado, a pesar de que las experiencias sociales y la inscripción del ideal puedan tener características compartidas para un sector social (o para un género o una generación), ellos no remiten de manera mecánica a la misma relación con las normas. Es una determinada articulación de las mismas la que constituirá el entramado de las diversas configuraciones de sujeto posibles en una determinada sociedad. Aunque las experiencias sean similares, y los ideales inscritos del mismo tenor, siempre queda el espacio de libertad, esto es la exigencia ética, que se abre para cada cual para definir sus relaciones con el mundo, con los otros y consigo mismo.

Decir que los sectores medios chilenos son trasgresores sería tan falso como sostener lo contrario, y, en todo caso, no conduce demasiado lejos. Lo importante es poner en relieve de qué manera en esta sociedad el desafío principal al que deben enfrentarse es a la relación entre un ideal de desplegada presencia y una realidad social que se encarga de manera constante de desmentirlo. Es en este interregno que el ordinario trabajo moral del sujeto, como venimos de verlo, es capaz de dar cuenta de las variantes en la relación que establecen los individuos con las normas en una misma sociedad sin, al mismo tiempo, pluralizar indefinidamente el análisis al reducirlo a variantes psicológicas individuales. 


\section{Bibliografía}

Araujo, Kathya (2009a): Dignos de su arte. Sujeto y lazo social en el Perú de las primeras décadas del siglo XX. Madrid/Frankfurt am Main: Iberoamericana/Vervuert.

- (2009b): Habitar lo social. Usos y abusos en la vida cotidiana en el Chile actual. Santiago de Chile: LOM.

Bellah, Robert N./Madsen, Richard/Sullivan, William M./Swidler, Ann/Tipton, Steven M. (1985): Habits of the Herat. Berkeley: University of California Press.

Da Matta, Roberto (1978): Carnavales, malandros y héroes. Hacia una sociología del dilema brasileño. México, D.F.: Fondo de Cultura Económica.

De Soto, Hernando (1986): El otro sendero. Lima: El Barranco.

Foucault, Michel (1990): La arqueología del saber. México, D.F.: Siglo XXI.

- (1998): Las palabras y las cosas. Una arqueología de las ciencias humanas. Madrid: Siglo XXI.

Garretón, Manuel A. (2000): La sociedad en que vivi(re)mos. Santiago de Chile: LOM.

Jocelyn-Holt, Alfredo (1999): El peso de la noche: nuestra frágil fortaleza histórica. Santiago de Chile: Planeta.

Larraín, Jorge (2001): Identidad chilena. Santiago de Chile: LOM.

Lechner, Norbert (2002): Las sombras del mañana. La dimensión subjetiva de la politica. Santiago de Chile: LOM.

Martuccelli, Danilo (2010): ¿Existen Individuos en el Sur? Santiago de Chile: LOM.

Méndez, Juan E./O'Donnell, Guillermo A./Pinheiro, Paulo S. (comps.) (2002): La (in)efectividad de la ley y la exclusión en América Latina. Buenos Aires: Paidós.

Nino, Carlos Santiago (1992): Un país al margen de la ley: estudio de la anomia como componente del subdesarrollo argentino. Buenos Aires: Emecé.

Nisbet, Robert A. ([1966] 1973): The Sociological Tradition. London: Heinemann Educational Books.

Nugent, Guillermo (1996): El poder delgado: fusiones, lejanías y cercanías en el diseño cultural peruano. Lima: Friedrich-Ebert-Stiftung.

- (1998): Composición sin título: sobre democracia y diversidad cultural en el Perú. Lima: Friedrich-Ebert-Stiftung.

- (2003): "Clase media: de la mano invisible a la clase invisible". En: Perú hoy. No. 4: La clase media ¿existe? Lima: Desco, pp. 15-46.

O’Donnell, Guillermo A. (1984): ¿Y a mi qué me importa? Notas sobre sociabilidad y política en Argentina y Brasil. Buenos Aires: CEDES.

PNUD (Programa de las Naciones Unidas para el Desarrollo) (1998): Informe Desarrollo Humano en Chile. Las paradojas de la modernización. Santiago de Chile: PNUD.

Schwartzman, Simon (2007): Coesão social, democracia e corrupção. São Paolo: IFHC. 
Shepard, Bonnie (2000): "El Doble Discurso sobre los Derechos Sexuales y Reproductivos en América Latina: el Abismo entre las Políticas Públicas y los Actos Privados". En: Revista Conciencia Latinoamericana, $\mathrm{N}^{\circ}$ 3. Córdoba: Católicas por el Derecho a Decidir.

Smulovitz, Catalina/Urribarri, Daniela (2007): Poderes judiciales en América latina: entre la administración de aspiraciones y la administración del derecho. São Paulo: IFHC.

Thome, Helmut (2003): "Das Konzept sozialer Anomie als Analyseinstrument”. En: Waldmann, Peter (ed.): Diktatur, Demokratisierung und soziale Anomie. Schriften der Philosophischen Fakultäten der Universität Augsburg, Nr. 70. München: Ernst Vögel, pp. 37-59.

Žižek, Slavoj (1992): El sublime objeto de la ideología. México, D.F.: Siglo XXI.

- (2001): El espinoso sujeto. Buenos Aires: Paidós. 



\section{Jacint Jordana}

\section{EI desarrollo del Estado regulador en América Latina}

\section{Introducción}

Las políticas de regulación y las instituciones regulatorias no son nuevas en América Latina. La difusión de nuevas regulaciones se remonta a los tiempos del Estado liberal, y en este trabajo se sostiene que durante el siglo XX la región experimentó un camino particular, diferente en algunos aspectos a otras partes del mundo, paralelo a su evolución económica y política. De hecho, aunque en ocasiones se ha planteado un vínculo, el surgimiento del Estado regulador en América Latina no se deriva de la ola de privatizaciones en la década de los noventa. Ya durante el siglo XIX podemos documentar casos pertinentes de regulación pública, cuando muchos países empezaron a elaborar normas con el fin de mejorar el desarrollo de algunos mercados específicos, o para prevenir riesgos significativos. A principios del siglo XX, la mayoría de los países de la región desarrollaron un importante número de innovaciones regulatorias, con el fortalecimiento de la intervención estatal. La presencia del Estado en los bancos centrales, la elaboración de nuevas leyes bancarias, la creación de nuevas agencias reguladoras, fueron iniciativas que se expandieron en la región durante el período de entreguerras. Además, durante la época de sustitución de importaciones, a partir de los años treinta, las actividades de regulación se hicieron más importantes en la región, en la medida en que la intervención gubernamental alcanzó intensamente a muchos sectores económicos. En el contexto de un Estado desarrollista en aumento, hasta los años setenta, la regulación era empleada con intensidad para proteger los mercados internos, la producción orientada a la exportación, o para articular actividades económicas públicas y privadas.

Posteriormente, durante las décadas neoliberales al final del siglo, se observa tanto la aplicación de políticas de desregulación como la aparición de un nuevo impulso regulatorio, con el objetivo de reconstruir el papel del Estado en la economía (y en la sociedad en su con- 
junto). El desmontaje de la regulación para la sustitución de importaciones fue un elemento importante en la agenda de modernización de muchos gobiernos latinoamericanos para hacer frente a la crisis económica durante los años ochenta y noventa. Sin embargo, el nuevo Estado regulador, que comenzó a construirse en la región durante la década de los noventa fue también un enorme desafío. El aumento repentino en la creación de instituciones reguladoras en América Latina durante el período más reciente fue una respuesta impresionante. Además, se introdujeron diseños innovadores de regulación en muchos sectores, a menudo muy sofisticados y técnicamente bien diseñados. Estos cambios supusieron un impacto significativo en la formulación de políticas, desafiando en cierta medida el papel de las instituciones políticas tradicionales. Paralelamente a la creación de nuevas instituciones reguladoras, la actividad normativa también se expandió en la región, y la apertura de los mercados al comercio exterior y la competencia externa también disparó la introducción de nuevas regulaciones en diferentes sectores productivos.

En estas páginas entendemos la regulación como una actividad del Estado para dirigir la economía y la sociedad, interviniendo en su funcionamiento mediante el establecimiento de reglas de comportamiento sobre las actividades de individuos, organizaciones y empresas, incluyendo las capacidades de supervisión, control y de sanción. El concepto de Estado regulador nos ayuda a identificar un tipo de tareas estatales distintas a las del Estado de bienestar o del Estado desarrollista, también presentes, con mayor o menor intensidad, en los distintos desarrollos estatales a lo largo del siglo XX. Menos conceptualizado que otros modelos ideales de Estado, el Estado regulador integra un conjunto de formas específicas de intervención pública, establecidas por medio de normas que generan un orden económico, político y social, con consecuencias indirectas para todos los actores afectados, sin la intervención directa de mecanismos de redistribución o distribución económica o social (Levi-Faur 2011).

Como el desarrollo de las regulaciones es sumamente interdependiente de las capacidades de los departamentos administrativos y las instituciones responsables de su supervisión directa y aplicación, en este trabajo nos centramos en el papel del Estado para impulsar la regulación en América Latina. Consideramos el Estado regulador como el fruto de la capacidad pública para supervisar y regular las activida- 
des económicas en el ámbito privado, no sólo con el objetivo de aumentar su eficiencia y reducir las externalidades negativas, sino también para intervenir en el control y la prevención de los riesgos para la población, derivados de las actividades económicas y políticas. El Estado regulador no es un invento neo-liberal; en este sentido, puede ser también muy activo en un contexto neo-mercantilista, con el objetivo de definir y orientar fuertemente las actividades económicas, interrelacionándose con un modelo de Estado desarrollista.

Este trabajo, organizado en tres partes, examina el desarrollo del Estado regulador en América Latina. En primer lugar, revisa el desarrollo de normativas estatales desde una perspectiva histórica, centrándose en la creación de mercados competitivos y la prevención de los riesgos sociales, y también debate las principales limitaciones en la ejecución de las políticas de regulación en la región. En segundo lugar, nos centramos en las características institucionales de los entes reguladores estatales en América Latina, teniendo en cuenta la influencia de modelos externos, así como las instituciones coloniales de la propia región. También se examina la proliferación de los organismos autónomos de regulación en diversos sectores y países durante las últimas décadas. Por último, se concluye con algunas observaciones acerca de los desafíos actuales para la consolidación del Estado regulador en América Latina.

\section{El desarrollo del Estado regulador durante el siglo $\mathrm{XX}$}

El desarrollo de la regulación estatal en América Latina fue bastante lento hasta las últimas décadas del siglo $\mathrm{XX}$, pero podemos rastrear muchos elementos que indican su aparición previa, por lo menos desde fines del siglo XIX. De hecho, su desarrollo fue un proceso de transformación institucional, fuertemente relacionado con la economía política de los países de la región, adquiriendo su propia dinámica e identidad durante su evolución, pero también muy receptivo a las características y singularidades de los modelos dominantes de instituciones de regulación en los Estados Unidos y Europa en cada momento.

Las discontinuidades institucionales y la inestabilidad política experimentada por la mayoría de países de América Latina después de su independencia a principios del siglo XIX, problemas que en muchos casos se prolongaron por varias décadas, impidieron el rápido desarro- 
llo normativo de los nuevos estados. Durante la mayor parte del siglo XIX, diversos países de América Latina mantuvieron las leyes coloniales españolas. Los esfuerzos por construir nuevas instituciones estatales, así como la inestabilidad política en aquellos momentos, retrasaron a menudo la elaboración de nuevos códigos civiles, comerciales y de minería hasta el último tercio del siglo. Además, numerosos intentos de introducir nuevas reglamentaciones no tuvieron éxito debido a los regímenes inestables, que producían rápidos cambios normativos, sin tiempo suficiente para ser aplicados adecuadamente (Dye 2006).

Sólo durante las últimas décadas del siglo XIX el proceso de construcción del Estado en América Latina fue más eficaz. Los gobiernos centrales se hicieron más fuertes, la violencia política terminó y los costos de transporte se redujeron, lo que permitió la aparición de nuevos desarrollos regulatorios. Además, los mercados se extendieron territorialmente, y su creación fue estimulada en muchos países por reformas políticas y revisiones de códigos legales, los cuales extendieron los principios liberales de regulación y facilitaron la aparición de una nueva élite económica en la escena política. De hecho, en muchos casos la consolidación de los Estados nacionales se produjo al mismo tiempo que el importante crecimiento económico vinculado a la construcción del ferrocarril, al crecimiento de la inversión extranjera directa y a la expansión de las exportaciones (Coatsworth 2006). Inclusive, era evidente para muchos actores contemporáneos que los Estados de América Latina debían desempeñar "un papel crucial en la constitución y la salvaguardia de las relaciones de mercado", dado que la mayoría de los mercados nacionales emergentes seguían siendo muy débiles y subdesarrollados (Topik 1999), creando una tensión adicional que exigía un fuerte desarrollo institucional.

Durante el período de entreguerras, los Estados comenzaron a asumir una intervención política más activa, incluyendo la regulación para proteger los mercados internos, la provisión de infraestructura y la producción industrial directa, con el fin de internalizar la actividad económica y sustituir importaciones (en un contexto de frágiles mercados externos). En este contexto, el desarrollo de la regulación bancaria moderna durante la década de 1920 fue muy intenso en la región. Crisis bancarias recurrentes y una organización económica más sofisticada desempeñaron un papel esencial para estimular las innovacio- 
nes reguladoras, pero las estrategias de modernización del Estado fueron también de crucial importancia en la actualización de esos marcos regulatorios. Aquí encontramos un episodio en el que la influencia externa se hizo especialmente visible; es el caso de las misiones de consultores de EE.UU. durante la década de 1920 y principios 1930. En varios países andinos, un economista de Princeton, E. W. Kemmerer, contribuyó a la reforma de las prácticas financieras, a fin de asegurar que la deuda externa se pagara a tiempo. El profesor Kemmerer tuvo una influencia importante para definir los nuevos marcos normativos en el área financiera de la región. Durante la década de 1920, una serie de países, como México, Colombia, Chile, Ecuador, Perú y Bolivia, crearon autoridades reguladoras, paralelamente a la creación de sus bancos centrales, bajo el asesoramiento de la misión Kemmerer.

En el marco de las estrategias de sustitución de importaciones, los Estados latinoamericanos tuvieron un papel directo en el fomento de la producción y también estuvieron involucrados, desde los años sesenta, en promover la producción de bienes orientados a la exportación. Administrativamente, esto implicó la elaboración de una nueva burocracia económica, enfocada a regular las relaciones con el sector privado, proteger los mercados internos, o también favorecer las exportaciones. Los nuevos instrumentos de control se centraron en orientar las políticas industriales y productivas de cada país, y la complejidad de la administración pública aumentó considerablemente. Fueron décadas en que el desarrollo de nuevas capacidades burocráticas en América Latina tuvo suma importancia, ampliando la presencia de los funcionarios públicos con un perfil más tecnocrático en diferentes áreas del estado. Sin embargo, la creación de una extensa burocracia a la sombra del Estado desarrollista también se asoció por muchos años con los regímenes autoritarios; a menudo, ello condujo a que los burócratas buscaran la protección de los políticos autoritarios y las fuerzas armadas, o a que tendieran a protegerse a sí mismos con la promoción de reglamentos sofisticados que implicaban una separación de su entorno social y económico (para el caso brasileño, véase Mattos 2006).

Aunque la estrategia proteccionista que dominó la política económica en este período a menudo impidió abrir los mercados a la competencia, algunos elementos de regulación del mercado también se introdujeron, por lo menos en algunos países. Tal vez el más importante 
fue la extensión de las regulaciones pro-competencia, centradas en la prevención de conductas anticompetitivas. En 1923 Argentina aprobó la primera legislación antimonopolio en América Latina, y en 1934 México promulgó una ley antimonopolio. Desde finales de 1950, Chile (1959), Colombia (1959-1964) y Brasil (1962-1963) también aprobaron una legislación para regular las prácticas anticompetitivas (Coate/Bustamante/Rodríguez 1992).

Cuando las estrategias de sustitución de importaciones y la lógica del Estado desarrollista se derrumbaron en la mayoría de los países de la región, fundamentalmente en los años ochenta, el modelo de Estado regulador no surgió en la región como alternativa de reserva. La estabilidad macroeconómica y las transiciones a la democracia fueron las principales prioridades, y sin duda los países latinoamericanos experimentaron momentos difíciles en relación con el contexto económico. La desregulación de la industria y la apertura comercial a menudo eran los objetivos más reclamados (Cardoso/Helwege 1992), ya que estos países a menudo se consideraban "entre las economías de mercado más reguladas del mundo, por lo menos en el papel" (Manzetti 2000), y la reducción de la participación estatal en la economía alcanzó un amplio consenso en la región, especialmente a partir de finales de los ochenta. Sin embargo, más que un cambio ideológico, este cambio de política fue provocado por un déficit fiscal derivado de la ineficacia de las políticas macroeconómicas en la década de 1980 (Fishlow 1990). De hecho, no es completamente claro que los argumentos neoliberales fueran hegemónicos en la región durante los años ochenta y noventa, aunque sí fueron muy evidentes en algunos países. Los procesos de democratización más amplios generaron con frecuencia un vibrante debate nacional sobre los objetivos de las medidas durante esos años y la competencia política fue un factor importante para el cambio de rumbo (Murillo/Martínez-Gallardo 2007). A pesar de las muchas reclamaciones en este sentido, la necesidad de un Estado sólido para definir las prioridades y aplicar las normas también fue firmemente defendida por muchos gobiernos, particularmente en México y Brasil, los dos principales Estados tradicionalmente desarrollistas de la región.

En cualquier caso, es bien sabido que una ola de privatizaciones se produjo en toda la región durante los años noventa, arrastrada por la crisis fiscal y nuevas ideas políticas, entre otros factores. Sin embargo, 
esto no era una particularidad latinoamericana (Levi-Faur 2003); en ese momento, América Latina, al igual que muchas otras regiones del mundo, pero de una manera más radical, experimentó cambios profundos en la manera en que sus economías se organizaban, a través de la liberalización de los diferentes sectores de servicios públicos y la integración de las economías de la región al mercado mundial (Edwards 1995). Sin duda, las privatizaciones contribuyeron a ampliar la regulación en la región, ya que abrieron nuevos sectores económicos para el mercado y crearon la necesidad de nuevas intervenciones reguladoras, a fin de estimular unos entornos empresariales más competitivos. Sin embargo, este objetivo no siempre se logró de manera coherente, y varios países terminaron después de sus privatizaciones con monopolios privados, permitiendo que el control de sectores económicos clave, quedara en manos de pequeños grupos empresariales. El reto de una competencia efectiva en los nuevos mercados, y también el fomento de los mercados más tradicionales, se convirtió así en un nuevo desafío para las nuevas instituciones reguladoras introducidas en la región (Chong/Benavides 2007; Manzetti 2000).

De hecho, la expansión de regulación en la región fue mucho más amplia que las consecuencias derivadas de los acontecimientos de privatización, ya que las reformas regulatorias alcanzaron a muchos otros sectores que no sufrieron de forma directa las iniciativas de privatización. Durante la década de 1990 y principios de 2000, se produjo una gran oleada de cambios políticos e institucionales en la región, en un contexto de reestructuración económica y grandes reformas del Estado, que coincidió con y contribuyó a la expansión del capitalismo regulador en todo el mundo (Lora 2007). Con el concepto de capitalismo regulador nos referimos a un modo de organización de las economías capitalistas que requiere de fuertes intervenciones concentradas, tanto públicas como privadas -autorregulación-, en diversos niveles de gobierno, para organizar la forma como operan los mercados y evitar situaciones de quiebra o colapso productivo, fruto de las dinámicas individuales de los actores que participan en los mercados buscando su propio interés (Braithwaite 2008; Jordana/Levi-Faur 2005). Aunque de forma tímida, en América Latina el Estado regulador también se extendió a nuevos ámbitos fuera de las iniciativas orientadas a mejorar de forma directa la eficiencia del mercado, como la regulación del riesgo en las áreas sociales y ambientales, y también 
mediante la pretensión de garantizar los derechos cívicos y democráticos (como los derechos de información, protección de derechos humanos, derechos electorales, etc.). La creación o reforma de las instituciones autónomas de regulación fue vista como la principal estrategia para desarrollar estas reformas normativas en la región, en la medida en que podía ayudar a renovar la burocracia, favorecer la introducción de marcos normativos actualizados, supervisar el comportamiento de los actores en los mercados privados, y estar más abierta a la formulación de políticas de regulación mediante procedimientos más democráticos.

\section{Instituciones reguladoras y el contexto político}

En esta sección, nos centramos en el aspecto institucional del desarrollo de la regulación estatal en América Latina, y nos preguntamos acerca de la existencia de distintos patrones de expansión. Sostenemos que algunas instituciones han evolucionado de una manera particular, en parte de forma endógena a su evolución política y administrativa, y en parte debido a la adaptación local de modelos extranjeros - tanto de los Estados Unidos como de algunos países europeos- que se hicieron populares en la región. Los temas discutidos aquí incluyen la aparición de instituciones de regulación, su impresionante expansión en las últimas décadas, y su variedad en diversos sectores y países.

Centrándonos primero en las tradiciones históricas, aún es posible encontrar en varios países de América Latina una cierta influencia de órganos administrativos especiales llamados Superintendencia y Junta, ambas formas de delegación burocrática que tienen su origen en la época colonial española. Mientras que las juntas tienen su origen en la época medieval, la figura de la Superintendencia se originó en el siglo XVI. De hecho, uno de los primeros casos documentados por los historiadores se refiere al Virrey del Perú, como Superintendente, ya en 1575. En los siguientes dos siglos las Superintendencias fueron empleadas para diferentes propósitos, y también tuvieron una consideración formal como un título dentro de la administración pública española. Se utilizaba para combinar dos labores diferentes: en primer lugar, controlar y supervisar las diferentes áreas de la administración pública, y en segundo lugar, identificar la alta complejidad de las tareas involucradas (Pietschmann 1983). Durante el siglo XVIII en particu- 
lar, su uso se hizo muy común en la administración colonial española, como una forma de modernizar la administración pública y el fortalecimiento de la capacidad de gestión y de supervisión del Estado absolutista (Céspedes des Castillo 1953; Pietschmann 1993). Tanto Superintendencias como Juntas fueron formas institucionales que se concentraron en administrar áreas específicas de interés público, separadas de la estructura general de la administración pública. La diferencia básica entre las dos estaba relacionada con su composición: mientras que la superintendencia se basaba en el titular de una sola oficina, la Junta era un órgano colegiado, integrado por varios miembros. Otra diferencia era que la Superintendencia solía tener un perfil de gestión, mientras que la Junta se concentraba en responsabilidades jurisdiccionales, aunque en muchos casos se combinaron en cierta medida ambas actividades (Bermejo 1984).

La Junta es una figura institucional utilizada todavía en varios ámbitos políticos, particularmente en la regulación monetaria. En este sentido, es posible aún encontrar en diferentes países latinoamericanos, un órgano colegiado denominado Junta Monetaria, como suprema autoridad en la regulación financiera (p.ej., Rep. Dominicana, Ecuador, Guatemala), y en muchos otros ámbitos también lo encontramos, en especial dedicado a los problemas concretos en materia de regulación. Por otro lado, la persistencia del modelo de la Superintendencia es mucho más reconocida como fórmula de delegación, por lo que muchos países de América Latina mantienen todavía este nombre para referirse a las autoridades de regulación, en lugar de "agencia" o "comisión".

Durante el siglo XIX, la mayoría de países latinoamericanos crearon superintendencias con fines especiales, manteniendo un fuerte parecido con las formas administrativas derivadas de su pasado colonial (no sólo las actividades de supervisión, sino también la concentración en tareas específicas y especiales). Así, en la década de 1920, cuando los gobiernos de América Latina crearon las primeras agencias reguladoras "modernas", particularmente en el área financiera, se les nombró en muchos casos superintendencias, siguiendo sus tradiciones administrativas locales. La introducción de la gobernanza mediante autoridades reguladoras se limitó inicialmente a unos pocos sectores -sobre todo del ámbito financiero-, en lugar de ser adoptadas de manera uniforme en varios de ellos. Sin embargo, desde entonces, el 
vínculo con los modelos administrativos históricos se ha establecido y renovado, facilitando la continuidad de las formas institucionales de delegación y convirtiéndose en referencia de otras iniciativas para diversos sectores de la región durante el resto del siglo.

Las estructuras reguladoras del ámbito monetario comenzaron a tomar forma cuando los bancos centrales fueron establecidos por las autoridades públicas, sustituyendo a la autorregulación de los bancos privados. Desde un enfoque de políticas sectoriales, este es esencialmente el sector que dio origen a la regulación estatal en América Latina. Los primeros casos de bancos centrales con control público surgieron en la década de 1920, y aunque las reformas eran promovidas por algunos intereses locales, su realización fue concretada por la ya mencionada Misión Kemmerer. La Misión dio asesoramiento para establecer las autoridades reguladoras de los servicios financieros, separadas de los bancos centrales, sobre la base de los diseños institucionales dominantes por entonces en los Estados Unidos. En este sentido, la Misión Kemmerer impulsó la adopción de innovaciones institucionales diseñadas bajo normas estadounidenses, aunque aplicadas sobre las existentes en América Latina, cuya tradición administrativa proporcionaba más responsabilidades al representante máximo del organismo, el superintendente o el presidente de la comisión reguladora.

Antes de la década de 1980, la expansión de las agencias reguladoras en la región se limitó principalmente a la esfera financiera, existiendo muy pocos casos en otros ámbitos. Por ejemplo, casi no existían agencias para el área de servicios públicos, ya que en este ámbito operaban en la región los monopolios públicos, por lo menos hasta finales de la década de 1980. Tal situación fue radicalmente distinta a los Estados Unidos, donde el Estado regulador se desarrolló en muchos frentes antes de la Segunda Guerra Mundial, con la creación de un modo de gobierno de carácter singular. Por el contrario, el contexto latinoamericano hasta 1980 era más similar a Europa, donde los servicios públicos estaban bajo control público, y la regulación social estaba poco desarrollada. Sólo en el área financiera había regulación pública en América Latina con un desarrollo institucional más grande que en Europa, aunque la calidad de sus instituciones reguladoras se deterioró fuertemente en los años 1960 y 1970 (lo que en cierto modo indujo a muchas de las reformas institucionales posteriores, durante la década de 1980). 
Sin embargo, fue en la década de 1990 cuando el número de nuevas agencias reguladoras en América Latina estalló. Un análisis reciente revela que el crecimiento de las instituciones reguladoras en la región durante las últimas dos décadas ha sido asombroso (Jordana/ Levi-Faur 2005). En el área financiera se crearon agencias para cubrir también las pensiones, los seguros y los mercados de valores, además de la regulación bancaria (Brooks 2009; Demaestri/Guerrero 2006). Este crecimiento fue especialmente importante en el área de servicios públicos, donde las privatizaciones en diversos sectores impulsaron la regulación del mercado en numerosos servicios en red (electricidad, agua, gas, telecomunicaciones, etc.), estimulando un intenso proceso de difusión que fue más allá de la difusión misma de las privatizaciones (Gutiérrez 2003; Montoya/Trillas 2007). Se crearon también agencias en el ámbito de la regulación social, aunque no de manera tan amplia como en las utilidades o las finanzas (Gilardi/Jordana/Levi-Faur 2007). Así, sectores como el farmacéutico y la seguridad de los alimentos mostraron un patrón modesto de difusión. En todo caso, la extensión de las agencias reguladoras en América Latina durante la década de 1990 no fue un fenómeno aislado. En ese mismo momento, se observó un patrón similar de creación de agencias en Europa y otras partes del mundo, incluidos los países en desarrollo de Asia y África.

Esta ola de innovaciones institucionales incluyó a menudo la concesión de una fuerte autonomía organizativa a los organismos reguladores, vis-à-vis el aparato estatal tradicional y los dirigentes políticos, un fenómeno que de hecho encontró escasa resistencia, dadas las tradiciones institucionales y la propia fragmentación de la administración pública en la región. También las nuevas agencias incluyeron mecanismos de delegación política, similares a los de los bancos centrales, con el apoyo entusiasta y publico de diversas organizaciones internacionales. Entre tales mecanismos destacan los mandatos de plazo fijo, las disposiciones para evitar tanto el despido de responsables como consecuencia de decisiones normativas como la reelección sucesiva de los miembros del consejo, a fin de limitar la influencia política sobre las decisiones de la agencia.

Los países de la región varían considerablemente en la intensidad de su impulso a la construcción de nuevos regímenes de regulación, y el diseño de las agencias reguladoras, a su vez, varía en gran medida. 
En general, las presiones externas y los modelos extranjeros facilitaron la difusión a gran escala de las agencias reguladoras, pero los responsables de la política nacional eran a menudo decisivos en la amplitud de las innovaciones y en la determinación de sus características institucionales (Jordana/Ramió 2009; Weyland 2006).

Como era de esperar, la imagen resultante después de la explosión no fue homogénea, hubo diferencias significativas entre sectores y países. Sin embargo, para los países latinoamericanos en general, la proliferación de las agencias no suponía un desmantelamiento del modelo administrativo weberiano. Los Estados de América Latina ya no mostraban claramente este modelo de administración pública en las décadas anteriores; la creación de agencias separadas de los ministerios, para concentrarse en diferentes tareas relacionadas con el desarrollo, era una práctica muy común a mediados del siglo XX, en el marco de la expansión de Estado desarrollista (Thurber 1973). En cierta medida, tal vez podría apuntarse que la fragmentación del aparato de Estado fue una continuidad de la estructura fragmentada de las instituciones coloniales, pero en todo caso, si cabría apuntar, de hecho, que el modelo de Estado administrativo weberiano nunca se impuso plenamente en los países de América Latina. Frente a los modelos europeos con estructuras jerárquicas bien diseñadas, la fragmentación de las estructuras de la administración pública era una referencia importante para entender el desarrollo del Estado en América Latina ya desde el siglo pasado, antes de la expansión del Estado regulador.

Después de su difusión en las últimas décadas, las agencias reguladoras son una realidad tangible en todos los países de América Latina. Son unidades de la administración pública, conectadas a otros sectores públicos como ministerios o cámaras legislativas, $\mathrm{y}$ también a nivel internacional con instituciones similares en otros países (Slaughter 2004). En el Estado regulador, un nuevo modo de gobernanza está emergiendo, y su articulación está siendo definida más por las redes relacionales de profesionales especializados en diferentes temas de regulación, que por las estructuras jerárquicas tradicionales. En América Latina, la lógica del "control a distancia", existente en la región con anterioridad, como muestra la institución administrativa tradicional llamada superintendencia, se combinó durante el siglo XX con las influencias externas para construir modernas instituciones reguladoras. Estas mostraron algunas cualidades distintivas: una independencia 
política débil, pero con una fuerte identidad profesional, concentrando experiencia técnica y recursos organizativos para hacer más fuerte la intervención pública en el sector específico bajo supervisión (Jordana/Ramió 2010). Aunque no en todos los casos, las agencias también proporcionan una mayor estabilidad para los funcionarios que trabajan en ellas, una característica especialmente importante, dadas las deficiencias de la administración pública en América Latina (Parrado/Salvador 2010). De hecho, su legitimidad intenta fundamentarse en la capacidad profesional y en la creación de condiciones de estabilidad para las operaciones de mercado e inversiones a largo plazo.

En suma, las instituciones reguladoras han evolucionado en el tiempo para adaptarse a las características políticas particulares de la región, como son los regímenes presidencialistas fuertes y unas administraciones públicas inestables, pero también sobre la base de tradiciones administrativas propias combinadas con modelos extranjeros (Ramió/Salvador 2008). Por ello, son el resultado de un largo camino en las transformaciones del Estado en la región, a partir de las tradiciones administrativas coloniales. Como hemos mencionado, durante décadas el desarrollo del Estado regulador coexistió con el estado desarrollista, y las influencias mutuas e interdependencias fueron intensas, algo que aún es posible observar particularmente en el caso de Brasil. Más recientemente tras el colapso del Estado desarrollista en varios países, el establecimiento de instituciones y políticas de regulación representó una respuesta para hacer frente a nuevas tensiones sociales y políticas existentes en la región, asumiendo el reto de legitimar su papel como el brazo operativo de un Estado capaz de gobernar efectivamente los sectores económicos.

Sin embargo, sin un esquema bien definido de anclaje en el contexto institucional más amplio del ámbito público, la base política sigue siendo débil para el Estado regulador. Así, por ejemplo, en el turbulento ambiente político de muchos países de América Latina, esta debilidad representa un peligro particularmente persistente para la consolidación de las agencias reguladoras. En este sentido, es importante que las instituciones políticas, judiciales, legislativas, etc., sean capaces de supervisar a los reguladores garantizando al mismo tiempo su autonomía (Jordana/Sancho 2004), y que dentro del el conjunto de interdependencias que emergen, encuentren su encaje institucional para permitir la gobernanza de los distintos sectores productivos. 


\section{Observaciones finales}

Si bien desde el siglo XIX los movimientos políticos de Estados Unidos en favor de la regulación tenían un enfoque progresista, con el objetivo de limitar las externalidades negativas del desarrollo capitalista en el país, en América Latina la introducción de amplias políticas de regulación fue a menudo vista como una medida neo-liberal, con el objetivo de transformar el Estado de manera regresiva. El hecho es que el desmantelamiento de las estructuras del Estado y la creación de nuevos marcos de política no fue un proceso fácil. La expansión de la regulación en América Latina a finales del siglo XX no se produjo bajo la presión de movilizaciones populares, y la mayoría de los cambios de política se introdujeron como innovaciones tecnocráticas en el marco de una ola de transformaciones económicas que incluían la privatización y la liberalización súbita de numerosos mercados. Desde un punto de vista intencional, puede decirse que en muchos casos la regulación no fue entendida en la región como una manera de controlar y domesticar a los mercados en favor de grandes segmentos de la población, bajo la preeminencia del interés público, sino que en buena parte fue introducida de forma instrumental frente a la crisis, y en ocasiones incluso como herramienta política que creó nuevas oportunidades para determinadas élites económicas.

Sin embargo, esta revolución reguladora, de base tecnocrática, trajo también nuevas oportunidades para mejorar los procesos políticos y limitar los abusos de los monopolios en la región. Por un lado, la mayoría de los organismos de regulación incluyen más capacidades de control sobre los participantes de los mercados, en relación con la situación previa, siendo las agencias en muchos casos capaces de seguir eficazmente la actividad de las principales empresas que operan en sus países, introduciendo de forma progresiva "reglas del juego" que obliguen a todos los actores, incluyendo las grandes empresas, a cumplir el marco regulador existente. Obviamente, no en todos los casos los organismos reguladores llevan a cabo su trabajo con éxito, y surgen muchos problemas de gobernanza en la regulación. Sin embargo, en su conjunto, estas nuevas instituciones representan una importante mejora de las capacidades de gobierno del sector público, y en la mayoría de los casos implican el fortalecimiento de las intervenciones del Estado mediante unos instrumentos de política más sofisticados y 
con menores distorsiones que nunca. La creación de agencias reguladoras también representa una oportunidad para mejorar la transparencia, el imperio de la ley, la participación y responsabilidad en muchas áreas de formulación de políticas. De hecho, la cantidad de información facilitada al público por las agencias reguladoras constituye claramente un paso muy importante en comparación con las anteriores tradiciones burocráticas de los Estados de América Latina, no muy amables en el suministro de información pública sobre sus decisiones. La realización de audiencias públicas, la difusión de las actas de sus reuniones oficiales, o las consultas de procedimiento, son diversas innovaciones administrativas introducidas por estas políticas de regulación, las cuales han creado nuevos espacios para ampliar la calidad de vida democrática.

Los resultados derivados del rediseño de los Estados de América Latina durante los años 1990 y 2000 tienen una estrecha relación con la búsqueda de un equilibrio social y económico en la región. El modelo liberal de finales del siglo XIX permitió a las élites económicas mantener un control efectivo de los Estados e introducir también algunas regulaciones pro-mercado, pero no permitió crear sociedades más inclusivas, solamente facilitó un modelo elitista de gobierno económico. El progreso de los movimientos sociales y políticos durante la mayor parte del siglo no encontró las condiciones para revertir esta tendencia, aunque generó numerosos conflictos sociales y políticos para definir las formas de acción estatal, y facilitó la intervención estatal directa en la economía (Draibe/Riesgo 2007).

En tiempos neoliberales, las políticas de regulación constituyeron una alternativa instrumental para solucionar las deficiencias de los Estados de América Latina en el control de los mercados, conteniendo la tentación de defender una presencia mínima del Estado en una economía abierta. El desarrollo del Estado regulador fue una opción para consolidar esta capacidad de intervención pública, en un marco abierto y democrático. En este sentido, debemos subrayar que la expansión de la regulación estatal en América Latina no es una consecuencia de la expansión del neoliberalismo en la región durante los años ochenta y noventa, sino un movimiento paralelo, de hecho orientado a aumentar la fuerza de los Estados latinoamericanos para poner en práctica los beneficios de la competencia económica y para evitar múltiples riesgos sociales y políticos (Faúndez 2005: 752). Asimismo, el desarrollo 
de tales capacidades del Estado ha ofrecido la oportunidad de equilibrar las políticas en favor de la libertad económica con las políticas en favor de los derechos económicos y sociales de los ciudadanos, evitando unos desequilibrios potencialmente explosivos.

\section{Bibliografía}

Bermejo Cabrero, José Luis (1984): "Superintendencias en la Hacienda del Antiguo Régimen". En: Anuario de Historia del Derecho Español, 54, pp. 409-448.

Braithwaite, John (2008): Regulatory Capitalism: How it Works, Ideas for Making it Work Better. Cheltenham: Edward Elgar.

Brooks, Sarah M. (2009): Social Protection and the Market in Latin America. The Transformation of Social Security Institutions. Cambridge: Cambridge University Press.

Cardoso, Eliana/Helwege, Ann (1992): Latin America's Economy: Diversity, Trends, and Conflicts. Massachusetts: MIT Press.

Céspedes del Castillo, Guillermo (1953): "Reorganización de la Hacienda virreinal peruana en el siglo XVIII". En: Anuario de Historia del Derecho Español, 23, pp. 329-370.

Chong, Alberto/Benavides, Juan (2007): "Privatization and Regulation in Latin America". En: Lora, Eduardo (ed.): The State of State Reform in Latin America. Palo Alto: Stanford University Press, pp. 263-289.

Coatsworth, John H. (2006): "Political Economy and Economy Organization". En: Bulmer-Thomas, V./Coatsworth, John H./Cortes Conde, Roberto (eds.): The Cambridge Economic History of Latin America. Vol. I: The Short Nineteenth Century. Cambridge: Cambridge University Press, pp. 137-273.

Coate, Malcolm B./Bustamante, René/Rodriguez, Armando E. (1992): “Anti-trust in Latin America: Regulating Government and Business". En: University of Miami Inter-American Law Review, 24, pp. 37-85.

Demaestri, Edgardo/Guerrero, Federico (2006): "What are the Perils of Separating Banking Regulation from the Central Bank's Orbit in Latin America and the Caribbean?". En: Journal of Financial Regulation and Compliance, 14, 1, pp. 7083.

Draibe, Sonia/Riesco, Manuel (2007): "Latin America: A New Developmental Welfare State in the Making?". En: Riesco, Manuel (ed.): Latin America. A New Developmental Welfare State Model in the Making? Houndmills/NewYork: Palgrave-UNRISD, pp. 21-116.

Drake, Paul W. (1989): The Money Doctor in the Andes. U.S. Advisors, Investors, and Economic Reform in Latin America from World War I to the Great Depression. Durham: Duke University Press.

Draibe, Sonia/Riesco, Manuel (2007): "Latin America: A New Developmental Welfare State in the Making?". En: Riesco, Manuel (ed.): Latin America: A New 
Developmental Welfare State in the Making? New York: UNRISD/Palgrave, pp. 21-113.

Dye, Alan (2006): "The Institutional Framework". En: Bulmer-Thomas, V./Coatsworth, John H./Cortes Conde, Roberto (eds.): The Cambridge Economic History of Latin America. Vol. II: The Long Twentieth Century. Cambridge: Cambridge University Press, pp. 169-207.

Edwards, Sebastián (1995): Crisis and Reform in Latin America. Oxford: Oxford University Press.

Faúndez, Julio (2005): "Democratization through Law: Perspectives from Latin America". En: Democratization, 12, 5, pp. 749-765.

Fishlow, Albert (1990): “The Latin American State". En: Journal of Economic Perspectives, 4,3 , pp. 61-74.

Gilardi, Fabrizio/Jordana, Jacint/Levi-Faur, David (2007): "Regulation in the Age of Globalization: The Diffusion of Regulatory Agencies across Europe and Latin America”. En: Hodge, Graeme (ed.): Privatization and Market Development: Global Movements in Public Policy Ideas. Cheltenham: Edward Elgar, pp. 127147.

Gutiérrez, Luis (2003): "Regulatory Governance in the Latin American Telecommunications Sector". En: Utilities Policy, 11, pp. 225-240.

Hopkins, Jack W. (1974): "Contemporary Research on Public Administration and Bureaucracies in Latin America". En: Latin American Research Review, 9, 1, pp. 109-139.

Inter-American Development Bank (2006): The Politics of Policies. Economic ans Social Progress in Latin America. 2006 Report. Washington, D.C.: IADB/Harvard University Press.

Jordana, Jacint/Sancho, David (2004): "Regulatory Designs, Institutional Constellations and the Study of the Regulatory State". En: Jordana, Jacint/Levi-Faur, David (eds.): The Politics of Regulation. Institutions and Regulatory Reforms for the Age of Governance. Cheltenham: Edward Elgar, pp. 296-319.

Jordana, Jacint/Levi-Faur, David (2005): "The Diffusion of Regulatory Capitalism in Latin America: Sectoral and National Channels in the Making of a New Order". En: Annals of the American Academy of Political and Social Science, 598, pp. 102-124.

- (2006): "Towards a Latin American Regulatory State? The Diffusion of Autonomous Regulatory Agencies across Countries and Sectors". En: International Journal of Public Administration, 29, 4-5, pp. 335-366.

Jordana, Jacint/Ramió, Carles (2009): "Agencias reguladoras e institucionalización del servicio universal en America Latina". En: Calzada, Joan/Costás, Antón/Jordana, Jacint (eds.): Más allá del mercado. Las políticas de servicio universal en América Latina. Barcelona: CIDOB, pp. 143-174.

- (2010): "Delegation, Presidential Regimes, and Latin American Regulatory Agencies". En: Journal of Politics in Latin America, 2, 1, pp. 3-30.

Levi-Faur, David (2003): "The Politics of Liberalisation: Privatization and Regulation-for-competition in Europe's and Latin America's Telecoms and Electricity Industries". En: European Journal of Political Research, 42, 5, pp. 705-740. 
- (2011): "Regulation and Regulatory Governance". En: Levi-Faur, David (ed.): Handbook on the Politics of Regulation. Cheltenham: Edward Elgar, pp. 3-21.

López, Garavito/Fernando, Luis (2003): "Una visión del desarrollo institucional de la Superintendencia Bancaria de Colombia, 1923-2003”. En: VV.AA.: 80 años de Superintendencia Bancaria en Colombia. Colombia. <www.superfinanciera. gov.co/ComunicadosyPublicaciones/80web/archivos/LuisFdoL\%F3pezGaravito. pdf $>(02.05 .2012)$.

Lora, Eduardo (ed.) (2007): The State of State Reform in Latin America. Palo Alto: Stanford University Press.

Llosa, Alicia C. (2006): "Boticas y Bodegas. The Development of Food and Drug Regulation in Peru". En: University of Miami Inter-American Law Review, 38, pp. 279-347.

Manzetti, Luigi (ed.) (2000): Regulatory Policy in Latin America: Post-privatization Realities. Miami: North-South Center Press.

Mattos, Paulo Todescan Lessa (2006): “A Formacäo do Estado Regulador”. En: Novos Estudios, 76, pp. 139-156.

Montoya, Miguel Á./Trillas, Francesc (2007): "The Measurement of the Independence of Telecommunications Regulatory Agencies in Latin America and the Caribbean”. En: Utilities Policy, 15, pp. 182-190.

Murillo, Maria V./Martínez-Gallardo, Cecilia (2007): "Political Competition and Policy Adoption: Market Reforms in Latin American Public Utilities". En: American Journal of Political Science, 51, 1, pp. 120-139.

Parrado, Salvador/Salvador, Miquel (2010): “The Institutionalization of Meritocracy in Latin American Regulatory Agencies". Manuscrito. Barcelona.

Pietschmann, Horst (1983): "Antecedentes españoles e hispanoamericanos de las intendencias". En: Anuario de Estudios Americanos, 40, pp. 359-372.

- (1993): "El desarrollo estatal de Hispanoamérica: enfoques metodológicos". En: Chronica Nova, 21, pp. 469-492.

Przeworski, Adam (2009): "The Mechanics of Regime Instability in Latin America". En: Journal of Politics in Latin America, 1, pp. 5-36.

Ramió, Carles/Salvador, Miquel (2008): “Civil Service Reform in Latin America: External Referents Versus Own Capacities". En: Bulletin of Latin American Research, 27, 4, pp. 554-573.

Slaughter, Anne-Marie (2004): A New World Order. Princeton: Princeton University Press.

Thurber, Clarence E. (1973): "Islands of Development: A Political and Social Approach to Development Administration in Latin America". En: Thurber, Clarence E./Graham, Lawrence S. (eds.): Development Administration in Latin America. Durham: Duke University Press, pp. 15-46.

Topik, Steven (1999): "The Construction of Market Society in Latin America: Natural Process or Social Engineering?". En: Latin American Perspectives, 26, 1, pp. 3-21.

Weyland, Kurt (2006): Bounded Rationality and Policy Diffusion. Social Sector Reform in Latin America. Princeton: Princeton University Press. 


\title{
Marianne Braig \\ Los derechos humanos como autorización para hablar. Metatexto universal y experiencias particulares
}

\begin{abstract}
Fue junto con Manuela cuando escuché por primera vez a los catequistas decir que no está bien que sólo esté mandando el hombre y que no está bien que sólo esté dando patadas a la mujer. [...] Decían que también tenemos derechos las mujeres de que nos toman en cuenta, de que nos quieren. Debemos ser iguales, juntos tenemos que pensar y decidir.
\end{abstract}

\section{Introducción}

En las últimas décadas, en el contexto pos dictatorial, la disputa por los derechos humanos quedó vigente en América Latina. No solo están presentes los activistas contra las violaciones de los derechos humanos atribuidas a las prácticas de las dictaduras militares o regímenes autoritarios. En el proceso de la transición a la democracia surgieron en América Latina nuevos movimientos sociales luchando por los derechos humanos en sus países (legal movements) y actores políticos que "tomaron la palabra" apoyándose en los derechos humanos "como forma de acción política". Frecuentemente se observa esta "toma de palabra", este empoderamiento por hablar, en el contexto de un referéndum constitucional o una consulta constitucional. Pero no necesariamente surgen legal movements en una disputa concreta por una reforma de la Carta Magna, sino por sus propias causas y motivos.

Podemos observar en América Latina que el señalamiento de las violaciones de los derechos humanos excedió cada vez más el límite de la violación de los derechos humanos políticos a priori, trayendo consigo los defectos de la democracia realmente existente, como por ejemplo los fraudes electorales, las desigualdades sociales, las discriminaciones raciales o las formas de impunidad.

1 Verónica, una mujer indígena, llora cuando habla de Manuela, fallecida el 22.12.1997 en Acteal, Chiapas (México) durante una matanza (Hernández Castillo 1998: 17). 
Al mismo tiempo el discurso de los derechos humanos involucra también a los hechos de ilicitud, que no están directamente inmersos en la relación entre el Estado y el individuo, sino más bien en espacios privados y entre particulares, como lo menciona Verónica en la cita anterior. La violencia doméstica contra las mujeres y los niños es, con seguridad, uno de los ejemplos más conocidos al respecto.

¿Pero qué significa la ampliación del discurso de los derechos humanos en un contexto jurídico cuyas características son definidas no tanto como defectuosas sino como corruptas? En la presente contribución tratamos de interpretar el hablar sobre los derechos humanos como una búsqueda social para expresar diferentes experiencias de injusticia en las protestas de diferentes grupos, tanto contra las circunstancias concretas, así como contra las formas en que se ejerce la injusticia. Lo que buscan los movimientos sociales al referirse a los derechos humanos es un lenguaje que les permite expresar la injusticia vivida en una forma jurídica. Para discutir la pregunta ¿qué es lo que convierte a los derechos humanos en un discurso legítimo sobre la experiencia de injusticia y hasta qué punto le condicionan barreras de sexo o de cultura?, nos orientamos en una contribución de Cornelia Vismann, ${ }^{2}$ que trata el texto de los derechos humanos como una "instancia elocutoria" (Instanz des Sprechens). Lo que nos interesa y tratamos de discutir con el apoyo del análisis de Vismann es si la autorización discursiva de las víctimas no solo hace hablar a los subalternos sino que los hace hablar más allá de una oposición "binaria" (Spivak 1994). La pregunta es si la referencia a un texto universal como los derechos humanos permite hablar sobre las experiencias de violencia vivida traspasando las fronteras territoriales, los contextos históricos, las diferencias étnicas y de género, y la polarización entre lo privado y lo público.

\section{Los derechos humanos como autorización de hablar}

En la búsqueda por el significado universal de los derechos humanos, los textos legales concretos de los diferentes estados no nos ayudan necesariamente - ya sea que faltan por completo, o porque están tem-

2 Cornelia Vismann (*26.05.1961 en Hankensbüttel; $† 28.08 .2010$ en Berlín) era profesora en derecho público, historiadora del derecho, filósofa y experta en teoría de comunicación. Este texto está basado en Vismann (1998). 
poralmente derogados o porque simplemente no se toman en consideración. Especialmente en regímenes autoritarios que no reconocen el Estado de Derecho y que no permiten una opinión pública crítica, falta el reconocimiento de los derechos humanos en la legislación. Pero tampoco los estados en transición de América Latina disponen de un instrumentario que pueda asegurar a sus ciudadanos sus derechos políticos y sociales, dentro y fuera del hogar. La gran mayoría de los Estados actuales -cualquiera que sean los atributos que caracterizan su democracia- son institucionalmente demasiado débiles para garantizar territorial y socialmente "la subsunción de lo privado bajo una burocracia disciplinadora de corte patriarcal y capitalista" (Benhabib 1992: 94) que permita la coexistencia de distintas formas de normas y valores. Valores sustentados por las iglesias y grupos religiosos, por las reglas y normas de diferentes sistemas sociales, entre otros, así como las distintas formas de hacer asuntos públicos o de imponer tabúes.

Pero como nos enseñan los textos de Vismann, los derechos humanos no existen solamente como instancia del derecho positivo, sino que se manifiestan en la voz de todos aquellos que denunciaron la injusticia. Así entendido, hay que reconstruir la disputa por los derechos humanos desde las iniciativas, acciones y movimientos sociales que toman la palabra de los derechos humanos para hablar sobre injusticias, desigualdades y violencias en diferentes contextos. En este sentido, Cornelia Vismann (1998: 283-304) ha calificado los derechos humanos como "instancia elocutoria". Tomando como ejemplo la Déclaration des droits de l'homme et du citoyen del año 1789, Vismann muestra el carácter ambiguo de los mismos: los derechos humanos fueron declarados como derechos y en consecuencia, formulados como textos legales, en los que la Asamblea Nacional, en este caso la francesa, concedió derechos a los ciudadanos franceses (aunque no todos fueron reconocidos como tales). Derechos humanos se considera a los derechos políticos ligados a ciertas condiciones y obligaciones de los ciudadanos, de los que en gran parte fueron excluidas las mujeres francesas y que no contenían ningún tipo de derecho. Pero al mismo tiempo, se trata de derechos que desde siempre fueron concedidos a todos los seres humanos y que son iguales en su aplicación e inalienables y que no están sometidos a ninguna condición ni dependen tampoco de las obligaciones del ciudadano. Son "derechos absolutos porque su existencia no está condicionada a ningún hecho que no sea el 
de la existencia del ser humano" (Denninger 1994: 80). Como se constata en el preámbulo de la Declaración, ${ }^{3}$ estos derechos absolutos forman un texto que fue escrito para evitar "el olvido". Según Vismann, a través de duplicar un texto o con la ayuda de un "truco lingüístico", todos los puestos legislativos están ocupados doblemente:

Hay dos legisladores: La Asamblea Nacional y el hombre; se formulan dos tipos de derecho: el de los ciudadanos franceses y el de todos los hombres; asimismo hay dos campos de aplicación: la República y la humanidad. Desde el punto de vista temporal esta Declaración está en vigor tanto desde que fue promulgada así como desde tiempos inmemoriales. Mediante la operación lingüística de una duplicación de todos los componentes legislativos, la Declaración marca la diferencia entre ciudadano (francés) y el hombre, entre la versión universal y particular, entre la validez histórica y la eterna, abriendo así el espacio en el cual la Declaración Universal de los Derechos Humanos se desarrolla paralelamente a la francesa y se sigue escribiendo, en cierto modo, por sí misma. Con ello se convierte literalmente en autolegislación que permite la autorización propia de cualquier individuo, mediante la autoridad del lenguaje jurídico - el cual funciona o se le apropia de forma semejante a un texto sagrado (Vismann 1998: 238ss.).

Sacando el texto de los derechos humanos de los contextos específicos de su origen, varían sus formas, pudiendo apropiárselo cada uno y cada una, trasladándolo a contextos diferentes para así reclamar cambios culturales y sociales.

De esta forma un texto legal de la Asamblea Nacional francesa se convierte en un metatexto, universalmente apropiable. Si se ve ligado a la codificación de los derechos políticos, los trasciende simultáneamente cuando, en lugar del legislador, del ámbito de aplicación y del titular de los derechos se presupone la misma unidad ficticia: el hombre, que es justamente una instancia abstracta (Vismann 1998: 284).

3 El preámbulo de la constitución francesa de 1791 fue la Declaración de los Derechos del hombre y del ciudadano dice: "Los representantes del pueblo francés, constituidos en Asamblea Nacional, considerando que la ignorancia, el olvido o el menosprecio de los derechos del hombre son las únicas causas de las calamidades públicas y de la corrupción de los gobiernos, han resuelto exponer, en una declaración solemne, los derechos naturales, inalienables y sagrados del hombre, a fin de que esta declaración, constantemente presente para todos los miembros del cuerpo social, les recuerde sin cesar sus derechos y sus deberes; a fin de que los actos del poder legislativo y del poder ejecutivo, al poder cotejarse a cada instante con la finalidad de toda institución política, sean más respetados y para que las reclamaciones de los ciudadanos, en adelante fundadas en principios simples e indiscutibles, redunden siempre en beneficio del mantenimiento de la Constitución y de la felicidad de todos". 
Con estos rasgos, la declaración de los derechos humanos es una infracción declarada del poder legislativo nacional, lo que significa una pérdida de soberanía de cada uno de los Estados, en el sentido de que al hombre se le concede el derecho a hablar y a contradecir cuando padece una injusticia por parte del Estado. Sin embargo, la Declaración francesa no sólo representa la lengua de los oprimidos en este momento histórico y en este lugar concreto, sino que los derechos humanos por sí mismos constituyen un lenguaje para poder declarar también otras experiencias de injusticia, pasadas y futuras.

Como "instancia elocutoria", los derechos humanos se presentan abiertos hacia nuevas experiencias de injusticia y reciben una dinámica propia, desligada del texto legal concreto. Los derechos humanos, al tratar el sentimiento de injusticia y experiencias que contradicen la ley, permiten hablar sobre las experiencias con el derecho, que no es tal, en los casos en que no está codificado o no se respeta. Pero esto implica también reclamar derechos concretos de un legislador concreto, siempre y cuando esté constituido como tal.

\section{El poder hablar de experiencias diferentes en el lenguaje de un texto abstracto}

Cabe preguntarse si esto es también válido para formas de violencia en los ámbitos privados e íntimos cuando estos se encuentran fuera del derecho codificado, tal y como lo explican la campaña internacional de las Naciones Unidas en los noventas "Los derechos de la mujer son derechos humanos" y las numerosas iniciativas regionales y locales para constituir la violencia sexualizada contra las mujeres como problema social. ${ }^{4}$ Es posible que los derechos humanos formulen también experiencias de injusticia fuera de las condiciones clásicas de opresión, aún cuando esto suponga ir contra el mainstream del mismo discurso pro derechos humanos. Este mainstream llegó a sus límites en los casos donde no era posible hacer responsable a ningún Estado de su fuerza represiva. El pensamiento clásico sobre los derechos humanos atrapado en la dicotomía entre lo privado y lo público, partía de la existencia de una dictadura que tortura y recorta las libertades

41993 Declaración de Viena: Todos los derechos humanos son universales, indivisibles e interdependientes y están relacionados entre sí. 1994. Convención Interamericana para Prevenir, Sancionar y Erradicar la Violencia contra la mujer. 
individuales o, por lo menos, la del Estado como sujeto de las opresiones, pero no disponía de jurisdicción en el caso de violaciones en lo privado.

Aunque en las décadas pasadas se haya reducido la cifra de estas formas clásicas de violaciones de derechos humanos en América Latina, éstas no se pueden considerar como superadas puesto que se mezclan con abusos difusos del poder, practicados por fuerzas paraestatales o por la mafia, los narcotraficantes, que quedan impunes. Pero si los derechos humanos no quieren perder su papel como "instancia elocutoria", sobre todo cuando ellos mismos no pueden funcionar como instancia de derecho, tienen que permitir una articulación discursiva de las violaciones que esté a la altura de esta transformación.

Esto implica también el poder formular las experiencias de injusticia concretas cuestionando la subyacente imagen del hombre que por regla general corresponde al varón blanco y burgués. Numerosos movimientos sociales y actores de la sociedad civil vuelven a recurrir al texto de fondo de los derechos humanos, texto que fue escrito contra el olvido, para que se cumpliese, sirviéndose del lenguaje de los derechos humanos para hacer públicas sus experiencias de injusticia. Pero es un camino largo de haber vivido una violencia física, de poder sentir que algo injusto está pasando, hasta ser consciente de que se trata de injusticia y que se tiene el derecho de reaccionar. ${ }^{5}$ También Verónica, mujer indígena de Chiapas, se refiriere a los derechos humanos, casi como un texto sagrado, para expresar su sentimiento de injusticia. Es por la palabra "derecho", inexistente en su idioma materno tzotzil, que Verónica ha podido abandonar a su marido, con el que la casaron a la edad de 14 años y con el que tiene siete hijos, y explicar a sus padres la situación (Hernández Castillo 1998). Justamente porque el hombre al que hacen referencia los derechos humanos es abstracto, cada individuo, como en el caso citado de Verónica, puede situarse en el texto en el lugar de la palabra "hombre", es decir, cada uno y cada una puede apropiarse una y otra vez del texto y dejarle hablar.

Cabe recordar que ya en la reunión constituyente de la Asamblea Nacional francesa no solamente no era un acto discursivo aislado sino una referencia práctica. El acto empírico histórico está entrelazado con

5 Como lo analiza Ströbele Gregor desde la experiencia de mujeres indígenas en los Andes (Ströbele-Gregor 1998: 45-56). 
acciones de grupos diferentes en lugares diferentes. La autodefinición del hombre abstracto (que identifica Vismann en la Declaración) permitió a muchos subalternos el "tomar la palabra" como habla de derecho. La proclamación de los derechos humanos llevó consigo en Haití, en el año 1791, un levantamiento de la población de color contra las clases superiores blancas, que culminó, en el 1804, con la liberación de los esclavos, el fin de la dominación francesa y en la proclamación de un Estado independiente. A los reyes de las colonias el metatexto permitió recordar que también eran hombres, seres humanos, como sujeto de derecho. En el mismo año en que tuvo lugar la reclamación de los colonizados, el 7 de septiembre de 1791, también Olympe de Gouges pidió la palabra para pronunciar la "Declaración de los Derechos de la Mujer y de las Ciudadanas". Su forma de proceder fue mucho más allá de la Declaración de los Derechos Humanos de 1948, ya que de Gouges utilizó justamente el metatexto y colocó a la mujer en el lugar del hombre. El esquema discursivo de igualdad y diferencia que articulan los derechos humanos no puede fallar más gráficamente que en la contraposición de ambos textos y hace más comprensible el hecho de que los derechos humanos de la mujer tienen que asegurarse también en el ámbito privado, como el matrimonio. ${ }^{6}$ De esta manera de Gouge abrió el camino para analizar la división entre lo público y lo privado y para acusar las violaciones de los derechos fundamentales en el matrimonio. Como ella, otras mujeres utilizan en muchos conflictos el lenguaje político de los derechos humanos, aún cuando éstos encierren una imagen del hombre definida por el status del ciudadano masculino. "Pues al servirse de este lenguaje, estaban solicitando su propia identidad. Con la misma acción cambiaron la cultura en la que se inspiraban" (Braig 2001: 25-38; Fox-Genovese 1998: 201; Gerhard 1990: 49-72).

Así leídos, los derechos humanos establecen un documento de autorización de los subalternos para formular experiencias de injusticia muy diversas y se relacionan con multitud de expresiones culturales de la subversión (también en lo privado). Ayudan a imaginar una instancia, cuyo actuar se legitima sin las leyes en vigor o, si es necesario,

6 En el articulo III se dice: El principio de toda soberanía reside esencialmente en la Nación que no es más que la reunión de la Mujer y el Hombre: ningún cuerpo, ningún individuo, puede ejercer autoridad que no emane de ellos. 
contra ellas. En los años ochenta del siglo pasado un gran número de organizaciones de familiares en todo el mundo se tomaron el derecho de hacer público su dolor privado y acusar a regímenes autoritarios, como lo hicieron las madres argentinas de la Plaza de Mayo, las viudas guatemaltecas, las madres del sábado turcas. Desde los años noventa, con la transformación neoliberal de la economía y de la política social, los movimientos sociales reaccionaron ante la marginación con la denuncia de una injusticia social a consecuencia de la falta de derechos sociales y constatando el aumento de la desigualdad económica y social. En los últimos tiempos ocurren actos violentos en espacios privados y públicos por actores privados, paraestatales y estatales que afectan la vida cotidiana y que se discuten como violación de los derechos humanos. Por el entrelazamiento entre actores estatales y no estatales, por ejemplo, en el combate contra el crimen organizado, la impunidad y la militarización de la seguridad pública por el estado, se articulan nuevos movimientos que forman legal coalitions (O'Donnell 1999) para exigir los derechos humanos. En el contexto mexicano de hoy día son otra vez familiares que rompen el silencio en manifestaciones de silencio para pedir paz con justicia y dignidad. ${ }^{7}$

$\mathrm{Al}$ igual que el reconocimiento de la violencia física y sexualizada y de otras formas de violencia estructural como problema social y político, resta la tarea de formular al mismo tiempo los derechos humanos como derechos codificados, y de reclamarlos en un Estado concreto que sea capaz de imponer sanciones.

La Declaración General de los Derechos Humanos posee así la función de un imperativo a expresarse - a la expresión de cada una de las declaraciones particulares de los derechos humanos, que se quedan sin nombrar en la versión general. La misma se irá completando hasta que todas las declaraciones particulares de los derechos humanos tengan lugar bajo el techo de las generales (Vismann 1998: 292 y ss).

7 Después de la muerte de su hijo, el poeta Javier Sicilia organiza una gran manifestación que sale el 5 de mayo 2011 de Cuernavaca, Morelos, para llegar el 8 de mayo al Zócalo de la Ciudad de México. Esta manifestación lleva por nombre "La marcha nacional por la paz con justicia y dignidad". Al finalizar la marcha en el Zócalo, Sicilia demandó al presidente de la república retirar el Secretario de Seguridad Pública, además de solicitar el "combatir corrupción, impunidad y ganancias del crimen". 


\section{Tomar la palabra como acción política}

Sin reforzar el lado político práctico de los derechos y la vinculación de lo discursivo, la "instancia elocutoria", con lo practico, "instancia del derecho" codificado, persiste el riesgo de que el metatexto de los derechos humanos se pierda en un cotorreo polifónico y en una cacofonía. Un vínculo podría formar la reforma de la propia constitución. Desde décadas las cartas magnas de los países de América Latina se encuentra en disputa y muchas de ellas han tenido cambios profundos. Fue por los movimientos sociales, especialmente por los legal movements de organizaciones indígenas, que en los noventas se realizaron reformas constitucionales significantes, especialmente en Colombia (1990-1991), Perú (1993), Ecuador (1998) y Bolivia (1994-1995, 2009). México fue el primer país del Subcontinente en ratificar el Convenio 169 sobre los Pueblos Indígenas de la Organización Internacional del Trabajo (OIT), pero no participó en este proceso de las reformas constitucionales que encontró su punto de referencia jurídico en el Convenio 169. En comparación con los otros países, la constitución mexicana ha sido objeto de pocas modificaciones (HernándezDíaz 2010: 141 y ss).

Es sobretodo el movimiento zapatista que tomó desde los noventas la palabra como forma de acción refiriéndose a la Carta Magna de la nación mexicana. Ningún otro movimiento social, ninguna otra guerrilla en Latinoamérica ha luchado tan fuertemente con las palabras y tan poco con las armas. Su estrategia de comunicación ${ }^{8}$ trató desde su comienzo de no conducir el discurso público como un monólogo y su finalidad no fue sólo la resonancia internacional, la cual durante algún tiempo fue ciertamente muy exitosa. La comunicación zapatista a través de comunicados tenía como finalidad desde su comienzo apuntar a la constitución nacional y al parlamento como núcleos centrales de la democracia posible, y no al sistema presidencial.

Con el pronunciamiento, mundialmente famoso y de alta empatía, "Ya basta", comienza el 1 de enero de 1994 una rebelión de las pala-

8 "El discurso no es simplemente aquello que traduce las luchas o los sistemas de dominación sino aquello por lo que y por medio de lo cual se lucha”, escribió en 1980 citando a Foucault (Die Ordnung der Diskurse, 1994) un estudiante de la UNAM en la ciudad de México, Vicente Guillén. Sobre el discurso como lucha: (Huffschmid 2004). 
bras, de los "indios", de las mujeres y niños al margen del mundo. Ellos se toman el derecho a hablar, a contradecir, y tomando la palabra, legitiman su existencia hasta ahora desconocida. Ironía y desmesura se expresan por años en escenificaciones múltiples de la propia existencia, de la cual la opinión pública nada sabía y tampoco quería saber y sigue sin querer saber (Huffschmid 2004).

Si uno solamente se fija en el silencio actual de esta forma de comunicación ejercido por varios años a niveles múltiples, y ciertamente original, se queda uno con el amargo resultado de que no fue mucho más que un monólogo creativo en el contexto de la tercera ola de la democratización. ${ }^{9}$

Cabe añadir que el "tomar la palabra" del movimiento Zapatista no solamente crea una opinión pública crítica, dentro de la cual los subalternos tienen un espacio de expresión, ya que estos al hablar, se manifiestan al mismo tiempo como ciudadanos que quieren participar en los procesos de decisión legislativos a través del articularse como protagonistas de la soberanía popular. Ya desde su primer comunicado se refieren a la constitución del país para legitimar su hablar:

Para evitarlo y como nuestra última esperanza, después de haber intentado todo por poner en práctica la legalidad basada en nuestra Carta Magna, recurrimos a ella, nuestra Constitución, para aplicar el Artículo 39 Constitucional que a la letra dice: 'La soberanía nacional reside esencial y originariamente en el pueblo. Todo el poder público dimana del pueblo y se instituye para beneficio de éste. El pueblo tiene, en todo tiempo, el inalienable derecho de alterar o modificar la forma de su gobierno.'

Después de sus primeros acciones en 1994 el movimiento neozapatista obligó al Estado mexicano de crear espacios de dialogo, espacios para poder hablar y ser escuchados, como la Comisión de Paz y Concordia para la Pacificación en Chiapas (COOPA). Era un órgano plural del poder legislativo con la tarea de mediación entre el poder ejecutivo y la guerrilla. Un resultado de esta negociación era, que se consideró en los Acuerdos de San Andrés, la necesidad de reformar algunos artículos de la Constitución (Hernández Díaz 2020: 143). En 2001 en el contexto de la Marcha Zapatista lograron indígenas (mujeres y hom-

9 Entre otros véase Huntington (1991). Para una versión critica de la comunicación véase (Maus 2007: 350-382). Maus se pregunta si, en el contexto de la democracia global, la cual se determina frecuentemente por un criterio único (que seria la existencia de una opinión critica mundial), no existe el peligro de reducir esta democracia a la mitad de su valor, convirtiéndola solo en comunicación. 
bres) hablar desde una posición subalterna frente al parlamento en sus idiomas propios para reclamar reformas constitucionales. En todo este tiempo logró el movimiento guerrillero no solo defenderse desde el inicio contra la represión, sino que sigue rechazando las ofertas clientelistas.

El verdadero mérito de los zapatistas radicó en dos cosas: en su capacidad para enlazar las demandas de democracia, justicia y libertad que ellos enarbolaban con la demanda indígena de autonomía, y en la tribuna nacional que construyeron para el debate de este tema, con lo que lograron que la reivindicación de los pueblos indos alcanzan una resonancia inusual. El vínculo resultó enormemente fecundo, y eficaz la apertura del espacio público (Díaz Polanco 1997: 171)

Aún no lograron la gran reforma de la Carta Magna como las organizaciones indígenas lo esperaban, encontraron puentes entre la "instancia elocutoria" y la "instancia del derecho". Así en la reforma constitucional de 2001 las organizaciones dejaron huellas notables, que hoy en día sirven como base para discutir la autonomía municipal y otras demandas de los movimientos indígenas.

\section{Bibliografía}

Benhabib, Seyla (1992): "Models of Public Space: Hannah Arendt, the Liberal Tradition, and Jürgen Habermas". En: Calhoun, Craig J.: Habermas and the Public Sphere. Cambridge: MIT-Press, pp. 73-98.

Braig, Marianne (2001): "Repensando los procesos de violencia en América Latina. La violencia sexualizada como violación de los derechos humanos". En: Bodemer, Klaus/Kurtenbach, Sabine/Meschkat, Klaus (eds.): Violencia y regulación de conflicto en América Latina. Caracas: Nueva Sociedad, pp. 25-38.

Braig, Marianne/Anne, Huffschmid (eds.) (2009): Los poderes de lo público. Madrid: Iberoamericana/Frankfurt am Main: Vervuert.

Denninger, Erhard (1994): Menschenrechte und Grundgesetz. Weinheim: Beltz Athenäum.

Díaz Polanco, Héctor (1997): La rebelión zapatista y la autonomía. México, D.F., Siglo XXI.

Fox-Genovese, Elisabeth (1998): "Freiheitskämpfe: Frauen, Sklaverei und Gleichheit in den Vereinigten Staaten". En: Hufton, Olwen H. (ed.): Menschenrechte in der Geschichte. Frankfurt am Main: Fischer Taschenbuch-Verlag, pp. 194-235.

Gerhard, Ute (1990): Gleichheit ohne Angleichung. Frauen im Recht. München: C.H. Beck. 
Hernández-Díaz, Jorge (2010): “La construcción de ciudadanías postliberales. Los reclamos de autonomía municipal y demandas indígenas en México". En: Latin American Research Review 45,4, pp. 138-165.

Hernández Castillo, Rosalva Aída (1998): La otra palabra. Mujeres y violencia en Chiapas antes y después de Acteal. México, D.F.: CIESAS.

Huffschmid, Anne (2004): Diskursguerilla: Wortergreifung und Widersinn. Die Zapatistas im Spiegel der mexikanischen und internationalen Öffentlichkeit. Heidelberg: Synchron Wissenschaftsverlag.

Huntington, Samuel (1991): The Third Wave. Democratization in the Late Twentieth Century. Norman: University of Oklahoma Press.

Maus, Ingeborg (2007): "Verfassung oder Vertrag. Zur Verrechtlichung globaler Politik". En: Niesen, Peter/Herborth, Benjamin (eds.): Anarchie der kommunikativen Freiheit. Jürgen Habermas und die Theorie der internationalen Politik. Frankfurt am Main: Suhrkamp, pp. 350-382.

O'Donnell, Guillermo (1999): "Horizontal Accountabilty in New Democracies". En: Schedler, Andreas/Diamond, Larry J./Plattner, Marc F. (eds.): The Self-restraining State. Power and Accountability in New Democracies. Boulder/London: Lynne Rienner Publishers, pp. 29-51.

Spivak, Guyatri (1994): "Can the Subaltern Speak". En: Willimas, Patrick/Chrisman, Laura: Colonial Discourse and Postcolonial Theory. New York: Colombia Press, pp. 66-111.

Ströbele-Gregor, Juliana (1998): "Gewalterfahrung von Frauen in den Anden. Unrechtsempfinden, Unrechtsbewusstsein, Rechtsdenken und Wandlungsprozesse in indianischen Dorfgemeinschaften". En: Braig, Marianne/Gerhard, Ute (eds): Frauenrechte sind Menschenrechte. Frankfurt am Main: J. W. Goethe-Universität, pp. 45-56.

Vismann, Cornelia (1998): "Menschenrechte: Instanz des Sprechens - Instrument der Politik". En: Brunkhorst, Hauke (ed.): Demokratischer Experimentalismus. Politik in der komplexen Gesellschaft. Frankfurt am Main: Suhrkamp, pp. 283-304. 


\section{Hans-Jürgen Burchardt}

\section{¿Democracia desigual o desigualdad democrática? Un acercamiento teórico a la realidad socio-política de América Latina}

Las sociedades latinoamericanas se caracterizan por ser, después de las del sur de África, las de tasas de desigualdad más altas del mundo (Wehr/Burchardt 2011). Una característica clásica y estructural es la alta concentración de ingresos. Sin embargo, la desigualdad extrema no sólo concierne a las disparidades de ingresos y de bienes económicos, sino también a los desiguales accesos a los principales bienes públicos como la educación, la seguridad social y la salud (Ferranti et al. 2004; Lopez/Perry 2008; Milanovič/Muñoz de Bustillo 2008). Estas diferentes dimensiones de la desigualdad social provocan una dinámica opuesta y potenciadora, que en los debates científicos se expresan, según las diversas interpretaciones, como "vicious circle" (World Bank 2006), "negative complementarities" (Hall/Soskice 2001; Schneider/Karcher 2010) o "poverty traps" (Sachs 2006).

Se trata de formas de desigualdad estructural en el sentido de restricciones efectivas y permanentes de más de una generación, que conciernen al acceso a los bienes públicos y a las posiciones sociales disponibles. Pese a que el origen y los factores determinantes de estos rasgos estructurales son hasta hoy objeto de numerosas controversias científicas y políticas, existe, sin embargo, un acuerdo en la suposición de que la desigualdad social en América Latina se solidificó, desde el siglo XIX hasta hoy, por encima del promedio del nivel internacional (Acemoglu/Robinson 2006; Coatsworth 2008; Engerman/ Sokoloff 2006; Frankema 2009). Esta persistencia sorprende, en particular, por el hecho de que los cambios históricos de América Latina permiten pasar revista a diferentes modelos de desarrollo económico, a diferentes experiencias democráticas $\mathrm{y}$, en parte, a un Estado de Bienestar amplio.

Estos resultados contradicen en tres aspectos las teorías y suposiciones de las ciencias sociales: en primer lugar, la desigualdad social 
se fortaleció de manera relativamente independiente de -en ocasiones altos- niveles de desarrollo económico así como de las estructuras económicas (Segura-Ubiergo 2007). Ninguna de las estrategias económicas, como la industrialización del mercado interno y la sustitución de importaciones a partir de los años 1930 o la fase del cambio político radical hacia el neoliberalismo de los años 1980 (Burchardt 2007), pudieron reducir, a largo plazo y de manera considerable, las tasas de la desigualdad social. El mismo "boom" económico de la última década no sólo condujo a una discreta disminución de las tasas de la desigualdad, sino sólo a un discreto cambio de tendencia. Los Coeficientes de Gini de la región se han acercado hoy al nivel de los años 1980, independientemente de que se trate de países con estructuras económicas industriales o agropecuarias (CEPAL 2010; LópezCalva/Lustig 2010).

En segundo lugar, subyace la breve suposición de que las políticas sociales latinoamericanas padecen de escasos recursos. Varias de las sociedades regionales pasan revista a las largas tradiciones del Estado de Bienestar. En países como Argentina, Brasil, Chile, Cuba y Uruguay se construyeron programas de seguro social ya desde la década de 1920 (Mesa-Lago 1978). El recorte social "neoliberal" de la década de 1980, condujo, en realidad, a más trastornos sociales en cuanto al aumento de la eficiencia prevista en la política económica y social (Rodrik 2006; Stiglitz 2004). Los gastos sociales tuvieron, sin embargo, en los últimos años un promedio de por encima del 15\% del Producto Interno Bruto (PIB) y del 50 al $60 \%$ del gasto público total en los países latinoamericanos (Segura-Ubiergo 2007: 15). Sin embargo, en América Latina las nuevas políticas fiscales, laborales y sociales apenas producen una contribución a la disminución de las desigualdades manifestadas o una redistribución de recursos y bienes (Wehr 2011). Estudios recientes señalan, más bien, que varios regímenes de bienestar son de carácter regresivo y tienden a perpetuar las disparidades sociales (Riesco 2007; Segura-Ubiergo 2007). Además, puede añadirse que los efectos de la redistribución de las medidas fiscales son evidentemente bajos, en parte, debido a la sola aplicación parcial del control de impuestos (Boeckh 2011; CEPAL 2005; 2008; Goñi/ López/Servén 2008; Lindert et al. 2006; Lopez/Perry 2008).

Por último y en tercer lugar, las fuerzas permanentes de las tasas de desigualdad de América Latina contradicen las teorías de la demo- 
cracia. Estas parten mayormente de la base, de que la participación democrática en los procesos de determinación política debería ir acompañada de mejoras sociales y de los electores que representan la mayoría de la población. Ellas surgen de las experiencias del desarrollo europeo, en el cual se constató una clara correlación entre la expansión del sufragio universal y una reducción de la desigualdad social (Acemoglu/Robinson 2006; Boix 2003; Huber/Stephens 2001; Lindert 2004). Otro es el caso en América Latina: desde los primeros pasos democráticos en el contexto de la descolonización a partir del siglo XIX, no se llegó a ninguna disminución de la desigualdad social (Annino 1995; Engerman/Sokoloff 2005; Posada-Carbó 1996; Sábato 1999). También las últimas tres décadas de democracia consolidada de la región continúan acompañadas de la persistencia e incluso con la agudización de las disparidades sociales. Esta coexistencia de la democracia y la desigualdad, según los demás análisis científicos, se debe a las deficiencias institucionales, permitiendo a las elites proteger sus privilegios a largo plazo, principalmente mediante factores informales (por ejemplo, compra de votos, corrupción y clientelismo) y bajo la exclusión de otros grupos de la población (Acemoglu/Robinson 2006; Engerman/Sokoloff 2005; 2006). Pero tal perspectiva posee un tipo de explicación limitada, ya que hoy los índices democráticos en América Latina frente a otras regiones mundiales como Asia, África y Europa Oriental dan testimonio de una consolidación democrática evidente, particularmente expresada por elecciones libres y justas (Freedom House 2010; PNUD 2004a). Es por eso que en "la región más democrática del Tercer Mundo" (Linz/Stephan 1996) hay que constatar más bien la paradoja entre la coexistencia de democracia consolidada y la persistente desigualdad (Burchardt 2010a).

A pesar de más de tres décadas de recuperación de la democracia, la mayor participación política no se ha traducido en participación social. Esto plantea nuevas incógnitas a la teoría de la democracia. Los estudios sobre las democracias latinoamericanas se basan mayormente, desde los años 90, en el análisis bajo el paradigma de la "teoría de la transición". Este enfoque se centra, principalmente, en los factores institucionales y considera a las democracias occidentales del mundo desarrollado como su orientación normativa (Ackerman 2006; Lynn Karl 1996). A partir de una perspectiva liberal-democrática basada en la primacía de la libertad individual y de la igualdad política 
jurídica, puede otorgar este enfoque validez universal a una concepción minimalista de la democracia y del espacio público, basada en el concepto unidimensional y elitista de la democracia de Schumpeter (1942) y en la idea de poliarquía de Dahl (1971; 1989). Esta perspectiva concede especial importancia a la celebración de elecciones e identifica a las elites, los gobiernos y los partidos como los actores políticos más relevantes (Munck 1996).

No cabe duda de que las evidencias empíricas obtenidas por la teoría de la transición demostraron que las democracias latinoamericanas presentan deficiencias visibles en comparación con las de los países de la OCDE (Burchardt 2007). Entre otros problemas, se destacó la debilidad de la justicia, la falta de división de poderes, el precario (auto)control estatal, la falta de responsabilidad de gestión, la existencia de enclaves autoritarios, la debilidad de las administraciones, así como de los partidos y las corporaciones (Alcántara Sáez/ Freidenberg 2001; Glade 1999; O’Donnell 1999). Los intentos de explicar estos déficits llevaron a un esfuerzo entusiasta por describir las democracias asignándoles distintos atributos. Así, se llegaron a constatar no menos de 550 subtipos de democracias (Carreras 1999; Collier/Levitsky 1995) para los que apenas 120 son regímenes formalmente democráticos ya existentes en el mundo a fines del siglo XX. Pero, más allá de las definiciones, la conclusión general sostuvo que el gobierno y el parlamento siguen siendo elegidos en gran medida a través de elecciones democráticas, pero luego el marco constitucional tiende a vulnerar, conformando "democracias iliberales" (Plattner 1997) o "democracias electorales" (Schedler 1999), que implican la continuidad de formas autoritarias de gobierno legitimadas por elecciones, una situación que O’Donnell (1994) definió como “democracia delegativa". Se trata de regímenes híbridos que incluyen una amplia franja gris entre la democracia y el autoritarismo (Carothers 2002), caracterizada por la capacidad de las elites de apropiarse paulatinamente de importantes recursos estatales, aún existiendo una oposición e instituciones democráticas desarrolladas, en un contexto de pluralismo débil, donde la participación se ejerce principalmente mediante el voto. Aunque se produzca, con cierta regularidad, la alternancia entre las elites políticas y la participación, tal alternancia no alcanza para que aquellas sean controladas. Las elites se aíslan con frecuencia de la sociedad y se enquistan en el poder. 
Esto significa que, contra lo que sostenía la teoría de la transición, la celebración de elecciones libres y de la existencia de una estructura institucional adecuada no conduce de manera lineal a la democratización política. Los fenómenos detallados anteriormente no serían "dolores de parto" para poder lograr la democracia liberal, sino que deben ser entendidos como características de un desarrollo propio. Tratar de mantener en pie el paradigma de la transición, resulta, por lo tanto, poco provechoso como base para la acción política; seguir transitando este sendero implicaría insistir en la peligrosa costumbre de tratar de imponer un concepto simple y a menudo equivocado a una realidad mucho más compleja (Carothers 2002).

\section{De la democracia a la teoría deficitaria}

Hasta hoy en día la promesa esencial de la teoría liberal de la democracia señala que, cuanto más democrático es un país, más justo será, y cuanto más justo, más democrático, pero esto no se ha concretado; contrariamente, en muchos países latinoamericanos la desigualdad social aumentó simultáneamente con la democratización, por lo cual se debería repensar la teoría de la democracia. En tal sentido, el análisis de las democracias latinoamericanas realizado por el Programa de las Naciones Unidas para el Desarrollo (PNUD), a comienzos del siglo XXI, llegó a la conclusión que la falta de atención a la dimensión social de la democracia erosiona su legitimación. Sin embargo, lo que sorprende no es tanto esta constatación, sino las conclusiones encomendadas por el PNUD a un conjunto de renombrados teóricos de la democracia (PNUD 2004b). El PNUD, en efecto, no investiga los motivos de estas evidentes inconsistencias de la teoría, a pesar de identificar las desigualdades sociales como un problema central. De tal modo que, tanto en el relevamiento empírico como en sus explicaciones teóricas, el estudio del PNUD sigue dominado por los enfoques institucionalistas. Las únicas reflexiones que van más allá se limitan a alertar sobre el eurocentrismo y, en algunos casos, subrayar la necesidad de ampliar el concepto de ciudadanía mediante la inclusión de los aspectos sociales (PNUD 2004b). Estas posiciones dominan hasta hoy día el debate, y demuestran que el problema de la persistencia de la desigualdad social poco ha llevado a innovaciones superadoras, tampoco en la polémica latinoamericana. 
Por el contrario, lo que resulta a veces difícil de reflejar en la teoría se impone rápidamente en la práctica. La cuestión social se impuso en la agenda política latinoamericana en los últimos años y contribuyó de manera considerable a la crisis profunda de la democracia representativa, que encontró su primera expresión política en la victoria de Hugo Chávez en 1998 (Burchardt 2010b). Esta crisis de representación continuó luego con cambios de gobierno en diferentes países, así como el ascenso de aquellos partidos que demostraron una mayor sensibilidad hacia la cuestión social. Justamente, lo llamativo de este cambio, que suele definirse como "giro a la izquierda", no es el éxito electoral de los gobiernos que prometen una mayor dedicación a los asuntos sociales, sino que el cimbronazo político incluyó, en la mayoría de los casos, una crítica vigente a la concepción liberal de democracia tal como la conocemos. Un caso típico lo presentan los movimientos indígenas, que se fueron expandiendo en la última década, hasta convertirse en una fuerza influyente, hoy constituyendo un factor político clave en muchos países de América Latina. Más que ampliar la democracia representativa, estos movimientos buscan establecer nuevas prácticas y nuevos modelos políticos basados en las experiencias autóctonas y en la diversidad cultural como modelos superadores de la democracia precedente (Madrid 2005; Van Cott 2005).

Algunos contemplan estos cambios con preocupación, tal como revela el debate acerca de los nuevos gobiernos latinoamericanos, los cuales demuestran un potencial para la profundización democrática pero que generan retrocesos autoritarios. Como es de esperar, cuando los criterios de evaluación se inspiran en la teoría de la democracia liberal, los gobiernos de Brasil y Chile son considerados positivos, mientras que los de Venezuela y Bolivia son cuestionados (Castañeda 2006; Mainwaring 2006; Schamis 2006; Vilas 2005; Weyland 2009). De esta manera, los estudios de la democracia evidencian una clara ceguera. A pesar de que son capaces de constatar las divergencias entre los regímenes surgidos en los últimos años y las democracias representativas precedentes, ignoran que estas diferencias surgieron como respuesta al fracaso de los procesos de representación democrática tradicional. Al confundir causa con efecto, la teoría de la democracia no sólo pierde la oportunidad de analizar las ineficacias -e incluso el fracaso- de la representación liberal democrática. También ofrece como única respuesta el retorno al anterior esquema represen- 
tativo y el restablecimiento de aquellas formas de régimen político que fueron justamente las que provocaron las desviaciones que tanto se critican.

Además, la teoría de la democracia impide ver los cambios políticos que se están registrando bajo estos nuevos gobiernos, tal como se evidencia al analizar la categoría del (neo)populismo, a la que se apela, una vez más, para describir la pérdida de calidad democrática. El populismo, en tanto expresión de antiinstitucionalismo, personalismo y paternalismo, suele considerar como estorbos los procedimientos regulados, las instituciones políticas y las organizaciones intermedias (Boeckh 2003), lo que lo convierte en sospechoso y hasta amenazante, según la perspectiva de la teoría de la democracia. Sin duda, el debilitamiento de las instituciones democráticas, así como la concentración del poder de decisión en un liderazgo carismático, tienden al autoritarismo. No habría que subestimar este peligro. Sin embargo, el populismo también es una forma política, que a veces ayuda a superar las crisis sociales y que contribuye a establecer un nuevo equilibrio social y político mediante el anticonformismo, la evocación de un colectivo imaginario, así como la fundación de un nuevo proyecto político (Aibar Gaete 2007; Arditi 2005). En algunos países de América Latina, el populismo ha logrado restablecer la comunicación entre gobernantes y gobernados que por el contrario la democracia representativa ya no garantizaba, convirtiéndose así en un vehículo de movilización política amplia que, teóricamente, podría desembocar en una ampliación de los derechos democráticos.

La oposición tajante entre la democracia liberal y el neopopulismo, como propone la teoría de la democracia, constituye un enfoque erróneo, porque confunde forma con contenido: el populismo no tiene ni pensamiento originario, ni teoría universal ni, mucho menos, una visión definida del ser humano o de la sociedad; simplemente este expresa la voluntad de redefinir el bien común sin optar por ningún régimen político en particular. En sus inicios, el populismo se desarrolló en sistemas autoritarios, pero en la década del 80 legitimó, entre otros, los ajustes estructurales neoliberales en América Latina en el marco de regímenes democráticos (Weyland 1999). Lo central es que la movilización política que promueve el populismo no debe confundirse con participación política, ya que no sólo supone una cierta movilización y participación en las decisiones, sino también procedi- 
mientos formalizados y normativas institucionales para garantizar su universalidad. El desafío de la democracia en aquellos países con regímenes (neo)populistas no se plantea, por lo tanto, en la existencia o no del populismo, sino en la convergencia (o no) entre movilización y participación. La variedad presente en muchos países aún no permite llegar a conclusiones claras.

Al mismo tiempo, las concepciones acerca de la democracia y las prácticas de participación autóctonas desarrolladas por los movimientos indígenas plantean otros interrogantes a la teoría de la democracia. Simultáneamente con la creciente importancia de las diferencias culturales y de las condiciones históricas específicas de cada contexto, que influyen tanto en la cultura política como en la construcción institucional de la democracia, se han acentuado los cuestionamientos a la concepción universalista de la democracia que subyace a la teoría de la transición (Carothers 2002; Ruiz Murrieta 2003). Esta teoría, en efecto, no ha logrado elaborar una propuesta para superar el fracaso de la representación política de los indígenas y de otros grupos sociales tradicionalmente discriminados e incluir asimismo las prácticas autóctonas de participación en su concepción de democracia.

\section{La democracia desigual en el debate teórico}

La concepción poco compleja de democracia propuesta por la teoría liberal de la democracia facilita el análisis empírico de los regímenes democráticos, pero no logra explicar satisfactoriamente importantes aspectos de las democracias relativamente desarrolladas de América Latina. Más aún, la realidad de la región se opone a algunos de sus supuestos centrales, basados en una visión universalista y occidental de la democracia. Sus supuestos metodológicos básicos, como su concepción lineal de los procesos de democratización hasta llegar a un modelo final estático, se encuentran en cuestión. En este contexto, es necesario replantear los enfoques metodológicos y teóricos de la democracia, asumiendo el desafío de redefinir las interdependencias entre la política y las variables socioeconómicas.

Como ya se señaló, la teoría de la transición presupone implícitamente que la libertad de mercado promoverá regímenes políticos democráticos y que éstos, a su vez, contribuirán al bienestar económico. Pero la evidencia empírica demuestra que, durante el período de recu- 
peración democrática en América Latina, la relación entre liberalización económica y liberalización política no es tan evidente (Evans 1995). Por el contrario, la profundización de la economía de mercado parecería haber tenido, hasta el momento, efectos más bien contraproducentes para la consolidación democrática: las políticas neoliberales generaron un incremento drástico del desempleo y de la pobreza contribuyendo de esta forma a la precarización de las relaciones de trabajo (Harvey 2005; Portes/Hoffmann 2003).

Es reconocido que los mercados laborales tienen un impacto como "primary stratification device" (Barrientos 2009: 89) e influyen fuertemente las diversas dimensiones de la desigualdad social: sea, por un lado, en la distribución del ingreso así como en las oportunidades de acceso a los sistemas de seguridad social (Barrientos 2009: 89), o sea, por otro lado, con respecto a las oportunidades de futuras generaciones (por ejemplo, el acceso a la educación). En ellos se destacan disparidades étnicas y diferencias específicas de género (ILO 2002) así como las diferencias socio-espaciales (urbano/rural) que constituyen importantes desigualdades horizontales (Kreckel 2004; Schwinn 2008). Los mercados de trabajo en América Latina son altamente fragmentados y segmentados: en ellos existe una menor parte de relaciones laborales altamente reguladas, seguido por las actividades informales de una gran parte o incluso de la mayoría de la población económicamente productiva. Esta informalidad es una característica estructural de la región que existe hace mucho tiempo y tiene hasta hoy en día una gran relevancia: alrededor del $50 \%$ de la población económicamente productiva de la región está todavía trabajando informalmente. Las relaciones recíprocas entre informalidad y estratificación social han sido demostradas empíricamente para América Latina: en la economía informal los salarios suelen ser claramente inferiores a los del sector de empleo formal. El empleo informal es acompañado a su vez de requisitos de baja calificación y un disminuido acceso a los componentes fundamentales del sistema social, en particular, el seguro de pensiones, el seguro de salud y el seguro de desempleo. Las mujeres y las minorías étnicas son afectadas de manera desproporcionada por la pobreza (Karcher 2011; Schneider/Karcher 2010). Esto, a su vez, implica una reducción de las oportunidades de importantes sectores de la población para hacer valer sus derechos políticos y civiles (PNUD 2004a). En conclusión, la democracia y el 
mercado no necesariamente tienen efectos sinérgicos: pueden, de hecho, volverse contradictorios.

Es necesario, por lo tanto, repensar la relación entre la democracia y la igualdad social. Ya existen enfoques que enfrentan este desafío, tanto en sus aspectos metodológicos como teóricos. Los intentos posiblemente más relevantes para enriquecer la teoría liberal-democrática con una dimensión socioeconómica se remontan a Amartya Sen y John Rawls. En sus consideraciones económicas sobre el desarrollo, Sen (2003) atribuye la función de garantizar la precisión efectiva del principio de libertad individual y la capacidad de acceder a los recursos económicos (entitlements), las oportunidades (opportunities) y las competencias sociales (capabilities). Según Sen, un sistema político y la cultura democrática constituyen el marco más propicio para garantizar la distribución de estos derechos de acceso y de oportunidades, que dependen principalmente de los recursos económicos, de las condiciones del intercambio y de los derechos jurídicos formales. Esto implica que la existencia de derechos formales de acceso no es suficiente para garantizar que éstos se hagan efectivos, lo cual implica reconsiderar la relación entre la desigualdad social, la participación política y los recursos económicos básicos. Al definir en términos de libertades la capacidad de decisión económica, las oportunidades y las competencias, la limitación o ausencia de las mismas pueden declararse como una falta de libertad. En síntesis, las dimensiones socioeconómicas se incluyen entre las variables de análisis de la teoría liberal.

En su filosofía política liberal, Rawls (2002) incorpora la dimensión de la "justa igualdad de oportunidades" a los principios de libertad individual e igualdad político-jurídica. Este afán se basa, al igual que en Sen, en el reconocimiento de que los factores sociales influyen sobre la percepción individual de las oportunidades, pudiendo perpetuar o incluso incrementar la desigualdad social. Por este motivo, es necesario crear instancias de regulación social y democrática que garanticen procedimientos equitativos y justicia en términos de equidad. Esta ampliación del concepto liberal de democracia mediante la inclusión de factores socioeconómicos inspiró también el debate latinoamericano sobre la relación entre democracia y desigualdad. El eje de esta discusión gira alrededor del concepto de ciudadanía, cuyo núcleo liberal de igualdad política se propone enriquecer con otras 
dimensiones, como la ciudadanía social y cultural. El objetivo de este debate, es convertir los derechos políticos formales en oportunidades reales de inclusión social a través de la reapropiación del concepto de ciudadanía, alrededor de cuya definición se desarrolla un conflicto permanente (Cheresky 2006; Dagnino/Olvera/Panfichi 2006; PNUD 2004b; Sandoval 2006).

Sin embargo, los enfoques de la teoría liberal que intentan incluir factores socioeconómicos en la teoría de la democracia se enfrentan, simultáneamente, con un enigma: ellos parten del concepto de un individuo que busca, en primer lugar, ampliar su libertad. En la teoría liberal, la producción originaria del talento o de las competencias individuales se realiza, por lo tanto, fuera de la acción social misma. En consecuencia, la acción social se centra únicamente en las formas de promover estas competencias, y no en su génesis. Por esta razón el incremento de la igualdad de oportunidades (enabling) garantiza una mayor justicia social, sin entrar en conflicto con el principio liberal de libertad.

Esto indica que la teoría liberal carece de una concepción acerca del poder del colectivo y de las estructuras sociales para estampar hábitos, competencias, acciones y preferencias de los actores. Asimismo, ignora totalmente un hallazgo sociológico básico: las acciones individuales, al igual que el desarrollo de los talentos, las competencias y hasta los estilos de vida, aunque no son definidas exclusivamente por el contexto social, sí se encuentran fuertemente condicionados por él. Por lo tanto, la reducción efectiva de la desigualdad debería producirse, no a través de posibilidades individuales o de la democratización en el acceso, sino mediante la promoción económica y el empoderamiento de las comunidades más pobres y de los sectores subalternos.

La concentración de la teoría liberal en la idea del individuo revela también la debilidad del debate sobre la ciudadanía. En realidad, reclamar los derechos ciudadanos y luchar por una mayor participación requiere contar con ciertos recursos. Sin embargo, los individuos menos favorecidos cuentan con menos recursos. En este sentido, se les plantea una exigencia desmesurada. Por este motivo, la ciudadanía participativa sólo está al alcance de aquellos ciudadanos que están en condiciones de reclamar sus derechos legalmente si esto fuera necesario. Por lo tanto, el debate sobre la ciudadanía carece de una concep- 
ción de la desigualdad social, a pesar de hacer de su disminución su principal bandera.

\section{3. ¿De la democracia a la igualdad?}

En síntesis, la integración de los aspectos sociopolíticos a la teoría de la democracia no se logrará ampliando los enfoques existentes, sino repensando la democracia. En última instancia, se debería tratar de avanzar en una convergencia entre la tradición liberal y otras teorías de la democracia. Esto no implica desconocer los aportes de la tradición liberal. A partir de una mirada hacia las experiencias autoritarias del nazismo y el socialismo soviético, pero también hacia las dictaduras militares latinoamericanas, se debe defender los límites que la teoría liberal traza entre lo público y lo privado. Sobre todo sería necesario revisar y redefinir constantemente las líneas de demarcación definidas por el liberalismo.

Para garantizar un proceso democrático y estimular el diálogo, es necesario que todos los sectores interesados en participar no sólo estén en igualdad de condiciones político-jurídicas, sino también que dispongan de los mismos recursos. Para ello resulta indispensable la promoción material e intelectual de las comunidades y de los sectores subalternos, de los grupos sociales más desfavorecidos y con menor capacidad para defender sus intereses. Sólo así se podrá ayudar a neutralizar los efectos de las asimetrías de poderes existentes (Cohen 1995). De esta manera, la participación democrática se vincula a la redistribución de recursos como forma de garantizar la participación equitativa de todos; según la definición de Fraser/Honneth (2006), se trata de la paridad participativa en el proceso de decisión.

En esta concepción, la democracia se define como un sistema político que garantiza no solamente la igualdad político-jurídica, sino también la inclusión social de los ciudadanos. Esto garantiza, además, la validez formal de los derechos básicos de libertad y el derecho a su concreción efectiva. Implica, a su vez, no asumir la igualdad entre los hombres como un hecho, sino como un objetivo y un mandato del Estado democráticamente legitimado. Supone también el reconocimiento de que el orden social que fundamenta esta democracia no es capaz de lograr por sí solo los niveles de justicia necesarios y que debe, por lo tanto, ser modificado. Se trata, en suma, de una "demo- 
cracia social", que no tiene un carácter puramente correctivo sobre el sistema existente, sino que dispone de un importante potencial para realizar reformas destinadas a modificar los fundamentos básicos del orden social.

Probablemente, en América Latina los actores políticos y económicos más poderosos tomen conciencia de esta conclusión. Por lo tanto, la persistencia de la desigualdad social, en el marco de regímenes liberales democráticos, podría explicarse como parte de una estrategia para conservar el poder e impedir el paso de la democracia liberal a la democracia social. Es posible encontrar indicios en este sentido, entre otros, en los estudios que demuestran cómo las elites latinoamericanas consiguen defender sus privilegios; por ejemplo, mediante las limitaciones en el acceso al derecho de elección, a la tierra o a la educación (Acemoglu/Robinson 2005; Huber et al. 2006). El objetivo de estos procesos de exclusión sería mantener limitada la cantidad de competidores por oportunidades específicas, bienes y recursos, para garantizar así el sometimiento de determinados sectores sociales. Estas restricciones parciales se dan en ámbitos situados antes de las instituciones democráticas, como la educación y los mercados laborales, y generan "disparidades participativas" que, a su vez, consolidan y amplían las estructuras de desigualdad existentes (Burchardt 2010a).

Resumiendo estas reflexiones se puede llegar a las siguientes conclusiones: por un lado, parece existir en la región un "Latin American equilibrium" (Robinson 2008), un equilibrio de coordinación de las elites, a través del cual ciertos grupos, a pesar de presiones de ajuste y frente a los cambios económicos, políticos e institucionales, logran asegurarse la protección de sus privilegios - incluso frente a grandes grupos de población y últimamente a través de tres décadas de legitimación democrática. Por otro lado, la observación de que las extremas disparidades no sólo son un resultado de la famosa "mano invisible", sino de "manos muy visibles" (Boeckh 2002: 526) y que justamente la política social en América Latina, (re)produce, de manera especial, la desigualdad social. Esto ofrece una nueva perspectiva analítica a la región: la política social-laboral de América Latina debe ser comprendida, por consiguiente, como uno de los campos políticos centrales, en el cual se lucha por la (re)distribución y por la perpetuidad o la modificación de la desigualdad social (Weinmann/Burchardt 2011). Acer- 
carse analíticamente a este campo y sus articulaciones recientes promete una nueva comprensión al fenómeno ya persistente de la desigualdad latinoamericana.

\section{Bibliografía}

Acemoglu, Daron/Robinson, James (2006): Economic Origins of Dictatorship and Democracy. Cambridge: Cambridge University Press.

Ackerman, John M. (2006): "Democratización: pasado, presente y futuro". En: Perfiles Latinoamericanos, 14, 28, pp. 117-157.

Aibar Gaete, Julio (ed.) (2007): Vox Populi - Populismo y democracia en Latinoamérica. México, D.F.: FLACSO.

Alcántara Sáez, Manuel/Freidenberg, Flavia (eds.) (2001): Partidos políticos de América Latina. Países andinos. Salamanca: Universidad de Salamanca.

Annino, Antonio (ed.) (1995): Historia de las elecciones en Iberoamérica, siglo XIX. México, D.F.: FCE.

Arditi, Benjamin (2005): "Populism as an Internal Periphery of Democratic Politics". En: Panizza, Francisco (ed.): Populism and the Mirror of Democracy. London: Verso, pp. 72-98.

Barrientos, Armando (2009): "Labour Markets and the (Hyphenated) Welfare Regime in Latin America”. En: Economy and Society, 38, 1, pp. 87-108.

Boeckh, Andreas (2002): "Die Ursachen der Entwicklungsblockaden in Lateinamerika: Einige entwicklungstheoretische Mutmaßungen”. En: Leviathan, 30, 4, pp. 509-529.

- (2003): "The Painful Transition of a Rentier State: Globalization and Neopopulist Regression in Venezuela". En: Barrios, Harald/Beck, Martin/Boeckh, Andreas, Segbers, Klaus (eds.): Resistance to Globalization. Münster: LIT, pp. 142-157.

- (2011): "Staatsfinanzierung und soziale Gerechtigkeit in Lateinamerika". En: Wehr/Burchardt 2011, pp. 71-90.

Boix, Carles (ed.) (2003): Democracy and Redistribution. Cambridge: Cambridge University Press.

Burchardt, Hans-Jürgen (2007): Tiempos de cambio - Repensar América Latina. El Salvador: Böll.

- (2010a): "The Latin American Paradox: Convergence of Political Participation and Social Exclusion”. En: Internationale Politik und Gesellschaft, pp. 40-51.

- (2010b): "Un misionero y sus misiones. Progresos y trabas de la nueva política social en Venezuela". En: Revista Politeia, 42, pp. 79-96.

Carothers, Thomas (2002): “The End of the Transition Paradigm”. En: Journal of Democracy, 13, 1, pp. 5-21.

Carreras, Sandra (1999): "Quince años en el laberinto democrático". En: Nueva Sociedad, 160, pp. 29-46. 
Casteñeda, Jorge (2006): "Latin America's Left Turn". En: Foreign Affairs, May/June, pp. 28-43.

CEPAL (Comisión Económica para América Latina y el Caribe) (2005): Social Panorama of Latin America 2004. Santiago de Chile.

- (2008): Social Panorama of Latin America 2007. Santiago de Chile.

- (2010): Social Panorama of Latin America 2009. Santiago de Chile.

Cheresky, Isidoro (2006): Ciudadanía, sociedad civil y participación política. Buenos Aires: Miño y Dávila.

Coatsworth, John (2008): "Inequality, Institutions and Economic Growth in Latin America”. En: Journal of Latin American Studies, 40, pp. 545-569.

Cohen, Rogers (1995): Associations and Democracy. The real Utopias Project. London: Verso.

Collier, David/Levitsky, Steven (1995): Democracy "with Adjectives": Finding Conceptual Order in Recent Comparative Research. Berkeley: University of California.

Dagnino, Evelina/Olvera, Alberto/Panfichi, Aldo (eds.) (2006): La disputa por la construcción democrática en América Latina. México, D.F.: Fondo de Cultura Económica.

Dahl, Robert A. (1971): Polyarchy. Participation and Opposition. New Haven: Yale University Press.

- (1989): Democracy and its Critics. New Haven: Yale University Press.

Engerman, Stanley/Sokoloff, Kenneth (2005): "The Evolution of Suffrage Institutions in the New World". En: Journal of Economic History, 65, 4, pp. 891-921.

- (2006): "The Persistence of Poverty in the Americas: The Role of Institutions". En: Browles, Samuel/Durlauf, Steven/Hoff, Karla (eds.): Poverty Traps. Princeton/Oxford: Princeton University Press, pp. 43-78.

Evans, Peter B. (1995): Embedded Autonomy: States and Industrial Transformations. Princeton: Princeton University Press.

Ferranti, David de/Perry, Guillermo E./Ferreira, Francisco H. G./Walton, Michael (2004): Inequality in Latin America: Breaking with History? Washington, D.C.: World Bank.

Frankema, Ewout (2009): Has Latin America Always been Unequal? A Comparative Study of Asset and Income Inequality in the Long Twentieth Century. Leiden/ Boston: Brill.

Fraser, Nancy/Honneth, Axel (2006): ¿Redistribución o reconocimiento?: un debate politico-filosófico. Madrid: Ediciones Morata.

Freedom House (2010): "Freedom in the World 2010 Survey Release". En: $<$ www.freedomhouse.org/template.cfm?page $=505>(08.10 .2010)$.

Glade, William (1999): "The Complementarity of Economic Restructuring and Rebuilding the State in Latin America". En: Bresser Pereira, Luis Carlos/Spink, Peter: Reforming the State: Managerial Public Administration in Latin America. Boulder: Lynne Rienner, pp. 75-89. 
Goñi, Edwin/López, J. Humberto/Servén, Luis (2008): Fiscal Redistribution and Income Inequality in Latin America. Washington, D.C.: The World Bank Development Research Group (Policy Research Paper No. 4487).

Hall, Peter A./Soskice, David (2001): "An Introduction to Varieties of Capitalism". En: Hall, Peter A./Soskice, David (eds.): Varieties of Capitalism. New York: Oxford University Press, pp. 1-68.

Harvey, David (2005): A Brief History of Neoliberalism. Oxford: Oxford University Press.

Huber, Evelyne/Stephens, John D. (eds.) (2001): Development and Crisis of the Welfare State. Parties and Policies in Global Markets. Chicago/London: The University of Chicago Press.

Huber, Evelyn/Nielsen, François/Pribble, Jenny/Stephens, John D. (2006): "Politics and Inequality in Latin America and the Caribbean”. En: American Sociological Review, 71, pp. 943-963.

ILO (International Labour Organisation) (2002): Women and Men in the Informal Economy: A Statistical Picture. Genève: ILO.

Karcher, Sebastian (2011): "Ungleichheit und das Trilemma lateinamerikanischer Arbeitsmärkte”. En: Wehr/Burchardt 2011, pp. 179-200.

Kreckel, Reinhard (2004): Politische Soziologie der sozialen Ungleichheit. Frankfurt a.M.: Campus.

Lindert, Kathy et al. (ed.) (2006): Redistributing Income to the Poor and the Rich: Public Transfers in Latin America and the Caribbean. Washington, D.C.: World Bank.

Lindert, Peter H. (2004): Growing Public. Social Spending and Economic Growth since the Eighteenth Century. 2 Vols. Cambridge: Cambridge University Press.

Linz, Juan/Stepan, Alfred C. (1996): Problems of Democratic Transition and Consolidation: Southern Europe, South America and Post-Communist Europe. Baltimore: Johns Hopkins University Press.

Lopez, Humberto/Perry, Guillermo (2008): Inequality in Latin America: Determinants and Consequences (World Bank Policy Research Paper Nr. 4504). Washington, D.C.: World Bank.

López-Calva, Luis/Lustig, Nora (eds.) (2010): Declining Inequality in Latin America. A Decade of Progress? New York/Washington, D.C.: United Nations Development Programme/Brookings Institution Press.

Lynn Karl, Terry (1996): "Dilemmas of Democratization in Latin America". En: Camp, Roderic Ai: Democracy in Latin America: Patterns and Cycles. Lanham: SR Books, pp. 21-46.

Madrid, Raul L. (2005): "Indigenous Parties and Democracy in Latin America". En: Latin American Politics \& Society, 47, 4, pp. 161-179.

Mainwaring, Scott (2006): "The Crisis of Representation in the Andes". En: Journal of Democracy, 17, 3, pp. 13-27.

Mesa-Lago, Carmelo (ed.) (1978): Social Security in Latin America: Pressure Groups, Stratification and Inequality. Pittsburgh: University of Pittsburgh Press. 
Milanovič, Branko/Muñoz de Bustillo, Rafael (2008): "La Desigualdad en la distribución de la renta en América Latina: situación, evolución y factores explicativos". En: America Latina Hoy, 48, pp. 15-42.

Munck, Gerardo L. (1996): Disaggregating Political Regime: Conceptual Issues in the Study of Democratization (Working Paper 228). Notre Dame: Kellogg Institute.

O’Donnell, Guillermo (1994): “Delegative Democracy”. En: Journal of Democracy, 5, pp. 55-70.

- (1999): Counterpoints. Selected Essays on Authoritarianism and Democratization. Notre Dame: University of Notre Dame Press.

Plattner, Marc F. (1997): "Liberalism and Democracy: Can't have One Without the Other". En: Foreign Affairs, 77, 2, pp. 171-180.

PNUD (Programa de las Naciones Unidas para el Desarrollo) (2004a): La democracia en América Latina. Hacia una democracia de ciudadanas y ciudadanos. Buenos Aires: Aguilar/Altea/Alfaguara.

- (2004b): La democracia en América Latina. Contribuciones para el debate. Buenos Aires: Aguilar/Altea/Alfaguara.

Portes, Alejandro/Hoffmann, Kelly (2003): Las estructuras de clase en América Latina: composición y cambios durante la época neoliberal. Santiago de Chile: CEPAL.

Posada-Carbó, Eduardo (1996): Elections before Democracy: The History of Elections in Europe and Latin America. Houndmills/New York: Palgrave Macmillan/St. Martin's Press.

Rawls, John (2002): La justicia como equidad: una reformulación. Barcelona: Paidós.

Riesco, Manuel (ed.) (2007): Latin America. A New Developmental State Model in the Making? Houndmills: Palgrave Macmillan.

Robinson, James A. (2008): “The Latin American Equilibrium”. En: Fukuyama, Francis (ed.): Falling Behind: Explaining the Development Gap between the United States. Oxford: Oxford University Press, pp. 161-193.

Rodrik, Dani (2006): "Development Lessons for Asia from Non-Asian Countries". En: Asian Development Review, 23, 1, pp. 1-15.

Ruiz Murrieta, Julio (2003): Democracia y participación política de los pueblos indigenas en América Latina. Paris: UNESCO.

Sábato, Hilda (ed.) (1999): Ciudadanía politica y formación de las naciones. Perspectivas históricas de América Latina. México, D.F.: FCE.

Sachs, Jeffrey D. (2006): The End of Poverty. New York: Penguin Books.

Sandoval, Luis Ortiz (2006): "Democracia sin ciudadanos: crítica de la teoría de la transición”. En: Perfiles Latinoamericanos, 14, 28, pp. 263-277.

Schamis, Hector (2006): “A 'Left Turn' in Latin America? Populism, Socialism, and Democratic Institutions”. En: Journal of Democracy, 17, 4, pp. 20-34.

Schedler, Andreas (1999): "Conceptualizing Accountability". En: Schedler, Andreas/Diamond, Larry/Plattner, Mark (eds.): The Self-Restraining State: Power and Accountability in New Democracies. Boulder/London: Lynne Rienner, pp. 13-28. 
Schneider, Ben Ross/Karcher, Sebastian (2010): "Complementarities and Continuities in the Political Economy of Labor Markets in Latin America". En: SocioEconomic Review, 8, 4, pp. 623-651.

Schumpeter, Joseph (1942): Capitalism, Socialism, and Democracy. New York: Harper.

Schwinn, Thomas (2008): "Zur Analyse multidimensionaler Ungleichheitsverhältnisse". En: Österreichische Zeitschrift für Soziologie, 33, 1, pp. 20-42.

Segura-Ubiergo, Alex (ed.) (2007): The Political Economy of the Welfare State in Latin America. Cambridge: Cambridge University Press.

Sen, Amartya Kumar (2003): Sobre ética y economía. Madrid: Alianza.

Stiglitz, Joseph (2004): The Post Washington Consensus Consensus. Initiative for Policy Dialogue Working Paper. New York: Columbia University.

Van Cott, Donna Lee (2005): "Building Inclusive Democracies: Indigenous Peoples and Ethnic Minorities in Latin America". En: Democratization, 12, 5, pp. 820837.

Vilas, Carlos M. (2005): "La izquierda latinoamericana y el surgimiento de regímenes nacional-populares”. En: Nueva Sociedad, 197, pp. 84-99.

Wehr, Ingrid (2011): "Wohlfahrtsregime und soziale Ungleichheit in Lateinamerika". En: Wehr/Burchardt 2011, pp. 257-281.

Wehr, Ingrid/Burchardt, Hans-Jürgen (eds.) (2011): Soziale Ungleichheiten in Lateinamerika. Neue Perspektiven auf Wirtschaft, Politik und Umwelt. Baden-Baden: Nomos.

Weinmann, Nico/Burchardt, Hans-Jürgen (2011): "Die Reise des jungen Offe - ein Besuchs- und Forschungsprogramm für Lateinamerika?". En: Wehr/Burchardt 2011, pp. 283-307.

Weyland, Kurt (1999): "Populism in the Age of Neo-liberalism". En: Conniff, Michael L. (ed.): Populism in Latin America. Tuscaloosa: University of Alabama Press, pp. 172-190.

- (2009): "The Rise of Latin America's two Lefts? Insights from Rentier State Theory". En: Comparative Politics, 41, 2, pp. 145-164.

World Bank (2006): Poverty Reduction and Growth. From Vicious to Virtuous Circles. Washington, D.C.: World Bank. 


\section{Ingrid Wehr*}

\section{On the Problematic Coexistence of Democracy and Blatant Social Inequality in Latin America}

\section{The Obstinate Persistence of Structural Social Inequality in Latin America}

At the beginning of the 21st century - with the exception of SubSaharan Africa - Latin America has the highest levels of inequality worldwide. These disparities do not only find their expression in extreme inequalities in income and assets, but also in a series of asymmetries concerning the distribution of and the access to a considerable number of material and public goods such as land, education, social security, and health. ${ }^{1}$ A look at the differences in income serves to illustrate these shocking disparities in a graphic manner: In the year 2005, a person belonging to the top decile of households, on average, earned 17 times more than a person belonging to the poorest $40 \%$ of households (CEPAL 2010: 185). In countries like Brazil, marked by higher-than-average income inequalities, the lowest decile's share of the national income equaled a meager $0.9 \%$ while the share of income earned by the richest decile was $43.5 \%$ (Barros et al. 2010: 134). What is interesting about the inequality levels in Latin America is the fact that sharp differences concerning the respective levels of development (measured by BIP/per capita) notwithstanding, all Central and South American countries without exception are characterized by above

* This is an adapted version of an article which originally appeared as "Wohlfahrtsregime und soziale Ungleichheit in Lateinamerika" in: Wehr, Ingrid/Burchardt, Hans-Jürgen (2011) (eds.): Soziale Ungleichheiten in Lateinamerika. Baden-Baden, pp. 257-281. I am grateful to the Nomos publishing house for having granted permission to publish an English version of it. I am also indebted to Hans-Jürgen Burchardt, Tanja Ernst, Rosa Lehmann, Reinhart Kößler and Beate Rosenzweig for constructive comments on earlier versions of this article. Jörg Baten contributed valuable information on the results of latest research by economic historians.

1 For an overview of the latest research on social inequality in the region see: CEPAL (2010); Deininger/Squire (1996); ECLAC (2009); Lopez/Perry (2008); Machinea/Hopenhayn (2005); Milanovič/Muñoz de Bustillo (2008). 
average inequality rates. Even those states showing relatively low levels of income inequality (i.e., Uruguay and Costa Rica) still exceed those of relatively inegalitarian industrial or newly industrialized countries in other regions (Segura-Ubiergo 2007: 263).

Apart from blatant income inequalities, Latin America is also notorious for its extreme concentration of land holdings. The Gini coefficient measuring the disparities of land distribution reveals national and regional standards well beyond those of other regions of the world (Deininger/Olinto 1999; Ferranti et al. 2004: 436; Frankema 2009: chap. 3). ${ }^{2}$ A case that may illustrate these extreme inequalities is that of Bolivia. Despite the agrarian reform of $1953,86 \%$ of Bolivian peasants in the 1980 s manage only $2.4 \%$ of the arable land while the lion's share has remained in the hands of a tiny minority $(0.22 \%$ of the population) of large landowners (Weisbrot/Sandoval 2008: 2-3). Such gross disparities of landholdings are the rule, rather than the exception in the region. In Frankema's (2009: 52) top twenty list of states that show the highest Gini coefficients concerning land distribution, there are no less than 16 Latin American countries. Remarkably, on a worldwide scale, Latin America is the only region ${ }^{3}$ showing very little intraregional differences relating to land concentration. ${ }^{4}$ Though claimed regularly by different social movements in the course of the 20th century, most noticeably in the context of the Mexican revolution, comprehensive land reforms contributing to a significant deconcentration of ownership patterns largely failed. Unlike East Asia, the reform processes of the 1950 s to 1970 s, which put an end to the traditional hacienda economy, left the extreme disparities in land ownership largely intact (Frankema 2009: 206; Kaltmeier 2011; UNRISD 2010: 63-65).

2 Ewout Frankema's analysis is based on a comprehensive data set of 110 countries worldwide. For a short overview see Frankema (2009, table A.3.1: 213217).

3 In this context "region" is not defined geographically but refers to a group of countries which, due to their specific (post)colonial experiences, dispose of comparable trajectories of socio-economic development and authority structures. About "region" as an analytical category see Bunce (2000: 722); Mainwaring/ Pérez-Liñán (2007).

4 This finding contradicts Easterly's (2007: 756s.) hypothesis that explains the concentration of land ownership with geographical and climatic factors, i.e., the prerequisites for cash-crop production. 
Similar disparities characterize the availability of public services such as health and education (Peters 2011; Tittor 2011). At the beginning of the 21 st century the vast majority of the Latin American population, among them women without work contracts within the formal economy, agricultural workers, indigenas and afro-decendentes still lacked access to adequate medical care and high quality education. Though public education and health care systems exist in practically all Latin American countries, they are notorious for their low quality and inability to sufficiently cover all ages, especially in rural areas. Compared to other regions of the global South illiteracy rates are rather low and school enrolment rates high. What differentiates Latin America's public education systems from those in other regions is their extremely low quality and high segmentation (Frankema 2009: chap. 4; Peters 2011). According to the World Bank Report "Poverty Reduction and Growth: Virtuous and Vicious Circles" (World Bank 2006: chap. 9) school careers are still mainly influenced by the parents' level of income and education. Low levels of education are closely linked to poor chances on the labor market.

As a consequence, a vast majority of Latin American citizens remain excluded within rather than from society (Kronauer 2006; Neves 2007: 206-210; Souza 2008). The aforementioned disparities concerning the distribution of income, assets, and the asymmetrical access to essential public goods constitute protracted, structural forms of social inequality transmitted from generation to generation. They are characterized by lasting constraints on the "opportunities of access to commonly disposable or desirable social goods and/or social positions" and thus "the life chances of affected individuals, groups or societies" (Kreckel 2004: 16).

An extensive and long-lasting debate across disciplines has been concerned with the origins and exact timing of these blatant social inequality rates in Latin America. Some area specialists argue that the extreme inequality levels form a continuum throughout Latin American history since the Conquista or a fatal "Latin American equilibrium" (Acemoglu/Robinson 2006; Engerman/Sokoloff 2005; 2006; Robinson 2008; 2010). Contrary to these claims of continuity, the latest research by economic historians has revealed that serious levels 
of social inequality are a relatively recent phenomenon. ${ }^{5}$ According to the preliminary findings of these analyses, which still lack a sufficient database, national income disparities in Latin America in earlier centuries did not differ significantly from those of European states in the 19th century before the Industrial Revolution (Williamson 2010). ${ }^{6}$ Despite some difficulties concerning reliable data, what can be taken as certain is the fact that the blatant regional inequality rates are mainly a product of the processes of state-building and economic modernization after the wars of independence. A number of recent studies show that income inequality throughout the region rose rapidly at the end of the 19th century and then remained above the international average until today, although revealing a wave-shaped pattern of secular inequality trends (Frankema 2009: 205-210).

Considering the fact that Latin America is characterized by a long - albeit variable - democratic history and relatively well-entrenched welfare regimes, the consistency of extreme inequality rates poses some important questions. Despite the growing democratic thrust, the significantly enhanced participation chances, so far, have not translated into improved social inclusion or the dismantling of structural social inequality. The unresolved tension between democratic processes of decision-making and ingrained social inequalities thus constitutes a permanent political problem with a high potential for conflicts and tensions. Additionally, it raises a number of questions that challenge comparative research on democratization and social inequalities.

\section{The Unresolved Tension Between Democracy and Inequality as a Theoretical Challenge}

The obstinate persistence of extreme and ingrained social inequality in the region resists conventional explanations put forward by moderni-

5 See Baten/Mumme (2010); Bértola et al. (2009); Coatsworth (2005; 2008); Dobado Gonzáles/García Montero (2010); Frankema (2009); Milanovič/Lindert/ Williamson (2008); Prados de la Escosura (2007).

6 In order to establish levels of inequality economic historians use a number of instruments: Apart from so-called social tables, documenting income disparities between different occupational groups, the analyses are based on information about differences concerning the educational level and heights of different population groups. 
zation theorists. These theories proceed from the assumption that within the wider context of economic and social modernization processes social inequality is a necessary by-product of a transitory nature. According to the Kuznets hypothesis (Kuznets 1955), ${ }^{7}$ quite popular during the Cold War era, alongside growing technological development the demand for qualified workers increases and - at the same time - demand for unqualified workers shrinks. This leads to elevated levels of income inequality during phases of economic innovation. As national states react with higher investments in human capital, the initial rise in income disparities can be attenuated in the transcourse of the innovation and industrialization process. Contrary to these projections, the blatant income disparities inside Latin American states did not change significantly despite profound modernization processes during the 20th and 21st centuries, neither do countries with higher levels of industrialization or economic development (measured by BIP per capita) show lower levels of income disparities than less developed ones (ECLAC 2009: 90). In a clear contradiction to Kuznets' assumptions, regional trends of income disparities do not show a U curve trajectory but a wave-like pattern. Despite these fluctuations, inequality levels in all countries of the region have remained above the international average since the end of the 19th century (Frankema 2009: 12, diagram 2.1).

The persistence of above-average inequality rates does not only challenge the basic assumptions of modernization theory, but also poses some problems for democratic theory. Theorists from Aristotle to James Madison and modern theorists in the field of political economy conventionally start from the assumption that democratic processes of decision making necessarily lead to a more egalitarian distribution of income, property, and the access to essential goods (Lenski 1966; for a summary see Merkel 2010: 57-58.). Different variations of the median voter theorem building on Meltzer's and Richard's model (1981) argue that political parties with a serious interest in winning the next election feel obliged to take into consideration the central interests of the median voter. The poorer the median voter

7 Kuznets identifies technological development as the central cause of changing income patterns. For recent research findings and a critical discussion of Kuznets see Escobar (1995: 80); Kahhat (2010); Korzeniewicz/Moran (2009: 3-5). 
the higher the pressure on the governing parties to redistribute income and assets through taxes and transfers.

In Latin America, however, contrary to the basic premise of all median voter models, the current democratization phase did not lead major redistributive efforts despite the extreme levels of inequality. Since the mid 1990s Latin American countries have made some successes as far as poverty reduction policies are concerned. Poverty has been reduced by $15 \%$, extreme poverty by $9.6 \%$ (CEPAL 2010: 19-20). This progress in poverty reduction, however, was not matched by a significant change in patterns of inequality. As (re-)democratization processes coincided with neoliberal structural reforms, inequality levels initially rose after the end of the authoritarian period. Starting in the late 1990s this trend gradually reversed, at least for some countries. The average regional Gini coefficient was reduced by 4\% (ECLAC 2009: 19; López-Calva/Lustig 2010). Comparing historical rates, the regional average is thus close to levels in the 1980s. On a global scale, national inequality rates nevertheless remain on an above-average level for all countries of the region without exception.

Some critics of the median voter theorem argue that the basic assumptions of the different models derived from Meltzer's and Richard's (1981) seminal article are too simplistic (Anderson/Beramendi 2008; Hettich/Winer 1999; Huber/Pribble/Stephens 2009: 177-180). These criticisms notwithstanding, the basic assumptions sustained by median voter models still point to some of the central questions of current research on democratization processes in Latin America. Why did improved democratic political participation not translate into improved social inclusion? Why did the longest democratic period in Latin American history since independence have practically no impact on inequality rates to date? Today, three decades after the beginning of the third wave (Huntington 1991) of democratization, three quarters of the Latin American population have to manage with less than the average income, that is, $40 \%$ with less than half of the average income (ECLAC 2001: 71). Findings of opinion polls clearly state that three quarters of the Latin American population are well aware of these inequalities and criticize them as unjust or extremely unjust (CEPAL 2009: 25).

A look at the results of comparative research on inequality and democracy in Europe reveals a clear link between the expansion of 
the suffrage during the 19th and 20th centuries and the reduction of income inequalities and access asymmetries, especially in as far as education opportunities are concerned (Acemoglu/Robinson 2000; 2006; Boix 2003; Huber/Stephens 2001; Lindert 2004). These findings do not hold true for Latin American electoral and democratic history. With the exception of the Caribbean, the great majority of the Latin American states became independent between 1810 and 1830 , that is, considerably earlier than most countries of the global South. The following processes of state and nation building were accompanied by an important surge in democratization. With the noticeable exception of Brazil, which remained a monarchy until 1889, all newly independent states chose republican, presidential forms of government. At the same time as - or even earlier than its European counterparts - male suffrage was expanded from the first half of the 19th century onwards. Electoral history was not smooth but instead characterized by a number of setbacks. On a global scale, however, suffrage regulations in a considerable number of Latin American countries were quite advanced, at least as far as (white) males were concerned (Annino 1995; Engerman/Sokoloff 2005; Posada-Carbó 1996; Sabato 1999; on the exclusion of women Caulfield/Chambers/Putnam 2005). What needs explanation is the fact that despite early decolonization and democratization processes, Latin American countries did not succeed in changing the overall pattern of above-average social inequality. The problematic coexistence of democratic processes of decision making and structural social inequality poses a number of tricky questions as it cannot be explained by institutional deficiencies or a lack of political participation, interest or of political culture on part of the citizens.

A closer look at the commonly used democracy indices clearly reveals Latin America's democratic edge as compared to other regions of the global South. Unlike most countries in Africa and Asia, Latin American political systems are characterized by comparatively free, fair and transparent electoral processes (PNUD 2004), and well-entrenched political participation rights. On the widely used Freedom House Index, produced on an annual basis, measuring explicitly political rights, Latin American countries score high compared to 
other regions, including parts of Eastern Europe. ${ }^{8}$ Political parties are generally allowed to operate without any major impediments, and party candidates are selected via democratic mechanisms. In the last couple of years a number of legal norms have been passed directed towards improved participation for groups formerly disadvantaged (women, indigenous groups, and Afro-Americans). ${ }^{9}$

Especially noteworthy in this context is the fact that citizen participation in politics is not confined to national, federal or local elections. Some states within the region are real laboratories for new forms of citizen participation and engagement, as shown most clearly in the vast experiences with participatory budgeting, a model now exported to Europe (Avritzer 2009). Contrary to the findings of electoral research focused on industrial states that indicate a link between active citizen participation and a higher socio-economic status, research on Latin America shows that poor and marginalized citizens do make use of their electoral rights on a regular basis (Fornos/Power/Garand 2004). Whereas in industrial states, economic crises lead to lower electoral participation (Schäfer 2010), data on Latin America indicate the opposite effect: electoral participation rises in times of crises. (Benton 2005). Consequently, the persistence of inequality and low priority assigned to social questions on the respective political agendas cannot be explained by widespread political exclusion or political apathy of marginalized citizens.

Neither can it be attributed to institutional deficits as the literature on democratic transitions suggests. Transitologists usually argue that Latin American democracies constitute a diminished subtype of the established, liberal democracies in the global North. Progress concerning electoral and political rights notwithstanding, Latin American political systems still suffer from institutional deficiencies ${ }^{10}$ in other areas of the broader political regime. Although democratic elections

8 In 2010 only Cuba was labeled as unfree. Nine (26\%) out of 35 Latin American states (including the Caribbean) were ranked as "partly free" on the basis of the index built on two scales on political and civic rights. This group comprised the following states: Bolivia, Colombia, Ecuador, Paraguay, Venezuela, Guatemala, Honduras, Nicaragua and Haiti.

9 For a summary on the political participation of women see Oettler (2011), for indigenous groups Ernst (2011).

10 For a typology of defect democracies in Latin America see Thiery/Merkel (2010). 
and political participation are central elements of democratic regimes, they are not sufficient for guaranteeing the political system's ability to take into consideration the needs and interests of the majority of the poor voters. According to this perspective, and in order to enhance responsiveness, a number of additional criteria have to be met:

Firstly, the vertical control of political representatives via regular, free, and fair elections has to be supplemented by a further, horizontal dimension of control guaranteeing the division of powers and greater overall accountability. Secondly, apart from political rights, strong civic (defence) rights are needed in order to define the limits of legitimate state power and strengthen the principles of the rule of law. And finally, democratically elected governments must have the power to decide on political issues without interference from internal (i.e., the military) or external actors (i.e., hegemonic powers like the United States) (Merkel 2010: 31-35).

Based on neo-institutionalist assumptions transitologists thus come to the conclusion that further institutional reforms are needed in order to transform what Guillermo O'Donnell appropriately called "low intensity democracies" into full-fledged liberal democracies. This perspective might be challenged, however, if we have a closer look at the democratic history of European countries. Recent research on European democratization processes (Acemoglu/Robinson 2000; 2006; Bangura 2007; Boix 2003; Huber/Stephens 2001; Rueschemeyer/Huber/Stephens 1992) contributed a vast body of studies and data indicating that early electoral reforms in $19^{\text {th }}$ century Europe did have a significant impact on gradually, but significantly lowering (income) inequality rates. ${ }^{11}$ Despite the fact that European political regimes at that time clearly classified as "deficient" according to current definitions, electoral reforms contributed to the transformation of existing inequality patterns. Consequently, deficient institutions alone do not suffice to explain why such a linkage does not exist in Latin America.

A look at the history of welfare regimes ${ }^{12}$ and social policy reforms further reveals that the missing link between the expansion of

11 Acemoglu/Robinson (2006) analyze the correlation between the expansion of electoral rights and distributional conflicts from a game-theory perspective, see also Boix (2003); for a critical review Ansell/Samuels (2010).

12 In contrast to the term welfare state, welfare regime is a broader concept that includes all institutions and practices to distribute resources. It comprises public policies as well as the informal sector, i.e., care by family members or the social communities. For a definition see Gough/Wood (2006: 1698). 
suffrage and a shift in patterns of inequality cannot be explained by a lack of welfare efforts either. Although commonly considered as one of the central achievements of "Western modernity", quite a number of middle-income countries in this region (Argentina, Brazil, Chile, Cuba and Uruguay) initiated public social policies at the same time or even earlier than their European counterparts, i.e., between the two world wars or shortly after World War II. Social security, public education, and public health systems in some cases date back to the 1920s (Kaufman/Nelson 2004: 249-257; Mesa-Lago 1978; Nelson 2004: 23-28).

On an international scale, Latin American states spend relatively large (relative to BIP per capita) amounts of the public budget on social policies. These comparatively generous social budgets, however, do not have an impact on lowering the blatant disparities of incomes and assets. On the contrary, due to their exclusive focus on a limited number of stake-holders (lawyers, the military, teachers, state employees and workers in key industries) and the fact that formal work contracts serve as gate-keepers for the access to the welfare regimes, social policies and transfers contribute to the reproduction of existing inequality levels (Wehr 2011).

Whether or not the current "left turn" ${ }^{13}$ might lead to a change in existing patterns of inequality is still an open question. Some authors, sharing a rather positive outlook on the current situation, have put forward the hypothesis that the current reform phase might lead to a second incorporation period, one with a similar thrust as the first reforms in the first half of the 20th century in the context of the implementation of state-induced industrialization and import substitution (Luna/Filgueira 2009; Wehr 2011). While leaving out the vast majority of social sectors working within the informal economy, stateinduced import substitution policies did require the incorporation, or rather cooptation of some social groups important to the economic development model: These groups included the rather heterogeneous

13 The following countries have a left or left-of-center government: Argentina (since 2003), Brazil (since 2003), Bolivia (since 2006), Ecuador (since 2007), El Salvador (since 2009), Guatemala (since 2008), Nicaragua (since 2007), Paraguay (since 2008), Uruguay (since 2005) und Venezuela (since 1999). The electoral defeat of the Chilean Concertación (2010) so far has not lead to a reverse trend. See Cameron/Hershberg (2010); Levitsky/Roberts (forthcoming). 
and thin middle classes like the military, lawyers, judges, teachers and other public employees as well as workers in some key industries. Within the current context of post-neoliberal reform agendas, these authors argue, serious attempts are being made by progressive governments to enlarge the rather exclusive circle of original stakeholders. Others, however, are more skeptical, and point to the institutional and structural limits to transformative social reforms (Cameron/Hershberg 2010; Levitsky/Roberts forthcoming; López-Calva/ Lustig 2010). These authors argue, that neither elites nor original stakeholders show a real interest in changing the existing exclusionary matrix. Poverty reduction programs, like the popular conditional cash transfer programs, they argue, constitute a cheap substitute for substantial and costly social reforms.

\section{Structural Social Inequality in the Context of Post-colonial Power Structures and Power Asymmetries}

In a nutshell, the fatal "Latin American equilibrium" (Robinson 2008), i.e., the persistence of above-average inequality rates despite early democratization processes and comparatively well-entrenched political rights and democratic decision-making processes challenges commonly held assumptions about the linkage between democratization processes and patterns of inequality. Even the democratic thrust of the latest wave of democratization starting in the 1980s as well as the restitution and expansion of political rights did not lead to any major changes concerning regional inequality rates so far. Despite some progress in the area of poverty reduction, the overwhelming majority of Latin American citizens still suffer from unequal access to and the distribution of commonly available or desirable goods. Contrary to the concerns articulated by early research on Latin American transition processes, the post-authoritarian regimes proved to be unexpectedly stable. This stability, however, coincided with extremely low levels of democratic quality and the persistence of blatant inequality.

So far, comparative research on Latin America has not answered the central question posed by the problematic coexistence of inequality and democratic decision-making processes in a satisfactory manner. These deficits and blind spots in the comparative research agenda can 
be explained by the fact that different areas of research have been largely locked into their respective silos as well as to a lack of interdisciplinary dialogue between the social and economic sciences and cultural and postcolonial studies. Only recently the tension between democratic decision-making processes and extreme rates of inequality gained more interest inside the Latin American research agenda. Apart from the already mentioned quantitative studies of economic historians, political scientists have made important contributions to the comparative research on long-term patterns of inequality within the region. Methodologically located within historical institutionalism, one strand of research concentrated on the development of critical junctures ${ }^{14}$ and path dependencies in the development of Latin American state structures, political institutions and power asymmetries (Coatsworth 2005; 2008; Ferranti et al. 2004; Engerman/ Sokoloff 2005; 2006; Robinson 2008; 2010). These studies share the assumption that despite a growing democratization pressure, the colonial oligarchical equilibrium based on limited elite coordination via vertical integration managed to reproduce itself and adapt to the major political and institutional reforms throughout the 20th century.

This perspective emphasizes not the persistence of specific institutions, but rather the persistence of an underlying political equilibrium which gives rise to strategies of income redistribution and social control [...] even if existing elites are destroyed, specific political and economic institutions may change, the underlying structures and incentives which gave rise to the previous equilibrium may still exist (Robinson 2008: 183186).

Growing pressure towards more egalitarian forms of social inclusion notwithstanding, underlying power structures and basic mechanisms of exclusion (property rights privileging the rich, constitutional guarantees of privileges; the disregard for meritocratic principles and electoral systems designed according to the needs of the powerful) proved unexpectedly resilient and adaptable to changing social demands despite considerable institutional change. Historical institutionalists are particularly interested in explaining how state structures, political institutions and power constellations change during different phases of (post-)colonial development and how elites manage to perpetuate their

14 For a discussion of the concept focusing on historical causes see Stinchcombe (1968: 101-129). 
privileges despite increasing democratization pressures. This implies analyses of distributional conflicts and of changes to the composition of distributional coalitions over time, including the strategies of disadvantaged social actors and groups fighting for participatory parity (Fraser 2003: 36-37) and a more egalitarian distribution of assets and life chances.

Apart from historical institutionalists, major contributions to the comparative research agenda on democracy and social inequality came from Latin American social scientists themselves. Often personally involved in the political struggle for (re-)democratization, this group of social scientists did not share the neo-institutionalist focus of their European and North American colleagues but instead put their emphasis on actor-centered approaches that focus on citizenship rights and forms of participatory democracy. In the context of ongoing democratization struggles and neoliberal structural reforms, these theorists investigated the scopes of action of different social actors and movements and coalitional strategies which might contribute to the transformation of the political system as such (Avritzer 2009; Cheresky 2006; Dagnino/Olvera/Panfichi 2006; for an overview Wehr 2008).

Despite the vast variety of perspectives characterizing the interdisciplinary research agenda on complex inequalities in Latin America, some common denominators and shared assumptions can be identified:

1) Taking intersectionality seriously: Unlike earlier research on inequalities, which was dominated by Marxist approaches within the social sciences, today's research on complex and multiple inequality regimes (for an explanation of the term see Walby 2009: 58-70) is greatly influenced by insights from gender studies that focus on the interrelations and mutual constitution of multiple sets of asymmetrical social relations: in addition to class, gender and ethnic belonging also play an important role in the analysis of intersectional inequalities.

2) The importance of political factors: Although economic factors like the different modes of integration into global markets and overall economic models and dependencies have an important impact on existing inequality regimes, they are not sufficient to ex- 
plain the blatant social disparities within the region. Current research, thus, places emphasis on the analysis of power structures on the local, national and transnational level contributing to the perpetuation of privileges and access asymmetries.

3) Overcoming methodological nationalism: Whereas much of the traditional research on social inequalities within the region was mainly constrained to the national (or local) level, recent investigations in different academic disciplines have made an explicit attempt to focus on interdependent and relational aspects of complex and multiple inequality regimes beyond the nation-state. Taking insights from the ongoing debates on entangled modernity and history (for conceptional issues see Randeria 1999), recent research has taken a renewed interest into international and transnational exchange processes and inter-regional interdependencies. Although current inequality regimes cannot be directly attributed to colonial legacies, in an indirect manner, legacies in a Braudelian sense, i.e., as longterm historically and structurally anchored prefigurations (Braudel 1972) play an important role in determining current inequality regimes. This has led to the insight that the multiple, not necessarily nested or hierarchically ordered inequality regimes (Walby 2009: 67), cannot be analyzed without taking into consideration inter-, trans- und interregional asymmetrical exchange and communication processes with different spatial and temporal scopes.

The unresolved tension between blatant social inequalities and relatively advanced democratic decision structures does not only present a continuous challenge to political decision-makers within the region but will also occupy the research agendas of social scientists for quite some while. 


\section{References}

Acemoglu, Daron/Robinson, James (2000): "Why Did the West Extend the Franchise? Democracy, Inequality, and Growth in Historical Perspective". In: The Quarterly Journal of Economics, 115, pp. 1167-1199.

Acemoglu, Daron/Robinson, James (eds.) (2006): Economic Origins of Dictatorship and Democracy. Cambridge: Cambridge University Press.

Anderson, Christopher/Beramendi, Pablo (2008): "Income Inequality and Democratic Representation”. In: Anderson, Christopher/Beramendi, Pablo (eds.): Democracy, Inequality, and Representation. New York: Russell Sage Foundation, pp. 3-24.

Annino, Antonio (ed.) (1995): Historia de las elecciones en Iberoamérica, Siglo XIX. México, D.F.: Fondo de Cultura Económica.

Ansell, Ben/Samuels, David (2010): "Inequality and Democratization: A Contractarian Approach”. In: Comparative Political Studies, 43, 12, pp. 1543-1574.

Avritzer, Leonardo (2009): Participatory Institutions in Democratic Brazil. Washington, D.C./Baltimore: Woodrow Wilson Center Press/Johns Hopkins University Press.

Bangura, Yusuf (2007) (ed.): Democracy and Social Policy. Basingstoke: Palgrave Macmillan.

Bangura, Yusuf et al. (2010): Combating Poverty and Inequality. Structural Change, Social Policy and Politics. Genève/New York: UNRISD.

Barros, Ricardo/Carvalho, Mirela de/Franco, Samuel/Mendonça, Rosane (2010): "Markets, the State, and the Dynamics of Inequality in Brazil". In: LópezCalva, Luis/Lustig, Nora (eds.): Declining Inequality in Latin America. A Decade of Progress? New York/Washington, D.C.: United Nations Development Programme/Brookings Institution Press, pp. 134-174.

Baten, Jörg/Mumme, Christina (2010): "Globalization and Educational Inequality during the 18th and 20th Centuries: Latin America in Global Comparison”. In: Revista de Historia Económica, 28, 2, pp. 279-305.

Benton, Allyson Lucinda (2005): "Dissatisfied Democrats or Retrospective Voters? Economic Hardship, Political Institutions, and Voting Behavior in Latin America". In: Comparative Political Studies, 38, 4, pp. 417-442.

Bértola, Luis et al. (2009): "Income Distribution in the Latin American Southern Cone during the First Globalization Boom and Beyond". In: International Journal of Comparative Sociology, 50, 5-6, pp. 452-485.

Boix, Carles (ed.) (2003): Democracy and Redistribution. Cambridge: Cambridge University Press.

Braudel, Fernand (1972): "Geschichte und Sozialwissenschaften - die 'longue durée"”. In: Wehler, Hans Ulrich (ed.): Geschichte und Soziologie. Köln: Kiepenheuer \& Witsch, pp. 189-215.

Bunce, Valerie (2000): “Comparative Democratization. Big and Bounded Generalizations”. In: Comparative Political Studies, 33, 6/7, pp. 703-734.

Cameron, Maxwell/Hershberg, Eric (eds.) (2010): Latin America's Left Turns. Politics, Policies and Trajectories of Change. Boulder: Lynne Rienner. 
Caulfield, Sueann/Chambers, Sarah/Putnam, Lara (eds.) (2005): Honor, Status, and Law in Modern Latin America. Durham/London: Duke University Press.

CEPAL (Comisión Económica para América Latina y el Caribe) (2009): Social Panorama of Latin America. Santiago de Chile.

- (2010): La hora de la igualdad: brechas por cerrar, caminos por abrir. Santiago de Chile.

Cheresky, Isidoro (2006): Ciudadania, sociedad civil y participación política. Buenos Aires: Miño y Dávila.

Coatsworth, John (2005): "Structures, Endowments, and Institutions in the Economic History of Latin America". In: Latin American Research Review, 40, 3, pp. 126144.

- (2008): "Inequality, Institutions and Economic Growth in Latin America". In: Journal of Latin American Studies, 40, pp. 545-569.

Dagnino, Evelina/Olvera, Alberto/Panfichi, Aldo (eds.) (2006): La disputa por la construcción democrática en América Latina. México, D.F.: CIESAS.

Deininger, Klaus/Olinto, Pedro (1999): Asset Distribution, Inequality and Growth (World Bank Policy Research Paper Nr. 2375). Washington, D.C.: World Bank.

Deininger, Klaus/Squire, Lyn (1996): “A New Data Set Measuring Income Inequality". In: World Bank Economic Review, 10, 3, pp. 565-591.

Dobado González, Rafael/García Montero, Héctor (2010): “Colonial Origins of Inequality in Hispanic America? Some Reflections Based on New Empirical Evidence". In: Revista de Historia Económica, 28, 2, pp. 253-277.

Easterly, William (2007): "Inequality does Cause Underdevelopment: Insights from a new Instrument”. In: Journal of Development Economics, 84, 2, pp. 755-776.

ECLAC (Economic Commission for Latin America) (2001): Social Panorama of Latin America 2001. Santiago de Chile.

- (2009): Social Panorama of Latin America 2009. Santiago de Chile.

Engerman, Stanley/Sokoloff, Kenneth (2005): "The Evolution of Suffrage Institutions in the New World". In: Journal of Economic History, 65, 4, pp. 891-921.

- (2006): "The Persistence of Poverty in the Americas: The Role of Institutions". In: Bowles, Samuel/Durlauf, Steven/Hoff, Karla (eds.): Poverty Traps. Princeton/Oxford: Princeton University Press, pp. 43-78.

Ernst, Tanja (2011): “(Post-)koloniale Kulturen der Ungleichheit. Zum Zusammenhang von Ethnizität, Ungleichheit und Demokratie in Lateinamerika". In: Wehr/Burchardt 2011, pp. 45-69.

Escobar, Arturo (1995): Encountering Development: The Making and Unmaking of the Third World. Princeton: Princeton University Press.

Ferranti, David de/Perry, Guillermo/Ferreira, Francisco/Walton, Michael (eds.) (2004): Inequality in Latin America and the Caribbean: Breaking with History? Washington, D.C.: World Bank.

Fornos, Carolina/Power, Timothy/Garand, James (2004): "Explaining Voter Turnout in Latin America, 1980-2000". In: Comparative Political Studies, 37 8, pp. 909940. 
Frankema, Ewout (2009): Has Latin America Always been Unequal? A Comparative Study of Asset and Income Inequality in the Long Twentieth Century. Leiden/ Boston: Brill.

Fraser, Nancy (2003): "Social Justice in the Age of Identity Politics: Redistribution, Recognition, and Participation”. In: Fraser, Nancy/Honneth, Axel: Redistribution or Recognition? A Political-Philosophical Exchange. London: Verso, pp. 7-109.

Gough, Ian/Wood, Geof (2006): "A Comparative Welfare Regime Approach to Global Social Policy”. In: World Politics, 34, 20, pp. 1696-1713.

Hettich, Walter/Winer, Stangley (1999): Democratic Choice and Taxation. A Theoretical and Empirical Analysis. Cambridge: Cambridge University Press.

Hicks, Alexander (ed.) (1999): Social Democracy and Welfare Capitalism: A Century of Income Security Policies. Ithaca: Cornell University Press.

Huber, Evelyne/Stephens, John D. (eds.) (2001): Development and Crisis of the Welfare State. Parties and Policies in Global Markets. Chicago/London: The University of Chicago Press.

Huber, Evelyne/Pribble, Jennifer/Stephens, John D. (2009): "The Politics of Effective and Sustainable Redistribution". In: Estache, Antonio/Leipziger, Danny (eds.): Stuck in the Middle. Is Fiscal Policy Failing the Middle Class? Washington, D.C.: World Bank, pp. 155-188.

Huntington, Samuel (1991): The Third Wave. Democratization in the Late Twentieth Century. Norman: University of Oklahoma Press.

Kahhat, Jaime (2010): "Labor Earnings Inequality: The Demand for and Supply of Skills". In: López-Calva, Luis/Lustig, Nora (eds.): Declining Inequality in Latin America. A Decade of Progress? New York/Washington, D.C.: United Nations Development Programme/Brookings Institution Press, pp. 25-38.

Kaltmeier, Olaf (2011): "Hacienda, Staat und indigene Gemeinschaften. Kolonialität und politisch-kulturelle Grenzverschiebungen von der Unabhängigkeit bis in die Gegenwart". In: Wehr/Burchardt 2011, pp. 29-44.

Kaufman, Robert/Nelson, Joan (eds.) (2004): Crucial Needs, Weak Incentives. Social Sector Reform, Democratization, and Globalization in Latin America. Washington, D.C.: Woodrow Wilson Center Press/The Johns Hopkins University Press.

Korzeniewicz, Roberto Patricio/Moran, Timothy Patrick (2009): Unveiling Inequality. A World-Historical Perspective. New York: Russell Sage Foundation.

Kreckel, Reinhard (ed.) (2004): Politische Soziologie der sozialen Ungleichheit. Frankfurt am Main: Campus.

Kronauer, Martin (2006): "Exklusion" als Kategorie einer kritischen Gesellschaftsanalyse. Vorschläge für eine anstehende Debatte”. In: Bude, Heinz/Willisch, Andreas (eds.): Das Problem der Exklusion. Ausgegrenzte, Entbehrliche, Überflüssige. Hamburg: Hamburger Edition, pp. 27-45.

Kuznets, Simon (1955): "Economic Growth and Income Inequality". In: American Economic Review, 45, 1, pp. 1-28.

Lenski, Gerhard Emmanuel (1966): Power and Privilege: A Theory of Social Stratification. New York: MacGraw-Hill. 
Levitsky, Steven/Roberts, Kenneth M. (eds.) (forthcoming): Latin America's "Left Turn": Democracy, Development, and Political Diversity. Johns Hopkins University Press.

Lindert, Peter H. (2004): Growing Public. Social Spending and Economic Growth since the Eighteenth Century. 2 vols. Cambridge: Cambridge University Press.

Lopez, Humberto/Perry, Guillermo (2008): Inequality in Latin America: Determinants and Consequences (World Bank Policy Research Paper Nr. 4504). Washington, D.C.: World Bank.

López-Calva, Luis/Lustig, Nora (eds.) (2010): Declining Inequality in Latin America. A Decade of Progress? New York/Washington, D.C.: United Nations Development Programme/Brookings Institution Press.

Luna, Juan Pablo/Filgueira, Fernando (2009): "The Left Turns as Multiple Paradigmatic Crises". In: Third World Quarterly, 30, 2, pp. 371-395.

Machinea, José Luis/Hopenhayn, Martín (2005): La esquiva equidad en el desarrollo latinoamericano. Una visión estructural, una aproximación multifacético. Santiago de Chile: CEPAL.

Mainwaring, Scott/Pérez-Liñán, Aníbal (2007): "Why Regions of the World Are Important: Regional Specificities and Region-Wide Diffusion of Democracy". In: Munck, Gerardo (ed.): Regimes and Democracy in Latin America. Theories and Methods. Oxford: Oxford University Press, pp. 199-229.

Meltzer, Allan H./Richard, Scott F. (1981): "A Rational Theory of the Size of Government”. In: Journal of Political Economy, 89, 5, pp. 914-927.

Merkel, Wolfgang $\left({ }^{2} 2010\right)$ : Systemtransformation. Eine Einführung in die Theorie und Empirie der Transformationsforschung. Wiesbaden: VS.

Mesa-Lago, Carmelo (ed.) (1978): Social Security in Latin America: Pressure Groups, Stratification and Inequality. Pittsburgh: University of Pittsburgh Press.

Milanovič, Branko/Lindert, Peter H./Williamson, Jeffrey G. (2008): Ancient Inequality (NBER Working Paper 13550). Cambridge: National Bureau of Economic Research.

Milanovič, Branko/Muñoz de Bustillo, Rafael (2008): "La desigualdad en la distribución de la renta en América Latina: situación, evolución y factores explicativos. Income inequality in Latin America: situation, evolution and explicative factors". In: America Latina Hoy, 48, pp. 15-42.

Nelson, Joan (2004): "The Politics of Health Sector Reform: Cross-National Comparisons”. In: Kaufman, Robert/Nelson, Joan (eds.): Crucial Needs, Weak Incentives. Social Sector Reform, Democratization, and Globalization in Latin Ameri$c a$. Washington, D.C.: Woodrow Wilson Center Press/The Johns Hopkins University Press, pp. 23-64.

Neves, Marcelo (2007): "Die Staaten im Zentrum und die Staaten an der Peripherie: Einige Probleme mit Niklas Luhmanns Auffassung von den Staaten der Weltgesellschaft". In: Neves, Marcelo/Voigt, Rüdiger (eds.): Die Staaten der Weltgesellschaft. Niklas Luhmanns Staatsverständnis. Baden-Baden: Nomos, pp. 181221.

Oettler, Anika (2011): "Gender Divisions: Politische Repräsentation und soziale Ungleichheit”. In: Wehr/Burchardt 2011, pp. 91-106. 
Perry, Guillermo et al. (2006): Poverty Reduction and Growth. From Vicious to Virtuous Circles. Washington, D.C.: World Bank.

Peters, Stefan (2011): "Bildung als Privileg”. In: Wehr/Burchardt 2011, pp. 201-225.

PNUD (Programa para el Desarrollo de las Naciones Unidas) (2004): La democracia en América Latina. Hacia una democracia de ciudadanas y ciudadanos. 3 vols. Buenos Aires: Alfaguara.

Posada-Carbó, Eduardo (1996): Elections before Democracy: The History of Elections in Europe and Latin America. Houndmills/New York: Macmillan/St. Martin's Press.

Prados de la Escosura, Leandro (2007): "Inequality and Poverty in Latin America: A Long-Run Exploration”. In: Hatton, Timothy/O'Rourke, Kevin/Taylor, Alan (eds.): The New Comparative Economic History. Essays in Honor of Jeffrey G. Williamson. Cambridge/London: MIT Press, pp. 291-315.

Randeria, Shalini (1999): "Geteilte Geschichte und verwobene Moderne". In: Rüsen, Jörn et al. (eds.): Zukunftsentwürfe. Ideen für eine Kultur der Veränderung. Frankfurt am Main: Campus, pp. 87-96.

Robinson, James A. (2008): “The Latin American Equilibrium”. In: Fukuyama, Francis (ed.): Falling Behind: Explaining the Development Gap Between the United States. Oxford: Oxford University Press, pp. 161-193.

- (2010): "The Political Economy of Redistributive Policies". In: López-Calva, Luis/Lustig, Nora (eds.): Declining Inequality in Latin America. A Decade of Progress? New York/Washington, D.C.: United Nations Development Programme/Brookings Institution Press, pp. 39-71.

Rueschemeyer, Dietrich/Huber, Evelyne/Stephens, John D. (eds.) (1992): Capitalist Development and Democracy. Chicago: University of Chicago Press.

Sabato, Hilda (ed.) (1999): Ciudadanía politica y formación de las naciones. Perspectivas históricas de América Latina. México, D.F.: FCE.

Schäfer, Armin (2010): "Die Folgen sozialer Ungleichheit für die Demokratie in Westeuropa". In: Zeitschrift für Vergleichende Politikwissenschaft, 4, pp. 121156.

Segura-Ubiergo, Alex (2007): The Political Economy of the Welfare State in Latin America. Cambridge: Cambridge University Press.

Souza, Jessé (2008): Die Naturalisierung der Ungleichheit: ein neues Paradigma zum Verständnis peripherer Gesellschaften. Wiesbaden: VS, Verlag für Sozialwissenschaften.

Thiery, Peter/Merkel, Wolfgang (2010): "Die dritte Demokratisierungswelle in Lateinamerika". In: Merkel, Wolfgang: Systemtransformation. Eine Einführung in die Theorie und Empirie der Transformationsforschung. Wiesbaden: VS, Verlag für Sozialwissenschaften, pp. 205-260.

Tittor, Anne (2011): "Institutionalisierte Ungleichheit im Gesundheitswesen: Zu den politischen Gründen für die Beibehaltung fragmentierter Gesundheitssysteme". In: Wehr/Burchardt 2011, pp. 227-256.

Walby, Sylvia (2009): Globalization and Inequalities. Complexity and Contested Modernities. Los Angeles: Sage. 
Wehr, Ingrid (2008): "Von der low-intensity democracy zur Staatsbürgerschaftsdemokratie? Einige kritische Anmerkungen zur lateinamerikanischen Staatsbürgerschaftsdebatte". In: Lateinamerika Analysen, 20, 2, pp. 94-124.

- (2011): "Wohlfahrtsregime und soziale Ungleichheit in Lateinamerika". In: Wehr/Burchardt 2011, pp. 257-281.

Wehr, Ingrid/Burchardt, Hans-Jürgen (eds.): Soziale Ungleichheiten in Lateinamerika. Neue Perspektiven auf Wirtschaft, Politik und Umwelt. Baden-Baden: Nomos.

Weisbrot, Mark/Sandoval, Luis (2008): “The Distribution of Bolivia's Most Important Natural Resources and the Autonomy Conflicts". In: Center for Economic and Policy Research. Washington, D.C., Issue Brief, July 2008.

Williamson, Jeffrey G. (2010): "Five Centuries of Latin American Inequality". In: Revista de Historia Económica, 28, 2, pp. 227-252.

World Bank (2006): Poverty Reduction and Growth. From Vicious to Virtuous Circles. Washington, D.C. 


\section{Thamy Pogrebinschi}

\section{Participatory Policymaking and Political Experimentalism in Brazil}

Since the adoption of the new constitution in 1988, Brazilian political institutions have been increasingly becoming more stable and solid: these include a now very competitive multi-party system, periodic and universal elections, an active and plural congress, a strongly accepted and highly approved presidency, an increasingly respected Supreme Court, a fair system of judicial review, a legitimate legal order, a quite comprehensive system of rights, a free and open media, not to mention the massive turnout in elections due to the pedagogic experience of compulsory voting, and the always clear electoral processes.

Additionally, and especially from 2003 onwards, one can observe in Brazil a surprising proliferation and empowerment of social movements, a flourishing public sphere, and a breakthrough of participatory and deliberative practices that are increasingly institutionalized and supported by the state, from the local to the national level. As has been stated by the Minister of the General-Secretary of the Presidency of Brazil in late 2010, since Lula (Luiz Inácio Lula da Silva, from the Workers Party - PT - President of Brazil from 2003 to 2010) took office "social participation has been adopted as a democratic method of public administration".

Participation seems to have indeed become a democratic method of governance in Brazil. As a method, participation enriches representative democracy. While turning political institutions into more representative bodies, this participation accommodates civil society within the state, and impels the redesign of both policymaking and lawmaking processes. Such institutional changes have for their turn

1 This statement was made on August 20th, 2010, in an official address from Minister Luiz Dulci to the press. The full address is available at: $<$ www. secretariageral.gov.br/noticias/ultimas_noticias/2010/08/20-08-2010-nota-aimprensa-resposta-do-ministro-luiz-dulci-as-declaracoes-de-jose-serra> (13.07.2011). 
been proving themselves to produce not only more legitimate political decisions, but also more effective social outcomes. If Brazil's noted poverty reduction is due to income transfer and other successful redistributive policies adopted by Lula's government, the political representation of minority groups (such as women, indigenous people, LGBT, elderly, youth, people with disabilities, among others) is certainly also an achievement of the institutionalization of participatory experiences that allow for a more stronger and effective advocacy of rights and policy inclusion (Pogrebinschi forthcoming). Given such a scenario, I cannot help but recall Dewey: "there is nothing more radical than insistence upon democratic methods as the means by which rad cal social changes be effected" (Dewey 1937: 339).

In this paper my goal is to discuss a participatory experiment that has been intensely institutionalized in Brazil over the past few years, in particular since the Worker's Party (PT) took power in 2003. Such experiment is called "national conference on public policy" ("conferência nacional de políticas públicas"), and it is designed to provide guidelines for the formulation of public policy through a conjoint process of deliberation gathering together representatives from the government and from civil society. After raising some empirical evidence on the process of institutionalization of the national policy conferences in Brazil, my aim is to draw on some theoretical issues and argue that political experiments like in Brazil allow for a more responsive and inclusive political representation (that I call constitutive representation) and a more legitimate and stable democratic movement (that I call pragmatic democracy).

\section{Participatory Policymaking: the National Conferences on Public Policy}

The national public policy conference is the largest and possibly the most innovative participatory experience presently taking place in Brazil. It is organized by the executive branch along with civil society groups, and comprises a national level process of deliberation structured according to diverse policy areas and issues. A national conference is the culmination of a process that starts at the local (municipal) level, and goes through all states of the federation. Attendance at the national conferences is usually made up of $60 \%$ civil society repre- 
sentatives and $40 \%$ delegates from state and public administration. Civil society's representatives are usually elected in the first levels of the process (municipal and state) when the conferences are entirely open to participation (at the local level), and state's representatives are in general nominated. Some conferences also include a specific proportion of representatives of workers concerned with the policy issue under deliberation. On average, a national conference has about 3.000 delegates, but the entire process from the local to the national level involves hundreds of thousand of people, and the largest one up to now has reached over 500,000 participants on all levels (National Conference on Public Security, held on August 2009). After each of the conference stages (local, state, and national), a document containing the policy guidelines deliberated by all participants is approved in a final plenary session. The expectation is that the federal government uses such documents as a source to draft policies related to the areas and issues deliberated in the national conferences. Instead of relying on the expertise of technicians, the inputs from civil society hope to be taken into consideration in the policymaking process.

And indeed data indicates that during Lula's government the national policy conferences have been proving themselves successful enough to affect the policies drafted by the federal administration (Pogrebinschi forthcoming; 2012), and to influence the legislation enacted by Congress (Pogrebinschi/Santos 2010). Such positive impacts of the national policy conferences certainly result from their process of institutionalization over the past few years as will be made clear in the following pages.

The first so-called national policy conference was held in Brazil in 1941. It was a conference on health, a policy area that has pioneered the use of participatory practices in the country due to the very active professional associations and social movements that have historically engaged politically with health policy issues. Although at that time the so-called health national conferences did not follow the same national structure, participatory composition and deliberative format practiced today, those events cannot be dismissed when one considers the origin and the background of the current national policy conferences. And they must be taken into consideration so as one can observe the process of institutionalization of Brazilian participatory experiment. 
Over 50 years, between 1941 and 1991, only twelve national public policy conferences were held in Brazil, and all of them related to health policies. Between 1992 and 200980 national conferences were held in Brazil aimed at the deliberation of 33 diverse policy issues. ${ }^{2}$ Table 1 below presents the sample of national public policy conferences held in the country since the enactment of the 1988 Constitution until 2009, according to the policy issue addressed, the years in which they took place, and the frequency achieved by them.

Table 1: National Public Policy Conferences: issues and frequency

\begin{tabular}{|r|l|l|c|}
\hline & Conference/Policy Issues & Years & Total \\
\hline 1 & Aquaculture and Fisheries & $2003 / 2006 / 2009$ & 3 \\
\hline 2 & Social Assistance & $\begin{array}{l}1995 / 1997 / 2001 / 2003 / \\
2005 / 2007 / 2009\end{array}$ & 7 \\
\hline 3 & Cities & $2003 / 2005 / 2007$ & 3 \\
\hline 4 & $\begin{array}{l}\text { Science, Technology and Innova- } \\
\text { tion in Health }\end{array}$ & $1994 / 2004$ & 2 \\
\hline 5 & Communication & 2009 & 1 \\
\hline 6 & Brazilian Communities Abroad & $2008 / 2009$ & 2 \\
\hline 7 & Culture & 2005 & 1 \\
\hline 8 & $\begin{array}{l}\text { Sustainable and Solidarity Rural } \\
\text { Development }\end{array}$ & 2008 & 7 \\
\hline 9 & Children and Adolescent Rights & $1997 / 1999 / 2002 / 2003 /$ & 2 \\
\hline 10 & $\begin{array}{l}\text { Rights of Persons with Disabili- } \\
\text { ties }\end{array}$ & $2005 / 2007 / 2009$ & 2 \\
\hline 11 & Rights of the Elderly & $2006 / 2008$ & 11 \\
\hline 12 & $\begin{array}{l}\text { Human Rights } \\
\text { numb }\end{array}$ & $\begin{array}{l}1996 / 1997 / 1998 / 1999 / \\
2000 / 2001 / 2002 / 2003 /\end{array}$ & $2004 / 2006 / 2008$ \\
\hline
\end{tabular}

2 In reality, and according to official data, the number of national policy conferences held in Brazil up to 2009 is a bit higher (about 10\% higher). I do only take into consideration the national policy conferences that can be considered a) deliberative, b) normative and c) national in scope. For a description of these criteria and my methodology to classify the national policy conferences, see Pogrebinschi/Santos (2010). 


\begin{tabular}{|c|l|l|c|}
\hline N. & Conference/Policy Issues & Years & Total \\
\hline 13 & Solidarity Economy & 2006 & 1 \\
\hline 14 & Basic Education & 2008 & 1 \\
\hline 15 & Indigenous Education & 2009 & 1 \\
\hline 16 & $\begin{array}{l}\text { Professional and Technological } \\
\text { Education }\end{array}$ & 2006 & 1 \\
\hline 17 & Sports & $2004 / 2006$ & 2 \\
\hline 18 & $\begin{array}{l}\text { Gays, Lesbians, Bisexuals, Trans- } \\
\text { vestites, and Transsexuals }\end{array}$ & 2008 & 1 \\
\hline 19 & $\begin{array}{l}\text { Management of Healthcare Work } \\
\text { and Education }\end{array}$ & $1994 / 2006$ & 2 \\
\hline 20 & Youth & 2008 & 1 \\
\hline 21 & $\begin{array}{l}\text { Medications and Pharmaceutical } \\
\text { Care }\end{array}$ & 2003 & 1 \\
\hline 22 & Environment & $2003 / 2005 / 2008$ & 3 \\
\hline 23 & Public Policies for Women & $2004 / 2007$ & 2 \\
\hline 24 & Indigenous peoples & 2006 & 2 \\
\hline 25 & Promotion of Racial Equality & $2005 / 2009$ & 2 \\
\hline 26 & Health & $1992 / 1996 / 2000 / 2003 /$ & 5 \\
\hline 27 & Environmental Health & 2008 & $\mathbf{8 0}$ \\
\hline 28 & Dental Health & 2009 & $1993 / 2004$ \\
\hline 29 & Workers Health & $1994 / 2005$ & 2 \\
\hline 30 & Indigenous Health & $1993 / 2001 / 2005$ & 2 \\
\hline 31 & Mental Health & $1994 / 2004 / 2007$ & 2 \\
\hline 32 & Food and Nutritional Security & 2009 & 2 \\
\hline 33 & Public Security & & 2 \\
\hline Total & & 2 \\
\hline
\end{tabular}

The above data reveals that out of the 33 policy issues ever deliberated in national policy conferences, human rights is the policy area with the largest number of conferences aimed at its deliberation: 11 national conferences on human rights were held over a period of 12 years, even though social participation has certainly enlarged throughout this period. Social assistance and children and youth rights follow thereafter: there were 7 conferences for each of these 
policy areas. In the case of children and youth rights, the 7 conferences occurred within a 12-year period, whereas in the case of the social assistance conferences, 7 of them were distributed within a 14-year time span. Health, the pioneering policy area in the history of national conferences and the only one found in the period preceding 1988, was the object of only 5 conferences after that year. However, it is worth noting that, starting in the 1990s, health policies become the object of specialized conferences on different health issues, which comprise specific conferences on "oral health" (2), "workers health" (2), "health of indigenous peoples" (3), "mental health" (2), "environmental health" (1), in addition to "management of labor and education in health" (2), "science, technology, and innovation in health" (2), "medication and pharmaceutical care" (1), responding altogether for 20 conferences in 17 years. Conferences on policy for "aquaculture and fishing", "cities", "environment", "food and nutritional safety" come next, with 3 conferences each. There were 2 conferences held on "sports", "rights of the persons with disabilities", "rights of the elderly", "Brazilian communities abroad", "promotion of racial equality" and "policies for women". All remaining policy areas listed in table 1 had only one national conference during the timeframe examined: "culture", "solidarity economy", "professional and technological education", "youth", "solidarity and sustainable rural development", "gays, lesbians, bisexuals, transvestites and transsexuals, "public safety", "communication", and "indigenous peoples".

Once the national conferences are aggregated and classified in policy area sets and one analyzes their frequency distribution, it becomes clear that "health" and "minorities" policy area sets lead the field, each one with 20 occurrences, divided into 9 different policy issues. Among the conferences within the health policy area set there have been the 5 aforementioned health conferences in addition to 15 specialized conferences in the subject, also summing up 20 conferences. The "minorities" policy area set includes the national conferences on the "rights of the elderly", "rights of people with disabilities", "gays, lesbians, bisexuals, transvestites and transsexuals", "indigenous people", "public policies for women", "children and youth rights", "promotion of racial equality", "youth", and "Brazilian communities abroad" therefore 20 conferences for 9 policy areas, being that 8 of them (the exception is only "children and youth rights") have only began to be 
addressed on national conferences in 2003. The policy area sets "state, economy and development" and "education, culture, social assistance and sports" come next, tied with 13 conferences apiece. The former policy area set is further divided into 7 policy issues: "solidarity economy", "aquaculture and fishing", "sustainable and solidarity rural development", "food and nutritional safety", "cities", "public safety" and "communications". The latter for its turn is further divided into 6 policy issues: "basic education", "professional and technological education", "indigenous education", "culture", "sports" and "social assistance". The national conferences on "human rights", due to its intense and stable frequency (11 editions, most of them held every two years since 1996), the vast number of policy guidelines produced, count as one in itself. The "environment" also constitutes a single separate policy area set due to its lack of convergence with the other policy areas, although only 3 conferences on this issue were held up to 2009.

Once the national conferences are classified according to policy area sets based on the convergence of the issues they deal with, it is possible to notice in the graph 1 below that, together, "health" and "minorities" are responsible for precisely half of all national policy conferences held thus far, with each one accounting for $25 \%$ of the total. In the first case, there is nothing striking about the fact that the pioneering policy area in national conferences is responsible for a fourth of the total figure, especially given the early and strong institutionalization of professional associations and social movements concerned with health policies. However, this is not the case with the "minorities" policy area set. It is indeed striking that the 9 policy issues it comprises account for a fourth of all national conferences held after 1988 given that 8 of their policy issues only started being deliberated in national conferences after 2003. One notices that since the beginning of the first term of Lula's government (2003), the national policy conferences became notably more comprehensive in terms of policies addressed, and also more plural and heterogeneous accordingly to the positive response of government to the demands of minority groups that claimed to have their interests and rights addressed in national conferences. 
Table 2: National conferences:

distribution according to policy area sets

\begin{tabular}{|c|c|c|c|}
\hline Policy area & Issues & $\begin{array}{l}\text { Quantity } \\
\text { of Issues }\end{array}$ & $\begin{array}{l}\text { Quantity of } \\
\text { Conferences }\end{array}$ \\
\hline Health & $\begin{array}{c}\text { Health } \\
\text { Oral health } \\
\text { Workers health } \\
\text { Health of indigenous peoples } \\
\text { Mental health } \\
\text { Environmental health } \\
\text { Science, technology, and innovation } \\
\text { in health Management of labor and } \\
\text { education in health } \\
\text { Medication and pharmaceutical care }\end{array}$ & 9 & 20 \\
\hline Minorities & $\begin{array}{c}\text { Rights of the Elderly } \\
\text { Rights of people with disabilities } \\
\text { Gays, lesbians, bisexuals, } \\
\text { transvestites and transsexuals } \\
\text { Indigenous people } \\
\text { Public policies for women } \\
\text { Rights of children and adolescents } \\
\text { Youth } \\
\text { Promotion of Racial Equality } \\
\text { Brazilian Communities Abroad }\end{array}$ & 9 & 20 \\
\hline Environment & Environment & 1 & 3 \\
\hline $\begin{array}{c}\text { State, } \\
\text { Economy } \\
\text { and } \\
\text { Development }\end{array}$ & $\begin{array}{c}\text { Solidarity Economy } \\
\text { Aquaculture and fishing } \\
\text { Sustainable and solidarity rural } \\
\text { development Food and nutritional } \\
\text { safety } \\
\text { Cities } \\
\text { Public Security } \\
\text { Communications }\end{array}$ & 7 & 13 \\
\hline $\begin{array}{c}\text { Education, } \\
\text { culture, } \\
\text { social } \\
\text { assistance and } \\
\text { sports }\end{array}$ & $\begin{array}{c}\text { Basic Education } \\
\text { Professional and Technological } \\
\text { Education } \\
\text { Indigenous Education } \\
\text { Culture } \\
\text { Sports } \\
\text { Social Assistance }\end{array}$ & 6 & 13 \\
\hline Human Rights & Human Rights & 1 & 11 \\
\hline
\end{tabular}


Graph 1: National conferences: distribution according to policy area sets

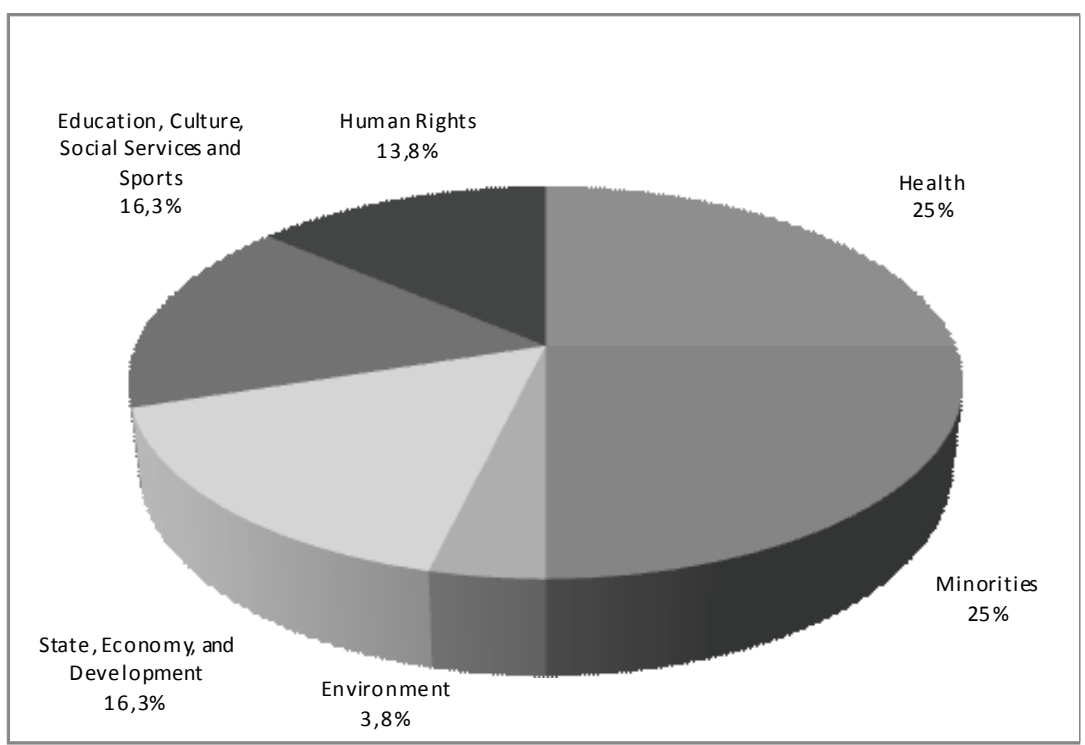

The pattern of distribution at the national conferences according to policy areas and frequency becomes more meaningful when they are listed in relation to the governments during which period in office they were held. The graph 2 below indicates that out of the 80 national policy conferences held from 1988 to 2009,55 took place during Lula's government (2003-2009). This means that $68.8 \%$ of all national policy conferences held during 21 years occurred within a 7 years period, an average of 8 conferences per year. ${ }^{3}$ In the 8 years of Fernando Henrique Cardoso's government (1995-2002) 17 conferences took place, that is, $21.3 \%$ of the total, averaging slightly above 2 conferences per year. The Itamar Franco government comes next (19921992), with 6 conferences held in 2 years and 2 months of mandate, comprising $7.5 \%$ of the total, followed by the Fernando Collor de Mello government (1990-1992), with only 2 conferences held during

3 In fact, official data and historical records would indicate an average of 10 national policy conferences per year since Lula took office, but as I have mentioned before the sample analyzed here only considers those conferences that are deliberative, normative, and national. 
his 2 year and 9 month long stint in office, accounting for $2.5 \%$ of the sample of national conferences that took place in Brazil from 1988 to 2009. One observes that, in as much as conferences begin to be institutionalized in the time of Fernando Henrique Cardoso's government (as it is the case for the national conferences on the rights of children and adolescents, as well as those on human rights), it was not until Lula's first term in presidency that their frequency became more significant, thus becoming incorporated into the Brazilian political agenda. No conferences were held from 1988 until the beginning of the Collor government in 1990, which explains why José Sarney's period in office (1985-1990) was excluded from these statistics.

Graph 2: National Conferences: distribution according to governments

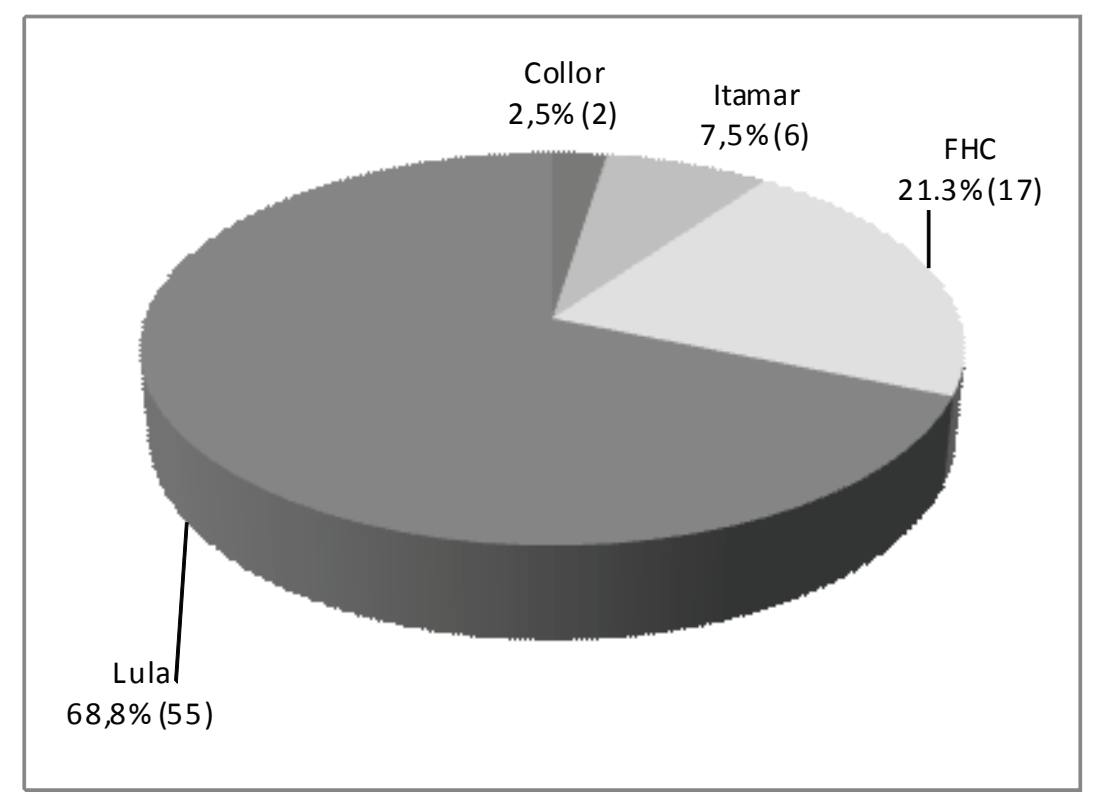

The pattern of distribution of the national conferences according to governments brings greater meaningfulness to the classification of policy area sets once the quantity of issues dealt with is analyzed. Table 3, below, reveals that of the 33 policy issues that were objects of national conferences in the last 21 years, 32 of them, that is, $97 \%$, were deliberated during Lula's government. The only issue not dealt 
with during this government up to 2009 was "mental health", which had previously been the object of two conferences, one in 1999 and the other one in 2001. ${ }^{4}$ However, looking at the policy guidelines that resulted from the national policy conferences one can see that mental health was addressed by several other national conferences held from 2003 to 2009 (Lula's period in office), as in the case of the conferences of "medication and pharmaceutical care" (2003), "human rights" (2003), "workers health" (2005), "rights of people with disabilities" (2006), and "gays, lesbians, bisexuals, transsexuals, and transvestites" (2008). It can therefore be stated (and this is entirely true if one takes 2010 into consideration) that Lula's government addressed the entire range of policy areas and issues dealt with in the history of national policy conferences in Brazil. The expansiveness of the policy areas and issues covered in the national conferences is certainly a sign of the process of institutionalization that they have been going through.

Besides Lula's, the other governments account for varying proportions of policy issues deliberated in national conferences out of the remaining 33 that constitute the sample. Two issues were tackled by Fernando Collor's government, each one in a separate national conference, which corresponds to $6 \%$ of the total sample of issues. Itamar Franco's government addressed 6 issues in 6 separate conferences, thus accounting for $18.2 \%$ of the total amount of issues in the sample. The data shows that these two governments, however, held national conferences that were almost exclusively dedicated to issues within the "health" policy area set. Other policy issues and areas will only be considered in the national conferences held during the two presidential terms of Fernando Henrique Cardoso, which account for 7 issues, that make up for $21.2 \%$ of the sample. Of these 7 policy issues deliberated during Cardoso's government, 3 belong to the "health" policy area set, 1 to the "minorities" policy area set, 1 to the "human rights" policy area set, 1 to the "state, economy, and development" policy area set, and finally 1 to the "education, culture, social assistance, and sports" policy area set. Table 3 displays these data.

4 Although the sample under analysis considers only the national policy conferences held until the end of 2009 , it is worth mentioning that the third national conference on mental health was held in 2010, in the last year of Lula's second mandate. 
Table 3: Policy issues deliberated by governments

\begin{tabular}{|c|c|c|c|}
\hline Presidency & \begin{tabular}{|c|}
$\begin{array}{c}\text { Quantity of } \\
\text { Conferences } \\
(\%)\end{array}$ \\
\end{tabular} & $\begin{array}{c}\begin{array}{c}\text { Quantity } \\
\text { of Issues } \\
(\%)\end{array} \\
\end{array}$ & Policy Issues \\
\hline $\begin{array}{l}\text { Fernando } \\
\text { Collor }\end{array}$ & $2(2.5 \%)$ & $2(6 \%)$ & $\begin{array}{c}\text { Health (1992) } \\
\text { Mental health (1992) }\end{array}$ \\
\hline $\begin{array}{l}\text { Itamar } \\
\text { Franco }\end{array}$ & $6(7.5 \%)$ & $6(18.2 \%)$ & $\begin{array}{c}\text { Oral health (1993) } \\
\text { Indigenous health (1993) } \\
\text { Workers health (1994) } \\
\text { Management of labor and education in } \\
\text { health (1994) } \\
\text { Science, technology, and innovation in } \\
\text { health (1994) } \\
\text { Food and nutritional safety (1994) }\end{array}$ \\
\hline $\begin{array}{l}\text { Fernando } \\
\text { Henrique } \\
\text { Cardoso }\end{array}$ & $17(21.3 \%)$ & $7(21.2 \%)$ & $\begin{array}{c}\text { Social assistance } \\
(1995,1997,2001) \\
\text { Rights of children and adolescents } \\
(1997,1999,2001) \\
\text { Human rights }(1996,1997,1998,1999, \\
\text { 2000, 2001,2002) } \\
\text { Health }(1996,2000) \\
\text { Indigenous health (2001) } \\
\text { Mental health (2001) } \\
\text { Food and nutritional safety (1994) }\end{array}$ \\
\hline $\begin{array}{l}\text { Lula Inácio } \\
\text { Lula da } \\
\text { Silva } \\
\text { (until 2009) }\end{array}$ & $55(68.8 \%)$ & $32(97 \%)$ & $\begin{array}{c}\text { Health }(2003,2008) \\
\text { Oral health }(2004) \\
\text { Workers health }(2006) \\
\text { Health of indigenous peoples }(2005) \\
\text { Environmental health (2009) } \\
\text { Science, technology, and innovation in } \\
\text { health (2004) } \\
\text { Management of labor and education in } \\
\text { health (2006) } \\
\text { Medication and pharmaceutical care } \\
\text { (2003) } \\
\text { Rights of the Elderly (2006, 2009) } \\
\text { Rights of people with disabilities } \\
\text { (2006, 2008) } \\
\text { Gays, lesbians, bisexuals, transvestites } \\
\text { and transsexuals (2008) } \\
\text { Indigenous people (2006) } \\
\text { Public policies for women (2004, } \\
\text { 2007) }\end{array}$ \\
\hline
\end{tabular}




\begin{tabular}{|c|c|c|c|}
\hline Presidency & $\begin{array}{c}\text { Quantity of } \\
\text { Conferences } \\
(\%)\end{array}$ & $\begin{array}{c}\text { Quantity } \\
\text { of Issues } \\
(\%) \\
\end{array}$ & Policy Issues \\
\hline $\begin{array}{l}\text { Lula Inácio } \\
\text { Lula da } \\
\text { Silva } \\
\text { (until 2009) }\end{array}$ & $55(68.8 \%)$ & $32(97 \%)$ & $\begin{array}{c}\text { Rights of children and adolescents } \\
(2003,2005,2007,2009) \\
\text { Youth }(2008) \\
\text { Promotion of Racial Equality } \\
(2005,2009) \\
\text { Brazilian Communities Abroad } \\
(2008,2009) \\
\text { Environment } \\
(2003,2005,2008) \\
\text { Solidarity Economy (2006) } \\
\text { Aquaculture and fishing } \\
\text { (2003, 2006, 2009) } \\
\text { Sustainable and solidarity rural } \\
\text { development }(2008) \\
\text { Food and nutritional safety } \\
\text { (2004, 2007) } \\
\text { Cities (2003, 2005, 2007) } \\
\text { Public Security }(2009) \\
\text { Communications }(2009) \\
\text { Basic Education }(2008) \\
\text { Professional and Technological } \\
\text { Education }(2006) \\
\text { Indigenous Education (2009) } \\
\text { Culture }(2005) \\
\text { Sports }(2004,2006) \\
\text { Social Assistance } \\
\text { (2003, 2005, 2007, 2009) } \\
\text { Human Rights } \\
\text { (2003, 2004, 2006, 2008) }\end{array}$ \\
\hline Total & 80 & 33 & \\
\hline
\end{tabular}

Table 3 indicates that considering the 8 policy issues deliberated in the national policy conferences held during the governments of Fernando Collor ("heath" and "mental health") and Itamar Franco ("oral health", "indigenous health", "workers health", "management of education and labor in health", "science, technology and innovation in health", and "food and nutritional safety"), Fernando Henrique Cardoso's government makes up for only 3 policy issues addressed ("social 
assistance", "children and youth rights", and "human rights"). This means that 22 out of 33 policy issues taken on by national conferences in 21 years were introduced during the first 7 years of Lula's government, that is, from 2003 onwards. Based on the previous classification of policy area sets, it is possible to notice that almost all national policy conferences classified under "minorities" (except for "children and youth rights"), "education, culture, social assistance and sports" (except for "food and nutritional health") and "environment" sets took place during Lula's government. Likewise, among the 8 policy issues that make up the "minorities" policy area set only one was deliberated in national policy conferences by governments preceding Lula's. Furthermore, with respect to the 8 policy issues included in the health policy area set, 2 became the object of conferences for the first time after 2003, despite the fact this is the area in which the very first national policy conferences have occurred. The pluralization of policy issues deliberated is also a sign of the process of institutionalization of the national public policy conferences.

It is worth noting that, in the period preceding 1988, 12 national conferences were held in Brazil, in which 5 issues were deliberated ("health", "oral health", "workers health", "indigenous health" and "mental health"), all of which are part of the health policy area set. If one is to consider the fact that out of the 8 policy issues considered by the governments of Fernando Collor de Mello and Itamar Franco, 5 had already been the object of national policy conferences before 1988. Fernando Henrique Cardoso's government had in reality only introduced 3 new policy issues to the entire range of 33 dealt with in national public policy conferences in Brazil. Lula's government was therefore responsible for introducing $66.7 \%$ of the policy issues that have been object of national public policy conferences in Brazil, considering its entire history both before and after 1988. This data is conveyed by the graph 3 . The policy innovation and groups inclusion and representation revealed by such data is derived from the close and strong relationship Lula's government has been maintaining with civil society over the years, allowing a considerable amount of professional and workers associations, as well as Non Governmental Organizations (NGOs) and social movements, to take an active part in the national public policy conferences. 


\section{Graph 3: Introduction of new issues by governments}

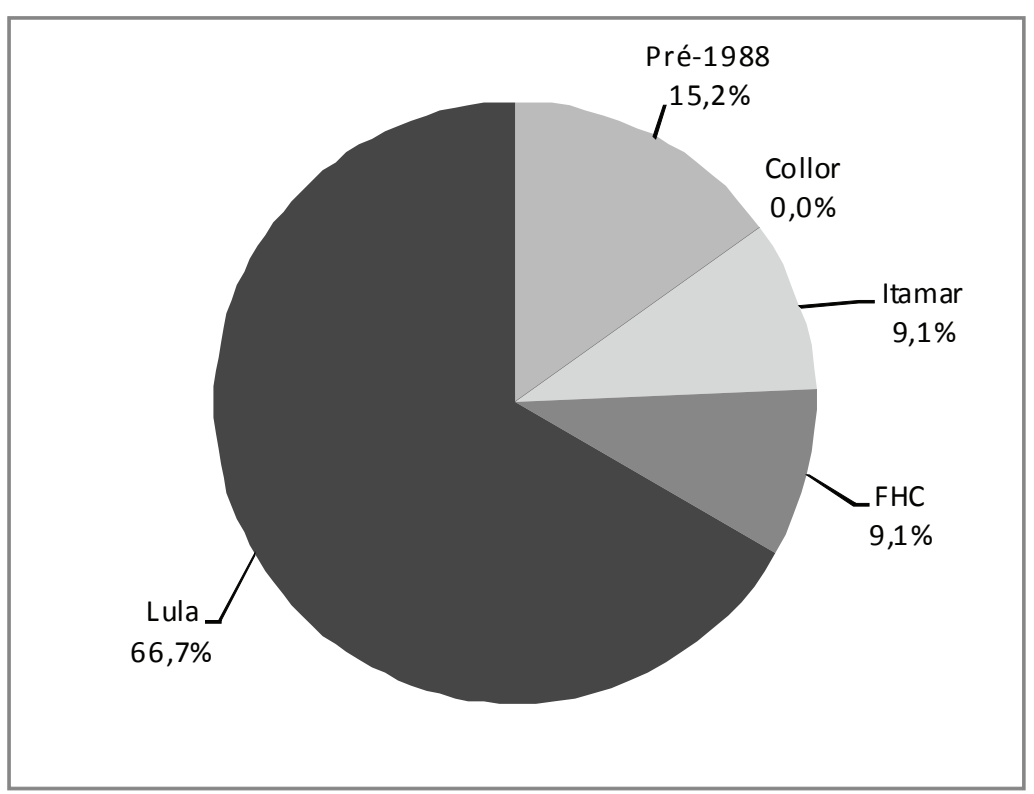

Of the 22 new policy issues that began to be addressed in national conferences after 2003 , the fact that 8 issues, that is $36.4 \%$ of the total, is concerned with minority groups is rather remarkable. Those 8 policy issues are distributed amongst 13 conferences, namely: the National Conference for the Promotion of Racial Equality (2005 and 2009), the National Conference for the Rights of the Elderly (2006 and 2009), the National Conference for Gays, Lesbians, Bisexuals, Transsexuals and Transvestites (2008), the National Conference for the Indigenous (2006), the National Conference for Women Public Policy (2004 and 2007) and the Conference for Brazilian Communities Abroad (2008 and 2009). This figure is particularly relevant. It shows that participatory experiments, such as the national policy conferences, are capable of strengthening political representation. This is so because they situate the executive (in charge of summoning and organizing the national conferences) and the legislative (able to convert the demands originating in the conferences into legislative proposals) as spheres of representation not only for political minorities, 
but also for social and cultural minorities - or, more to the point, minority groups whose interests are eventually but not directly taken into account in party politics. The participatory processes such as the national conferences are considered privileged spaces in which those interests can be defined and thereafter reach the elected representatives through other channels, ultimately being able to reconfigure how political parties mediate interests (Pogrebinschi forthcoming).

This piece of information also displays the increasing institutionalization of the national policy conferences: they have become not only extensive and more frequent, but also more wide-ranging and inclusive after 2003 with the beginning of the Lula's government. Since then, national conferences have comprised an increasing number of policy areas and have covered a vast plurality of new issues for public policy design, several of them social and cultural policies targeted at minorities. The contours of these policy areas are defined to a large extent by the particular nature of the minority groups that take part into the national conferences and yet, at the same time, exhibit features that cross-cut and cross over to different policy issues dealt with in various conferences.

The policy guidelines deliberated and approved in the national conferences under the "minority" policy area set aim to respond to the demands of the women (at the national conferences of public policies for women), the indigenous people (at the conference for indigenous peoples), the elderly (at the conferences for the rights of the elderly), the people with disabilities (at the conferences for the rights of persons with disabilities), the gays, lesbians, bisexuals, transvestites and transsexuals (at the conference named so), of children and youth (at the conferences on children and youth rights) of different races and ethnicities (at the conferences for the promotion of racial equality), and of Brazilian communities abroad (at the conferences on Brazilian communities abroad). Such specific minority policy guidelines necessarily touch other public policy areas, such as health, education, social assistance and culture. Hence, starting in 2003, the national policy conferences have become not only wideranging, but more inclusive as well, since, in addition to including increasingly more diverse and heterogeneous social groups traditionally represented by civil society (distributed among NGOs, social 
movements, workers' unions, business entities and other professional or non-professional entities), they have began functioning as spaces in which social and cultural minorities can represent their hitherto fragmented and scattered interests that had not been channeled into other forms of political participation and representation (Pogrebinschi forthcoming).

With an examination of the policy guidelines that have been approved at the end of the deliberation procedures in national public policy conferences, it is possible to notice how these participatory experiments in fact present themselves as spaces that favor the formulation of legislative expectations for the social and cultural minorities. The policy area set classified as "minorities", which comprises, as demonstrated earlier, 9 issues which are further subdivided into 20 conferences (17 of them on 8 issues, taking place after 2003), responds alone for $18 \%$ of policy guidelines which claim for incisive legislative action. This number is quite significant for at least two reasons.

First, because those minority groups have become, during the same period the objects of new secretariats and national councils created in Brazil's federal executive branch with the goal of bringing them closer to the government and designing public policies according to their interests and demands. This is the case, for example, of the Special Secretariat for Public Policies for Women and the Secretariat for the Promotion of Racial Equality, which have been very active alongside national policy councils dedicated to these same issues. One can thus assume that the demands of those groups have been fairly considered by specific administrative measures, which actually seem naturally more suited to the task of designing specific social and cultural policies. It is thus it significant that there is a large number of minority groups demands that still require legislative responses - in other words, a large number of claims for rights and recognition, and a strong indication that there is a persistent need in Brazil to formally include minority groups.

Second, the demands of those minority groups are frequent and, by nature, rather particular and require actions that are somewhat more sector-specific. This is another reason that would explain the need to contemplate these demands through administrative measures, and not legislative ones. The fact that the number of policy guidelines 
classified as part of the "minority" policy area set is almost as large as those relative to the "health" one indicates a tendency towards the dissemination of the demands presented by minority groups. Health is certainly one of the areas which, given the universal nature of its policies, requires its demands to be addressed in the legislative sphere. This explains why a larger number of policy guidelines have been identified for this policy area set, reaching $21 \%$ of the total. Graph 4 presents this data.

Graph 4: Distribution of policy guidelines directed to the Legislative Branch according to policy area sets

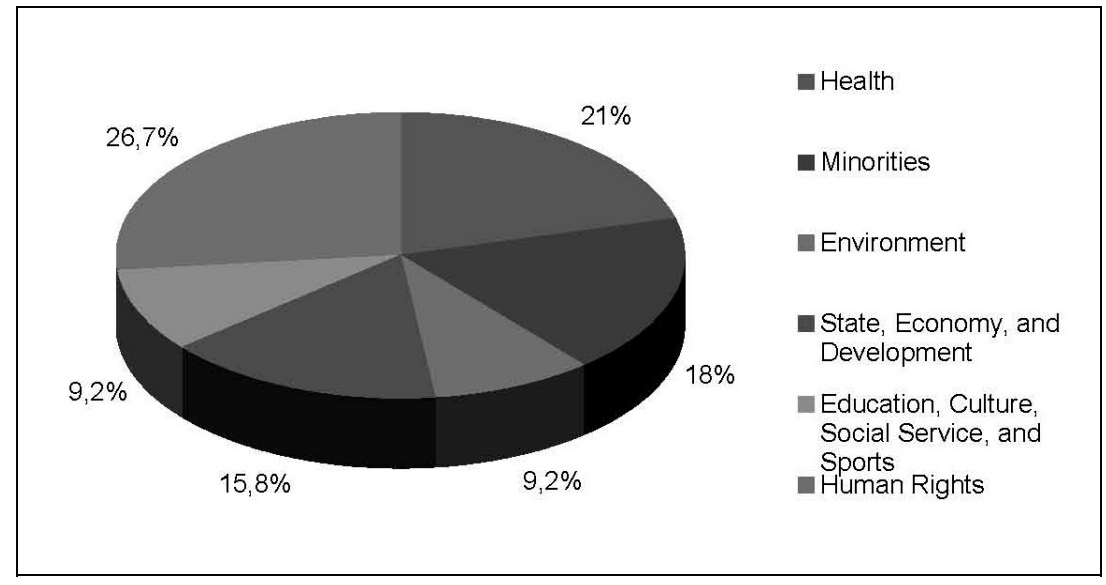

As one can see, by way of the national conferences civil society groups have an important part in public policy design, and play a fundamental role in the process through which political decisions have been taken in Brazil. While transforming liberal democracy from the inside, Brazilian democracy has been allowing for a dialectical relation among state and civil society, whose supposed contradiction might be overcome by the increase of mediations such as the participatory experiments that take place along with representative institutions. The national policy conferences enlarge citizens' and group's direct participation, however that does not mean that the traditional political institutions have become less able to represent them. 


\section{Constitutive Representation and Pragmatic Democracy}

The process of institutionalization at the national conferences on public policy in Brazil reveals these as a participatory experiment that may potentially strengthen political representation. First, the national policy conferences do not present themselves as an alternative side of representative institutions since they have been created within them: it is the executive branch that summon, convene, and organize the national conferences together with civil society organizations involved and affected by the policy area to be deliberated in the conferential process. Second, they do not compete against representative institutions since they act in cooperation with them: the legislative branch has been quite responsive to the demands brought up by civil society in the national conferences (Pogrebinschi/Santos 2010), and the executive has been consistently turning the guidelines deliberated in those participatory practices into policies to be applied in national scale (and this is precisely its purpose when it summons the conferences to convene) (Pogrebinschi forthcoming). Third, they do not imply a parallel type of representation since they do not engender simply "informal" or "social" types of representation: through the national policy conferences, minority groups have a chance to have their interests politically represented through representatives in both the legislative and executive branches that have not been elected by them nor have been elected to represent the type of interests favored by them.

The national policy conferences are thus a case that empirically supports an argument I have been making on a theoretical level (Pogrebinschi 2010a): participation and deliberation should be taken as constitutive parts of representation. In fact, they have always been so - elections, lobby and interests groups are certainly forms of participation, as well as parliamentary commissions and floor activities have always involved deliberation. In the past few years, however, new forms of participation and deliberation have arisen, and although they consistently require the intervention of representative institutions in order to be conclusive, decisional and binding, they are often thought of as pointing to a different (because less representative or indirect) form of democracy. Over the last years there has been significant work done on the representative dimension of both participa- 
tory practices and civil society actors, and particularly on the need to recast and re-theorize political representation in face of the challenges brought about by the participatory and deliberative practices of democracy, among other things (Avritzer 2007; Castiglione/Warren 2006; Mansbridge 2003; Urbinati 2006; Urbinati/Warren 2008).

Such new participatory and deliberative practices certainly avoid the electoral side of representative democracy when they are implemented in civil society, as have been correctly pointed out by several political theorists (Avritzer 2007; Barber 1984; Bohman 1996; Castiglione/Warren 2006; Cohen 1997; Dryzek 2000; Fishkin 1991; Gutmann 1996; Habermas 1998; Manin 1996; Rosanvallon 1998; 2006; Sintomer 2007; Urbinati 2006). However, such practices can only be considered politically representative when they are conclusive, and thus produce decisions on political issues that impact on the political system even if they are not binding. There is yet no other way to do so then through representative institutions and elected representatives. Those, for their turn, have been showing themselves over the last few years as more open and responsive to the participatory and deliberative practices. The most known, successful and replicated case of participation, the participatory budgeting, was after all the product of a specific government, and its implementation and success have been proven to be dependent on the election of certain political parties (Avritzer 2009).

Participatory and deliberative practices of democracy are often linked to civil society's ability to associate, mobilize and coordinate social groups and institutions, as if it were able to govern itself through its own self-empowerment, regardless of the state. The precise role both state and civil society have been playing in the national policy conferences' institutionalization is, however, shaped throughout the process. Even though all conferences are summoned to convene by a normative act issued by the Executive branch, some of them are a clear result of civil society's demands that have been fairly responded by the government. This cooperative undertaking is ultimately what defines which policy areas and issues will be prioritized, and will later possibly become object of the national policy plans and programs to be implemented in Brazil.

However, the political and redistributive effects of participatory experiments can only be undertaken by the state, and it is certainly 
partly the awareness of this fact that has been giving rise to the process of their increasing institutionalization. In Latin America, where participatory experiences proliferate and scale up as to reach the national level, institutionalization seems to be the rule. And this rule is in most of the cases designed and applied by the state, which houses civil society's initiatives and propose new ones along with it. Institutionalized participation is thus something that goes together with the state.

As participatory and deliberative practices become political in their scope and institutionalized in their form, one moves towards a form of constitutive representation. Such kind of representation takes institutionalized political participation and deliberation as its constitutive parts. And it is constitutive representation that lies at the basis of the most recent transformation of representative government, one in which the mediations between state and civil society have been changing so as to also transforms the relationship between those that have at least since the foundation of political modernity been seen as separate spheres.

I do therefore agree with Manin (1996) when he claims that there is historically no crisis of representative democracy, but a metamorphosis of representative government. However, despite his description of the démocratie du public (based on communicative expertise) as its last stage, I believe it is time to go further and recognize another transition not only in the meaning of political representation, but also in the kind of government it implies. That is why I would like to argue that constitutive representation is one of the manifestations of a pragmatic model of democracy.

What I call pragmatic democracy involves both a normative conception of democracy and an analytical approach to comprehending and evaluating it, which, despite its pragmatist inspiration, does not imply any particular conception of democracy endorsed by the thinkers commonly associated to this philosophical tradition. By democracy I understand a form of mediation between the state and civil society, and I assume pragmatism might be a fruitful theoretical tool in explaining the type of relationship between the state and civil society observed in the contemporary world and, particularly, in Brazil. If democracy is a form of mediation between the state and civil society, by pragmatic democracy I understand a mediation which, from a 
normative perspective, is meant to overcome the contradiction between the state and civil society through the suppression of the false dualism between representation, on one hand, and participation and deliberation, on the other one.

More specifically, by democracy I understand an open-ended set of institutions, experiences and practices whose scope is the mediation between the state and civil society. The performance of democracy varies according to how well such mediation functions. Democracy's success, in turn, is measured by how successful the overcoming of the antagonism between the state and civil society is. The more a given institution, experience or practice succeeds in closing the gap between the state and civil society, the greater is its capacity to promote democracy. In other words, the narrower the structural separation and functional differentiation between the state and civil society, the greater the degree of democracy achieved by a given political regime.

The irrefutably normative character of pragmatic democracy is also manifest in the fact that it builds upon a critique of the normative character of contemporary theoretical work on deliberative and participatory democracy with intention of championing a broad conception of political representation that is informed by empirically sustained institutional analyses. Thus, whereas the concept of pragmatic democracy is assumedly normative in its scope, this does not apply to the extent of its range. As much as what I call pragmatic democracy, in its conceptual genesis, is vulnerable to being used as a reference for other equally normative theoretical work on democracy, this does not prevent its employment as an analytical tool useful in describing the behavior of existing institutions and political practices, particularly those in Brazil.

As Brazil's national public policy conferences become increasingly institutionalized, they present themselves as a very relevant mediation between the state and civil society, and one in which participation and deliberation come true as representation. If the propelled crisis of political representation is not extensive to Brazil, perhaps this is the case because the country has been successful in institutionalizing participation and deliberation, which has transformed both politically in scope because they deal with essential political issues and make an impact on the policymaking. Instead of 
a crisis, the country faces a transformation in its representative government, one that moves it away from liberal democracy dualisms (such as state versus civil society, political versus social, universal versus particular, individuals versus groups, representation versus participation), and brings it closer to a pragmatic democracy in which such false contradictions might be dialectically overcome through political experimentalism.

Political experimentalism as a method of pragmatic democracy implies converting facts into norms, practices into institutions, and ends into means. It calls for the political empowerment of social groups by furthering the institutionalization of democratic practices conducted in, for, and through civil society. Experimentalism is the invention of the new and the transformation of the old, the replacement of normativity with factuality. Situated somewhere between the ideals of revolution and reform, experimentalism is politics conjugated in the future perfect tense: contingence renders democracy at once an experience and an experiment.

Applied at the political level, experimentalism requires the adoption of a critical stance towards principles and a practical attitude towards facts. To critically interrogate principles implies substituting action for speculation and contemplation. Facts shall be the driving force behind any political action aspiring social intelligence; these facts aim at creative interventions into the future through the transformation of present conditions, and that implies substituting experimental methods of democracy for the fixity of the liberal principles that for centuries have been shaping it. Facts revise principles, and once they are conferred normative strength one might rely on them as sources of legitimacy for political action. In other words, taking facts as the driving force of political action means assuming the social demands present in each and every context as determinants of institutional choices and decisions. If facts are the bearers of social demands, they must also be the conductors of political and institutional innovations.

Taking political experimentalism as a method requires facts to be heard and to be taken seriously, and such disposition to lead contingency drive political decisions ultimately is conducive to pragmatic democracy. A pragmatic democracy questions the principle of a separation of power, much like what happens when the executive 
branch and the legislature cooperatively define Brazil's policy agenda in convergence with the deliberations that take place in the national policy conferences. A pragmatic democracy challenges the centrality of individual rights when social and cultural groups' rights become a key focus of both policymaking and lawmaking, turning particular demands into universal policies and thus redefining the meaning of political equality. A pragmatic democracy interrogates the electoral foundation of liberal democracy, allowing interests to bypass the party system and achieve representation in the legislature through participatory institutions. A pragmatic democracy redefines representation as the main political mediation by institutionalizing participation and deliberation. And, finally, a pragmatic democracy redesigns institutions in such a way as to blow the separation of state and civil society, as it happens when the latter act along with the state, and achieves that from within it.

Once endorsing constitutive representation, a pragmatic democracy must also experiment with forms of accountability that go beyond elections, democratic criteria other than the majority rule, and legitimating mechanisms able to transcend both by privileging ex post assessments (that is, assessments based on the consequences of decisions) rather than ex ante assessments (based on the choices of the decision maker). Political experimentalism makes it possible to deal with the problems of justification, evaluation and legitimacy of democracy on the basis of the consequences engendered by the actions of institutions and political actors. The true parameters for gauging democracy become the desirability, feasibility and acceptability of such consequences. That, in turn, brings one closer to a realistic practice of democracy, and not an idealized version thereof.

This approach must be further developed in order to account for the fact that Brazil's national policy conferences allow all those citizens and groups who are affected by the design of public policies and share the consequences of their implementation to have their interests represented in political institutions, despite their choices in a previous election. The conference process has been legitimizing itself as a democratic method through the positive effects it have been producing on political institutions, and this can be especially measured by the introduction of new areas and issues dealt with in 
policymaking, and by the inclusion of new groups and demands in the lawmaking.

Such cooperation among state and civil society, representative institutions and participatory practices, presents the national policy conferences as a method of pragmatic democracy in which social ends might be successfully realized through democratic experimental means. By bringing civil society within the state, the national public policy conferences shall be taken as both a form of deepening democracy and democratizing policymaking. The national level practices of participation in Brazil seem to be a very fertile soil where the germination of participation can lead to the blossoming of representation. Let the contingency of contemporary world tell us how liberal democracy can be definitely and decisively challenged by such experimental way of doing politics. And let Brazilian reality keeps teaching us lessons on that.

\section{References}

Avritzer, Leonardo (2007): "Sociedade Civil, Instituições Participativas e Representação: da Autorização à Legitimidade da Ação". In: Dados (Rio de Janeiro), 50, 3, pp. 443-464.

- (2009): Participatory Institutions in Democratic Brazil. Baltimore: Johns Hopkins University Press.

Barber, Benjamin (1984): Strong Democracy: Participatory Politics for a New Age. Berkeley: University of California Press.

Bohman, James (1996): Public Deliberation. Pluralism, Complexity, and Democracy. Cambridge: MIT Press.

Castiglione, Dario/Warren, Mark (2006): "Rethinking Democratic Representation: Eight Theoretical Issues". Manuscript prepared for delivery at the Centre for the Study of Democratic Institutions, University of British Columbia.

Cohen, Joshua (1997): "Deliberation and Democratic Legitimacy". In: Bohmann, James/Rehg, William (eds.): Deliberative Democracy. Essays on Reason and Politics. Cambridge: MIT Press, pp. 67-91.

Dewey, John ([1937] 1998): "Democracy is Radical". In: The Essential Dewey. Vol. I: Pragmatism, Education, Democracy. Bloomington: Indiana University Press, pp. 337-339.

Dryzek, John S. (2000): Deliberative Democracy and Beyond. Oxford: Oxford University Press.

Fishkin, James (1991): Democracy and Deliberation: New Directions for Democratic Reform. New Haven: Yale University Press. 
Fung, Archon/Wright, Erik Olin (2003): Deepening Democracy: Institutional Innovations in Empowered Participatory Governance. London: Verso.

Gutmann, Amy (1996): Democracy and Disagreement. Cambridge: Harvard University Press.

Habermas, Jürgen (1998): Between Facts and Norms. Contributions for a Discourse Theory of Law and Democracy. Cambridge: MIT Press.

Manin, Bernard (1996): Principes du Gouvernement Représentatif. Paris: CalmannLevy.

Mansbridge, Jane (2003): "Rethinking Representation". In: American Political Science Review, 97, 4, pp. 515-528.

Pogrebinschi, Thamy (2010a): Relatório Final da Pesquisa "Entre Participação e Representação: as conferências nacionais e o experimentalismo democrático brasileiro". Brasília: Ministério da Justiça.

- (2010b): "Democracia Pragmática". In: Dados, 53, 3, pp. 657-693.

- (2012): "Participation as Representation. Democratic Policymaking in Brazil". In: Cameron, Max/Hershberg, Eric/Sharpe, Kenneth: New Institutions for Participatory Democracy in Latin America. Voice and Consequence. Houndmills, Basingstoke: Palgrave Macmillan, pp. 53-75.

- (forthcoming): “Turning Participation into Representation: Innovative Policymaking for Minority Groups in Brazil". In: Sirianni, Carmen/Girouard, Jennifer (eds.): Varieties of Civic Innovation: Deliberative, Collaborative, Network, and Narrative Approaches. Nashville: Vanderbilt University Press. Forthcoming.

Pogrebinschi, Thamy/Santos, Fabiano (2010): "Participation as Representation: The Impact of National Public Policy Conferences on the Brazilian Congress". APSA 2010 Annual Meeting Paper.

Rosanvallon, Pierre (1998): Le people introuvable. Histoire de la representation démocratique en France. Paris: Gallimard.

- (2006): La contre-démocratie. La politique à l'âge de la defiance. Paris: Seuil.

Sintomer, Yves (2007): Le pouvoir au peuple. Jurys citoyens, tirage au sort et démocratie participative. Paris: La Découverte.

Urbinati, Nadia (2006): Representative Democracy: Principles and Genealogy. Chicago: Chicago University Press.

Urbinati, Nadja/Warren, Mark (2008): “The Concept of Representation in Contemporary Democratic Theory". In: Annual Review of Political Science, 11, pp. 387412. 
2. Activismo judicial: eficacia y legitimación 



\section{Martín Aldao \\ Teorías de la democracia y activismo judicial ${ }^{*}$}

\section{Introducción}

Los movimientos sociales se articulan, en general, en torno a demandas no satisfechas por el sistema político y jurídico. A su vez, y en tanto el derecho, en democracia, pretende operar como garantía de la igual autonomía pública y privada de todos los individuos, la existencia misma de estos pone de manifiesto un déficit de comunicación entre lo que podríamos denominar una esfera pública estatal -entendida en términos de administración- y una esfera pública política - entendida en términos de ciudadanía- en el marco de los exigentes presupuestos normativos de los estados democráticos de derecho. Ahora bien, una vez que los canales tradicionales de participación política aparecen obturados, ¿de qué modo logran estas formas de participación política un acceso a la esfera pública? Si bien el control de constitucionalidad puede parecer un buen candidato para cumplir provisoriamente este rol, la comprensión política de la jurisdicción implicada en este enfoque enfrenta una serie de objeciones conceptuales vinculadas a la comprensión de lo público, de la democracia y de la igualdad en el plano político, y a la naturaleza de los derechos humanos y al papel del control de constitucionalidad en el plano jurídico. Estos son los problemas que me propongo abordar en este artículo.

* Agradezco a Laura Clérico y Ernesto Fabián Mieles González por sus comentarios previos a la presentación y a los asistentes al seminario por sus comentarios durante la misma. 


\section{Fricciones entre las concepciones predominantes de la democracia y la participación política de los movimientos sociales}

\subsection{Teoría política}

En primer lugar es preciso trazar una serie de distinciones conceptuales en lo que atañe a la comprensión del Estado, de la democracia y de la ciudadanía para obtener una mejor comprensión del rol de los movimientos sociales dentro del marco del estado democrático de derecho En particular se intentará distinguir dentro del ámbito público aquello que corresponde a la participación política y aquello que corresponde a la administración pública propiamente dicha, con el objetivo de dar cuenta de una realidad (la de los movimientos sociales) que no corresponde ni a la administración pública ni a lo que habitualmente se entiende como sector privado. Luego se diferenciará representación política de autogobierno con el objetivo de resolver los cuestionamientos vinculados a la legitimidad democrática de los movimientos sociales. Por último se ponen en cuestión los elementos homogeneizadores de los principales modelos de la democracia deliberativa, que en alguna medida siguen atrapados en una comprensión monolítica de lo público, que impide comprender el carácter muchas veces focalizado de la actividad de los movimientos sociales.

\subsubsection{Estado y esfera pública}

En primer lugar es preciso analizar el proceso a través del cual se conjugan una esfera pública entendida en términos de administración estatal y otra entendida en términos de democracia. Con ese objetivo voy a retomar la periodización propuesta por Günter Frankenberg, en el medida en que permite distinguir las diferentes formas jurídicas que adoptan las nociones de público y de privado (Frankenberg 1998).

La esfera pública adquiría el rol que le atribuimos hoy en día en los comienzos de la Modernidad. En la medida en que los enfrentamientos religiosos habían dado por tierra con la fundamentación teológica del ordenamiento político, esta se traslada al soberano absoluto. En esta primera etapa el Derecho Público se encuentra constituido en torno de las prerrogativas de la corona, las relaciones entre el Estado y la Iglesia, y del Rey con sus súbditos. Ocupa un lugar preponderante respecto del Derecho Privado y tiene su legitimidad 
en la figura del Rey. En este período el Derecho Privado tendría un papel marginal, siempre sujeto a la revisión del soberano y limitado por los intereses de este. Es sobre esta nueva base que se colocan los cimientos del moderno Derecho Público. La esfera privada contra la que se yergue el Estado como nueva esfera pública predominante es todavía una confusa mezcla de los antiguos privilegios feudales y de los derechos reclamados por la naciente burguesía, que en principio apenas comparten un ambiguo derecho de propiedad. Se trata de pacificar y organizar las múltiples fuerzas que, disgregadas en el territorio de la nación, pugnan entre sí por imponer sus intereses. El modelo de Hobbes resulta especialmente adecuado para comprender este proceso puesto que el soberano se constituye a través de la absorción de las facultades feudales, que habían adquirido rasgos privados durante el medioevo (Habermas 2004: 43). La imposición efectiva del Estado como máximo regulador de la sociedad ya no puede remitir su legitimidad a una voluntad divina, y sólo puede manifestarse a través de un Derecho Público que es, fundamentalmente, transaccional. En este período los principales brazos de un Derecho Público unificado consisten en la organización de una burocracia dependiente del gobierno central, un sistema impositivo relativamente centralizado y el establecimiento de un brazo armado regular que permite el monopolio de la coacción. De este modo queda cristalizada una esfera pública que funciona como cabeza de la nación. Este rol preponderante se manifiesta de dos modos que deben ser distinguidos. Por un lado se constituye en sede de la soberanía, la cual, a través de la razón de Estado, se impone como instancia última de decisión en un territorio determinado. Por otro lado, en el proceso de organización y centralización de competencias, la esfera pública estatalizada toma a su cargo la administración de los recursos de la nación. ${ }^{1}$ Como muestra Foucault (2005: 373 y ss.), las potestades de soberanía y administración deben ser analizadas por separado. El poder de dar la muerte y de declarar el estado de excepción corresponde a la primera y ponen de manifiesto el carácter omnipotente de lo público. La capacidad de regular el intercambio, la producción y

1 Si bien con el surgimiento de nuevas técnicas agrícolas, acompañadas por los procesos de enclosures, se empieza a producir también una serie de cambios en el ámbito privado, estos producirán sus efectos más importantes en el período siguiente. 
la salud corresponden a la segunda y resaltan, por el contrario, la dependencia de la esfera pública respecto de la privada, en la medida en que la prosperidad de lo privado funciona como patrón de eficacia de lo público. Y es la búsqueda de prosperidad lo que prepara el camino para el pasaje al modelo limitado del Estado constitucional liberal. $^{2}$

Con el surgimiento de la burguesía como clase económica y políticamente relevante, se invierte la relación entre esfera pública y privada característica del período anterior. El Derecho Privado va a ir ganando preponderancia en la regulación de una sociedad que se ve a sí misma como autosuficiente. El contrato, la autonomía de la voluntad y la libre concurrencia son las principales características de un Derecho Privado que se impone en clave polémica con el Derecho Público. Este, a su vez, se ve recluido en el Derecho Constitucional -concebido fundamentalmente como un límite a las prerrogativas del soberano- y a la regulación de la creciente administración estatal (Frankenberg 1998). Con el objeto de comprender este período puede resultar de utilidad recurrir a la distinción habermasiana de dos liberalismos (Habermas 2004: 167). Así como el Estado moderno sólo pudo constituirse a partir de una racionalidad propia (la razón de Estado), la burguesía requirió del desarrollo de la economía política para poder oponer sus derechos (privados) a la soberanía (pública) de la Corona. Como resulta evidente de la necesidad de desarrollar procesos constitucionales, las prerrogativas del individuo aparecen ya desde el comienzo dependiendo de su reconocimiento por una esfera pública estatal preexistente. Como muestra Habermas (2004: 112), la sociedad burguesa se desprende de las ataduras corporativas amparándose en la majestad administrativa del soberano forjada en el período anterior. En segundo lugar, el naciente Derecho Privado surge con un universalismo tal que le imprime la forma de Derechos Fundamentales. En este sentido, tanto el Bill of Rights como la Déclaration des droits de l'homme et du citoyen surgen en clave polémica con los privilegios feudales así como con la soberanía de la Corona, más identificados con una todavía

2 Pero al mismo tiempo, el poder absoluto de lo público es justo aquello que, una vez encarnada la esfera público política en el Estado a través de los recientes procesos de democratización, va a autorizar la restricción de las libertades liberales desarrolladas en el período que sigue. 
ambigua idea de libertad individual que con la prerrogativa de la propiedad privada, que apenas constituye un signo y un instrumento de aquella libertad. Será recién con los procesos de industrialización, acumulación del capital y aumento del pauperismo que la legislación y la jurisprudencia irán reconfigurando la esfera privada en términos de privilegios, vedados tanto al Estado como al resto de los individuos, en lo que vendría a ser una segunda forma del liberalismo. Es importante captar esta configuración superpuesta del Derecho Privado como estructura de la libertad y de los privilegios, dependiente del reconocimiento estatal. En tanto estructura de la libertad permite dar cuenta de las reticencias a abandonar los esquemas liberales en el derecho; en tanto estructura del privilegio, el motivo por el cual aquellos ciudadanos que se sienten desplazados de sus derechos tienden a volcar sus demandas al Derecho Público en términos de restricción de libertades privadas de las que no pueden gozar. ${ }^{3}$

Las declaraciones de derechos, acopladas a la comprensión liberal de la sociedad, sancionaron junto a la libertad, la igualdad ante la ley y la seguridad, el derecho de propiedad tal como aparentemente había sido concebido por los romanos. Esto es cierto, pero relativo. La conceptualización moderna de la idea de individuo carece de los severos límites comunitarios a los que se encontraba sujeta durante la antigüedad y el medioevo. Así como el pater familias tenía una serie de responsabilidades socialmente impuestas, el innegable despotismo del señor feudal se encontraba inmerso en el sistema de dones y contradones, atado a una infinidad de compromisos hacia arriba y hacia abajo que impedían sistemáticamente la acumulación indefinida de potestades. Un vez que el soberano absoluto hubo concentrado sobre sí el grueso de las potestades públicas, era cuestión de tiempo para que se produjera un cambio análogo en el ámbito privado. Así en Inglaterra surgen las primeras instituciones del derecho burgués, a saber, la sociedad de carácter capitalista, el crédito real, el papel-valor, elementos de derecho mercantil y de navegación, y los cuerpos reguladores de la explotación minera, así como también de la libre concurrencia mercantil. Más adelante, en 1794 se sanciona en Alemania el Allgemeines Landrecht, en 1804 el Code Civil francés y en 1811 el

3 Que se traduciría en el enfrentamiento entre democracias liberales y populistas. 
Allgemeines Bürgerliches Gesetzbuch en Austria (Habermas 2004: 111).

El proceso es, sin embargo, gradual, y recién hacia el siglo XIX se termina de desplazar el eje de la propiedad desde la comunidad familiar hacia el propietario individual (Habermas 2004: 113). De este modo queda configurada una esfera privada neutralizada respecto del poder, puesto que el mercado es la libre concurrencia de los individuos productores; y aparentemente emancipada respecto de la dominación, puesto que las intromisiones estatales interrumpen y obstaculizan el libre desarrollo de la sociedad civil (Habermas 2004: 115). Es así que los criterios rectores del Estado liberal de derecho son la libre concurrencia en el ámbito privado y la legaliformidad en el ámbito público. En última instancia se trata del modelo que había prefigurado Hobbes, compuesto por una multitud de individuos atomizados respecto de la sociedad y sometidos a una esfera pública cuya función principal es el mantenimiento de un sistema de reglas bien definidas.

Ya en el siglo XX el desarrollo del capitalismo industrial, el intervencionismo estatal y el fortalecimiento de un movimiento obrero enfrentado con el paradigma del libre mercado convergen para producir un renacimiento del Derecho Público que, si bien sigue siendo en alguna medida la expresión de la voluntad del soberano, poco tiene que ver ya con aquella omnímoda voluntad del Leviatán que Hobbes reclamaba para el absolutismo. De este modo se produciría una transformación jurídica en tres planos: a través de una recomprensión del Derecho Constitucional en términos democráticos, del fortalecimiento del rol de un parlamento representativamente integrado y del reconocimiento del individuo como ciudadano (Frankenberg 1998). Bajo la forma de "oleadas" se introducen en los Estados modernos las instituciones del voto universal, el derecho del trabajo y de la seguridad social y los derechos humanos entre otros, que reclaman por un lado el sometimiento del Estado al mandato popular y por el otro la limitación de las potestades individuales surgidas en torno del derecho de propiedad tal como había sido instituido en el período anterior. Junto a una sociedad mercantilmente configurada en oposición al Estado surge una sociedad política, informalmente representada en la opinión pública pero que en última instancia desemboca en las resoluciones de los cuerpos legislativos. De este 
modo se configura una esfera pública mediadora entre la sociedad y el Estado que tendría la función de garantizar las libertades clásicas liberales (nucleadas en torno del derecho de propiedad), pero reformuladas en términos, no ya de privilegios, sino de aspiraciones sociales, que podríamos denominar esfera público-política propiamente dicha, y que se distingue, por sus presupuestos, su estructura, su dinámica y sus objetivos del Estado moderno.

\subsubsection{Concepciones de la democracia}

Análogamente, el proceso de producción del derecho en las sociedades contemporáneas se asienta sobre la superposición de dos modelos teóricos radicalmente distintos. Por un lado el complejo coactivo administrativo del Estado moderno, y por el otro el idealizado autogobierno de los griegos. De este modo se superpone una lógica de la soberanía, que funciona sobre el presupuesto según el cual el conjunto de los individuos que integran la sociedad son incapaces de alcanzar un acuerdo estable y duradero sin la presencia de un tercero ajeno al conflicto $-\mathrm{y}$ por ende trascendente respecto de una sociedad que es pensada como intrínsecamente conflictiva-; y por el otro una lógica del autogobierno, que opera sobre el presupuesto según el cual la autonomía de cada individuo posee idéntico valor, y por ende que el único modo legítimo de imponer límites a las conductas de los hombres es a través de la participación de los mismos en la determinación de las reglas según las cuales deben organizarse (Sieckmann 2003). Es en torno al problema de cómo ha de insertarse la democracia dentro del aparato del Estado que ha surgido el paradigma representativo.

El mecanismo representativo tiene la función de introducir la voluntad de la ciudadanía en el aparato del Estado a través del proceso electoral. En este sentido la elección periódica de gobernantes y legisladores garantiza un mínimo de influencia ciudadana, y por ende de legitimidad, en las estructuras políticas que regulan la existencia de la sociedad a través de la competencia electoral. Así es que las leyes vigentes, en un idealizado circuito de transmisión de la voluntad popular, reciben su autoridad de los legisladores democráticamente elegidos a través de las urnas. Una concepción tal de la democracia ubica en el parlamento el locus privilegiado de la expre- 
sión de la voluntad popular. Tal como fuera pensado por Sieyes, el modelo representativo garantizaba la traducción de la voluntad general de la nación en la ley, de modo tal que la asamblea legislativa queda convertida en supremo árbitro de la legitimidad del derecho.

Si bien en sus orígenes se esperaba de este modelo la gradual democratización efectiva de la sociedad, y aún cuando es preciso reconocer que ha permitido realizar algunos progresos en este sentido, lo cierto es que la representación se ha convertido en un cuello de botella que impide la efectiva representación de una multiplicidad de intereses que surgen de la sociedad. La gradual alineación de los políticos profesionales respecto de la ciudadanía y la autonomización del sistema político, así como también el desarrollo de grupos de interés que gozan de un acceso privilegiado al poder legislativo, han terminado por distorsionar de tal modo el rol del parlamento al punto que hoy resulta poco razonable afirmar que representa los efectivos intereses de la ciudadanía. ${ }^{4}$

En este contexto de incapacidad del poder legislativo para representar de modo efectivo a la ciudadanía surge el paradigma deliberativo de la democracia, a través del cual se busca reconducir al parlamento hacia su rol original de portavoz de la ciudadanía.

El trabajo de Habermas comienza mucho antes de lo propiamente político, con una crítica de la concepción tradicional del sujeto y del conocimiento, y la posterior elaboración de una ética discursiva que, intentando escapar de las aporías de la metafísica de la modernidad, se aferra no obstante a algún tipo de racionalidad. El primer paso consiste en despegar la argumentación práctica de la pesada herencia descriptivista (que compartirían tanto las tesis objetivistas como las escépticas) a través de la formulación del problema desarrollada por S. Toulmin: en cuestiones morales, la pregunta no debe formularse en términos de adecuación a valores, sino más bien de acuerdo al peso de las razones esgrimidas por una y otra posición (Habermas 1985:

4 El nivel de degradación del ideal democrático en su versión representativa resulta bien visible en los trabajos de Popper o Schumpeter, quienes, con el objetivo de salvar la idea de democracia representativa han propuesto interpretaciones claramente desencantadas de los procesos políticos democráticos, pero que no obstante retienen algo de aquella originaria voluntad del pueblo. Así ambos se refugian en las posibilidades que el proceso electoral ofrecería para deshacerse de aquellos representantes que no respondan a la voluntad de la ciudadanía (D’Auria 2004). 
72). Se reemplaza, entonces, una "razón práctica" por una "racionalidad comunicativa" (Habermas 2005: 71) en la cual la verdad moral ya no es ni un lugar fijo al que aproximarse, ni una utopía inalcanzable, sino más bien un presupuesto que es exigido por la comunicación (Habermas 1985: 104). Este camino procedimental permite a Habermas rechazar los principios morales dogmáticamente establecidos en los que descansan las éticas tradicionales (Habermas 1985: 111). Este paso resulta central en la medida en que introduce la participación de los implicados (en este caso, la ciudadanía) como algo más que una mera mejora epistemológica, en el orden de las condiciones de posibilidad de la racionalidad política.

En este sentido, el proceso democrático entendido comunicativamente dota al Estado de derecho de una legitimidad fundada en la formación de la opinión pública, retomando la importancia que al primero le da el liberalismo clásico, y a la segunda el republicanismo. Esta conceptuación del procedimiento democrático lo ubica tanto dentro como fuera del Estado y permite captar el proceso por el cual la legislación transforma la deliberación pública (en sentido amplio) en poder utilizable administrativamente (Habermas 2005: 375). La racionalización es, entonces, más que mera legitimación (liberalismo) y menos que constitución del poder del Estado (republicanismo). Tomando de la epistemología la distinción entre contexto de justificación y contexto de descubrimiento, Habermas ubica a la deliberación institucionalizada en el primero y a la formación informal de la opinión pública en el segundo (Habermas 2005: 384). El derecho es introducido, entonces, como el puente que permite comunicar la idealizada "sociación" comunicativamente pura y las sociedades complejas efectivamente existentes (Habermas 2005: 405). La democracia se justifica, entonces, en la medida en que permitiría evitar la autonomización del sistema administrativo (el Estado) y lo orienta a limitar el mercado. De este modo logra reconstruir el proceso político de un modo que puede dar cuenta tanto de las acciones estratégicas (orientadas hacia los propios fines y predominantes en el mercado y en la burocracia política) como de las acciones comunicativas (que impregnan el mundo de la vida y constituyen el elemento legitimante del Estado democrático de derecho) (Habermas 2005: 416). 


\subsubsection{Deliberación y desigualdad estructural}

El modelo de Habermas deja sin responder, sin embargo, la pregunta por los modos concretos en que los impulsos comunicativos del mundo de la vida que constituyen la "fuente" de la justicia y la legitimidad del derecho (Habermas 2005: 221, 238, 252, 257) se harían efectivos, en la medida en que queda atado a conceptos normativos excesivamente abstractos y a requisitos de funcionamiento óptimo poco menos que utópicos (Jorba Galdós 2006: 51). De este modo la soberanía popular queda desdibujada en una esfera pública sin forma ni contenido constante (Jorba Galdós 2006: 57). Aquello de lo que Habermas no da cuenta en su "idealización" del ideal de una esfera pública burguesa -universalmente accesible, racional y ajena a las diferencias de clase-, es que esta se construye ya a partir de una serie de exclusiones.

Desde esta perspectiva el reconocimiento de los espacios públicos autónomos demanda modificaciones estructurales en el espacio público-político institucionalizado (el parlamento), de modo tal que la unidad de este último no obture las desigualdades estructurales a las que se encuentran sometidos los primeros. Tras la aparente universalidad de una única esfera pública comprehensiva de toda la ciudadanía, se desarrollaría en realidad un debate supervisado por aquellos grupos que resulten socialmente dominantes (Fraser 1990: 66). De este modo la estimulación de contra-públicos subalternos permitiría extender el espacio discursivo del que surgen las leyes. Los problemas, los valores, los intereses -en última instancia, el vocabulario- a partir del cual se construye el derecho no son meros insumos para la formación de opinión, sino que juegan además un papel fundamental en la formación de identidades (Fraser 1990: 68). Si tomamos en cuenta la importancia del derecho en la formación de las condiciones a través de las cuales se facilita, o bien se obstaculiza, la expresión de los espacios públicos autónomos, entonces una fragmentación del espacio público productor del derecho parece necesaria para garantizar la retroalimentación comunicativa a la que debe estar sujeta el parlamento (Young 1989: 258). En otros términos, que una concreción de los presupuestos democráticos de los Estados de derecho contemporáneos requiere no sólo de la aceptación estatal de los contrapúblicos subalternos, sino también de la adecua- 
ción del modo de producción del derecho legítimo, de modo tal que se reduzcan las distorsiones producidas por los poderes sociales y se evite al mismo tiempo la tendencia a obturar todos aquellos discursos que históricamente se han visto excluidos de la producción del derecho.

Esto implica también una reformulación del concepto de ciudadanía, que ya no parece caber dentro del uniformador ideal de una esfera público-política omnicomprensiva (tal como la imaginara Kant), en la que se disolverían todas las diferencias de clase, género y cultura. Por el contrario, es preciso diseñar nuevos dispositivos de transmisión y aplicación -esto es particularmente importante si se quiere evitar un mero retorno al corporativismo- de la voluntad política de los ciudadanos, de modo tal que puedan adecuarse a las particularidades de cada grupo.

\subsection{Teoría jurídica}

La dogmática jurídica ofrece, no obstante, algunas herramientas que podrían servir para resolver los problemas planteados en el ámbito de la teoría política. En particular una recomprensión del derecho que permita despegarlo de las instancias tradicionales de interpretación, o en otros términos, "ablandarlo" a fin de que pueda ser apropiado por los movimientos sociales. En segundo lugar, una reconstrucción del recurso al control de constitucionalidad no ya en términos de control de poderes dentro de la esfera del gobierno, sino como una instancia paralela de producción del derecho, democráticamente legitimada. En último lugar, se expone el dispositivo del jurado constitucional, entendido como un paso más en lo que podríamos denominar desalienación del derecho respecto de la ciudadanía (Gargarella 2007: 205 y ss.).

\subsubsection{Los derechos humanos desde una perspectiva normativa}

Si bien estas consideraciones probablemente puedan extenderse a otros ámbitos del derecho, voy a centrarme en el derecho internacional de los derechos humanos (DIDH) en la medida en que parece ser un buen candidato para las intervenciones jurídicas de los movimientos sociales. Habitualmente, y esto no carece de consecuencias, la cuestión de la naturaleza normativa del DIDH parece ocupar un 
lugar preponderante en la discusión, ya sea de modo explícito (porque se la expone) o tácito (porque se la da por sentada). Concebir el DIDH como un catálogo de derechos, válidos por sí mismos, a través de los cuales se sintetiza el "conocimiento moral" de occidente tiene la evidente ventaja de proporcionarnos un marco normativo claro a través del cual sería posible zanjar con relativa eficacia las cuestiones relativas a la vigencia de los derechos humanos. Esta perspectiva, no obstante, presenta diversos problemas. En primer lugar resulta cuanto menos dudoso que sea posible identificar, con un razonable nivel de precisión, un conjunto de valores morales objetivos y universalmente válidos. Todos los intentos realizados en ese sentido, desde la antigüedad griega hasta nuestros días, no sólo han conducido a la justificación de aquello que los sectores dominantes de una sociedad identificaban como lo bueno, sino que además produce numerosas aporías en sociedades cultural, social y económicamente heterogéneas como las nuestras, en las cuales el respeto por las autonomías individuales y colectivas intenta reemplazar el ímpetu homogeneizador característico de la modernidad occidental (Young 1989: 250). Por otro lado, parece claro que una concepción tal del DIDH se asienta en una comprensión monológica de la racionalidad, puesto que el criterio para determinar el correcto funcionamiento de los sistemas políticos locales se fundamenta en el grado de adecuación de los mismos a estos "ideales", evaluación habitualmente delegada en expertos internacionales. Íntimamente vinculado con lo anterior, una comprensión tal del conjunto de atribuciones que compondrían la "dignidad humana", tiene el indeseable efecto secundario de obscurecer el funcionamiento de la democracia, privilegiando la función del representante $\mathrm{y}$, en consecuencia, debilitando el rol de la autonomía del ciudadano y minando en consecuencia el respaldo efectivo de las instituciones democráticas. Por último, la consideración del DIDH en términos absolutos, si bien parece adecuada a su positivización en el derecho internacional y en los textos constitucionales, no alcanza a dar cuenta de las instancias de interpretación y efectivización de los mismos.

Por el contrario, entiendo que el punto crucial en la discusión sobre el alcance y la validez de los derechos humanos, y en particular de las normas que les dan cuerpo, consiste en desprendernos de la pesada herencia platónica que nos conduce a identificar lo justo de 
acuerdo a su mayor o menor correspondencia con un ideal objetivo (Habermas 1985). En ese sentido es necesario desarrollar una defensa de los derechos humanos cuya robustez no radique tanto en el alcance de los mismos, sino en su fundamento de legitimidad, esto es, en la participación informada de la ciudadanía. En otros términos, que se asiente en una comprensión igualitaria y no paternalista de la sociedad. Esto no implica renunciar a la defensa de un cuerpo robusto de derechos, sino más bien un cambio de perspectiva en su defensa. Si los derechos humanos son importantes, y deben ser respetados, no es porque sean justos o buenos en sí, sino porque hay buenos argumentos para sostenerlos, en un contexto en el cual la bondad o fortaleza de los argumentos depende de su capacidad para ser apropiados por los ciudadanos. Esta postura no apunta, sin embargo, a desconocer los déficits de reconocimiento que se verifican en nuestras sociedades sino más bien a que estos sólo pueden ser resueltos, de un modo duradero, a través del incremento de las instancias de participación, en lugar del recurso a una suerte de "despotismo ilustrado", en el cual le cabe a los técnicos y a las autoridades un papel preponderante en la resolución de los problemas de la población.

De este modo la teoría del discurso nos permite evitar la trampa del platonismo, sin por ello forzarnos a caer en un subjetivismo moral generalizado. Esta perspectiva implica, y esto tampoco carece de consecuencias, poner en primer plano la cuestión de la racionalidad. Entendida en términos de argumentación intersubjetiva, la racionalidad propuesta por la teoría del discurso nos permite reemplazar el criterio de la adecuación por el más flexible y realista criterio de la argumentación racional. Así, el DIDH deja de operar como fuente de los valores normativos, aunque pueda preservar su papel como fuente de obligaciones para los Estados -y esta distinción resulta de la mayor importancia-, pasando a ser el saldo provisorio -aunque no por ello menos obligatorio- de un debate universal respecto del contenido y los alcances de aquellas atribuciones que consideramos imprescindibles de la dignidad humana. Esta perspectiva nos proporciona, además, otras dos ventajas. En primer lugar refuerza el papel de los individuos en la interpretación y aplicación del DIDH, permitiendo la reapropiación de este por aquellos para quienes fue creado -los afectados-. En segundo lugar, permite habilitar las instancias para su adaptación cuando esta fuese 
necesaria por un conflicto de identidades, ofreciendo una salida razonable para aquellos que, desde la perspectiva del multiculturalismo -y con buenas razones-, han aprendido a desconfiar de los monolíticos valores occidentales.

Todo esto no implica, sin embargo, desconocer el peso del DIDH en la argumentación constitucional, puesto que, en tanto derecho positivo, no sólo constituye una fuente de obligación para los Estados, sino que además goza de una validez prima facie en tanto determinaciones de los contenidos y alcances de las nociones nucleares de autonomía pública y privada de los individuos, sobre las que se asienta y desarrolla la estructura normativa del Estado democrático de derecho. Nos evita, sin embargo, caer en dogmatismos normativos, que tienden a confundir lo que alguna vez fue justo para un relativamente reducido grupo de representantes, con aquello que es justo para todos y cada uno de los habitantes del planeta.

Planteado el problema en estos términos, pierden preponderancia las cuestiones relativas a una ingeniería constitucional mundial, frente a la cuestión del establecimiento de instancias de participación ciudadana en la resolución de cuestiones relativas al DIDH. Y es en este punto en donde una reconstrucción participativa de la argumentación constitucional permite un testeo deliberativo de la determinación de los contenidos, alcances y vigencia del DIDH por parte de los movimientos sociales. Sin embargo, una recomprensión como la propuesta del DIDH nos enfrenta con los problemas de la indeterminación y falta de efectividad que tradicionalmente se oponen a las perspectivas deliberativas. Es en este contexto que el principio de proporcionalidad, estructurado a través de los parámetros formales del modelo de la ponderación, nos devuelve algunas de las certezas a las que renunciamos al abandonar la concepción centralizada del DIDH.

\subsubsection{Argumentación constitucional y participación política}

En lo que respecta al litigio la argumentación constitucional nos ofrece una conexión directa con el paradigma deliberativo de la democracia. La vinculación del modelo de la ponderación con la comprensión deliberativa de la democracia viene dada ya por su común asentamiento sobre los presupuestos de la racionalidad discursiva, de 
modo tal que el eje de la validez se desplaza desde la decisión racional (orientada a la maximización del beneficio individual) hacia la argumentación (orientada al establecimiento de acuerdos comunes). Esto no implica, sin embargo, el desconocimiento de actitudes estratégicas, sino su sujeción a la pretensión de corrección. A su vez, esta sólo puede articularse a través de las reglas del discurso práctico racional, fundamentalmente la exigencia de participación en la argumentación de todos aquellos implicados en las consecuencias de este debate (Alexy 2006).

El punto crucial, desde esta perspectiva, es que una argumentación productora de normas vinculantes no puede ser una mera argumentación sobre los afectados, sino que debe ser una argumentación con ellos (Alexy 2006). Visto desde este ángulo el fundamento de legitimidad de las normas en un Estado de derecho democrático no radica en la libre interpretación del texto constitucional por los representantes, sino en el consentimiento, expreso o tácito, de la ciudadanía. Es en este sentido que Alexy distingue entre un aspecto volitivo y otro discursivo de la representación democrática (Alexy 2003: 59-76). De este modo, junto a la representación política tradicional que le cabe al parlamento, resulta plausible hablar de una representación argumentativa que podría caberle a los tribunales siempre y cuando cumplan una serie de condiciones relativas no sólo a la argumentación desplegada, sino también a la inclusión de las partes en los procesos argumentativos (Sabel/Simon 2004).

Desde esta perspectiva la aplicación del modelo de la ponderación puede ofrecer cuando menos dos ventajas en términos de democratización del sistema político. En primer lugar permite explicitar el rol político de los tribunales en lo que atañe a la interpretación de las normas de DIDH, de modo tal que se debilita el monopolio simbólico del poder legislativo sobre las decisiones políticas, contrarrestando la tendencia a la autonomización de los representantes, al mismo tiempo que se pone de manifiesto que el control de legalidad ejercido dentro del marco del modelo de la subsunción es, en la práctica, una función política que implica el sostenimiento de las decisiones políticas adoptadas por el parlamento, sea local o supranacional. En segundo lugar, permite la ampliación de los canales de participación política en la medida en que permite la recepción de intereses y argumentos elimi- 
nados a través del filtro mayoritario que caracteriza a la representación parlamentaria.

Así, mientras se espera del legislador que produzca reglas para un conjunto de casos generales, y en tanto sean producidas por los representantes elegidos a través del sistema electoral, podemos asignarles a estas una legitimidad prima facie, de modo tal que puedan ser distinguidas de las reglas producidas por gobiernos de facto, tarde o temprano estas reglas operan como restricciones, orientaciones y permisiones concretas respecto de los ciudadanos (Sieckmann 2003: 105). Una vez sancionadas, entonces, y para que sean consideradas legítimas en un sentido fuerte, tarde o temprano deben entrar en consideración, de forma directa o indirecta, los intereses de los afectados (Clérico 2009: 271). De otro modo no estaríamos hablando de democracia en sentido estricto - esto es, como autogobierno-, sino del gobierno de los representantes, que vendría a tener la estructura de una aristocracia popularmente elegida.

Ahora bien, esto no implica que cualquier clase de ponderación aplicada por los tribunales constituya, necesariamente, una práctica democrática, pero sí nos permite abrir una brecha en el cerrado normativismo kelseniano, que confundía lo público con el Estado, en la estrecha comprensión intra-estatal de la división de poderes característica del liberalismo, como así también en una excesiva identificación del DIDH con aquellas actividades que desarrollan los organismos supranacionales, de modo tal que se disminuye el abismo entre representantes y representados en la argumentación que sustenta y legitima la producción de normas políticamente vinculantes. Entendido de este modo el control de constitucionalidad parece cortado a la medida de un "test deliberativo", en tanto, por su estructura y dinámica, puede permitir una manifestación de los intereses de los afectados, y por ende una verificación del consentimiento de los mismos, respecto de las normas a las cuales se encuentran sujetos.

Aun resuelto el problema de la legitimidad, quedan abiertas todavía las cuestiones relativas a la pérdida de límites que parece implicar esta politización del control de constitucionalidad. Entre estas podemos distinguir, en primer lugar la cuestión de los estándares mínimos en materia de DIDH (su función de "corta fuegos" respecto de los vaivenes típicos de las coyunturas políticas), y en segundo lugar la de la posibilidad de establecer criterios que permitan jerar- 
quizar la potencial heterogeneidad de demandas que abriría un mecanismo de estas características.

Con respecto al primer problema, y en tanto conecta con la teoría del discurso práctico racional, y a través de esta con una comprensión deliberativa de la democracia, el modelo de la ponderación nace ya con una serie de límites intrínsecos que impiden su asimilación a un cálculo irrestricto de costos y beneficios. En otros términos, si se toma como punto de partida para la construcción del discurso práctico a los intereses argumentados de la totalidad de los ciudadanos, no resulta posible, entonces, justificar en este modelo, restricciones injustificadas a la autonomía de aquellos sin caer en contradicción. Es en esta línea que se desarrolla la dogmática de la prohibición de exigencia de lo insoportable, entendida como una serie de criterios que permiten diferenciar la carga y el peso de los argumentos en los casos de restricciones a los derechos fundamentales, atribuyéndoles a estos un status especial. De este modo la exigencia de la concordancia práctica para la solución de una tensión entre derechos fundamentales requiere que como resultado de la ponderación se llegue a una relación de prioridad equilibrada, que requiere a su vez tomar en serio los derechos fundamentales (y por ende reforzar la exigencia de argumentación) cuando sufren restricciones intensas. Así es posible desarmar la exigibilidad de la restricción en tres perspectivas, a saber, (a) la del afectado, (b) la de la comunidad y (c) la de un individuo argumentativo (Clérico 2009: 281). De este modo se reconstruye una suerte de "sobreproporcionalidad" que deberían cumplir las restricciones a derechos fundamentales que, sin caer en una posición dogmática respecto de los valores morales, permite determinar, dentro del marco de la argumentación práctico-jurídica, el estatus especial de los derechos.

Resta, entonces, el segundo problema, esto es, la determinación de criterios que permitan juzgar las pretensiones de determinación del alcance y contenido del DIDH. En este punto la noción de paridad participativa, desarrollada por N. Fraser, parece ser un buen criterio para zanjar la cuestión de la relevancia normativa de las pretensiones que puedan esgrimirse en la arena constitucional (Fraser 2006). Deducida directamente de las nociones de autonomía pública y privada, la idea de paridad participativa, en la medida en que exige a quien argumenta que demuestre que su pretensión promueve la pari- 
dad en la participación -entendida como la participación en la vida social en calidad de igualdad con el resto-, nos permite distinguir las reivindicaciones justificadas de las injustificadas, sin por ello cristalizar valores o intereses específicos -que necesariamente van a coincidir con los de aquellos grupos predominantes en las instancias de producción del derecho.

Por supuesto que ambas soluciones se encuentran fuertemente atadas a la capacidad de los operadores judiciales para retomar los argumentos de los individuos involucrados, pero esta dependencia es más débil que en otros modelos de la argumentación jurídica en la medida en que tiende puentes entre el discurso jurisdiccional y el discurso público. Por otro lado, el desarrollo de una dogmática racional de la argumentación constitucional no sólo permite establecer patrones que limitan la discrecionalidad judicial, sino que además permite conectar los progresos de la dogmática en materia de argumentación constitucional con propuestas aun más radicales $-\mathrm{y}$ consistentes- tales como el establecimiento de "jurados constitucionales" (Ghosh 2010: 327).

Que la ponderación, al forzar la explicitación de los argumentos que privilegian un derecho sobre otro, imponga a los tribunales la tarea de justificar sus decisiones, no implica que estas se encuentren automáticamente justificadas. Por el contrario, desde una comprensión deliberativa de la democracia, no puede existir tal cosa como una justificación definitiva de una norma socialmente vinculante, sino apenas una validez prima facie de las disposiciones emanadas de los órganos del Estado o del DIDH; validez que se encuentra directamente conectada con (a) los argumentos desplegados en su justificación, y fundamentalmente (b) la posibilidad de testear dichos argumentos con aquellos que pueda esgrimir de modo directo la ciudadanía. La ponderación entendida como una técnica que permite formalizar el balanceo de principios y el intercambio de argumentos, así como la aplicación del principio de proporcionalidad, entendido como un modo de reabrir la discusión pública que dota de legitimidad a cualquier disposición vigente en un Estado democrático de derecho, no sólo no obstaculizan sino que permite fortalecer el procedimiento democrático, sino en un sentido material -que siempre depende más de la ciudadanía que de las instituciones-, al menos en un sentido formal. Desde este punto de vista resulta crucial no sobreestimar el 
papel de la ponderación en el marco de la jurisprudencia constitucional, puesto que la utilidad de esta herramienta no radica en resolver los problemas vinculados al incumplimiento del DIDH, sino más bien en racionalizar los métodos que se emplean para resolverlos.

\subsubsection{Jurados constitucionales populares}

Para concluir, y en orden a distinguir la práctica de la argumentación constitucional del control de constitucionalidad en su acepción tradicional, creo que puede resultar de utilidad recurrir al trabajo de Eric Ghosh. Si bien la tesis de los jurados constitucionales populares es desarrollada con el objetivo de resolver las críticas relativas a los aspectos antidemocráticos del control de constitucionalidad, esta resulta de la mayor utilidad en el contexto de la discusión respecto de la participación política de los movimientos sociales.

El control de constitucionalidad en materia de derechos fundamentales viene enfrentando un fuerte escepticismo respecto de sus posibilidades democráticas, escepticismo fundado en el hecho de que los jueces carecen de la legitimación democrática que sí poseerían los legisladores. Con el objetivo de salvar este obstáculo se han ensayado hasta el momento tres posibles soluciones. Por un lado, el jurista Robert Alexy propone la noción de representación argumentativa (Alexy 2006). De acuerdo a esta interpretación de la democracia, la relativamente más fuerte sujeción del discurso jurisdiccional a los parámetros de la racionalidad argumentativa habilitaría su consideración como una instancia de representación democrática, en la medida en que tanto jueces como ciudadanos participarían de una misma "racionalidad". Una segunda alternativa, de corte menos teórico, radicaría en el acercamiento de los jueces y la ciudadanía (Ewing 2000) a través del establecimiento de instancias de formación específicas para jueces y una mayor participación de las legislaturas en los procedimientos de designación y control de los operadores judiciales.

No obstante, y al margen de las ventajas y desventajas implicadas por una y otra alternativa, me interesa concentrarme en la propuesta de "jurados constitucionales" desarrollada por Eric Ghosh en tanto conecta de un modo más directo con la cuestión de los movimientos sociales, la democracia y el derecho. En este sentido 
Ghosh define los "jurados constitucionales" como aquellos que resolverían conflictos de derechos, y a la "revisión constitucional" como la revisión de la adecuación de la legislación y las políticas públicas a los estándares de derechos humanos, con el objetivo de diferenciarla de la revisión judicial tradicional. La conformación de estos jurados constitucionales se asentaría sobre un mecanismo de sorteo y se complementaría con "encuestas deliberativas". Estas consistirían en la selección de ciudadanos con el fin de que participen en jornadas de discusión sobre las mismas temáticas que serían competencia de los jurados constitucionales. Un mecanismo de estas características tendría, en principio, dos ventajas. En primer lugar reforzaría las habilidades democráticas y participativas de los individuos seleccionados. En segundo lugar, y a través de la difusión de sus resultados, permitiría desarrollar una suerte de "opinión pública participativa", vinculante cuando menos en términos informales o morales para los jurados constitucionales.

De este modo sería posible escapar a la habitual dicotomía entre una democracia electoral lastrada de populismo y un control judicial lastrado de elitismo. En particular, respecto de este punto, me parece relevante mencionar y cuestionar una comprensión muy generalizada en lo que hace a las cuestiones de democracia y argumentación, y que consiste en suponer que entre la participación popular y la racionalidad existe algo así como una relación inversamente proporcional. Esto se asienta sobre dos presupuestos cuanto menos problemáticos. En primer lugar asume una comprensión excesivamente estrecha de la racionalidad, típica de ámbitos académicos, según la cual una argumentación es más racional cuanto más compleja y sofisticada, que desconoce (y por ende obtura la consideración de) las prácticas argumentativas y asamblearias concretas de la población en numerosos ámbitos. En segundo lugar, y conectado con el punto 2.1.1 (Teoría política del Estado y la esfera pública) de esta exposición, superpone acríticamente la democracia con el aparato estatal, de modo tal que se termina exigiendo a las instancias de participación estándares, en términos de alcance, planificación y competencia, que son en realidad los de una administración de un Estado nacional y no los de la democracia propiamente dicha. En este sentido es probable que el mayor nivel de democratización que pueda alcanzar un Estado se reduzca a la representación parlamen- 
taria, pero no implica que con esta se agoten todas las formas relevantes de la democracia entendida como el ejercicio del autogobierno, sobre todo en lo que atañe a la resolución de violaciones focalizadas de derechos, de las que habitualmente se ocupan los movimientos sociales.

\section{Conclusiones intermedias}

A modo de recapitulación podríamos decir que se identificaron tres niveles o escalones de problemas políticos, a saber, (a) la asimilación acrítica de Estado y la participación pública de la ciudadanía, (b) la asimilación acrítica de la democracia y el parlamentarismo y (c) la homogeneización de la ciudadanía. La primera tiene la consecuencia de obturar la gestión social del espacio público, forzando a los movimientos sociales a ubicarse bien bajo los parámetros de una publicidad estatal, bien bajo los parámetros de una sociedad civil en la que se confunden empresas, Organizaciones no gubernamentales (ONGs) y movimientos sociales de base, ninguno de los cuales se adecua a sus rasgos específicos. La segunda trae como consecuencia el constante cuestionamiento de la legitimidad política de los movimientos sociales, adoptando una posición de suma cero respecto a la institucionalización de la democracia, y cerrando el camino a formas paralelas y alternativas al parlamentarismo para el ejercicio de la ciudadanía. La tercera, que puede ser vista como una consecuencia del modelo centralizado del Estado y de la democracia, tiende a obstaculizar las demandas de reconocimiento de sectores sociales subrepresentados.

Por otro lado es posible retomar una serie de insumos teóricos de la dogmática jurídica que pueden servir para ir salvando estos obstáculos, al menos en el plano conceptual, a saber (a) una reconstrucción deliberativa/participativa de la interpretación de los derechos constitucionales, (b) una comprensión en clave de democracia deliberativa del control y de la argumentación constitucional y (c) la idea de jurados constitucionales populares. El primero permite resolver los problemas de reconocimiento, en la medida en que replantea la construcción del derecho no ya desde los representantes, sino a partir del involucramiento de los implicados. En el segundo caso, la comprensión de la revisión constitucional permite reconstruirla en 
términos de revalidación democrática de las normas vigentes, ya considerando el caso concreto, de un modo que el poder legislativo jamás podría hacerlo. Por último, la noción de jurados constitucionales permitiría retirar, al menos parcialmente, la interpretación concreta de la ley del cerrado ámbito de los poderes públicos -en el sentido de estatales, para devolverla a la ciudadanía, ya no entendida en ese sentido abstracto cuya representación monopoliza el parlamento, sino como el grupo de individuos efectivamente afectados por el déficit de derechos que se cuestiona. Aun cuando todo esto no nos permite afirmar que estamos ante la solución definitiva a los problemas de democratización de nuestras sociedades, sí al menos nos permite salvar algunos obstáculos y empezar a avanzar en esa dirección.

\section{Bibliografía}

Alexy, Robert (2003): "Los derechos fundamentales en el Estado constitucional democrático". En: Carbonell, Miguel (ed.): Neoconstitucionalismo(s). Madrid: Trotta, pp. 311-336.

- (2006): "Ley fundamental y teoría del discurso". En: Cardinaux, Nancy et al. (coords.): Las razones de la producción del derecho. Buenos Aires: Facultad de Derecho-UBA, pp. 19-38.

Campagne, Fabián A. (2005): Feudalismo tardio y revolución: campesinado y transformaciones agrarias en Francia e Inglaterra (siglos XVI-XVIII). Buenos Aires: Prometeo.

CELS (Centro de Estudios Legales y Sociales) (2008): La lucha por el derecho: litigio estratégico y derechos humanos. Buenos Aires: Siglo XXI.

Clérico, Laura (2009): El examen de proporcionalidad en el Derecho Constitucional. Buenos Aires: Eudeba.

D’Auria, Aníbal (2004): Análisis político: poder, derecho y democracia. Buenos Aires: La Ley.

Ewing, Keith D. (2000): “A Theory of Democratic Adjudication: Towards a Representative, Accountable and Independent Judiciary". En: Alberta Law Review, 38, pp. 708-733.

Foucault, Michel (2005): Seguridad, territorio, población. Buenos Aires: FCE.

Frankenberg, Günter (1998): "Remarks on the Philosophy and Politics of Public Law”. En: Legal Studies, 18, pp. 177-187.

Fraser, Nancy (1990): "Rethinking the Public Sphere: A Contribution to the Critique of Actually Existing Democracies”. En: Social Text, 25, 26, pp. 56-80. 
- (2006): "La justicia social en la era de la política de la identidad: redistribución, reconocimiento y participación”. En: Fraser, Nancy/Honneth, Axel: ¿Redistribución o reconocimiento? Madrid: Morata, pp. 17-88.

Gargarella, Roberto (2007): El derecho a la protesta: el primer derecho. Buenos Aires: Ad-Hoc.

Ghosh, Eric (2010): "Deliberative Democracy and the Countermajoritarian Difficulty: Considering Constituitional Juries”. En: Oxford Law Review, 30, 2, pp. 327372.

Habermas, Jürgen (1985): Conciencia moral y acción comunicativa. Barcelona: Península.

- (2004): Historia y crítica de la opinión pública. Barcelona: Gustavo Gili.

- (2005): Facticidad y validez: sobre el derecho y el estado democrático de derecho en términos de teoría del discurso. Madrid: Trotta.

Jorba Galdós, Laia (2006): “Ciudadanos y esfera pública: Una revisión de los modelos de implementación de la democracia deliberativa". En: Revista española de ciencia politica, 14, pp. 47-69.

Sabel, Charles F./Simon, William H. (2004): "Destabilizing Rights: How Public Law Litigation Succeeds”. En: Harvard Law Review, 117, 8, pp. 1015-1101.

Sieckmann, Jan-R. (2003): "On the Tension Between Moral Autonomy and the Rational Justification of Norms". En: Ratio Juris, 16, pp. 105-122.

Young, Iris Marion (1989): "Polity and Group Difference: A Critique of the Ideal of Universal Citizenship". En: Ethics, 99, 2, pp. 250-274. 



\section{José Rodrigo Rodriguez/Marta Rodriguez de Assis Machado \\ Law and Public Sphere: Spaces for Interaction and Flow Directions}

\section{Introduction}

This paper presents the agenda of empirical research on the relationship between the public sphere and the law that was recently launched at the Brazilian Center of Law and Democracy (Núcleo Direito Democracia - NDD) ${ }^{1}$ and at Direito $G V .^{2}$ We will first present the assumptions that guide our task in the empirical field, resulting in a particular way of seeing democracy and the relations between society and the state. Then, we will briefly present the main partial results of empirical research ${ }^{3}$ developed by this group in nine Brazilian state Courts of Appeal, on the anti-racism struggle in Brazil and its relationships to Brazilian institutions. Based on this data, we will make a preliminary analysis.

The research examines the decisions rendered by the Court of Appeals of the State of São Paulo that deal with racism, racial discri-

1 The Law and Democracy Nucleus is a research group of Centro Brasileiro de Análise e Planejamento (CEBRAP), a Brazilian interdisciplinary think thank dedicated to investigate theoretically and empirically the relations between Law and Democracy in the tradition of critical theory.

2 "Direito GV" is a Brazilian Law School that develops a Law \& Development research agenda.

3 Other research studies, undertaken by NDD, raise and nurture the reflection we do here: one of them aimed to organize the legislation on gender in Brazil and seek out decisions on discrimination of women in the labor and electoral justices; and the other study compared three judicial review mechanisms, the Commission on Constitution and Justice, the Federal Supreme Court and presidential vetoes from selected themes (Rodriguez/Nobre 2010). Both were funded by the project "Pensando o Direito" (Thinking About Law) organized by the Office for Legislative Affairs of the Ministry of Justice of Brazil (SAL) and the United Nations Development Program (UNDP). Those interested can see the reports posted on the SAL website (<www.portal.mj.gov.br/ data/Pages/MJ5C2A38D7PTBRIE. $\mathrm{htm}>$ ). One of them has also been posted in the Revista da Presidencia da República (Journal of the Presidency): Nobre/Rodriguez (2009). 
mination and racial defamation. ${ }^{4}$ We will briefly present the results and then discuss some of the problems the project faced to outline a model for studying the interaction between law and public sphere.

To do that, the first part of this paper will identify some areas of interaction between the law and the public sphere, which we incorporate into our research. In the second part, we will reflect on the directions of the flow of arguments and demands within the public sphere especially within formal institutions with a view to outline these spaces of interaction. In the conclusion of the paper, we will point out the next steps of our empirical research.

\section{Spaces for Interaction and Social Movements}

A key objective of the research program on Law and Public Sphere is to show that formal institutions, especially law, are not only spaces dominated by technical rationality; that is, law is not an instrument to obtain unambiguous solutions for actual cases submitted to it. This is an area of deliberative dispute for the sense of legal standards and for the correct interpretation of the legal rules. The creation of laws does not put an end to the struggle for the creation of rights, which forms a new arena for debate for the solution of concrete cases.

For a technical and textual view of the law that goes along with the traditional concept of separation of powers, the interaction between the law and the public sphere lies outside of it: legal rules are the main source of law and function as an instrument of the legal will of the people. That is why the judges are seen as la bouche de la loi, responsible for subsuming specific cases to abstract rules to reach the correct solution for each case. ${ }^{5}$

For this design, at least in its ideal setting, the grounds for the decision of concrete cases are the rules of law based, in turn, on the will of the people expressed through the parliament. The basis of the decision, therefore, would not be problematic and would not be subject to dispute. Obviously, there may be disagreements among judges about what should be the appropriate legal rule to the case, but

4 There is no space in this paper to display all the results obtained, neither is it our main purpose in this paper. For a full description, see Machado/Püschel/Rodriguez (2009).

5 For a full exposition of these problems, see Rodriguez (2010). 
everyone's goal is the same: finding the appropriate rule and subsuming the case to it.

This way of conceiving the operation of the law has lost ground in legal theory, at least since the second half of the twentieth century. ${ }^{6}$ This theoretical shift is linked to structural changes that have changed both the way of making laws and the action of the judiciary and the traditional configuration of the three branches of power. For example, standards became increasingly important as a legislative tool and as an instrument to solve conflicts among the interpretation of legal rules. There is no space here to describe in detail these changes (Rodriguez 2010). For our purposes, it must be said that, at least since the second half of the twentieth century, legal theory can hardly affirm the existence of a single legal-technical solution for each case. ${ }^{7}$

A consensus was gradually formed, ruling out to subsume as a potential model for the rationality of law and for the actions of judges (Alexy 1989), as it is clear that there is always more than one possible answer for each case. In fact, judges do not simply apply a general rule to a concrete case. The literature on the law has shown that judges take decisions that cannot be described as an act of mere application of a general rule or of subsuming a case to a general rule. For this reason, the theory of law starts to reflect on this space for the choice of judicial authority.

Doing that has consequences to the separation of powers. After all, the obligation to apply general rules created by the Parliament is due to the fact that these rules were created by the people through his representatives. If judges have the power to choose among different possible decisions to the same case and do not find a single decision that follow directly from the general rules, everything changes. Judges must explain why that decision was rendered rather than another; oth-

6 One could say this way of conceiving the law is formalist as opposed to nonformalist visions that do not value the autonomy of the law. Our conception of the law disagrees with the one we have just described, but does not devaluate autonomy. That is why it would be more precise to say we stand for a "new formalism" and a new conception of the law's technique, as will be clarified later on in this article.

7 Our concern here is only the standpoint of theory. It would be necessary to rebuild the judicial practices historically, that is, judgments of courts, so as to have a clear picture of how the judges of each time used to think. There are very few studies of this kind in Brazil, for example, see Lopes (2010). 
erwise a purely arbitrary decision would be characterized in opposition to the ideals of the rule of law. Obviously, this change in the legal rationality is also a change in the rationale of the separation of powers.

Indeed, many theoreticians of law hastened to say, vis-à-vis this state of affairs, that this choice would be, in fact, merely arbitrary, subjective, "political", as Hans Kelsen put it (Kelsen 1967). Obviously, in light of an ideal of legal security that sought to find one answer for each case based on legal rules, those scholars were right. However, since the early twentieth century the theory of law began to investigate whether this ideal would work with an improper model of rationality to deal with law, thus designing an ideal of legal security impossible to achieve.

Such theorists have requested new models of rationality to tackle the indeterminacy of court action, but without considering it subjective or irrational. The question of the theory of law is then the following: If it is impossible to describe the court action as the identification of a single correct answer for each case, is it possible to consider it from another model of rationality? If yes, what would this model look like?

The paths chosen by theorists to carry out this task were various. The history of these attempts is intertwined with the history of the legal theory in the second half of the twentieth century. Some authors, such as Theodor Viehweg, were inspired by Aristotle's Topics that sought another model of rationality (Viehweg 1979). Others, like Chaim Perelmann, based their thoughts on Aristotle's Rhetoric (Perelmann 1999). In more recent times, we have witnessed the revival of Kantian practical reason in the work of Jürgen Habermas, Robert Alexy and Klaus Günther, in the form of a theory of argumentation (Alexy 1989; Günther 1993; Habermas 1996). In any case, their goal is to think of the activity of addressing concrete cases in rational terms, but according to another rationale.

This theoretical move is perceived by some authors as the recognition of the failure of law as a regulatory mechanism, a sign of its "dedifferentiation" in relation to the spheres of morality, politics, economics, etc. ${ }^{8}$ After all, the autonomy of law would lie precisely in the ability to decide cases based on legal arguments, that is, on legal rules,

8 For this point, see Luhmann (1983). 
from which it is possible to draw precise solutions to the case concerned. ${ }^{9}$

This alleged "loss of technicality" of legal decisions would be a threat to the ability of the law to regulate society and stabilize expectations. The law would lose its specificity by allowing judicial officers to decide on the basis of moral, ethical, religious norms. Of course, for those authors seeking other ways to think about the rationality of law, this movement would not necessarily result in "de-differentiation" or "de-technicization" of the law. What could happen would be a change in the patterns of the limits between the law and the other social spheres, that is, another legal technique would emerging that would be appropriate for the characteristics of today's society.

If you think of this second theoretical register, such a change in rationality can be seen even as a strengthening of the rule of law by strengthening democracy. Indeed, a legal language that is less technical, less specialized, or, put another way, less technocratic, could help ordinary citizens understand the legal debates, enabling court decisions to be discussed in the non-specialized public sphere. Besides this, such change may facilitate the participation of citizens in public debate that results in the making of final decisions. Legal language is then open to non-specialized considerations, setting the scene for a debate where there is easy access to the problems concerned.

For instance, in cases of high-voltage politics, the Brazilian Federal Supreme Court (STF) has convened public hearings ${ }^{10}$ of cases tried by the court. Moreover, the court has admitted, in a much more permissive way, that civil society organizations and individuals provide amicus curiae $^{11}$ to inform the court of any relevant arguments and information to the case at trial. Additionally, the justices of the Brazilian Federal Supreme Court have interacted with the press during the trial of cases to put forward their diverging points of view in the nightly news watched in Brazil on Globo channel. During

9 The key author here is Max Weber. For a more systematic description of the Weberian argument, see Trubek (1972).

10 The Federal Supreme Court can organize public hearings to get information it believes relevant to a case (see art. 9, $\S 1^{\circ}$, Federal law 9.868 de 1999). Actually, the court has been using this possibility to hear civil society in controversial cases.

11 Amicus curiae is a procedural instrument that allow civil society to speak before the Federal Supreme Court (see art. $7^{\circ}, \S 2^{\circ}$, Federal Law 9.868/99). 
some of the Federal Supreme Court deliberations, justices were interviewed live on national television every day, before or after they made their votes public.

This is a research agenda to be explored, but either way, it seems clear that the Brazilian judiciary has opened itself to the public on various issues it examines. Indeed, this whole process could be interpreted, according to a more traditional view of the problem (Rodriguez 2010), as a violation of separation of powers in its most traditional sense and an advancement of the judiciary on the legislative branch of power.

Again, if we look at this process as a shift in the rationality of the law, we can say that there is a new model of a separation of powers in operation. In this model, the judiciary performs other duties according to another rationale and, therefore, its interaction with the public sphere then changes. Instead of merely applying the political will of the people expressed in the law, this power establishes its own and independent relationship with the public sphere (Kirchheimer 1961), ${ }^{12}$ developing institutional spaces for this interaction to occur. ${ }^{13}$

The decision making process becomes, in this scenario, a space for interaction between the law and the public sphere. By losing its logic and deductive characteristics, the basis of decisions becomes problematic, therefore, liable to be disputed by the interested parties, whether those directly involved in the case or third parties indirectly involved in the decision. The fundamental legal issue that emerges is setting the terms of this dispute, namely the creation of a procedure and a proper rationale to deliver a well-justified and convincing decision for those directly concerned in the case and the participants of the public sphere.

A third important element is precisely the growing interaction between judges and the media, just mentioned above. A case in point is the judges' increased exposure to TV and newspapers and the strategic postponement of important decisions (or individual judges requesting to see records, thus deferring their decision) with a view to, for a

12 To be precise, Kirchheimer talks about "public opinion" and not "public sphere".

13 As mentioned in notes 10 and 11, the law authorizes the Federal Supreme Court to promote public hearings before his deliberation and decision of a case. The same court admits the presentation of Amicus Curiae by several NGOs and associations interested in the cases under the court's jurisdiction. 
few weeks, the public's perception of the case on trial. But these are, as yet, impressionable perceptions, because this is a field that still lacks empirical research.

At this point, it is important to open a parenthesis. Individuals, groups and social movements can directly file lawsuits in order to produce certain results from the judiciary branch of power. This type of action is often called strategic litigation. The discussion about the flow of society's demands towards the judiciary should certainly take this phenomenon into account.

For the purpose of this paper, we will not go into further detail of this phenomenon in Brazil. But it is important to call attention to the phenomenon and the fact that Brazil has a peculiarity in this field. The demands that arise in society are not brought to the judiciary only by NGOs, lawyers working pro bono or legal assistance services.

Brazil has the Public Attorney's Office (MP), a state authority that has the power to file suits on behalf of society. ${ }^{14}$ Therefore, to obtain a complete picture of the problems that concern us, we must also study the interaction of the Public Attorney's Office with society. We will explore this point in more detail in the next section.

Let us get back to the main topic. All institutional mechanisms that promote the interaction between society and the judiciary are related, after all, to the characteristics of legal technique. Its goal is to inform the court about the possible grounds for choosing between the various possible legal solutions with regard to the same case. ${ }^{15}$

Such mechanisms, which may serve to enrich the debate on such fundamentals and, by consequence, on the possible answers to be given to individual cases, can increase the legitimacy of the justification

14 Of course this raises the questions: How and why the MP decides to sue someone? The public sphere should control this decision. But how?

15 The fear of advancing a non-legal rationality in the context of judicial decisions does not seem to remain solid, at least in the Federal Supreme Court. There is little influence of arguments not related to law in this court, according to a research conducted in 2010 (Rodriguez 2010). The core problem of the Federal Supreme Court seems to be the difficulty of forming a solid decision-making rationale: each judge develops a profile in order to deal with the sources of law and raises different grounds in the solution of the same case, which creates an argumentative chaos of technical arguments. See the research quoted and Vojvodic/Cardoso/Machado (2009). 
to the solution adopted and the decision taken. ${ }^{16}$ By bringing more arguments into the judiciary, this contributes to reducing the risk of decision makers disclosing their justification of any socially relevant views and interests. ${ }^{17}$

Interestingly, in Brazil, some social movements have organized themselves to push their demands inside the courts, but some have not. For example, the judiciary's actions on issues like health and education are very intense, in contrast to the actions geared to the matters of gender and racism.

As we will see shortly, some social movements have organized their discourse and demands around the purpose of passing laws in parliament and requiring that the judiciary promote a textual, precise, dispute-free law enforcement. However, other social players have devised specific strategies to serve on the judiciary. Describing this picture, which remains unexplored by scholars of law and social sciences in Brazil, is one of the purposes of our research.

Below are some thoughts on what has happened in the field of combating racism in Brazil.

\section{An Example of Research: the Crimes of Racism and Racial Discrimination}

Two issues are very significant in the processes of passing laws against race discrimination in Brazil. On the one hand, it is possible to recognize that the symbolic role of the law is emphasized. It can be said that the black movement, a key player in the juridification of this issue, has focused demands to lawmakers around strategies intended to expand, harden or improve the criminalization of discrimi-

16 We put this statement in the conditional mode because I have no news of research on the legitimacy of the decisions of the judiciary before the public sphere.

17 Here we disagree with Ronald Dworkin and his theory of interpretation as integration, where the judge alone has the Herculean task of rebuilding the tradition for a well-justified response (see Dworkin 1988). Our vision of this problem involves a combination of institutional constraints and hermeneutic models able to bring into the judiciary as many voices as possible in order to get a welljustified solution. We would call this model of justice a polyphonic one. On the concept of institutional constraints and hermeneutic models (see Rodriguez 2011). 
natory and prejudiced acts and, to a large extent, these demands were satisfied by the legislative branch of power.

A discussion of other forms of intervention and other fields of action within the law has just started to gain a greater importance, in particular by the participation of Brazil in the World Conference Against Racism sponsored by the UN in 2001 in Durban, which discussed affirmative measures both on the agenda of state authorities ${ }^{18}$ and in the legislative branch of power. ${ }^{19}$ This discussion has gained force ever since.

Furthermore, a set of diagnoses of insufficiency or ineffectiveness of criminal laws set in motion the valorization of other forms of intervention. When we look back to the sixty years of criminal legislation against racism and racist practices in Brazil, we see that the enactment of a new law was generally preceded and encouraged by criticisms to some previous law by those players working in the formal and/or informal public sphere. News statutes have been created in order to solve the efficiency problems of the older ones, but this process has not produced the expected outcomes when they are examined from the point of view of the social movements.

The first anti-racism statute, "Afonso Arinos Law", was enacted in $1951 .{ }^{20}$ It addressed discriminatory conduct as misdemeanors. The-

18 A case in point is the fact that several ministries have adopted a quota system for the promotion of employees; the establishment in May 2002 of the program "Programa de Ações Afirmativas" (Affirmative Actions Program), aimed at increasing the participation of black people, women and people with disabilities in leadership positions throughout the federal administration; the implementation of a quota system in some universities. Moreover, after the Federal Supreme Court declared the constitutionality of the principle of that affirmative action, even the judiciary branch of power adopted the requirement of a minimum percentage of black people employed in companies providing services to the courts.

19 The issue of that affirmative action was taken to Parliament with more emphasis on discussion of the law on social and racial quotas in federal and state universities (PL 73/1999, authored by Rep. Nice Lobão, with its various amendments and attachments, still pending in the House of Representatives) and the Statute of Racial Equality (Senate Bill - PLS 213/2003), a bill authored by Senator Paulo Paim (PT-RS), which was under debate in Congress since 1998 and was approved only in 2008. These projects focus on establishing a set of affirmative actions that involve "special programs and measures adopted by the State to correct racial inequalities and to promote equal opportunities" (PLS 213/2003).

20 Federal Statute 1390, July, 3, 1951. Named after the Congress representative that presented it, "Afonso Arinos Law" was the first Federal statute to explicitly prohibit racial discrimination in Brazil. 
reafter, incisive demands were made to criminalize such acts, and as a response, racism was made a serious, "unbailable and indefensible crime" by the Brazilian Constitution of 1988 .

The federal legislation promulgated after this constitution focused on regulating and defining punishable conducts - the main statute is Act $7716 / 1989$, with the original text altered a couple of times by other statutes.

The inclusion of Article 20 into Act 7716/1989, through Act 9459/1997, which describes the practice, inducement or incitement to discrimination or prejudice, responds to the criticism that the previous law described the crimes in an overly detailed fashion and made it too difficult to enforce the law.

Article 2 of Law \# 9.459/97 of 1997 is another law also added to the penal code and is a form of aggravated slander, with a sentence one to three years confinement plus a fine, "if the grievance derives from affronts to race, color, ethnicity, religion or origin". ${ }^{21}$

This change was, as justified in the bill of law, intended to correct one of the points mentioned as the most problematic for the enforcement of the previous law: the fact that slander due to race and color continued to be considered by the courts as mere ordinary slanders, with much lighter punishments than those given out for in the "Caó Law". ${ }^{22}$

So, in this matter, in Brazil we have three types of crimes: i) acts involving the refusal to serve a person or deny access in any way to her based on race, skin color, ethnicity, religion or nationality; ii) a general description of the crime of racism, as "practicing, inducing or inciting discrimination or prejudice based on race, color, ethnicity, religion or nationality"; iii) an aggravated slander, "if the grievance derives from insults to race, color, ethnicity, religion or origin".

It is worth noting that in the first two types of conduct the public prosecutor undertakes the criminal proceedings, while racial slander is undertaken by private individual initiative. This also meant being sued by a criminal private prosecution filed by the victim.

An exception to the general system of public prosecution, criminal private prosecutions offer practical difficulties with regard to their

21 Article 2 of Law \# 9.459/97 of 1997.

22 Federal Statute n. 7.437, December 20, 1985. 
processing, as these actions lie within several limits, including strict formal assumptions, statutory limitation period of six months for filing the lawsuit, payment of court costs, and requires an attorney. Moreover, one of the foundations of criticism also refers to the fact that submitting a crime to a criminal private prosecution also means, in our system, that the victim's interests in the prosecution is more important than the public interest, that is, it would have an undesirable symbolic effect, in addition to the problematic practical effects.

In addition, as we will see, once the distinction between racism and racial slander is not clear and indisputable, the fact that these two crimes are subject to different legal procedures has considerable consequences.

To develop further our understanding of the enforcement and ineffectiveness of laws against racism, we collected rulings made by nine Brazilian Courts of Appeals (from the following Brazilian federal States: Acre, Bahia, Mato Grosso do Sul, Paraíba, Pernambuco, Rio de Janeiro, Rondônia, Rio Grande do Sul and São Paulo) from 1998 to 2010 .

A search for rulings of the above Courts of Appeal related to racism was carried out using the databases available at the Lawyers' Association of São Paulo (Associação dos Advogados de São Paulo AASP) and at the websites of the Courts of Appeal with updates that run through September 2010. The search used the keywords "racism" ("racismo"); "higher degree slander" ("injúria qualificada"); "racial slander" ("injúria racial"); and "racial discrimination", and came back with 2061 rulings. Manual searches discarded non-penal rulings, as well as cases which debated exclusively procedural or incidental matters, leaving 201 court decisions - this number therefore represents all cases of crimes related to racism, racial discrimination or racial offenses made public by the Brazilian Courts of Appeal researched.

Of those decisions, there were: 118 criminal appeals; 43 criminal interlocutory appeals ("Recursos em sentido estrito"); 31 writs of habeas corpus; five criminal actions conducted directly by Court of Appeal (special jurisdictions); two appeals against liberatory decisions on Habeas Corpus; two atypical proceedings involving petitions to prosecute public officers and one prejudicial appeal arguing the nonimpartiality of the judge ("Exceção de Suspeição"). 
As can be seen in the graph below, most of these cases (118 in all) reached the court after the announcement of the judgment of merit (condemning or absolving) in the first instance. A significant number of cases though were tried in court before the judgment of merits 29 after the judge's initial ruling that accepted the charge and 43 after the judge's initial ruling that rejected the complaint, thwarting the continuation of the case.

As for Courts of Appeal rulings, if we only take into consideration the decisions that analyzed the merits of the case - either an acquittal or conviction (118 in total) - it became evident that the court condemned more than it absolved: 55 convictions compared with 41 absolutions. When it came to decisions taken by the court when something was questioned before it ended in the first instance, the number of cases closed by the Appeal Court's decision - based on rejection of charges, extinction of punish ability, dismissal or annulment of the case - compared with those that were determined to be tried are as follows: 58 decisions of the first kind compared with 33 of the second, which represents $34.3 \%$ of the decisions determining the untimely end of the criminal action compared to $26.1 \%$ determining its continuation, respectively. The significance of the first output is one important factor that plays a role in the general dissatisfaction about how the judiciary deals with criminal cases related to racism.

Taking into consideration all 201 cases (that is, convictions and absolutions, as well as decisions taken to proceed or annul cases), we notice a prevalence of cases in which a decision was taken to end a case prematurely (58 cases between rejections, extinction of punishability, dismissal or annulment of the case). And following this: 55 convictions; the 41 absolutions and the 33 procedural decisions to continue the case. 


\section{Graph 1: Decisions of Brazilian Courts of Appeal}

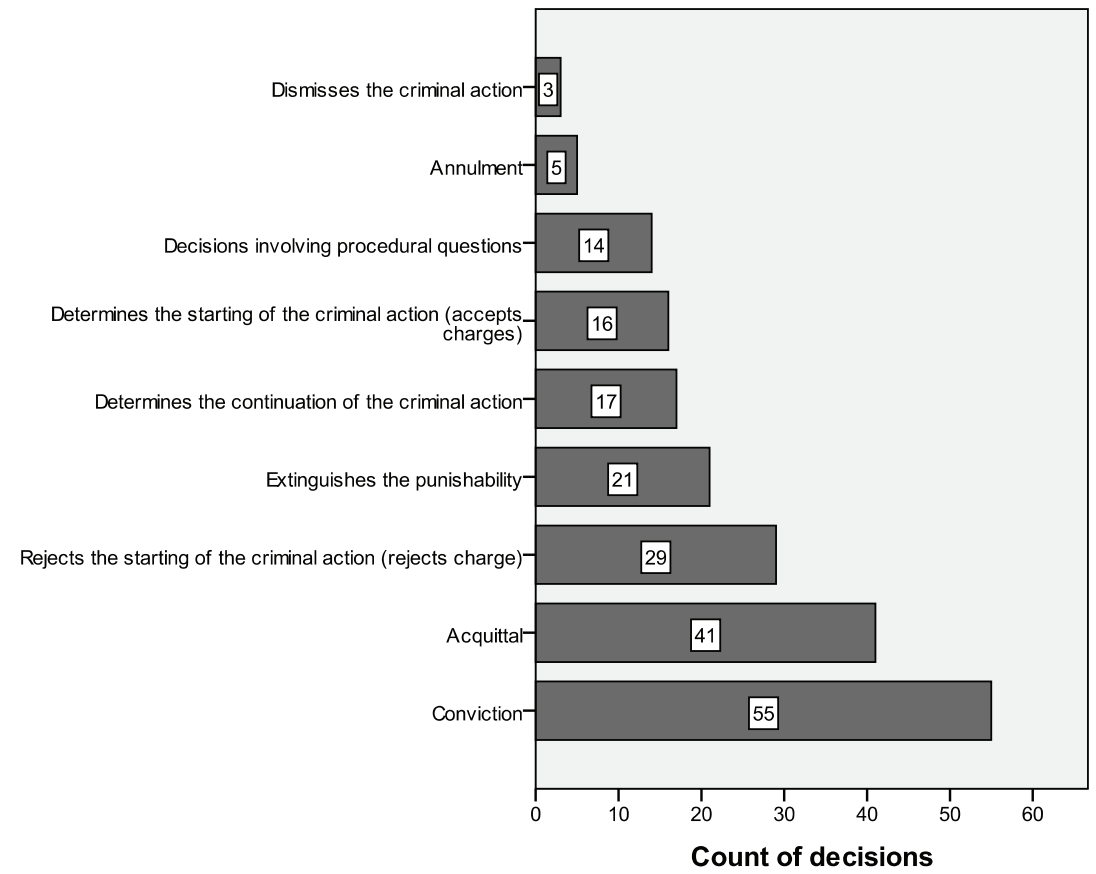

Convictions were, as indicated in the graph, for the most part (49), for slander (plain slander or racial slander), with or without sentencing increases. We located only three convictions for the crime of racism in accordance with Article 20 of Law No. 7.716/89; one conviction based on the denial or obstruction of employment (Article 4 of the same law) one conviction, for preventing access of a public place (Article 8 of the same law); and one conviction for preventing marriage or social contact (Article 14).

It is remarkable that there are such low number of cases involving racism and situations of discrimination. 


\section{Graph 2: Charges of the convictions}

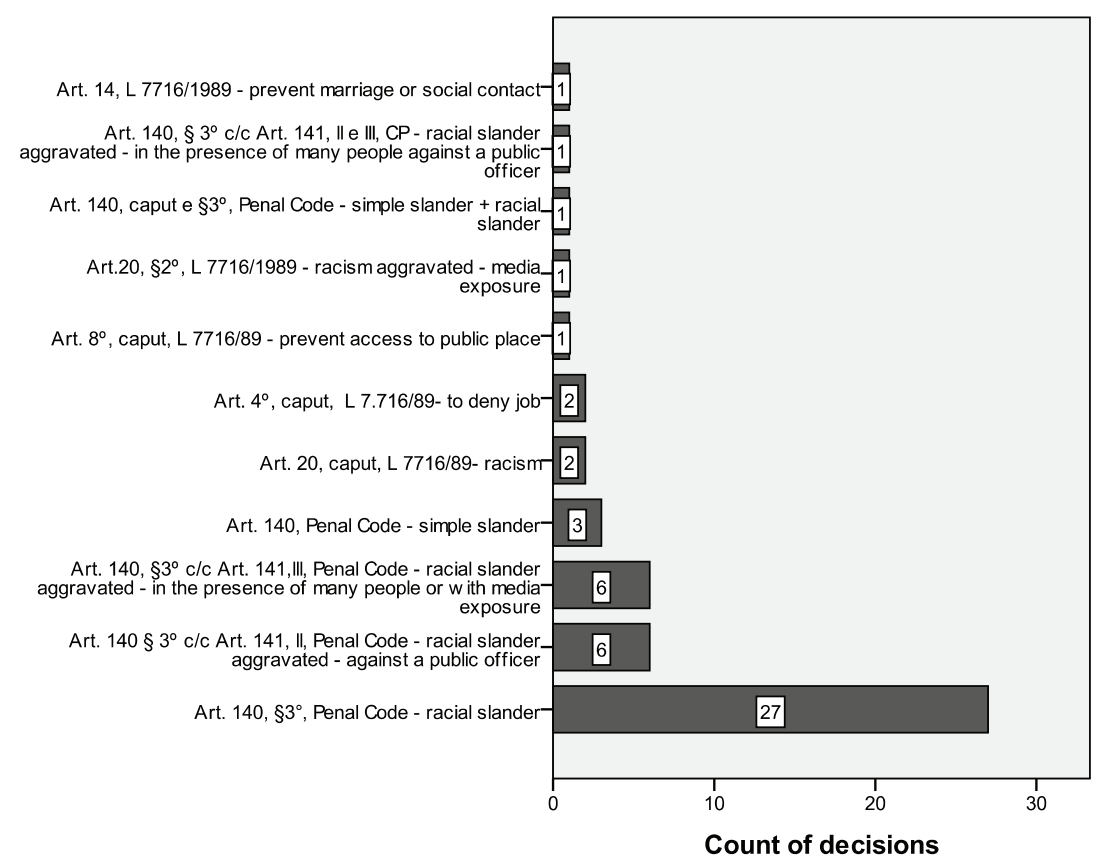

As for the sentences handed out, 10 of the 55 convictions amounted to one year in prison and a fine of ten days, which corresponds to the minimum sentence for high degree slander. In 24 cases, the sentence was fixed at 16 months, which corresponds to the minimum legal limit for high degree slander with a one third increase based on circumstances from Article 141 of the Penal Code (in the presence of many people or with media exposure or against public officer). The harshest sentence was three years of imprisonment, set by the courts in two cases. In many cases, penalties of imprisonment were replaced with community service. In two cases, the convictions were followed by an exoneration, as it took too long to persecute according to the legal limit of time ("extinção da pretensão executória da pena"). ${ }^{23}$

23 They were calculated in our research together with the cases of convictions because we deem it relevant that the procedure came to an end and reached a legal conclusion that recognized the perpetrator's responsibility and wrongdoing and just suspended the execution of the penalty. 
The graph below (n.3) shows the number of absolutions. They were justified in half the cases (19 of 41) based on a lack of evidence. In 20 of the cases of absolution the judges analyzed the merits of the case and declared lack of a crime. Within this context, it is significant to the argument that the offender did not act with harmful intent, or in bad faith, even though it was clear in the offence that it involved a racial nature, and the second instance decision made by the court does not deny this.

\section{Graph 3: Reasons for acquittals}

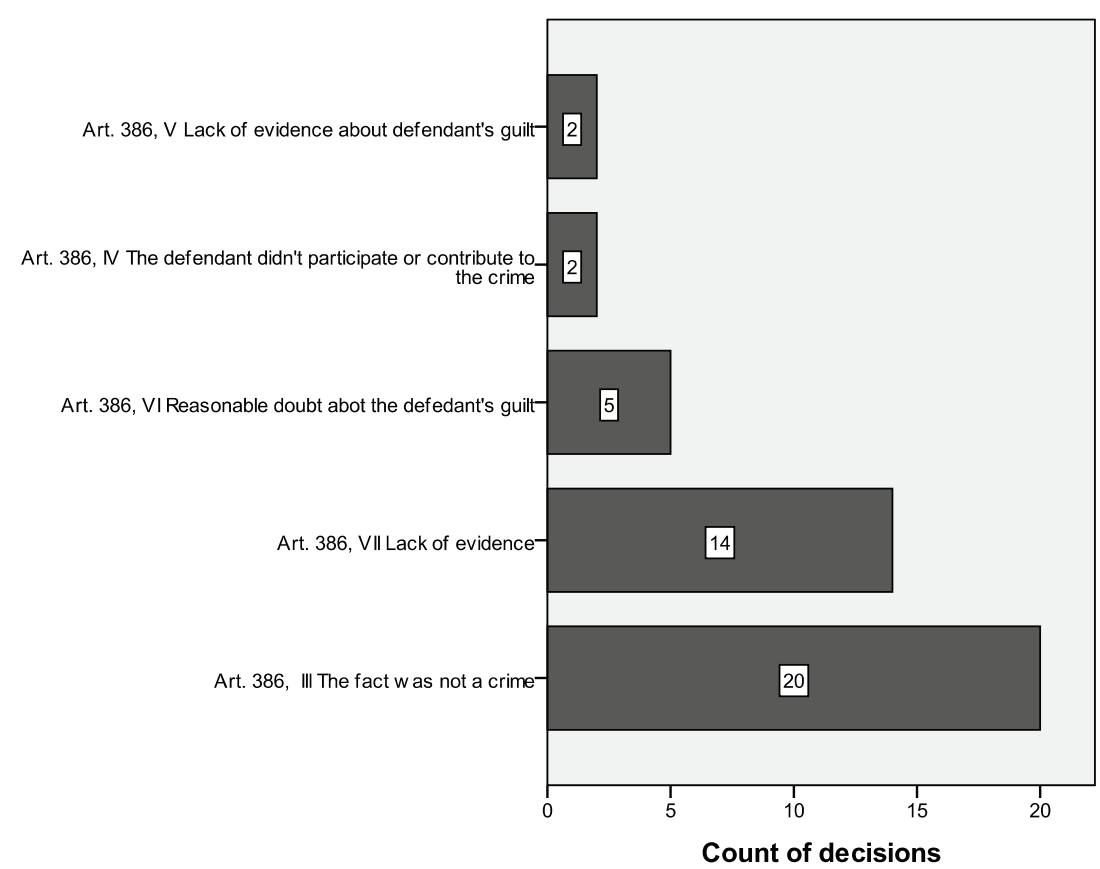

These results allow for some conclusions. In the first place, they contradict the perception that no convictions were upheld at least in terms of the Courts of Appeal. Overall, the number of convictions reached approximately $27.3 \%$ (or 55 rulings), which is significant. Nevertheless, it is worth mentioning that the convictions were mostly for crimes of plain slander or racial slander. Racism or discrimination appeared only in eight cases of convictions. The definition of the 
facts submitted to the judiciary, mostly related to verbal offenses with a racial slurs as racial slander and not as the crime of "racism" is criticized by victims and by actors of social movements.

What seems also troublesome and frustrating from the point of view of the judicial system is that many cases in which trials end before the judge could even declare a sentence: the 58 cases in which the court decided on an early closure of the case.

This number is not only superior to the cases in which the court proceeded with the case (33), but also represents the most common outcome of the cases tried by Courts of Appeal: it represents 27.9\% of the total cases analyzed.

To understand these results, one must be sensitive to the inner workings of the country's legal system, more specifically, the dynamic of the application of criminal and procedural rules. The main questions to be considered are linked to the problem of changing the classification of racial cases (racism/racial slander).

As we have mentioned, one of the most significant controversies found was the debate over the qualification of the facts of what defines racism or racial slander. In some cases, the court in its decisions reevaluated the previous legal definition of the crimes as racism, establishing that the case should be considered as either plain slander or racial slander. The change in the definition of what is racism or slander has the practical effect of dismissing cases for their lack of timeliness in filing the initial charge. This happens because of the different ways in which each case is processed: racism is tried through a public penal trial - that means, it is tried by the State Prosecutor ("Ministério Público"); while racial slander should be tried through private criminal action, that is, by the offended party who seeks a lawyer and has six months from the time she/he learns who the perpetrator of the offense is to file a charge.

The different procedures for these crimes outline a problematic situation: every time that racism is changed into racial slander, after the six month deadline mentioned above, it will no longer be possible to initiate the required procedure. Even if the deadline has not expired yet, the decision may be handed down so late in the game that the offended party barely has time to bring together a penal case.

For this reason it is very common to recognize a lack of timeliness as an output for these cases. 
We must not presume that this is the desired result of judges when they call for the case to be reassessed. Especially since the classification of cases brought about by insults of a racial type, such as racial slander, is justifiable from a legal point of view. There are intrinsic elements to the system of legal argumentation that show that the court's classification of this type of conduct as racial slander, although these elements are far from being the only form of dogmatic interpretation that can be considered plausible. This analysis will not be developed in this text (see Machado/Püschel/Rodriguez 2009).

The dispute over how to interpret facts and apply the law by means of dogmatic debate is absolutely normal. To think of the application of statutes without considering the indeterminacy of legal norms and the room for dogmatic argumentation is a mistake. In these cases, the judge applying the law must be familiar with a whole range of categories (such as "racism", "racial discrimination", "racial slander", and principles of interpretation of criminal statutes), hence increasing the range of interpretations and the indetermination of norms.

The situation becomes problematic here - determining the premature termination of cases - because of the different procedural regimes involved in the dispute and the paradoxical procedural rules applied to the problem: namely, that the recognition of a new classification that subjects the case to new procedures harkening back to a preceding moment and end up suppressing rights. In other words, the offended party is required to have taken measures that were not necessary at the outset, due to a change in legal requirements, and under threat of seeing the case closed.

The rule that determines the six-month deadline from the moment the perpetrator's identity is made known is a decisive factor when one considers the problematic results found. The difficulty in upholding a solution that escapes the application of this penal procedure rule, which has no legally established exceptions, shows us that we are facing a systemic problem. This problem would be better resolved by means of a change in legislation, so the crime of racial injury could then be tried by means of a criminal procedure to be initiated by the public prosecutor. This situation has motivated the recent change in the legislation, with Law \# 12.033/2009, which altered the prosecution regime for the racial slander - it must now be prosecuted by 
the public prosecutor, after a formal authorization of the offended part ("ação penal pública mediante representação").

This change will also help to avoid the procedural problems faced by privately sought penal cases such as, problems of access to justice, difficulties arising from briefing, and questions involving how to comply with the stricter rules involving the submission of a criminal action, all of which prompted the closure of many cases.

In addition, as we have already mentioned, most of the dismissals and acquittals were due to a lack of evidence. The Inter-American Commission on Human Rights in its report on human rights in Brazil (1997) specifically mentioned the relevance of this issue that was revealed by the data collected. It stated that

Law \# 7.716 proved to be "difficult to enforce since it establishes mechanisms to facilitate proof that a crime has been committed. Moreover, by making it necessary to prove that discrimination was intended leads to situations in which the aggressor and the aggrieved must confront one another and the offense must be proved objectively". ${ }^{24}$

Proper critique of the suitability or its lack thereof in these rulings can be made only after a qualitative appraisal of these cases taking into consideration the principle of the judge's freedom to evaluate evidence. As hard as it is to evaluate cases that involve intersubjective insults, already difficult to prove, the number of dismissals and absolutions due to a lack of evidence points to the need to reevaluate legal institutions and the way they deal with racism in the courts.

This matter is certainly worth looking into. We do not know, for example, if the difficulties over proof arise from badly briefed cases (which can be corrected through measures that improve the quality of legal services and the quality of police investigations and guidance), or the out-of-date doctrine (which sees in the category of "criminal intent" a need for proof of a psychological order and hence to vie for the prevalence of another mode of understanding the elements that comprise the notion of crime), or "excess demand" on the court's behalf or some sort of predisposition to absolve (which should certainly be the object of democratic and critic control, but which can

24 Inter-American Commission on Human Rights. Report on the Situation of Human Rights in Brazil, 1997 (<www.cidh.oas.org/countryrep/brazil-eng/indexbrazil.htm> (04.02.2009). 
only be confirmed through empirical analyses), or even the fact that most of the cases depend on personal evidence.

It is evident that the premature closure of the cases is not the kind of response expected from social movements or affected parties who submit their demands to the legal system. But there are whole series of possible explanations for the termination of these cases that cannot be reduced to the unproven thesis that the legal system is impermeable to cases dealing with racism, or that it is somehow acting in an ideological manner and has an interest in undermining antiracist legislation.

In fact, we did found rulings that describe racist attacks as "archaic slang, devoid of racist content" or "destitute of any pejorative meaning" or still the inexistence of the intent of depreciating the group - and this kind of reasoning when neither the event itself, nor the identity of the perpetrator were being questioned. It is only in the context of these cases that one can firmly state that the judge trying the case was insensitive to racial conflict. However, this happened on a smaller scale: in six cases of absolutions and in five cases of annulments of the case. These cases represent only $8.1 \%$ of cases.

With regard to the analysis of law enforcement, this research sought to investigate more closely the general claim that the judiciary is insensitive to racial issues when we look at the low number of convictions. It seems that an evaluation of the effectiveness or ineffectiveness of Brazilian laws against racism should not be summed up or connected primarily to the number of convictions, but to the dynamics of creating and enforcing the law. This led us, among other things, to investigate more closely the behavior of the judiciary when faced with cases of racism. Thus, we sought to further understand the decisions and their grounds beyond the concrete result only measured by the number of convictions.

The empirical study is still ongoing and the data collected has not yet been able to provide a snapshot of the Brazilian judiciary's attitude regarding this theme. However, the results already obtained seem relevant. Firstly, they relativize the idea that the law is not enforced. An analysis that affirms the "effectiveness" of the law from the number of convictions overlooks the specific issues found inside the legal system and fails to point out new pathways for further dis- 
cussion on the use of legal instruments in the anti-discriminatory fight, nor does it consider its limitations and possibilities.

Moreover, the results mentioned above have made visible the presence of issues that have significantly influenced the unsatisfactory outcome of cases: the problem of disqualification and preemption, evidentiary stage, and the difficulties inherent in the processing of cases according to the regime of private prosecution.

In addition to the data itself, what is clear in this research is that it is not possible to explain the results without taking into consideration a number of factors that are questioned at the time of law enforcement, as well as paying close attention to the stumbling blocks of the legal system.

Clearly, those in charge of enforcing the law are required to deal with a variety of categories ("racism", "racial defamation", principles of criminal law enforcement), which increase the possibilities of interpretation, thus increasing the indeterminacy of legal rules. The more possibilities judges have to decide the concrete cases, the more outcomes they will come up with. As a statute created a new category, one can say the creation of this statute increased Law's indeterminacy. In the cases analyzed, there was a divergence between the legal classification given to the fact - and the reclassification made by the court, which ultimately influenced the final problematic effect, is a justifiable way to decide this divergence.

Moreover, strictly technical-procedural issues should also be considered to understand the issue: the differences filing a criminal action and differences in processing schemes among those offenses yet to be criminalized is key to the problem of preemption or nullity, which is a cause of dismissal for most cases. This might not happen if we had at our hands two crimes against the public order. That is, at this point, one cannot overlook the paradoxical effect that the difference in regimes results in the discussion of classification of the case.

Furthermore, as for the lack of evidence, a criticism of the appropriateness or inappropriateness of that decision would only be possible from a qualitative analysis of the case, when one considers the principle of free findings of the judge.

Recognizing the specificities of legal reasoning and modus operandi of the criminal justice system does not mean giving up criticizing the practical results of that system. Instead, it makes it possible 
to go beyond a pessimistic and generalizing conclusion that judges are racists or that our judiciary system is insensitive to the struggle for equality, in order for further research on the elements that contribute to the lack of responses considered unsatisfactory.

As for the relationships between social movements and the law, we advocate that understanding the dynamics and the logic of the legal system also helps to see the possibilities and limitations of each legal instrument in evaluating and deciding on legal strategies of action to be taken both before the parliament and in the courts.

\section{Directions of Flow: Demands and Formal Institutions}

As shown in the first part of this paper, the judiciary has developed its own spaces for interacting with society. This includes room for making decisions, whose foundations are in dispute, as well as the mechanisms intended to bring to the decision-making venues interests to the arguments of various origins. Having said this, one wonders how these arguments arrive in those spaces; that is, what is the direction of flow of arguments between the law and the public sphere.

When we consider the filing of a lawsuit by a group, association, political party, social movement, or any other politically active entity, the direction of movement seems to be from the public sphere to the legal system. These players compel the judiciary examine to their own arguments in deciding on the demands put on this branch of power. This would be ideally preceded and followed by turmoil in the public sphere, which would challenge formal institutions in several ways, including lawsuits.

One of the topics to be researched on this problem is whether or not there are strategies for litigation organized by social movements, interest groups, and other societal entities. It would be wise to look for entities created solely to file lawsuits and take actions before the legislative branch of power and the government at large on issues relating to a particular topic and how they do it: do they hire permanent attorneys, seek attorneys in the market, seal relationships with other entities composed of attorneys, have relationships with the Public Attorney's Office (MP)?

In all these cases, it is clear that the flow of demands would clearly be in the direction from the society to formal institutions, preceded 
by a debate in the public sphere and the construction of a strategy involving the judiciary, since it is regarded as one of the more relevant political arenas.

However, one must also consider that this is not the only possible direction for the flow of demands put forward by society. For example, when we reflect on the Public Attorney's Office and individuals as initiators of lawsuits, we can see that the direction of flow can be different. The Public Attorney's Office, for instance, files suits independently, even if they are not linked to social movements or interest groups, i.e., not resulting from a current pressure from the public sphere.

Similarly, an individual may also bring about action despite being disconnected from any interest group whatsoever. In both cases, these actions may deal with topic or arguments that could mobilize the public sphere.

Here the direction of flow is, then, reversed: the encouragement comes from a formal institution and becomes relevant because it was discussed by and then disclosed for some reason by a media outlet or another tool of communication. ${ }^{25}$ In all these cases, the judge, the individual and the Public Attorney's Office discuss relevant issues involving various societal entities and, precisely because of that, the interested parties discuss and try to influence the judicial decision to be rendered.

One can imagine, hypothetically, that the same thing can occur when a judge develops a given argument to justify his/her decision, and subsequently that argument awakens the public sphere, even in a case that is not inserted into a strategy of militancy. For example, in a recent case involving a football player labeled as gay by the media, the court issued its opinion on the relationship between homosexuality and football, which had wide repercussions and led several governmental organizations devoted to the cause of gays and lesbians to take action. ${ }^{26}$

25 In many issues, the MP has conducted independent investigations to sue individuals, the state or private firms that have gained public interest afterwards.

26 The judge was punished by his declarations. See "TJ de São Paulo mantém punição de censura a juiz do caso Richarlyson", Última Instância (<www. ultimainstancia.uol.com.br>; 19.05.2011). 
A relevant research topic could be further developed on how and why these individuals, judges or public attorneys have developed such arguments or put forward such demands. Drawing an ideological profile of individuals, understanding the circumstances under which they were inserted at that particular time, and understanding the internal policies of institutions and their relationships to society are all likely to shed light on this problem. As mentioned above, it may be possible that the actions filed or decisions taken by these players take advantage of a climate of unrest in the public or a latent issue which, when treated by a state authority, begins to mobilize opinions and grab the attention of the media.

In any case, what matters here is to raise the main issues and make clear that the flow of demands will not always be from the public sphere to the formal institutions; the opposite may occur by virtue of the filing of actions or the development of arguments by a judge, an individual, or the Public Attorney's Office.

\section{Next Steps}

Empirical investigations carried out by CEBRAP in a concerted effort with Direito $G V$ began by examining the debates on cases of gender and racism within the judiciary, which has motivated theoretical reflections on the characteristics of jurisdictional rationality and separation of powers in Brazil. In one word, a glaringly obvious phenomenon is the conflict of interpretations that has imposed the need to rethink several points in legal theory. It can be said that the core issue is to deal with this conflict and explain its origin and dynamics.

This question can be thought of as the relationship between the judiciary and society. As already seen, this research is intended to reflect on the meaning of various institutional mechanisms designed to make the judiciary permeable to society and, on the other hand, to investigate how the demands are formed and how they come to the judiciary. After all, there may be demands addressed by other mechanisms of conflict resolution.

One goal of our research is to identify the flows of society's demands to the judiciary, but also being clear that the relationship between society and state in this case has its peculiarities. As al- 
ready seen, there may be demands that arise from formal institutions, but are targeted to the public sphere, as they try to speak on behalf of specific social interests. For this reason, research on this point of the problem cannot work with a tight definition of state and society.

In fact, this problem also appears when we study the judiciary in isolation. After all, the mechanisms that are being created to relate to society are also redesigning the separation of powers in Brazil and, consequently, the boundaries between society and state.

\section{References}

Alexy, Robert (1989): A Theory of Legal Argumentation. Oxford: Clarendon Press.

Dworkin, Ronald (1988): Law's Empire. Cambridge: Harvard University Press.

Günther, Klaus (1993): The Sense of Appropriateness: Application Discourse in Morality and Law. New York: State University of New York.

Habermas, Jürgen (1996): Between Facts and Norms: Contributions to a Discourse Theory of Law and Democracy. Cambridge: Polity Press.

Kelsen, Hans (1967): Pure Theory of Law. Berkeley: University of California Press.

Kirchheimer, Otto (1961): Political Justice: The Use of Legal Procedure for Political Ends. Princeton: Princeton University Press.

Lopes, José Reinaldo de Lima (2010): O Oráculo de Delfos. O Conselho de Estado no Brasil Império. São Paulo: Saraiva.

Luhmann, Niklas (1983): Sistema Jurídico e Dogmática Jurídica. Madrid: Centro de Estudios Constitucionales.

Machado, Marta Rodriguez de Assis/Püschel, Flavia Portella/Rodriguez, José Rodrigo (2009): "The Juridification of Social Demands and the Application of Statutes: an Analysis of the Legal Treatment of Antiracism Social Demands in Brazil”. In: Fordham Law Review, 77, 4, pp. 1535-1558.

Machado, Marta/Machado, Maíra/Cutrupi, Carolina/Scabin, Claudia (forthcoming): "Anti-racismo no Brasil: uma aproximação à atividade legislativa e à aplicação do direito pelo Tribunal de Justiça de São Paulo". In: Cadernos Direito GV.

Nobre, Marcos/Rodriguez, José Rodrigo (2009b): "Mulheres e políticas de reconhecimento no Brasil". In: Revista Jurídica Virtual da Presidência da República, Brasília, Online, 11, pp. 1-59.

- (2010): Igualdade de Direitos entre Mulheres e Homens. Brasília: Ministério da Justiça SAL.

Perelmann, Chaïm (1999): Logique juridique: Nouvelle rhétorique. Paris: DallozSirey.

Rodriguez, José Rodrigo (2010): “The Persistence of Formalism: Towards a Situated Critique beyond the Classic Separation of Powers". In: The Law \& Development Review, 3, 2, pp. 41-77. 
- (2011): "Zonas de autarquia nas decisões jurisdicionais: Estado de Direito, Indeterminação e Democracia" In: Vilhena, Oscar Vieira/Dimoulis, Dimitri (ed.): O Estado de Direito e os Desafios do Desenvolvimento. São Paulo: Saraiva.

Rodriguez, José Rodrigo/Nobre, Marcos (coord.) (2010): Processo Legislativo e Controle de Constitucionalidade. Brasília: Ministério da Justiça SAL (projeto Pensando o Direito) (<www.portal.mj.gov.br/main.asp?View $=\{329 D 6 E B 2-$ 8ABO-4606-B054-4CAD3C53EE73\}>) (13.7.2011).

Trubek, David M. (1972): "Max Weber on Law and the Rise of Capitalism". In: Wisconsin Law Review, 730, pp. 720-753.

Viehweg, Theodor (1979): Tópica e Jurisprudência. Brasília: Ed. UnB.

Vojvodic, Adriana. M./Cardoso, Evorah. L. C./Machado, Ana Mara F. (2009): "Escrevendo um romance, primeiro capítulo: precedentes e processo decisório no STF”. In: Revista Direito GV, 9, pp. 21-44.

Werle, Denílson et al. (forthcoming): “Anti-racismo, Estado de direito e esfera pública”. In: Lavalle, Adrián (org.): O horizonte da politica: questões emergentes e agendas de pesquisa. São Paulo: UNESP. 



\section{Daniel Bonilla}

\section{Parejas del mismo sexo en Colombia: tres modelos para su reconocimiento jurídico y político}

En los últimos cinco años, la Corte Constitucional colombiana se ha pronunciado en siete ocasiones sobre el estatus jurídico y los derechos de las parejas del mismo sexo. En este conjunto de sentencias, el tribunal se toma en serio el tema de los derechos de las minorías sexuales y ofrece un grupo de argumentos complejos para evaluar el estatus jurídico y político que deberían tener los miembros de la comunidad LGBT $^{1}$ en una democracia liberal como la colombiana. En este artículo, argumento en primera instancia, que con esta línea jurisprudencial la Corte Constitucional ha dado pasos fundamentales para eliminar la discriminación que existe en Colombia en contra de la comunidad LGBT (Bonilla 2008). Por un lado, las sentencias C-075/2007, C-811/2007, T-856/2007, C-336/2008, C-798 de 2008 y T-1241/ 2008, C-029/2009 ${ }^{2}$ reconocen por primera vez en la historia del país

1 LGBT son las siglas que designan colectivamente a las personas lesbianas, gays, bisexuales y transgénero. Este artículo fue originalmente publicado en Anuario de Derechos Humanos, Universidad de Chile, 2010.

2 La Corte Constitucional promulga dos tipos de sentencias: por un lado, las sentencias tipo " $\mathrm{C}$ ", en donde se hace un control abstracto de constitucionalidad y, por ende, donde la argumentación se concentra en si existe coherencia o no entre una norma inferior y la Constitución. Este tipo de casos no vincula a ningún ciudadano concreto en el proceso. Por el otro, las sentencias tipo "T", donde la Corte revisa casos de tutela ya decididos por jueces inferiores en los que se alega que el Estado, o en algunos casos los particulares, violan por acción u omisión los derechos fundamentales de uno o más individuos.

En julio de 2011 la Corte Constitucional decido el caso C-577/11. En este caso, la corte declaró constitucional el artículo 13 del código civil que define el matrimonio como un contrato que se acuerda entre un hombre y una mujer. Sin embargo, en esta sentencia la Corte también reconoció que las parejas del mismo sexo son una de las formas de familia que la Constitución de 1991 protege y urgió al Congreso a que legislara sobre el tema. Esta sentencia todavía no ha sido publicada. Véase Corte Constitucional, Comunicado de Prensa No. 30, Julio 26 de 2011, disponible en <www.corteconstitucional.gov.co/comunicados/ 
la existencia jurídica de las parejas del mismo sexo y les otorga un conjunto importante de derechos y obligaciones constitucionales y legales. Estos derechos y obligaciones tocan temas tan variados como la dignidad humana, la igualdad, la salud, las pensiones y la nacionalidad de los miembros de las parejas del mismo sexo.

Por el otro, este conjunto de sentencias da un giro importante a la jurisprudencia de la Corte sobre los derechos de la comunidad LGBT. Con anterioridad a la expedición de la sentencia C-075/2007, la Corte había reconocido los derechos de los homosexuales en tanto individuos, pero se había negado de manera sistemática a reconocer la existencia jurídica de las parejas del mismo sexo y, por tanto, a reconocer que sus miembros eran titulares de derechos. Además, estas siete sentencias evidencian un giro importante, aunque no definitivo, en la interpretación que tiene la sociedad colombiana sobre la comunidad LGBT. El hecho de que estas sentencias fueran aprobadas por unanimidad o mayorías notables en una Corte que está constituida por varios magistrados comprometidos con posiciones políticas conservadoras refleja los cambios que se han venido dando en nuestro país en torno a la valoración social de las minorías sexuales que lo constituyen. Este giro se confirma por el hecho de que las sentencias fueran respaldadas o, por lo menos no cuestionadas, por amplios sectores de la población. Finalmente, estos fallos contribuyen a una mejor comprensión, evaluación y solución del problema que genera el no reconocimiento jurídico de las parejas del mismo sexo. Este grupo de sentencias, además de aproximarse a los dilemas teóricos y prácticos que genera la inexistencia jurídica de este tipo de parejas a través de los argumentos tradicionales de la autonomía y la igualdad, lo hace a través del argumento de la dignidad -mucho menos usado para acercarse a este tipo de problemas.

En segunda instancia, argumentaré que las razones que justifican este conjunto de sentencias responden a tres modelos distintos para comprender, evaluar y reconocer jurídicamente las parejas del mismo sexo: el modelo de la dignidad, el modelo de la igualdad y el modelo de la autonomía. Si bien los dos primeros modelos son complementarios entre sí, analizaré como éstos y el modelo de la autonomía son

No.\%2030\%20comunicado\%2026\%20de\%20julio\%20de\%202011.php> (28.06.2012). 
mutuamente excluyentes (Burt 2009). ${ }^{3}$ Igualmente, revisaré cómo la línea jurisprudencial de la Corte Constitucional colombiana que reconoció la existencia jurídica de las parejas del mismo sexo se fundamenta en modelos que están teórica y prácticamente en tensión.

Finalmente, analizaré como el modelo de la dignidad ofrece notables ventajas comparativas frente a los modelos alternativos porque (i) identifica el problema que está en juego de la manera más clara, precisa, sencilla y comprehensiva posible; (ii) explicita en forma precisa los obstáculos para solucionar el problema político y jurídico que implica el no reconocimiento jurídico de las parejas del mismo sexo; (iii) establece un criterio sólido para determinar la utilidad de los mecanismos que buscan neutralizarlo; y (iv) interpreta lúcidamente los modelos con los que compite y la perspectiva de moralidad política que sustenta nuestro sistema político-jurídico, esto es, el liberalismo.

Para justificar estos argumentos dividiré este artículo en tres partes. En la primera parte presentaré la estructura básica de las decisiones de la Corte Constitucional colombiana que reconocieron jurídicamente a las parejas del mismo sexo y que le otorgaron un notable número de derechos. En la segunda parte, analítica y crítica, justificaré los argumentos que permiten afirmar que este conjunto de sentencias constituyen un paso importante hacia la eliminación de la discriminación que existe en Colombia en contra de la comunidad LGBT. En la tercera parte expondré las características centrales de los modelos de la autonomía y la igualdad y presentaré las que considero son sus principales debilidades. Del mismo modo, en esta sección, expondré los elementos constitutivos del modelo de la dignidad y presentaré los argumentos que permiten afirmar que esta perspectiva normativa ofrece una más clara y completa explicación y fundamentación de la posición que promueve el reconocimiento jurídico de las parejas del mismo sexo.

3 Las consecuencias jurídicas y políticas sustanciales y procedimentales que generan estos modelos son distintas e incompatibles. 


\section{El reconocimiento jurídico de las parejas del mismo sexo en Colombia}

La línea jurisprudencial articulada por la Corte Constitucional colombiana sobre parejas del mismo sexo puede dividirse en tres partes: reconocimiento, consolidación y expansión. En la primera, conformada por la sentencia C-075 de 2007, el tribunal constitucional por primera vez en la historia de Colombia reconoció la existencia jurídica de las parejas del mismo sexo. La Corte decidió que la Ley 54 de 1990, que regula todas las materias relacionadas con la unión marital de hecho, era aplicable tanto a las parejas heterosexuales como a las del mismo sexo. Señaló que el artículo 1 de la Ley 54, que definía la unión marital de hecho como aquella institución compuesta por un hombre y una mujer que cohabitan por al menos dos años, era constitucional únicamente si era aplicable también a las parejas homosexuales. Esta interpretación condicionada de su artículo 1, implicó que el resto de los preceptos que componen la Ley 54, que regulan los aspectos patrimoniales de la unión marital de hecho, fueran aplicables a todas las parejas, heterosexuales y homosexuales, que existen en el país.

La Corte señaló de manera inequívoca que su decisión se circunscribe únicamente a la Ley 54 de 1990. Este argumento resulta de particular importancia pues el artículo 1 de esta ley era el único que definía de manera clara y precisa la unión marital de hecho en el ordenamiento jurídico colombiano y constituía un referente ineludible para interpretar el amplio número de preceptos que precisan derechos y obligaciones para las personas que constituyen uniones maritales de hecho -normas que regulan materias tan distintas como la obtención de la ciudadanía, los seguros de automóviles y la obligación que tienen los padres y madres de proveer una cuota de alimentos para sus hijos. Si la Corte lo hubiera querido, con esta sola sentencia hubiera podido hacer una transformación global del sistema jurídico colombiano de manera que todas las normas que regulan la unión marital de hecho y sus consecuencias fueran aplicables tanto a las parejas heterosexuales como a las parejas del mismo sexo. ${ }^{4} \mathrm{Si}$ bien esta sen-

$4 \quad$ La demanda que cuestionó la constitucionalidad de la Ley 54 de 1990 solicitó a la Corte que reconociera que la Ley 54 era un referente interpretativo de las otras normas que hacen referencia a la unión marital de hecho y, por tanto, le pidió al 
tencia no tuvo este efecto, abrió el camino para que nuevas demandas que tuvieran como objetivo cuestionar la constitucionalidad de las normas jurídicas que hicieran referencia a la unión marital de hecho pero que siguieran siendo aplicadas únicamente a las parejas heterosexuales.

La segunda parte de esta línea jurisprudencial, constituida por las sentencias C-811/2007, C-336/2008, C-798/2008, T-856/2007 y $\mathrm{T}-1241 / 2008$, confirma la regla jurisprudencial que indica que las parejas del mismo sexo pueden constituir uniones maritales de hecho, y amplió los derechos y obligaciones que están en cabeza de sus miembros (GDIP 2010). La primera sentencia reconoció que las normas que regulan la afiliación al sistema contributivo de salud de las parejas heterosexuales que conforman una unión marital de hecho son también aplicables a las parejas del mismo sexo. La segunda sentencia señaló que tanto los miembros de las parejas heterosexuales como las del mismo sexo pueden ser titulares de la pensión de sobrevivientes. ${ }^{5}$ La tercera sentencia indica que tanto los miembros de las parejas del mismo sexo como las heterosexuales pueden ser titulares del derecho a recibir una cuota de alimentos por parte de su pareja una vez se ha terminado la vida en común. Las últimas dos sentencias de revisión de tutela confirman el derecho que tienen los ciudadanos que hacen parte de parejas del mismo sexo a ser afiliados al sistema contributivo de seguridad social, por un lado, y a recibir la pensión de sobreviviente, por el otro. Estas sentencias concretan en dos casos de control concreto de constitucionalidad las reglas jurisprudenciales establecidas en los casos de control abstracto que fueron decididos anteriormente. ${ }^{6}$

tribunal que generara un efecto dominó que hubiera transformado radicalmente el ordenamiento jurídico colombiano. La demanda fue presentada por el Grupo de Derecho de Interés Público de la Universidad de los Andes y la organización no gubernamental Colombia Diversa.

5 Esto es, que cuando un integrante de la pareja que recibe una pensión muere, el que le sobrevive puede sustituirlo como beneficiario de este derecho.

6 En la sentencia T-1241/2008, la Corte Constitucional ordenó a la Caja de Retiro de las fuerzas armadas reformar todos sus procedimientos de manera que los miembros de las parejas del mismo sexo puedan hacer uso de su derecho a la sustitución pensional. Sin embargo, no concedió la tutela en tanto que el ciudadano que presentó la tutela no adjuntó pruebas suficientes de su calidad de compañero 
La tercera etapa de esta línea jurisprudencial, que expande de manera radical el número de derechos y obligaciones que están en cabeza de los miembros de las parejas del mismo sexo, tiene como único, pero muy importante componente, la sentencia C-029/2009 (GDIP 2010). Esta sentencia surge como consecuencia de una demanda que cuestionó la constitucionalidad de 26 normas jurídicas que diferenciaban injustificadamente entre las parejas del mismo sexo y las parejas heterosexuales. ${ }^{7}$ Las normas que la Corte Constitucional declaró constitucionales de manera condicionada en esta sentencia pueden ser reunidas en los siguientes cinco grupos: penales, civiles y comerciales, seguridad social, políticas y aquellas relacionadas con el conflicto armado. La Corte señaló que este conjunto de normas jurídicas dirigidas a las parejas heterosexuales son constitucionales únicamente si se aplican también a las parejas del mismo sexo. ${ }^{8}$

El primer grupo de normas hace referencia a temas penales tan disímiles como el derecho a no declarar, denunciar o formular queja en contra de los compañeros permanentes en cualquier materia disciplinaria, penal y penal militar; ${ }^{9}$ el beneficio de prescindir de la sanción penal no privativa de la libertad cuando el sujeto pasivo del delito es el compañero permanente; ${ }^{10}$ y la agravación punitiva para el sujeto activo de una conducta delictiva de la cual su compañero permanente es la víctima. ${ }^{11}$

permanente de la persona que murió, y a quien la Caja de Retiro de las fuerzas armadas estaba obligada a pagarle una pensión.

7 Esta demanda fue presentada por las organizaciones no gubernamentales Colombia Diversa y Dejusticia, así como por el Grupo de Derecho de Interés Público de la Universidad de los Andes.

8 La Corte, sin embargo, se inhibió de decidir sobre la constitucionalidad de las normas que incluyen los conceptos de familia, familiar o grupo familiar.

9 Artículos 8-b, 282, 303, 385, Ley 906 de 2004; Artículos 222, 431, 495, Ley 522 de 1999; y Artículo 71, Ley 734 de 2002.

10 Artículo 34, Ley 599 de 2000 y Artículo 18, Ley 1153 de 2007.

11 Artículos 104, 170, 179, 188-B, 245, Ley 599 de 2000. La sentencia se refiere también a los siguientes temas penales: aplicación de la sanción prevista para quien cometa el delito de inasistencia alimentaría (Artículo 233, Ley 599 de 2000); aplicación de la sanción para el sujeto activo del delito de malversación y dilapidación de bienes familiares cuando se es tutor o curador de los bienes del compañero permanente (Artículo 457, Código Civil y Artículo 236, Ley 599 de 2000); aplicación del castigo para quien cometa los delitos de violencia intrafamiliar (Artículo 229, Ley 599 de 2000 y Artículo 2, Ley 294 de 1996) y 
El segundo conjunto de normas, civiles y comerciales, giran en torno a temas tan diversos como la constitución del patrimonio inembargable de familia, ${ }^{12}$ la afectación de la vivienda familiar con el fin de proteger los bienes y vivienda de las parejas ${ }^{13}$ y la obligación de pagar una cuota de alimentos al compañero permanente una vez se haya terminado la vida en común. ${ }^{14}$

El tercer grupo de normas, reunidas bajo la categoría "seguridad social", se refiere a la posibilidad de que los miembros de las parejas del mismo sexo obtengan los beneficios que en materia de salud y pensiones reciben los miembros de las parejas heterosexuales que pertenecen a la fuerza pública, ${ }^{15} \mathrm{y}$ a que las personas que hacen parte de parejas del mismo sexo obtengan los subsidios familiares que reciben los miembros de las parejas heterosexuales, por ejemplo, los de vivienda y educación. ${ }^{16}$

El cuarto conjunto de normas regula las materias relacionadas con el régimen de inhabilidades e incompatibilidades y las restricciones al acceso y ejercicio de la función pública y la contratación estatal, ${ }^{17}$ así como la aplicación de los requisitos para adquirir la nacionalidad por adopción. ${ }^{18}$ Finalmente, el quinto grupo de normas hace referencia a cuestiones tan importantes como el derecho que tienen los compañeros permanentes de las personas que han sido sujetos pasivos de delitos atroces a que se presuman como víctimas y que, por tanto, tengan derecho a la verdad, justicia y reparación. ${ }^{19}$

amenaza contra testigo o su compañero permanente (Artículo 454-A, Ley 599 de 2000).

12 Artículo 4, Ley 70 de 1931.

13 Artículos 1 y 12, Ley 258 de 1996.

14 Artículo 11, Código Civil.

15 Artículo 3, Ley 923 de 2004; Artículo 24, Decreto 1795 de 2000.

16 Artículos 1, 27, Ley 21 de 1982; Artículo 7, Ley 3 de 1991.

17 Artículo 14, Ley 190 de 1995; Artículo 1, Ley 1148 de 2007; Artículo 8, Ley 80 de 1993; Artículos 40, 84, Ley 734 de 2002; Artículos 283, 286, Ley 5 de 1992.

18 Artículo 5, Ley 43 de 1993.

19 Artículos 5, 7, 15, 47, 48, 58, Ley 975 de 2005; Artículo 11, Ley 589 de 2000; Artículos 14, 15, Ley 971 de 2005; Artículo 2, Ley 387 de 1997. La sentencia también hace referencia al derecho que tienen los compañeros permanentes de las víctimas de los delitos de desaparición forzada, secuestro y toma de rehenes a ser beneficiarios de las medidas de protección civil que el gobierno tiene la obligación de proveer (Artículo 10, Ley 589 de 2000; Artículos 2, 26, Ley 986 de 2005); y el derecho a que las parejas del mismo sexo tengan la posibilidad de 
La línea jurisprudencial articulada por la Corte Constitucional en estas siete sentencias es consistente con las decisiones y los argumentos que las justifican. Todas las sentencias parten de la premisa que indica que los miembros de las parejas del mismo sexo son sujetos de derecho y, por ende, titulares de un conjunto importante de obligaciones y derechos particulares. Del mismo modo, los siete fallos se fundan en los mismos tres pilares jurídicos que fueron fijados por la sentencia C-075/2007: dignidad, libre desarrollo de la personalidad e igualdad. $^{20}$

Estas tres categorías jurídicas son definidas por la Corte Constitucional apelando a interpretaciones estándar del cuerpo teórico del liberalismo. Cada una de éstas, a su vez, se constituye en el eje de uno de los tres modelos que justifican el reconocimiento jurídico de las parejas del mismo sexo que analizaré en la tercera sección de este escrito (libre desarrollo de la personalidad/modelo de la autonomía; igualdad/modelo de la igualdad y dignidad/modelo de la dignidad).

Para la Corte la dignidad es a la vez un atributo que tienen todos los seres humanos y un principio que funda el Estado Social de Derecho. ${ }^{21}$ La Corte argumenta que la dignidad es una cualidad que tienen todas las personas por el solo hecho de pertenecer a la especie humana; una consecuencia de la capacidad que tienen todos los indi-

hacer uso de los mecanismos que permiten el acceso a la tierra en áreas rurales a los miembros de las parejas heterosexuales (Artículos 61, 62, 80, 159, 161, 172, Ley 1152 de 2007).

20 A este respecto señala la Corte en la sentencia C-075 de 2007, "[e]n ese escenario, para la Corte, la ausencia de protección en el ámbito patrimonial para la pareja homosexual resulta lesiva de la dignidad de la persona humana, es contraria al derecho al libre desarrollo de la personalidad y comporta una forma de discriminación proscrita por la Constitución".

21 La Corte señala a este respecto, "Esta Corporación ha expresado que la dignidad humana es un valor superior y un principio fundante del Estado Social de Derecho, conforme al cual todas las personas deben recibir un trato acorde con su naturaleza humana. Ha señalado la Corte que '... dentro del sistema constitucional colombiano, el principio de dignidad constituye el centro axiológico a partir del cual se derivan las obligaciones de protección, respeto y promoción de los derechos constitucionales y el aseguramiento del cumplimiento de los deberes constitucionales, bajo la égida del orden justo'. Para la Corte, “[p]or dignidad se entiende la supremacía que ostenta la persona como atributo inherente a su ser racional, cuya valoración y reconocimiento no puede estimarse como la causa o el efecto de alguien o de algo (es decir, como objeto), sino como un fin superior que subyace en sí mismo". (Notas al pie eliminadas). 
viduos de escoger sus proyectos morales y de justicia haciendo uso de la razón. Es decir, la dignidad es un atributo que surge como consecuencia de la autonomía y la racionalidad que son propias de la naturaleza humana. De esta forma, es la cualidad que garantiza la igualdad básica de todos los seres humanos. En tanto que somos dignos, argumenta la Corte, todos somos iguales.

Para la Corte, este atributo es a su vez un principio constitucional que constituye la premisa de la cual se deducen los derechos fundamentales de las personas. Estos derechos son los instrumentos que permiten defender la dignidad humana de las intervenciones indebidas del Estado y de los particulares. Los derechos fundamentales son las herramientas que permiten que la naturaleza humana sea protegida y tenga la posibilidad de florecer. Consecuentemente, para la Corte, el principio de dignidad tiene una dimensión negativa y una positiva. ${ }^{22}$ Por un lado, el Estado tiene el deber de abstenerse de adelantar cualquier tipo de acción que vulnere la autonomía de los seres nos; ${ }^{23}$ por el otro, tiene el deber de garantizar las condiciones materiales mínimas que permiten que la autonomía pueda ejercerse. ${ }^{24}$ Para

22 "De manera general, de acuerdo con la jurisprudencia constitucional, la dignidad humana, como principio fundante del Estado, es el presupuesto esencial de la consagración y efectividad del sistema de derechos y garantías contemplado en la Constitución y tiene, por consiguiente, valor absoluto no susceptible de ser limitado bajo ninguna circunstancia. De este modo, si bien la Constitución impone como límite al libre desarrollo de la personalidad los derechos de los demás y el orden jurídico, tal límite no puede llevarse al extremo de instrumentalizar a la persona para el logro del interés general en condiciones que afecten su dignidad. Finalmente cabe señalar que, de acuerdo con la jurisprudencia, el principio de dignidad humana, comporta un mandato constitucional que determina no sólo un deber negativo de no intromisión sino también un deber positivo de protección y mantenimiento de condiciones de vida digna". (Notas al pie eliminadas).

23 Esto es lo que la Corte ha llamado de manera diciente el derecho que tienen los individuos a "vivir como se quiera" y a "vivir sin humillaciones". Ver, por ejemplo, Corte Constitucional, Sentencia T-881 de 2002, MP: Eduardo Montealegre Lynett; Corte Constitucional, Sentencia C-221 de 1994, MP: Carlos Gaviria Díaz; Corte Constitucional, Sentencia T-881 de 2002, MP: Eduardo Montealegre Lynett; Corte Constitucional, Sentencia C-521 de 1998, MP: Antonio Barrera Carbonell. De igual forma, ver La Demanda, en Parejas del mismo sexo: el camino hacia la igualdad - Sentencia C-075/07, Colombia Diversa - Universidad de los Andes, 2008, pp. 106-110.

24 Esto es lo que la Corte ha llamado la dimensión material del principio de dignidad. Esta dimensión se concreta en el derecho constitucional de creación juris- 
la Corte, la autonomía no se puede poner en práctica si los individuos no pueden satisfacer sus necesidades vitales básicas, por ejemplo, las relacionadas con la salud o el número de calorías necesarias para sobrevivir.

Para la Corte Constitucional, el libre desarrollo de la personalidad es un derecho que protege de manera amplia la autonomía de los individuos. La Corte lo entiende, fundamentalmente, como el derecho a "ser dejado solo", es decir, el derecho a que el Estado y otros individuos se abstengan de cruzar la frontera que protege el espacio en donde las personas articulan, transforman e intentan materializar su proyecto de buen vivir. De esta forma, el libre desarrollo de la personalidad concreta, promueve y protege el principio de dignidad humana. ${ }^{25}$ Ahora bien, para el tribunal constitucional, siguiendo con la interpretación estándar que tiene el liberalismo de la autonomía individual, el libre desarrollo de la personalidad se entiende como un derecho relativo. El orden jurídico y los derechos de los demás se constituyen en límites legítimos para la autonomía de los sujetos.

Por último, la Corte entiende la igualdad, apelando nuevamente a una interpretación estándar del canon liberal, como el derecho a que casos análogos sean tratados de manera análoga y que casos disímiles deban ser tratados de manera disímil. Para la Corte, en consecuencia, este derecho implica que los sujetos no pueden ser discriminados por parte del Estado y que cualquier trato diferenciado de la administración debe ser adecuadamente justificado -en particular, cuando quienes son tratados de manera diferente son grupos de individuos que han sido históricamente discriminados en la comunidad política.

Esta línea argumentativa es seguida fielmente por las otras seis sentencias que constituyen la línea jurisprudencial sobre parejas del

prudencial al mínimo vital. Ver, por ejemplo, Sentencias SU-225 de 1998, SU995 de 1999, C-778 de 2003, T-326 de 1992 y T-533 de 2002.

25 " [...] [E]sta Corte ha entendido que el derecho al libre desarrollo de la personalidad consagra una protección general de la capacidad que la Constitución reconoce a las personas para autodeterminarse, esto es, a darse sus propias normas y desarrollar planes propios de vida, siempre y cuando no se afecten derechos de terceros o el orden jurídico". (Nota al pie eliminada). 
mismo sexo (C-811/2007, T-856/2007, ${ }^{26}$ y C-336/2008, T-1241/ $2008,{ }^{27}$ C-798/2008 y C-029/2009).

Ahora bien, la Corte establece una conexión estrecha entre las normas demandadas y las acciones de la administración cuestionadas en los siete casos relacionados con las parejas del mismo sexo, por un lado, y la violación tanto de los derechos a la igualdad y el libre desarrollo de la personalidad como del principio de dignidad humana, por el otro. Señala que las parejas del mismo sexo y las parejas heterosexuales son iguales en todas las materias definidas y reguladas por la figura de la unión marital de hecho. Para la Corte no hay diferencias jurídicamente relevantes para distinguir a las parejas del mismo sexo y a las heterosexuales en estas materias. Las dos son formas de asociación que permiten que los individuos compartan su vida sexual, afectiva y patrimonial. Por tanto, cualquier interpretación de estas normas que excluya de su ámbito de aplicación a las parejas del mismo sexo es inconstitucional en tanto que diferencia injustificadamente entre dos formas de asociación a las que pueden legítimamente apelar los ciudadanos para materializar sus proyectos de buen vivir.

A su vez, estas normas restringen indebidamente la autonomía de los individuos. ${ }^{28}$ El no reconocimiento jurídico de las parejas del mismo sexo desincentiva y hace menos viables los proyectos de buen vivir que involucran la vida en común de individuos con orientaciones sexuales no tradicionales. Finalmente, este conjunto de normas viola la dignidad humana, esto es, la capacidad que tienen los seres humanos para escoger e intentar materializar a través de la razón sus

26 Ver secciones 4 y 5 de la sentencia T-856/2007 en donde se citan las sentencias C-075 de 2007 y C-811 de 2007 como precedentes obligatorios para decidir el caso de tutela que se revisa.

27 Ver secciones 4.2 y 4.3 de la sentencia T-1241/2008 en donde se citan tanto la sentencia C-336 de 2008 como la sentencia C-075 de 2007 como fundamento de la decisión que la Corte Constitucional toma en esta tutela.

28 De manera paradigmática indica la Corte en la sentencia C-075 de 2007, "Dicho de otra manera, la decisión legislativa de no incluir a las parejas homosexuales en el régimen patrimonial previsto para las uniones maritales de hecho, comporta una restricción injustificada de la autonomía de los integrantes de tales parejas y puede tener efectos lesivos, no solo en cuanto obstaculiza la realización de su proyecto de vida común, sino porque no ofrece una respuesta adecuada para las situaciones de conflicto que se pueden presentar cuando por cualquier causa cese la cohabitación". 
proyectos de buen vivir. ${ }^{29}$ Para la Corte Constitucional, el no reconocimiento jurídico de las parejas del mismo sexo niega la pertenencia plena al género humano de los miembros de este tipo de parejas. Este conjunto de normas y acciones estatales no permiten que las personas "vivan como quieran", "vivan sin humillaciones" y tengan acceso a unas condiciones materiales mínimas para sobrevivir. ${ }^{30}$

\section{La importancia de las sentencias}

El conjunto de siete sentencias en donde la Corte Constitucional colombiana reconoce la existencia jurídica de las parejas del mismo sexo y les concede a sus miembros un conjunto amplio de derechos es relevante por las siguientes cuatro razones. En primera instancia, con estas decisiones la Corte ataca de manera frontal un problema que debilita seriamente al ordenamiento jurídico-político colombiano: la existencia injustificada de dos tipos de ciudadanía. De un lado, los ciudadanos heterosexuales, que son definidos por el sistema jurídico como ciudadanos de primera categoría; del otro, los ciudadanos con orientaciones sexuales alternativas, que son tratados por este mismo sistema como ciudadanos de segunda categoría.

Los fallos de la Corte Constitucional deben ser interpretados como un cuestionamiento radical al uso de la orientación sexual como un

29 Paradigmáticamente señala la Corte en la sentencia C-075 de 2007, "En el ámbito del problema que ahora debe resolver la Corte, resulta claro que la falta de reconocimiento jurídico de la realidad conformada por las parejas homosexuales es un atentado contra la dignidad de sus integrantes porque lesiona su autonomía y capacidad de autodeterminación al impedir que su decisión de conformar un proyecto de vida en común produzca efectos jurídico patrimoniales, lo cual significa que, dado un régimen imperativo del derecho civil, quedan en una situación de desprotección que no están en capacidad de afrontar. No hay razón que justifique someter a las parejas homosexuales a un régimen que resulta incompatible con una opción vital a la que han accedido en ejercicio de su derecho al libre desarrollo de la personalidad, ni resulta de recibo que la decisión legislativa de establecer un régimen para regular la situación patrimonial entre compañeros permanentes, sea indiferente ante los eventos de desprotección a los que puede dar lugar tratándose de parejas homosexuales".

30 La Corte hace referencia al caso de los miembros de parejas del mismo sexo de bajos recursos económicos que sobreviven a su pareja y no tienen derecho a la sustitución pensional o a aquellos que una vez se separan de su pareja o ésta muere no tienen derecho al patrimonio que construyeron conjuntamente en tanto que éste estaba a nombre únicamente de la persona que murió o de quien se separó. 
criterio para determinar quiénes pueden acceder a la ciudadanía plena. Conforme con la Corte, en una democracia liberal como la colombiana el Estado debe tratar a todos sus ciudadanos con igual consideración y respeto. El Estado no puede hacer uso de los recursos a su disposición, el derecho y la fuerza pública, por ejemplo, para promover los proyectos de buen vivir de algunos de sus ciudadanos.

La vida en pareja constituye una de las formas a través de las cuales los seres humanos intentan materializar sus proyectos de buen vivir. Es un medio a través del cual buscan concretar sus compromisos morales. Permitir que el sistema jurídico desconozca su existencia no solo envía a la sociedad un mensaje en donde se califica negativamente a las orientaciones sexuales no tradicionales, asunto que no es competencia del Estado, sino que también les impone unos costos muy altos a quienes las encarnan, por ejemplo, marginación social y gastos económicos relacionados con el manejo y liquidación del patrimonio común. Sin embargo, el costo más alto que tienen que pagar los miembros de las parejas del mismo sexo está relacionado con el hecho de que el sistema jurídico les niega su plena humanidad. Para el sistema jurídico, estas personas no son miembros completos del género humano; su autonomía y racionalidad son restringidas radicalmente en tanto que el resultado de su ejercicio es calificado negativamente por el Estado.

El segundo argumento tiene que ver con el giro radical que le da la Corte Constitucional a su jurisprudencia. Hasta la sentencia C-075 de 2007, el Tribunal no había reconocido a los miembros de las parejas del mismo sexo como sujetos de derecho, aunque había protegido los derechos de personas con orientaciones sexuales no tradicionales en su condición de individuos (Lemaitre 2005). Entre 1991 y 2007, la Corte señaló que las instituciones de formación de la fuerza pública no pueden expulsar a sus miembros por el sólo hecho de que éstos sean homosexuales; que los colegios públicos y privados no pueden expulsar a los estudiantes homosexuales porque consideren que su orientación sexual es inmoral y que la homosexualidad no es una falta al honor militar o a los deberes que tienen los docentes de los colegios públicos. ${ }^{31}$ Sin embargo, durante este mismo periodo la

31 En las sentencias T-097 de 1994 M.P. Eduardo Cifuentes Muñoz, T-101de 1998 M.P. Fabio Morón Díaz, C-481 de 1998 M.P. Alejandro Martínez Caballe- 
Corte señaló que el Estado está facultado constitucionalmente para prohibir que las parejas del mismo sexo adopten niños, que es constitucional que en Colombia un homosexual no pueda afiliar al sistema de seguridad social a su pareja y que la Constitución acepta que la ley que regula la unión marital de hecho sea aplicable únicamente a las parejas heterosexuales. ${ }^{32}$

Con la expedición de la sentencia C-075 de 2007, la Corte reconoce que el ámbito de discrecionalidad que tiene el legislador para regular las prácticas sociales no es ilimitado en materias relacionadas con la orientación sexual. El argumento central que había servido para declarar la constitucionalidad de las normas que regulaban cuestiones relacionadas con las parejas heterosexuales, pero omitían cualquier referencia a las parejas del mismo sexo, acepta ahora la Corte, no tiene fundamento cuando están en juego principios constitucionales estructurales, como la dignidad, y derechos fundamentales de los ciudadanos como la igualdad y el libre desarrollo de la personalidad. El legislador no puede dejar de regular cuestiones relacionadas con las parejas del mismo sexo cuando crea normas que regulan las parejas heterosexuales dado que, en principio, por lo menos en cuestiones patrimoniales no hay diferencia entre una y otra forma de asociación. De este modo, la libertad del legislador tiene fronteras negativas y positivas. El legislador no debe, en principio, regular cuestiones relacionadas con la orientación sexual de los ciudadanos. No obstante, cuando tenga la potestad, debe hacerlo de manera coherente con la protección de los derechos y principios básicos de un Estado Social de Derecho y no puede dejar de incluir los casos análogos a los que pretende regular en primera instancia.

ro, C-507de 1999 M.P. Vladimiro Naranjo Mesa, T-618 de 2000 M.P. Alejandro Martínez Caballero, se concede el amparo de los derechos fundamentales a los individuos homosexuales.

32 En las sentencias C-098 de 1996 M.P. Eduardo Cifuentes Muñoz (unión marital de hecho), T-618 de 2000 (afiliación al sistema de seguridad social), T-999 de 2000 M.P. Fabio Morón Díaz (afiliación al sistema de seguridad social), T-1426 de 2000 M.P. Álvaro Tafur Galvis (afiliación al sistema de Seguro Social), SU-623 de 2001 M.P. Rodrigo Escobar Gil (afiliación al sistema de seguridad social)1, C-814 de 2001M.P. Marco Gerardo Monroy Cabra (adopción); T-725 de 2004 (derecho a residencia de la pareja del mismo sexo en la isla de San Andrés); y T-349 de 2006 (sustitución pensional), no se reconocen los derechos de las parejas homosexuales. 
Ahora bien, es importante recordar que los cambios articulados por la Corte Constitucional son formales, esto es, meras transformaciones en el ordenamiento jurídico. El avance en el reconocimiento de la igual dignidad de los seres humanos es un avance jurídico que apenas acerca a la comunidad política colombiana a los ideales de la revolución francesa. En materia de orientación sexual estamos hasta ahora aproximándonos al siglo XVIII. La discriminación social y la violencia en contra de la comunidad LGBT sigue siendo un hecho evidente en Colombia (Colombia Diversa 2007).

No obstante, este reconocimiento jurídico tiene valor simbólico y material. Por un lado, la comunidad política por primera vez reconoce las estrechas conexiones que existen entre la igual dignidad de todos sus ciudadanos y su orientación sexual. El discurso políticojurídico cambió con este conjunto de sentencias y, consecuentemente, las reglas de juego dentro de la polis se transformaron. De este modo, la imaginación jurídico-política se amplía y se reduce a la vez. El conjunto de titulares de la ciudadanía plena incluyen ahora a los miembros de la comunidad LGBT y no es posible ya excluir de la polis a las personas que no se reconocen como heterosexuales. Además, no hay que perder de vista el poder que tiene el derecho para cambiar los imaginarios sociales. El derecho, con la carga emotiva positiva con la que generalmente se le asocia y el aparato coercitivo que tiene a su servicio, está ahora del mismo lado de la diversidad sexual. A largo plazo, este hecho, adecuadamente utilizado, puede contribuir a cambiar las prácticas sociales que discriminan a las minorías sexuales.

Por el otro lado, esta transformación jurídica confirió a los ciudadanos herramientas poderosas para oponerse a las acciones estatales y del sector privado que violan el derecho que tienen los colombianos a vivir de acuerdo con su orientación sexual. Los miembros de las parejas del mismo sexo tienen hoy a su servicio los instrumentos que el sistema jurídico le otorga a las personas para defender sus derechos fundamentales, en particular, la acción de tutela, las acciones civiles que permiten compensar los daños causados a las víctimas y las acciones penales (que permiten sancionar a quienes se nieguen a cumplir con los mandatos constitucionales).

En tercera instancia, este conjunto de sentencias evidencian el cambio que se ha dado en la última década en la manera como la 
sociedad colombiana percibe a las minorías sexuales. La Corte Constitucional es una institución compuesta por nueve magistrados, muchos de los cuales defienden posiciones conservadoras en materias sociales -perspectivas que la mayoría de las veces están influenciadas por la doctrina de la iglesia católica. Es diciente, por consiguiente, que este conjunto de sentencias haya sido aprobado por consenso o por amplias mayorías dentro del Tribunal Constitucional. La sentencia hito, aquella que abrió la línea jurisprudencial, fue aprobada por ocho magistrados. La única disidencia, que se concretó en el salvamento de voto del magistrado Araujo, se generó porque la sentencia no había ido lo suficientemente lejos en la protección de los derechos de los miembros de las parejas del mismo sexo. En la práctica, entonces, hubo un consenso dentro de la Corte en torno a la idea de que la Constitución de 1991 exige que se reconozca a las parejas del mismo sexo. ${ }^{33}$

De igual forma, el hecho de que buena parte de la comunidad política apoyó o no se opuso a los fallos promulgados por la Corte Constitucional, evidencia que el país ha dado algunos pasos hacia el reco-

33 Una situación muy similar se presentó en los otros seis casos decididos por la Corte Constitucional. Igualmente, la votación en la sentencia C-811/2007 fue de siete votos a favor y dos en contra. Los salvamentos de voto fueron de los magistrados Araujo y Pinilla, aunque el magistrado Araujo, nuevamente, se opuso al fallo por no ser suficientemente amplio en la protección de los derechos de la comunidad LGBT. En la sentencia C-336/2008 la votación fue de seis votos a favor y dos en contra. El magistrado Cepeda estuvo ausente de la sala plena en la que se decidió el caso y los magistrados Araujo y Pinilla, de nuevo, salvaron su voto y reiteraron los argumentos, muy distintos, que expusieron en las sentencias anteriores. En la sentencia C-798 de 2008, la decisión fue de siete votos a favor y dos en contra - con los magistrados Pinilla y Escobar en la minoría; y en la sentencia C-029/2009, la votación fue de ocho votos a favor y uno en contra (salvamento de voto parcial del magistrado Pinilla). Finalmente, en las sentencias T-856/2007 y T-1241/2008, que en tanto casos de revisión de tutela se deciden por paneles compuestos por tres magistrados, las votaciones fueron 3-0, es decir, hubo unanimidad en el panel en torno a que la línea jurisprudencial establecida por la Corte Constitucional sobre la materia era aplicable a los casos bajo estudio. De esta forma solo ha habido un miembro de la Corte que de manera recurrente se ha manifestado en contra del reconocimiento de algunos derechos para los miembros de las parejas del mismo sexo, el magistrado Nilson Pinilla (El magistrado Escobar solo fue disidente en uno de los siete casos decididos por la Corte Constitucional relacionados con el reconocimiento jurídico de las parejas del mismo sexo). 
nocimiento de la diversidad sexual. Este hecho se hizo explícito en el amplio y positivo cubrimiento que tuvieron los casos en los medios de comunicación, ${ }^{34} \mathrm{y}$ en el hecho de que buena parte de la jerarquía católica aceptó estas transformaciones jurídicas en tanto tenían que ver con cuestiones civiles, particularmente asuntos patrimoniales, relacionadas con la vida en pareja. ${ }^{35}$ Estos temas, argumentaron muchos de los jerarcas católicos, son de competencia del Estado, no de la iglesia ${ }^{36}$. La narrativa con la que se describen a las minorías sexua-

34 Ver, por ejemplo, "Colombia legitima el vínculo entre los gays", Diario El Universo, en <www.eluniverso.com/2007/02/09/0001/14/70DBA374EAE04 92DA8D2D463B9C70EA0.aspx> (01.06.2010); "Corte Constitucional reconoce derechos patrimoniales a parejas 'gay'", Revista Semana, en <www.semana. com/wf_InfoArticulo.aspx?idArt=100889> (01.06.2010); "Fallo sobre derechos patrimoniales de parejas homosexuales genera controversia", RCN Radio, en $<$ www.ren.com.co/noticia.php3?nt=17978> (01.06.2010); "Sentencia de la Corte sobre derechos patrimoniales de parejas homosexuales es explicada por Rodrigo Escobar Gil (La W)", Periódico El Tiempo, en <www.eltiempo.com/ multimedia/audio/actualidad/AUDIO-WEB-PLANTILLA AUDIOS-

3430967.html?id_ recurso $=3430967 \&$ id_articulo $=3430779>\quad(01.06 .2010)$; "¿Cuáles son los alcances del fallo de la Corte, que garantiza los derechos patrimoniales de las parejas del mismo sexo?", Caracol Radio, en <www. caracol.com.co/noticias/388790.asp> (01.06.2010); "Parejas homosexuales ganan sus derechos patrimoniales", Periódico El Colombiano, en <www.elcolombiano. com.co/BancoConocimiento/P/parejas_homosexuales_ganan_sus_derechos_ patrimoniales/parejas_homosexuales_ganan_sus_derechos_patrimoniales.asp $>$ (01.06.2010).

35 No obstante, la jerarquía católica se opuso firmemente a que se reconociera el derecho al matrimonio o la adopción de los miembros de las parejas del mismo sexo.

36 La agencia de noticias católica ACIPRENSA - lo que todo católico necesita saber, reportó al respecto: "A finales de septiembre, el Presidente de la Conferencia Episcopal de Colombia, Mons. Luis Augusto Castro, expresó que aunque la Iglesia no tiene nada que decir 'en contra del patrimonio y la seguridad social de los homosexuales', estos objetivos se pueden alcanzar sin necesidad de 'introducir una figura de matrimonio camuflado y sin dar un golpe más duro a la estructura familia"'. En: <www.aciprensa.com/noticia.php?n=14432> (01.06.2010). La cadena Caracol reportó en el mismo sentido lo siguiente, "El secretario general de la Conferencia Episcopal Colombiana, monseñor Fabián Marulanda, señaló que dentro de los principios de respeto y no discriminación hacia los homosexuales, 'está bien que se garanticen los derechos patrimoniales de las uniones homosexuales'. El prelado señaló que lo importante para la Iglesia Católica es que las parejas del mismo sexo no alcancen el mismo nivel del matrimonio de las parejas heterosexuales, y agregó que el clero tampoco aceptaría que se les otorgara a las uniones 'gay', el derecho de adopción" (<www. caracol.com.co/nota.aspx?id=388585>, 01.06.2010). 
les, por tanto, ha venido cambiando en Colombia. De un discurso centrado en el pecado o en la enfermedad se van dando pasos importantes hacia uno centrado en el reconocimiento a la diferencia sexual. ${ }^{37}$

Finalmente, la jurisprudencia de la Corte Constitucional contribuye a reflexionar en torno al reconocimiento de la diferencia sexual de una manera novedosa cuando hace uso del principio de dignidad humana. Cuando el Tribunal apela a este principio para justificar sus decisiones, ofrece algunas herramientas conceptuales que permiten comprender y evaluar de manera rica, compleja y fresca los problemas que genera para una democracia liberal el no reconocimiento jurídico de las parejas del mismo sexo. Sin embargo, en tanto que la Corte también se apoya en los derechos a la igualdad y el libre desarrollo de la personalidad para fundamentar sus fallos, su argumentación genera algunas importantes tensiones teóricas.

\section{Los modelos de la autonomía, la igualdad y la dignidad}

El reconocimiento jurídico de las parejas del mismo sexo puede comprenderse y fundamentarse apelando a tres modelos distintos: autonomía, igualdad y dignidad. Ahora bien, aunque la igualdad y dignidad ofrecen herramientas conceptuales y prácticas complementarias, el modelo de la autonomía resulta incompatible con las otras dos estructuras normativas. El modelo de la dignidad y el de la igualdad interpretan el problema que es objeto de estudio de manera distinta y generan consecuencias sustanciales y procedimentales para la comunidad política que son inconciliables con el modelo de la autonomía (Burt 2009). ${ }^{38}$ Es importante precisar que cada uno de estos modelos recoge como su eje central a uno de los derechos a los que apela la Corte Constitucional para justificar su línea jurisprudencial. De igual forma, es necesario señalar que los tres modelos coexisten, en tensión, dentro de cada una de las sentencias promulgadas por la Corte sobre el reconocimiento jurídico y derechos de las parejas del

37 No hay que olvidar que la sodomía fue un delito en Colombia hasta 1980 y que la Asociación Estadounidense de Psiquiatría, referente fundamental para la psiquiatría colombiana, sólo hasta 1973 eliminó a la homosexualidad de su listado de enfermedades mentales.

38 En este texto, Burt argumenta que el modelo de la igualdad y el de la autonomía son irreconciliables. 
mismo sexo. Finalmente, los modelos no aparecen de manera completa en las sentencias de la Corte Constitucional colombiana; solo sus elementos estructurales lo hacen. Esta sección del artículo, por tanto, busca precisar y desarrollar los contenidos de estos elementos, explicitar sus fundamentos y analizar sus consecuencias teóricas y prácticas.

El modelo de la autonomía argumenta que las cuestiones relacionadas con la vida sexual y afectiva incumben únicamente a los individuos involucrados. El Estado no tiene competencia alguna para involucrarse en asuntos que tienen que ver con los proyectos de buen vivir de sus ciudadanos. Las personas, argumenta el modelo de la autonomía, tienen el derecho a "ser dejados solos" (Warren/Brandeis 1980); tienen el derecho a que el Estado no invada el espacio íntimo donde articulan, modifican e intentan volver realidad sus compromisos morales. ${ }^{39}$ En términos de la Corte Constitucional colombiana,

[...] el derecho al libre desarrollo de la personalidad consagra una protección general de la capacidad que la Constitución reconoce a las personas para autodeterminarse, esto es, a darse sus propias normas y desarrollar planes propios de vida, siempre y cuando no se afecten derechos de terceros o el orden jurídico. Para la Corte este derecho se vulnera "cuando a la persona se le impide, en forma irrazonable, alcanzar o perseguir aspiraciones legítimas de su vida o valorar y escoger libremente las opciones y circunstancias que le dan sentido a su existencia y permiten su realización como ser humano". 40

Este modelo se entrecruza con el argumento del liberalismo que defiende la separación entre la órbita de lo privado y la de lo público (Dworkin 1993: 49-66). El ámbito de lo privado, argumentan los liberales, es el ámbito de la moral, el espacio donde el individuo construye su proyecto de buen vivir. El ámbito de lo público es el ámbito de la justicia, el espacio donde se construye la estructura básica

39 Este es un modelo que se ha utilizado para justificar tanto el reconocimiento de las parejas del mismo sexo como otros derechos relacionados con la sexualidad. Es, como se ha visto, uno de los argumentos que fundamenta la línea jurisprudencial de la Corte Constitucional colombiana que reconoce la existencia jurídica de las parejas del mismo sexo. Sin embargo, también ha sido un modelo utilizado en el contexto anglosajón para justificar fallos de la Corte Suprema de Justicia tan importantes como Roe v. Wade (aborto), Griswold v. Connecticut (derecho de la parejas casadas a usar anticonceptivos), y Lawrence v. Texas (junto al argumento de la igualdad permitió que se declararan inconstitucionales las normas que sancionaban las relaciones sexuales entre parejas del mismo sexo).

40 Sentencia C-075/2007 (itálica en el original). 
de la comunidad política; la esfera donde se distribuye el poder político y los recursos escasos que controla la sociedad. La frontera que divide estas dos esferas tiene como objetivo precisar firmemente los límites que configuran el espacio de acción legítima del Estado, esto es, precisar los contornos que fijan el espacio de lo político. El Estado, por consiguiente, no puede cruzar la frontera que divide estas dos esferas sin violar dos de los principios básicos del liberalismo: aquel que indica que el Estado debe tratar con igual consideración y respeto a todos los asociados y aquel que señala que cada individuo tiene derecho a construir y materializar su proyecto moral sin intervención alguna del Estado (Dworkin 1998: 180-204).

Ahora bien, este modelo tiene debilidades importantes. En primera instancia, es una perspectiva radicalmente individualista que entiende a los seres humanos como mónadas sin conexiones relevantes con la comunidad (Williams 1991: 165-180). El modelo de la autonomía parte del supuesto de un sujeto fuerte que construye (y debe construir) su identidad de manera solitaria. La satisfacción de esta necesidad, para el modelo de la autonomía, se garantiza jurídica y políticamente a través del derecho a ser libre, esto es, el derecho que tienen las personas a ser dejadas solas (Allen 2000). De esta forma, el modelo de la autonomía ve con desconfianza las relaciones humanas (West 1988), pues constituyen obstáculos para la construcción libre del sujeto.

El modelo pierde de vista que la autonomía no se ejerce en abstracto sino en contextos que limitan, pero al mismo tiempo constituyen al individuo. Los horizontes de perspectivas en los que los sujetos están ineludiblemente inmersos prescriben cuáles son las opciones vitales disponibles para el sujeto, así como el valor moral que cada una de ellas tiene (Taylor 1994: 67-76). La autonomía, por tanto, se ejerce dentro de las fronteras establecidas previamente por este entramado de interpretaciones de la realidad (Kymlicka 1996: 120122). El sujeto no dispone de una cantidad infinita de posibilidades de ser en el mundo para construir su identidad individual, sino solo de las alternativas que existen dentro de la comunidad a la que pertenece.

El modelo de la autonomía oscurece la dimensión comunitaria que tiene el género y, por tanto, la dimensión política que tiene el problema del no reconocimiento jurídico de las parejas del mismo sexo (Burt 2009: 17). Escoger entre los roles disponibles para cada gene- 
ro, violentarlos y ser cuestionado, o materializarlos y ser reconocido, por ejemplo, solo tiene sentido socialmente (Burt 2009: 17). Los individuos -mónadas, si existieran- no tendrían mayores problemas con el rompimiento de los roles asignados socialmente al género al que supuestamente pertenecen, pues la construcción de su identidad individual no depende de forma alguna de la mirada que "el otro" tiene de nosotros y que constantemente nos proyecta. Estos sujetos olvidan que la vida en pareja es a la vez una cuestión privada y pública: compete de manera directa y especial a los individuos, pero éstos la entienden en buena parte a través de los lentes interpretativos que la comunidad provee. El reconocimiento jurídico de las parejas del mismo sexo, entonces, tiene como objetivo que la comunidad política declare formalmente que ser parte de una pareja del mismo sexo es tan valioso, genéricamente, como de una pareja de heterosexuales. No reconocerlas jurídicamente implica someter a los miembros de las parejas del mismo sexo a una estructura oficial de subordinación que los condena a una posición de inferioridad moral frente a los individuos de parejas heterosexuales.

En segunda instancia, el modelo de la autonomía pierde de vista la violación del derecho de igualdad y el principio de dignidad humana que genera el no reconocimiento de las parejas del mismo sexo. En relación con la igualdad, el modelo de la autonomía es incapaz de ver que parte del problema radica en que las parejas del mismo sexo son tratadas de manera distinta a como son tratadas las parejas heterosexuales. La cuestión no es sólo que los individuos tengan la posibilidad de compartir su vida con quienes así lo decidan, asunto que el modelo de la autonomía recoge y protege, sino en las consecuencias jurídicas y políticas que genera la distinción injustificada entre parejas del mismo sexo y las heterosexuales. El modelo de la autonomía, por tanto, oscurece el problema de igualdad que atraviesa la jurisprudencia de la Corte Constitucional colombiana sobre las parejas del mismo sexo. Para la Corte,

Las mismas consideraciones que permiten establecer que en relación con la situación patrimonial de las parejas homosexuales existe un déficit de protección a la luz del ordenamiento constitucional, llevan a la conclusión de que el régimen de la Ley 54 de 1990 [...] en la medida en que se aplica exclusivamente a las parejas heterosexuales y excluye de su ámbito a las parejas homosexuales, resulta discriminatorio. Así, no obstante las diferencias objetivas que existen entre los dos tipos de pareja, 
y las específicas consideraciones que llevaron al legislador del año 1990 a establecer este régimen de protección, fundadas en la necesidad de proteger a la mujer y a la familia, no es menos cierto que hoy por hoy puede advertirse que las parejas homosexuales presentan requerimientos análogos de protección y que no existen razones objetivas que justifiquen un tratamiento diferenciado.

La marginación del derecho de igualdad de la manera como se comprende y evalúa el no reconocimiento jurídico de las parejas del mismo sexo genera dos problemas que están estrechamente entrelazados: uno de igualdad tenue y otro de igualdad fuerte. El problema de igualdad tenue tiene que ver con el hecho de que dos casos análogos son tratados de manera diferente, pues no parece haber diferencias fundamentales que justifiquen un trato diferenciado por parte del sistema jurídico. Tanto las parejas del mismo sexo como las heterosexuales son formas de asociación que tienen como objetivo permitir que dos personas compartan su vida afectiva, sexual y financiera.

El problema de igualdad fuerte es que el hecho de que parejas heterosexuales sean reconocidas jurídicamente y las parejas del mismo sexo no lo sean, tiene como justificación una diferenciación más profunda entre los miembros que componen uno y otro tipo de asociación. Los primeros son reconocidos como miembros plenos del género humano mientras que los segundos son excluidos del mismo (Burt 2009: 14, 17). El modelo de la autonomía es incapaz de comprender que el núcleo del problema que produce el silencio jurídico frente a las parejas del mismo sexo está relacionado con el no reconocimiento de los miembros de este tipo de parejas como miembros plenos del género humano. Desconoce que las relaciones de pareja constituyen elementos centrales para desarrollarse como seres humanos. Este hecho se hace más evidente cuando las razones para la exclusión de las parejas del mismo sexo del ordenamiento jurídico son de corte religioso y apuntan a indicar que las relaciones sexuales y afectivas entre individuos del mismo sexo son contra natura.

El modelo de la autonomía concentra toda la atención en la decisión que toman los individuos de hacer parte de una pareja del mismo sexo y no en el contenido de la decisión (Burt 2009: 11), y en las consecuencias simbólicas y materiales que ésta genera. El modelo se limita a defender que la decisión de conformar una pareja debe ser

41 C-075/2007. 
respetada por el Estado en tanto que fue una decisión tomada por dos adultos capaces. La materia de la decisión le resulta irrelevante. No exige, por tanto, que el Estado actúe para reconocer la existencia de las parejas del mismo sexo sino que reclama que el Estado se abstenga de actuar frente a cualquier tema que tenga que ver con la vida sexual y afectiva de las personas y, consecuentemente, pierde de vista que el Estado ya se puso en movimiento injustificadamente para reconocer únicamente la existencia jurídica de las parejas heterosexuales.

En relación con el principio de dignidad humana, el modelo de la autonomía es incapaz de evidenciar que tras el problema de igualdad tenue que surge como consecuencia del no reconocimiento jurídico de las parejas del mismo sexo subyace un problema de desconocimiento de las características del ser humano que el liberalismo califica como constitutivas de todos los miembros de la especie: su autonomía y racionalidad (Waldron 1998: 227). Como se analizará en detalle en los próximos apartes, el modelo de la igualdad (así como el de la autonomía) no describe de manera precisa y completa el problema: la cuestión no es que seamos dignos porque somos iguales sino que somos iguales porque somos dignos. El no reconocimiento jurídico de las parejas del mismo sexo viola la igualdad en un sentido fuerte porque viola la dignidad humana, no viceversa.

El modelo de la igualdad ofrece una interpretación distinta a la que articula el modelo de la autonomía sobre los problemas teóricos y prácticos que genera el no reconocimiento jurídico de las parejas del mismo sexo. Para esta perspectiva, como se evidenció arriba, el problema central es la violación del derecho a la igualdad en un sentido tenue y en un sentido fuerte. La igualdad en un sentido tenue se viola cuando se utiliza injustificadamente la orientación sexual de los ciudadanos como criterio para distribuir derechos y obligaciones básicos entre los ciudadanos. La igualdad en un sentido fuerte se transgrede cuando se distingue infundadamente entre dos grupos de sujetos, los miembros de las parejas del mismo sexo y los de parejas heterosexuales, para negarle a los primeros su calidad de seres humanos. La jurisprudencia de la Corte Constitucional colombiana sobre parejas del mismo sexo se concentra en el problema de igualdad tenue. La argumentación del tribunal, cuando hace referencia al derecho de igualdad, se concentra en denunciar el carácter injustificado de la distinción que hace el ordenamiento jurídico entre parejas del mismo 
sexo y parejas heterosexuales. El problema de igualdad fuerte no aparece explícitamente en la jurisprudencia de la Corte. Más bien, aparece implícitamente y como un problema directamente relacionado con el principio de dignidad humana. ${ }^{42}$

El modelo de la igualdad tiene la virtud de explicitar la dimensión política que tiene la orientación sexual, el carácter dialógico de la construcción de la identidad individual y el papel que juega el derecho en este proceso. El entramado de posibilidades que ofrece la comunidad en la que se está inmerso condiciona y carga de sentido las decisiones que los individuos toman en torno a su vida sexual y afectiva. Este modelo también evidencia las conexiones que existen entre el principio de igual ciudadanía y el principio que afirma la igualdad básica de todos los seres humanos, y exige que el Estado haga lo necesario para proteger el derecho a la igualdad del que son titulares los miembros de las parejas del mismo sexo.

No obstante, el modelo de la igualdad, tanto como el modelo de la intimidad, es incapaz de dar cabal cuenta del problema central que genera el no reconocimiento de las parejas del mismo sexo. Este modelo pierde de vista que la igualdad en sentido tenue depende de la igualdad en sentido fuerte y que ésta, a su vez, es un derecho que depende del principio de dignidad humana. Si como se argumenta desde el modelo de la igualdad, lo que está realmente en juego no es si los criterios para distinguir entre miembros de las parejas del mismo sexo son o no plausibles sino la pertenencia misma al género humano. Como se mencionó arriba, los seres humanos no somos dignos porque somos iguales sino que somos iguales porque somos dignos. El hecho de que se considere que la autonomía y la racionalidad son características centrales de los seres humanos y que se tenga la convicción de que todos los seres humanos nacen con esas capacidades es lo que

42 Para la Corte en la sentencia C-075/2007, “[...] La afectación de la dignidad, finalmente, también se desprende de una manera directa, de la ausencia de reconocimiento jurídico de las opciones vitales de las personas. Ello se produce en este caso porque la realidad de las parejas homosexuales y de las personas que las integran no es reconocida y resulta invisible para el ordenamiento jurídico, puesto que, no obstante que dichas personas han obrado en ejercicio de una opción protegida por la Constitución, son ignoradas por el ordenamiento jurídico cuando se trata de resolver los conflictos patrimoniales que pueden surgir de tal decisión". 
posibilita que se pueda calificar a todos los miembros de la especie como fundamentalmente iguales.

De igual modo, el modelo de la igualdad oscurece el hecho de que el no reconocimiento jurídico de las parejas del mismo sexo violenta también la autonomía de sus miembros. La cuestión no es, como se articula desde el modelo de la autonomía, que el Estado debe abstenerse de actuar en materias relacionadas con la vida sexual y afectiva de las personas. El asunto es que debe hacerlo, reconociendo jurídicamente a las parejas del mismo sexo, de manera que las personas puedan efectivamente ejercer su autonomía. La omisión del Estado en esta materia envía un doble mensaje: las orientaciones sexuales alternativas son cuestionables moralmente y quien escoja vivir conforme a ellas tendrá que pagar notables costos (económicos, sociales, políticos) que las personas heterosexuales no tienen que pagar.

En contraste, el tercer modelo gira en torno al principio de la dignidad humana. Este principio señala, como se ha dicho antes, que todos los seres humanos somos dignos en tanto que tenemos la capacidad de articular, modificar y materializar, haciendo uso de la razón, proyectos de buen vivir y de justicia. Es decir que, como lo señala continuamente la jurisprudencia de la Corte Constitucional colombiana sobre parejas del mismo sexo, ${ }^{43}$ los miembros de la especie humana somos iguales en tanto que somos fundamentalmente seres autónomos y racionales. Estas capacidades comunes son violadas, argumenta el modelo de la dignidad, cuando el ordenamiento jurídico no reconoce a las parejas del mismo sexo. Los proyectos de buen vivir de la mayoría de las personas incluyen una dimensión de vida en pareja que se niega de manera radical para los individuos con orientaciones sexuales alternativas cuando no se reconocen las parejas del mismo sexo. El Estado, con su omisión, está evitando que las personas tomen autónomamente una decisión sobre el tipo de vida que quieren vivir que no afecta negativamente los derechos de terceras personas. Está limitando de manera radical e injustificada la potestad misma de escoger libremente un proyecto de vida. El Estado, con su inacción, está indicando que prefiere una orientación sexual -la heterosexualpor sobre otra -la homosexual-y que, por tanto, los individuos deberían escoger la primera y no la segunda.

43 Ver notas al pie 21 y 22. 
La cuestión no es solo que las personas puedan vivir con la pareja de su elección sin que el Estado las sancione, sino que éste reconozca la vida de las parejas del mismo sexo como una alternativa válida para la comunidad política. Este reconocimiento tiene un valor simbólico poderoso, el reconocimiento de los miembros de las parejas del mismo sexo como seres humanos iguales a los heterosexuales; y un valor material, relacionado con la reducción de los costos patrimoniales de la vida en pareja y la disminución de la discriminación y la violencia en contra de la comunidad LGBT.

El modelo de la dignidad ofrece varias ventajas frente a los modelos con los que compite. En primera instancia es una estructura normativa comprehensiva. Incluye tanto una dimensión de igualdad como una de autonomía. El modelo no es producto de un eclecticismo débil que busca combinar el modelo de la igualdad con una reinterpretación del modelo de la autonomía. La igualdad y la autonomía se aparejan estructuralmente en el concepto de dignidad humana. De hecho, los derechos de igualdad (tenue) y del libre desarrollo de la personalidad son instrumentos que se derivan y sirven para la defensa de la dignidad. La igualdad, en el modelo de la dignidad, se entiende como igualdad básica (fuerte) de los seres humanos. Esta igualdad es una función de la autonomía y racionalidad de las que gozan todos los individuos. De hecho, la igualdad tenue, que hace parte del modelo de la igualdad, y que depende de la igualdad fuerte, es una concreción y desarrollo de esta última. Es un derecho que otorga las herramientas para evaluar cuándo es legítimo que los miembros de la comunidad política sean tratados de manera diferenciada y cuáles serían las razones que permitirían cuestionar o fundamentar tales distinciones.

La autonomía, en el modelo de la dignidad, se entiende como una facultad básica que tienen todos los seres humanos y que solo puede ejercerse de manera efectiva si se cumple dos requisitos: la satisfacción de algunas necesidades materiales básicas, como la de ingerir cierto número de calorías diariamente, y la existencia de un marco jurídico-político amplio y respetuoso de los diversos proyectos de buen vivir que son posibles dentro de la comunidad de manera que los ciudadanos tengan la potestad real de escoger los que consideren más 
valiosos de entre ellos (Grant 2007). ${ }^{44}$ De esta manera, la dignidad incluye, en los términos de la Corte Constitucional colombiana, tres dimensiones que se entrecruzan: el derecho a vivir como se quiera, el derecho a vivir sin humillaciones y el derecho a un mínimo vital.

En segunda instancia, la vaguedad del principio de dignidad y la posibilidad de fundamentarlo desde diversas perspectivas lo convierte en un espacio discursivo privilegiado para alcanzar acuerdos amplios dentro de una comunidad política plural (Siegel 2008: 101; 2009: 10). El alto grado de generalidad del principio podría interpretarse en contra de la defensa del mismo. El significado de la dignidad humana, se podría argumentar, depende del intérprete, y por tanto, está a merced de las relaciones de poder que existen dentro de la comunidad política. Sin embargo, ésta parece ser una característica típica de todos los principios - no solo del de dignidad humana. Además, la vaguedad de los principios no es perpetua. A medida que son interpretados, particularmente por operadores jurídico-políticos con autoridad, su contenido se va precisando. Este contenido se vuelve obligatorio y, por consiguiente, se convierte en una guía para la conducta de las personas. Del mismo modo, el reconocimiento de que el contenido preciso del principio tiene un carácter contingente permite su variación como consecuencia de las transformaciones que vive la comunidad política.

Igualmente, dado que el principio puede llenarse de contenido y fundamentarse apelando a distintos tipos de argumentos -morales y seculares, religiosos e históricos-, un número amplio de personas puede aceptar que es un principio que vale la pena defender y entrar en procesos deliberativos que tengan como objetivo precisar su contenido. Así, personas que creen que el principio de dignidad humana debería salvaguardarse porque es una consecuencia de que los seres humanos hayan sido creados a imagen y semejanza de la divinidad (Bognetti 2005: 89; Lorberbaum 2002; Ritschl 2002: 87; Safrai 2002) o quienes creen que la autonomía y racionalidad son características esenciales de los seres humanos (Gewirth 1992: 99-109) y quienes consideran que este es un principio construido históricamente para defender bienes que nos parecen valiosos, pueden estar de acuerdo

44 En este artículo se exploran las conexiones entre la igualdad y la dignidad en la jurisprudencia alemana y surafricana. 
en que la dignidad es uno de los ejes en torno a los cuales debe estructurarse una comunidad política (Rao 2008: 201-256).

En tercera instancia, el modelo de la dignidad explica de manera clara, precisa y sencilla el problema que está en juego y lo interpreta y resuelve de manera que entronque con una interpretación iluminadora de la tradición política que sustenta el ordenamiento político - jurídico colombiano: el liberalismo.

Los modelos de la dignidad, la igualdad y la autonomía nos ofrecen una serie de herramientas conceptuales útiles para aproximarnos al problema del no reconocimiento jurídico de las parejas del mismo sexo, en particular, y de la discriminación por razones de orientación sexual, en general. Sin embargo, no podemos olvidar que el fin último no es interpretar más ricamente el problema, sino eliminarlo en la práctica. El asunto no es solo de claridad, precisión y sutileza jurídica y filosófica, sino de lucha política; de la construcción de una sociedad más igualitaria en donde la dignidad de todas las personas sea efectivamente protegida.

\section{Bibliografía}

Allen, Anita (2000): "Privacy". En: Jaggar, Alisson M./Young, Iris Marion (eds.): A Companion to Feminist Philosophy. Oxford: Blackwell.

Bognetti, Giovanni (2005): "The Conception of Human Dignity in European and US Constitutionalism”. En: Nolte, Georg (ed.): European and U.S. Constitutionalism. Cambridge: Cambridge University Press, pp. 85-107.

Bonilla, Daniel (2008): "Igualdad, orientación sexual y derecho de interés público: la historia de la sentencia C-075/07". En: Parejas del mismo sexo: el camino hacia la igualdad. Bogotá: Universidad de los Andes/Colombia Diversa.

Burt, Robert (2009): "Regulando la sexualidad: Libertad frente a Igualdad". En: Seminario en Latinoamérica de Teoría Constitucional y Política (SELA) (<www.law.yale.edu/intellectuallife/sela2009.htm>; 08.06.2011).

Colombia Diversa (2010): "Derechos Humanos de lesbianas, gays, bisexuales y transgeneristas en Colombia 2006-2007". En: <www.colombiadiversa.org/ index.php?option $=$ com_content\&task $=$ view\&id $=563 \&$ Itemid $=370>$ (01.06.2011).

Dworkin, Ronald (1993): Ética privada e igualitarismo político. Barcelona: Paidós.

- (1998): "Liberalism". En: Nida-Rümelin, Julian/Vossenkuhl, Wilhelm (eds.): Ethische und politische Freiheit. New York/Berlin: Walter de Gruyter. 
Gewirth, Alan (1992): "Human Dignity as the Basis of Rights". En: Meyer, Michael J./Parent, William A. (eds.): The Constitution of Rights: Human Dignity and American Values. Ithaca: Cornell University Press, pp. 99-109.

GDIP (Grupo de Derecho de Interés Público de la Universidad de los Andes) (2010): Informe para el $18^{\circ}$ Congreso Internacional de Derecho Comparado. Washington, D.C.: GDIP.

Grant, Evadne (2007): “Dignity and Equality”. En: Human Rights Law Review, 7, 2, pp. 299-329.

Kymlicka, Will (1996): Ciudadanía multicultural. Barcelona: Paidós.

Lemaitre, Julieta (2005): "Los derechos de los homosexuales y la Corte Constitucional: (casi) una narrativa de progreso". En: Bonilla, Daniel/Manuel, Iturralde (eds.): Hacia un nuevo derecho constitucional. Bogotá: Universidad de los Andes, pp. 181-217.

Lorberbaum, Yair (2002): "Blood and the Image of God: On the Sanctity of Life in Biblical and Early Rabbinic Law, Myth and Ritual". En: Kretzmer, David/Klein, Eckart (eds.): The Concept of Human Dignity in Human Rights Discourse. Den Haag: Kluwer Law International, pp. 55-85.

Rao, Neomi (2008): “On the Use and Abuse of Dignity”. En: Constitutional Law. Columbia Journal of European Law, 14, 2, pp. 201-256.

Ritschl, Dietrich (2002): "Can Ethical Maxims be Derived from Theological Concepts of Human Dignity”. En: Kretzmer, David/Klein, Eckart (eds.): The Concept of Human Dignity in Human Rights Discourse. Den Haag: Kluwer Law International.

Safrai, Chana (2002): "Human Dignity in a Rabbinical Perspective". En: Kretzmer, David/Klein, Eckart (eds.): The Concept of Human Dignity in Human Rights Discourse. Den Haag: Kluwer Law International, pp. 99-109.

Siegel, Reva B. (2008): "Dignity and the Politics of Protection: Abortion Restrictions Under Casey/Carhart”. En: Yale Law Journal, 117, pp. 1694-1800.

- (2009): "La dignidad y el debate del aborto". En: Seminario en Latinoamérica de Teoría Constitucional y Política (SELA) (<www.law.yale.edu/intellectuallife/ sela2009.htm>; 08.06.2011).

Taylor, Charles (1994): Ética de la autenticidad. Barcelona: Paidós.

Waldron, Jeremy (1998): "The Theoretical Foundations of Liberalism". En: NidaRümelin, Julian/Vossenkuhl, Wilhelm (eds.): Ethische und politische Freiheit. New York/Berlin: Walter de Gruyter, pp. 226-248.

Warren, Samuel/Brandeis, Louis (1980): “The Right to Privacy". En: Harvard Law Review, 4, pp. 193-220.

West, Robin (1988): "Forward: Taking Freedom Seriously". En: Harvard Law Review, 55, pp. 43-106.

Williams, Patricia (1991): "On Being the Object of Property". En: Bartlett, Katherine/Kennedy, Rosanne: Feminist Legal Theory: Readings in Law and Gender. Oxford: Westview Press, pp. 165-180. 



\section{Fabiola Fanti}

\section{Las políticas de salud ante los tribunales: un estudio sobre la ciudad de São Paulo ${ }^{1}$}

\section{Introducción}

La Constitución Federal de 1988 intensificó en Brasil un fenómeno ya observado en varias democracias contemporáneas en las últimas décadas: el de la utilización de los tribunales como un importante lugar de influencia del proceso político decisorio. Las cortes han sido cada vez más demandadas para expedirse sobre cuestiones que involucran políticas públicas y, mediante sus decisiones, terminan teniendo un rol relevante en la definición de estas. En este contexto, dentro del amplio espectro de posibilidades de uso del Poder Judicial como arena política, se ha tornado cada vez más importante el impacto de las decisiones de este Poder en las políticas sociales, principalmente en las políticas de salud.

En parte, este proceso fue posible gracias a la arquitectura institucional originada por la Constitución Federal de 1988. Si, por un lado, esta amplió el rol de derechos fundamentales de los ciudadanos, tanto en lo que respecta al acceso al Judicial como en relación con los derechos sociales, por otro lado también amplió los medios procedimentales para garantizarlos. Esta combinación facilitó el acceso del ciudadano individualmente o de la sociedad civil a los tribunales, por medio de procedimientos comunes, haciendo posible el cuestionamiento judicial de la efectividad de las políticas públicas (o de la falta de ella). Así, las cortes se han configurado en lugares propicios para la alteración de políticas sociales por medio de acciones basadas en el argumento de la garantía de los derechos sociales.

En el caso específico de las políticas sociales de salud, se puede afirmar que, en la última década, hubo una creciente ola de acciones

1 Este artículo concentra los resultados de mi tesis de maestría, titulada Políticas de saúde em juízo: um estudo sobre o município de São Paulo, defendida en el Departamento de Ciencia Política de la Universidad de São Paulo (USP, Brasil) en enero de 2010. 
judiciales contra el Gobierno Federal, los Estados y los municipios (deforma conjunta o por separado), bregando por una serie de servicios de salud, entre los que el acceso a los medicamentos es el más demandado. Este proceso comenzó a mediados de la década de los 1990, con acciones que demandaban remedios antirretrovirales para el tratamiento del SIDA y, con el correr del tiempo, se generalizaron para pedidos de una variada gama de medicamentos ${ }^{2}$ (Scheffer/Salazar/Grou 2005). Tal fenómeno, conocido como "judicialización de la salud", ha logrado destacarse en la opinión pública, en el medio político y académico por la dimensión creciente que está tomando.

El presente artículo intenta contribuir al entendimiento de los procesos de uso de las instancias de la justicia común como camino por el cual los ciudadanos buscan el enforcement de derechos sociales constitucionalmente garantizados y, así, poder influir en las políticas públicas de los municipios a partir de los mecanismos institucionales relacionados con el Poder Judicial. En otras palabras, se pretende estudiar cómo sucede el uso de la justicia común como lugar para demandar la garantía del derecho a la salud, así como también evaluar en qué medida esta viene modificando las opciones del administrador en el diseño de la política pública y mediante cuáles mecanismos. Para esto, como objeto de estudio, se han seleccionado las demandas por salud propuestas contra el Municipio de São Paulo a través del Poder Judicial, así como el análisis de la forma en que las decisiones judiciales sobre dichas acciones se reflejan en la política municipal de salud.

\section{Poder Judicial y Políticas de Salud: la visión de la Salud Pública y del Derecho}

En los últimos años, se abrió un nuevo campo de estudio en Brasil que buscó entender la relación entre las demandas relacionadas con la salud, dirigidas al Poder Judicial, y las políticas públicas gubernamentales creadas en esta área. Los dos campos disciplinares que más se dedicaron a este tema fueron el de Salud Pública y el del De-

2 Existe una serie de trabajos que traen como resultado estos datos, pudiendo citarse como ejemplos: Viera/Zucchi (2007); Messeder/Osório-de-Castro/Luiza (2005). 
recho, siendo realizadas diversas investigaciones empíricas sobre el tema, con los más diversos enfoques analíticos. ${ }^{3}$

Los trabajos producidos en el área de Salud Pública tienen, como cuestión central, la relación entre las acciones judiciales que requieren el suministro de medicamentos y las políticas gubernamentales que cuidan del asunto. ${ }^{4}$ Dentro de este amplio espectro de análisis, fue realizada una serie de trabajos empíricos, con distintos abordajes metodológicos, recogiendo y analizando las decisiones del Poder Judicial, o incluso haciendo análisis de las propias acciones que disputaban sobre la garantía del derecho constitucional a la salud, por medio del acceso a los medicamentos.

Los artículos producidos en el área del Derecho trabajan sobre la participación de la justicia común en políticas sociales que involucran el derecho a la salud. ${ }^{5}$ En líneas generales, tales trabajos, a partir de diferentes recortes de investigación, abordan el asunto de las limitaciones institucionales del Poder Judicial para decidir sobre derechos sociales, así como problemas de justicia distributiva que pueden generar estas decisiones tomadas en el contexto de casos individuales.

De forma general, estos estudios traen un diagnóstico compartido sobre las acciones llevadas a la justicia común, demandando cuestiones que involucran políticas de salud del Poder Ejecutivo. Dicho diagnóstico puede sistematizarse a partir de los siguientes tópicos: (1) el principal tema encontrado en las demandas analizadas está relacionado con pedidos de suministro de medicamentos; (2) la principal forma de proposición de las demandas es de tipo individual; (3) la gran mayoría de las acciones es juzgada como procedente. Los trabajos que analizan períodos mayores de tiempo muestran también que (4) el número de demandas viene creciendo. En aquellos trabajos

3 Debido a la limitación de espacio, en este artículo no es posible rehacer una exposición detallada de la literatura referida. Por este motivo, se expone aquí sólo una versión resumida. Por su parte, una versión completa puede ser encontrada en Fanti (2009) (<www.teses.usp.br/teses/disponiveis/8/8131/tde02032010-171419/>; (30.09.2011).

4 Como principales trabajos encontrados, se pueden citar Messeder/Osório-deCastro/Luiza (2005); Scheffer/Salazar/Grou (2005); Marques/Dallari (2007); Viera/Zucchi (2007); Borges (2007); Viera (2008).

5 Como principales trabajos en el área del Derecho que estudian el tema, pueden ser citados: Ferreira et al. (2004); Lopes (2006); Terrazas (2008) y Wang (2009). 
que buscan analizar la influencia de estas decisiones en las políticas de salud, se presentan indicios de que (5) existe una relación entre el crecimiento de las acciones juzgadas como procedentes y la inclusión de medicamentos en las listas de la política de asistencia farmacéutica del Sistema Único de Salud (SUS).

Por otro lado, si bien existen elementos comunes entre los diagnósticos de ambos campos disciplinares presentados, sus evaluaciones parecen distinguirse en lo que respecta a las críticas formuladas sobre la actuación del Poder Judicial en la decisión sobre demandas por medicamentos. La mayor crítica que viene de los trabajos del área de Salud Pública es la de que las cortes no tienen en cuenta decisiones de los gestores de salud relacionadas con la asignación de recursos, y también que la política de medicamentos estipulada no forma parte de una planificación mayor que busca atender a toda la comunidad. Otro argumento recurrente en los textos es que el Poder Judicial concede medicamentos únicamente con base en el derecho constitucional a la salud, sin tomar en cuenta criterios clínicos, técnicos o científicos, o incluso si hay -en la lista del SUS- algún medicamento equivalente a aquel demandado, por el que podría ser sustituido.

Sobre las investigaciones elaboradas en el campo del Derecho, los autores critican que las decisiones del Poder Judicial parecen distorsionar el carácter distributivo de las políticas de salud, en la medida en que beneficiarían capas de la población con mayores ingresos e información, generando beneficios sólo para quienes tengan acceso a las cortes. Los trabajos también señalan los efectos negativos de la demanda individual de asuntos relacionados con la salud, en la medida en que esta no sería la forma más adecuada para lograr que el Ejecutivo haga cambios significativos en la política pública. Existe también la crítica sobre que el Poder Judicial no tiene en cuenta las consecuencias económicas de los pedidos concedidos en sus fallos.

Sobre estas críticas, las cuales revelan un carácter fuertemente normativo, cabe hacer aquí algunas consideraciones. En general, los estudios presentados se enfocan en el análisis de datos sobre las acciones judiciales y sus resultados, dejando afuera un estudio más amplio sobre la estructura general de las demandas, involucrando las políticas de salud y de la influencia de las decisiones de la justicia común sobre estas. 
Se puede decir que los artículos que hacen la crítica sobre el desconocimiento y la desconsideración de la política de asistencia farmacéutica por parte de la justicia común carecen de un estudio más profundo sobre el tenor de las decisiones para verificar si, de hecho, esta afirmación se sustenta. Además, la crítica que señala el beneficio de personas con mejores condiciones socio-económicas por los fallos viene, la mayoría de las veces, sin la compañía de estudios más enfáticos sobre los demandantes de estas acciones. Las críticas de que las acciones individuales son menos efectivas que las colectivas, para la readecuación de la política pública del Poder Ejecutivo, tampoco realizan estudios sobre las consecuencias de cómo se da la influencia de las decisiones relativas a estas en las propias políticas. Finalmente, tales críticas son, por lo general, dirigidas al Poder Judicial, sin tener en consideración un análisis más global sobre los demás actores involucrados en el fenómeno, imputando a las cortes una centralidad excesiva.

En este contexto, el presente artículo pretende desarrollar uno de los puntos centrales que se mostraron insuficientes en los análisis presentados, es decir, la falta de una sistematización de cuáles son las formas de accionamientos de la justicia común en los casos que involucran a la salud pública, cuáles son los actores más relevantes en el proceso y cuáles son los principales efectos de las decisiones en las políticas mencionadas. Son, justamente, estas cuestiones que serán delineadas a continuación.

\section{Metodología de la investigación}

Para que el objetivo arriba propuesto sea alcanzado, este trabajo se apoyó en tres fuentes de datos: (1) decisiones del Tribunal de Justicia del Estado de São Paulo (TJ/SP) en acciones demandando el suministro de medicamentos desde el Municipio de São Paulo; (2) entrevistas con actores relevantes en este proceso; y (3) documentos recogidos con los entrevistados y datos secundarios presentados en la bibliografía específica sobre el tema.

Dichas decisiones judiciales fueron pronunciadas entre octubre de 2007 y diciembre de 2008 por las Cámaras de Derecho Público del $\mathrm{TJ} / \mathrm{SP}$ y seleccionadas por medio del sistema de búsqueda dispuesto 
en la página de la institución en Internet. ${ }^{6}$ Son fallos en grado de recurso sobre acciones propuestas contra el Municipio de São Paulo, cuestionando políticas sociales de salud. Fueron encontrados 191 fallos envolviendo cuestionamientos del derecho a la salud contra el Municipio de São Paulo, de forma aislada o en conjunto con el Estado de São Paulo. De estas, se optó la selección, para el análisis, de solamente las 132 apelaciones civiles encontradas, que son los fallos definitivos en grado de recurso en segunda instancia que discuten el mérito de la acción.

Las entrevistas, de cuño cualitativo, tuvieron el objetivo de profundizar la comprensión sobre las características de la demanda por políticas sociales municipales en la justicia común, enriqueciendo los datos recolectados con la lectura y el análisis de las sentencias finales y añadiendo nuevas informaciones a aquellas obtenidas junto a las decisiones del TJ/SP. En este contexto, la elección de los entrevistados se dio por la relevancia de los mismos en el proceso de demanda de cuestiones involucrando la política municipal de salud en la justicia común.

Se buscó, de este modo, en primer lugar, realizar entrevistas con el demandado por las acciones, es decir, el Municipio de São Paulo. Para esto, se buscaron informaciones en la Procuraduría General del Municipio (PGM) y en la Secretaría Municipal de Salud. La PGM es el órgano de la Intendencia Municipal responsable por, entre otras atribuciones, hacer su defensa en acciones judiciales en las que el Municipio sea o vaya a ser demandado. Se realizó una entrevista con Kátia Leite, ${ }^{7}$ Procuradora del Municipio que actúa en el Departamento Judicial de la PGM, llamado Jud. 3, una división interna de este departamento que cuida de la defensa del Municipio de São Paulo en los casos en el que este es demandado en recursos de amparo (en Brasil, mandados de segurança), acciones populares, solicitudes de órdenes judiciales preliminares (en Brasil, liminares), y habeas data, así como en acciones relativas a responsabilidad civil extracontractual, contractual y de competencia residual.

La Secretaría Municipal de Salud es el órgano de la Intendencia responsable por la gestión del Sistema Único de Salud (SUS), así

6 Veáse <www.tj.sp.gov.br>. (30.09.2011).

7 Entrevista realizada el día 28 de abril de 2009. 
como por la formulación e implantación de políticas, programas y proyectos conectados a la salud en el Municipio de São Paulo. Esta posee una estructura bastante compleja, formada por órganos de la administración directa, indirecta e instituciones pactantes y contratadas por el SUS. Tales órganos tienen como función la implantación de las directrices formuladas por la Secretaría Municipal de Salud. ${ }^{8}$ Es dirigida por el mismo Secretario Municipal de Salud y su gabinete es "responsable por la definición de políticas, normas e estándares para el área de salud del Municipio, en conjunto con el Consejo Municipal de Salud", así como por el "establecimiento de sistemas administrativos de apoyo gerencial a los distritos de salud y de convenios de cooperación técnica, científica y administrativa con otros órganos e instituciones". ${ }^{9}$ El gabinete del Secretario Municipal cuenta con varias asesorías para auxiliarlo en sus tareas.

Se realizó una entrevista con Adline Debus Pozzebon, ${ }^{10}$ que es Asesora Jurídica del gabinete del Secretario. La función de la Asesoría Jurídica es enviar las informaciones necesarias sobre la política de salud para que la Procuraduría General del Municipio haga su defensa, y enviar esas informaciones al Poder Judicial, cuando este las solicita, y viabilizar el suministro de los medicamentos e insumos cuando el Municipio de São Paulo es condenado a hacerlo.

Con respecto a los autores de las acciones, se seleccionaron los entrevistados en base al banco de datos formado por las decisiones arriba citadas. Como la página en Internet del $\mathrm{TJ} / \mathrm{SP}$ no provee informaciones más específicas acerca de los proponentes de las acciones, se eligió entrevistar a sus representantes legales.

Analizando el citado banco de datos, se constató que ningún abogado había propuesto un número significativo de acciones, a excepción de un bufete de abogados que propuso 17 acciones. Este bufete, cuando se trató de consultarlo, no estuvo dispuesto a conceder una entrevista. Sin embargo, se puede afirmar que todas las acciones propuestas por éste se refieren a pedidos de cinco medicamentos de

8 Fuente: <www.prefeitura.sp.gov.br/cidade/secretarias/saude/organizacao/index. php? $=1341>$. (30.09.2011).

9 Fuente: <www.prefeitura.sp.gov.br/cidade/secretarias/saude/organizacao/quem e_quem/index.php?p=4696>. (30.09.2011).

10 Entrevista realizada el día 9 de junio de 2009. 
alto costo, ${ }^{11}$ utilizados principalmente para tratamientos de cáncer. El valor de mercado, por cada caja de estos medicamentos, varía entre $1.450,00 €$ y $3.800,00 €$, siendo que uno de estos ni siquiera fue aprobado por la Agencia Nacional de Vigilancia Sanitaria (ANVISA).

Como ya fue observado más arriba, el otro gran grupo de representantes legales de los autores de las acciones son la Procuraduría da Asistencia Judicial (PAJ) y la Defensoría Pública del Estado de São Paulo. La PAJ es un órgano vinculado con la Procuraduría General del Estado de São Paulo, y tiene por función prestar asistencia judicial gratuita a los ciudadanos de bajos ingresos que no puedan pagar un abogado "sin perjuicio del sustento propio o de su familia". ${ }^{12}$ En 2006, la Ley Complementaria del Estado de São Paulo n 998 instituyó la Defensoría Pública, que pasó a ejercer las funciones antes realizadas por la PAJ, poseyendo los mismos criterios para brindar asesoramiento gratuito a la población. ${ }^{13}$ Cabe resaltar, no obstante, que dicha institución es autónoma con relación al Estado de São Paulo.

La Defensoría Pública, entre sus diversos sectores de atención, cuenta con uno que asume la función de representar a los ciudadanos que tengan demandas para ser propuestas contra el Estado de São Paulo y sus municipios, que es el llamado Sector de Hacienda Pública. Es, en el marco de este sector, que son propuestas las acciones que involucran el cuestionamiento de las políticas de salud del Municipio de São Paulo, objeto de este trabajo. En este sentido, se entrevistó a la Coordinadora del Sector de Hacienda Pública, Vânia Casal, ${ }^{14}$ responsable por la distribución de los casos entre los defensores.

Todavía teniendo en cuenta, como forma de selección de los entrevistados, que estos sean representantes de los autores de las acciones, la última persona entrevistada fue Cláudia Cimardi, ${ }^{15}$ quien era Procuradora del Sector de Hacienda Pública de la PAJ entre 1992 y 2006. Ella fue responsable por la proposición de 40 de las 131 ac-

11 Son estos medicamentos: Mabthera, Glivec, Exjade, Velcade y Revlimid.

12 Fuente: <www.pge.sp.gov.br/institucional/assistencia.htm>.(30.09.2011).

13 Fuente: < $\quad$ www.defensoria.sp.gov.br/dpesp/Default.aspx?idPagina=2868>. (30.09.2011).

14 Entrevista realizada el día 14 de octubre de 2009.

15 Entrevista realizada el día 23 de octubre de 2009. 
ciones citadas arriba. Así, a partir de esta breve exposición de la metodología empleada en el artículo, se pasa a la presentación de los datos obtenidos y de los análisis realizados.

\section{Contestación de las políticas municipales en juicio: formas y actores}

Existen dos formas más acentuadas de accionamiento del Poder Judicial en asuntos relativos a las políticas municipales de salud. La primera de estas formas se configura en la utilización de la justicia común como medio de forzar al Poder Ejecutivo para garantizar derechos sociales. Esta forma se puede dar de dos maneras: por la vía individual, o sea, el ciudadano utiliza procedimientos comunes para proponer la acción y demandar sus derechos en juicio; y por la vía colectiva, realizada por el Ministerio Público (MP) y por la Defensoría Pública al proponer acciones civiles públicas en nombre de un grupo de individuos. La segunda forma se constituye a partir del cuestionamiento directo de la política municipal con respecto a su constitucionalidad, por medio de una acción civil pública (ACP) o una acción directa de inconstitucionalidad (ADIN) de la ley municipal, en la justicia común. Hecha esta breve introducción general, sigue, entonces, la presentación más detallada de cada una de las formas arriba descritas.

\subsection{Enforcement de derechos: formas individuales}

La forma más común de demandar al Municipio de São Paulo en cuestiones relacionadas con políticas de salud es aquella realizada por el ciudadano individualmente, mediante procedimientos comunes, con el objetivo de efectivizar el derecho a la salud.

Por procedimientos comunes se entienden aquí los que pueden ser usados por cualquier persona sin que haya necesidad de legitimidad específica para la proposición de la acción, como es exigida, por ejemplo, en acciones relativas al control de constitucionalidad concentrado o incluso en la acción civil pública. Las dos acciones más usadas en el caso de demanda de medicamentos o insumos son el 
recurso de amparo (mandado de segurança) ${ }^{16}$ y la acción de rito ordinario. ${ }^{17}$

La proposición de ambos tipos de acción arriba descritos exige que los autores tengan asesoría jurídica de abogados particulares o de entidades que presten asistencia judicial gratuita. A partir de las informaciones dispuestas por el TJ/SP sobre las decisiones aquí analizadas, es posible identificar el tipo de representación legal utilizado por los autores: de las 131 acciones analizadas, 62 fueron propuestas por abogados particulares, 57 por la PAJ o por la Defensoría Pública del Estado de São Paulo, una por el Ministerio Público estatal, dos por entidades de asesoría jurídica prestadas por facultades de Derecho y las nueve restantes no pudieron ser identificadas (ver gráfico 1). Con excepción de los abogados particulares, las instituciones citadas tienen en cuenta la falta de recursos del autor como criterio para proponer la acción en su nombre.

16 El recurso de amparo es un tipo de acción previsto constitucionalmente, que tiene como objetivo proteger el derecho líquido y cierto, "cuando el responsable por la ilegalidad o abuso de poder [que amenace dicho derecho] fuera una autoridad pública o un agente de persona jurídica en el ejercicio de atribuciones del Poder Público". O sea, el recurso de amparo es la acción destinada "a ofrecer, con prontitud, una tutela contra actos estatales que violan derechos líquidos y ciertos, y con esto, recomponer el deseado equilibrio entre la autoridad ejercida por el Estado y los principios garantizadores de la ciudadanía y del patrimonio" (Dinamarco 2002, vol. III, pp. 739-740; traducción propia).

17 La acción de rito ordinario es aquella utilizada como garantía de un derecho o cumplimiento de una obligación civil, "de aplicabilidad general a todas las causas para las cuales la ley no determine la aplicación de algún otro [procedimiento]" (Dinamarco 2002, vol. III, p. 345). La acción de rito ordinario, con las modificaciones impuestas por la Reforma del Código Procesal Civil en 1994, pasó a dar la posibilidad de que el autor pida la tutela anticipada del objeto de la acción. Tal tutela tiene como objetivo 'neutralizar los efectos maléficos del transcurso del tiempo sobre los derechos', ofreciendo al autor de la acción, "desde luego, el goce integral o parcial del propio bien o situación por la que litiga" (Dinamarco 2002, vol. III, p. 161). 
Gráfico 1: Asesoría Jurídica del autor de la acción

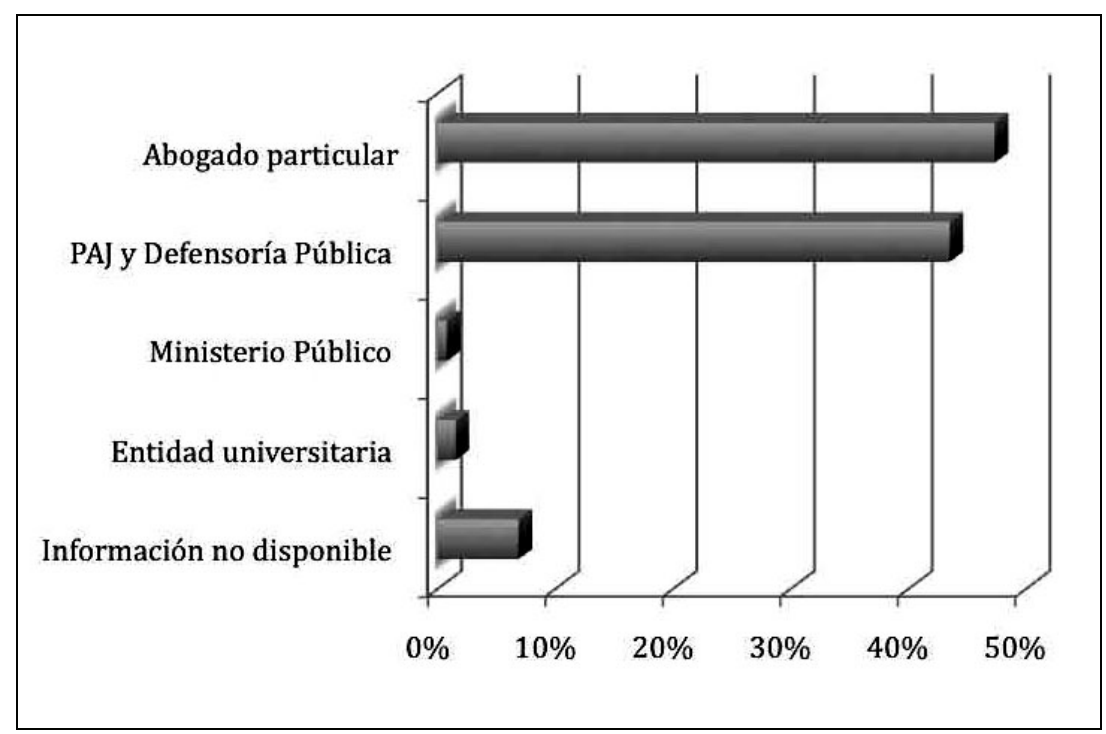

Fuente: Tribunal de Justicia del Estado de São Paulo.

Si se consideran solamente las acciones en las que puede ser identificada la representación jurídica del autor, se puede afirmar que en el $51 \%$ de los casos, los proponentes de las acciones usaron abogados particulares, y en el $49 \%$ restante, usaron la asesoría jurídica gratuita. Dichos datos señalan que, por lo menos, la mitad de ellos cuenta con bajos ingresos, según los criterios de selección de las instituciones citadas.

Con relación al pedido de las acciones, se puede decir que la cuestión más demandada en juicio es la del suministro de medicamentos e insumos. De acuerdo con Cláudia Cimardi, tales demandas empezaron siendo dirigidas al Poder Judicial, alrededor de 1998, en pequeña cantidad, con un volumen creciente a lo largo del tiempo, llegando a tres o cuatro acciones propuestas por día contra el Municipio y el Estado de São Paulo en 2006. Según Kátia Leite, procuradora del Municipio de São Paulo, desde el comienzo de este proceso hasta alrededor de 2005, los medicamentos más pedidos eran aquellos relacionados con el tratamiento de la diabetes, siendo que la mayor parte de esas demandas eran conducidas por la PAJ. Aún en 2005, 
cuando el Municipio pasó a distribuir un kit diabetes, ${ }^{18}$ compuesto por medicamentos e insumos para el tratamiento de la enfermedad, el número de acciones con ese tipo de demanda cayó de manera considerable.

Conforme a Kátia Leite, el estándar actual de acciones que se refieren a la diabetes son de personas que ni siquiera buscaron la red pública de salud para la recepción del kit, accionando directamente al Judicial, o son acciones que se refieren a pedidos de medicamentos e insumos de valor elevado que no están contenidos en la política de asistencia farmacéutica. Entre estos, el caso más relevante sería el de pedidos por bombas de infusión de insulina, que llegan a costar cerca de 6.270,00 € por mes. En el caso de este tipo de pedidos, la demanda ya no llega mediante la Defensoría Pública, sino por medio de abogados particulares, con presentación de prescripciones médicas y exámenes de hospitales y laboratorios privados de alto costo. Queda claro, entonces, el cambio del parámetro del demandante en el caso de pedidos de tratamiento de diabetes, que parecen ser de personas con mejores condiciones financieras y que tienen acceso a informaciones de que existen tratamientos más modernos.

Según Kátia Leite y Adline Pozzebon, otro tipo de pedido muy frecuente en las acciones es el de medicamentos de alto costo para el tratamiento de enfermedades como cáncer y hepatitis C. De acuerdo con las entrevistadas, en general tales medicamentos son bastante onerosos, con precios que varían, en promedio, entre los 1.350,00€ $\mathrm{y} \operatorname{los} 2.240,00 €$ por mes y, en algunos casos, hay dificultades para su importación, o incluso aún no hay registro en la Agencia Nacional de Vigilancia Sanitaria (ANVISA). Por lo general, dichas acciones también serían propuestas por abogados particulares. En este caso, aún sería común que el Estado de São Paulo y el Gobierno Federal sean demandados conjuntamente con el Municipio. Las acciones en que el Gobierno Federal es demandado deben ser juzgadas por la Justicia Federal. En los casos en que solamente el Municipio y el

18 Uno de los cambios sucedidos por la distribución del kit diabetes fue que, antes de su distribución, los pacientes del SUS tenían que ir hasta las Unidades Básicas de Salud para realizar la medición de glucemia. Con la distribución de dicho kit, pasó a ser entregado a los pacientes un aparato de medición de glucemia y los demás medicamentos e insumos para aplicar la insulina, para que el paciente haga ese procedimiento en su domicilio. 
Estado aparecen como partes pasivas de la acción, la competencia para su sentencia es la justicia común. Ambas entrevistadas, incluso, remarcaron que el suministro de medicamentos de alto costo no es de responsabilidad municipal, ya que el Municipio no recibe recursos del SUS para la compra de ese tipo de productos.

Conforme a todas las entrevistadas, otra importante demanda en acciones contra el Municipio es la de los pañales geriátricos para niños con parálisis cerebral, ancianos o personas con mal de Alzheimer. El número elevado de acciones pidiendo dicho insumo se debe, según Vânia Casal, al hecho de que tales pañales son recurrentemente prescritos por médicos de la red municipal de salud; no obstante, no se encuentran en la lista de insumos suministrados de acuerdo a la política de salud. Las entrevistadas afirmaron que la mayor parte de los pedidos de medicamentos e insumos realizados mediante acciones es concedida por los jueces. Sin embargo, parece existir una modificación en el parámetro de dichas decisiones. Según Kátia Leite, ha aumentado el número de fallos que dan procedencia parcial al pedido del autor, lo que significa que la concesión de medicamentos e insumos es realizada con algunas limitaciones. Como ejemplo de esto, se pueden citar: el condicionamiento de la entrega del medicamento a la presentación de la prescripción de una receta médica actualizada donde conste el nombre del autor de la acción, para que se compruebe que el medicamento todavía es necesario; la limitación del suministro de los medicamentos sólo a aquellos descritos en la petición inicial, y no a "todos aquellos que el autor vaya a necesitar", como está dispuesto en algunas decisiones; y la sustitución, cuando sea posible, del medicamento pedido en la acción por el correspondiente que conste en la lista de medicamentos de la política pública. El intento de que el juez falle de manera parcialmente procedente ha sido una de las estrategias de la Procuraduría General del Municipio en su defensa, ya que el modelo anterior de las decisiones era el de concesión integral del pedido del autor. En otras palabras, la PGM, al defender al Municipio en tales acciones, pide subsidiariamente que, en caso de que la acción sea juzgada como procedente, el juez limite el pedido del autor a los medicamentos descritos en la petición inicial o, de ser posible, que estos sean distribuidos por el SUS. 
La pericia médica para verificar la necesidad y la adecuación del medicamento demandado ha sido más comúnmente usada por los jueces federales (o sea, cuando el Gobierno Federal también está en el polo pasivo de la acción), principalmente en los casos de medicamentos de alto costo. Kátia Leite y Adline Pozzebon rubricaron que, cuando una nueva acción de pedido de medicamentos llega a la Justicia Federal, es común que el juez envíe un oficio para la PGM para que esta se manifieste en 72 horas informando si el medicamento está incluido en la política de asistencia farmacéutica del Municipio y si está regularizado por la ANVISA. Posteriormente, los magistrados solicitan una pericia médica para evaluar si aquel medicamento específico es el adecuado para la realización del tratamiento de la enfermedad que el autor acomete. Los jueces buscan saber si el autor ya hizo uso de tratamientos suministrados por la red pública que no surtieron efecto y si existe alguna posibilidad de sustituir el medicamento solicitado por otros que sean suministrados por el SUS. Según Kátia Leite, la Justicia Federal se ha empeñado en establecer criterios objetivos para la toma de decisiones. De acuerdo con la entrevistada, esto no se observa en la justicia común, en la medida en que sería rara la solicitud de informaciones sobre el caso y de pericia médica para la concesión del pedido.

Otra cuestión que envuelve a la demanda individual por medicamentos tiene que ver con el alto número de acciones que solicitan tratamientos que ya están incluidos en la política municipal de salud. Las entrevistadas presentan explicaciones diferentes sobre este fenómeno. Kátia Leite y Adline Pozzebon consideran que esto sucede así porque los autores no quisieron someterse a los procedimientos administrativos exigidos por la red pública de salud para el suministro del medicamento, o porque hay falta de información por parte de los proponentes de las acciones, quienes no conocen los servicios de salud que ya son ofrecidos. Por su parte, Vânia Casal y Cláudia Cimardi creen que este hecho se debe a fallas en el suministro de medicamentos en las Unidades de Salud o a las informaciones incorrectas del lugar de retiro de medicamentos dadas a los pacientes del SUS.

Hecha esta presentación general de las características de las demandas individuales por medicamentos e insumos, se pasa a la des- 
cripción de la forma colectiva de demanda de las políticas de salud del Municipio.

\subsection{Enforcement de derechos: formas colectivas}

La investigación en el banco de datos del TJ/SP, sobre decisiones que involucran políticas de salud del Municipio de São Paulo, encontró una sola proposición colectiva con respecto al tema: una acción civil pública de autoría del Ministerio Público estatal pidiendo la reforma de una sala de primeros auxilios municipal. Se cree que se obtuvo este resultado por el hecho de que las decisiones que componen el banco de datos del TJ/SP corresponden a apenas el cinco por ciento de los casos juzgados por el Tribunal, sin que haya criterios objetivos para la elección de los mismos. De esta forma, se buscó, complementariamente, explorar más el campo de la demanda colectiva en el área de salud por medio de entrevistas, en la medida en que los datos hasta entonces obtenidos se mostraron limitados para el entendimiento de la cuestión. El indicio de una menor utilización de la acción colectiva como estrategia jurídica fue confirmado por todas las entrevistadas.

La acción civil pública es la principal forma para demandar cuestiones que involucren políticas de salud de forma colectiva. La demanda colectiva envolviendo políticas municipales de salud es realizada, mayoritariamente, por el Ministerio Público, y en número bien menor por la Defensoría Pública (o anteriormente a su creación, por la PAJ). No existe proposición de acciones civiles públicas por parte de asociaciones vinculadas con la salud. En algunos casos, lo que ocurre es que esas asociaciones procuran al Ministerio Público para que sea este quien proponga acciones civiles públicas relacionadas con sus demandas.

Otra diferencia que se puede apreciar entre las acciones colectivas y las acciones individuales se relaciona con el objeto que estas demandan. Como ya fue afirmado, la única acción de carácter colectivo encontrada en el banco de datos elaborado, fue una acción civil pública propuesta por el Ministerio Público contra el Municipio de São Paulo, que tuvo como pedido "sanar las irregularidades constatadas por el Consejo Regional de Medicina en la Sala de Primeros 
Auxilios Dr. José Sylvio de Camargo". ${ }^{19}$ Tal acción fue juzgada como procedente en primera instancia, decisión que fue confirmada en el fallo del TJ/SP. Adicionalmente, Kátia Leite informó que existen otras acciones civiles públicas con el mismo perfil que demandaban la realización de obras de infraestructura necesarias en determinadas unidades y hospitales de la red de salud pública del Municipio de São Paulo, también propuestas por el Ministerio Público. Según ella, en general, dichas acciones, fueron juzgadas como procedentes por el Poder Judicial y, no obstante, trajeron "dificultades de ejecución", en la medida en que habían pedido muchos genéricos y era necesaria la asignación de una gran suma de recursos para esto. Adline Pozzebon también relató que hay una acción civil pública ${ }^{20}$ que fue propuesta en abril de 2008 por el Ministerio Público Federal contra el Gobierno Federal, el Estado y el Municipio de São Paulo, demandando la implantación de 57 Centros de Atención Psicosocial (CAPs) y 28 Residencias Terapéuticas en el período de dos años en la ciudad de São Paulo. Tal acción fue juzgada como procedente en primera instancia. Por estos casos, se puede inferir que las acciones civiles públicas permiten a las cortes la posibilidad de apreciar otras demandas, diferentes de las relacionadas con el suministro de medicamentos e insumos, tales como los referidos pedidos de mejora y ampliación de las unidades de salud de la red municipal. Dichas acciones han sido, por regla general, juzgadas como procedentes.

La constatación de que las acciones colectivas traen objetos distintos al de suministro de medicamentos e insumos puede ser confirmada por un trabajo realizado por Daniel Wang (2009). En efecto, su investigación se destinó al estudio de las acciones civiles públicas propuestas por la Fiscalía de Salud Pública del Ministerio Público del Estado de São Paulo, entre 2000 y 2008. Durante este período, fueron propuestas 62 acciones civiles públicas por dicha Fiscalía, siendo que, de estas, 32 "tutelaban el derecho a la salud por medio de la exigencia de acción del Estado que implicase gastos públicos" (Wang 2009: 72). Entre estas últimas, el 28\% (nueve acciones) tra-

19 Tribunal de Justicia del Estado de São Paulo, Sexta Cámara de Derecho Público, Apelación Civil con Revisión $n^{\circ}$ 729.063-5/0-00, juzgada el día 2 de junio de 2008, Relator Sidney Romano dos Reis.

20 Acción Civil Pública. $19^{\circ}$ Juzgado en lo Civil Federal de la Capital/ São Paulo. Proceso $n^{\circ}$ 2008.61.00.012274-9. 
taban sobre pedidos de medicamentos e insumos, el 66\% (21 acciones) se referían a pedidos de solución de problemas de infraestructura y falta de profesionales y recursos en unidades públicas de salud, hospitales, salas de primeros auxilios y unidades básicas de salud, y el restante seis por ciento demandaba sobre otros asuntos (Wang 2009: 73). En relación a los resultados de dichas acciones, Wang señala que, en siete de las nueve acciones civiles públicas que solicitan medicamentos, existen informaciones sobre la concesión de orden judicial preliminar: en cinco fueron concedidas y, en dos, no. En cuanto a las acciones que tratan sobre mejoras en el funcionamiento de unidades públicas de salud, en los 13 casos en que hay información sobre el resultado de la demanda, se sabe que nueve fueron juzgadas como procedentes, y cuatro no (Wang 2009: 74).

Según Wang, además de la Fiscalía de Salud Pública, otras dos fiscales actúan en el área tutelar del derecho a la salud en el marco del Ministerio Público del Estado de São Paulo: la Fiscalía de Personas con Capacidades Diferentes y la Fiscalía de la Infancia y la Juventud. La diferencia entre las tres se da en la medida en que, mientras que la primera propone acciones civiles públicas con carácter colectivo, las otras dos trabajan, en general, con casos individuales, siendo que la

actuación en el área de salud [de estas fiscalías] es cada vez más residual, ya que el procedimiento estándar es que las demandas por medicamentos o tratamientos médicos sean enviados a la Fiscalía de Salud Pública (Wang 2009: 68-69).

Wang encontró 19 acciones propuestas por dichas fiscalías, siendo sólo dos referentes a casos colectivos. ${ }^{21}$ Según el autor, tales acciones civiles públicas tuvieron buena receptividad en el Poder Judicial, siendo que "de los 17 procesos en que existe información sobre la concesión o no de órdenes judiciales preliminares, en apenas una ocasión ésta no fue concedida" (Wang 2009: 71).

El autor, todavía, indica que otra forma importante que tiene la Fiscalía de Salud Pública para accionar al Poder Ejecutivo son las

21 Según el autor, en lo relativo al tema de dichas acciones civiles públicas, "[u]na se refiere a la falta de tratamientos y medicamentos en la red pública para pacientes portadores de epilepsia, y la otra se refiere a la implantación del Servicio de Atención Móvil de Urgencia (SAMU) en la región del Barrio de Engenheiro Marsilac" (Wang 2009: 69). 
investigaciones civiles públicas. Estas se configuran en un intento de solución del problema todavía en fase administrativa, conducida por el Ministerio Público, para la investigación y el esclarecimiento de los hechos relacionados con la demanda, anteriormente a la proposición de una acción civil pública (Ley $\mathrm{n}^{\circ} 7.345 / 85$, párrafo primero del artículo $8^{\circ}$ ). En el caso de que haya acuerdo entre las partes, o cuando no existan pruebas suficientes para la consideración de la acción civil pública, la investigación civil pública es archivada sin que se llegue a su proposición (Ley $\mathrm{n}^{\circ} 7.345 / 85$, artículo $9^{\circ}$, encabezado). Wang señala que, entre 2006 y 2008, hubo 66 acciones archivadas, siendo que 35 de estas trataban sobre asuntos relacionados con la prestación de servicios de salud. Entre estos casos, el mayor número (once casos) se refiere a "irregularidades en unidades de salud (infraestructura, atraso en la atención de pacientes, falta de profesionales y materiales)". Las cuestiones relativas al suministro de medicamentos e insumos sumaron nueve casos (Wang 2009: 76).

El autor presenta, además, los motivos por los cuales dichas investigaciones civiles públicas fueron archivadas: en el 59\% de los casos, fue por el cumplimiento del pedido del Ministerio Público; en el $20 \%$, no fue constatado el problema investigado; en el $6 \%$, se dio así debido a la presentación de algún plan del Poder Ejecutivo para solucionar el problema; en otro $6 \%$ de los casos, ya existe un esfuerzo por parte del Poder Ejecutivo para atender el pedido; en el 5\%, hay incompetencia del Ministerio Público para demandar la cuestión en juicio; y en el restante 3\% de los casos, no fue identificado el motivo por el que las investigaciones civiles públicas fueron archivadas (Wang 2009: 78).

A partir de estos resultados, Wang señala una tendencia de disminución en el número de acciones propuestas por la Fiscalía de Salud Pública y de aumento en el número de investigaciones civiles públicas archivadas sin la proposición de acciones. Por lo tanto, existen indicios de que sea creciente el uso de "formas y soluciones de conflictos prejudiciales", en las que "el asunto se resuelve sin necesidad de acción judicial, pero con la posibilidad de usarla como poder de negociación en reuniones con el poder público" (Wang 2009: 67).

Aún en lo relativo a demandas llevadas al Poder Judicial que no tenían como objeto el suministro de medicamentos e insumos, Vânia Casal informó que la Defensoría Pública propuso dos accio- 
nes civiles públicas bregando por mejoras o por la continuidad en la prestación de servicios de salud en la red pública, una contra el Estado de São Paulo y la otra contra el Municipio. La primera fue propuesta en abril de 2009, conjuntamente con el Ministerio Público, y fue motivada por una remodelación en las actividades del Hospital Brigadeiro hecho por la Secretaría de Salud del Estado de São Paulo, debido a reformas que allí serían realizadas. Dicha remodelación transfirió a distintas unidades del sistema público de salud la atención que era efectuada en el Sector de Endocrinología del Hospital. Sin embargo, allí eran prestados servicios de endocrinología altamente especializados que no tenían cómo ser provistos en nuevos locales. El pedido de la acción es justamente el de que tal atención fuera mantenida. Esta acción aún está en proceso, siendo desatendido el pedido de los autores de una orden judicial preliminar, después de no haberse logrado una conciliación entre las partes en una audiencia específicamente convocada a tal efecto por el juez entendido en la causa.

La otra acción civil pública fue propuesta por la Defensoría contra el Municipio de São Paulo en marzo de 2009 y tenía como objetivo la solución de la inadecuación de la prestación del servicio de salud en la región sur de la ciudad que, a pesar de concentrar un gran número de ciudadanos "en situación de vulnerabilidad en diferentes aspectos", no presenta Unidades Básicas de Salus y Servicios Ambulatorios de Especialidades en número suficiente para atender la demanda de la región, y así terminan ofreciendo un "servicio de atención de salud extremadamente demorado, deficiente y desprovisto de información al usuario". En este contexto, el pedido de la acción era que fuera concedida una orden judicial preliminar para que, en el plazo de 90 días, fuesen realizados los exámenes, consultas y cirugías de pacientes en espera mayor a 90 días en la red pública municipal de salud de la región sur de la ciudad. Si la atención solicitada no fuera brindada, el pedido era que el Municipio costease los gastos de este servicio en la red privada de salud. ${ }^{22}$ La acción fue desestimada sin el juicio de mérito, porque el juez entendió que la Defenso-

22 Datos retirados de la sentencia proferida sobre el caso en el $7^{\circ}$ Juzgado de Hacienda Pública del Foro Central, Comarca de la Capital/ São Paulo, el día 13 de abril de 2009, en el proceso número 053.09.009867-9. 
ría Pública no tiene legitimidad para proponer la acción, en la medida en que el objeto tutelado, o sea, intereses difusos que serían efectivizados con obligación de hacer, tienen su protección reservada al Ministerio Público. Según Vânia Casal, la Defensoría Pública apeló la decisión, que por el momento aguarda su envío al TJ/SP. Según la entrevistada, a pesar de que han llegado nuevas demandas para la proposición de otras acciones civiles públicas al Sector de Hacienda Pública de la Defensoría, esto no sucede por falta de estructura para tal fin. Dicha unidad es pequeña, compuesta por sólo cinco defensores, y en promedio cada uno de ellos se encarga de entre 1.100 y 1.200 casos sobre diferentes temáticas. Casal explica que, para que las acciones civiles públicas sean propuestas, es necesario que se realice un estudio extenso sobre la demanda a ser tratada. Como el trabajo cotidiano del Sector es bastante intenso, faltan funcionarios para que dichas demandas sean juzgadas.

Un intento de resolver el problema, de acuerdo con Vânia Casal, ha sido realizar convenios entre la Defensoría y el Ministerio Público para la presentación de las acciones civiles públicas. Ella cuenta que el caso del Hospital Brigadeiro fue el primer trabajo conjunto entre las dos instituciones. Otro ejemplo de los convenios entre las dos instituciones, según la entrevistada, es el proyecto de proponer una acción civil pública para luchar por la provisión de pañales para personas con retraso mental que los necesitan.

Aunque, en su mayor parte, las acciones colectivas propuestas contra el Municipio de São Paulo tengan como objeto otras demandas diferentes al suministro de medicamentos e insumos se observó la existencia de algunas de estas. Según Adline Pozzebon, hay cuatro acciones civiles públicas propuestas por la Fiscalía de la Infancia y la Juventud del Ministerio Público con el pedido de suministro de dietas nutricionales para grupos de niños. Tales acciones fueron propuestas entre mayo de 2006 y abril de 2007, y tuvieron órdenes judiciales preliminares concedidas por el Poder Judicial. Adline Pozzebon informa, además, que el Estado posee un programa para el suministro de dichas dietas, y recibe transferencias de recursos para su costeo. En este caso, como tales acciones fueron propuestas conjuntamente contra los dos entes de la Federación y la orden judicial preliminar determinó el suministro, el Municipio tuvo que cargar con los gastos de la compra de dichas dietas, aún sin recibir 
dinero específico para esto. Con eso la Secretaría Municipal de Salud tuvo que utilizar recursos de otros programas para el cumplimiento de la decisión judicial, lo que trajo perjuicios en lo relacionado con otras inversiones en el área de salud que podrían haber sido realizadas. La entrevistada destaca, asimismo, que si la demanda hubiera sido direccionada sólo contra el Estado de São Paulo, no hubieran existido perjuicios de esa naturaleza para dicho ente, debido a que este posee un programa organizado para tal fin, con dinero asignado específicamente para este objetivo.

Otra acción colectiva con pedido de medicamentos e insumos, citada por Adline Pozzebon, fue propuesta por la Fiscalía de Salud Pública del Ministerio Público en nombre de los pacientes del SUS portadores de la enfermedad pulmonar obstructiva crónica. ${ }^{23} \mathrm{El}$ pedido se refiere al suministro, por parte del Municipio, no sólo de medicamentos e insumos, sino también de oxígeno para ser consumido por los portadores de dicha enfermedad en sus domicilios. Según la entrevistada, tal tratamiento ya es dispuesto por el Municipio. En el caso de esta acción, la orden judicial preliminar fue juzgada favorablemente al pedido del Ministerio Público, y el Municipio está buscando hacer un acuerdo con esta institución, en el contexto de la propia acción civil pública.

Finalmente, según lo citado por todas las entrevistadas, existe, aún, una acción civil pública bregando por medicamentos e insumos para el tratamiento de diabetes, propuesta por la PAJ en enero de 2005. Dicha acción parece tener relevancia acentuada, no sólo por la centralidad que la cuestión de la diabetes tiene en las acciones demandando políticas de salud en el Municipio de São Paulo, sino también por la dimensión y la cobertura del pedido. Esta acción tiene como demandados al Estado y al Municipio de São Paulo y pide la condena de ambos entes en la

obligación de dar, gratuitamente, a las personas residentes en el Municipio de São Paulo, que comprueben el diagnóstico de DIABETES, independientemente de la clasificación de éstas, conforme a la prescripción médica, en la cantidad y periodicidad indicada individualmente, de forma continua, regular y sin interrupciones, de:

23 Acción Civil Pública. $12^{\circ}$ Juzgado de Hacienda Pública, Foro Central, Comarca de la Capital/ São Paulo, proceso número 053.020308-0. 
1. todos los medicamentos para el control y tratamiento de diabetes y/o de las enfermedades y/o disfunciones de órganos derivados de este síndrome;

2. todos los insumos necesarios para el control del nivel de glucemia, especialmente insulinas de todas las especies, que sean necesarias para el diabético, en conformidad con la indicación médica (humanas y animales, de acción ultra-rápida, rápida, intermedia, prolongada, lenta, ultra-lenta, premezclada y otras);

3 . todos los productos de autocontrol del nivel de glucemia, especialmente aparatos portátiles medidores (glucómetro), cintas reactivas descartables para el aparato medidor de glucemia y acetonemia, lancetas;

4. todos los productos de autoaplicación de medicamentos y de insulinas que sean prescriptos a los diabéticos, especialmente jeringas y agujas adecuadas.

La acción fue juzgada como procedente en primera instancia. Sin embargo, sólo será ejecutada si se mantiene la decisión en las instancias superiores y cuando no haya más posibilidades de recurso, o sea, cuando "transite en juzgado". La condena del Estado y del Municipio se dio en los términos del pedido realizado en la petición inicial, arriba transcrito, sin que se limite su objeto. Ambos apelaron la decisión y la acción está siendo evaluada por el TJ/SP.

De acuerdo con Cláudia Cimardi, que fue una de las procuradoras que propuso dicha acción civil pública, la decisión de entrar con el referido pedido se realizó por la gran demanda que llegaba a la Procuraduría, por parte de personas que tenían dificultad para acceder a los medicamentos e insumos para el tratamiento de la diabetes. Según la entrevistada, los casos ya habían sido resueltos efectivamente mediante la demanda individual, y juzgados, en regla, como procedentes. Por lo tanto, la acción también tuvo el objetivo de presionar al Estado y al Municipio para que organicen mejor el servicio de suministro de medicamentos e insumos para la diabetes como un todo, tornándolos regularmente más eficientes. Cimardi cree, incluso, que es posible que, cuando la acción civil pública sea juzgada definitivamente, el problema que le dio razón de ser ya haya sido resuelto. Esto es así porque, a lo largo del tiempo, con las innumerables acciones individuales juzgadas como procedentes, el servicio fue tornándose mejor, con menos fallas. 


\subsection{Argumentación sobre la constitucionalidad de políticas municipales de salud}

Esta forma de accionamiento del Poder Judicial se diferencia de las otras dos formas expuestas anteriormente, porque la acción propuesta no busca la efectuación del derecho a la salud, sino la suspensión de la política pública formulada por el Poder Ejecutivo. Este es un medio negativo de debatir la política municipal de salud, ya que no se da por vía del enforcement de derechos, sino por el intento de frenar la política mediante la discusión de su constitucionalidad. En base a los datos recogidos, hay indicios de que esta no es apenas la forma menos utilizada de cuestionamiento de políticas municipales de salud, sino también la que tuvo menos éxito en su apreciación por la justicia común. A través de las entrevistas, se llegó a sólo dos ejemplos de esta forma de cuestionar la política municipal en juicio: una acción directa de inconstitucionalidad de la ley municipal y una acción civil pública, ambas juzgadas como improcedentes.

Ambas acciones tenían como objetivo cuestionar la orientación dada por la gestión del Intendente Gilberto Kassab a la política municipal de salud, a través de la que realizó la contratación de las llamadas Organizaciones Sociales para la gestión de una parte de la re$\mathrm{d}$ pública de salud. De acuerdo con el artículo $1^{\circ}$ de la Ley Municipal $\mathrm{n}^{\mathrm{o}}$ 14.132, de 2006, son calificadas como Organizaciones Sociales, por el Poder Ejecutivo, las "personas jurídicas de derecho privado, sin fines de lucro, cuyas actividades sean dirigidas a la salud". Conforme al Diario Folha de São Paulo, hasta septiembre de 2009 había un total de nueve contratos firmados por la Intendencia Municipal con ocho Organizaciones Sociales para realizar la gestión de 119 unidades de salud de la red municipal, entre AMAs (unidades de Asistencia Médica Ambulatoria), UBSs (Unidades Básicas de Salud) y el Programa de Salud de la Familia, además de los Hospitales de Cidade Tiradentes y de M'Boi Mirim. ${ }^{24}$ El citado diario también informó que "teniendo en cuenta sólo el primer semestre de 2008, de los 985 millones de Euros dirigidos en el área de salud, 276 millones fueron gastados en esas contrataciones". El mismo modelo es adop-

24 "Juíza proíbe entidades privadas de gerir AMAS". Diario Folha de São Paulo, edición del día 9 de septiembre de 2008, Suplemento "Cotidiano". 
tado por el Gobierno del Estado de São Paulo para la gestión de hospitales.

En este contexto, fueron propuestas dos acciones en la justicia común en la tentativa de frenar tal política de salud de la administración de Kassab, con base en el argumento de que esta es inconstitucional, porque la Ley que la regula no precisa de licitación para la celebración de tales contratos de gestión, lo que sería indispensable en la medida en que se trata de ejecución de actividades de interés público. La primera de estas acciones es una acción directa de inconstitucionalidad de la ley municipal, ${ }^{25}$ propuesta por el Directorio Estadual del Partido de los Trabajadores (PT), cuestionando la constitucionalidad de la ya referida Ley Municipal $\mathrm{n}^{\circ} 14.132$ en relación con la Constitución del Estado de São Paulo. La acción fue juzgada como improcedente en febrero de 2007. La otra se trata de una acción civil pública propuesta por el Ministerio Público del Estado de São Paulo contra el Municipio en mayo de 2006 alegando la inconstitucionalidad y la ilegalidad de la creación de las unidades de Asistencia Médica Ambulatoria (AMAs) por la Intendencia Municipal en la medida en que se firman contratos con las Organizaciones Sociales para su gestión sin tenerse en cuenta las reglas de licitación y de concurso público. De la misma manera, tal acción fue juzgada como improcedente en primera instancia en noviembre de 2007 y en este momento se encuentra en procesamiento de los recursos en el TJ/SP.

Vale decir que este mismo caso fue propuesto en 2006 contra el Municipio de São Paulo por el Ministerio Público Federal, habiendo sido juzgado como procedente en primera instancia por la Justicia Federal en agosto de 2008. No obstante, la sentencia aún no fue ejecutada, o sea, no hubo suspensión de los contratos firmados entre las Organizaciones Sociales y la Intendencia Municipal de São Paulo, estando el caso en juzgamiento de recurso en el Tribunal Regional Federal. ${ }^{26}$ Aún cabe mencionar que las Organizaciones Sociales ya habían sido instituidas por la Ley Federal n ${ }^{\circ}$ 9.637, de 1998, durante el gobierno del expresidente Fernando Henrique Cardoso. La consti-

25 Tribunal de Justicia del Estado de São Paulo, Acción Directa de Inconstitucionalidad de la Ley n ${ }^{\circ}$ 130.726-0/7-00, Relator: Juez Renato Nalini.

26 "Juíza proíbe entidades privadas de gerir AMAS". Diario Folha de São Paulo, edición del día 9 de septiembre de 2008, Suplemento "Cotidiano". 
tucionalidad de dicha Ley está siendo cuestionada desde 1998 en el Supremo Tribunal Federal, mediante una Acción Directa de Inconstitucionalidad propuesta por el Partido de los Trabajadores (PT) y por el Partido Democrático Laborista (PDT), con un rechazo a la orden judicial preliminar que pedía la suspensión inmediata de tal Ley.

\section{Efectos de las decisiones de la justicia común en la política municipal de salud}

Algunos de los trabajos que tratan sobre la cuestión de la influencia del Poder Judicial en las políticas de salud señalan la existencia de una relación entre el aumento de la demanda por ciertos medicamentos a través de la justicia común y la inclusión de estos en la política pública del Poder Ejecutivo (Messeder/Osório-de-Castro/Luiza 2005), así como también que la demora en la inclusión de tratamientos más modernos en las políticas generan el aumento de tales acciones (Scheffer/Salazar/Grou 2005). Las entrevistas realizadas en este estudio llevan a la misma inferencia de que la presión hecha mediante acciones judiciales por ciertos medicamentos, combinadas con el alto número de pleitos juzgados como procedentes, de hecho, generó efectos sustantivos en las políticas municipales de salud.

El caso más evidente es, de acuerdo con las entrevistadas, el de la política de diabetes. Por un lado, la inclusión en la política de distribución de un kit diabetes con no sólo medicamentos, sino también con insumos para medir la glucosa del paciente, generó una disminución en el número de acciones, así como una alteración en el tipo de demandas enviadas al Poder Judicial. También existen indicios de que el alto número de acciones hizo que dicha política se tornase más eficiente con el paso del tiempo.

En el mismo sentido, el alto número de condenas en acciones demandando el suministro de pañales descartables, basadas en prescripciones provenientes, en su mayoría, de médicos de la propia red municipal de salud, hizo que los gestores del área de salud del Municipio de São Paulo planearan la creación de una política para atender tal demanda. Esto se puede explicar, según Adline Pozzebon, por ser menos costoso para el Municipio adquirir tales productos en grandes cantidades, por medio de licitación y suministrarlos regularmente, que 
hacer la compra en pequeños lotes para hacer frente a la atención de las demandas individuales concedidas por medio de las decisiones judiciales.

Sin embargo, la influencia de la gran cantidad de decisiones juzgadas como procedentes en las políticas de salud, motivada mayoritariamente por demandas individuales como ya fue demostrado, no puede ser explicada solamente en términos de la inclusión de medicamentos e insumos en las listas oficiales. Otro importante efecto de este fenómeno fue el convenio firmado entre la Defensoría Pública y la Secretaría de Salud del Estado de São Paulo, puesto en práctica en marzo de 2008, que tuvo como objetivo evitar, al máximo, que nuevas acciones fueran propuestas, mediante la tentativa de resolver la demanda de suministro de medicamentos o insumos del ciudadano aún durante la fase administrativa.

Según Vânia Casal, Coordinadora del Área de Hacienda Pública de la Defensoría que articuló el acuerdo con la Secretaría de Salud, el convenio fue motivado por la dificultad de acceso de la población a medicamentos e insumos que ya estaban incluidos en las listas de las políticas de salud, lo que generaba una gran demanda para la solución del problema mediante acciones judiciales. En otras palabras, muchos de los medicamentos e insumos que eran pedidos ya estaban estandarizados por el Poder Ejecutivo, pero las personas tenían dificultad para retirarlos. Ella relata que muchos pacientes atendidos en la red pública de salud no recibían la orientación exacta de dónde deberían retirar el medicamento o insumo prescripto, o se deparaban con la falta de estos en los puestos de distribución. Antes del convenio, el ciudadano procuraba a la Defensoría Pública, que proponía una acción para el suministro del tratamiento. Con su entrada en vigor, el ciudadano pasó a ser enviado a una etapa administrativa que tiene como objetivo solucionar el problema sin que sea necesario llevarlo al Poder Judicial.

Tal etapa administrativa se da de la siguiente manera: la Defensoría Pública brinda una atención inicial al ciudadano, buscando que sea verificada su demanda por medicamentos o insumos. Posteriormente, dicha persona es enviada, por medio de un oficio, para el sector de selección farmacéutica del Servicio Ambulatorio Médico de Especialidades (AME) Maria Zélia, perteneciente a la red de salud pública del Estado de São Paulo, donde es verificada la prescrip- 
ción médica hecha para esta persona. En caso de que el medicamento o insumo ya esté incluido en las listas oficiales de las políticas de salud, estatal o municipal, la persona recibe la orientación del local exacto donde el producto deberá ser retirado, al momento de la atención o por telegrama algunos días más tarde. De lo contrario, en el mismo lugar, el ciudadano hace un pedido administrativo para que la Secretaría de Salud evalúe si, en aquella situación, es viable proveer el tratamiento, incluso si no está estandarizado por el Poder Ejecutivo. O sea, aunque el medicamento o insumo demandado no esté incluido en las políticas de salud, es posible que sea suministrado sin necesidad de que sea propuesta una acción judicial, tras un breve proceso administrativo. Si después de este trámite la persona no recibe el telegrama indicando el lugar de retiro del producto, o no lo consigue retirar en el lugar indicado, o si en otro caso, lo hubiera pedido mediante un proceso administrativo negado, se da la orientación para que esta persona vuelva a la Defensoría Pública para la proposición de una acción judicial. En esta situación, será evaluado por el defensor, contra cuál ente será propuesta la acción: el Estado o el Municipio.

Cabe resaltar, además, que, aunque tal convenio haya sido firmado sólo entre la Defensoría Pública y la Secretaría de Estado, se puede decir que este también surte efectos en el número de acciones propuestas contra el Municipio de São Paulo. Esto es así porque, según Vânia Casal, las personas atendidas por el convenio son tanto aquellas con recetas médicas de la red pública municipal de salud como de la estatal. O sea, en la medida en que muchas demandas son resueltas en la etapa administrativa, menos acciones son propuestas también contra el Municipio. En contrapartida, luego de realizada la selección farmacéutica, el lugar indicado para el retiro del medicamento también puede ser un puesto de la red de salud municipal.

Vânia Casal, asimismo, informa que la Defensoría Pública ha hecho reuniones con la Secretaría del Estado de São Paulo para lograr la inclusión directa del Municipio en el referido convenio. Cuenta que el convenio de la Defensoría Pública con la Secretaría de Salud fue facilitado por el hecho de que hay una mayor proximidad institucional entre ambas, por estar vinculadas al Estado de São Paulo.

La entrevistada señala también que la mayor demanda relativa al Municipio llevada a la Defensoría Pública es por pedidos de suminis- 
tro de pañales descartables, como fue descrito arriba. En estos casos, dichas demandas no llegan a pasar por esta etapa administrativa, en la medida en que no existe una política municipal de distribución de las mismas. La entrevistada informa que entre el $70 \%$ y el $80 \%$ de las prescripciones de pañales provienen de la red municipal.

De acuerdo con Vânia Casal, el convenio entre la Defensoría Pública y la Secretaría de Salud trajo algunos beneficios en relación a la situación anterior. Uno de los más importantes es la mejor atención del ciudadano, en la medida en que este tiene acceso al medicamento de forma más rápida mediante esta vía, que cuando la acción judicial es propuesta. Otra gran ventaja del convenio es que, con este, el Poder Ejecutivo logra evaluar mejor dónde están las fallas del suministro de medicamentos e insumos en la red pública de salud. Aún más si se tiene en cuenta que la red de distribución de medicamentos e insumos es bastante compleja, ya que cuenta con varios puntos de distribución. En ese sentido, la entrevistada resalta que la mayor parte de demandas por medicamentos e insumos que llegan a la Defensoría Pública se origina en fallas en el suministro. Y, más que la falta de estos en los puestos de distribución, el gran problema es la falla al momento de dar informaciones a los ciudadanos sobre el lugar correcto del retiro del medicamento.

Otro punto positivo muy importante, alcanzado con el convenio entre la Defensoría Pública y la Secretaría de Salud, según Vânia Casal, es la caída del $80 \%$ en el volumen de las acciones propuestas. Así, de acuerdo con la entrevistada, antes del convenio, eran propuestas entre 100 y 120 acciones por mes contra el Estado y el Municipio de São Paulo bregando por medicamentos e insumos. Tras la puesta en práctica del convenio, pasaron a ser propuestas entre 20 y 30 acciones por mes solamente. Hubo, por lo tanto, una disminución sustancial. Actualmente, la mayor parte de las acciones interpuestas por la Defensoría Pública se refiere a solicitaciones de medicamentos o insumos que tuvieron el pedido administrativo de suministro negado, además de los pedidos de pañales. En muchos casos, después de dicho proceso, la Secretaría de Estado indica que el medicamento pedido posee un producto similar en la lista de la política pública, y que solamente este podrá ser provisto. No obstante, el médico que realizó la prescripción afirma que el similar no surte los mismos efectos, no siendo, de esta forma, igualmente eficaz. Es muy común que esto 
ocurra en los casos de pedidos de insulinas específicas, para casos peculiares de diabetes. En este contexto, la Defensoría ha propuesto la acción para que la discusión de la posibilidad o no de la sustitución sea haga en el juicio.

Otro efecto en las políticas de salud consecuente del gran número de condenas del Municipio en acciones demandando el suministro de medicamentos e insumos fue la creación de una farmacia por parte de la Secretaría de Salud del Municipio para la distribución de aquellos medicamentos e insumos concedidos por vía judicial. En 2005, fue instalada una estructura, dentro del propio edificio de la Secretaría, para atender la demanda creciente de suministro de medicamentos concedidos judicialmente, donde los beneficiados por tales decisiones los retiran.

No fue posible evaluar en números los efectos de las condenas para la concesión de medicamentos e insumos en el presupuesto de la Secretaría de Salud del Municipio de São Paulo, en la medida en que no existen datos sistematizados con respecto a estas, según informó Adline Pozzebon. Ella afirma que, cuando el Municipio es condenado a suministrar medicamentos que ya son distribuidos regularmente, no existen gastos subsiguientes para la Secretaría de Salud, debido a que estos ya fueron adquiridos para abastecer a la red pública municipal. No obstante, cuando el caso se trata de la concesión de medicamentos que no constan en la lista de la política pública, termina habiendo una reasignación de recursos dentro del propio presupuesto de la salud. En otras palabras, es necesario retirar recursos de otros programas para que sean hechas tales compras.

Entre los medicamentos e insumos no incluidos en la política de salud que el Municipio es condenando a suministrar, están los ya citados pañales y los medicamentos de alto costo. De acuerdo con Adline Pozzebon, esos últimos son los que originan los mayores gastos con su compra. Ella dice que en muchos de los casos de suministro de medicamentos de alto costo, estos ya son provistos por el Estado, como es el caso del tratamiento para cáncer y hepatitis. Cuando el Municipio es condenado a suministrar un medicamento de alto costo, aunque este ya sea distribuido por el gestor estatal, él es obligado a realizar la compra. No existe comunicación entre el Estado y el Municipio con respecto a las condenas para el suministro de medicamentos. La entrevistada afirma que, en los casos en que ambos en- 
tes son condenados concomitantemente al cumplimiento de un pedido, puede haber duplicidad en el suministro de los medicamentos.

Para Adline Pozzebon, el impacto de las decisiones que conceden el suministro de los medicamentos es mucho mayor para el Municipio que para el Estado de São Paulo, en la medida en que su presupuesto es significativamente menor. Esto se debe a que, de acuerdo con la entrevistada, el gestor estatal recibe la mayor parte de las transferencias federales del SUS en el contexto del programa de asistencia farmacéutica, ya que tal ente es responsable por la exención de los medicamentos más caros. El Municipio, por su parte, es responsable por la atención básica y, por este motivo, tiene gastos y presupuesto menores en comparación con el Estado. Así, las condenas con medicamentos de alto costo comprometen parcelas muy significativas del presupuesto municipal con su compra.

\section{Conclusiones}

A partir de las informaciones presentadas, se puede notar que hay dos caminos más acentuados para demandar cuestiones relacionadas con las políticas de salud del Municipio de São Paulo a través del Poder Judicial. La primera de estas formas se da por vía indirecta, teniendo como objetivo el enforcement del derecho a la salud, de forma tanto individual como colectiva. Dicha estrategia es denominada aquí como indirecta porque, aunque no tenga el objetivo de alterar la política pública, termina produciendo consecuencias sustantivas en las mismas. La mayor parte de las condenas del Municipio mostró estar vinculada con acciones individuales que tienen por objeto el suministro de medicamentos e insumos. Es también, con relación a esas acciones, que parece comprobarse, en mayor medida, la influencia de las condenas del Poder Ejecutivo en la alteración de sus políticas de salud, ora en la forma de la inclusión de medicamentos e insumos en su lista oficial, ora en la forma de la creación de acuerdos institucionales que procuran evitar la resolución judicial de las demandas. Así, aunque el Municipio no esté directamente vinculado al convenio realizado entre la Secretaría de Salud del Estado y la Defensoría Pública, va a estar directamente afectado por el convenio. Las acciones terminan teniendo el efecto de calibrar la política de salud en dos sentidos: (1) detectar y aminorar las fallas 
del suministro de medicamentos e insumos y (2) llevar al Poder Ejecutivo demandas de la población que no siempre son percibidas por este.

En efecto, presentamos indicativos de que la sumatoria de esas acciones, propuestas en gran volumen, hace que el Municipio acabe por readecuar sus políticas de salud como forma de disminuir las decisiones contrarias a este. En este sentido, se debe tener en cuenta que, cuando el Ejecutivo es condenado por el Judicial, tiene muy poco margen para la negociación sobre cómo aquella decisión va a ser implementada, pudiendo existir perjuicios financieros y políticos mayores que los que habría si, al percibir el problema, lo resolviese de acuerdo a sus preferencias. De esta forma, en muchos casos, es más fácil alterar la política como forma de evitar las demandas y, posteriormente, tener que cumplir decisiones judiciales aún más costosas desde el punto de vista político o financiero.

El enforcement del derecho a la salud por la vía judicial es realizado también de forma colectiva, es decir, por medio de acciones civiles públicas propuestas por el Ministerio Público y por la Defensoría Pública del Estado de São Paulo. En estos casos, como pudo verse, hay otros objetos siendo demandados, tales como la mejora y ampliación de la infraestructura de la red pública de salud y de los servicios prestados por esta. Esta vía, sin embargo, se muestra no sólo como la menos utilizada, sino que también revela un mayor índice de fallos improcedentes por parte del Poder Judicial. Además, incluso cuando son juzgadas como procedentes, existe más dificultad de ejecución de las decisiones por parte de la Secretaría de Salud del Municipio. También en este campo de la acción colectiva se pudo constatar que crece la disposición tanto de los órganos solicitantes como del Municipio de São Paulo para realizar acuerdos prejudiciales para la resolución de las demandas. Existe el indicativo de que los casos de enforcement del derecho a la salud realizados colectivamente, muchas veces se resuelven mediante investigaciones civiles públicas en las que hay un acuerdo entre el Ministerio Público y el Poder Ejecutivo, en el sentido de resolver la demanda por medio de acuerdos prejudiciales, asumiendo el Judicial, en esta situación, el papel de mediador del conflicto, sin que haya necesidad de la proposición de la acción. 
Se observó, asimismo, una tercera vía de demandas relacionadas con las políticas de salud municipales, en las que el Ministerio Público cuestiona directamente la política pública en relación a su constitucionalidad, por medio de acciones civiles públicas, o aún, a semejanza de lo que sucede en el control concentrado de constitucionalidad en el Supremo Tribunal Federal, a través de acciones directas de inconstitucionalidad de la ley municipal interpuestas por partidos políticos. El objetivo de estas acciones no es garantizar derechos sociales en juicio, sino vetar la política de salud como un todo. En esos casos, al contrario de lo que ocurre con la primera forma, hay una restricción bastante mayor por parte del Judicial de dar lugar a esas acciones.

Así, dada la exposición de los principales resultados a los que llegó esta investigación, se puede afirmar que el comportamiento de la justicia común revela particularidades que deben ser incluidas en el entendimiento del Poder Judicial brasileño. Entre ellas, se puede notar que el cambio sustantivo de las políticas de salud se da, principalmente, mediante procedimientos comunes, los que cualquier ciudadano tiene legitimidad para proponer. Otro asunto observado es que, cuando los pedidos de las acciones se relacionan con el enforcement de derechos, aunque estos sean colectivos, el Judicial tiende a ser más receptivo que cuando el pedido es para que una política sea declarada inconstitucional y después suspendida. Las demandas que llegan por la vía individual son las que tienen más éxito en la justicia común, así como las que más generan efectos en las políticas de salud.

Además de estas particularidades, el estudio de caso muestra que el Poder Judicial desempeña un papel importante en el proceso político más amplio, en el que se muestra como un canal posible para las demandas que la sociedad transmite al Gobierno. El fenómeno descrito nos lleva a la comprensión del Poder Judicial no sólo como un "output" del sistema político, sino como uno de sus varios "inputs", es decir, como un medio para acceder a las demandas formuladas por la sociedad dentro del proceso político formal. 


\section{Bibliografía}

Borges, Daniela da Costa Leite (2007): Uma análise das ações judiciais para o fornecimento de medicamentos no âmbito do SUS: o caso do Estado do Rio de Janeiro. Dissertação de mestrado. Rio de Janeiro: Fundação Oswaldo Cruz.

Dinamarco, Cândido Rangel (2002): Instituições de processo civil. 3 vols. São Paulo: Malheiros.

Fanti, Fabiola (2009): Políticas de saúde em juízo: um estudo sobre o município de São Paulo. Dissertação de Mestrado. São Paulo: Universidade de São Paulo.

Ferreira, Camila Duran et al. (2004): "O judiciário e as políticas de saúde no Brasil: o caso AIDS": Concurso de Monografias, Prêmio IPEA 40 anos. En: <www. Getinternet.ipea.gov.Br/SobreIpea/40anos/estudantes/monografiacamila.doc $>$ (01.10.2010).

Jornal Folha de São Paulo (2008): "Juíza proíbe entidades privadas de gerir AMAS". En: Caderno Cotidiano, 9 de septiembre de 2008.

Lopes, José Reinaldo de Lima (2006): “Os tribunais e os direitos sociais no Brasil Saúde e Educação". En: Lopes, José Reinaldo de Lima: Direitos sociais: teoria e prática. São Paulo: Método, pp. 221-264.

Marques, Silvia Badim/Dallari, Sueli Gandolfi (2007): “Garantia do direito social à assistência farmacêutica no Estado de São Paulo". En: Revista de Saúde Publica, 41, 1, pp. 101-107.

Messeder, Ana Márcia/Osório-de-Castro, Claudia Garcia Serpa/Luiza, Vera Lucia (2005): "Mandados judiciais como ferramenta para garantia do acesso a medicamentos no setor público: a experiência do Estado do Rio de Janeiro, Brasil". En: Cadernos de Saúde Pública, 21, 2, pp. 525-534.

Novaes, Adelina de Oliveira et al. (2007): "As bases de jurisprudência nos tribunais de São Paulo". En: Congresso 180 anos do direito no Brasil e a Democratização do Acesso a Justiça. Encontro preparatório ao V Congresso da ABEDI (Associação Brasileira de Ensino do Direito).

Scheffer, Mário/Salazar, Andréa Lazzarini/Grou, Karina Bozola (2005): “O remédio via justiça: um estudo sobre o acesso a novos medicamentos e exames em HIV/Aids no Brasil por meio de ações judiciais". En: Ministério da Saúde, Série Legislação, 3, pp. 24-38.

Terrazas, Fernanda Vargas (2008): O Poder Judiciário como voz institucional dos pobres: o caso das demandas judiciais por medicamentos. Dissertação de mestrado. São Paulo: Universidade de São Paulo.

Viera, Fabiola Sulpino (2008): "Ações judiciais e direito à saúde: reflexão sobre a observância aos princípios do SUS". En: Revista de Saúde Publica, 42, 2, pp. 365-369.

Viera, Fabiola Sulpino/Zucchi, Paola (2007): "Distorções causadas pelas ações judiciais à política de medicamentos no Brasil". En: Revista de Saúde Publica, 41, 2, pp. 214-222.

Wang, Daniel (2009): Poder Judiciário e participação democrática nas políticas de saúde. Dissertação de mestrado. São Paulo: Universidade de São Paulo. 

3. Política, derecho y protesta 



\section{Marco Estrada Saavedra \\ Alteraciones comunicativas: democracia, medios de difusión y la Asamblea Popular de los Pueblos de Oaxaca}

\section{Introducción}

Una manera de introducir el tema de este capítulo puede ser recordando lo sucedido el $1^{\circ}$ de diciembre de 2004, día en que Ulises Ruiz Ortiz asumiría el cargo de gobernador del estado de Oaxaca. En esa fecha, Ruiz Ortiz convalidó la toma de las bodegas del periódico Noticias, ordenada por José Murat, el anterior mandatario, por parte de supuestos "comuneros" del municipio de Santa Cruz Amilpas. Como resultado de estas acciones fallecería una persona. No contento con lo anterior, el flamante mandatario orquestaría más adelante, en cooperación con un sindicato cercano al régimen prísta, un pseudo conflicto laboral en torno al contrato colectivo de trabajo de Noticias, con el fin de desaparecer un medio crítico e incómodo para su gestión. Ello derivaría en el cierre violento del diario por más de un año (Martínez Vásquez 2007: 36; Osorno 2007: 29).

Esta "anécdota" condensa a la perfección la relación que el gobierno actual de Oaxaca entablaría en el sexenio (2004-2010) con los opositores, en general, y con los medios de comunicación, en particular. He referido estos hechos porque nos dan luces para entender el significado político y social de la "toma de los medios" por parte de la Asamblea Popular de los Pueblos de Oaxaca (APPO) durante el conflicto de 2006.

A pesar de su importancia, las relaciones entre medios de comunicación y movimientos sociales han sido un tema muy poco estudiado en la sociología (Neidhardt 1994). En América Latina se ha puesto más bien atención a la configuración y redefinición del espacio público por parte de los actores colectivos (Bolos 2003; 2008; Cunill 1999; Estrada Saavedra 1995). Para el caso específico de la APPO, la "toma de los medios" en aquel candente verano de 2006, no ha mere- 
cido hasta ahora gran atención. Únicamente existe un trabajo sociológico que se ocupa de tan inusual e importante evento (Zires 2009). Por lo demás, la producción científica en torno al conflicto oaxaqueño ha sido magra, debido, en parte, a la relativa cercanía temporal que aún guardamos con aquellos sucesos. ${ }^{1}$ Como es natural, han predominado hasta este momento las publicaciones periodísticas, testimoniales, partidistas y de denuncia de violación de los derechos humanos (Beas Torres 2007; CCIODH 2007; Denham/C.A.S.A Collective 2008; Giarracca 2008; Martínez Vásquez 2007; Osorno 2007; Sotelo Marbán 2008), así como una notable producción de DVDs y CDs (Mal de Ojo/Contraimagen 2007; SNTE-Sección XXII/CNTE/ Radio Plantón 2007; Videohackers 2007). Aunque estas publicaciones se caracterizan por su falta de análisis sociológico y politológico, el material que contienen, sin embargo, es sumamente rico en información, imágenes y audios, por lo que son, de verdad, una fuente primaria fundamental para el estudio de la "Comuna de Oaxaca".

En este escrito buscaré responder las siguientes cuestiones: 1) ¿qué funciones cumplieron los medios de difusión "tomados" en la organización y movilización de la APPO? 2) ¿Cómo operaron y realizaron estos su trabajo informativo? Y 3) ¿cuál fue la relación entre los medios de difusión y el público appista? No obstante, antes de abordar estas preguntas, delinearé, de manera sucinta, el marco teórico-metodológico utilizado. ${ }^{2}$

1 Estudios académicos sobre los antecedentes del conflicto social y la APPO se encuentran en Cortés (2006), algunas colaboraciones en el número 24/25 de Cuadernos del Sur (2007) y en Martínez Vásquez (2009).

2 El material empírico de este escrito es producto del trabajo de campo que, desde 2008, llevo a cabo junto con la Dra. Silvia Bolos, en el marco de un proyecto de investigación sobre la constitución, organización y movilización de la APPO. Los lineamientos generales de esta investigación pueden consultarse en Bolos y Estrada Saavedra (2010). Deseo agradecer a la Universidad Iberoamericana y al Consejo Nacional para la Ciencia y la Tecnología por el financiamiento a nuestro trabajo. Asimismo doy las gracias a las fundaciones Alexander-von-Humboldt y Thyssen por la beca que me han otorgado como científico visitante en el Lateinamerika-Institut de la Freie Universität Berlin durante 2010. Con este estipendio he podido tener el tiempo y los medios necesarios para escribir este capítulo. 


\section{La APPO como un sistema de protesta}

En términos teóricos y metodológicos, concibo a la APPO no como un movimiento social, sino, más bien, como un "sistema de protesta". Este es una forma especial de los sistemas sociales, ${ }^{3}$ que se caracteriza por su constitución y producción mediante comunicaciones orientadas al conflicto. Estas comunicaciones se expresan temáticamente como movilizaciones de protesta en contra de diferentes oponentes (como el gobierno, las organizaciones eclesiales, las empresas, los medios de comunicación) o de las consecuencias no previstas de la operación de los sistemas de funciones de la sociedad (como la política, la economía, la ciencia o el arte). ${ }^{4}$

La complejidad de un sistema de protesta puede ser aprehendida por medio de la distinción de diferentes niveles de análisis. En efecto, mediante la diferencia sistema/entorno puede observarse cualquier sistema de protesta tanto en sus elementos, procesos, funciones y estructuras internos como, también, en relación a sus comunicaciones externas, interpenetraciones y acoplamientos estructurales con otros sistemas sociales (incluyendo los sistemas de funciones) de su entorno. Esta distinción fundamental ha de complementarse ulteriormente con otras tres más: la interacción, la organización y la sociedad. ${ }^{5}$ Mientras que la última, vista analíticamente, pertenece al entorno del sistema de protesta, las primeras dos distinciones tienen que ver con su constitución interna. En otras palabras, los participantes en el sistema de protesta pueden ser observados 1) ya sea en las interacciones cotidianas de sus respectivos medios sociales o mundos de vida, 2) como miembros de la organización sistémica en sus diferentes

3 Sobre el concepto de sistema social, véase Luhmann (1987).

4 Sobre la concepción de los "movimientos de protesta" de la teoría de sistemas, véase Ahlemeyer (1989; 1995); Hellmann (1996; 1998; 2000); Japp (1984; $1986 a ; 1986 b ; 1990)$ y Luhmann $(1992 ; 1996 ; 1998)$. Aunque emparentada con ella, mi modelo analítico varía de manera significativa con respecto a la concepción alemana. En este texto no me es posible, sin embargo, desarrollar estas diferencias. Sobre el tema véase Estrada Saavedra (2008).

5 Cualquiera que conozca la obra de Niklas Luhmann, sabrá que estas distinciones hacen referencia a tres tipos fundamentales e irreductibles de sistemas sociales (Luhmann 2005). Como no me siento obligado a seguir la ortodoxia "bielefeldiana" ni a hacer un culto improductivo, sociológicamente, a la "gran teoría", echo mano del instrumental conceptual de la teoría de sistemas para comprender y explicar, teórica y empíricamente, los sistemas de protesta. 
roles, posiciones de autoridad y relaciones de poder entre sí, o bien 3) como un unidad colectiva inserta en un conflicto con, al menos, un oponente y entablando relaciones de alianza y oposición con diferentes actores, grupos, organizaciones e instituciones. Esta complejidad le permite al sistema de protesta referirse, al mismo tiempo, a diversos sistemas de funciones y a sus respectivas organizaciones.

La APPO puede ser considerada teóricamente como un sistema de protesta porque: 1) se diferencia de su entorno; 2) logra su autopoiesis creando estructuras propias de comunicación, organización, movilización, producción y distribución de recursos y bienes colectivos; 3) crea su propia forma: la protesta; 4) construye su propia perspectiva de observación: la crítica sociopolítica y la denuncia contestataria; 5) elabora sus propios mecanismos de conducción (élites y liderazgos), reclutamiento (motivación y selección de miembros) e identidad (diferenciación del entorno); 6) entabla alianzas y produce redes de interacción y comunicación con otros sistemas de protesta, organizaciones, formadores de opinión pública, organizaciones no gubernamentales, etc.; 7) inicia eventos de protesta y conflicto con otros sistemas sociales, especialmente con las organizaciones de los sistemas de funciones, por ejemplo universidades, empresas, iglesias, partidos políticos, diarios, etc.; y, 8) critica los efectos de la diferenciación de los sistemas sociales. ${ }^{6}$ En este sentido, la APPO está compuesta por diferentes subsistemas especializados (como por ejemplo, los de la dirección política, la organización, la seguridad, la protesta simbólica o el de los medios de difusión) ${ }^{7}$ que, en su conjunto, conforman este sistema de protesta.

En relación a su composición organizativa y al origen de sus elementos constituyentes, se puede diferenciar a la APPO metodológicamente en tres segmentos: 1) la Sección 22 del Sindicato Nacional de Trabajadores de la Educación (SNTE), 2) las organizaciones populares y 3) los sectores no organizados o "independientes" de la

6 Siguiendo la enumeración anterior, los puntos 1 a 5 corresponderían a los niveles de análisis de la interacción y la organización, mientras que el 6 y 7 al de la sociedad.

7 Estos subsistemas especializados hacen referencia, respectivamente, a la Asamblea General, la movilización colectiva coordinada, las barricadas, los colectivos de artistas y los medios tomados. 
población ${ }^{8}$. Esta tríada de segmentos se encuentra, por su parte, internamente diferenciada en distintos grupos, fracciones, tendencias políticas y corrientes ideológicas, por lo que resultaría reduccionista suponer una homogeneidad del sistema de protesta, en general, y de los diferentes subsistemas, en particular. Esto implica, por tanto, que

8 Como el Frente Amplio de Lucha Popular (FALP), el Consejo Indígena Popular de Oaxaca (CIPO), el Frente Popular Revolucionario (FPR), la Organización Indígena de Derechos Humanos de Oaxaca (OIDHO), el Comité Democrático Ciudadano (CODECI), el Consejo de Defensa del Pueblo (CODEP), la Organización de Pueblos Indígenas Zapoteca (OPIZ), el Ayuntamiento Popular de San Blas Atempa, Nueva Izquierda de Oaxaca.

También conformaron la APPO los sindicatos agrupados en el Frente de Sindicatos y Organizaciones Democráticas de Oaxaca (FSODO), entre los cuales se encuentra el Sindicato de Trabajadores y Empleados de la Universidad Autónoma Benito Juárez de Oaxaca (UABJO) y la Sección 35 de la Secretaría de Salud. Asimismo se integraron un conjunto de organizaciones no gubernamentales como Educación Alternativa (EDUCA), el Comité de Apoyo al Movimiento Popular de Oaxaca (CAMPO), la Liga Mexicana de Derechos Humanos (LIMEDH), la Red de Derechos Humanos de Oaxaca, la Casa de la Mujer "Rosario Castellanos" y decenas de organizaciones de atención a diversas problemáticas en el estado.

Diversas agrupaciones de jóvenes (universitarios, punks, anarcos, etc.) de las colonias, grupos de ciudadanos y vecinos de barrios de la ciudad se sumaron al movimiento así como organizaciones indígenas tales como Servicios del Pueblo Mixe (SER), la Unión de Organizaciones de la Sierra Juárez de Oaxaca (UNOSJO), la Unión de Comunidades Indígenas de la Sierra Norte del Istmo (UCIZONI), el Frente Indígena Oaxaqueño Binacional (FIOB). En el proceso, se formaron nuevas organizaciones: la Coordinadora de Mujeres de Oaxaca y la Coordinadora Estudiantil (cfr. Martínez Vásquez 2007: 69ss.).

De acuerdo también con Víctor Raúl Martínez Vásquez, se pueden identificar distintas vertientes en este conjunto de organizaciones sociales. Una vertiente sindicalista estructurada, con amplia experiencia, agrupadas en el FSODO; organizaciones de la izquierda social con demandas económicas identificada con el socialismo, algunas de ellas agrupadas en la Coordinadora por la Unidad Nacional contra el Neoliberalismo. Una segunda que agrupa a organizaciones civiles inscritas en la lógica de la sociedad civil, con agendas puntuales y diversas pero con coincidencias en los temas de inclusión, participación, justicia y democracia. Se pueden incluir aquí las CEBS identificadas con los derechos humanos. La tercera indígena identificada con los acuerdos de San Andrés y reivindicando posiciones culturalistas, agrarias, de poder local autónomo y pluralismo jurídico. Una cuarta urbana conformada por grupos de colonos y vecinos con demandas de servicios, protección del patrimonio histórico y cultural, condiciones de vida urbana. La quinta compuesta por distintas expresiones políticas como la izquierda parlamentaria, grupos y personas identificadas con el PRD, el PT y Convergencia. Otros con posiciones de izquierda revolucionaria como el FPR. Finalmente, los marginados urbanos: chavos banda y niños de la calle (cfr. Martínez Vásquez 2007: 73ss.). 
cada uno de los subsistemas de la APPO tiene, aparte de las orientaciones generales de comunicación y acción, orientaciones particulares que, en determinados momentos, pueden ser compatibles y, en otros, divergir y entrar en contradicción entre sí. De esta manera, el segmento formado por los miembros del magisterio orienta sus comunicaciones y acciones colectivas típicamente de acuerdo a la lucha sindical, la negociación y el conflicto propios del sistema político institucional (estatal y federal). En cambio, los segmentos de las organizaciones populares y de los sectores no organizados de la población orientan las suyas típicamente fuera y en contra del sistema político. ${ }^{9}$ En su conjunto, esto generó grandes problemas de coordinación y dirección en el sistema de protesta, pero también una gran capacidad de movilización, conflicto y negociación, así como de aprendizaje colectivo y de innovación de los repertorios de protesta, tanto en los espacios sociales como en los institucionales, que depararon grandes dificultades a los oponentes del sistema de protesta (gobiernos estatal y federal, contra-movimiento local) para lidiar con la APPO.

\section{El pueblo toma la palabra: el contexto de la toma de los medios de difusión}

Como sucedía tradicionalmente desde hace un poco más de dos décadas en Oaxaca, los maestros, miembros de la Sección XXII del SNTE, iniciaron su ciclo de movilizaciones el $1^{\circ}$ de mayo de 2006 para demandar mejoras saláriales y laborales de diferente orden con el gobierno de Oaxaca. ${ }^{10}$ La negociación entre el gremio magisterial y el gobierno resultaron especialmente difíciles en ese año. Como medida de presión, los 70 mil maestros decidieron establecer el 22 de ese mismo mes un "plantón" en el zócalo de la ciudad hasta que se diera satisfacción cabal al contenido de su "pliego petitorio". Debido a que ninguna de las partes cedía en sus demandas, el diálogo quedó roto. En consecuencia, los docentes paralizaron prácticamente la ciu-

9 Lo cual no significa que no se vinculen y, posteriormente, entablen diálogos y negociaciones con los actores y las instituciones del sistema político, como es el caso de las organizaciones populares.

10 Sobre la historia de la Sección XXII del SNTE, véase Yescas Martínez/Isidoro y Zafra (2006). Para la organización misma del gremio magisterial, tanto a nivel nacional como en Oaxaca, consúltese Armenta Muñoz (2005). 
dad. Como respuesta, las autoridades estatales decidieron desalojar violentamente el zócalo en la madrugada del 14 de junio de 2006. Los maestros resistieron a la policía y, con el apoyo inesperado de una parte significativa de los ciudadanos de Oaxaca, logrando recuperar la plaza central hacia las diez de la mañana. Tres días después, una coalición impresionante de organizaciones sociales y políticas de diferente signo ideológico, liderada por el magisterio, decidió constituir lo que se conocería como la Asamblea Popular de los Pueblos de Oaxaca. Su objetivo principal era la renuncia inmediata del gobernador Ulises Ruiz Ortiz.

A partir de entonces y hasta finales de noviembre 2006, la APPO controló prácticamente la ciudad de Oaxaca. Por esta razón, las autoridades públicas de todos los niveles (municipal, estatal y federal), así como los representantes de los poderes legislativo y judicial, dejaron de ejercer sus funciones.

Conforme escalaba la polarización entre la APPO y el gobierno de Oaxaca, el tratamiento informativo de los medios de difusión estatal y nacional mostraba un creciente rechazo hacia el plantón del magisterio y a la revuelta popular de la asamblea (Zires 2009).

Justo en este contexto, en el que la información mediática se había convertido en un recurso gubernamental para desprestigiar a los grupos contestatarios, tuvieron lugar una serie de tomas de medios de difusión por parte de los appistas. La represión del 14 de junio de $2006,{ }^{11}$ que incluiría, como enseguida veremos, la interrupción, por varias semanas, de las transmisiones de Radio Plantón, dio lugar, unas horas más tarde, a la ocupación de Radio Universidad por parte de los estudiantes de la Universidad Autónoma Benito Juárez de Oaxaca (UABJO). Un mes y medio después, el $1^{\circ}$ de agosto, tras la denominada "marcha de las cacerolas", un nutrido grupo de mujeres se apropiaría de las instalaciones de la radio y la televisión estatales. Veinte días más tarde, después de la destrucción de sus antenas de transmisión, los appistas se apoderarían sorpresivamente de 12 radiodifusoras comerciales en la ciudad de Oaxaca, de las cuales sólo dos, Radio Oro y Radio La Ley, operarían varias semanas consecutivas. No

11 Entre junio y diciembre de 2006, 23 personas fueron víctimas mortales de la violencia política y cientos más de violaciones a sus derechos humanos. Al respecto, pueden consultarse CCIODH (2007) y Sotelo Marbán (2008). 
fue sino hasta los días finales de noviembre que la última radiodifusora tomada, Radio Universidad, dejaría de emitir su señal tras resistir varios días la violenta represión de la Policía Federal Preventiva (PFP).

\section{Las funciones sistémicas de los medios de difusión en la APPO}

Con fines analíticos, resulta útil distinguir tres tipos de medios de difusión. ${ }^{12}$ Los autogestionados (como Radio Plantón), los ocupados (como Radio Universidad, Canal 9 de TV Oaxaca y las radiodifusoras comerciales, como Radio La Ley o Radio Oro, y las radios comunitarias como, por ejemplo, en el municipio de Zaachila) y los alternativos e independientes (como Ojo de Agua, Indymedia, y los diarios La Jornada y Noticias). Lo que aquí propongo es que se pueden entender a los medios autogestionados y ocupados como un "subsistema" de la APPO. Los medios alternativos e independientes los trataré como un "cuasi subsistema", ya que, si bien tienen una existencia anterior a la asamblea, colaboraron estrechamente con la $\mathrm{APPO}$, por lo que de facto asumieron funciones sistémicas para ésta. ${ }^{13}$

Como subsistema especializado, el conjunto de los medios de difusión en cuestión cumplió cinco funciones para la APPO. En relación con su entorno, difunden, primero, las razones y los objetivos de la protesta appista para informar al público telespectador y radioescucha ${ }^{14}$ con el fin de contrarrestar lo que consideraban una versión parcial, malintencionada y propagandística del conflicto oaxaqueño difundida por los medios de comunicación gubernamentales (estatal y federal), las cadenas televisivas nacionales (TV Azteca y Televisa) y los diarios de circulación nacional y estatal en aras de desacreditar sus movilizaciones contestatarias. En segundo término, al difundir la versión del conflicto de la APPO más allá del territorio oaxaqueño, abrían, por un lado, un espacio de denuncia de la repre-

12 Sobre el concepto de "medios de difusión", véase Luhmann (1998), en especial el capítulo 2.

13 En sentido estricto, Ojo de Agua debería ser incluido dentro de la clasificación como "subsistema", porque participó en la APPO a través de la formación del colectivo Mal de Ojo y con muchos más miembros y colaboradores que los integrantes de Ojo de Agua.

14 Si consideramos a los diarios La Jornada y Noticias, entonces debemos incluir al público lector. 
sión gubernamental para llamar la atención de la opinión pública (nacional e internacional) y, así, proteger a los appistas de mayores agresiones; y, por el otro, creaban la posibilidad de lograr apoyos y alianzas de actores externos o de la población oaxaqueña aún no movilizada.

En tercer lugar, los medios de difusión ${ }^{15}$ contribuyeron, internamente, a generar una perspectiva de observación del sistema de protesta, que le permitiera, mediante esquemas cognitivos y normativos, construir significativamente la realidad y dotar de sentido a los eventos y las comunicaciones e interacciones de los diferentes participantes en el conflicto. En cuarto término, al informar a los participantes en la protesta (tanto a personas y grupos no organizados como a los militantes miembros de organizaciones populares integrantes de la APPO) acerca del estado que guardaba, en un determinado momento, el conflicto y las negociaciones con autoridades federales o al promover iniciativas de movilización (por ejemplo, participar en una marcha o resguardar determinada barricada), los medios de difusión fungían como mecanismos internos de coordinación de las comunicaciones e interacciones sistémicas. En efecto, la ausencia de una dirigencia plenamente reconocida, de una estructura organizativa institucionalizada y funcionalmente efectiva y de mecanismos intra-sistémicos de control, supervisión y comunicación; y frente al hecho de la participación masiva de personas y grupos no miembros de las organizaciones sociales sumadas a la APPO, que -a diferencia de los appistas militantes en organizaciones populares (como FPR, NIOAX o la Sección XXII del magisterio)- no seguían las orientaciones de dirigencias organizacionales, ni estaban sometidas a los mecanismos de control internos de estas. Esta cuarta función de los medios de difusión resultó fundamental para promover la participación constante en las diferentes formas de la movilización contestataria. Con sus comunicaciones, los medios de difusión appistas contribuyeron, en quinto y último lugar, a conformar una identificación entre los participantes de la protesta.

15 Aquí me refiero únicamente a aquellos medios de difusión autogestionados y ocupados por la APPO, y no a los alternativos e independientes. 
Por razones de espacio voy a centrar mi atención en cuatro medios de difusión: Radio Plantón, Radio Universidad, Ojo de Agua y Canal 9 , que caracterizaré sólo con trazos muy rápidos.

Radio Plantón es la radiodifusora de la Sección XXII del magisterio. Empezó a operar en mayo de 2005. Sus transmisiones diarias incluían noticias, música, entrevistas y toda suerte de programas de análisis y culturales desde una visión de izquierda.

Como su nombre lo indica, Radio Universidad es la radiodifusora de la UABJO, que tenía ya años operando. Después del intento de desalojo de los maestros del zócalo, la aprehensión de algunos locutores de Radio Plantón y la destrucción parcial de su equipo de transmisión, los estudiantes universitarios tomaron la radio ese mismo día para apoyar a los maestros. En ese momento, Radio Universidad se incorporó a la APPO como componente de uno de sus subsistemas.

Por otro lado, fundado en 1998, Ojo de Agua es un centro de producción de documentales que trabaja, particularmente, con comunidades y organizaciones indígenas de Oaxaca y Puebla. El proyecto de esta pequeña asociación se conforma de tres áreas: capacitación, producción y difusión, que se dirigen a potenciar las capacidades comunicativas y el aprendizaje y uso de tecnologías de la comunicación de los indígenas.

Finalmente, el Canal 9 de la televisión del estado de Oaxaca se incorporó al subsistema de la APPO tras ser tomado por un nutrido grupo de mujeres, el 1 de agosto, después de realizar una marcha en contra del gobierno de Ulises Ruiz.

\section{Organización, operación y programación de los medios de difusión}

La "toma de los medios" no fue exclusivamente un asunto político y judicial; para los ocupantes significó, además, un verdadero desafío intelectual y técnico, porque, en la mayoría de los casos, desconocían la operación de los aparatos de transmisión radiofónica y televisiva. El caso del Canal 9 ejemplifica muy bien esta situación. Las mujeres que ocuparon sus instalaciones no abrigaban, unas horas antes, ninguna intención de operarlo. Su propósito era más modesto: obtener 
el compromiso de que se les entrevistara para que pudieran expresar las razones de su protesta.

Sin embargo, las mujeres se apropiaron, de manera sorpresiva, de la televisora y desalojaron al personal de la misma. De inmediato surgió la interrogante: ahora que se tiene el medio, ¿qué hacer con él? La primera respuesta consistió en coordinarse entre ellas para, después, decidir sobre el objetivo central de su acción:

En las primeras horas de la toma [del Canal 9], había una tensión muy fuerte, porque había tanta gente y no sabíamos quién era quién y cuáles [eran] sus intenciones. En fin, alrededor de las 7 de la tarde nos organizamos, en la explanada de las instalaciones, a pesar de que no nos conocíamos. Como la mujer es, en general, muy disciplinada, lograron crear diferentes grupos de seguridad, comida, higiene, solidaridad y economía (entrevista con Nancy Mota, integrante de COMO, 27 de julio de 2009).

Para la abrumadora mayoría de las ocupantes, el mundo de la teledifusión era tierra incógnita: muchas no habían visto antes, por ejemplo, tantos monitores, consolas de control, cámaras, platos, etc; y mucho menos sabían cuál era su función y cómo se utilizaban. Se encontraban estupefactas, ya que justo en esos momentos empezaron a atisbar las dimensiones de su intrepidez y el tamaño de su responsabilidad: "Nos reíamos mucho porque decíamos: "ya tomamos la televisión, pero y ahora qué [hacemos con ella]" (entrevista con Nancy Mota). De nueva cuenta, la solución a sus incertidumbres se resolvió por medio de la auto-organización: "Entonces, se decide hacer grupos de producción, televisión y radio y quién operaría los aparatos y grabar las conferencias y todas las marchas" (entrevista con Nancy Mota). Afortunadamente, entre los appistas presentes en el Canal 9, se encontraban algunos estudiantes universitarios que poseían algunas nociones básicas en el uso y la función de los aparatos:

En lo personal, estudié la carrera de tecnología educativa. Tuvimos la suerte que algunos chavos independientes de la Asamblea Universitaria tenían un poco de conocimientos [en la materia], porque estudiaban para técnicos. Había otro chavo que había trabajado en una radio comercial. Todos juntos empezamos a picar los aparatos y ver cómo funcionaban. Lo bueno es que [los operadores] habían dejado al aire la señal... Yo formé parte de la producción de la televisión. Ya que teníamos el medio en nuestras manos, había que reconocer su importancia y sacarle provecho. Teníamos que dar información argumentando adecuadamente y sin titubear. Hacia las 9:30 ya habíamos preparado todo y estábamos listas para transmitir. Teníamos que salir pronto al aire, porque ya se empezaba a escuchar el golpeteo por parte de todas 
las radios [pro oficialistas oaxaqueñas]. Se decía que [los policías] iban a ir por nosotras, porque [la toma de la estación] era un delito federal. Dos amigos se ocuparon del master y el switscher, y yo de la dirección de cámaras. Un grupo de compañeras amas de casa, obreras, estudiantes y militantes de organizaciones sociales se sentaron en el escenario para salir al aire. ¡Era el primer programa y era tan emotivo ver a la mujer oaxaqueña! (entrevista con Nancy Mota).

En relación al tema de la organización del trabajo y el aprendizaje, el caso de Ojo de Agua resulta, particularmente interesante, porque se trata de un centro especializado en la producción de documentales en video. Aquí se puede observar cómo el involucramiento en la dinámica de la movilización y la protesta modifica las rutinas organizativas. Debido a su experiencia profesional, Ojo de Agua se convirtió en un espacio de encuentro, intercambio y colaboración con otros medios. Inclusive, fungió como plataforma para el procesamiento de información:

Compañeros, conocidos desde hace tiempo, nos visitaban y traían fotos, videograbaciones y material, que rápidamente lo recibíamos y empezábamos a editar en la oficina y, después, lo subíamos a la página de Indymedia. Así es como surgió nuestro involucramiento con el movimiento social. De pronto, nos dimos cuenta de que todos estábamos juntos respondiendo a lo que estaba sucediendo. En este sentido, nuestra participación no fue planeada (entrevista con Joaquina [pseudónimo], integrante de Ojo de Agua, 22 de julio de 2009).

Por otra parte, al aprendizaje del manejo técnico de los aparatos, se agregó un nuevo reto para los ocupantes de los medios de difusión. Los appistas tomaron conciencia muy pronto de la importancia y la oportunidad política sin igual que representaba controlar dichos medios. Por esta razón, casi de inmediato surgieron disputas ideológicas y de poder entre ellos mismos: ¿quiénes deberían hacerse cargo de la transmisión y producción de programas radiofónicos y televisivos?

Para las grandes organizaciones populares, el control sobre los medios de difusión ocupados implicaba aumentar su influencia en la dirección de la APPO y su capacidad de reclutamiento de posibles nuevos miembros. La situación de Radio Universidad ilustra muy bien este punto. Tras la toma de sus instalaciones, su barra programática habitual se modificó. Entonces, se creó una barra alternativa y un cronograma para organizar los tiempos y los turnos de operación y transmisión por facultad universitaria. Conforme pasaba el tiempo, diferentes organizaciones estudiantiles -como la Unión de Jóvenes 
Revolucionarios de México (UJRM) o el Frente de Estudiantes Universitarios (FEU), que, a su vez, formaban parte de organizaciones populares y políticas mayores con intereses, también, en la universidad- empezaron a sumarse a las tareas radiofónicas y a disputarse la conducción y la definición de los contenidos de los programas; es decir, el sentido de la radio y el uso que, según ellos, debería darsele en la "lucha política". Por supuesto, esto ocasionó tensiones en el "equipo" de Radio Universidad: un sector, identificado con las organizaciones populares y políticas, se proponía utilizar a la radio sólo como un "medio de propaganda y agitación", mientras que otro, de estudiantes independientes,

quería darle más contenido y mensaje a la comunicación para que [sembrara] algo [más] en la gente. No se trataba de dar un mensaje [propagandístico] directo, sino de generar análisis y de que la gente también hiciera propuestas. Nosotros pensábamos que teníamos que canalizar así todo el enojo y el llanto que la gente expresaba en las denuncias (entrevista con Julia [pseudónimo], locutora de Radio Universidad, 15 de abril de 2009).

A pesar de estas disputas ideológicas y por el poder, Radio Universidad y Canal 9 lograron armar, con muy escasos recursos, improvisación y mucho deseo de aprender, una barra de programas variada e interesante para un público segmentado (urbano y rural, infantil, juvenil y adulto), en las que se incluían programas culturales, noticiosos y de análisis. Buscando que diferentes sectores de la APPO, como el magisterial, el de las mujeres, los indígenas, los jóvenes, los universitarios o el de las Organizaciones No Gubernamentales (ONG's) tomaran el micrófono o aparecieran frente a las cámaras.

Al ser un centro de producción de documentales, la situación de Ojo de Agua era diferente a la de otros medios de difusión, ya que, abandonando su rutina laboral e incursionando en actividades un tanto ajenas a sus objetivos principales, empezó a trabajar de facto como una oficina de redacción.

Había compañeros en la calle haciendo entrevistas; otros salían en la noche a grabar lo que pasaba en las barricadas o simplemente a platicar con las personas... Otros compañeros se quedaban en las oficinas para editar el material en cuanto llegara. Pero no había algo así como un jefe de redacción; prácticamente se subía [a la red] todo el material que nos llegaba, porque eran testimonios importantes de violaciones [a los derechos humanos] (entrevista con Joaquina [pseudónimo], integrante de Ojo de Agua, 22 de julio de 2009). 


\section{Alterando la lógica mediática}

Si bien "la toma de medios de difusión" por parte de la APPO fue algo significativo e importante para su lucha, esta no ha sido empero una experiencia excepcional entre los movimientos sociales. En efecto, muchos otros lo han hecho con anterioridad. Lo realmente notable y novedoso del caso oaxaqueño es que la APPO modificó, por un tiempo, la relación de los medios con el público, el modo y el sentido de operación de los mismos.

Efectivamente, el público cambió su papel tradicional de radioescucha pasivo por el de comunicador desde las calles, plazas y barricadas. En este sentido, las radios se convirtieron en un medio de difusión autogestionado por la APPO no sólo porque sus instalaciones hayan sido ocupadas y operadas por sus simpatizantes, sino, sobre todo, porque el "público radioescucha" appista asumió activamente la tarea de informar y de usar el medio como instrumento de comunicación al interior y al exterior de la APPO. La experiencia de Radio Universidad resulta ejemplar:

[En la radio] se construyó una red entre los que estaban en la radio dándole vida y toda la gente que llamaba [telefónicamente] y enviaba mensajes [de texto] como, por ejemplo, "aquí hay una caravana de la muerte", "estamos viendo policías que pasan balaceando", etc. Incluso había un programa que se llamaba Las Barricadas, que pasaba desde las 10 de la noche hasta [muy altas horas de la madrugada]. En él, la gente informaba sobre lo que estaba pasando $y$, también, pedía informes sobre otros sucesos... La radio se retroalimentaba por toda la información que pasaba la gente y reaccionaba a las demandas de la gente (entrevista con Anselmo [pseudónimo], locutor de Radio Universidad, 24 de septiembre de 2008).

Quizá la toma del Canal 9 de la televisión oaxaqueña da cuenta, de manera más nítida, de la modificación radical de la lógica mediática convencional. Primero, porque las mujeres appistas asumen directamente el control técnico de la producción y difusión de los programas, así como el resguardo, mediante barricadas, de las instalaciones transmisoras. Por si esto fuera poco, segundo, las appistas no sólo asumen el papel de generadoras y transmisoras de comunicación mediática, sino que, además, sus voces se escuchan en la radio y sus imágenes se ven en la televisión. De tal suerte, la diferencia entre los roles de emisor y público se dislocaron y fusionaron. Las mujeres transmiten 
para sí mismas y para el conjunto de la población appistas. En tercer lugar, el "pueblo" aparece, se ve y se reconoce a sí mismo más allá de las imágenes en el que se le muestra como objetos de información policíaca, de políticas de asistencia pública o de folclor, burla, denigración y discriminación, como se acostumbra en la televisión pública y comercial (vid. Mal de Ojo TV/Contraimagen 2007). Con ello fueron subvertidos, temporalmente, los códigos estéticos y lingüísticos convencionales en la televisión y la radio (Zires 2009).

Al abrirse el espacio mediático a las voces y demandas de amplios sectores de la población se sentaron las bases para lograr una identificación emocional y discursiva con la APPO. En efecto, la expresión directa y sin censura de todo tipo de sentimientos a través de los canales radiofónico y televisivo producía efectos de catarsis, tanto en el que exponía su dolor personal como en el público. Además, para muchos de los que se comunicaban con las radiodifusoras, vivían, quizás por primera vez en su vida, la experiencia de que su opinión y sus sentimientos se escucharan y se les considerara como valiosos e importantes. Escuchar su voz en la radio o ver su imagen en la televisión significó para muchos un reconocimiento a su persona y a su dignidad. Todo ello generó fuertes lazos de identificación con la APPO y la "Comuna de Oaxaca".

Por otro lado, los medios de difusión se convirtieron en espacios públicos virtuales. La experiencia de Radio Universidad ilustra muy bien este fenómeno: ésta no fue sólo un espacio de transmisión de información, sino, también y de manera prominente, de deliberación política. Ante la imposibilidad de una participación directa de la mayoría de los appistas en las asambleas llevadas a cabo en el zócalo de Oaxaca, la radiodifusión contribuyó a construir foros de opinión y delinear posibles proyectos políticos.

[Se discutía mucho que el sentido de la lucha] que no era sólo derrocar a Ulises Ruiz, sino que había que buscar más allá de ese primer paso. Había que retomar lo que se estaba haciendo: la construcción de relaciones [sociales] distintas y de un poder popular. Primero se convirtió en una consigna, "todo el poder al pueblo". Luego fue analizado también por [el pueblo] y surgió [la opinión] de que el poder no nos lo va a dar nadie: ya lo estamos ejerciendo. Los locutores empezaron a hablar de qué es el poder popular. Incluso había un programa en el que regalábamos un disco con las mejores canciones del movimiento a la gente que llamara y nos dijera qué es el poder popular. Mucha gente decía que se trataba de tomar el gobierno; otros hablaban, en cambio, de las barri- 
cadas, las reuniones o las asambleas (entrevista con Anselmo [pseudonimo], locutor de Radio Universidad, 24 de septiembre de 2008).

En resumen, el sentido de la comunicación de la radio y la teledifusión fue modificado para ponerla al servicio de la lucha popular appista en contraposición a las lógicas mercantiles y gubernamentales hasta entonces dominantes.

Por otra parte, la toma de los medios puede ser entendida como parte de un proceso de construcción de "medios alternativos y populares". En este sentido, el equipo de Radio Plantón comprende su trabajo como la "necesidad de defensa del derecho constitucional de información de la población". En Radio Plantón se tiene la convicción de que la radio habría que asumir la función de construir ciudadanía para "organizar a la sociedad" (vid. SNTE-Sección XXII/ CNTE/Radio Plantón 2007). Este tipo de periodismo se ejerce como una actividad política, que busca cuestionar el monopolio de la construcción de la verdad informativa de las grandes corporaciones de los medios de comunicación.

Lo anterior tiene consecuencias en la manera de comprender el proceso informativo, pues este se hace más horizontal, ya que abre la posibilidad de que cualquier persona pueda aportar textos, audios e imágenes, que den cuenta de historias y la manera en que la viven los involucrados en los eventos "desde dentro". La forma en que operó Mal de Ojo en los días del conflicto ejemplifica muy bien lo anterior:

Muchas de estas personas [que ponían material a nuestra disposición] no eran profesionales. Simplemente tenían una cámara o, inclusive, un teléfono celular y sacaban videos o fotos (entrevista con Joaquina [pseudónimo], integrante de Ojo de Agua, 22 de julio de 2009).

\section{Conclusiones}

En la medida en que los medios de difusión proappistas se revelaron como un poderoso factor de formación de opinión pública y movilización contestataria, el gobierno estatal no desperdició tiempo ni ocasión para descalificarlos y censurarlos de diferentes maneras. Inclusive puso en operación, de manera clandestina e ilegal, Radio Ciudadana y la página web "oaxacaenpaz". Estas criminalizaron el movimiento y convocaron a radioescuchas e internautas a denunciar a líderes y miembros de la APPO, a agredirlos y hasta a eliminarlos físicamente. Para ello, hacían públicas sus fotografías y direcciones 
particulares y de trabajo, así como los nombres de sus familiares. Con un discurso racista y clasista orientado a provocar odio, calificaban a los appistas de "criminales, terroristas, malvivientes, indios, sucios y feos". En su opinión, todos ellos merecerían ser asesinados para que los "auténticos" y "bien nacidos" oaxaqueños y demás "ciudadanos ejemplares" pudieran vivir por fin en paz y orden (vis. Martínez Vásquez 2007: 96, 105s., 180s; Beas Torres 2007: 184s.; Méndez et al. 2009: 147s.). En los últimos días de noviembre, todos los medios de difusión tomados fueron sacados del aire mediante una represión masiva orquestada por la Policía Federal Preventiva.

Las estaciones de televisión y radio tomadas fueron, primero, bloqueadas y, después, recuperadas en su totalidad por las autoridades públicas federales y estatales, con lo que se desestructuraría, de manera significativa, el subsistema de difusión de la APPO; sin embargo, este no dejó de existir y de operar del todo, aunque en menor escala y bajo nuevas condiciones. En efecto, Radio Plantón ha seguido trasmitiendo, aunque su señal es interferida con frecuencia. Asimismo, Ojo de Agua ha coproducido hasta la fecha, bajo la denominación Mal de Ojo, una serie de documentales. Y si tomamos en cuenta a los diarios Noticias y La Jornada, la APPO ha mantenido, hasta el día de hoy, cierta presencia mediática y capacidad de divulgar sus acciones, opiniones y proyectos.

Por otro lado, teniendo en cuenta la heterogeneidad, pluralidad política-ideológica y los conflictos entre las diferentes organizaciones y grupos que componían la asamblea, habría que preguntarse, entonces, cómo fue posible que, contra toda probabilidad, se haya generado un discurso relativamente "homogéneo" y una perspectiva de observación "compartida" en el subsistema de difusión de la asamblea. La respuesta resulta, necesariamente, compleja. En primer lugar, lo "común" entre los diferentes "elementos" que conformaban al subsistema de difusión, en particular, y al sistema de protesta, en general, era el esquematismo básico $\mathrm{APPO} /$ gobierno entre todos compartido. A la manera de la relación entre código y programa en los sistemas funcionales, este era reespecificado por cada uno de los involucrados (elementos del subsistema o del sistema) de acuerdo a semánticas de protesta singulares, que fueron elaboradas por dichos elementos ya sea desde el lugar de la experiencia individual en el conflicto (por 
ejemplo, el discurso del "pueblismo" de los barricaderos) ${ }^{16}$ o con anterioridad a su incorporación a la asamblea. Expresado de otra manera, la oposición discursiva fundamental "APPO versus gobierno" fungía como un lenguaje común, el cual tenía diferentes dialectos para observar, describir y explicar la realidad. Así, a pesar de la multiplicidad de las esferas de deliberación colectiva al interior del sistema de protesta (por ejemplo, las asambleas de las barricadas barriales, los muros intervenidos por los colectivos de artistas con su protesta gráfica, etc.), las diversas observaciones de los participantes de estos foros conservaban un "aire de familia".

Además, esta relativa "homogeneidad" en la perspectiva de observación era resultado, asimismo, de la interacción conflictiva entre la asamblea y el gobierno. En efecto, con el fin de obtener mayores posibilidades de éxito en su lucha político-social, al interior de la APPO se exhortaba (e incluso coaccionaba) a la "unidad" frente al "enemigo". De tal suerte, hacia fuera las posiciones "oficiales" de la asamblea eran fijadas por sus voceros, a pesar de que hacia dentro resultaban polémicas, por decir lo menos. En todo caso, el observador externo percibía en estas comunicaciones $-\mathrm{y}$, en consecuencia, en las del subsistema de difusión- un "discurso appista" más o menos coherente.

Después del sangriento restablecimiento del "orden institucional", Ulises Ruiz reconoció la importancia del control de los medios de difusión e inició una costosa campaña mediática, a nivel estatal y nacional, para "mejorar" la imagen de su gobierno y propagar la idea de que en "Oaxaca no pasa nada" y se "respira un clima de paz social". A pesar de la propaganda oficialista, las protestas sociales continuaron en los años siguientes, aunque de manera descoordinada. Sin embargo, los agravios acumulados pudieron, paradójicamente, encontrar una vía de expresión en las elecciones para gobernador y congreso local en julio de 2010. En efecto, gracias a la alianza opositora, que gozaría del apoyo del magisterio y de muchas de las organizaciones populares que conformaron la APPO, por primera vez en Oaxaca se lograría una alternancia en el poder después 80 años de gobiernos priístas.

16 Sobre el tema, véase Estrada Saavedra (2010), en particular pp. 923ss. 


\section{Bibliografía}

Ahlemeyer, Heinrich W. (1989): "Was ist eine soziale Bewegung? Zur Distinktion und Einheit eines sozialen Phänomens”. En: Zeitschrift für Soziologie, 18, 3, pp. 175-191.

- (1995): Soziale Bewegungen als Kommunikationssystem. Einheit, Umweltverhältnis und Funktion eines sozialen Phänomens. Opladen: Leske + Budrich.

Armenta Muñoz, Aldo (2005): El sindicalismo mexicano frente a la reforma del Estado. El impacto de la descentralización educativa y el cambio político en el Sindicato Nacional de Trabajadores de la Educación 1992-1998. México, D.F.: Universidad Iberoamericana.

Bailon Corres, Jaime (1999): Pueblos indios, élites y territorio. Una historia política de Oaxaca. México, D.F.: El Colegio de México.

Beas Torres, Carlos (ed.) (2007): La batalla por Oaxaca. Oaxaca: Ediciones Yope Power.

Bolos, Silvia (coord.) (2003): Participación y espacio público. México, D.F.: Universidad Ciudad de México.

- (2008): Mujeres y espacio público: construcción y ejercicio de la ciudadanía. México, D.F.: Universidad Iberoamericana.

Bolos, Silvia/Estrada Saavedra, Marco (2010): "Protesta social y democratización: un estudio sociológico sobre la constitución, organización y movilización de la Asamblea Popular de los Pueblos de Oaxaca (2005-2010)". En: Estudios Sociológicos, vol. XVIII, núm. 82, pp. 231-254.

CCIODH (Comisión Civil Internacional de Observación por los Derechos Humanos) (2007): Informe sobre los hechos de Oaxaca. Barcelona: CCIODH-UACM.

Cortés, Joel Vicente (coord.) (2006): Educación, Sindicalismo y gobernabilidad en Oaxaca. Oaxaca: SNTE.

Cunill, Nuria (1999): Repensando lo público a través de la sociedad. Nuevas formas de gestión pública y representación social. Caracas: Nueva Sociedad.

Denham, Diana/C.A.S.A Collective (2008): Teaching Rebellion. Stories from the Grassroots Mobilization in Oaxaca. Oakland: P.M. Press.

Estrada Saavedra, Marco $\left({ }^{2} 1995\right)$ : Participación política y actores colectivos. México, D.F.: Universidad Iberoamericana/Plaza y Valdés.

- (2008): Sistemas de protesta. Manuscrito inédito.

- (2010): "La anarquía organizada: las barricadas como el subsistema de seguridad de la Asamblea Popular de los Pueblos de Oaxaca". En: Estudios Sociológicos, vol. XVIII, núm. 84, pp. 903-939.

Giarracca, Norma (2008): Cuando hasta las piedras se levantan. Oaxaca, México, 2006. Buenos Aires: Antropofagia.

Hellmann, Kai-Uwe (1996): Systemtheorie und neue soziale Bewegungen. Identitätsprobleme in der Risikogesellschaft. Opladen: Westdeutscher Verlag.

- (1998): "Systemtheorie und Bewegungsforschung. Rezeptionsdefizite aufgrund von Stildifferenzen oder das Außerachtlassen von Naheliegendem". En: Rechtshistorisches Journal, 17, pp. 493-510. 
- (2000): “... und ein größeres Stück Landschaft mit den erloschenen Vulkanen des Marxismus. Oder: Warum rezipiert die Bewegungsforschung Luhmann nicht?". En: De Berg, Henk/Schmidt, Johannes (eds.): Rezeption und Reflexion. Zur Resonanz der Systemtheorie Niklas Luhmanns außerhalb der Soziologie. Frankfurt am Main: Suhrkamp, pp. 411-439.

Japp, Klaus P. (1984): "Selbsterzeugung oder Fremdverschulden. Thesen zum Rationalismus in den Theorien sozialer Bewegungen". En: Soziale Welt, 35, 3, pp. 313-329.

- (1986a): "Kollektive Akteure als soziale Systeme?". En: Unverferth, HansJürgen (ed.): System und Selbstproduktion. Zur Erschließung eines neuen Paradigmas in den Sozialwissenschaften. Frankfurt am Main/Bern/New York: Peter Lang, pp. 166-191.

- (1986b): "Neue soziale Bewegungen und die Kontinuität der Moderne". En: Berger, Johannes (ed.): Die Moderne-Kontinuitäten und Zäsuren (Soziale WeltSonderband 4). Göttingen: O. Schwartz, pp. 311-333.

- (1990): "Das Risiko der Rationalität für technisch-ökologische Systeme". En: Halfmann, Jost/Japp, Klaus Peter (eds.): Riskante Entscheidungen und Katastrophenpotentiale. Elemente einer soziologischen Risikoforschung. Opladen: Westdeutscher Verlag, pp. 34-60.

Luhmann, Niklas (1987): Soziale Systeme. Grundriss einer allgemeinen Theorie. Frankfurt am Main: Suhrkamp.

- (1992): Sociología del riesgo. Jalisco: Universidad Iberoamericana/Universidad de Guadalajara.

- (1996): Protest. Systemtheorie und soziale Bewegungen. Herausgegeben und eingeleitet von Kai-Uwe Hellmann. Frankfurt am Main: Suhrkamp.

- (1998): Die Gesellschaft der Gesellschaft. Frankfurt am Main: Suhrkamp.

- (2005): "Interaktion, Organisation, Gesellschaft". En: Soziologische Aufklärung 2. Aufsätze zur Theorie der Gesellschaft. Wiesbaden: VS, Verlag für Sozialwissenschaften, pp. 9-24.

Mal de Ojo TV/Contraimagen (2007): Morena. DVD. Oaxaca, marzo s/e.

Martínez Vásquez, Víctor Raúl (2007): Autoritarismo, movimiento popular y crisis política: Oaxaca 2006. México, D.F.: UABJO/Instituto de Investigaciones Sociológicas/Centro de Apoyo al Movimiento Popular Oaxaqueño/A.C./EDUCA/ Consorcio para el Diálogo Parlamentario y la Equidad.

- (coord.) (2009): La APPO: ¿rebelión o movimiento social? Oaxaca: $\mathrm{UABJO/Instituto} \mathrm{de} \mathrm{Investigaciones} \mathrm{Sociológicas.}$

Méndez, Citlalli/Kast, Nicole/Cruz, Kiado/Cruz, Yesika (eds.) (2009): Oaxaca 2006: lo vimos, lo vivimos. Narraciones en movimiento. Oaxaca: Oaxaca Libre/ Universidad de la Tierra/Swarthmore College/Medios de Información Alternativos y Revolucionemos Oaxaca.

Neidhardt, Friedhelm (ed.) (1994): “Öffentlichkeit, öffentliche Meinung, soziale Bewegungen”. Kölner Zeitschrift für Soziologie und Sozialpsychologie (Sonderheft $34)$.

Osorno, Diego Enrique (2007): Oaxaca sitiada. La primera insurrección del siglo XXI. México, D.F.: Grijalbo. 
Recondo, David (2007): La política del gatopardo. Multiculturalismo y democracia en Oaxaca. México, D.F.: CIESAS/CEMCA.

SNTE-Sección XXII-Oaxaca/CNTE/Radio Plantón (2007): Radio Plantón otra vez al aire 92.1. DVD. Oaxaca: SNTE-Sección XX.

Sotelo Marbán, José (2008): Oaxaca: insurgencia civil y terrorismo de Estado. México, D.F.: ERA.

Yescas Martínez, Isidoro/Zafra, Gloria (2006): La insurgencia magisterial en Oaxaca. Oaxaca: IEEPO/IISUABJO.

Videohackers (2007): Brad, uma noite mais nas barricadas. DVD. Videohackers/Indymedia/Familia Bastos producciones-Brasil/Producciones IntermediaEspaña, s/e.

Zires, Margarita (2009): "Estrategias de comunicación y acción política. Movimiento social de la APPO”, en: Martínez Vásquez, Víctor Raúl (coord.): La APPO: ¿rebelión o movimiento social? (Nuevas formas de expresión ante la crisis). Oaxaca: UABJO-Instituto de Investigaciones Sociológicas, pp. 161-196. 



\section{Juliana Ströbele-Gregor

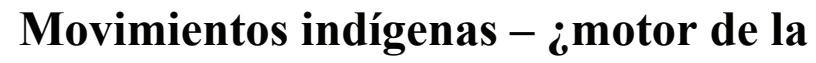 democratización de las sociedades andinas?}

\section{Introducción}

Desde finales de los años 1990, los pueblos indígenas son actores fuertes y dinámicos en el campo político de América Latina. Especialmente en Bolivia y Ecuador, sus organizaciones etno-políticas han reemplazado al sindicalismo clásico del movimiento obrero como fuerza política, como motor de movilización y como portavoces de demandas sociales.

Ya desde los años 1980, la etnización de lo político ha ido aumentando constantemente (Ströbele-Gregor 2009). Reivindicaciones y visiones de sociedad hasta entonces expresadas en la terminología de la lucha de clases se justifican cada vez más a través de discursos de legitimación étnica. En este contexto, los movimientos indígenas están asumiendo un rol importante, por lo menos en aquellos países en los que los indígenas representan una gran parte de la población.

En las ciencias sociales y culturales existe un amplio debate sobre la construcción del "indio" e "indígena", tanto desde la perspectiva histórica, como social y cultural, que se intensificó a partir fines de los años 1980. En este texto no voy a profundizar en ese debate, pero quiero destacar que en él tuvo un papel clave la definición que propuso el Relator Especial de las Naciones Unidas, Subcomisión de Prevención de la Discriminación y Protección de Minorías, MartínezCobo en su estudio de 1986 sobre "El problema de la discriminación contra la población indígena". ${ }^{1}$ Según su definición, comunidades, pueblos y naciones indígenas son aquellos que tienen una continuidad histórica con las sociedades anteriores a la invasión española y precoloniales que se desarrollaron en sus territorios y que constituyen ahora sectores no dominantes de la sociedad. Estas comunidades

1 UN Doc. E./CN.4/Sub.2/1986/7/Add. 4.para 379 (1986). La versión en español: Martínez-Cobo (1987). 
tienen la determinación de preservar, desarrollar y transmitir a futuras generaciones sus territorios ancestrales y su identidad étnica como base de su existencia como pueblo, de acuerdo con sus propios patrones culturales (Martínez-Cobo 1987: 379ss.). El Convenio 169 de la Organización Internacional del Trabajo (OIT) (1989), que establece los derechos fundamentales relativos a los pueblos indígenas, comparte la misma definición establecida por Martínez-Cobo. En ambas definiciones se reflejan los discursos esencialistas. Estas definiciones poco consideran los cambios culturales y sociales que han ido transformando la vida cotidiana y las auto-definiciones de los así llamados "indígenas": la migración, la educación formal-estatal, los medios de comunicación, la vida urbana, las nuevas estructuras políticas que incluyen la promesa de participación democrática, etc. y que han abierto nuevos espacios de acción. Estos procesos de transformación y las múltiples construcciones de identidad fueron analizados por varios autores (véase p.ej. Assies/Van der Haar/Hoekema 2000; Canessa 2005; García Serrano 2008; Dresler/Fahmel/Noack 2007). La importancia de los documentos de los organismos de las Naciones Unidas consiste más bien en el reconocimiento formal de la existencia de estos pueblos y de sus reivindicaciones sociopolíticas y culturales. Por tanto, estas definiciones no fueron y no son instrumentos analíticos para estudiar la construcción de identidades sino que se trata de instrumentos políticos en la lucha por el reconocimiento de los propios derechos de estos pueblos. En su lucha por el reconocimiento de la diversidad cultural de las sociedades latinoamericanas, los así llamados "indios" han adoptado las definiciones y adscripciones de Martínez-Cobo y de la OIT como arma política, aplicándolas a sus diversas situaciones de vida.

La filósofa Nancy Fraser, en su concepto de "injusticia", ofrece un enfoque teórico de análisis sobre situaciones de desigualdad y marginación en diferentes mundos de vida que puede ser aplicado a los pueblos indígenas más allá de discursos esencialistas y etnicistas. Además en su modelo de "reconocimiento y distribución" propone las estrategias para superar las desigualdades dentro de las sociedades e iniciar los cambios necesarios hacia una mayor justicia social $(2000 ; 2003)$. Desde mi punto de vista, las ideas de Fraser abren una nueva perspectiva para analizar los movimientos indígenas. 
A continuación quiero plantear dos cuestiones: 1) ¿Por qué desde finales de los años 1980, en las discusiones en torno a las transformaciones sociales los pueblos indígenas pudieron asumir un rol protagónico en los países andinos? 2) En los debates en torno a la democratización de la sociedad, muchos portavoces indígenas usan una y otra vez el término de "democracia indígena". ¿Qué significa este término y cómo se refleja este concepto en las estructuras de las organizaciones indígenas? Mis ejemplos se refieren sobre todo a Bolivia, ${ }^{2}$ tomando también en cuenta el caso de Ecuador.

\section{El panorama social político de la movilización indígena}

El punto de partida de los procesos de organización y movilización de los pueblos indígenas en Latinoamérica son las extremas desigualdades sociales y por tanto conflictos sociales no resueltos, así como las expectativas no cumplidas con relación a la igualdad de oportunidades sociales, al reconocimiento cultural, a la superación de la pobreza y la situación de marginalidad. La cuestión de cómo y por qué los pueblos indígenas se han convertido en un nuevo sujeto histórico requiere un análisis de los cambios sociales en varios niveles y en su dimensión histórica. Aquí no es posible profundizar en esta dimensión. Pero por lo menos quiero remitir al hecho de que los movimientos de resistencia y las visiones de autonomías indígenas tienen una larga tradición desde la época colonial, hecho que está muy presente en la conciencia política de la gente.

En las repúblicas fundadas después de la Independencia, esencialmente no se produjeron cambios positivos respecto a la exclusión y al bajo estatus de los "indios", pues las oligarquías adaptaron y ampliaron las estructuras de explotación a sus necesidades. La exclusión social de los indígenas, sobre todo en el área rural, se incrementó aún. También cuando en el transcurso del siglo XX se introdujeron formalmente los derechos ciudadanos generales, en lo que respecta a sus condiciones sociales reales, los "indios" -es decir, en los países andinos o en Guatemala, la población rural y gran parte de los pobres urbanos- siguieron marginados como ciudadanos "de tercera clase". Esto significaba, por ejemplo, que en algunos países el sufragio estaba

2 Ver la versión más amplia: Ströbele-Gregor (2009). 
restringido a personas alfabetizadas; el ascenso social y el reconocimiento respectivo tenía mucho que ver con el fenotipo, de dominio correcto de la lengua española y/o de apellido de la persona. Ser de color más oscuro, llevar un nombre indígena o hablar español con un acento aymara, quechua o maya o de otra lengua indígena ya funcionaba como instrumento de exclusión. La participación política y hasta la representación les fue negada; incluso hoy en día, en muchos países la expulsión de sus tierras y la extrema pobreza siguen estando al orden del día.

Los movimientos indígenas no representan en absoluto un grupo de población homogénea; más bien son expresión de la heterogeneidad y diversidad cultural de los pueblos indígenas y con ello también de diferentes visiones de sociedad y de diferentes intereses. Los términos "indio" o "indígena", que fueron adoptados por estos movimientos etno-políticos como autodenominación en el discurso político para legitimizar demandas comunes fundamentales y para demarcarse de los grupos dominantes postcoloniales, tienen su origen, como es sabido, en la época colonial. Se trata de una construcción social por medio de la cual los pueblos sometidos del subcontinente fueron subsumidos en un grupo homogéneo e incorporados en el sistema social jerárquico de los conquistadores.

La autodenominación "indígena" u "originario" en el discurso político actual tiene una doble función: por un lado expresa las afinidades sociales e históricas frente a los grupos dominantes mestizos o de procedencia europea y remite a la historia colonial y postcolonial. Por otro lado, implica el rechazo del modelo de un Estado nacional que apunta a la asimilación, una construcción del postcolonialismo en los diferentes Estados latinoamericanos. Si bien la construcción de un nuevo sujeto político que se autodenomina "indígena" / "indio" / "originario" surgió en el contexto de procesos sociales específicos en cada país, los debates en las conferencias internacionales sobre los pueblos indígenas en Barbados en 1971 y en 1976 tuvieron una influencia decisiva en la construcción de la identidad política y en los procesos organizativos de estos pueblos. Y el hecho de que el término "indígena" se haya impuesto en los debates e instituciones internacionales -Naciones Unidas, Banco Mundial, Organización Internacional del Trabajo, etc.-, refuerza su importancia en los debates sociales a nivel nacional. 
El surgimiento de los movimientos indígenas y sus reivindicaciones sociales, sobre las que más adelante vamos a entrar con más detalle, chocan -como no podría ser de otra manera- con el rechazo y la resistencia de aquellos sectores de la sociedad cuyos privilegios se pretende abolir. Detrás de sus argumentos de que se quiere dividir a la sociedad y de que se pone en tela de juicio la nación, están las pretensiones de estos grupos de poder, que hasta ahora han controlado al Estado y a la sociedad, y que no están dispuestos a ver recortada su influencia tradicional. Estos sectores dominantes, que siempre han recurrido a categorías étnicas que resaltaban que ellos eran blancos para expresar la superioridad que se adjudicaban en su imagen jerárquica de la sociedad, y que denominan a los campesinos o los sectores subalternos "indios", ahora cuestionan la categoría identitaria "indígena" u "originario" y niegan la legitimidad de las demandas políticas y sociales que se derivan de ello. Actualmente, en Bolivia esto se viene dando masivamente.

\section{Condiciones de vida y demandas de transformación de la sociedad}

Como demuestran, por ejemplo, estudios del Banco Mundial (2005), la pobreza y extrema pobreza marcan las condiciones de vida de la mayoría de los pueblos indígenas de Latinoamérica. Esto es válido para la población urbana y aún más para la población rural. Además, la pobreza no se puede medir solamente por los ingresos monetarios. Significa también una educación escolar y servicios de salud deficientes, así como la amplia exclusión de la participación social en la distribución y el uso de los recursos. Hasta ahora, las respectivas sociedades nacionales han hecho poco a favor de una mejora fundamental real de las condiciones de vida, a pesar de las reformas legales que varios Estados promulgaron en los años 1980 a favor de la población indígena. Si bien en el proceso de modernización y descentralización del Estado se fortalecieron las estructuras de autogestión en varios países, la rebelión de octubre de 2003 en Bolivia mostró que hasta entonces la población indígena siguió sintiéndose excluida de procesos de toma de decisiones políticas y económicas (Ströbele-Gregor 2009). La desigualdad, la falta de recono- 
cimiento y la injusticia son por tanto características centrales de estas situaciones de vida.

En varios países, organizaciones locales, regionales y nacionales movilizan a la gente para manifestaciones, bloqueos de caminos estratégicos o tomas organizadas de pozos hidrocarburíferos y de mega represas. Con apoyo de organizaciones no gubernamentales (ONGs) denuncian públicamente las destrucciones del medio ambiente, los efectos sociales de los megaproyectos, la tala ilegal de madera y la biopiratería, así como la complicidad de las instituciones públicas en este tipo de proyectos. Exigen seguridad en la tenencia de la tierra y seguridad alimentaria, reformas agrarias, acceso a la educación y los servicios de salud, y territorios bajo su propia gestión. La demanda de autonomía en el sentido del derecho a un desarrollo autodeterminado basado en valores culturales propios ("desarrollo con identidad") está aumentando. Esto incluye un sistema de salud, de justicia y de educación propio, sin olvidar el desarrollo económico. Al respecto, los pueblos indígenas remiten al Convenio 169 de la Organización Internacional del Trabajo (OIT), "Sobre pueblos indígenas y tribales en países independientes", que ha sido ratificado por 14 Estados latinoamericanos, ${ }^{3}$ aunque esté siendo escasamente implementado.

Los indígenas no sólo exigen condiciones de vida dignas, el reconocimiento de sus culturas y una participación social y política adecuada; también reclaman la profunda democratización de la sociedad respectiva y del orden mundial dominante, incluyendo la renuncia a las estructuras económicas neoliberales.

\section{Nancy Fraser: reconocimiento y distribución}

La situación vivencial y las demandas de los pueblos indígenas me llevan al enfoque de Nancy Fraser. Su pensamiento filosófico está centrado en torno a los términos "reconocimiento" y "redistribución". Con el término "injusticia" (injustice) remite además a la dimensión normativa. Al respecto, distingue entre dos concepciones de injusticia analíticamente distintos:

3 Argentina, Bolivia, Chile, Colombia, Costa Rica, República Dominicana, Ecuador, Guatemala, Honduras, México, Paraguay, Perú y Venezuela. 
La primera es la injusticia socioeconómica que está arraigada en la estructura socioeconómica de la sociedad. Los ejemplos incluyen la explotación (donde los frutos del trabajo de la persona son apropiados en beneficio de otros), la marginalización económica (la persona es limitada a trabajos no deseados o mal pagados o se le niega del todo el acceso a un trabajo que genere ingresos) y la privación (se le niega a la persona un adecuado estándar de vida material)... La segunda concepción de la injusticia es cultural o simbólica. Aquí, la injusticia está arraigada en patrones sociales de representación, interpretación y comunicación. Los ejemplos incluyen la dominación cultural (la persona está sujeta a patrones de interpretación y comunicación asociados a otra cultura y que son ajenos y/o hostiles a los propios); el no reconocimiento (la persona es invisibilizada mediante prácticas de representación, comunicación e interpretación autoritarias de la propia cultura) y la falta de respeto (la persona es sistemáticamente difamada o menospreciada en representaciones culturales públicas estereotipadas y/o en las interacciones cotidianas) (Fraser 1997: 13). ${ }^{4}$

Consecuentemente, en su modelo del estatus, Fraser (2000) propone concebir el reconocimiento como una cuestión de estatus social. Desde esta perspectiva, no se trata del reconocimiento de una identidad de grupo específica, sino del estatus

de miembros individuales del grupo como interlocutores plenos en la interacción social. Por consiguiente, el reconocimiento erróneo (misrecognition) no significa la desvalorización y deformación de la identidad de grupo, sino la subordinación social en el sentido de ser impedido a participar como par en la vida social (Fraser 2000: 113).

Según Fraser, las experiencias de desigualdad e injusticia son las causas fundamentales de las demandas presentadas en los discursos de identidad cultural, que expresan la insistencia en la diferencia cultural y en la identidad étnica en la arena política. Al construir los grupos sociales dominantes "otredad" (otherness) y al asignar a los "otros" (others) un estatus social bajo y derechos limitados, se intensifica la privación y marginalización económica de los últimos. La construcción social de la otredad por parte de las clases dominantes para legitimar la jerarquía socio-política y la dominación de los pueblos indígenas tiene sus raíces en la conquista. Aníbal Quijano lo expresa perfectamente cuando dice:

la codificación de las diferencias entre conquistadores y conquistados en la idea de raza, es decir, una supuesta diferente estructura biológica que ubicaba a los unos en situación natural de inferioridad respecto de los

4 Traducción del ingles de todas las citas de Fraser: Gudrun Birk. 
otros. Esa idea fue asumida por los conquistadores como el principal elemento constitutivo, fundante, de las relaciones de dominación que la conquista imponía. Sobre esa base, en consecuencia, fue clasificada la población de América, y del mundo después, en dicho nuevo patrón de poder (Quijano 2000: 246).

A su vez, la negación de una representación social apunta a su invisibilización y al encubrimiento de la injusticia. Las relaciones intersectoriales de estos factores refuerzan la desigualdad estructural, al tiempo que apoyan el estatus social superior del grupo dominante. Fraser ve en la distribución desigual de los recursos y de los privilegios el fondo de la injusticia.

El enfoque de Fraser agudiza la vista. Ofrece un conjunto de instrumentos teóricos adecuados para el análisis de la situación de la población indígena, tal y como la he presentado más arriba. Pues efectivamente, lo que caracteriza la situación de los pueblos indígenas desde la época colonial es el acceso desigual a los recursos, privilegios, la participación política y la representación autónoma. Consecuentemente, en el centro de sus demandas frente al Estado se sitúan reivindicaciones respecto a la autonomía de los territorios y la propiedad de los recursos naturales que albergan a la justicia y a la participación política adecuada.

Otro aspecto relevante son las reflexiones de Fraser acerca del cambio fundamental de la situación social de los desfavorecidos. Según Fraser, lógicamente este cambio no se puede limitar al reconocimiento de la diversidad e identidad cultural. Sin embargo, podemos observar que muchas organizaciones indígenas en América Latina han ido empleando esta estrategia discursiva para legitimar sus reivindicaciones. En los años 1990 eso llevó a las reformas constitucionales en muchos países -pero exceptuando la nueva Constitución y la política identitaria en Bolivia-, Fraser acierta con precisión en el hecho de que a pesar de que las reformas constitucionales en aquellos países definen el Estado nacional como multiétnico y pluricultural, y garantizan el reconocimiento de la diversidad cultural, así como derechos colectivos especiales para los pueblos indígenas, el alcance de estos derechos es escaso. Estas reformas constitucionales llevaron a nuevos discursos de los gobernantes y planes de políticas públicas, pero sin tener mayores consecuencias prácticas en las políticas concretas (Meentzen 2007). Esto se demuestra, por ejemplo, en la esca- 
sa implementación práctica por la clase política dominante y por la burocracia. Por lo general, sus altos funcionarios no se han deshecho de su sentimiento de superioridad como "blancos" históricamente arraigado. Acostumbrados a disponer del poder dentro del Estado, muestran poca disposición para crear nuevas estructuras democráticas, instituciones y símbolos que limiten su poder.

El modelo de estatus de Fraser dirige la mirada a las condiciones sociales que constituyen la desigualdad y el reconocimiento erróneo (misrecognition) y lo encubren con adscripciones como "cultura", etnia y raza. Fraser desglosa las instituciones sociales y los patrones de acción e interpretación por medio de los cuales se construye y mantiene la diferencia. De esta manera, postula un análisis diferenciado de las estructuras sociales y económicas y de la intersección entre clase, etnia, cultura, género, experiencias cotidianas y sus significados en diferentes niveles sociales.

Las "políticas de reconocimiento" alternativas requieren, según Fraser, "una política no identitaria" (Fraser 2000: 120). Esta comprende las estructuras estatales, leyes, valores y normas sociales, así como formas adecuadas de representación. Adicionalmente, es necesaria la redistribución de los recursos materiales. Esta dimensión de redistribución atañe a la estructura económica de la sociedad, es decir a su constitución, a la distribución de la propiedad, al mercado laboral, a la educación, al acceso social a los recursos y a la definición de clases sociales (Fraser 2000: 116).

Según Fraser, sería necesario entonces redistribuir los recursos y crear las estructuras e instituciones correspondientes. Esto no significa que la autora omita la identidad cultural como una importante categoría del reconocimiento. Aclara que en su modelo del estatus, la política de reconocimiento no termina en la identidad, sino que busca remedios institucionales para daños institucionalizados. Exige una política que busca superar la subordinación de estatus lo cual requiere el reconocimiento de formas social y culturalmente ancladas y con eso el cambio de valores que regulan la interacción y promueven la participación igualitaria ("paridad de la participación") en la vida social (Fraser 2000: 116). Esto significa la reingeniería de las instituciones políticas y administrativas y de las estructuras de toma de decisiones. Las organizaciones indígenas han adoptado exactamente estas demandas a partir de sus experiencias negativas con los pocos 
cambios que resultaban de las reformas constitucionales. - Pero a la vez mantienen los discursos esencialistas y culturalistas en función de legitimar sus reivindicaciones. Esto precisamente lleva a propuestas ideológicas como la de la "democracia indígena" e incluye el peligro de un chauvinismo indígena - como lo podemos observar actualmente en los seguidores del Felipe Quispe y en algunos sectores aymarahablantes en Bolivia.

\section{5. Éxitos políticos de los movimientos indígenas}

El planteamiento de Fraser agudiza la vista a las acciones políticas de los movimientos indígenas. El estado del arte: desde los años 1990, los movimientos indígenas han logrado una influencia decisiva en el escenario político y han obtenido éxitos en sus demandas. De sus filas vienen parlamentarios, alcaldes, administraciones municipales, senadores y en este momento el Presidente de Bolivia. En el escenario político, ya para 1989 consiguieron la aprobación del Convenio 169 de la OIT sobre los derechos de los pueblos indígenas; después de décadas de cabildeo lograron la aprobación en septiembre de 2007 de la Declaración de la Naciones Unidas sobre los derechos de los pueblos indígenas, así como de las correspondientes directrices para su implementación. Han logrado que se realicen reformas de algunas Constituciones nacionales y leyes, y en Ecuador y Bolivia incluso la aprobación de nuevas Constituciones. A esta presencia política y a la eficacia de los discursos indianistas han contribuido los debates internacionales sobre los derechos humanos, los derechos de minorías y sobre el reconocimiento de la diversidad cultural, así como el compromiso de organizaciones de apoyo y expertos internacionales que acompañaron estos debates.

En Bolivia y Ecuador, las organizaciones indígenas tienen un radio de acción a nivel nacional que supera ampliamente el propio movimiento. A ello ha contribuido la cooperación con actores no indígenas. Un factor es la alianza política con otros movimientos sociales para la persecución de objetivos y demandas comunes, lo que luego se refleja en acciones conjuntas. Estas demandas se centran en la redistribución del poder y de los recursos, y en el reconocimiento de la diversidad. Entre los ejemplos al respecto tenemos la resistencia contra el ajuste estructural neoliberal, el cual afectó en 
primer lugar fuertemente a la población pobre, así como la privatización de servicios públicos, la introducción del dólar como moneda nacional en Ecuador o también el aumento de los precios de la gasolina y por tanto del transporte; en Bolivia fue la lucha contra la privatización - principalmente del suministro de agua- y contra los negociados de gas natural y petróleo del gobierno de Sánchez de Losada (2002-2003), interpretados como la continuación de la larga historia del remate de recursos naturales del país. Y en rechazo a los partidos políticos tradicionales, apuntaron a la representación propia y a un cambio democrático de la sociedad que respetara y reconociera la diversidad. Las organizaciones indígenas lograron convertirse en portavoz de las reivindicaciones de amplios estratos sociales. El eje de las alianzas han sido demandas relativas a la redistribución y el reconocimiento.

El surgimiento de reivindicaciones a nombre de los pueblos indígenas ha puesto en la agenda política las cuestiones de poder, por lo menos en Ecuador y Bolivia. Con la presidencia de Evo Morales, su reelección el 6 de diciembre de 2009 y la aprobación de la nueva Constitución mediante un referéndum en enero de 2009, el proceso de transformación ha logrado un progreso decisivo en este país. Que este proceso se enfrenta a la resistencia masiva de viejos grupos de poder, sobre todo de las oligarquías del Oriente, y que en 2008 el país estuvo al borde de una guerra civil, muestra cuán dura es la lucha de poder desencadenada por la transformación a que aspiran los movimientos indígenas y sociales.

\section{6. ¿Qué significa "democracia indígena"?}

En el discurso político de las organizaciones etno-políticas y aún más de intelectuales indígenas en Bolivia, se escucha cada vez más el término "democracia indígena" como alternativa a la democracia representativa de cuño occidental. Quiero abordar brevemente la práctica a la que se refiere este término. Después me dedicaré a la cuestión de cómo, ante este trasfondo, se está empezando a configurar en la actualidad la representación política de los pueblos indígenas en Bolivia.

5 Esta parte se basa en mi publicación de 2008: "Kanon mit Gegenstimme Soziale Bewegungen und Politik in Bolivien". 
En los países andinos, la autogestión a nivel comunal en comunidades indígenas tiene una larga tradición (para Ecuador, véase Blum 1999). Ha sido la base para los crecientes procesos organizativos en Ecuador desde finales de los años 1960 y en Bolivia desde mediados de los años 1970. La autogestión comunitaria comprende formas de participación que incluyen a las mujeres pero con derechos limitados. También entre los migrantes indígenas-mestizos en las ciudades andinas, la vida social y económica está basada en la organización autónoma (entre la gran cantidad de bibliografía, véase Golte/Adams 1987; Lazar 2007; Speiser 2004; Steinhauf 1991; StröbeleGregor 2011). El alto grado de organización autónoma y de disciplina organizativa es 'un rasgo de los aymaras y quechuas, y por lo tanto tiene sus raíces culturales en la comunidad andina y en zonas de migración urbana, pero también en la experiencia de la ignorancia estatal, que ha excluido a esta población de una representación política propia ${ }^{6}$ que defendiese sus intereses.

Sin embargo, las formas de participación dentro de las organizaciones sociopolíticas no corresponden a estructuras democráticas en el sentido de la democracia representativa occidental, aunque incluyen formas de democracia directa. Entre estas se encuentra la participación en la asamblea, un elemento central de todas las organizaciones indígenas. La asamblea es el espacio del debate y de la toma de decisiones. Esta participación no siempre es voluntaria, se basa más bien en un sobreentendido social que sanciona el rechazo a participar (Seoane/Nacci 2007: 103 y s.). En la cultura política aymara y quechua, las nociones fundamentales en las que se basa la convivencia son la armonía de grupo y la preeminencia de la colectividad frente al individualismo, el consenso en las decisiones, la reciprocidad, el servicio a la colectividad, la dignidad y el respeto. ${ }^{7}$

6 Bajo representación política se entiende aquí la representación política propia de intereses.

7 John Cameron (2010) lo resume su reciente estudio sobre "Democracia y gobierno indígena en América Latina - Luchas por la democracia local en los andes", de esta manera: "al interior de la comunidad rural, los miembros tienen una comprensión diferente de democracia, lo cual prioriza la redistribución de los recursos sobre los cambios específicos en la forma en que toman las decisiones. Es decir, la democracia implica una redistribución equitativa de los recursos públicos”. “...mientras los académicos y legisladores occidentales tienden a asociar la democracia con la protección de los derechos ciudadanos individua- 
El comportamiento divergente y el disenso de la comunidad son sancionados socialmente, con el objetivo de restablecer la armonía. Esto significa que a nivel político no existe el voto minoritario. Donde no se logra el consenso se da la ruptura. Un ejemplo ilustrativo de ello es la historia de la Central Sindical Campesina Indígena de Bolivia (CSUTCB) o de la Coordinadora de las Organizaciones Indígenas de la Cuenca Amazónica (COICA), que se han dividido varias veces.

La participación se inserta en estructuras verticales. Es obligatorio poner en práctica las decisiones de los dirigentes elegidos, representantes en el nivel superior de la organización, también cuando estas no necesariamente corresponden a las decisiones de organizaciones locales específicas. La disciplina organizativa y el poder de sanción posibilitan esto. En campañas como el bloqueo de caminos interurbanos durante la rebelión de octubre de 2003 en Bolivia, la planificación central fue un elemento importante para aumentar exitosamente la presión sobre el gobierno. La idea de representación, aunque estructuralmente existente en las organizaciones indígenas "modernas" como son el sindicato o las organizaciones etno-políticas a nivel local, regional e internacional, está culturalmente poco arraigada más allá del nivel local. Si bien los representantes indígenas son elegidos por la asamblea y aunque tienen que rendir cuentas, las estructuras supra locales, que fueron retomadas del movimiento sindical para poder actuar en tanto representación de intereses frente al Estado y a nivel internacional, no están interiorizadas. En los niveles organizativos más altos, el control social de los dirigentes es débil. Aquí se da un espacio para la consecución de intereses propios. Esto fomenta la desconfianza en las bases frente a los dirigentes, aunque va acompañada de las expectativas basadas en el principio de reciprocidad de que existe gratificaciones materiales y ventajas sobre todo para el propio grupo de procedencia o los seguidores directos (clientela). Esto a su vez fomenta la desconfianza entre aquellos grupos a los que el dirigente, debido a su cargo, también tiene que representar, pero que no pertenecen a su propio grupo de procedencia o clien-

les, muchas comunidades indígenas y campesinas le otorgan un valor mucho más alto al derecho colectivo de autogobierno" (Cameron 2010: 85). 
tela. Estas son contradicciones y escollos bien conocidos también en democracias representativas occidentales.

También las organizaciones políticas indígenas de los pueblos de tierras bajas, como la confederación CIDOB (Confederación de los Pueblos Indígenas de Bolivia) en Bolivia o las organizaciones regionales afiliadas a ella, como por ejemplo la organización de los guaraníes, APG (Asamblea del Pueblo Guaraní), o de los pueblos del Beni, CPIB (Central de los Pueblos Indígenas del Beni), están estructuradas formalmente según el modelo de los sindicatos. Sin embargo, las diferencias culturales entre los pueblos de las tierras bajas, por un lado, y los aymaras y quechuas, por el otro, se expresa también en su práctica organizativa. Por ejemplo, entre los primeros, la participación toma mucho más en cuenta la decisión individual. La influencia de los dirigentes se basa en gran medida en su carisma y en sus redes sociales, y su relación con el Estado se caracteriza por el pragmatismo y la flexibilidad. En oposición a los aymaras, los pueblos de las tierras bajas no mantienen posiciones políticas maximalistas ideológicamente inmutables. Si bien es la demanda por territorios, autogobierno y poder de disposición sobre los recursos naturales en sus tierras la que desde finales de los años 1980 ha conducido a un movimiento fuerte y a la ampliación de las organizaciones, no obstante, siempre han demostrado una gran flexibilidad de negociación en la persecución de sus demandas y también han valorado los éxitos parciales como pasos hacia el objetivo. Así, a principios de los años 1990, en Bolivia exigieron una legislación propia, la Ley Indígena, que debía atender sus demandas (Libermann/ Godínez 1992). La base para ello fue el Convenio 169 de la OIT. Los gobiernos de ese entonces rechazaron esa legislación. No obstante, en 1992, el Presidente de la República, Paz Zamora, se vio obligado a reconocer por primera vez mediante decreto cinco territorios indígenas autónomos. Acto seguido, el movimiento de tierras bajas renunció de momento a una Ley Indígena y persiguió la idea de una Asamblea Constituyente. Esta demanda la había planteado por primera vez durante su famosa marcha desde las tierras bajas hacia la sede de gobierno en 1990, con la que hizo hincapié en sus demandas por la tierra. Esta demanda fue retomada durante la rebelión de 2003. 2006 el nueve gobierno de Evo Morales convocó la Asamblea Constituyente. 


\section{Conclusión}

En varios países latinoamericanos, las organizaciones indígenas han logrado ejercer un rol protagónico en los debates y conflictos sociales, porque -en el contexto de sus condiciones de vida- lograron de manera convincente poner en la agenda política cuestiones como el reconocimiento, la redistribución y la justicia social en el sentido de Fraser. Lograron convertirse en portavoces de los subalternos y formar alianzas con otras poblaciones discriminadas o desfavorecidas socialmente. De esta manera, son ellos los que han puesto en marcha los amplios procesos de transformación.

Pero también debe destacarse que estos procesos no son lineales, más bien se caracterizan por altibajos. Un ejemplo es Ecuador.

En Ecuador, desde fines de los años 1980, el movimiento indígena llegó a tener un papel protagónico en la arena política. Sus organizaciones a nivel local, regional y nacional establecieron alianzas con otros movimientos sociales, con organizaciones de las iglesias católicas y protestantes y con estudiantes para articular las masivas protestas contra las medidas económicas de los gobiernos en turno que afectaron ante todo a los estratos subalternos de la sociedad ecuatoriana. Además reivindicaron justicia social y mayor distribución igualitaria de los ingresos del Estado, el reconocimiento como naciones indígena y autogestión (García Serrano 2002: 76-79; Ojeda Segovia 2005). Este amplio movimiento social liderado por la CONAIE (Confederación de Nacionalidades Indígenas del Ecuador) ha sido igualmente el fundamento del partido político Movimiento Plurinacional Pachakutik - Nuevo País, fundado en 1996. Los diversos levantamientos nacionales protagonizados por los pueblos indígenas del Ecuador a partir de 1990 (García Serrano 2002) han sido la expresión de esta fuerza política y de su estrategia de alianzas. El protagonismo del movimiento indígena hizo posible la victoria electoral del pacto entre el militar Lucio Gutiérrez y el partido Pachakutik-Nuevo País en 2002. Por primera vez una mujer indígena, la abogada Nina Pacari, militante de la CONAIE y de Pachakutik, fue nombrada ministra de asuntos exteriores; varios representante de $\mathrm{Pa}$ chakutik y de la CONAIE ocuparon altos cargos en el nuevo gobierno. Pero este éxito electoral pronto se convirtió en un fracaso político de Pachakutik y de la CONAIE. No habían elaborado un 
programa de gobierno adecuado ni acuerdos vinculantes que correspondían a las demandas de los movimientos sociales y los representantes indígenas no tenían la capacidad de imponerse en las políticas del gobierno. Ante esta situación, las bases indígenas criticaron duramente a la política de Pachakutik y de la CONAIE y exigieron que sus representantes se retirasen del gobierno. A partir de este momento el conflicto entre las bases y la CONAIE no se ha superado; la CONAIE perdió su protagonismo. Hasta la actualidad, ni Pachakutik ni la CONAIE podían recuperar su liderazgo de los movimientos sociales. Los pobres resultados electorales de Pachakutik en las elecciones presidenciales de 2006 y en la Asamblea Constituyente en 2008 y la política del actual Presidente Correa son una muestra de la pérdida de influencia de las organizaciones en la arena política. El Presidente Correa no toma en cuenta las demandas indígenas por mayor participación, por reconocimiento político y social y por redistribución en el sentido de Fraser.

En Bolivia, el desarrollo de la alianza entre movimiento indígena y movimientos sociales no-indígenas tomó un rumbo diferente. En 2005, Evo Morales, representante del Movimiento al Socialismo (MAS) - un partido sui generis que abarca tanto a movimientos sociales no-indígenas como indígenas- fue elegido presidente de la República y reeligido en 2009. La demanda indígena por una Asamblea Constituyente que incluye la participación indígena y los estratos subalternos para elaborar la nueva Constitución del Estado, se cumplió.

En la nueva Constitución boliviana, las regiones indígenas autónomas se fundamentan en formas de autogestión y representación culturalmente autónomas. Y en el sentido de Nancy Fraser, la Constitución prevé el reconocimiento y la redistribución para crear justicia social, política y cultural. La Constitución prevé cuatro niveles de autonomía, entre ellos autonomías indígenas a nivel local y supra local. Además se reconocen formas tradicionales de autogestión local. Adicionalmente, la Constitución estipula formas de democracia directa, como plebiscitos, consultas populares/audiencias para temas políticos centrales. También estas innovaciones son logros de los movimientos sociales e indígenas.

El nuevo marco jurídico es el fundamento de la transformación del Estado, favoreciendo el nuevo sujeto político: "los pueblos indí- 
gena originario campesinos". Pero hay que resaltar que la fundamentación jurídica sólo es un primer paso. La puesta en práctica de la creación de justicia -el reconocimiento y la distribución- en el sentido de Fraser, requiere la elaboración democrática y participativa del nuevo modelo de desarrollo, estrategias específicas para procesos de negociación orientados a la superación de las desigualdades entre grupos sociales e intereses adversos y las respectivas políticas públicas. En este proceso el gobierno juega un papel clave. En el caso de Bolivia, el gobierno de Evo Morales no ha cumplido con las expectativas de la mayoría de la población boliviana.

\section{Bibliografía}

Assies, Willem/Van der Haar, Gemma/Hoekema, André (2000): The Challenge of Diversity. Amsterdam: Thela Thesis.

Barie, Cletus Gregor (2003): Pueblos Indigenas y derechos constitucionales en América Latina: un panorama. La Paz/México, D.F.: Comisión Nacional para el Desarrollo de los Pueblos Indígenas/Gobierno de México.

Blum, Volkmar (1999): Nation und Gesellschaft im mittleren Andenraum: Exklusion und Inklusion, Rassismus, Ethnizität und Hybridität. Habilitationsschrift am Fachbereich Politik und Sozialwissenschaften. Berlin: Freie Universität.

Cameron, John (2010): "Democracia y gobierno indígena en America Latina - Luchas por la democracia local en los andes". En: Bolivia Post-Constituyente. Tierras, territorios y autonomías indígenas. Memoria del Seminario Internacional, 26-28 de octubre 2009 en La Paz. La Paz: Fundación Tierra, pp. 85-87.

Canessa, Andrew (ed.) (2005): Natives Making Nation. Gender, Indigeneity, and the State in the Andes. Tucson: University of Arizona Press.

Dresler, Wildtrud/Fahmel, Bernd/Noack, Karoline (eds.) (2007): Culturas en movimiento. Contribuciones a la transformación de identidades étnicas y culturas en América. México, D.F./Berlin: Universidad Nacional Autónoma de México/IAIPK.

Fraser, Nancy (1997): Justice Interruptus: Critical Reflections on the Post-Socialist' Conditions. New York: Routledge.

- (2000): "Rethinking Recognition”. En: New Left Review, 3, pp. 107-120.

- (2003): "Soziale Gerechtigkeit im Zeitalter der Identitätspolitik. Umverteilen, Anerkennung und Beteiligung". En: Fraser, Nancy/Honneth, Axel: Umverteilung oder Anerkennung? Eine politisch-philosophische Kontroverse. Frankfurt am Main: Suhrkamp.

García Serrano, Fernando (2002): "Política, Estado y movimiento indígena: nuevas estrategias de negociación en tiempos de la dolarización”. En: Indiana 17/18, pp. 69-82 [Dossier: Nuevas Tendencias de los movimientos indígenas en los Países 
Andinos y Guatemala a comienzos del nuevo milenio. Coordinado por Juliana Ströbele-Gregor].

- (comp.) (2008): Identidades, etnicidad y racismo en América Latina. Quito: FLACSO Ecuador/Ministerio de Cultura.

Golte, Jürgen/Adams, Norma (1987): Los caballos de Troya de los invasores. Estrategias campesinas en la conquista de la Gran Lima. Lima: IEP.

ILO (International Labour Organisation) (1989): Convention 169: Convention Concerning Indigenous and Tribal Peoples in Independent Countries. Genève: ILO.

La Razón (2009): “7 de cada 10 bolivianos se ven mestizos". En: Edición Digital, Marzo 3 (<www.la-razon.com/versiones/20090303_006655/ nota_247_771442.htm>; 10.03.2009).

Lazar, Sian (2007): El Alto, Rebel City. Self an Citizenship in Andean Bolivia. Durham: Duke University Press.

Libermann, Kitula/Godínez, Armando (coords.) (1992): Territorio y dignidad. Pueblos Indigenas y Medio Ambiente en Bolivia. La Paz: ILDIS/Editorial Nueva Sociedad.

Martínez-Cobo, J. R. (1987): Estudio del Problema de la Discriminación contra las Poblaciones Indígenas. Vols. 1-5. New York: Naciones Unidas. Versión en ingles: UN Doc. E./CN.4/Sub.2/1986/7/Add. 4 para 379 (1986).

Meentzen, Angela (2007): Políticas Públicas par los pueblos indígenas en América Latina. Los casos México, Guatemala, Ecuador, Perú y Bolivia. Lima: KAS.

Ojeda Segovia, Lautaro (2005): “Análisis politológico del proceso de construcción de la autonomía multicultural en el Ecuador". En: Gabriel, Leo/López y Rivas, Gilberto (coords.): Autonomías Indígenas en América Latina. Nuevas formas de convivencia política. México, D.F.: Plaza y Valdés, pp. 331-426.

Quijano, Aníbal (2000): "Colonialidad del poder, eurocentrismo y América Latina”. En: Lander, Edgardo (comp.): La colonialidad del saber: eurocentrismo y ciencias sociales. Perspectivas Latinoamericanas. Buenos Aires: CLACSO, Consejo Latinoamericano de Ciencias Sociales, pp. 201-246.

Rabeneik, Manfred (2005): "Indigene Interessenorganisation und Armutsbekämpfung in Ecuador". En: KAS - Auslandsinformation, 1/2005, pp. 13-29 (<www.kas.de/ $\mathrm{wf} / \mathrm{doc} / \mathrm{kas}$ 6080-544-1-30.pdf?050211103906>; 05.01.2009).

Seoane, José A./Nacci, María José (2007): “Movimientos sociales y democracia en América Latina, frente al 'neoliberalismo de guerra'". En: De la Fuente, Manuel/Hufty, Marc (eds.): Movimientos sociales y ciudadanía. La Paz: Plural, pp. 85-126.

Speiser, Sabine (2004): "Indigene Völker in Städten - präsent und doch nicht wahrgenommen". En: GTZ (ed.): Indigene Völker in Lateinamerika und Entwicklungszusammenarbeit. Eschborn: GTZ, pp. 169-188.

Spivak, Gayatari Chakravorty ([1985] 1996): "Subaltern Studies. Deconstructing Historiography”. En: Landry, Donna/MacLean, Gerald (eds.): The Spivak Reader. London: Routledge, pp. 203-236.

Stefanoni, Pablo (2007): "Sieben Fragen und sieben Antworten zu Bolivien unter Evo Morales". En: Nueva Sociedad 209, deutsche Sonderausgabe. Mai-Juni, pp. 51-73. 
Steinhauf, Andreas (1991): "Diferenciación étnica y redes de larga distancia entre migrantes andinos: El caso de Sanka y Colcha". En: Bulletin Institute Francaise études andines, 20, 1, pp. 93-114.

Ströbele-Gregor, Juliana (2007a): “Autoridad, poder y liderazog. Observaciones conceptuales acerca de la práctica de los pueblos indígenas”. En: Birle, Peter/Hofmeister, Wilhelm/Maihold, Günther/Potthast, Barbara (eds.): Elites en América Latina. Madrid/Frankfurt am Main: Iberoamericana/Vervuert, pp. 105-124.

- (2007b): "Kanon mit Gegenstimmen - Soziale Bewegungen und Politik in Bolivien". En: Schmalz, Stefan/Tittor, Anne (eds.): Jenseits von Subcomandante Marcos und Hugo Chávez. Soziale Bewegungen zwischen Autonomie und Staat. Festschrift für Dieter Boris. Hamburg: VSA, pp. 129-141.

- (2009): "Die Ethnisierung des Politischen. Politische indigene Bewegung in Ecuador und Bolivien“. En: Gerlach, Olaf/Hahn, Marco/Kalmring, Stefan/Kumitz, Daniel/Nowak, Andreas (eds.): Globale Solidarität und linke Politik in Lateinamerika. Berlin: Dietz, pp. 193-206.

- (2011): "The Construction of an Indigenous Culture and Identity in El Alto and Its Impact on Everyday Life and in the Political Arena". En: Butler, Martin/Gurr, Jens Martin/Kaltmeier, Olaf (eds.): EthniCities - Metropolitan Cultures and Ethnic Identities in the Americas. Trier: Wissenschaftlicher Verlag, pp. 31-40. 



\section{Jonas Wolff \\ Movimientos sociales y la lucha por la democratización de la democracia: experiencias recientes en América del Sur}

\section{Introducción ${ }^{1}$}

La estabilidad de la democracia en países caracterizados por marcadas desigualdades sociales requiere, entre otras cosas, que sectores sociales marginados cuenten con capacidades reducidas de movilización, articulación e incidencia política. Al mismo tiempo, esa relativa discriminación política obviamente atenta contra principios básicos de la democracia: principios como la participación justa y la representación equitativa. En los últimos años, distintos movimientos sociales en América del Sur lograron superar los obstáculos a la acción colectiva, reivindicando mayor presencia e incidencia política. En el presente ensayo se compara tres experiencias recientes: los movimientos piquetero en Argentina, indígena en Ecuador y campesino-indígena en Bolivia. Los tres movimientos sociales, en ciertos momentos, han sido capaces de desafiar a los regímenes democráticos para lograr una apertura política. En los tres casos, el ascenso de "nuevos" sujetos políticos ha conllevado tanto una desestabilización (temporal) de la democracia como un impulso importante de democratización, pero los éxitos más estructurales en términos de una "profundización" de la democracia son bastante diversos. La pregunta es: ¿En qué medida -bajo qué condiciones y con qué estrategias- han contribuido los movimientos sociales a una democratización de la democracia en sus países correspondientes?

Tanto el punto de partida general como la pregunta concreta sólo tienen sentido desde la perspectiva de un concepto de democracia

1 La presente contribución se basa en una presentación en el taller internacional "El Bicentenario de la Independencia y la(s) Democracia(s) en América Latina: Balance y Perspectivas", 12-13 de febrero de 2010, Lateinamerika-Institut, Freie Universität Berlin. Agradezco los comentarios de varios participantes del taller, los editores de este libro y Niels Graf. 
específico. Tomando en serio la idea de la democracia realmente existente como poliarquía (Dahl 1989; Lindblom 1977), tal democracia formal siempre queda lejos del ideal, pero puede aproximarse más o menos a este. ${ }^{2}$ Así se puede distinguir la pregunta por la existencia (formal) de la democracia, de la pregunta por su calidad. Y, con ello, no es una contradicción en sí misma decir que la estabilidad de una determinada democracia (formal) puede depender de su limitación factual en términos de capacidades reales de participación y representación. Del mismo modo es así posible hablar de y analizar procesos de democratización (o profundización) de la democracia.

En el marco de este artículo no es posible analizar y comparar en detalle las experiencias y resultados de los tres movimientos sociales mencionados. La idea es más bien poner a debate cuatro observaciones generales que se basan en estas experiencias. ${ }^{3}$ Primero, se confirma la tesis planteada por Sidney Tarrow (1998) de que el resultado más probable de movimientos sociales exitosos en un sistema democrático es un ciclo de reformas - pero el caso boliviano demuestra que, bajo condiciones especiales, tales reformas pueden ser bastante profundas. Segundo, los casos de Argentina y Ecuador, sin embargo, demuestran la dinámica más típica: haber entrado como fuerza minoritaria en procesos e instituciones políticos para transformar las reglas de juego, siendo más bien las reglas de juego las que al final transforman al movimiento social y sus representantes. Radicalizando esta observación se podría argumentar, tercero, que cierta ruptura institucional es necesaria para abrir posibilidades de cambios políticos que sean más estructurales. Las experiencias de los gobiernos de Evo Morales (Bolivia) y Rafael Correa (Ecuador) pa-

2 Aunque tal aproximación no es un proceso linear que se puede analizar en términos de más (democracia) o menos (defectos). El problema de fondo aquí es que la democracia es siempre un ensamblaje de principios contradictorios (por ejemplo, el principio de la soberanía popular versus su limitación constitucional).

3 En este sentido, las cuatro observaciones desarrolladas recurren empíricamente a una investigación académica que se basa en estudios de casos sistemáticamente elegidos, analizados y comparados (con metodología clara y explícita) (Wolff 2008; 2009). Pero no representan, en rigor, el resultado de esta investigación sistemática (que tenía otra pregunta). La idea del presente ensayo es más bien identificar unos rasgos generales para ponerlos a debate como tesis muy preliminares. Bajo esta reserva, la selección de los tres casos sí tiene mucho sentido con respecto al tema de este artículo (véase la introducción al capítulo 3). 
recen confirmar esta tesis, pero también sugieren una cuarta observación que choca abiertamente con el discurso de democracia de base que caracteriza a los movimientos sociales analizados: La fuerza y el éxito político de los movimientos, al menos en una parte importante, dependen de líderes fuertes que son capaces de unir a movimientos, organizaciones y grupos sociales heterogéneos bajo un proyecto político.

Estas cuatro observaciones no resultan en una respuesta clara, sino en más preguntas. A modo de conclusión, se propone sistematizar estas preguntas retomando el concepto de las "escalas de justicia" propuesto por Nancy Fraser (2009). Siguiendo a Fraser, se puede analizar las demandas y los éxitos de los movimientos sociales en tres dimensiones sustanciales de justicia (redistribución, reconocimiento y representación) y con respecto a diferentes niveles geográficos hacia donde se puede dirigir y donde se debe tratar las reivindicaciones (del nivel local hacia el nivel global). Pero antes de presentar las cuatro observaciones y la conclusión-interrogante, es preciso resumir brevemente tanto el contexto político en el cual se forman los movimientos sociales como los propios ciclos de movilización.

\section{El contexto: el "triángulo" latinoamericano}

La "tercera ola de democratización" (Huntington 1991) en América Latina ha dado lugar a una situación política que se caracteriza, en términos muy generales, por una estabilidad básica de la democracia. Ya con respecto a la "década perdida" de los años 1980, Karen Remmer enfatizó que el enigma no es "la fragilidad de la democracia, sino su vitalidad sorprendente a pesar de restricciones económicas tan severas" (Remmer 1990: 335). Las experiencias de la nueva "media década perdida" entre 1998 y 2002 (Ocampo 2002) corroboraron esta observación: En países como Argentina (2001/2002) o Ecuador (1999/2000) crisis económicas muy dramáticas provocaron una escalada de conflictos sociales y acabaron también en serias crisis políticas, pero sin que se produjera una ruptura del régimen democrático (Wolff 2008).

Cuando hablamos de una estabilidad básica de la democracia en América Latina, hablamos de una estabilidad democrática bastante 
particular. Por un lado, investigadores -y los diferentes índices que intentan medir la calidad de la democracia- enfatizan los "defectos" de los sistemas democráticos latinoamericanos, sobre todo con respecto al estado de derecho, el control horizontal de los poderes estatales y el sistema de partidos. Por otro lado, hay que mencionar la situación socioeconómica que se caracteriza, en general, por la persistencia de pobreza masiva y desigualdad profunda. Así el Programa de las Naciones Unidas para el Desarrollo, en su informe La democracia en América Latina. Hacia una democracia de ciudadanas y ciudadanos, sintetizó esta "nueva realidad sin antecedentes" en la imagen de un "triángulo" que tiene como vértices la democracia electoral, la pobreza y la desigualdad (PNUD 2004: 36).

Sin entrar en detalles del debate sobre cuestiones de teoría de la democracia, basta decir que la persistencia de pobreza masiva y de múltiples desigualdades sociales implica que la democracia es y sigue siendo una democracia bastante formal. No es sólo que la extensión de derechos políticos en la región no fuera acompañada -ni seguida- por un fortalecimiento de derechos sociales (Oxhorn 2003: 36). Es más: que el ejercicio real de los derechos políticos y civiles queda muy lejos de la norma formal tiene que ver, entre otras cosas, precisamente con el estado muy precario de derechos sociales de ciudadanía.

Grupos sociales que son marginados en términos socio-económicos se caracterizan, normalmente, por tener reducidas capacidades de movilización, articulación e incidencia política. Y al revés: grupos privilegiados social y económicamente tienden a tener ventajas tanto en su capacidad organizativa como en su acceso al sistema político (Offe/Wiesenthal 1980; Lindblom 1977). En este sentido se puede entender la observación de Carlos Strasser que argumentó que el triunfo mundial de tanto la democracia como la desigualdad al fin del siglo XX indica que ambos están ligados en una "asociación perfectamente posible" (Strasser 2000: i). En estas condiciones, democratización (o profundización) de la democracia requiere precisamente la reducción de tales asimetrías, es decir más movilización, articulación e incidencia política por parte de los sectores marginados. En la medida que movimientos sociales impulsan a tales procesos, actúan como motores de democratización. 
Al mismo tiempo, aunque la situación descrita obviamente atenta contra principios básicos de la democracia -como la participación justa y la representación equitativa-, la estabilidad de la democracia en países caracterizados por marcadas desigualdades sociales depende de este equilibrio entre marginación política y falta de capacidad movilizadora (Kurtz 2004; Wolff 2009). Tal equilibrio había sido el resultado de la "doble transformación", es decir de los procesos simultáneos de democratización política y reestructuración socio-económica: ${ }^{4}$ la transición hacia la democracia en la región coincidió con el abandono del modelo ISI (industrialización por sustitución de importaciones). La crisis económica de los años 1980 y las reformas neoliberales acabaron en una subida de las tasas de desempleo y subempleo, en un crecimiento de la pobreza y la economía informal y en una reducción del sector público. Así se debilitó la capacidad movilizadora tanto de los trabajadores oficiales y organizados como de las organizaciones populares en general. La transformación neoliberal del estado - un proceso que comprendió el desmontaje de las instituciones corporativistas y la retirada selectiva del estado de ciertas funciones públicas- también disminuyó los incentivos para la acción colectiva así como la importancia del referente principal de la movilización (el propio estado). Del mismo modo la crisis ideológica de la izquierda después del derrumbe de la Unión Soviética y el discurso tecnocrático del pensamiento neoliberal contribuyeron a esta tendencia despolitizadora. Así, en la fase post-transicional y neoliberal, los sectores populares se caracterizaron por procesos de desmovilización y despolitización que limitaron tanto su participación institucionalizada y su representación política como su capacidad de manifestarse colectivamente afuera de y en contra de las instituciones. El resultado ha sido la "atomización enojada (angry atomization en el original inglés, J.W.) de la sociedad" de la cual habló Guillermo O'Donnell (1993: 1365), una situación que se manifestó en el descontento extenso documentado en las encuestas del Latinobarómetro, "interrumpido por estallidos de actividad, a veces violentos, pero generalmente infrecuentes, altamente inorgánicos (aunque

4 En torno a esta ambivalencia de la “doble transformación” véase Kurtz (2004), Oxhorn/Starr (1999), Smith/Acuña/Gamarra (1994), Wolff (2005). 
normalmente no-espontáneos) y de muy corta duración" (Waisman 1999: 47).

Es esta paradójica combinación entre el empoderamiento formal (a través de la democratización política) y el desempoderamiento fáctico (a través de la crisis y la reestructuración económicas) que ayuda a entender la persistencia del mencionado "triángulo" latinoamericano. En caso contrario, la "lógica movilizadora" de la democracia (Waisman 1999) implicaría que los sectores populares o reivindican sus derechos a través del voto o se rebelan activamente en contra del sistema político. En consecuencia, cuando procesos de movilización social rompen el equilibrio mencionado, el régimen democrático se ve sometido a serias presiones.

\section{Los movimientos: un breve recorrido}

No es que en la fase después de la transición (o el retorno) a la democracia no hubiera habido movimientos sociales y protesta social en América Latina, pero en general la democratización fue acompañada por una tendencia de desmovilización social (Calderón 1985; Eckstein 2001; Roberts 1997). Sin embargo, alrededor del cambio de siglo fuertes movimientos sociales en diferentes países sudamericanos llamaron la atención: lograron superar los obstáculos a la acción colectiva por parte de sectores marginados, movilizando partes relevantes de los sectores populares para reivindicar mayor presencia e incidencia política. Entre la diversidad de (más o menos) nuevos movimientos sociales (Eckstein/Wickham-Crowley 2003; Johnston/Almeida 2006) destacan tres casos:

- Primero, los "piqueteros": el movimiento -o el "movimiento de movimientos" (Colectivo Situaciones 2002)- de trabajadores desocupados en Argentina es notable principalmente por dos razones: el gran tamaño del sector informal en las sociedades latinoamericanas y las dificultades estructurales que normalmente impiden la organización de los desempleados (así que Pierre Bourdieu calificó al movimiento de los parados como un "milagro social" [Bourdieu 1998]).

- Segundo, el movimiento indígena ecuatoriano: este movimiento destaca porque representaba en los años 1990 el movimiento indígena $-\mathrm{y}$ tal vez el movimiento social- más fuerte de la región 
(Yashar 2005: 85; Van Cott 2005: 99) y porque es -a diferencia del caso boliviano- un movimiento netamente indígena que apunta a representar una parte significativa, pero minoritaria de la sociedad ecuatoriana.

- Tercero, el movimiento campesino-indígena en Bolivia: esta confluencia de movimientos y organizaciones sociales obviamente es importante porque representa un caso de éxito excepcional donde - con el gobierno de Evo Morales a partir del 2006- representantes del movimiento logran tomar, dominar y transformar las instituciones políticas (y eso, en general, por vía democrática).

Es por la combinación de semejanzas y diferencias que la comparación de estos tres casos es interesante. Con respecto a la identidad, se compara un movimiento netamente indígena (Ecuador), otro fuertemente indígena, pero con una identidad más amplia (Bolivia) y un tercero sin referencia étnica alguna (Argentina). Con respecto al éxito político, se compara casos en los cuales los movimientos, respectivamente, ocuparon el gobierno (Bolivia), participaron oficialmente, pero muy brevemente en el gobierno (Ecuador) o sólo lograron tener cierta influencia informal en el gobierno (Argentina). Al mismo tiempo, todos los tres movimientos se basaron en procesos de organización y movilización "desde abajo" con fuerte anclaje territorial pero alcance nacional, aglutinaron reivindicaciones materiales específicas con demandas globales por un cambio político y económico estructural, y lograron establecerse -al menos por un tiempo determinado- como representantes reconocidos de sectores social, económico y políticamente marginados a nivel nacional (Wolff 2007).

\subsection{El movimiento de trabajadores desocupados de Argentina ${ }^{5}$}

El fenómeno de los piqueteros surge de ciudades petroleras en las cuales la privatización de la petrolera estatal Yacimientos Petrolíferos Fiscales (YPF) significó no "solo" la pérdida de muchos puestos de trabajo, sino el desmontaje de todo un estado de bienestar paralelo que afectó comunidades locales enteras (Auyero 2004; Svampa/Pe-

5 Sobre el movimiento piquetero véase por ejemplo Colectivo Situaciones (2002); Delamata (2004); Dinerstein (2003); Epstein (2006); Mazzeo (2004); Oviedo (2004); Pacheco (2004); Svampa/Pereyra (2004); Wolff (2007, 2008: Cap. 4). 
reyra 2004: 103-151). Según Maristella Svampa y Sebastían Pereyra (2004: 103), los cortes de ruta y las puebladas en Cutral-Co-Plaza Huincul (Neuquén) en 1996 y en General Mosconi-Tartagal (Salta) a partir de 1997 pueden considerarse como las "dos grandes experiencias "modelos" del movimiento piquetero que después se extendió por todo el país: en 1997 ya hubo 170 piquetes en toda Argentina, cifra que subió a 252 (1999), 514 (2000) y 1.383 (2001) para llegar, finalmente, a 2.336 cortes de ruta en el año de crisis abierta (2002) (Nueva Mayoría 2005). Fue especialmente el crecimiento de movimientos de trabajadores desocupados en la provincia de Buenos Aires y sobre todo en el conurbano bonaerense que implicó la llegada del movimiento piquetero al escenario de la política nacional.

Aunque en el "estallido social" del 19 y 20 de diciembre 2001 no fueron los piqueteros (ni otros grupos organizados), sino más bien los ciudadanos sueltos los protagonistas (Colectivo Situaciones 2003; Dinerstein 2003), la masificación de la protesta social en los años 2001 y 2002 sí fue marcado por los movimientos de trabajadores desocupados como actor (o tipo de actor) más importante (Wolff 2008: 428-429). Por un lado, el alza de protesta social protagonizada por los piqueteros sentó las bases para el "estallido" a finales de diciembre de 2001; por otro lado, después de los días de diciembre, mientras rápidamente perdió fuerza la protesta de la clase media urbana, el movimiento piquetero supo aprovecharse de la debilidad del gobierno interino de Eduardo Duhalde. Los movimientos de trabajadores desocupados, con todas sus divisiones internas, se transformaron en interlocutores indispensables del gobierno nacional y contribuyeron, con su fuerza movilizadora, a la extensión masiva de medidas (planes) sociales a partir del enero 2002. En general, más allá de los pocos días alrededor de diciembre de 2001, el movimiento piquetero se presentó como el único nuevo protagonista de la protesta social con capacidad movilizadora sostenible.

Sin embargo, con la elección de Néstor Kirchner en el 2003 se abrió "un nuevo escenario" para el movimiento piquetero:

La política de Kirchner consistió en poner en acto, simultáneamente, el abanico de estrategias disponibles para integrar, cooptar, disciplinar y/o aislar al conjunto del movimiento piquetero, discriminando entre las diferentes corrientes y organizaciones (Svampa/Pereyra 2004: 212). 
Al mismo tiempo, Kirchner recuperó la fuerza tradicional del Peronismo de apelar e incorporar "desde arriba" a los sectores populares e inició una serie de cambios políticos exigidos por la protesta social. Así, y en una situación de recuperación económica después de la crisis, las demandas (y las formas de protesta) de los piqueteros perdieron mucho de su resonancia pública. Como resultado, una parte importante de los movimientos de trabajadores desocupados decidió entrar en cooperación más o menos explícita con el gobierno, mientras que la otra parte que se mantuvo en la oposición se vio cada vez más marginada políticamente. El movimiento piquetero -que siempre había sido un movimiento de movimientos muy heterogéneos- se desintegró en múltiples corrientes, con casi todas las organizaciones dividiéndose en varias partes (Wolff 2007).

\subsection{El movimiento indígena de Ecuador ${ }^{6}$}

El movimiento indígena ecuatoriano surge de una nueva dinámica de movilización y organización indígena que se desarrolla en los años 1970 tanto en la Amazonía como en la Sierra ecuatoriana. Estos procesos de organización explícitamente indígena confluyeron en 1986 en la creación de la Confederación de Nacionalidades Indígenas del Ecuador (CONAIE), confederación nacional que aglutina en su seno a las organizaciones regionales más importantes de los pueblos y nacionalidades indígenas del Ecuador. ${ }^{7}$ Con el gran "levantamiento indígena" de 1990, la CONAIE apareció en el escenario de la política nacional: provocado por nuevas concesiones para la explotación de petróleo en territorios indígenas, la CONAIE convocó a protestas que incluyeron el bloqueo de carreteras, marchas masivas, la invasión de latifundios y la toma de edificios públicos; en el marco de este levantamiento, la CONAIE por primera vez puso sus reivindicaciones políticas en la agenda nacional. En 1995, la

6 Sobre el movimiento indígena ecuatoriana véase por ejemplo Barrera et al. (2004); León Trujillo (1994); Ramírez Gallegos (2009); Selverston-Scher (2001); Van Cott (2005: Cap. 4); Yashar (2005: Cap. 4); Wolff (2007, 2008: Cap. 5); Zamosc (2007).

7 La Confederación de Nacionalidades Indígenas de la Amazonía Ecuatoriana (CONFENIAE), la Confederación de los Pueblos de Nacionalidad Kichua del Ecuador (ECUARUNARI) y la Confederación de Nacionalidades Indígenas de la Costa Ecuatoriana (CONAICE). 
CONAIE -junto con otros movimientos rurales y urbanos- decidió crear el Movimiento de Unidad Plurinacional Pachakutik - Nuevo País. A través de Pachakutik se introdujo a las instituciones democráticas: al Congreso Nacional, a las diferentes instituciones políticas a nivel subnacional y, en 1997, a la asamblea constituyente de entonces.

En el marco de la crisis económica en 1999, la CONAIE encabezaba la protesta social contra las medidas de austeridad y ajuste que trataba de imponer el gobierno de Mahuad. Esta escalada de protestas culminó en enero del 2000 con el derrocamiento de Mahuad por una alianza del movimiento indígena con un sector rebelde de las Fuerzas Armadas. Durante unas horas, un "triunvirato de salvación nacional" -incluyendo el presidente de la CONAIE, Antonio Vargas- reemplazaba al presidente elegido. El alto comando militar rápidamente terminó esta rebelión que se había convertido en golpe, pero dos años después retornó aquella alianza indígena-militar: en el 2002 ganó las elecciones presidenciales el ex coronel Lucio Gutiérrez con Pachakutik y CONAIE como sus aliados más importantes. Cuando asumió la presidencia Gutiérrez, el movimiento indígena por primera vez llegó a formar parte del gobierno nacional. Pachakutik era parte de la coalición gobernante; la líder indígena Nina Pacari ocupó la Cancillería y el ex presidente de la CONAIE, Luis Macas, obtuvo el Ministerio de Agricultura y Ganadería. Pero la coalición entre CONAIE/Pachakutik y Gutiérrez no duró más que unos pocos meses. Gutiérrez rápidamente empezó a girar el rumbo hacia alianzas con las élites de la Costa, con los partidos políticos de la derecha, con el gobierno de Estados Unidos y con el Fondo Monetario Internacional. Hasta fines del año 2003, todos sus aliados de campaña declararon la oposición abierta al gobierno de Gutiérrez: CONAIE y Pachakutik, pero también otros movimientos social urbanos, organizaciones rurales, sindicatos y fuerzas políticas de izquierda en general. Sin embargo, más allá de declaraciones de enfrentamiento radical al "traidor" Gutiérrez, este conjunto de organizaciones sociales no fue capaz de movilizar ningún tipo de resistencia significativa al gobierno. Notablemente, todos los intentos por parte de la CONAIE de iniciar un nuevo levantamiento indígena en contra de Gutiérrez fracasaron. 
En los años 1990, como ya se ha mencionado, el movimiento indígena ecuatoriano era considerado como el movimiento étnico más fuerte de América Latina (Van Cott 2005: 99; Yashar 2005: 85). En el marco de un ascenso político espectacular la CONAIE y su "brazo político" Pachakutik se convirtieron en desafiantes serios del sistema establecido, de sus representantes y prácticas tradicionales. En enero del 2000 protagonizaron una rebelión que derrocó al Presidente Jamil Mahuad, en 2003 participaron por unos meses en el gobierno de Lucio Gutiérrez. Desde la ruptura de la alianza con Gutiérrez, sin embargo, el movimiento indígena entró en una situación de crisis. Se redujo marcadamente no sólo su papel como protagonista de la protesta social sino también su fuerza política dentro de las instituciones democráticas. Así el movimiento indígena no desempeñó ningún papel activo ni en la caída del Presidente Gutiérrez en 2005, ni en la elección de Rafael Correa en 2006, ni durante el primer año del gobierno de Correa en 2007 (Ramírez Gallegos 2009: 89-90; Wolff 2011).

\subsection{El movimiento campesino-indígena de Bolivia ${ }^{8}$}

Dada la fuerte tradición corporativista en Bolivia, el contemporáneo movimiento social e indígena en este país surge, a diferencia del caso ecuatoriano, en el seno de estructuras sindicales. Pero como en el Ecuador, fueron organizaciones que se identificaron explícitamente como representantes de la población indígena que, a partir de los años 1970, ganaron fuerza y, en los años 1990, protagonizaron la protesta social. Así la Confederación Sindical Única de Trabajadores Campesinos de Bolivia (CSUTCB), que representa sobre todo a los campesinos indígenas del Altiplano boliviano y surge del movimiento katarista, y las Seis Federaciones del Trópico Cochabambino, que organizan los cocaleros del Chapare, se implantaron como las organizaciones sociales más fuertes del país. Al mismo tiempo, la Confederación de Indígenas del Oriente Boliviano (CIDOB) se estableció como representación de la población indígena de las Tierras Bajas y, en 1990, con una larga marcha "por territorio y dignidad" simbólicamente apareció en el escenario nacional (Ströbele-Gregor 1994: 106).

8 Sobre el movimiento indígena-campesino véase por ejemplo Postero (2004); Ströbele-Gregor (1994; 2006); Van Cott (2005: Cap. 3); Yashar (2005: Cap. 5). 
Como en el caso ecuatoriano, en los años 1990 empieza, por un lado, un ciclo de protesta social protagonizado por estas organizaciones campesino-indígenas (Crabtree 2005) y se da, por otro lado, un proceso de integración política de estos "nuevos actores" en las instituciones políticas del país (Van Cott 2005: Cap. 3). El actual presidente Evo Morales representa claramente estas dos partes del surgimiento del movimiento indígena-campesino. Morales aparece en la política nacional como líder del movimiento cocalero, un movimiento que surge como organización netamente sindical, pero termina adoptando el discurso y una serie de reivindicaciones explícitamente indígenas. En 1995, y bajo el liderazgo de Evo Morales y los cocaleros, se funda el movimiento político Asamblea por la Soberanía de los Pueblos (ASP) que en 1999 es reemplazado por el Movimiento al Socialismo (MAS). El MAS se define como "instrumento político" de los movimientos sociales y combina un discurso indígena con una agenda más amplia (social-clasista). En contraste, el Movimiento Indígena Pachakuti (MIP), fundado en el 2000 por el líder aymara Felipe Quispe, promueve un discurso exclusivamente indígena. En general, a partir de 1995 las diferentes organizaciones campesino-indígenas logran entrar a las instituciones políticas, tanto a nivel local como a nivel nacional. En el 2002, el MAS y el MIP en conjunto ganan casi un tercio de los escaños en el Congreso Nacional y Evo Morales pierde la elección presidencial en contra de Gonzalo Sánchez de Lozada solo en la segunda vuelta (en el Congreso).

A partir del 2000 también se agudizan los conflictos sociales, empezando en el 2000 con la "guerra del agua" de Cochabamba y culminando en la "guerra del gas" que, en octubre del 2003, termina anticipadamente con el mandato de Sánchez de Lozada. La combinación de protesta social y auto-integración política desemboca a finales del 2005 en la elección, por mayoría absoluta, de Evo Morales como primer presidente indígena de Bolivia. Morales después inicia un cambio político profundo que incluye tanto una reorientación de las políticas económicas y sociales como una reestructuración del sistema político a través de una Asamblea Constituyente (Ernst/Schmalz 2009). 


\section{Experiencias, logros y condiciones: cuatro observaciones}

En sentido muy general, los tres movimientos sociales han sido capaces de desafiar y desestabilizar a los regímenes democráticos existentes - una desestabilización que fue, a mi modo de ver, necesaria para forzar una apertura política hacia sus representantes y reivindicaciones. Así los piqueteros no sólo pusieron en la agenda política las reivindicaciones urgentes de las víctimas de un modelo económico que se mostró insostenible social y al final también económicamente; además contribuyeron a la apertura forzada de un sistema político que se había vuelto cerrado y alejado de gran parte de la población (Petras/Veltmeyer 2005: 28-59). El movimiento indígena ecuatoriano, por su parte, consiguió su incorporación a un sistema político que, aunque formalmente garantizaba la igualdad política de toda la población, mantuvo fuertes características de exclusión que, en particular, afectaron a la población indígena (Wolff 2011). Como los movimientos sociales en Bolivia, forzaron la apertura $-\mathrm{y}$ finalmente el colapso- de una "democracia pactada" que basó su estabilidad y gobernabilidad, entre otras cosas, en un juego de compromisos intra-élites en el cual tres partidos dominantes gobernaron en alianzas cambiantes (Whitehead 2001).

En los tres casos, entonces, el ascenso de "nuevos" sujetos políticos ha conllevado tanto una desestabilización de la democracia (por lo menos temporal) como un impulso importante de democratización. En el marco de la presente contribución no es posible analizar ni comparar estos procesos de movilización, desestabilización e incorporación en detalle. ${ }^{9}$ En lo que sigue, se enfoca más bien la situación actual con el propósito de identificar algunas conclusiones con respecto a logros (y fracasos o límites) en términos de democratizar la democracia. Comparando los efectos de los tres movimientos sociales en la democracia en los países correspondientes, quiero poner a debate cuatro observaciones:

(1) Sidney Tarrow, en su libro Power in Movement, argumentó que, bajo condiciones democráticas, el resultado más probable de movimientos sociales exitosos es un ciclo de reformas (Tarrow 1998: 161).

9 Para un intento de hacer esto véase Wolff $(2007 ; 2008)$. 
Según Tarrow, este resultado es independiente del hecho de que, con frecuencia, movimientos sociales fuertes no apuntan a tales reformas limitadas, sino a un cambio social profundo o incluso a una subversión total del orden social. Ahora, en términos muy generales los tres casos confirman el argumento. Pero la experiencia boliviana sobrepasa la idea detrás de la imagen del "ciclo de reformas". La noción de una "revolución democrática" sí tiene una base real en la transformación actual de Bolivia (Ernst/Schmalz 2009; Nueva Sociedad 2007). Sin poder entrar en una evaluación de esta transformación, parece claro que el ascenso político de los movimientos sociales e indígenas alrededor del MAS, el gobierno de Evo Morales y el proceso constituyente han contribuido a una clara ampliación de la democracia en términos de representatividad, responsividad y participatividad. Eso incluye una importante "sustancialización" de la democracia, en el sentido que creció, de manera significativa, la idea de que en procesos democráticos se decide sobre cosas políticamente sustanciales. ${ }^{10}$

Así, el caso boliviano es algo muy especial. Depende de circunstancias que un movimiento social normalmente no tiene:

- El estatus mayoritario de la población indígena en combinación con su historia de discriminación y marginación;

- el papel de EEUU y de la lucha contra las drogas en combinación con la relevancia económica y simbólica de la hoja de coca;

- los resultados de las reformas neoliberales en combinación con el potencial económico del gas;

- la incapacidad de las élites políticas de abrir sustancialmente al sistema de "democracia pactada" para dar respuestas a las nuevas demandas en combinación con los procesos de apertura institucional por vía de reformas políticas (como las leyes de descentralización y participación popular de los años 90);

- la fuerza tradicional de las organizaciones sociales y sus estructuras de movilización existentes en combinación con las nuevas dinámicas de movilización indígena y el liderazgo de Evo Morales.

10 Obviamente eso no quiere decir que no haya también tensiones y conflictos entre el gobierno del MAS y los movimientos sociales en general e indígenas en particular (cf. Stefanoni 2009: 103-104). 
(2) A diferencia de este caso tan particular, las experiencias en Argentina y Ecuador demuestran una dinámica diferente, y probablemente la dinámica normal: para un movimiento social, entrar como fuerza minoritaria en procesos e instituciones políticos para transformar las reglas de juego conlleva el gran riesgo de que las reglas de juego más bien transformen al movimiento y sus representantes.

Esa tendencia se puede observar claramente en el caso de las organizaciones piqueteras que entran en cooperación con el estado - y, en concreto, con el gobierno: lógicas clientelares, procesos de cooptación política, relaciones jerárquicas y la manipulación de la base social desde arriba tienden a sobreponerse sobre lógicas más participativas, horizontales y democráticas que al menos constituyeron una dimensión importante del movimiento piquetero original. Aquellas organizaciones piqueteras que se opusieron a la participación en este juego político, perdieron fuerza y, por regla general, se retiraron al nivel local enfatizando un "trabajo territorial" (Blank 2009) que puede ser muy interesante en varios términos, pero que tiene una relevancia muy limitada para la política nacional. En el nivel del estado central, lo que hubo como "profundización" de la democracia en Argentina propulsada por la protesta social, es decir la mejora en términos de responsividad, representatividad, participación y control institucional, ${ }^{11}$ quedó, en gran parte, en un cambio coyuntural e informal que dependía de la habilidad y la buena voluntad del Presidente Kirchner. Los efectos más estructurales se dieron en el área de derechos humanos -con respecto a las violaciones de derechos humanos bajo la dictadura militar-, es decir en un campo que no tenía mucho que ver con las reivindicaciones piqueteras. ${ }^{12} \mathrm{El}$

11 Con respecto a responsividad y representatividad, el Presidente Néstor Kirchner, durante todo su mandato, respondió claramente a demandas importantes de una gran mayoría del electorado y era visto por mayorías abrumadoras de la población como un representante creíble de sus intereses. En términos de participación, Kirchner (y ya su antecesor Eduardo Duhalde) se abrió al diálogo con muchos sectores de la sociedad. Y en términos de control institucional, Kirchner inició un par de reformas (limitadas) con vista a despolitizar la Corte Suprema y recuperar ciertas competencias parlamentarias (en el control de decretos ejecutivos).

12 Obviamente las reivindicaciones de los piqueteros tenían mucho que ver con derechos humanos en un sentido más amplio que incluye derechos económicos y sociales. Sin embargo, las iniciativas del gobierno de Kirchner en cuanto a los 
movimiento de trabajadores desocupados contribuyó a la ampliación de políticas sociales durante los gobiernos de Duhalde y Kirchner, forzó el reconocimiento político de las organizaciones piqueteras (es decir, su inclusión como interlocutor oficial del gobierno) y -en parte- logró ser incorporado con propios representantes al gobierno. Pero estos éxitos eran más concesiones informales y coyunturales que derechos conquistados, así que su durabilidad dependía de alianzas variables, lazos personales y una continua fuerza movilizadora por parte del movimiento piquetero.

En el caso del movimiento indígena ecuatoriano la balanza es un poco más complicada. En comparación con el movimiento de desempleados en Argentina, el de los indígenas en el Ecuador se caracteriza por una propia fuerza mayor: es más homogéneo (en términos relativos), más anclado en comunidades locales, tiene reivindicaciones más coherentes y una trayectoria de más larga data. Por consiguiente, el movimiento indígena, durante todo el ciclo de movilización, ha logrado unos cambios estructurales muy importantes: respecto al reconocimiento del movimiento como actor político, a su representación política, al reconocimiento de los pueblos y nacionalidades indígenas con sus derechos específicos. Estos logros han sido institucionalizados $\mathrm{y}$, en parte, hasta constitucionalizados, así que su vigencia y durabilidad no dependen de una continua movilización indígena. $^{13}$

Sin embargo, la experiencia de la participación política directa del movimiento indígena ecuatoriano (sobre todo en el gobierno de Lucio Gutiérrez) confirma el problema de adaptación inversa. Con la entrada al juego político, desde el inicio, surgieron clivajes entre dirección y base dentro de cada una de las organizaciones y se agravaron los conflictos de competencia entre las diferentes organizaciones. Al

crímenes estatales durante las dictaduras militares entre 1976 y 1983 se referían a los derechos humanos en un sentido más estrecho de derechos civiles básicos.

13 Ejemplos importantes incluyen la participación en instancias legislativas y ejecutivas en todos los niveles del estado a través del partido Pachakutik (y, en este momento, dentro del partido oficialista Alianza PAIS [Patria Altiva y Soberana]); el establecimiento de instituciones estatales explícitamente dedicadas a reivindicaciones indígenas (como la Dirección de Educación Intercultural Bilingüe, la Dirección Nacional de Salud de los Pueblos Indígenas y el Consejo de las Nacionalidades y Pueblos del Ecuador); y la inclusión de derechos (colectivos) indígenas en las constituciones de 1998 y de 2008. 
mismo tiempo, la apertura política fue acompañada por estrategias estatales que apuntaban a profundizar estas tensiones a través de la cooptación focalizada de líderes y segmentos del movimiento indígena. Durante el gobierno de Lucio Gutiérrez se intensificaron ambos procesos: la decepción por la participación fracasada en el gobierno potenció las dinámicas internas de debilitamiento y división. Y el presidente las empujó con más recursos y más habilidades que sus predecesores. Con sus ofertas clientelistas Gutiérrez se aprovechó tanto del distanciamiento entre dirección y base como de la fragmentación del mapa organizativo del movimiento ecuatoriano: incorporó representantes de diversas organizaciones indígenas al gobierno y a través del aparato estatal -especialmente a través de diversos programas sociales e inversiones en proyectos de infraestructura local, pero también a través de su partido Sociedad Patriótica-, consolidó redes clientelares hacia el nivel local para "disputarle al movimiento indígena su centro fundamental: las comunidades" (Dávalos 2005: 62).

(3) Comparando las actuales transformaciones políticas en Ecuador -bajo el gobierno de Rafael Correa- y en Bolivia -a partir de la primera elección de Evo Morales- con los cambios políticos que efectuaron los gobiernos de Néstor Kirchner y Cristina Fernández de Kirchner en Argentina, surge una tercera observación: parece que cierta ruptura institucional es necesaria para abrir posibilidades de cambios políticos que sean más estructurales.

Lo que caracteriza en Argentina el tratamiento de la crisis social y política a partir del 2001 es el intento -muy exitoso- por parte de los gobiernos de turno de evitar todo tipo de cambio político-institucional que sea más que adaptaciones muy específicas controladas desde arriba. Como ya se ha mencionado, Néstor Kirchner como presidente absorbió una parte importante de las reivindicaciones de la protesta social - y absorbió también una parte importante de la estructura del movimiento piquetero. Pero lo hizo manteniendo casi todas las estructuras y lógicas político-institucionales preexistentes (Arzadún 2008; Wolff 2008: 167-180).

En el caso ecuatoriano se puede comparar las dos experiencias de Lucio Gutiérrez y Rafael Correa. Gutiérrez, elegido con base en una alianza y una agenda de cambio político (si bien ambivalente), deci- 
dió mantenerse dentro del margen de las instituciones establecidas y respetó las correlaciones de fuerzas fijadas institucionalmente; así desde el inicio de su presidencia rompió con todas las promesas de su campaña presidencial y rompió sus acuerdos con el movimiento indígena (Barrera et al. 2004; Lucas 2003). En contraste, Rafael Correa desde el inicio anunció y tomó otro rumbo: decidió romper con las instituciones establecidas y en concreto con el poder de los partidos establecidos con su poder de veto (la llamada "partidocracia"); el mecanismo elegido fue la Asamblea Constituyente "de plenos poderes" que suspendió $\mathrm{y}$, en la fase de transición después de la aprobación de la nueva constitución, temporalmente sustituyó al Congreso (Ospina Peralta 2009). El resultado hasta ahora puede no ser muy fácil de evaluar, pero al menos abrió un camino hacia cambios políticos profundos que corresponden, en una parte importante, a las reivindicaciones del movimiento indígena (Wolff 2010). Entonces quedan muchas preguntas respecto a las perspectivas de la "revolución ciudadana" proclamada por Rafael Correa, pero es difícil pensar en un camino alternativo que hubiera respetado la capacidad de veto del Congreso y así de los partidos establecidos sin abandonar toda la idea de un cambio político real. Que el movimiento indígena tiene una posición muy ambivalente respecto a este proceso de cambio y una relación muy complicada (y con muchas tensiones y conflictos) con el gobierno de Correa, es otra historia (Kaltmeier 2010: 5-6; Simbaña 2010).

En Bolivia la Asamblea Constituyente y la nueva constitución sin ninguna duda constituyen elementos cruciales del proceso de "refundar Bolivia" promovido por el gobierno de Evo Morales (Ernst/Schmalz 2009; Stefanoni 2009). Aunque la idea de un "gobierno de los movimientos sociales" conlleva tensiones importantes -por ejemplo "entre el mando-obediencia estatal y la acción colectiva sindical" (Stefanoni 2009: 104)-, en términos relativos los movimientos campesino-indígenas bajo el gobierno de Evo Morales gozan de un acceso, una participación y una responsividad política bastante excepcional: tanto en comparación temporal con el status quo como en comparación espacial con otros países de la región (y del mundo). Sin embargo, una pregunta abierta es si realmente era necesaria tal ruptura institucional para lograr los cambios conseguidos. Aún así -con la elección de una Asamblea Constituyente- el gobierno y las 
fuerzas oficialistas tuvieron que negociar con la oposición todos los pasos importantes del cambio constitucional; la última revisión de la propuesta de nueva constitución, al final, la hizo el propio (viejo) Congreso con mayoría de dos tercios (Romero/Böhrt/Peñaranda 2009). A diferencia de Ecuador, en el caso boliviano parece que la importancia del proceso constituyente está más en el nivel simbólico (un nivel ya de por sí muy importante) - en términos de refundar un nuevo estado plurinacional que se constituye, por fin, bajo el protagonismo de la mayoría indígena (Vega 2009).

Pero tanto Bolivia como Ecuador demuestran también otra cosa: si bien la ruptura institucional abre posibilidades hacia una profundización de la democracia, tal camino es solo una posibilidad. La desestabilización y transformación de la institucionalidad democrática también puede provocar reacciones no democráticas y violentas por parte de los perdedores de tal transformación, o puede facilitar mecanismos de gobernación cada vez más autoritarios. Desde la perspectiva de los movimientos sociales, el problema es que, como movimientos sociales, su papel es desafiar a las instituciones (y no reforzarlas), pero para lograr una profundización de la democracia que no sea sólo coyuntural se necesita instituciones fuertes y con relativa autonomía de las correlaciones de fuerza sociales.

(4) Una cuarta observación que surge de la comparación del cambio político en los tres países no es muy agradable, ni desde la perspectiva de los movimientos sociales en particular, ni desde una perspectiva democrática en general. La observación se refiere a la importancia de líderes fuertes, líderes que son capaces de unir a movimientos, organizaciones y grupos sociales siempre heterogéneas bajo un proyecto político que depende, en gran medida, de la persona del líder y su credibilidad. Esta observación no se refiere solo al papel decisivo de Evo Morales, Rafael Correa y Nestór Kirchner en los distintos procesos de cambio político, es decir a los jefes de estado. También a nivel de los propios movimientos sociales destaca la importancia de representantes individuales. Dentro de los diferentes movimientos sociales puede haber mecanismos de participación, delegación y control social, pero su papel político a nivel nacional depende, en gran medida, de líderes fuertes que se manejen bien tanto en la esfera pública como en el ámbito político, que den dirección 
política y presencia nacional a la organización correspondiente. Así todos -el movimiento indígena ecuatoriano con Luis Macas, Antonio Vargas y otros, el movimiento campesino-indígena boliviano con Evo Morales y Felipe Quispe y las grandes organizaciones piqueteras en Argentina con Luis D'Elía o Juan Carlos Alderete- tienen sus "líderes históricos" y jefes eternos (normalmente, pero no sólo hombres).

\section{Preguntas a modo de conclusión}

Cerrando este recorrido por la experiencia de tres movimientos sociales en América del Sur, se puede concluir que la problemática de las "escalas de justicia" en el doble sentido propuesto por Nancy Fraser (2009) atraviesa los tres movimientos tratados. Si se interpreta las reivindicaciones de los tres movimientos como demandas de justicia, la tipología de Fraser nos da -a modo de conclusión- una serie de preguntas importantes así como una sistemática para analizar las demandas y los éxitos de los movimientos sociales:

Por un lado, está muy presente (y difícil de tratar) la problemática de la sustancia -el qué- de la justicia: ${ }^{14}$ ¿Cómo combinar las reivindicaciones de redistribución, representación y reconocimiento en una agenda y estrategia política coherente? ¿Cómo evitar, por ejemplo, que respuestas estatales de corto plazo, que satisfacen ciertas demandas de redistribución, logren desactivar reivindicaciones de tipo más estructural? ¿Cómo impedir que cierto reconocimiento global quede en lo simbólico sin consecuencias en términos de representación y redistribución? ¿Y cómo minimizar el riesgo de que una mayor representación política termine siendo un fin en sí? Finalmente, si se logra iniciar una transformación política profunda (como en el caso boliviano), la gran pregunta es cómo conciliar demandas de justicia tan heterogéneas: reivindicaciones que se refieren a dimensiones y principios de justicia muy diferentes. ${ }^{15}$ En términos de respuestas globales, se podría decir que los movimientos indígenas en

14 En Scales of Justice, Fraser distingue tres dimensiones sustanciales de justicia: redistribución, reconocimiento y representación.

15 Así, con respecto a las demandas indígenas, una pregunta importante (y no resuelta) se refiere a la relación entre reivindicaciones basadas en derechos individuales de tipo liberal y reivindicaciones colectivas de tipo cultural (Feldt/Ströbele-Gregor 2009: 15-16). 
Bolivia y Ecuador tuvieron éxitos impresionantes en cuanto a reconocimiento, consiguieron bastante respecto a su representación (aunque con cierto retroceso actual en Ecuador), pero alcanzaron hasta ahora muy poco en términos de redistribuir recursos económicos. Los movimientos piqueteros en Argentina, al contrario, lograron cierta redistribución de recursos (aunque de manera bastante limitada), pero en cuanto a reconocimiento y representación sus éxitos han sido muy temporales e informales.

Por otro lado, la problemática de las "escalas de justicia" según Fraser se refiere al nivel adecuado (en términos geográficos) hacia donde dirigir las reivindicaciones, el marco adecuado donde tratarlas. Los tres movimientos surgen del nivel local y tienen su fuerza por el anclaje en las comunidades locales. Por consiguiente, una serie de reivindicaciones importantes tiene como marco de referencia el ámbito local: por ejemplo, la demanda de autonomía y auto-gobierno indígena, pero también la demanda de autonomía y autogestión en el caso de "proyectos productivos" del movimiento piquetero (Wolff 2007: 9-18). Pero al mismo tiempo el marco principal al cual se refieren los movimientos sociales es el estado-nación, aunque también incluyen reivindicaciones que tienen que ver con estructuras transnacionales de gobernación (y se dirigen a actores como el Fondo Monetario Internacional o el gobierno de EEUU). Por este lado también entra una serie de problemas: ¿Cómo conciliar las demandas de autonomía local con las reivindicaciones nacionales? ¿Cómo evitar que respuestas puntuales a reivindicaciones locales logren desactivar la demanda por un cambio político más estructural? ¿Cómo impulsar el tratamiento de las reivindicaciones al nivel del estado-nación sin contribuir al refortalecimiento de un estado centralista que contradice la intención democratizadora en general y las demandas de autonomía en particular? Y al revés: ¿Cómo luchar por autonomía y reivindicaciones locales sin socavar las capacidades del estado-nación que son imprescindibles para tratar la mayoría de las reivindicaciones? Otra vez en términos de respuestas tentativas, se podría concluir que los movimientos indígena-campesinos en Bolivia lograron articular demandas locales, nacionales e internacionales. Por consiguiente, sus éxitos son mayores en todos los niveles, aunque incluso en Bolivia son siempre éxitos ambivalentes: por ejemplo, hay tensiones importantes entre el gobierno de Evo Morales -que se 
autodefine como gobierno de los movimientos sociales- y las organizaciones indígenas más importantes. Sin embargo, el movimiento indígena ecuatoriano y los piqueteros argentinos tenían muchos más problemas en desarrollar y mantener una posición coherente en cuanto a articular sus demandas políticas generales con sus diversas reivindicaciones particulares - una situación que les hizo muy vulnerables frente a estrategias clientelares de cooptación y división.

Este artículo termina, lamentablemente, con más preguntas que respuestas. Pero -y no sólo para tener una excusa elegante- se puede decir que terminar con preguntas en vez de respuestas es adecuado para el tema ya que la democratización de la democracia es un proceso de búsqueda abierta. Y en tal búsqueda probablemente el papel más importante de los movimientos sociales es poner en el tapete temas, demandas y preguntas cruciales - las respuestas, a fin de cuentas, sólo pueden surgir de los procesos empíricos de interacción, lucha y transformación política.

\section{Bibliografía}

Arzadún, Daniel (2008): El peronismo: Kirchner y la conquista del reino. Análisis de la reconfiguración de las relaciones de poder en el interior del Partido Justicialista Nacional durante el gobierno de Néstor Kirchner. Buenos Aires: Sudamericana/COPPPAL.

Auyero, Javier (2004): “The Moral Politics of Argentine Crowds". En: Mobilization, 9, 3, pp. 311-326.

Barrera, Augusto et al. (2004): Entre la utopía y el desencanto. Pachakutik en el gobierno de Gutiérrez. Quito: Editorial Planeta.

Blank, Martina (2009): Zwischen Protest und trabajo territorial. Soziale Bewegungen in Argentinien auf der Suche nach anderen Räumen. Berlin: Tranvía.

Bourdieu, Pierre (1998): "Die Arbeitslosenbewegung - ein gesellschaftliches Wunder". En: Bourdieu, Pierre: Gegenfeuer. Wortmeldungen im Dienste des Widerstands gegen die neoliberale Globalisierung. Konstanz: UVK, pp. 103-105.

Calderón, Fernando (ed.) (1985): Los movimientos sociales ante la crisis. Buenos Aires: Universidad de las Naciones Unidas.

Colectivo Situaciones (2002): "Multiplicidad y contrapoder en la experiencia piquetera". En: MTD de Solano/Colectivo Situaciones (eds.): La Hipótesis 891. Más allá de los piquetes. Buenos Aires: Ediciones De mano en mano, pp. 117-140. 
- (2003): "Der 19. und 20. Dezember: Ein Aufstand neuen Typs". En: Brand, Ulrich (ed.): ‘Que se vayan todos! Krise und Widerstand in Argentinien. Berlin: Assoziation A, pp. 27-51.

Crabtree, John (2005): Patterns of Protest. Politics and Social Movements in Bolivia. London: Latin America Bureau.

Dahl, Robert A. (1989): Democracy and its Critics. New Haven: Yale University Press.

Dávalos, Pablo (2005): "Ecuador: Plan Colombia, crisis institucional y movimientos sociales". En: Revista OSAL (Observatorio Social de América Latina), 6, 18, pp. 57-67.

Delamata, Gabriela (2004): "The Organizations of Unemployed Workers in Greater Buenos Aires" (CLAS - Center for Latin American Studies; Working Paper no. 8) (<www.clas.berkeley.edu:7001/Publications >; 18.11.2004).

Dinerstein, Ana C. (2003): "Power or Counter Power? The Dilemma of the Piquetero Movement in Argentina Post-crisis". En: Capital \& Class, 81, pp. 1-8.

Eckstein, Susan (ed.) (2001): Power and Popular Protest. Latin American Social Movements (updated and expanded edition). Berkeley: University of California Press.

Eckstein, Susan Eva/Wickham-Crowley, Timothy P. (eds.) (2003): What Justice? Whose Justice? Fighting for Fairness in Latin America. Berkeley: University of California Press.

Epstein, Edward (2006): "The Piquetero Movement in Greater Buenos Aires: Political Protests by the Unemployed Poor During the Crisis". En: Epstein, Edward/ Pion-Berlin, David (eds.): Broken Promises? The Argentine Crisis and Argentine Democracy. Lanham: Lexington, pp. 95-115.

Ernst, Tanja/Schmalz, Stefan (eds.) (2009): Die Neugründung Boliviens? Die Regierung Evo Morales. Baden-Baden: Nomos.

Feldt, Heidi/Ströbele-Gregor, Juliana (2009): Indigene Völker und Konflikt. Stärkung indigener Organisationen in Lateinamerika. Eschborn: GTZ.

Fraser, Nancy (2009): Scales of Justice. Reimagining Political Space in a Globalizing World. New York: Columbia University Press.

Huntington, Samuel P. (1991): The Third Wave. Democratization in the Late 20th Century. Norman: University of Oklahoma Press.

Johnston, Hank/Almeida, Paul (eds.) (2006): Latin American Social Movements. Globalization, Democratization, and Transnational Networks. Lanham: Rowman \& Littlefield.

Kaltmeier, Olaf (2010): "Educación intercultural, políticas de identidad y ciudadanía”. En: Ströbele-Gregor, Juliana/Kaltmeier, Olaf/Giebeler, Cornelia (eds.): Construyendo Interculturalidad: Pueblos Indigenas, Educación y Politicas de Identidad en América Latina. Eschborn: GTZ, pp. 3-8.

Kurtz, Marcus J. (2004): "The Dilemmas of Democracy in the Open Economy. Lessons from Latin America”. En: World Politics, 56, 1, pp. 262-302.

León Trujillo, Jorge (1994): De campesinos a ciudadanos diferentes. El levantamiento indígena. Quito: Abya-Yala. 
Lindblom, Charles E. (1977): Politics and Markets. The World's Political-Economic Systems. New York: Basic Books.

Lucas, Kintto (2003): El movimiento indígena y las acrobacias del Coronel. Quito: Tinají.

Mazzeo, Migue (2004): Piqueteros. Notas para una tipología. Buenos Aires: Fundación de Investigaciones Sociales y Políticas.

Nueva Mayoría (2005): "El 2005 está mostrando el mayor nivel mensual de cortes de rutas y vías públicas desde 2003”. En: Nueva Mayoría.com, 17.08.2005 (<www.nuevamayoria.com>; 02.09.2005).

Ocampo, José Antonio (2002): "Media década perdida". En: El País, 25.08.2002 (<www.elpais.com>; 04.03.2010).

O’Donnell, Guillermo (1993): “On the State, Democratization and Some Conceptual Problems: A Latin American View with Glances at Some Postcommunist Countries". En: World Development, 21, 8, pp. 1355-1369.

Offe, Claus/Wiesenthal, Helmut (1980): "Two Logics of Collective Action: Theoretical Notes on Social Class and Organizational Form”. En: Zeitlin, Maurice (ed.): Political Power and Social Theory. A Research Annual, 1, pp. 67-115.

Ospina Peralta, Pablo (2009): "Transiciones. Ecuador después del referéndum". En: CEP (Comité Ecuménico de Proyectos) Análisis de Coyuntura ( $<$ www. cepecuador.org>; 19.08.2009).

Oviedo, Luis (2004): Una historia del movimiento piquetero. De las primeras coordinadoras al Argentinazo. Buenos Aires: Ediciones Rumbos.

Oxhorn, Philip (2003): "Social Inequality, Civil Society, and the Limits of Citizenship in Latin America". En: Eckstein, Susan Eva/Wickham-Crowley, Timothy P. (eds.): What Justice? Whose Justice? Fighting for Fairness in Latin America. Berkeley: University of California Press, pp. 35-63.

Oxhorn, Philip/Starr, Pamela K. (eds.) (1999): Markets and Democracy in Latin America. Conflict or Convergence? Boulder: Lynne Rienner.

Pacheco, Mariano (2004): Del piquete al movimiento. Parte 1: de los origines al 20 de diciembre de 2001. Buenos Aires: Fundación de Investigaciones Sociales y Políticas (Cuadernos de la FISyP, no. 11).

Petras, James/Veltmeyer, Henry (2005): Social Movements and State Power. Argentina, Brazil, Bolivia, Ecuador. London: Pluto Press.

PNUD (Programa de las Naciones Unidas para el Desarrollo) (2004): La democracia en América Latina. Hacia una democracia de ciudadanas y ciudadanos. Buenos Aires: Alfaguara.

Postero, Nancy (2004): “Articulations and Fragmentations: Indigenous Politics in Bolivia". En: Postero, Nancy/Zamosc, Leon (eds.): The Struggle for Indigenous Rights in Latin America. Brighton: Sussex Academic Press, pp. 189-216.

Ramírez Gallegos, Franklin (2009): "El movimiento indígena y la reconstrucción de la izquierda en Ecuador: el caso del Movimiento de Unidad Plurinacional Pachakutik-Nuevo País". En: Ospina, Pablo/Kaltmeier, Olaf/Büschges, Olaf (eds.): Los Andes en movimiento. Identidad y poder en el nuevo paisaje político. Quito: Corporación Editora Nacional, pp. 65-94. 
Remmer, Karen L. (1990): "Democracy and Economic Crisis: The Latin American Experience". En: World Politics, 42, 3, pp. 315-335.

Roberts, Kenneth M. (1997): "Beyond Romanticism: Social Movements and the Study of Political Change in Latin America". En: Latin American Research Review, 32, 2, pp. 137-151.

Romero, Carlos/Böhrt, Carlos/Peñaranda, Raúl (2009): Del conflicto al diálogo. Memorias del acuerdo constitucional. Quito: fBDM/FES-ILDIS.

Selverston-Scher, Melina (2001): Ethnopolitics in Ecuador. Indigenous Rights and the Strengthening of Democracy. Coral Gables: North-South Center Press.

Simbaña, Floresmilo (2010): "Las relaciones entre el movimiento indígena y el gobierno". En: La Tendencia, 10, pp. 43-47.

Smith, William C./Acuña, Carlos H./Gamarra, Eduardo A. (eds.) (1994): Latin American Political Economy in the Age of Neoliberal Reform. Theoretical and Comparative Perspectives for the 1990s. New Brunswick: Transaction Publishers.

Stefanoni, Pablo (2009): "Indianismo y nacionalismo revolucionario: un análisis del gobierno de Evo Morales". En: Ospina, Pablo/Kaltmeier, Olaf/Büschges, Olaf (eds.): Los Andes en movimiento. Identidad y poder en el nuevo paisaje politico. Quito: Corporación Editora Nacional, pp. 95-106.

Strasser, Carlos (2000): Democracia \& Desigualdad. Sobre la "democracia real" a fines del siglo XX. Buenos Aires: CLACSO.

Ströbele-Gregor, Juliana (1994): "From Indio to Mestizo...to Indio: New Indianist Movements in Bolivia". En: Latin American Perspectives, 21, 2, pp. 106-123.

- (2006): "Für ein anderes Bolivien - aber für welches? Indigene Völker und Staat in Bolivien”. En: Bopp, Franziska/Ismar, Georg (eds.): Bolivien. Neue Wege und alte Gegensätze. Berlin: Wissenschaftlicher Verlag, pp. 279-326.

Svampa, Maristella/Pereyra, Sebastían (2004): Entre la ruta y el barrio. La experiencia de las organizaciones piqueteros. Buenos Aires: Editorial Biblos.

Tarrow, Sidney (1998): Power in Movement: Social Movements and Contentious Politics. New York: Cambridge University Press.

Van Cott, Donna Lee (2005): From Movements to Parties in Latin America. The Evolution of Ethnic Politics. Cambridge: Cambridge University Press.

Varios Autores (2007): "Bolivia: ¿el fin del enredo?". Tema Central en: Nueva Sociedad, 209, pp. 31-172.

Vega, Oscar (2009): "Wege zum guten Leben. Der bolivianische Verfassunggebungsprozess". En: Ernst, Tanja/Schmalz, Stefan (eds.): Die Neugründung Boliviens? Die Regierung Evo Morales. Baden-Baden: Nomos, pp. 17-31.

Waisman, Carlos H. (1999): "Civil Society, State Capacity, and the Conflicting Logics of Economic and Political Change". En: Oxhorn, Philip/Starr, Pamela K. (eds.): Markets and Democracy in Latin America. Conflict or Convergence? Boulder: Lynne Rienner, pp. 43-59.

Whitehead, Laurence (2001): "Bolivia and the Viability of Democracy". En: Journal of Democracy, 12, 1, pp. 6-16. 
Wolff, Jonas (2005): "Ambivalent Consequences of Social Exclusion for Real-existing Democracy in Latin America: the Example of the Argentine Crisis". En: Journal of International Relations and Development, 8, 1, pp. 58-87.

- (2007): "(De-)Mobilising the Marginalised. A Comparison of the Argentine Piqueteros and Ecuador's Indigenous Movement”. En: Journal of Latin American Studies, 39, 1, pp. 1-29.

- (2008): Turbulente Stabilität. Die Demokratie in Südamerika diesseits ferner Ideale. Baden-Baden: Nomos.

- (2009): "De-Idealizing the Democratic Civil Peace: On the Political Economy of Democratic Stabilisation and Pacification in Argentina and Ecuador". En: Democratization, 16, 5, pp. 998-1026.

- (2010): Elitenwandel in Ecuador. Soziopolitische Akteure und politische Perspektiven. Berlin: Friedrich-Ebert-Stiftung.

- (2011): "Del gobierno a la crisis. Acerca del debilitamiento del movimiento indígena ecuatoriano". En: Büschges, Christian/Kaltmeier, Olaf/ Thies, Sebastian (eds.): Las culturas políticas en la región andina. Madrid/Frankfurt am Main: Iberoamericana/Vervuert, pp. 281-295.

Yashar, Deborah J. (2005): Contesting Citizenship in Latin America. The Rise of Indigenous Movements and the Postliberal Challenge. Cambridge: Cambridge University Press.

Zamosc, Leon (2007): "The Indian Movement and Political Democracy in Ecuador". En: Latin American Politics \& Society, 49, 3, pp. 1-34. 


\section{Sérgio Costa}

\section{¿Unidos e iguales? Anti-racismo y solidaridad en el Brasil contemporáneo ${ }^{1}$}

El tipo ideal de la solidaridad moderna, del cual parten invariablemente la sociología y la ciencia política, es aquel patrón que se consolidó en unos pocos países de Europa Occidental, en los siglos XVIII y XIX. Es en ese momento que, según sintetiza Brunkhorst (2002: 11), las diferentes fuentes y modelos de solidaridad preexistentes -incluyendo desde la "amistad cívica" de los griegos y la fraternidad y el amor al prójimo cristianos, hasta la reciprocidad estamental y aristocrática- convergen y se funden en la "solidarité républicaine", entendida como "solidaridad democrático-igualitaria entre ciudadanos". La solidaridad moderna es definida así como algo que va más allá del mero sentimiento colectivo de pertenencia entre semejantes. Se trata de una categoría del orden de la sociedad (Gesellschaft) y no de la comunidad (Gemeinschaft), ya que conlleva y "unifica dialécticamente contrastes, contradicciones y diferencias" (Brunkhorst 2002: 15).

Así, más que el compartir trazos de semejanza, como se constata, por ejemplo, en la solidaridad entre los miembros de un mismo estamento en una sociedad estamental, la solidaridad moderna requiere la igualdad entre los que la comparten. Al final de cuentas, sin ese acto de compartir la condición de iguales portadores de los mismos derechos y deberes, la solidaridad moderna, racional y, de algún modo, dependiente de la elección y del consentimiento individual no podría reproducirse.

El surgimiento del patrón moderno de solidaridad se da, en Europa Occidental, de forma simultánea e interdependiente con el Estadonación. De un lado, se constituye en el ámbito del Estado-nación, el nuevo eje de identidad en torno al cuál se rearticularían los vínculos de pertenencia colectiva, antes dedicados a la localidad, a la provincia. De esa manera, la nación moderna demarca el contexto afectivo-

1 Una versión anterior en portugués de ese artículo salió publicada en Pensamiento Iberoamericano, 1, pp. 231-250. 
simbólico en el que la solidaridad moderna gana sus contornos. A través del control del Estado sobre el territorio, a su vez, quedan establecidas las fronteras físicas y, en consecuencia, los límites demográficos de la comunidad política que comparte la solidaridad cívica. Esa delimitación del Estado-nación, en los ámbitos demográfico, territorial y simbólico es condición para la democracia moderna, en la medida que: i) define quiénes son, efectivamente, los ciudadanos que, bajo el principio de igualdad de estatus político, se constituyen como autores y destinatarios de las reglas comunes establecidas ii) demarca la jurisdicción, esto es, el espacio físico donde prevalecen las reglas acordadas iii) asegura la reproducción de la "solidaridad entre extraños", vinculándolos, imaginariamente, como iguales, a través de la pertenencia nacional (Habermas 1998: 126ss.; 2005: 109 ss.). ${ }^{2}$

La sociología y la ciencia política no nos ofrecen referencias teórico-metodológicas para estudiar las relaciones entre la solidaridad moderna y el Estado-nación que escapan al modelo brevemente descrito encima. Sin embargo, aplicar simplemente tal modelo al estudio de la cohesión y de la solidaridad social en las sociedades post-esclavistas y postcoloniales de América Latina lleva, inevitablemente, a descodificar todas las diferencias encontradas como una falta que debe compensarse. Es decir, quién toma esa secuencia histórica específica observada en Europa Occidental como si se tratase de un modelo general seguido, necesariamente, en todas las partes, llega, inevitablemente, a la conclusión de que la ciudadanía, la solidaridad y el Estado-nación realmente existentes en América Latina se presentan como estructuras (aún) no existentes o copias imperfectas del modelo europeo. Las diferencias sincrónicas son, de ese modo, proyectadas sobre un eje cronológico transformando el ser de las instituciones y de las sociedades latinoamericanas en un venir a ser del ideal normativo extraído de una "Europa hiper-real" (Chakrabarty 2000; Randeria 2005; Boatcă/Costa 2010).

2 Debe resaltarse que, incluso en Europa Occidental, la igualdad ciudadana no incluía originalmente a toda la población: “[...] sólo después de duras luchas políticas, los trabajadores, las mujeres, los judíos, los gitanos, los homosexuales y los exiliados pasaron a ser reconocidos como seres humanos con derecho a un tratamiento plenamente igualitario" (Habermas 1998: 179). 
Para escapar a esa trampa metodológica, busco, en el presente artículo, operar con las categorías extraídas de la historia europea de modo explícitamente comparativo. Esto es, en vez de tomarlas como la materialización de presupuestos teóricos que deberían repetirse en todas partes, busco describir cómo los procesos a los que esas categorías se refieren se desarrollaron, efectivamente, en el caso brasileño que me compete aquí estudiar.

Con la intención de discutir las tensiones entre racismo, antiracismo y solidaridad en Brasil y, en especial, la relación entre los afro-descendientes y el conjunto de la nación, el presente artículo comienza por la historia, buscando delimitar, en su primera parte, las fases del proceso de incorporación de indígenas y afro-descendientes a la nación brasileña. La segunda sección describe las principales líneas de controversia en el debate actual en torno de las políticas compensatorias dirigidas a los afro-descendientes, en cuanto la tercera y última parte está dedicada a un breve balance conclusivo, en el que exploro los contrastes entre la construcción de la solidaridad moderna en Brasil y el modelo europeo occidental.

\section{Apogeo y declive del discurso del mestizaje}

El proceso moderno de constitución de la identidad nacional de Brasil está entreverado de tropiezos variados, además de inflexiones importantes en la forma de auto-representar la nación. Así, la transición del Imperio a la República al final del siglo XIX está marcada, en los ámbitos de la reflexión intelectual y de los discursos políticos, por la fuerte influencia del racismo científico, recibido de Europa y, más tarde, de los Estados Unidos. En ese contexto, los ideólogos fundadores de la nación brasileña se veían enfrentados a la dificultad de conciliar los postulados de la "superioridad racial" e intelectual del

3 Las referencias al sustantivo raza y a los adjetivos derivados, además de expresiones correlativas como ario, mestizo, degeneración o regeneración racial reproducen aquí el vocabulario de los debates de la época. Desde hace algunos años, la investigación genética mostró que, desde el punto de vista biológico, no hay elementos que posibiliten agrupar los trazos fenotípicos como el color de la piel, el tipo de cabello, los formatos de la nariz, etc. en grupos raciales distintos genéticamente. En el uso que se hace de esas expresiones, aún hoy, se trata de clasificaciones culturales arbitrarias que, como se sabe, pueden, en virtud del prejuicio existente, presentar consecuencias importantes para la distribución de las oportunidades sociales, así como para las relaciones cotidianas (ver Costa 2006). 
tipo humano de piel clara e identificado con el origen europeo a la realidad de la población brasileña, caracterizada por la amplia variedad de tipos físicos y coloraciones de piel. ${ }^{4}$

Es bajo el marco de este imaginado dilema que se construye aquello que se reconocía, conforme a los patrones de la época, como las primeras reflexiones científicas sobre el proceso de formación nacional (Hofbauer 2006; Schwarcz 1993). Aquí se organizan, desde muy temprano, dos formas distintas de interpretar y aplicar, al caso brasileño, los nuevos descubrimientos de la ciencia racista internacional. La primera de esas vertientes tiene como su principal exponente al médico forense Raimundo Nina Rodrigues (1862-1906) que, a través de sus investigaciones en la región del Recôncavo de Bahía, buscaba fundamentar su resistencia a la constitución de "familias inter-raciales". La segunda vertiente, fundada, inicialmente, sobre los trabajos del jurista y crítico literario Sylvio Romero (1851-1914), defendía que la mezcla de tipos físicos variados llevaría al blanqueamiento paulatino de la población, vislumbrando en ello las posibilidades de "regeneración racial" de los brasileños. De cada uno de ese conjunto de ideas se desprendían, como se muestra más abajo, perspectivas distintas para la incorporación de los afro-descendientes en la nación brasileña.

Nina Rodrigues acompañaba de cerca las investigaciones de la antropología criminal italiana, capitaneada por Cesare Lombroso (18361909) y buscaba, así, establecer los nexos entre el desarrollo moral y el grado de "progreso biológico-racial" de cada una de las diferentes "razas". Se desprenden de ahí las posiciones de Nina Rodrigues en el contexto del debate penal y jurídico de la época: para él, cualquier

4 Por ocasión de la proclamación de la República en 1889, Brasil contaba con cerca de 14.333.000 habitantes, distribuidos, conforme el censo de 1890 de la siguiente manera: indígenas 440.000, blancos 6.302.000, negros 2.098.000, pardos 5.934.000. En el período entre 1851-1960, Brasil recibió aproximadamente: 1.732.000 emigrantes provenientes de Portugal, 1.619.000 de Italia, 694.000 originarios de España, 250.000 de Alemania, 229.000 de Japón (cf. Pena et al. 2000). Entre 1551 y 1860 llegaron a Brasil cerca de 4.029 .800 africanos esclavizados, más del $40 \%$ de los poco más de 10 millones de africanos traídos al conjunto de las Américas en el ámbito del tráfico negrero (ver Alencastro 2000: 69). Según el último censo realizado en $2010,47 \%$ de los aproximadamente 190 millones de brasileños son blancos, 43\% son pardos, 8\% "pretos" (negros), siendo el restante de la población indígenas y descendientes de asiáticos (<www.ibge.gov.br>, 01.09.2011). 
proyecto de igualdad jurídica y política de los individuos pertenecientes a las diferentes "razas" ignoraría el hecho elemental de que, independientemente de la voluntad individual, los afro-descendientes se encontraban imposibilitados biológicamente para alcanzar el grado de madurez moral de los blancos, hecho éste que hacía inviable su integración, sin distinciones, como ciudadanos, portadores de los mismos derechos y deberes de los blancos. Siguiendo tal argumentación, Nina Rodrigues reivindicaba que la imputabilidad penal fuese atribuida con base en las posibilidades de "desarrollo biológico-moral" de cada "raza".

Aunque defendiese que algunos "mestizos" pudiesen escapar al designio de la "degeneración", Nina Rodrigues condenaba vehementemente la "mezcla de razas", defendiendo que una elite blanca, mantenida apartada de esa mezcla, asumiese la posición de dirección de la nación (Nina Rodrigues 1935; [1894] 1938). ${ }^{5}$

Sylvio Romero era un lector contumaz de la bibliografía racista publicada en Europa y principalmente en Alemania, acompañando con especial interés los trabajos de Ernst Haeckel (1834-1919). Su defensa de la "mezcla racial regeneradora" se fundaba en la creencia de que cualquier perspectiva de futuro para la nación brasileña necesitaba enfrentar el problema en lo que entendía era su raíz última, es decir, la fuente biológica; para el era necesario, en una palabra, blanquear la población. Para ello, sería necesario encontrar formas de impedir que los descendientes de europeos y los alemanes, en particular, se concentrasen en grupos étnicos cerrados; deberían, al contrario, esparcirse por todo el país, distribuyendo su "capital eugenésico" por las diferentes regiones.

5 Aunque Nina Rodrigues haya tenido muchos seguidores en Brasil, estos procuraron librar la obra del autor de la influencia marcadamente racista. De hecho, las ideas del autor sólo vendrían a ser suscritas en toda su plenitud, décadas más tarde, por el investigador nazi Heinrich Krieger (1940), para quién Nina Rodrigues fue el único pensador brasileño que aceptó la evidencia de que son necesarias intervenciones legales que garanticen el tratamiento diferenciado en el campo político y jurídico de las varias "razas". En su reconstrucción del debate en torno del racismo científico en Brasil, Krieger se muestra enfático al condenar todas las vertientes que preconizaban la "mezcla de razas", insistiendo en el riesgo de la degeneración y afirmando que la mezcla no llevaría a un paulatino blanqueamiento, sino a un rápido oscurecimiento de la población. 
Romero atribuía a los indígenas y a los negros un lugar ambiguo en el interior de la nación. En el campo cultural, aceptaba que los legados indígena y afro-brasileño eran elementos constitutivos de la singularidad brasileña. Sin embargo, al mismo tiempo entendía que el "mestizaje" sucesivo debería conducir al desaparecimiento paulatino de los trazos físicos y de las marcas "raciales" de los indígenas y negros, de forma que se constituyese una nación de blancos:

De los tres pueblos que constituyeron la actual población brasileña, el que dejó un rastro más profundo fue por cierto el portugués; le sigue el negro y después el indígena. Sin embargo, mientras la acción directa de las dos últimas tiende a disminuir, con la internación del salvaje y la extinción del tráfico de negros, la influencia europea tiende a crecer con la emigración y por la natural propensión a que prevalezca el más fuerte y el más hábil. El mestizo es la condición para la victoria del blanco, fortaleciéndole la sangre para adaptarlo a los rigores del clima. Es en su forma aún grosera una transición necesaria y útil, que camina para aproximarse del tipo superior (Romero [1888] 1953: 149, cursivas añadidas).

Más tardíamente, ya en los años 1920 a 1940, Oliveira Vianna (18831951) retomaría la idea del mestizaje blanqueador, pudiendo ser tratado, bajo tal aspecto, como un continuador explícito de la obra de Sylvio Romero. Oliveira Vianna (1923) estudia en detalle la distribución geográfica de los diversos "grupos raciales" que constituyen la población brasileña, mostrando, a través de proyecciones demográficas, que el blanqueamiento paulatino de la población era un hecho ineludible, asentado en dos procesos combinados: la emigración y la tendencia de los emigrantes y sus descendientes a casarse con brasileños, de un lado, y la fecundidad mayor de los blancos, por el otro.

Las premisas racistas, de las que partían los primeros ideólogos de la nación brasileña, no llegaron a ser institucionalizadas en la forma de políticas concretas, como regímenes legales de apartheid. No obstante, permanecieron durante muchas décadas como referencia importante para la constitución de los valores y patrones de comportamiento dominantes en Brasil (Costa/Gurza 2006).

La influencia del racismo científico sólo perdería su ímpetu con la consolidación, en los años 1930, del discurso nacionalista que recusaba las jerarquías racistas y celebraba las virtudes de Brasil como "crisol de razas y culturas". Desde el punto de vista intelectual, el sociólogo y antropólogo Gilberto Freyre (1900-1987) es la expresión- 
síntesis de esa nueva manera de representar a la nación. Para ello, Freyre reconstruye la formación de la nación brasileña desde la colonia (Freyre [1933] 1999) mostrando como se comprueba, en ese proceso, la constitución de una "brasilidad" como amalgama exitosa de los tres grupos fundadores de la nación: indígenas, portugueses y africanos. Políticamente, la nueva ideología nacionalista ganaría, bajo el llamado Estado Nuevo - la dictadura populista de Getúlio Vargas (1937-1945)- su incorporación más acabada.

Se constituyen, en ese momento, las bases de una ideología del mestizaje que, en sus aspectos culturales, orientaría la acción de los gobiernos brasileños hasta por lo menos el final de la dictadura militar en 1985. En tal cuerpo ideológico, la afirmación de una "brasilidad mestiza" -en los términos sistematizados intelectualmente por Freyrees mantenida como prerrequisito de la constitución de la comunidad política nacional. ${ }^{6}$

Se trata aquí de la construcción de un discurso nacionalista no racial (Davis 1999), en el sentido preciso de que evita la raza en cuanto criterio legítimo de adscripción social, la meta-raza a la que se refiere Freyre o la profesada "unidad de la raza" del discurso varguista (Carneiro 1990: 35) se convierten en una metáfora de la nacionalidad. No son, por lo tanto, conceptos raciales, sino no raciales, a pesar de que se valiesen de la semántica de la raza. Es decir, la raza sólo gana sentido en el cuerpo de una ideología que diferencia y segmenta los grupos humanos conforme a marcas exteriores. Un discurso que rompe con tales distinciones es un discurso no racial, lo que no significa obviamente que se trate de una ideología anti-racista o no racista e incluso que sea neutra en relación a la permanencia de las desigualdades motivadas por el racismo.

El discurso del mestizaje en Brasil comporta como en otros países latinoamericanos (Martínez-Echazábal 1998) una dimensión de género. Tanto en el trabajo de Freyre, cuanto bajo la dictadura de Getúlio

6 La comparación de Senkman (1997: 133ss.) entre el varguismo y el peronismo es esclarecedora para mostrar como la lógica de la identidad en ambos casos no "buscaba excluir, sino integrar todos los agregados al pueblo para redefinir la nueva nación”. Así, se incluyen, en el caso brasileño, en la nueva identidad nacional "las masas urbanas de color" tratadas por las oligarquías del café, en la República Vieja, como "un Otro en el interior de la nación" (Senkman 1997: 133). 
Vargas, se congela la imagen de la mujer sin subjetividad propia y sin vida cívica y política autónoma; en ese constructo político, la mujer se realiza y se completa en cuanto objeto de deseo masculino. ${ }^{7}$

En su expresión social, el discurso del mestizaje es aristocrático, romantiza las desigualdades, banalizándolas. No hay, sin embargo, una justificación moral para las desigualdades que esté apoyada en la creencia en alguna jerarquía natural/biológica entre los diferentes miembros de la nación. Para que se transforme en una cuestión moral, la igualdad política precisa ser políticamente construida e individualmente interiorizada como un valor, lo que simplemente no se dio en la historia brasileña. La justicia social no es un bien natural, es un valor político que determinada sociedad puede construir, o no.

En su aspecto cultural, el discurso del mestizaje inaugurado en los años 1930 procura disciplinar la heterogeneidad existente, seleccionando, a través de la acción discursiva y política sistemática, aquellas manifestaciones que conforman la identidad nacional, restringiéndose expresiones divergentes, de ahí su trazo heterofóbico. En ese contexto expresiones de la cultura afro-brasileña como la capoeira o el samba, antes despreciadas e incluso criminalizadas por la policía y por el Estado, pasan a ser iconos de la identidad nacional, mereciendo el apoyo explícito del Estado (Röhrig-Assunção 2005). Al mismo tiempo, se restringen las expresiones de lo que se consideraba cultura alienígena, como las escuelas bilingües y las festividades y asociaciones mantenidas por emigrantes y sus descendientes.

En su dimensión racial, el rechazo del concepto de raza del debate público presenta resultados ambiguos. Por un lado, el racismo biolo-

7 En varias manifestaciones públicas, programas de gobierno y proyectos de ley, el principal creador de la ideología varguista, el ministro de Educación Gustavo Capanema, buscaba asegurar que la mujer no extrapolase sus papeles de madre y esposa, de tal suerte que se garantizase la estabilidad del núcleo familiar. Así, su Plan Nacional de Educación de 1937 propuso un currículo de enseñanza media especial para niñas entre 12 y 18 años y que se destinaba a prepararlas para "la vida en el hogar". De forma similar, el estatuto de la familia, también idealizado por Capanema, determinaba en su artículo 13 que "a las mujeres les será dada una educación que las torne predispuestas al matrimonio, deseosas de la maternidad, competentes para la cría de los hijos y capaces de la administración de la casa" (Schwartzman/Bomeny/Costa 1984: 112). El artículo 14, a su vez, definía que "no podrán las mujeres ser admitidas sino a los empleos propios de la naturaleza femenina, y dentro de los estrictos límites de la convivencia familiar" (Schwartzman/Bomeny/Costa 1984: 112). 
gicista pierde su legitimidad, por otro, el racismo presente en las relaciones y en las estructuras sociales permanece intocado. En el ámbito del discurso del mestizaje y del conjunto de prácticas políticas que le acompañan, el énfasis en el blanqueamiento, en aquel sentido biológico hasta entonces dominante, es sustituido por el discurso de la modernización, en el sentido económico y social. Ese trazo del discurso del mestizaje en cuanto apuesta en el futuro y decurrente idealización de la modernidad, me parece, tantas décadas después, que continúa relativamente intocado. Es todavía la religión civil brasileña, la que elige presidentes, legitima políticas públicas excluyentes y convierte a los "atrasados" en culpables de su miseria. Es en la conjunción con el nacionalismo modernizador que se reformulan y se generalizan adscripciones sociales negativas de fondo racial y regional. Así, en el catálogo de los prejuicios establecidos, el negro en cualquier región carga el estigma del atraso, el migrante que viene del noreste del país al sur se transforma en sinónimo del atraso y el país como un todo, delante de un mitificado "primer mundo" se autorrepresenta como la encarnación del atraso.

Un mito que persistió desde los años 1930 y que parece ir deconstruyéndose a partir de los años 1980 es el de la brasilidad inclusiva y abierta, capaz de integrar en su interior armónicamente las diferencias. De hecho, fenómenos como la rearticulación del Movimiento Negro, el surgimiento de un movimiento feminista, la introducción en el debate público del tema de la homosexualidad, el crecimiento de las iglesias no católicas, el fortalecimiento del movimiento indígena, la reconstrucción de una etnia quilombola ${ }^{8}$ y la recuperación de una etnicidad híbrida por parte de los descendientes de emigrantes conforman un contexto de pluralismo cultural que contrasta con la imagen, que se estructura desde los anos 1930, de la nacionalidad unitaria capaz de traducir todas las reivindicaciones de reconocimiento de la diferencia bajo la clave de la brasilidad.

8 Se refiere aquí a poblaciones que viven en quilombos (palenques), o sea, territorios urbanos o rurales ocupados por grupos asociados por lazos de ancestralidad al pasado de resistencia a la esclavitud. En el marco global de difusión del multiculturalismo esas comunidades ancestrales son redescubiertas y reconstruidas en el ámbito del derecho de la política tanto en Brasil como en otros países de América Latina marcados por una fuerte presencia de afro-descendientes en su población (ver Costa 2011a; 2011b). 


\section{Del racismo al anti-racismo}

Con base en las investigaciones ya disponibles en el campo de la sociología del racismo y del anti-racismo, se puede afirmar que negros y blancos no disponen de las mismas oportunidades sociales en Brasil. Se trata, por lo tanto, de una sociedad inicua, en un sentido que va más allá de la constatación de que existen desigualdades sociales: lo que se percibe es que el reconocimiento de los méritos y las recompensas individuales no son distribuidos con base en un criterio universal, como el de la justa bonificación del esfuerzo personal, sino con base en marcas corporales, es decir, en características intangibles por la acción transformadora del individuo. $\mathrm{O}$ sea, la sociedad se presenta política y jurídicamente como liberal, en el sentido de que se orienta por el principio individualista de la ciudadanía, pero en realidad funciona como una sociedad estamental o de castas que limita sistemáticamente las oportunidades de ascensión social de los grupos demográficos, conforme se distancien del conjunto de las características físicas que son asociadas, imaginariamente, al origen europeo.

Las diferencias de los indicadores sociales entre los negros (incluidas aquí las categorías del censo de pretos [negros] y pardos) y los blancos se manifiestan en todos los campos posibles y presentan en muchos casos niveles de disparidad semejantes a aquellos observados en las desigualdades de género. Es decir, si se toma el conjunto de negros y el conjunto de blancos brasileños, por un lado, y el conjunto de hombres y mujeres, por otro, se observa que, para algunos indicadores sociales, la desigualdad entre esos grupos es comparable. Los datos sobre los ingresos medios son particularmente expresivos de las desigualdades relacionadas con el género y el color de la piel en Brasil. Así, de acuerdo con el balance publicado por las Naciones Unidas y por el Instituto de Pesquisa Económica Aplicada (IPEA), el principal instituto de investigaciones sociales vinculado al gobierno brasileño, en 2004, las mujeres blancas recibían, de media, un $61 \%$ de lo que ganaban, de media, los hombres blancos. Los hombres negros, a su vez, recibían de media, la mitad del salario medio de los hombres blancos, mientras que las mujeres negras recibían de media el $64,5 \%$ de lo que ganaban, de media, los hombres negros y solamente el $32 \%$ del rendimiento medio de los hombres blancos (<www.ipea.gov.br/ igualdaderacial $>$, 16.10.2011). 
Además, las diferencias de ingreso no pueden ser explicadas por los niveles de escolaridad, ya que, en media, las mujeres están más escolarizadas que los hombres e incluso las desigualdades de salario entre los blancos y los negros, estos últimos, menos escolarizados en la media, son apenas en parte consecuencia de las diferencias de escolaridad:

[...] las diferencias de escolaridad entre blancos y negros explican apenas una parte de la desigualdad salarial. Parte significativa de esa diferencia sólo es explicada por la discriminación propiamente dicha, lo que viene siendo comprobado por una serie de estudios desarrollados en esa área. Algunos de ellos llegan a señalar que el 53\% de las diferencias de rendimiento entre negros y blancos puede ser explicada por la pura discriminación (Pinheiro et al. 2006: 41).

La propia sociedad brasileña se autopercibe como racista. Encuestas de opinión representativas para el conjunto del país constatan que casi $90 \%$ de la población reconocen que hay prejuicio de color en Brasil aunque solo $4 \%$ de la población se reconozcan como racista (Santos/Silva 2005).

Si la presencia del racismo no es ya contestada en ningún sector representativo en el espacio público brasileño, los medios para combatirlo son, hoy, objeto de una intensa y rica polémica, no sólo en los medios académicos, sino también en la política institucional e incluso dentro de los propios movimientos sociales. Particularmente controvertidas son las llamadas políticas de acción afirmativa o discriminación positiva inspiradas en las medidas de combate al racismo adoptadas en los Estados Unidos, desde la emergencia del movimiento de los derechos civiles.

Las políticas de acción afirmativa vienen siendo implementadas en Brasil desde el comienzo de la presente década e implican, fundamentalmente, cuotas para afro-descendentes en cargos públicos de dirección y para el acceso a las universidades. La legitimación de ese tipo de política se benefició fuertemente del clima de discusión sobre el racismo en Brasil desencadenado por la Conferencia de la ONU contra el racismo y la discriminación realizada en Durban, África del Sur, en 2001. Los encuentros preparatorios de la Conferencia y la amplia cobertura de las discusiones por los medios de comunicación introdujeron la necesidad de combatir el racismo en la agenda pública motivando reacciones inmediatas del gobierno federal que, de for- 
ma simultánea a la Conferencia estableció las primeras medidas más efectivas de discriminación positiva, junto a algunos ministerios (Costa 2006). Además de eso, en consonancia con las recomendaciones surgidas de la Conferencia, se creó en 2003, la Secretaría Especial de Políticas de Promoción de la Igualdad Racial (SEPPIR), con estatus ministerial, y responsable de acciones de considerable impacto público. Cabe destacar el apoyo a dos proyectos de ley que se convirtieron en los últimos meses en objeto de una enconada controversia política. Se trata de la Ley de Cuotas (Proyecto Legislativo 73/1999) y del Estatuto de la Igualdad Racial (Proyecto Legislativo 213/2003). La Ley de Cuotas establece la obligatoriedad de que el $50 \%$ de las plazas en las universidades públicas sean ocupadas por alumnos egresados de escuelas públicas, tomándose en cuenta, la proporción de indígenas y afro-descendientes ${ }^{9}$ en la población de la región donde se sitúa la institución en cuestión. La Ley de Cuotas, aunque más de 80 universidades públicas han adoptado medidas de admisión preferencial de afro-descendientes, continuaba en finales de 2011 retenida en el Senado Federal. ${ }^{10}$ El Estatuto de la Igualdad Racial implica un conjunto amplio de medidas de promoción de la igualdad racial. La ley ha tramitado por casi 10 años en el parlamento de Brasil hasta ser aprobado en 2010, después de la supresión de los puntos más controversiales del proyecto original como la obligación de identificación a partir de categorías raciales (Cardoso 2010; Costa 2010).

De forma general, los que defienden políticas de acción afirmativa como cuotas, entienden que éstas cumplen un objetivo estratégico doble. En un primer nivel, se prestan a la compensación y a la corrección de las desigualdades de acceso a los bienes públicos. Al mismo tiempo, deben favorecer el proceso de construcción de la identidad

9 No existe unanimidad en la nomenclatura usada para referirse a la población afro-descendientes en la legislación de Brasil. Los movimientos sociales antiracistas se refieren unas veces a afro-descendientes, otras a negros. El censo poblacional adopta dos categorías: pretos (negros) y pardos. Los documentos oficiales que reglamentan las políticas de acción afirmativa se refieren a los beneficiarios de esas medidas ora como afro-descendientes, ora como negros o "pretos" y pardos.

10 El proyecto de ley surgido y aprobado en 2008 en la Cámara de Diputados necesita, conforme el sistema bicameral de Brasil, pasar por la votación en el Senado Federal (<www.camara.gov.br/proposicoesWeb/fichadetramitacao?idPro posicao $=15013>, 10.10 .2011)$. 
racial de los afro-descendientes, fortaleciendo la movilización social y la construcción de las víctimas del racismo como sujeto político. Lo que se defiende es que, si los afro-descendientes son discriminados por sus trazos físicos, se debe estimular que se articulen, políticamente, como negros, de tal suerte que hagan de las características que son, hoy, objeto de prejuicio, razón de orgullo y fuente de compensación social (Silverio 2003). De acuerdo con esos autores, el llamado mito de la democracia racial que nace en los años 1930 opera como un manto que impide a las víctimas del racismo darse cuenta de la discriminación e inhibe su acción política. Las políticas de acción afirmativa se prestarían, por eso, a "hacer caer la máscara" ideológica que aún recubre la realidad de la opresión racial (Guimarães 2000). Los que se oponen a las políticas de acción afirmativa buscan mostrar que tales medidas suponen la existencia de una sociedad bi-racial que no se corresponde con la historia brasileña de asimilación de todos los grupos de color en el cuerpo de la nación. De acuerdo con tal interpretación, las distinciones extremadamente opuestas entre grupos de color, como el "negro es negro, blanco es blanco", que ven como característico de la sociedad estadounidense, no tienen sentido en Brasil. Prevalecería, entre los brasileños, una escala cromática móvil entre el claro y el oscuro, definida siempre en el ámbito de las relaciones sociales concretas y no con base en una polarización previa blanco/ negro (para una compilación amplia de ese debate ver Grin 2010).

Además, el ideario del mestizaje no sería apenas una ideología, manipulada por el Estado y por las elites con el propósito de legitimación de un orden social inicuo. Según tal visión, se trata de un conjunto de prácticas y valores interiorizados como legítimos y que, por encontrarse enraizados en la cultura y la historia del país, son expresión de una identidad personal y cultural que sus portadores quieren ver preservada. Así, conforme Fry, la celebración de la mezcla no condujo históricamente al ocultamiento del racismo, sino al surgimiento de un mito refundador de la nación: "Vista de esa manera, la democracia racial es un mito en el sentido antropológico del término: una afirmación ritualizada de principios considerados fundamentales a la constitución del orden social" (Fry 2001: 52).

En lugar del énfasis en la conciencia racial, la categoría fundamental que utilizan estos críticos de la acción afirmativa es la de ciudadanía universal como posibilidad y referencia a la integración justa 
de todos los brasileños. Ello no implica la desconsideración de la realidad marcada por el acceso desigual a los derechos de ciudadanía y a los bienes públicos. No obstante, la referencia a la ciudadanía universal permanece, con todo, como meta y objetivo (Maggie 2001; Fry 2005).

\section{Conclusiones: anti-racismo y solidaridad}

La constitución del Estado-nación en Brasil no coincide, como en el modelo europeo-occidental, con la emergencia de algún tipo de solidaridad igualitaria. La esclavitud sobrevive, todavía 66 años en la nación independiente y, aún después de su abolición, en 1888, no se establece el tratamiento igualitario de los diferentes grupos de color que componen la población brasileña. Así, hasta los años 1930 los ideólogos fundadores de la nación, de forma general, no creían que se pudiese unir en la misma comunidad política a blancos, indígenas, negros y "mestizos", grupos a los cuales eran atribuidas capacidades y facultades innatas muy distintas. Según las ideologías nacionalistas dominantes hasta esa ocasión era necesario o mantener "las razas inferiores" en condición de subordinación legal o promover la mezcla de razas, de modo que las "razas inferiores" desapareciesen. O sea, la nación se constituye, en esa primera fase, como una comunidad de desunidos y desiguales.

Bajo el dominio del discurso del mestizaje a partir de los años 1930, las dudas sobre la posibilidad de unidad de la nación cultural y "racialmente" heterogénea son disipadas, constituyéndose, desde entonces, un cimiento discursivo hacia una fuerte identificación de todos los brasileños con la nación. Aún así, no se puede decir que la solidaridad entre iguales haya sido establecida en ese período, ya que la distribución de oportunidades sociales continuó fuertemente influenciada por los trazos físicos de los ciudadanos. El discurso del mestizaje, por lo tanto, une a los brasileños, sin garantizar la emergencia de la nación igualitaria.

En el momento presente, un conjunto de leyes y políticas públicas promete establecer finalmente la nación de iguales, en el sentido de neutralizar la importancia de trazos exteriores, como el color de la piel, a favor del reconocimiento de los méritos individuales. Los críticos de esas medidas entienden, sin embargo, que políticas basa- 
das en clasificaciones raciales "separarían" la nación, cuyo "mito fundador" es precisamente la inexistencia de las divisiones raciales. Según esos críticos, aunque las políticas de acción afirmativa produjesen más igualdad, ellas destruirían la cohesión al interior de la nación sin concretar, por lo tanto, el ideal de la solidaridad igualitaria.

Como las medidas de acción afirmativa son muy recientes, es difícil evaluar se ellas, de hecho, contribuirán para finalmente construir la nación de unidos e iguales o, si al contrario, producirán desunión sin corregir las desigualdades.

De forma abstracta, las políticas afirmativas, al atender diferenciadamente a un grupo particular, no hieren el principio de igualdad y de neutralidad del Estado. Según mostramos en otro contexto (Costa/Werle 2000), valiéndonos de la distinción de Forst (1993: 189ss.), la neutralidad del Estado puede ser interpretada bajo tres perspectivas:

a) neutralidad de las consecuencias: las reglas establecidas tienen las mismas consecuencias para todas las comunidades que comparten un mismo sistema político;

b) neutralidad de la justificación: los principios de justicia no pueden ser fundados en valores éticos substantivos, sino en conceptos morales universalmente aceptados, por lo tanto, imparciales;

c) neutralidad de los objetivos: el Estado liberal no defiende cualquier concepción del bien en detrimento de otras concepciones.

En esos términos, medidas de acción afirmativa que favoreciesen a los afro-descendientes no están orientadas por la neutralidad de las consecuencias, en la medida en que atienden diferenciadamente a un grupo particular. La atención prioritaria a un grupo, en la medida que no represente un privilegio no compromete la legitimidad del Estado liberal, pues puede ser justificada como mecanismo de compensación de desigualdades. Más importantes son, por eso, la neutralidad de la justificación y de los objetivos. Las acciones afirmativas pueden ser justificadas de forma neutra, desde que su defensa se base en el principio del restablecimiento de la igualdad de oportunidades.

Lo que es difícil de aceptar es el argumento utilizado por algunos de los defensores de esas políticas cuando afirman que las medidas son necesarias para construir la identidad política de los afro-descendientes. En ese caso, no se verificaría la neutralidad de los objetivos de la acción del Estado, sino su adhesión a una concepción de bien 
particular y la imposición autoritaria de una forma cultural de vida específica, a saber, las identidades racializadas. Es decir, si el Estado adopta medidas de acción afirmativa para construir la identidad política del conjunto de los afro-descendientes no estará siendo neutro en sus objetivos, sino que haciendo elecciones previas para los ciudadanos.

También, de forma abstracta, se puede decir que las políticas de acción afirmativa, necesariamente, no socavan la fuente histórica de la solidaridad nacional, asentada en el mito de la democracia racial. Según muestran algunos trabajos recientes, los movimientos anti-racistas no niegan, completamente, los ideales de la mezcla contenidos en el discurso del mestizaje, sino que los usan de manera variable y crítica, construyendo su identidad en el espacio de la "afirmación de la contribución del negro a Brasil y a una etnización que quiere liberar a la cultura negra del crisol de la brasilidad, cuando éste deja de ser visto como igualitario" (Almeida 2000: 154; Sansone 2003). A partir de esos estudios, es posible suponer que, para sus beneficiarios, las políticas de acción afirmativa no representan, necesariamente, la negación de la nación que se articula más allá de las divisiones raciales. Al contrario: las políticas de acción afirmativa pueden servir incluso para mostrar a los afro-descendientes que la superación de la discriminación es un ideal compartido por todos los brasileños.

Más complicadas políticamente, me parecen las reacciones que pueden ser observadas ya entre los críticos de los sistemas de cuotas, algunos de ellos importantes formadores de la opinión pública brasileña (Azevedo 2007). Para esos críticos, las políticas de acción afirmativa son un sistema de creación de privilegios para una nueva elite negra. La reacción a esas políticas observada aquí no se basa en el enaltecimiento de las virtudes de la "nación mestiza" y no discriminadora, sino en la defensa de los intereses supuestamente amenazados de los blancos. ${ }^{11}$ Los avances de las conquistas de los afro-descendientes,

11 Ese tipo de oposición neo-conservadora a las políticas de acción afirmativa fue bastante estudiado en los Estados Unidos, donde se observa la articulación de una nueva "whiteness", es decir, la afirmación de la identidad política como ciudadano blanco (West 1996). Hasta recientemente, la crítica a los movimientos antiracistas en Brasil estaba siempre basada en la idea de que, en Brasil, las clasificaciones raciales no existen puesto que se trata de una "nación genuinamente mestiza". Hoy, con los avances de las políticas afirmativas, comienza a construirse en Brasil un discurso político muy próximo al modelo americano de "white- 
cuando van acompañados de reacciones de ese tipo, pueden efectivamente exasperar las divisiones raciales y minar las bases de la solidaridad cívica. Así, en lugar de la convivencia democrático-igualitaria, como aquella que se busco criar de Europa Occidental, la lucha presente por la igualdad acabaría anulando la solidaridad y las posibilidades de coexistencia entre los diferentes grupos de color. En suma, no hay aún elementos para prever con seguridad en que medida las políticas que vienen siendo implementadas en Brasil afectarán los patrones de solidaridad y cohesión existentes. Si de ellas nacerá una sociedad más cohesionada y más igualitaria o, al contrario, un país más desigual y fragmentado es algo que depende aún de disputas políticas que se encuentran en pleno andamiento.

\section{Bibliografía}

Alencastro, Luiz Felipe de (2000): O trato dos viventes. Fiormação do Brasil no Atlântico Sul - Séculos XVI e XVII. São Paulo: Companhia das Letras.

Almeida, Miguel V. (2000): Um mar da cor da terra. Raça, cultura e política da identidade. Oieieras: Celta.

Azevedo, Reinaldo (2007): “O movimento dos Sem-Bolsa". En: Veja, Ed. 2020, 08/08/2007, pp. 106-107.

Boatcă, Manuela/Costa, Sérgio (2010): "Postcolonial Sociology: A Research Agenda". En: Rodríguez, Encarnación G./Boatcă, Manuela/Costa, Sérgio (eds.): Decolonizing European Sociology. Transdisciplinary Approaches. Surrey: Ashgate, pp. 13-32.

Brunkhorst, Hauke (2002): Solidarität. Von der Bürgerfreundschaft zur globalen Rechtsgenossenschaft. Frankfurt am Main: Suhrkamp.

Cardoso, Teresa (2010). Por acordo, plenário aprova Estatuto da Igualdade Racial, sem cotas (<www.senadorpaim.com.br/verImprensa.php?id=810-por-acordoplenario-aprova-estatuto-da-igualdade-racial-sem-cotas $>, 10.10 .2011)$.

Carneiro, M. Luiza (1990): "Sob a máscara do nacionalismo. Autoritarismo e antisemitismo na Era Vargas (1930-1945)". En: Estudios Interdisciplinarios de América Latina y el Caribe, 1, 1, pp. 23-40.

Chakrabarty, Dipesh (2000): Provincializing Europe: Postcolonial Thought and Historical Difference. Princeton: Princeton University Press.

ness", conforme muestra el siguiente ejemplo: "Hoy es ella [la clase media] el verdadero 'negro' de Brasil: paga impuestos abusivos; no utiliza un miserable servicio del estado, siendo obligada a cargar con los costes de la salud, educación y seguridad [...] y, ¿por qué no recordarlo?, nadie la protege: estado, ONG, iglesias, nada..." (Azevedo 2007: 106). 
Costa, Sérgio (2006): Dois Atlânticos. Teoria social, anti-racismo, cosmopolitismo. Belo Horizonte: UFMG.

- (2007): "Ein Ort für den schwarzen Körper: Antirassismus in Brasilien". En: Diehl, Paula/Koch, Gertrud (eds.): Inszenierungen der Politik. München: Fink, pp. 141-160.

- (2010): “Au-delà du métissage. Antiracisme et diversité culturelle sous les deux gouvernements Lula". Problèmes d'Amérique latine, 78, pp. 91-112.

- (2011a): "Perspectivas y políticas sobre racismo y afro-descendencia en América Latina y el Caribe". En: Hopenhayn, Martín/Sojo, Ana (eds.): Sentido de pertenencia en sociedades fragmentadas: América Latina en una perspectiva global. Buenos Aires: Siglo XXI/CEPAL, pp. 173-188.

- (2011b): Researching Entangled Inequalities in Latin America. The Role of Historical, Social, and Transregional Interdependencies. Berlin: Working paper no. 9, desiguALdades (<www.desigualdades.net/bilder/Working Paper/ WP_Costa_Online.pdf $>$, 31.03.2012).

Costa, Sérgio/Gurza L., Adrián (2006): "Cohesión social y coexistencia intercultural en América Latina". En: Cotler, Julio (ed.): La cohesión social en la agenda de América Latina y de la Unión Europea. Lima: Instituto de Estudios Peruanos Ediciones, pp. 247-279.

Costa, Sérgio/Werle, Denilson L. (2000): "Reconhecer as diferenças: Liberais, comunitaristas e as relações raciais no Brasil". En: Avritzer, Leonardo/Domingues, J. Maurício (orgs.): Teoria social e modernidade no Brasil. Belo Horizonte: UFMG, pp. 82-117.

Davis, Darrién J. (1999): Avoiding the Dark - Race and the Forging of National Culture in Modern Brazil. Aldershot: Ashgate Publishing.

Forst, Rainer (1993): "Kommunitarismus und Liberalismus: Stationen einer Debatte". En: Honneth, Axel (org.): Kommunitarismus. Eine Debatte über die moralischen Grundlagen moderner Gesellschaften. Frankfurt am Main: Campus, pp. 181-212.

Freyre, Gilberto ( $\left.{ }^{36} 1999\right)$ : Casa Grande e Senzala. São Paulo/Rio Janeiro: Record.

Fry, Peter H. (2001): "Feijoada e soul food 25 anos depois". En: Estenci, Neide et al. (orgs.): Fazendo Antropologia no Brasil. Rio de Janeiro: DP\&A, pp. 35-56.

- (2005): A Persistência da Raça: ensaios antropológicos sobre o Brasil e a África Austral. Rio de Janeiro: Civilização Brasileira.

Grin, Monica (2010): Raça. Debate público no Brasil. Rio de Janeiro: Mauad.

Guimarães, Antônio S. (2000): "Prefácio". En: Guimarães, Antônio S./Huntley, Lynn (eds.): Tirando a Máscara. Ensaios sobre o racismo no Brasil. São Paulo/Rio de Janeiro: Paz e Terra, pp. 11-30.

Habermas, Jürgen (1998): Die postnationale Konstellation. Politische Essays. Frankfurt am Main: Suhrkamp.

- (2005): Zwischen Naturalismus und Religion. Frankfurt am Main: Suhrkamp.

Hofbauer, Andreas (2006): Uma história de "branqueamento" ou o "negro" em questão. São Paulo: UNESP.

Krieger, Heinrich (1940): “Die Rassenfrage in Brasilien”. En: Archiv für Rassen- und Gesellschaftsbiologie, 34, 1, pp. 9-56. 
Maggie, Yvonne (2001): “Os novos Bacharéis. A experiência do Pré-Vestibular para Negros e Carentes". En: Novos Estudos, 59, pp. 198-202.

Martinez-Echazábal, Lourdes (1998): “'Mestizaje' and the Discourse of National/ Cultural Identity in Latin America, 1845-1959". En: Latin American Perspectives, Issue 100, vol. 25, no. 3, pp. 21-42.

Nina Rodrigues, Raimundo ( $\left.{ }^{2} 1935\right)$ : Os africanos no Brasil. São Paulo: Cia Editora Nacional.

- ([1894] $\left.{ }^{3} 1938\right)$ : As raças humanas e a responsabilidade penal no Brasil. São Paulo: Companhia Ed. Nacional.

Oliveira Vianna, Francisco J. (1923): Evolução do povo brasileiro. São Paulo: Monteiro.

Pena, Sérgio D. J./Carvalho-Silva, Denise R./Alves-Silva/Juliana; Prado, Vânia F.; Santos, Fabrício R. (2000): "Retrato Molecular do Brasil". En: Ciência Hoje, 27, 159, pp. 16-25.

Pinheiro, Luana/Fontoura, Natália/Prata, Ana Carolina/Soares, Vera (2006): "Retrato das Desigualdades - $2^{\mathrm{a}}$ edição". Brasília: UNIFEM/IPEA.

Randeria, Shalini (2005): "Verwobene Moderne: Zivilgesellschaft, Kastenbindungen und nicht staatliches Familienrecht im (post)kolonialen Indien". En: Brunkhorst, Hauke/Costa, Sérgio (eds.): Jenseits von Zentrum und Peripherie: Zur Verfassung der fragmentierten Weltgesellschaft. München: Hampp, pp. 169-196.

Röhrig-Assunção, Matthias (2005): Capoeira. The History of an Afro-Brazilian Martial Art. London/New York: Routledge.

Romero, Sylvio ([1888] 1953): História da literatura brasileira. Rio de Janeiro: José Olympio.

Sansone, Livio (2003): Blackness without Ethnicity. Constructing Race in Brazil. London: Palgrave Macmillan.

Santos, Gevanila G./Silva, Maria P. (eds.) (2005): Racismo no Brasil: Percepções da Discriminação e do Preconceito Racial no Século XXI. São Paulo: Fundação Perseu Abramo.

Schwarcz, Lilia M. (1993): O espetáculo das raças. São Paulo: Cia das Letras.

Schwartzman, Simon/Bomeny, Helena M. B./Costa, Vanda M. R. (1984): Tempos de Capanema. São Paulo/Rio de Janeiro: EDUSP/Paz e Terra.

Senkman, Leonardo (1997): "La lógica populista de la identidad y alteridad en Vargas y Perón: Algunas implicaciones para los immigrantes”. En: Cuadernos Americanos, 66, pp. 130-152.

Silvério, Valter R. (2003): "Os caminhos do anti-racismo na construção da democracia brasileira”. En: Teoria \& pesquisa, 42-43, pp. 27-40.

West, Cornel (1996): "Affirmative Action in Context". En: Curry, George E. (ed.): The Affirmative Action Debate. Cambridge: Perseus, pp. 31-38. 



\section{Carla Gras \\ Elites rurales contemporáneas: cambio tecnológico, liderazgo empresarial y acción política en la Argentina sojera ${ }^{1}$}

\section{Introducción}

Las ciencias sociales en Argentina ofrecen una cartografía pormenorizada de las mutaciones que conocieron su estructura social y las identidades sociales y políticas de distintos actores en las últimas décadas. En esa cartografía, el estudio de las transformaciones ocurridas entre los sectores económica y socialmente predominantes ha ocupado un lugar relativamente menor en comparación con el abordaje de los sectores populares o de las clases medias (Heredia 2005). Al mismo tiempo, se observa la persistencia de ciertos supuestos referidos a la coherencia entre los intereses de estos sectores y su posición económica, y al papel casi excluyente que los intereses económicos tienen en sus formas de organización y presencia en la vida pública y política.

En el caso de las elites rurales, estos supuestos asumen formas bien precisas. Así, se da por descontada la relación entre su liberalismo económico, su oposición acérrima a toda forma de regulación o posicionamiento por parte del Estado frente a las condiciones que sustentan su dinámica de acumulación, y sus formas de organización y presión en el espacio público. Asimismo, se presume su naturaleza anti-democrática tanto en lo que refiere a sus valores y creencias políticas como al tipo de arreglos institucionales que propician para defender sus intereses. Con las reformas de mercado y del Estado en los

1 Una versión anterior fue presentada al Taller "El Bicentenario de la independencia y la(s) democracia(s) en América Latina”, realizado el 12 y 13 de Febrero de 2010 en Berlín. La revisión y ampliación de la misma se vio beneficiada por los comentarios allí recibidos. Agradezco especialmente la atenta lectura y aportes de Claudia Lozano. Este trabajo fue elaborado en el marco de la estadía de investigación en el Lateinamerika-Institut, Freie Universität Berlin y el IberoAmerikanisches Institut, financiada por una beca de la Fundación Alexander von Humboldt. 
años '90 y el desarrollo de un nuevo patrón socio productivo en el agro -que dio lugar a una mayor concentración de la tierra y la producción, y a una intensificación de la capitalización- la pregunta sobre cómo el poderío económico de los sectores beneficiados se reflejaba en la política pública pareció perder relevancia, al darse por supuesto que esa traducción operaba sin fallas.

En este trabajo proponemos dialogar con estas asunciones, interrogándonos por los comportamientos políticos de las elites rurales en la Argentina contemporánea. Desde mediados del siglo XIX, el peso económico, social y político de los grandes productores ha sido fundamental en la historia del país. Si bien la importancia de la producción agropecuaria en términos de su contribución a la economía nacional ha conocido distintos momentos, cabe destacar su dinámica de crecimiento en las últimas dos décadas, proceso asociado al cambio técnico y a la biotecnología. Desde distintos enfoques disciplinarios, numerosos estudios han analizado la relación entre la expansión de cultivos transgénicos -con sus impactos en la organización y gestión de los procesos de trabajo, las demandas de capital y conocimientos, etc. - y los profundos cambios en la estructura productiva y social del agro argentino. En otros trabajos, hemos subrayado cómo ese patrón tecnológico demandó nuevos modos de entender y practicar la actividad agropecuaria, favoreciendo el ingreso de nuevos actores, obligando a unos a cambiar sus prácticas, y expulsando a un número no menor de otros (Gras/Hernández 2008). Menos se conoce acerca de la medida en que esos cambios tecnológicos y sociales se expresan en los comportamientos políticos de los actores que adquirieron posiciones relevantes a partir de los mismos. Nuestra hipótesis es que el cambio técnico ha sido vehículo también de transformaciones en sus identidades (sus representaciones, ideas y creencias respecto de lo que son) y que ello tiene consecuencias en sus modalidades de presencia en la vida pública y política, demandas y formas de acción.

Estas preocupaciones cobran relevancia en el contexto actual gracias a la conjunción de una serie de factores. Entre ellos, uno de los más importantes y quizá menos problematizado refiere a la recomposición de la propia elite, tanto en lo que refiere a los perfiles como a las trayectorias y orígenes sociales de quienes hoy integran las capas superiores de la estructura agraria. Un segundo factor es la complejización de las formas de representación de intereses donde las orga- 
nizaciones tradicionales de carácter gremial coexisten con asociaciones profesionales. Estas últimas conforman verdaderas traductoras de los valores e ideas respecto de las bondades del cambio técnico, y del nuevo tipo empresarial que el mismo requiere, constituyéndose en nexos que permiten articular comportamientos productivos, económicos, sociales y políticos de maneras significativas para los actores. Además, muchas veces han sido más eficaces para influir en decisiones de política pública, logrando concitar mayor adhesión entre la elite que las corporaciones que históricamente se arrogaron su representación. Nos interesa explorar aquí las modalidades que asume la presencia de las elites en la vida pública y política -en particular en su relación con el Estado -a partir de constatar esa diversificación de formas de agregación y representación de intereses. Finalmente, nos interesa abordar la dimensión política, centrándonos en la producción de ideas y nociones que movilizan su accionar, moldeando el modo en que perciben sus intereses y su posición en la sociedad. ${ }^{2}$ Para ello, tomaremos como caso de análisis el reciente conflicto entre los productores agrarios y el gobierno de Cristina F. de Kirchner por la política de derechos a las exportaciones (retenciones). Como observamos en nuestra investigación, ${ }^{3}$ el mismo fue un momento de debate político al interior de la elite en el que se fueron (re)construyendo núcleos de sentido respecto de su papel en el sector agropecuario y en la sociedad más amplia, su relación con los sectores subordinados (agrarios y no agrarios), con el Estado, etc. Sostendremos que en el marco del conflicto se pusieron en juego estas otras dimensiones además de la presión corporativa en torno a una medida desfavorable para el sector agropecuario -que perjudicaba los niveles de

2 La historiografía se ha ocupado profusamente de estas cuestiones, en especial para el período que va desde la conformación del Estado nacional hacia mediados del siglo XIX hasta la $1^{\circ}$ Guerra Mundial. En ese marco, el trabajo de Hora (2009) resultó particularmente inspirador para situar los interrogantes de mi investigación en perspectiva histórica.

3 En el marco de mi investigación actual ("Dinámicas sociales y políticas en el nuevo escenario agrario: actores, prácticas institucionales y representaciones ideológicas"), me he centrado en la indagación sobre las nuevas formas de acción política de la burguesía agraria en el período post 2001. Mi abordaje es el de estudios de caso, utilizando entrevistas, documentos institucionales, material periodístico y la observación no participante de distintos espacios de interacción como asambleas y seminarios. 
ganancia de la elite- y se planteó la necesidad de darle a ello una expresión política.

\section{El agro argentino y sus actores principales}

Desde mediados del siglo XIX la dinámica del sector agropecuario estuvo entrelazada con la posición dominante de un conjunto de grandes terratenientes capitalistas asentados en la región pampeana, principal productora de los bienes exportables (carne y cereales) sobre los que se asentó la integración del país al mercado internacional. Como señala Hora (2009), el lugar de privilegio de estos grupos no solo se sustentaba en la propiedad de amplios volúmenes de tierra que controlaban, sino también en su carácter innovador en lo que respecta a los métodos de producción. Así, según el autor, estos grupos combinaban dos características: poderío económico y dinamismo empresarial.

La crisis mundial de 1929 introdujo inflexiones importantes en el modelo económico, iniciándose un proceso de sustitución de importaciones que, aunque complejizó la morfología social del país, no transformó sustantivamente las bases de la posición dominante de estos terratenientes. Con la profundización del proceso de industrialización, el poder de esta elite fue diezmándose, tanto por la importancia que cobraban los sectores industriales, como por la consolidación de pequeños y medianos agricultores, beneficiados por políticas de acceso a la propiedad de la tierra y al crédito durante el primer peronismo. No obstante, los grandes productores retendrían una cuota significativa de poder al controlar el principal canal de obtención de divisas del país, el que a su vez jugaba un rol sustantivo en el proceso de industrialización, al ser esos mismos bienes parte básica de la canasta alimenticia de las clases trabajadoras. Como ha señalado O'Donnell (1977), aún cuando la elite agraria -junto con otras fracciones de la burguesía pampeana- ya no fuera el pivote central del capitalismo argentino, tenía la capacidad de defenderse de cualquier intento de reestructurarla ${ }^{4}$ así como de lograr transferencias de ingreso en su beneficio, en momentos en que la relación entre exportación/consumo interno derivaba en crisis de balanza de pagos. La vigencia del modelo

4 Por ejemplo, el intento en 1973 de sancionar un impuesto a la renta normal potencial de la tierra. 
de industrialización sustitutiva (hasta los años '70) sería también la etapa del llamado "estancamiento pampeano", caracterizada por la pérdida de dinamismo o retroceso de la producción de granos y de la ganadería vacuna ${ }^{5}$ (Obschatko 2003).

Posteriormente, la actividad agropecuaria comienza un proceso de cambio que le devolvería su rol protagónico en la economía argentina. Un elemento destacado en la evolución positiva de la producción y la productividad fue la incorporación de tecnologías -insumos industriales, semillas híbridas, mecanización de labore-, que se consolida en las últimas décadas con la expansión de la biotecnología. Ello tuvo impactos en el patrón productivo: se registra un creciente abandono relativo de la ganadería y el incremento de la producción de granos, especialmente de soja transgénica, que es exponencial desde $1995^{6}$. A diferencia de la carne y el trigo que se destinaron históricamente tanto al mercado mundial como al doméstico, la soja se exporta casi en su totalidad.

La utilización de un nuevo "paquete" tecnológico ${ }^{7}$ impulsó la intensificación en el uso del capital, modificando los umbrales mínimos para sostenerse en la producción. Así, durante toda la década de 1990 se registró un incremento sostenido del tamaño mínimo para una explotación rentable, proceso en el que también incidió la política ma-

5 Los debates políticos y académicos sobre esa etapa incorporaban factores tales como el comportamiento de los niveles de inversión y rentabilidad, su relación con las políticas de transferencia de la renta agropecuaria a otros sectores de la economía, así como también el carácter de las elites agropecuarias, en especial de los grandes ganaderos, visualizados por una parte significativa de la literatura como una clase oligárquica que vivía de la renta derivada de su control sobre la tierra.

6 En 1990 la superficie con soja rondaba los cinco millones de hectáreas, alcanzando los siete millones en 1997. Entre ese último año y 2009 la superficie sembrada con soja de hectáreas más que se duplicó, alcanzando los 18 millones. La producción tuvo un crecimiento aún más intenso, pasando de 18.732.172 toneladas en 1997 a cerca de 47 millones y medio en 2007. Las dos campañas siguientes registran caídas en la producción, como consecuencia, entre otros factores, de la sequía. En la última campaña (2009), la producción fue de casi $31 \mathrm{mi-}$ llones de toneladas (Estimaciones Agrícolas, Ministerio de Agricultura, Ganadería y Pesca de la Nación).

7 Es usual en la bibliografía local referirse al conjunto de innovaciones como "paquete" tecnológico para dar cuenta del modo en que ellas están concatenadas e implicadas unas con otras: la semilla transgénica con el glifosato, un tipo de tecnología de siembra (la siembra directa), de organización laboral, de gestión. 
croeconómica, modificando drásticamente la estructura de costos de las empresas. ${ }^{8}$

Los cambios no sólo afectaron a los pequeños y medianos agricultores, dejando a muchos de ellos afuera de la producción, ${ }^{9}$ sino también a empresarios de mayor tamaño. Lo que importa subrayar aquí es la transformación en el perfil de las capas empresariales y en especial de quienes ocupan los estratos superiores en términos de los recursos controlados. Se trata de un cambio importante que no solo refiere a la existencia de una franja "ganadora", que concentra mayores volúmenes de tierra y producción, sino también a las formas de control que ejercen sobre ellos y las relaciones que establecen tanto con actores poderosos (como las empresas transnacionales de semillas, los grandes exportadores) como con aquellos que ocupan posiciones de menor poder relativo (pequeños y medianos propietarios y/o productores, contratistas de maquinaria). El cambio en el perfil empresarial encuentra en los llamados pooles de siembra su expresión más acabada: se trata de empresas con acceso al capital financiero que manejan el know-how de gestión y el management que articula los distintos recursos del sistema, de los cuales uno de los más preciosos es la información y el saber experto para programar con anticipación más de un ciclo productivo. ${ }^{10}$ Así, a través de contratos formales e informales con distintos agentes gerencian cientos de miles de hectáreas, propias y/o alquiladas a terceros. Sin entrar en el debate sobre qué tipos de actores adoptaron esta forma de organización empresarial, cabe retener la complejización de las posiciones de los actores que lideran el sector agropecuario en Argentina, mediante relaciones donde la propiedad de la tierra -tradicional soporte de las elites agro-

8 La política neoliberal afectó especialmente al sector agropecuario: baste recordar la eliminación de casi todos los impuestos a las exportaciones; la supresión de aranceles a la importación de bienes de capital, lo que se tradujo en una renovación importante del parque de maquinarias; así como también la eliminación de casi todos los organismos reguladores y la privatización de los servicios públicos. Otro aspecto sustantivo fue la retracción del Estado del mercado financiero, lo que afectó el acceso al crédito.

9 Según datos de los censos agropecuarios entre 1988 y 2002 desaparecieron 88.000 explotaciones agropecuarias $(21 \%)$ y el tamaño promedio de las mismas aumentó un $25 \%$ para alcanzar 587 hectáreas en 2002.

10 Al respecto, véase Hernández (2007). 
pecuarias- y el capital se combina y/o deja lugar a otros vínculos y relaciones de producción.

En definitiva, al hablar hoy de grandes explotaciones agropecuarias estamos refiriendo a empresas que operan superficies superiores a las 5.000 hectáreas, que controlan bajo distintas formas de tenencia de la tierra y de relación con el capital, y modalidades de organización laboral. Según el Censo Agropecuario de 2002, estos estratos representaban el $2 \%$ del total de explotaciones agropecuarias y controlaban casi el $50 \%$ de la superficie cultivada. ${ }^{11}$ Según algunos estudios, la cúpula empresarial del sector agrario se ubica en los rangos de superficies superiores a las 20.000 hectáreas, incluyendo territorios en países limítrofes. La consolidación económica de esta burguesía y de la elite que la corona se hace evidente a partir de 2002 en una coyuntura que combina altos precios internacionales y una mejora sustantiva de los precios relativos del sector a partir de la aplicación de un nuevo régimen cambiario.

¿Cómo se relaciona el cambio en la morfología empresarial con la pregunta sobre la reproducción o recomposición de las elites agropecuarias? Es decir, ¿en qué medida los nuevos comportamientos empresariales se corresponden con el ingreso de nuevos actores a la elite o con la transformación de los preexistentes? Y ¿qué lugar tiene el cambio tecnológico en la consolidación de estos perfiles empresariales que no solo muestran características de mayor concentración sino que también se erigen como prototipo de la posibilidad de persistencia/inclusión en el actual modelo productivo? No podemos dar una respuesta acabada, sino pistas surgidas del análisis de distintas fuentes. ${ }^{12}$ Así, si se tiene en cuenta el origen y las trayectorias de los titulares de grandes explotaciones, podemos hablar de un proceso de recomposición resultante de distintos movimientos: por un lado, el ingreso de actores extra agrarios que entran a la actividad atraídos por las altas tasas de retorno en los últimos diez años; por el otro, la reconversión del perfil de los descendientes de los tradicionales gran-

11 Los censos relevan información sobre explotaciones agropecuarias, pero no permiten reconstruir las relaciones de propiedad y/o control de más de una explotación por parte de una misma persona física o jurídica.

12 Entrevistas en profundidad a diez empresarios grandes, fuentes periodísticas (suplementos rurales de los diarios La Nación y Clarín), entrevistas a informantes clave. 
des propietarios - proceso relacionado con un compromiso más activo y profesionalizado con la gestión de los campos familiares-; finalmente, la movilidad social ascendente registrada entre las franjas superiores de la agricultura familiar pampeana. Como pude constatar en distintas entrevistas, en las experiencias de los actores la adopción de tecnología -en las dimensiones materiales y prácticas señaladasconstituyó el mecanismo que les explica que, partiendo de lugares tan diversos del espacio social, hayan arribado -más allá del volumen de recursos que controlan- a un punto común: una manera de ser productores. En palabras de un entrevistado:

Nada más tener la cabeza abierta, actitud de aprender. Hay profesionales $\mathrm{y}$ hay tipos de escuela primaria y todos son buenos empresarios [...] no es un problema de escala, es un problema de actitud: medir, ensayar, probar...lo mismo hacerlo en gran escala que en maceta, como digo yo (Orlando, noviembre de 2008).

La cuestión no es menor ya que les permite construir representaciones sobre el modelo como uno con potencialidad inclusiva, lo que tiene consecuencias, como veremos, para las creencias y valores que sostienen sus comportamientos políticos, haciéndolos legítimos a sus propios ojos.

\section{Las corporaciones agrarias}

Desde mediados del siglo XIX, la representación de los grandes estancieros pampeanos estuvo en manos de la Sociedad Rural Argentina (SRA), creada en 1866. En su análisis sobre el ruralismo terrateniente, Hora subraya al describir a la SRA la "acusada vocación modernizante, a la vez técnica y política, (que) singularizaba a los promotores de la primera asociación rural del país" (Hora 2009: 25). Para el autor, desde sus orígenes esta entidad manifestó la necesidad de transformar a los grandes terratenientes en "líderes" de una transformación que reconvirtiera el perfil del propio empresariado y el contexto en el que actuaban (Hora 2009: 25). Dicho contexto no solo refería a variables macroeconómicas, de mercado sino también a modelos de producción y tecnología agraria. Así, "cambio y modernización" constituían uno de los rasgos más originales del grupo fundador de SRA, que buscaba enraizarse como representación del conjunto de los terratenientes. Sostiene Hora que el liderazgo de esta elite estaba asentado 
en una "indudable legitimidad" en lo que refiere a su papel social (la prosperidad económica de la cual eran sus actores principales), y a los modos de construcción de poder (articulación de sectores subalternos; alianzas y vínculos con la industria procesadora de materias primas, con el comercio y con las finanzas).

La relación entre esta próspera elite y el régimen político, resaltada por los análisis académicos, se vio complejizada a partir de 1912, cuando una nueva ley electoral (Ley Sáenz Peña) permitió el acceso de grupos hasta entonces excluidos de la política, y en el ámbito rural, se conformó la Federación Agraria Argentina (FAA), expresión de una oposición -terratenientes/colonos- que estructuró políticamente las existentes líneas de fractura de la estructura agraria. En otro trabajo, Hora señala que en ese contexto, la elite no solo se vería enfrentada a la mayor permeabilidad del régimen político a las demandas de los grupos subalternos sino también a un creciente cuestionamiento de su enorme riqueza, particularmente al hecho de que ella deviniera de la propiedad de la tierra (Hora 2005: 72). La mayor heterogeneidad del mapa institucional, la conflictividad agraria (de las cuales la emergencia de FAA daba cuenta) y la complejización de las formas de construcción y agregación de intereses, se profundizaron años más tarde, con la creación en 1936 de la Confederación de Asociaciones Rurales de Buenos Aires y La Pampa (CARBAP), integrada por antiguos socios de la SRA, enfrentados a los capitales norteamericanos que controlaban la industrialización y comercialización de carne. Así, la pretensión de ser articuladora del conjunto de actores de la economía agroexportadora y de encarnar los valores y modelos de nación y sociedad deseable (Palomino 1988), se vieron contestados, y el liderazgo de SRA resquebrajado.

En el plano nacional, y como consecuencia de la industrialización y el crecimiento urbano, la posición del sector agropecuario en la economía fue cambiando; la irrupción del peronismo en 1945 profundizó la pérdida de gravitación económica y social de los grandes terratenientes. Sin embargo, como hemos señalado, dada su posición en la estructura económica, la burguesía agraria y su elite retuvieron para sí la capacidad de negociar y presionar al Estado para obtener ventajas y/o no ser perjudicadas en sus intereses.

El núcleo ideológico de estos grandes productores se organizó en torno a la libertad de los mercados, la subsidiariedad del Estado y 
la salvaguarda de la propiedad privada -principios que organizan sus demandas públicas-, en apelaciones generales a la defensa del "campo" como una unidad y a su rol preponderante para el conjunto de la nación. Estos elementos conformaban un sistema coherente de ideas, fortalecido en la segunda posguerra, por la oposición al peronismo. Plantea Heredia (2003), que el universo ideológico de la elite agropecuaria y de su portavoz principal, la SRA quedó estrechamente asociada al antiperonismo y a la condena de toda forma de populismo. Debe incluirse aquí a las Confederaciones Rurales Argentinas (CRA), entidad que agrupa a CARBAP y otras regionales similares, que comparten esos principios ideológicos, si bien diferenciándose en las estrategias discursivas y de acción privilegiadas (Nun/Lattuada 1991). El tipo de acción corporativa desarrollada se caracterizó en esta etapa por un

ejercicio de influencia personal, el contacto directo con los funcionarios, un profundo conocimiento de los mecanismo formales e informales del proceso de toma de decisiones y, en general, una fuerte presencia en la estructura de poder, derivada de sus estrechos vínculos con otros grandes grupos de intereses (Nun/Lattuada 1991: 65).

En el caso de CRA, con menor acceso a esas redes de influencia, se observaría una mayor inclinación por acciones de confrontación con el Estado y de "presión por choque". Más allá de estas diferencias, las políticas de precios y de impuestos fueron históricamente los puntales de la acción de estas entidades. Este tipo de corporativismo ha buscado recomponer cierto orden de cosas (la contribución a la economía y a la identidad nacional de la actividad agropecuaria), en momentos en que dicho orden está en crisis o amenazado, lo que fue eficaz para bloquear políticas públicas que buscaran incidir globalmente sobre las condiciones en que ha operado el sector agropecuario. En este sentido, es posible trazar un hilo conductor que va desde la pérdida de centralidad del agro frente a la emergencia de otros sectores y actores dinámicos en la posguerra, a la concentración de la acción corporativa en la defensa sectorial y el abandono de aquellas prácticas que construían a los grandes productores como agentes centrales de cualquier proyecto de modernización de la economía y la sociedad nacionales, rasgos que, como mencionamos antes, identificaron en su origen a la SRA. 
Pero no eran solo estas formas de representación de intereses las únicas reconocibles entre las elites rurales argentinas. Si en el país la representación electoral -propia de las mediaciones neocorporativas- no caracterizó sus formas de influencia, sí lo tuvieron en las últimas décadas, y de manera significativa en los '90, las asociaciones profesionales. Ubicadas sobre la expertise técnica y la innovación tecnológica, estas entidades conforman actores importantes para el estudio de los canales de construcción y articulación de los intereses dominantes, así como también para la construcción de un liderazgo social y político, a partir de la restitución y resignificación de la importancia material y simbólica de la tecnología en los imaginarios sociales sobre el progreso.

\section{Retomando las tradiciones: técnica y política}

Hacia inicios de la década de 1960, surge otro tipo de organización con la que comienza a referenciarse la elite agropecuaria: la Asociación Argentina de Consorcios de Experimentación Agrícola (AACREA). Es una red de consorcios de empresarios organizados como grupos de trabajo para intercambiar información y ser asesorados en materia tecnológica, de gestión empresarial, etc. Inicialmente conformada por grupos de la elite pampeana, en los ' 70 comienza a incluir a chacareros. ${ }^{13}$ Aún cuando el proceso no fue fácil, es menester señalar que las transformaciones que había atravesado la estructura agraria -que se profundizaron en las décadas siguientes- habían ido reconfigurando el histórico antagonismo colono/oligarquía, y que espacios como los grupos CREA fueron, con el transcurso del tiempo, estructurando experiencias que llevarían a los propios actores a percibir las líneas de fractura de la estructura social de un modo distinto.

La idea inicial de los fundadores era sencilla: buscar en conjunto la forma de resolver problemas técnicos comunes. La iniciativa retomaba el interés y el impulso dado por los pioneros de la SRA a la innovación técnica y a la transformación de la gestión empresarial, algo

13 El término identifica a una heterogénea capa de productores, que incluye desde productores basados en el trabajo familiar con cierta capacidad de acumulación (homologable a la figura del farmer norteamericano) hasta la pequeña burguesía agraria. En términos políticos, refiere al proceso histórico de lucha de los colonos inmigrantes por el acceso a la propiedad de la tierra, y a la constitución de una identidad definida por oposición a la oligarquía terrateniente. 
que parecía haber perdido vigor en aquella entidad, al menos en la visión de los terratenientes que fundan AACREA. En efecto, como hemos analizado en otro trabajo, los documentos institucionales que recogen discursos de los fundadores son enfáticos en señalar a sus pares que la evolución negativa de la producción y la rentabilidad -recordemos, es la etapa del estancamiento pampeano-, o los problemas que afectaban a sus explotaciones no lograrían ser resueltos simplemente a través de políticas de precios o impuestos. Se requería asimismo de transformaciones técnicas en los procesos productivos, la organización interna de las empresas y la gestión. Así, desde su emergencia, pone en juego al conocimiento experto como principio legitimador de su existencia y Leitmotiv de sus objetivos, generando un ámbito de acción que podía ser sustraído fácilmente de la discusión y el escrutinio político.

Estas apelaciones eran críticas de la eficacia de la acción corporativa tradicional y de la presión política para obtener beneficios, al menos como única estrategia para responder a las situaciones que por entonces se planteaban. Lo que debía cambiar también era la "mentalidad" de esa elite propietaria, que había quedado atrapada en la reacción antiperonista, ubicando en la intervención del Estado populista la raíz de todos los males.

En suma, se necesitaba, en la visión de estos hombres, de una verdadera vocación de liderazgo para transformar el perfil empresarial de la elite agraria para que ella pudiera "ser la punta de lanza de una nueva agricultura", que permitiera al sector agropecuario retomar su lugar en la economía y en la sociedad nacional en un momento histórico -la segunda posguerra- en que un mundo en crecimiento necesitaba alimentos. Ello requería de una nueva manera de entender y practicar la actividad agropecuaria y de una nueva identidad empresarial. Desde sus inicios, esta asociación profesional ${ }^{14}$-como también de otras que surgieron en los '90, como la Asociación Argentina de Productores en Siembra Directa (AAPRESID)- convoca

14 AACREA agrupa actualmente a unos 1800 socios, cuyas empresas superan, en promedio, las 2.500 hectáreas. Originalmente, predominaban los productores ganaderos (y entre ellos, de invernada). Actualmente, ese perfil ha cambiado, integrando entre sus filas a los productores sojeros más importantes. Un análisis de esta organización profesional, los núcleos de su identidad institucional y su relación con la construcción de una clase dirigente, puede verse en Gras (2009). 
al empresariado rural de un modo preciso con incitaciones prácticas a la acción, primero "tranqueras" adentro (a través de la capacitación y la experimentación), y luego "tranqueras afuera". Las primeras han impulsado, a lo largo de los años, cambios en la organización de la producción y en las estrategias desarrolladas por los empresarios, la construcción de redes, la profesionalización de la gestión. Como hemos señalado, estos cambios son parte de la recomposición de las elites agrarias.

Por su parte, las acciones "tranqueras afuera" han buscado conectar a la clase empresarial con el Estado, movilizando otros tipos de recursos y mecanismos de influencia, como el asesoramiento. Si bien esto no es estrictamente novedoso, sí lo es la recurrencia, casi con exclusividad, al conocimiento científico como base y fuente de las interacciones. Con menor centralidad y gravitación económica y política, las elites agrarias encontraban en la ciencia y la modernización lo que -siguiendo a Boltanski/Chiapello (2002)- puede definirse como una lógica legítima de justificación. Pero la legitimidad que lograban como agentes productivos y económicos hegemónicos no era traducible sin más en legitimidad para actuar en otros ámbitos, como el político. En ese marco, ubicamos los comportamientos que la elite fue desplegando en las últimas décadas, a partir de los cuales iría cimentando la asociación entre su liderazgo tecnológico y la construcción de un liderazgo sociopolítico.

Una primera esfera de acción en ese sentido es la que le permite resituarse como actores con proyectos y propuestas, y no sólo como sector que busca defender las posiciones alcanzadas. En esa esfera, el papel de las asociaciones profesionales es central. Con ellas adquiere relevancia la influencia en el diseño y ejecución de políticas públicas -en particular aquellas que moldean las condiciones de producción del sector agropecuario y que inciden en su dinámica de acumulación-; influencia cuya legitimidad es construida a partir de la autoridad que otorga el discurso tecno-científico. Las interacciones entre AACREA y los llamados policy-makers han sido cambiantes a lo largo del tiempo, y en ese sentido los grados de autonomía estatal y la mayor o menor apertura de esos puntos de acceso no son ajenos a las transformaciones en las instituciones estatales y en las características organizativas y perfil de los miembros de AACREA. 
Uno de los ámbitos fundamentales donde AACREA ha desarrollado influencia es el de la política tecnológica. Un ejemplo bastará para ilustrarlo: su participación en la Mesa Directiva del Instituto Nacional de Tecnología Agropecuaria (INTA), principal instrumento del Estado nacional para impulsar innovaciones tecnológicas y productivas, mediante la investigación en desarrollo y extensión. Desde hace varias décadas AACREA integra, mediante un representante, su Consejo Directivo, encargado de fijar las políticas y estrategias globales del organismo. Si bien las corporaciones (SRA, CRA) también tienen presencia en este órgano del INTA, la impronta de AACREA es reconocible en una de las políticas más importantes que ese organismo puso en marcha en la década de 1990, el programa Cambio Rural. Al mismo tiempo, allí se deciden las investigaciones que el INTA financia y luego transfiere a través de las redes de extensionistas a los productores. En esta materia, AACREA ha sido una fuerte militante de la investigación en biotecnologías y de la organización de metodologías de transferencia.

El programa Cambio Rural -cuya población destinataria son pequeños y medianos empresarios- tuvo como premisa la transferencia de tecnologías de producción y de gestión, y una dinámica de implementación semejante a la metodología de los grupos CREA. Este programa es un ejemplo elocuente de la influencia en decisiones que son a la vez estratégicas para los intereses de la elite agropecuaria: articulando con el Estado para establecer prioridades de agenda, y proponiendo la construcción de lo que llaman "redes público-privadas" para promover ciertos cambios sustantivos en el modelo productivo (la transformación de productores en "empresarios", entre las capas de la producción familiar; la identificación de la tecnología y el management como explicación del éxito o fracaso de los productores). Esos cambios se apoyaron en mecanismos de promoción de ciertos modelos organizativos y en la "desatención" de actividades que quedaron desplazadas en el nuevo modelo. Por último, en el ámbito de la innovación tecnológica AACREA y AAPRESID participan en distintas iniciativas como contraparte del aparato estatal de ciencia y técnica.

Todas estas instancias de interacción con las instituciones estatales fueron fundamentales para la construcción de un ambiente económico $-\mathrm{y}$ también político- que favoreció la puesta en marcha de 
cambios que fueron parte importante de la instauración del nuevo patrón de acumulación agraria. Cabe insistir, una vez más, en la doble dimensión de esos cambios -uso de biotecnología, y desarrollo de un tipo de gestión y comportamiento empresarial- y su relación con la construcción de liderazgo de las elites contemporáneas. ${ }^{15}$

Por último, ¿qué implica la emergencia de estas asociaciones profesionales que se asientan sobre su carácter técnico para influir en los procesos decisorios, y que mediante su actividad han sido eficaces en la pretensión hegemónica de construir un perfil de empresariado moderno, a través de mecanismos tan variados como la organización de maestrías de agronegocios, programas de radio, prensa? Es decir, ¿qué implica en relación con la presencia de otro tipo de organización como SRA o CRA? Si bien es cierto que particularmente la SRA evidenció una crisis en su capacidad de representación de intereses en los años '90 (Heredia 2003), ello no implica el reemplazo de un tipo de práctica corporativa por otra. Antes bien conviene pensar en el modo en que ambas convergen -en qué contextos y situaciones- para cimentar la capacidad de influencia de la elite a través de distintos dispositivos de acumulación de poder.

\section{Tranqueras afuera: liderazgo social y político en tiempos de conflicto}

Si bien la intervención en la esfera de la política pública permitió fortalecer el liderazgo político de este empresariado moderno -habían devenido la "punta de lanza" de la nueva agricultura-, la actuación en ámbitos más amplios que el sectorial, era aún restringida.

El contexto que se abre con la crisis de 2001 funcionó como un estímulo potente para la emergencia de preocupaciones al interior de la elite respecto de su rol en la sociedad más amplia. Tras la explosión del régimen de convertibilidad, algunos representantes de las elites agrarias comenzaron a plantearse su lugar en el proceso de sa-

15 Es interesante en este sentido señalar, en contrataste con lo ocurrido con Brasil, el escaso cuestionamiento público y conflictividad respecto de la centralidad de las biotecnologías (Newell 2009). Por otra parte, la relativamente marginal discusión en torno del modelo sojero puede también explicarse por la efectiva construcción de un imaginario -construcción en la que las asociaciones profesionales han jugado un rol central- de continuidad de la Argentina como país agrario, donde el agro vuelve a ofrecer posibilidades de crecimiento y desarrollo. 
lida de la profunda crisis económica, social y política que le siguió. Estas preocupaciones pueden observarse, por ejemplo, en los temas con los que AACREA convocaba en sus congresos, tanto a sus pares como a intelectuales, líderes políticos y religiosos, con alto predicamento ante la opinión pública: en 2001, el lema fue "Comprender, organizarse, actuar"; en 2002 "Somos parte de una Argentina posible" y en 2007 "El campo trabajando más allá del campo". Otro tipo de iniciativas de esta entidad fueron los programas de "Formación de Líderes" y EDUCREA (programa de apoyo a escuelas rurales), a través de los cuales buscaban sensibilizar a los propios empresarios sobre la necesidad de involucrarse activamente en problemáticas sociales, y revertir cierto desinterés por el compromiso político.

Sin embargo, esa vocación no trascendía el ámbito de las interacciones sociales locales y las iniciativas de tono asistencialista, apoyadas en discursos religiosos. Tampoco había en la política gubernamental situaciones que propiciaran otro tipo de ejercicio que el que llevaban adelante SRA o CRA. Cabe mencionar que en 2002 las retenciones a las exportaciones se habían reinstaurado, y que más allá de reclamos puntuales de las entidades, inicialmente la medida no movilizó gran oposición de los empresarios.

Con la presidencia de Cristina F. de Kirchner, el escenario comenzó a cambiar, con medidas como la instauración de cupos de exportación para el control de los precios internos y los aumentos en las alícuotas de las retenciones. A ello se sumó en 2007 la crisis financiera internacional -que incidió en los precios de los commoditiesy en el plano interno, una de las sequías más importantes de las últimas décadas. En marzo de 2008 el Ministerio de Economía anunció un nuevo aumento de las retenciones -llevando dicho impuesto del $35 \%$ al $44 \%$ en el caso de la soja-, dándole un carácter móvil para acompañar las variaciones de los precios internacionales, lo que disparó el conflicto. Durante casi cuatro meses se sucedieron cortes de ruta, movilizaciones y el cese de la comercialización de productos. En julio, luego de que el decreto presidencial fue girado al Parlamento, el Senado rechazó el aumento y las retenciones volvieron a su anterior nivel. Si bien los cortes de ruta cesaron, la movilización de los productores pampeanos continuó con asambleas y diversos actos, que se prolongaron con distinta intensidad durante 2008 y 2009. 
Nos interesa retomar el conflicto por una serie de razones. En primer lugar, porque al plantearse en el espacio público como un problema de distribución de ganancias extraordinarias, se cuestionaba la relación construida por las elites entre su vocación de cambio técnico y modernizadora, y su legitimidad como clase empresarial. En efecto, sus ganancias provenían -afirmaban- de la inversión en tecnologías y no del control patrimonial sobre la tierra. En segundo lugar, porque el conflicto los conectaba ya no solo con aquello que había movilizado principalmente su actuación hasta entonces (la consolidación de un nuevo perfil empresario) sino también con temas (como la distribución de la renta) en relación a los cuales las fuerzas políticas populares los habían denostado históricamente. El conflicto nos interesa especialmente en conexión con esta segunda dimensión: en efecto, ¿si se trata de elites renovadas, modernas (en su propia construcción), cómo se posicionaban políticamente en un espacio público donde se disputaba la distribución de la renta agropecuaria, precisamente en torno a cuya concentración su legitimidad social había sido largamente cuestionada desde que el Estado y la política devinieron más permeables a las demandas de otros sectores?

Es en ese marco que nos interesa abordar las ideas políticas que las elites fueron (re)creando a lo largo del mencionado conflicto, particularmente en referencia a: a) la relación con el Estado, cuestión que la amplia desregulación del mercado en los '90 había quitado del medio como "problema" para el empresariado rural, y b) las formas políticas que su liderazgo productivo y económico requería, lo que involucraba revisar tanto su relación con las capas inferiores de la burguesía, como las formas organizativas hasta entonces adoptadas. Ambos aspectos, que señalaremos brevemente en lo que sigue, se revelaron como los más sustantivos en nuestro trabajo de campo.

\section{La crítica a la política económica}

Este es el nudo principal de la reacción tanto de elite como de la pequeña burguesía rural, y el que menos controversias despierta entre los diversos grupos que componen el llamado "campo". Medidas como el aumento de las retenciones -sin considerar sus impactos diferenciales según el tamaño de las explotaciones- o la creación de la Oficina Nacional de Control Comercial Agropecuario (ONCCA) -a 
través de la cual el gobierno había intervenido en el mercado de exportación, asignando cupos y autorizaciones de venta-, incidían de manera no menor en las ganancias empresariales y en rentabilidad de sus inversiones. Muchos reeditaban las viejas demandas de libre mercado y la desconfianza a la intervención estatal. "La gente se enfureció por el carácter expropiador de las retenciones, y que todo el tiempo te cambien las reglas del juego, así nadie puede producir", nos decía un empresario en una asamblea a fines de 2008. A ello agregaban la crítica a lo que consideraban la falta de racionalidad de las medidas, que habían constituido un freno "artificial" al crecimiento del sector agropecuario.

Ahora realmente (la plata) estaba puesta en la producción, entonces ipararlo artificialmente! Las retenciones lo paran artificialmente... Con un $10 \%$ de retenciones Duhalde levantaba a la Argentina, con un $20 \%$ Kirchner hacía maravillas, con un $30 \%$ dibujaba pajaritos de colores en los techos de todas las casas Es como que fue demasiada avidez por las retenciones (Francisco, febrero de 2009).

La crítica no está solamente basada en la referencia a la situación empresarial sino que también retomaba la de los chacareros, agitando el fantasma de la expulsión de productores -que todavía estaba en la memoria de aquellos- adjudicándola ya no a la lógica del actual modelo agropecuario sino a los desaciertos de la política económica.

Otras veces, la crisis era por varios factores, estaban sí políticas poco favorables para la producción, como el 1 a 1 , pero también te había permitido tecnificarte, y estaban los problemas del clima, de los precios internacionales bajos. En cambio, ahora todas esas variables eran favorables y la política del gobierno provocó esta crisis, donde vamos a ir cayendo, yo no sé cuantos irán a quedar en pie. Deben querer concentrar 4 o 5 para poder controlarlos mejor,

opinaba un pequeño productor participante de la asamblea mencionada. Las voces de los empresarios eran coincidentes:

que un gobierno nacional genere una normativa que destruya las riquezas es absurdo (Gerardo, marzo de 2009).

En segundo lugar, la crítica involucraba el argumento sobre cómo las medidas de gobierno perjudicaban las relaciones virtuosas que el comportamiento de una clase empresarial moderna había cimentado entre el campo y la ciudad. Hablaban así de un tipo de desarrollo que había comenzado a mostrar sus posibilidades de integración social en el interior del país. 
Yo creo que quedó muchísimo en los pueblos. Porque no te olvides que estas empresas que tenían ganancias no es que se iban con lo que estaban ganado, pagan lo que se llama impuesto a las ganancias. O sea que en la medida en que vos ganás, pagás, no es que te llevas la ganancia. Y básicamente la gente que vive en el interior y vive del campo, en general reinvierte en su zona. Es muy común que se reinvierta hasta el $100 \%$, es mucho más probable que en los grandes conglomerados urbanos haya gente ahorrando en pesos, fuera de su país o en dólares, que en el interior. En el interior compras un terreno, edificas una casa, la gente compra dos vacas más, todos crecen, por eso es inconcebible que no se defienda eso (...) ha dejado un movimiento importantísimo de gente, tremendo. Y bueno cuando empieza a aflojar, empieza a aflojar todo el consumo local, y está bien, habrá menos ricos, menos riqueza, pero también va a haber más pobres, de eso no tengo dudas (Francisco, octubre de 2008).

Otro rasgo, derivado del anterior, fue asimismo subrayado de manera sistemática a lo largo del conflicto, por los dirigentes agropecuarios, sus representados y la prensa: esa misma riqueza que el "campo" producía y reinvertía localmente, impulsando el bienestar local, también llegaba a los grandes aglomerados urbanos, a través de los planes sociales, financiados con las retenciones. La crítica era que, además de excesivas, las retenciones habían servido, en manos de "una clase política corrupta", no a los fines inicialmente previstos, sino a consolidar el clientelismo y la construcción de formas de control social de los actores económicos (mediante subsidios) que atentaban contra las formas republicanas de gobierno:

Mirá, con 90 mil millones de pesos que entraron por cuatro años de retenciones, si hubiesen estado aplicados exclusivamente a la pobreza y a la indigencia, hoy en Argentina no habría ni pobres ni indigentes (Gastón, noviembre de 2008).

Para finalizar este punto diremos que estos discursos sobre el modelo de desarrollo están sustentados en creencias muy generales que pueden movilizar, como se observa, voluntades distintas. Aun así, interesa subrayar -como se advierte en los distintos testimonios- que los entrevistados asignan a las retenciones un carácter anteriormente no presente en sus reacciones corporativas: esto es, a sus ojos perjudican un proceso virtuoso donde el cambio técnico podría asociarse al crecimiento económico y al desarrollo social. Esta forma de concebir el papel del cambio técnico no se interroga por las mediaciones que ligan las distintas dimensiones y la medida en que ellas son construidas y disputadas socialmente. 
El crecimiento que las economías locales observaron luego de 2002 son para la elite una muestra acabada de cómo el modelo contiene mecanismos de distribución de la riqueza, ${ }^{16}$ desde esa certeza plantean críticas a la clase política: para ellos, las retenciones no habían contribuido a mejorar la situación social de otros sectores sino a fortalecer manejos clientelares. Así, se presentaban a la sociedad entrelazando el reclamo por la renta con otro "cívico" por las formas republicanas. En ese contexto, para los entrevistados comienza a plantearse la necesidad de una representación política propia que asegurara sus intereses y la consideración de sus puntos de vista en las políticas del Estado.

\section{Crítica a la clase política y la apuesta por un programa propio}

El conflicto por las retenciones movilizó críticas al partido de gobierno y su manejo del Estado, tanto de la burguesía y sus elites rurales como de sectores urbanos, reeditando de manera inédita representaciones clasistas y lógicas binarias que el país había conocido décadas atrás y que parecían perimidas (Gras/Hernández 2009; Svampa 2008). No es nuestra intención aquí profundizar en ellos sino en las ideas que sobre la política y la relación de la elite agraria con el Estado pueden leerse a través del prisma que el conflicto ofrece.

Si bien la crítica de los empresarios se concentraba en el partido de gobierno, también alcanzaban a los opositores. En otras palabras, la relación con la clase gobernante en sentido amplio fue auscultada, en la medida en que los grados de autonomía que ella adquiere en distintos momentos históricos intervienen de manera directa en las capacidades concretas de los actores agrarios -en particular de sus grupos dominantes- para asegurarse, a través de la política pública, las condiciones de su reproducción y expansión.

Es en ese punto donde empieza a ser discutida la necesidad de alguna otra forma de acción en defensa de los intereses del sector, además de las corporativas. Hay allí dos discusiones que solo podremos mencionar brevemente. La primera tiene que ver con la medida en que el actual mapa institucional del sector agropecuario asegura la representación de los intereses de sus actores dominantes. Se plan-

16 Este es un punto de controversias con otras miradas y representaciones sobre el actual modelo agrario en Argentina, véase Gras/Hernández (2009). 
tea así en las asambleas y documentos de distintos grupos que participan de los debates, la necesidad de una forma organizativa (que algunos llaman "la $5^{\circ}$ gremial") que trascienda la lógica de las representaciones actuales, asentadas sobre las líneas de fractura de la estructura social. Numerosos entrevistados han sostenido que esos clivajes ya no son centrales, por lo que el "sector" debiera encontrar una forma de representación donde la "diversidad" esté contenida. En estas ideas, el campo de poder interno es concebido como plural pero no antagónico. Esa construcción implica también definir sus límites en el plano simbólico: al hablar de "sector" nuestros entrevistados excluyen a los grupos campesinos que están presentes en el agro argentino, planteando que ellos no son parte de la política agraria sino que deben ser atendidos por políticas sociales. Pero la exclusión no es solo el no reconocimiento de los campesinos como sujetos ligados productivamente a la tierra: en algunas situaciones y contextos, puede asumir otras dimensiones -dramáticas- como reflejan los violentos desalojos de campesinos en el norte de Córdoba y en Santiago del Estero.

La segunda discusión refiere a la medida en que las estrategias para mantener/ampliar su capacidad de influencia en la vida pública y política debería incluir la participación electoral. En varias asambleas se dio ese debate, que puede resumirse en dos posturas: continuar con la acción gremial y la búsqueda de acuerdos formales y/o informales con el gobierno, o bien, involucrarse en la dinámica partidaria, ampliando la base de apoyo política con la búsqueda de aliados (grupos de desocupados desplazados del entramado de poder del actual gobierno, clases medias del interior del país).

Tenemos temas que hay que atender ya por lo cual seguramente hay que salir a cortar rutas pero también hay que trabajar para adelante. Tenemos que participar sí o sí en política porque este es un problema político. No lo hemos hecho antes y el no haber participado en política es lo que transformó nuestra actividad, nuestra vida, nuestro modo de vivir en una porquería, porque los políticos son una manga de chorros y son los que nos están gobernando. Para eso tenemos que ir a cada partido, antes de las elecciones, para formar el candidato, o bien para poner un candidato propio, para comprometerlos en qué van a hacer en el caso agropecuario cuando sean gobierno,

sostenía un empresario en una asamblea a principios de 2009. 
En tal sentido, al definir al conflicto como "político" -y ya no sólo "económico" como había sido inicialmente- los empresarios hacían referencia en primer lugar al hecho que la trama institucional existente (sus corporaciones) no lograba articular una comunicación institucional más o menos previsible con las autoridades. En las asambleas se escuchaban críticas veladas o explícitas al modo en que ellas ejercían su representación en el conflicto y, a lo que entendían, se revelaban como los límites de la discusión y negociación sectorial enmarcada en los mecanismos clásicos (audiencia con autoridades, negociación con ministros). En segundo lugar, la definición del conflicto como político hacía referencia a la necesidad, que comenzaban a plantearse, de acceder a los mecanismos de reclutamiento y formación de la clase política, "formar" sus propios dirigentes políticos. Al respecto, uno de los productores agropecuarios más grandes del país nos señalaba:

yo no creo para nada en un partido agrario, esa no es la idea [...] lo que entiendo es que nosotros tenemos que darles influencia positivamente, la mayor cantidad de los partidos políticos para que muchos de los que se dedican sanamente a la política puedan por lo menos escuchar y tratar de entender nuestra visión de una Argentina integrada donde creemos que la agro industria tiene mucho que aportar a las generaciones posteriores de todos los argentinos [...] es la lógica de tratar de buscar que muchos políticas de distintos partidos entiendan estas cosas que pensamos nosotros, entonces darle un marco ideológico (entrevista, marzo de 2009).

La estrategia adoptada (cuya dinámica y efectos es aún pronto para sopesar adecuadamente) fue participar electoralmente, incorporándose a distintos partidos de la oposición. Así, en las elecciones de junio de 2009 en las que se renovaron parcialmente el parlamento nacional y algunas legislaturas provinciales, varios "agrodiputados" obtuvieron sus bancas. En el marco de una crisis política en ciernes en el país y, en el ámbito rural, de cambios en el escenario que permitió el crecimiento espectacular del complejo sojero en los últimos años, sus actores principales se preguntan -por primera vez al menos desde la transición democrática abierta en 1983- por la necesidad de una representación electoral, y discuten nuevas formas de participación política, que traduzcan y hagan efectivo lo que para ellos es evidente: la visibilidad que alcanzaron los coloca en una situación que les demanda encontrar el modo en que su poder económico se traduzca en poder político. En ese marco, cobran sentido las actividades que desde las 
asociaciones profesionales vienen realizando, como la formación de líderes locales o los emprendimientos de responsabilidad social empresaria. En ellas va construyéndose un etos que orienta y da sentido a la acción, que les va permitiendo pensarse como una clase dirigente y un factor de poder, tal como se refleja en las opiniones de un integrante de la elite:

Claramente somos el poder político más importante que tiene la Argentina y el sector con mayor capacidad de movilización, increíblemente. Además de tener nuestro poder económico, aunque no esté puesto al servicio político todavía. Está más puesto al servicio de armar un poder político pero queremos ver cómo tiene que ser el modelo de ese movimiento para poder ayudar a que todas estas ventajas comparativas generen más riqueza. Necesitamos relacionarnos mejor con el movimiento político, con los movimientos sociales, con la sociedad urbana, con la universidad (entrevista, marzo 2009).

En el inicio del siglo XXI, el campo vuelve a demandar un lugar en la distribución del poder acorde a su capacidad para producir riquezas. En este trabajo pretendimos acercarnos a algunos de los rasgos que singularizan las prácticas de sus actores dominantes, observando algunas de las relaciones sociales y políticas que privilegian.

Los eventos recientes no son meramente una demanda específica por una medida económica. También se desplegaron, con todas sus tensiones y contradicciones, dimensiones complejas para pensar las relaciones entre elites económicas, clase política, desarrollo y democracia. En efecto, la actual elite se define por la consolidación de una base técnico-productiva y empresarial moderna que no tiene a la propiedad de la tierra como resorte exclusivo de su poderío. Pero solo en los últimos años, y particularmente en el marco del conflicto con el gobierno, comenzaron a plantearse la traducción de su capital económico en capital político; la insospechada movilización que lograron -de otros actores agrarios como los chacareros, de grupos urbanos, en particular en las localidades del interior del país- les mostró -a otros actores, como los partidos políticos y a ellos mismos- el liderazgo que podían ejercer.

Por primera vez en la historia, ese liderazgo parece dar un lugar significativo a la construcción de conexiones institucionales en la arena pública y político-democrática. Pero también puso en evidencia que el modelo socio productivo que dinamizan no tiene los mismos 
efectos de inclusión para todos los actores. Ese modelo que busca consolidarse y legitimarse como hegemónico en la arena pública puede ser sometido también a la crítica en ese mismo espacio.

\section{Bibliografía}

Boltanski, Luc/Chiappello, Eve et al. (2002): El nuevo espíritu del capitalismo. Madrid: Akal.

Gras, Carla (2009): "El nuevo empresariado agrario: sobre la construcción y dilemas de sus organizaciones". En: Gras, Carla/Hernández, Valeria A. et al. (comps.): La Argentina rural. De la agricultura familiar a los agronegocios. Buenos Aires: Biblos.

Gras, Carla/Hernandez, Valeria A. (2008): "Modelo productivo y actores sociales en el agro argentino". En: Revista Mexicana de Sociología, 70, 2, pp. 227-259.

- (2009): "El fenómeno sojero en perspectiva: dimensiones productivas, sociales y simbólicas de la globalización agrorrural en la Argentina", en Gras, Carla/Hernández, Valeria A. et al. (comps.): La Argentina Rural. De la agricultura familiar a los agronegocios. Buenos Aires: Biblos, pp. 15-37.

Heredia, Mariana (2003): "Reformas estructurales y renovación de las elites económicas en la Argentina: estudio de los portavoces de la tierra y el capital". En: Revista Mexicana de Sociología, 65, 1, pp. 77-115.

- (2005): La sociología en las alturas. Aproximaciones al estudio de las clases/ elites dominantes en la Argentina (Apuntes de Investigaciones del CECYP, año IX, $\left.\mathrm{n}^{\circ} 10\right)$. Buenos Aires: CECYP.

Hernández, Valeria A. (2007): "El fenómeno económico y cultural del boom de la soja y el empresariado innovador”. En: Desarrollo Económico, 47, 187, 331-365.

Hora, Roy (2005): La burguesía terrateniente: Argentina, 1810-1945. Buenos Aires: Capital Intelectual.

- (2009): Los estancieros contra el Estado. La Liga Agraria y la formación del ruralismo politico en la Argentina. Buenos Aires: Siglo XXI.

Newell, Peter (2009): "Bio-Hegemony: The political economy of agricultural biotechnology in Argentina”. En: Journal of Latin American Studies, 41, pp. 27-57.

Nun, José/Lattuada, Mario L. (1991): El gobierno de Alfonsín y las corporaciones agrarias. Buenos Aires: Manantial.

Obschatko, Edith S. de (2003): El aporte del sector agroalimentario al crecimiento económico argentino, 1965-2000. Buenos Aires: IICA.

O’Donnell, Guillermo (1977): "Estado y Alianzas en la Argentina, 1956-1976". En: Desarrollo Económico, 16, 64, pp. 523-554.

Palomino, Mirta L. de (1988): Tradición y Poder: La Sociedad Rural Argentina (1955-1983). Buenos Aires: CISEA-GEAL.

Svampa, Maristella (2008): Cambio de época. Movimientos sociales y poder político. Buenos Aires: Siglo XXI. 
4. (In-)seguridad y violencia 



\section{María Carolina Agoff \\ Del sentimiento de injusticia y el rol de las nuevas legislaciones contra la violencia de género en México}

Ciertas circunstancias resultan ideales para reflexionar y analizar la vivencia de la violencia entre las personas afectadas. En México, es posible encontrar tal situación ya que se observa, por un lado, un aumento dramático en los últimos años de la delincuencia y de la violencia delictiva, y por el otro, unas instituciones del Estado que parecen rebasadas por este fenómeno y que se muestran incapaces de contenerlo. ${ }^{1}$

En este contexto de incontables asesinatos por parte del narcotráfico y de violaciones a los derechos humanos por parte del Estado, donde ya se contabilizan 28.000 muertos (cifra correspondiente a octubre de 2010) desde el inicio de la llamada "guerra al narcotráfico", con tasas de feminicidio altísimas (y no sólo en el caso internacionalmente conocido de Ciudad Juárez), migración indocumentada, trata de personas, etc., se han generado iniciativas legislativas para proteger a las mujeres frente a la violencia de género.

Aún dentro de este panorama de extrema violencia social, la casa sigue siendo uno de los lugares más peligrosos para las mujeres en México. Según datos de la Encuesta Nacional sobre la Dinámica de las Relaciones en los Hogares 2006 - ENDIREH (INEGI 2006), el $26,08 \%$ de las mujeres experimentó violencia física y/o sexual de parte de su novio, compañero o marido el año previo a la realización de la encuesta. De ese porcentaje sólo el $22,93 \%$ se dirigió a agencias gubernamentales de procuración de justicia. De acuerdo a los datos de esta misma encuesta, las víctimas de violencia de pareja de tipo física y sexual buscan ayuda en primer lugar entre sus familiares y en

1 Esto ha generado distintas iniciativas por parte del gobierno federal. Dentro de ellas se encuentra la reforma procesal penal más importante desde 1917 que intenta garantizar el debido proceso en los juicios penales y al mismo tiempo, restringe garantías de ese debido proceso para la delincuencia organizada. 
segundo lugar, acuden a cuerpos policiales o autoridades públicas. De todos modos un porcentaje mayoritario de $77,07 \%$ decide no buscar ayuda en instituciones gubernamentales, como tampoco denunciar a su pareja.

Así, en una cultura reinante de ilegalidad y de profunda desconfianza en las instituciones y en el papel del Estado como regulador de los conflictos, se producen legislaciones novedosas que apuntan a prevenir, sancionar y erradicar la violencia contra las mujeres. Nos referimos a las leyes federales: Ley General para la igualdad entre hombres y mujeres (aprobada en el 2007) (Cámara de Diputados 2007a), y Ley federal de Acceso a una vida libre de violencia (Cámara de Diputados 2007b).

Son estas las circunstancias que reflejan una tensión esencial entre dos fuerzas opuestas, la impunidad y la defensa de los derechos.

Entiendo que las cuestiones de fondo atañen a la posibilidad y eventualmente a la eficacia para combatir la violencia de género a través de la esfera del derecho y también a los modos en que se vinculan los ciudadanos con el Estado a través de los derechos. ${ }^{2}$ Mi propósito, no obstante, es indagar cuestiones relacionadas con la tensión entre la ley y la costumbre, teniendo como antecedente que la ley, a diferencia de los usos y costumbres, propone un idioma moderno e igualitario. Así, la cuestión que también plantea Segato (2003) en relación a la violencia moral es: ¿de qué modo puede incidir la ley en el sistema moral? o ¿cuál es la capacidad de impacto de la legislación sobre el arraigo de la violencia de pareja en la costumbre?

En lo que sigue me propongo abordar algunos elementos que se derivan de la mencionada tensión entre la ley y la costumbre, y de la posibilidad de la apropiación subjetiva de derechos por parte de mujeres víctimas de violencia de pareja dentro de este marco. Para ilustrar este punto se van a desarrollar tres temas relacionados con el tránsito hacia una cultura de los derechos. El primer punto concierne al surgimiento de un sentimiento de injusticia asociado a la vivencia de violencia de pareja y que antecede -al menos lógicamente- a la

2 Otra arista fundamental para entender este fenómeno pero que no pretendo abordar acá es la de la implementación de derechos y los problemas vinculados a la aplicación de la ley, la burocracia estatal, la violencia institucional, la ausencia del Estado de Derecho en ciertas regiones, la legislación, la falta de instrumentos, etc. 
apropiación de un derecho. Hay en las mujeres una experiencia agraviante no percibida que precede al reconocimiento de la violencia como delito y por tanto a la apropiación subjetiva de un derecho que las salvaguarda de la violencia de pareja. El segundo punto alude al conflicto entre normatividades de distinto sentido (moral y derecho) que pueden constituir un obstáculo para la apropiación y para el ejercicio efectivo del derecho a una vida libre de violencia. Y en tercer lugar se muestran los indicios incipientes de la eficacia simbólica de estas nuevas legislaciones, en particular de la capacidad y legitimidad del derecho para nombrar o nominar y para dar forma a nuevas identidades.

Por último, expondré una cuestión relacionada con la necesaria movilización de estas legislaciones, para concluir que a pesar de la cultura de ilegalidad reinante y la profunda desconfianza en las instituciones, hay un uso particular del derecho, en el plano simbólico, que da buena cuenta de los variados modos en que las sociedades pueden interpretar el derecho y movilizarlo para sus propios fines.

\section{Del sentimiento de injusticia}

Una forma de análisis del sentido de injusticia experimentado por las víctimas es el estudio del tipo de argumentación que los propios actores construyen cuando quieren dar cuenta de las acciones de los demás o de ellos mismos. ${ }^{3}$

En efecto, la violencia de pareja se puede analizar desde las normas, valores e ideologías que están en la base de esta acción y que dan un marco explicativo a las motivaciones de quienes ejercen violencia, de quienes intentan explicarla en tanto víctimas, y de su justificación y legitimación. Así, la investigación empírica permite desentrañar los argumentos que se dirimen alrededor de esta forma parti-

3 Las personas explican sus propios actos y comprenden el sentido de las acciones de los otros mediante procesos de atribución y reconstrucción de motivos (Wright 1979; Schütz 1993). Nos referimos con esto a una concepción social de los motivos que puede ser entendida también como un repertorio lingüístico socialmente preestablecido y apropiado para interpretar o explicar conductas en una situación dada. Los denominados "vocabularios de motivos" (Wright Mills 1981) permiten hacer justificables las acciones ante los demás y ante uno mismo, ya que se inscriben dentro del marco de aquello que socialmente es aceptado como razones de la acción. 
cular de la violencia y facilita la reconstrucción de las orientaciones normativas y valorativas asociadas, y también del sentido de injusticia implícito en la experiencia de violencia.

En la vida cotidiana, las personas raramente se ven en la necesidad de remontarse al principio de justicia que sostiene sus argumentos, pero frente a la crítica, se origina el trabajo de justificación y reconstrucción (Boltanski 2000). Lo valioso de este análisis es que hace explícitos los valores y el principio de justicia detrás de las disputas conyugales que forman parte de la dinámica de violencia.

Hemos constatado que las mujeres ofrecen dos tipos de explicaciones subjetivas sobre las razones de la violencia que ejercen sus compañeros hacia ellas. ${ }^{4}$ Están aquellas que atribuyen la violencia a fuerzas externas al hombre, como expresión incontrolada de afectos, fruto de las frustraciones laborales, de problemas de infancia, del consumo de alcohol, etc. Estas mujeres no parecen sentirse víctimas de una injusticia, sino que dan muestras de un sufrimiento que se vive como inevitable y, en casos extremos, como legítimo (Moore 1978: 458 y ss.). Al respecto existe evidencia de una extendida creencia, en hombres y mujeres, de que la violencia de pareja no intencional es aceptable y que sin intención no hay atribución de responsabilidad (Eisikovitz/Winstok/Fishman 2004).

El otro tipo de explicaciones sobre el origen de la violencia de pareja, apunta a la idea de un acto consciente de parte del maltratador. La violencia que se experimenta como castigo intencional de parte del hombre y que se origina en el supuesto "mal comportamiento" de la mujer, no favorece las mismas explicaciones exculpatorias, ni resulta igualmente tolerable. Aquí las explicaciones subjetivas de las víctimas dan cuenta de motivaciones asociadas a la voluntad de encauzar, imponer o castigar ciertos comportamientos de la mujer y sugieren que la violencia resulta un medio de restablecer el control hegemónico del hombre.

4 Se trata de dos investigaciones empíricas de naturaleza cualitativa. La primera realizada en el 2003 en el Instituto Nacional de Salud Pública (INSP) y la Secretaría de Salud de México (INSP, SSA 2003). La segunda investigación fue financiada por CONACYT (Consejo Nacional de Ciencia y Tecnología) y se llevó a cabo en el año 2008. La muestra de ambas investigaciones empíricas estaba compuesta por mujeres víctimas de violencia de pareja entre los 18 y los 65 años, con un perfil de usuarias de servicios de salud públicos. 
Los argumentos que se esgrimen durante el conflicto que conduce a la violencia ponen de manifiesto el vocabulario de motivos legitimado socialmente y la relación de subordinación de la mujer al hombre que se expresa de manera paradigmática en la frase de uso corriente "pedir permiso al marido".

Aquellas mujeres cuyas explicaciones subjetivas ubican el origen de la violencia en la motivación consciente de dominio masculino, muestran un umbral menor de tolerancia a la violencia y atribuyen claramente la responsabilidad del maltrato al hombre abusador, aunque dan cuenta de sentimientos ambivalentes. No cabe duda que estas mujeres experimentan la violencia que se ejerce contra ellas con un profundo malestar.

Así, los relatos de las víctimas sugieren que la experiencia de violencia se vive al menos de los siguientes modos:

a) como un sufrimiento legítimo, asociado al incumplimiento de ciertas expectativas de comportamiento femenino en el ámbito doméstico;

b) como algo inevitable, que adquiere la forma fatalista de la frase "es mi cruz"; o entendido como parte de un destino "natural" en toda mujer; ${ }^{5}$

c) como un "castigo inmerecido", pero lejos aún de ser considerado una transgresión o una conducta condenable o sancionable como delito.

Sólo el último modo deja en evidencia un sentimiento de injusticia aunque todavía atado a una comprensión tradicional de los roles de género, entendidos como el deber ser de las mujeres en sus relaciones de pareja, y que son en gran parte responsables de "los niveles de tolerancia social que encubren la identificación de la violencia y contribuyen a su perpetuación dentro del ámbito privado" (Güezmes/Palomino/Ramos 2002: 56).

5 El concepto de "preferencias adaptativas" podría ofrecer una explicación a la experiencia subjetiva de violencia que expresa la imposibilidad de percibir la injusticia. Amartya Sen y Jon Elster hablan de preferencias adaptativas cuando la gente no puede evaluar un tipo de trato como injusto, humillante o malo, pues ajusta sus expectativas a las condiciones de deprivación en las que vive (Nussbaum 1999). 
Los sentimientos de vergüenza y culpa expresados en sus testimonios también dejan en evidencia que las mujeres difícilmente pueden cuestionar -hasta ahora- las normas y valores sociales que orientan el comportamiento de hombres y mujeres, y que constituyen la base de la justificación y legitimación de la violencia. ${ }^{6}$ De acuerdo a este conjunto de orientaciones valorativas y normativas tradicionales, el matrimonio resulta una suerte de "camino obligado" tanto para hombres como para mujeres, pero a diferencia del caso de los hombres la identidad femenina y los roles sociales de la mujer están exclusivamente definidos en el marco de su matrimonio y familia. Aún en sociedades tan disímiles a la mexicana como la india, encontramos las mismas definiciones de la ideología familiar: las buenas madres son estoicas y abnegadas, las buenas esposas, castas y obedientes, y las buenas hijas, virginales y hacendosas (Sitaraman 1999).

En este contexto de normas y valores sociales es donde la violencia cobra un sentido particular: se trata de una sanción legítima ("es que tu no lo cuidas" o "es que tú lo provocas") o de una falta permisible ("ay señor, no exagere") o de un destino que hay que aceptar ("por eso pasamos todas", "es tu cruz"). Por su parte, la vivencia de violencia como "castigo inmerecido" sugiere la posibilidad de justificar la violencia o merecerla en ciertos casos (en el caso de incumplimiento de las expectativas depositadas en ellas, como mujeres). Con ello se observa una comprensión particular de la injusticia que pone de manifiesto la distancia que separa aún a la violencia como "castigo inmerecido" de la violencia como delito o como algo inaceptable. ${ }^{7}$

\section{Del conflicto entre normatividades}

La particular relación de influencia recíproca entre la identidad social, la valoración intersubjetiva y el reconocimiento jurídico (Honneth 1997), nos brinda una vía analítica fructífera para comprender

6 La vergüenza nos habla de una experiencia de humillación (y no de injusticia) en el sentido descrito por Margalit y según el cual uno se avergüenza o se ve humillado por un rasgo de la autodefinición conectado a la pertenencia a un grupo en particular, en este caso el de las mujeres (Margalit 1996).

7 Es decir, no hay lo que Felstiner/Abel/Sarat (1980-81) llaman perceived injurious experience; para ello se requiere identificar la ofensa como tal, y nombrarla. 
las dificultades que supone la apropiación y ejercicio de un derecho individual a una vida libre de violencia y a una comprensión de la dignidad atada a la integridad y a la autonomía, como garantías individuales. ${ }^{8}$ En efecto, la investigación empírica deja en evidencia el obstáculo que supone el conflicto entre normatividades, o entre diferentes formas del reconocimiento -el jurídico y el moral-. Se trata de la tensión entre, por un lado, las normas sociales que guían el ejercicio de rol de género y la valoración social a nivel intersubjetivo y, por otro lado, las normas jurídicas que traducen el problema social a términos individuales, "atentando" contra el status naturalizado de las mujeres como madres-esposas. Ambas formas del reconocimiento social están reñidas y dificultan el surgimiento e internalización de una cultura de derechos emancipatoria.

La coerción que ejercen las expectativas sociales de conformación de una familia, junto al mandato fatalista expresado en la frase "es tu cruz" que se transmite de madre a hija, refuerzan el deber de la sumisión al marido y contribuyen a naturalizar la violencia y a tolerarla.

Precisamente, la violencia de pareja es un conflicto social que deja en evidencia que las familias, con mucha frecuencia, lejos de ser una fuente de apoyo para las víctimas, imponen a las mujeres un imperativo de sometimiento al hombre y a su violencia.

Son en especial las mujeres de la familia política (suegra, hermanas) quienes colaboran en la creación de contextos de vulnerabilidad, a través de la descalificación moral de la mujer, y que facilitan la aparición de la violencia o incluso la propician. ${ }^{9}$

En los casos estudiados, los efectos negativos de los vínculos familiares se hacen particularmente evidentes al observar el contexto

8 Honneth (1997) desarrolla un concepto de persona y un sí mismo dependiente de tres formas del reconocimiento intersubjetivo -amor, derecho y respeto o valoración social-. Estas tres formas del reconocimiento tienen como contracara tres formas de desdén o menosprecio, experiencia que puede constituirse como motivo de acción en la conformación de conflictos sociales.

9 En los casos extremos, la familia política basuriza (como forma extrema de la descalificación moral y el desprecio) a la mujer como nuevo miembro de la familia. Según Silva Santisteban (2008) la basurización es el mecanismo simbólico que justifica, legitima la construcción del subalterno o excluido y asegura así su instrumentalización. Sobre la "colaboración" femenina a la dominación del hombre ver Bourdieu (2000). 
familiar como un entramado compuesto por precarias condiciones materiales de existencia, por la posición de la mujer en la estructura familiar y por el conjunto de normas y valores sociales que pautan la relación entre los géneros (Agoff/Herrera/Castro 2007). La idea de la preservación de la integridad familiar a través de arreglos tradicionales asociados a la residencia patrilocal y a la dependencia económica del varón, ponen aún más en riesgo a las mujeres. Son también las expectativas e ideales de familia y conyugalidad y de embarazos dentro del matrimonio lo que lleva a las familias a someter a sus hijas a matrimonios forzados en casos de embarazos. Lagarde (1990) ha puesto de manifiesto estas orientaciones valorativas de la sociedad mexicana que brindan una explicación al fenómeno de los matrimonios forzados. Y si bien la justificación de estos arreglos se expresan en la forma de expectativas morales y cumplimiento de estos ideales, no debe dejarse de tener en cuenta que con frecuencia se trata de arreglos que obedecen a una muy precaria situación económica y a la presión por encontrar una fuente de sostén económico para la hija embarazada.

Estas normas y valores poco tienen que ver con la realidad cotidiana de hombres y mujeres, con sus formas reales de comportamiento y experiencias. Pero precisamente, es tal la distancia que separa la norma de la realidad, que la fuerza de las adscripciones normativas es reforzada de un modo más intenso y frecuente (Hausen 1990: 269). Lo que, no obstante, no deja de tener una importancia decisiva, es que este conjunto de normas e ideales constituyen la base de la legitimación de la violencia contra la mujer.

Resulta evidente que en este medio familiar la mujer se ve privada de recursos, de poder y de libertad como resultado de las desigualdades económicas, generacionales y de género, todo lo cual produce un ámbito de gran vulnerabilidad. ${ }^{10}$

En síntesis, la fuerza de los usos y costumbres para regular la vida social y el rol que juega la comunidad como la fuente del reconocimiento social por excelencia supone indudablemente un obstáculo

10 La ENDIREH 2006 revela cifras que dan buena cuenta de que la familia no constituye en estos casos una fuente de apoyo: casi dos de cada tres mujeres $(64,6 \%)$ toma otro camino que el de recurrir a su familia. El 11,43\% de las mujeres con violencia física o sexual dicen no acudir a las autoridades públicas para que no se entere su familia (Frías 2010). 
para que las mujeres tomen conciencia de sus derechos y los ejerzan. Son los valores tradicionales los que tienen primacía sobre cualquier otra forma del reconocimiento y estos pautan el reconocimiento de una identidad e ideal femenino en la conformación y mantenimiento de una familia. Frente a la violencia de pareja, apelar a los derechos, a la dignidad o valores más individuales vinculados al respeto y a la autonomía puede poner en riesgo la posibilidad de autoafirmación que les confiere a las mujeres un matrimonio unido.

De este modo, las mujeres violentadas - para defender su integridad individual-, se enfrentan a la cuestión no sólo de perder su propia valoración social, sino frente al dilema de "traicionar" a su pareja y a su familia, cuyos status están también sujetos a su "buen comportamiento" y sometimiento. Otras culturas también hacen responsable a la mujer del honor de la familia y de la deshonra que cae sobre todos los miembros familiares en caso de que ella no "salve el matrimonio", al no velar por la unidad y continuidad del grupo familiar (Chatzifotiou/Dobash 2001).

Denunciar y usar la ley significa, para una mujer, acudir a la ayuda de un tercer partido, fuera de la familia y la comunidad, y esto puede generar ostracismo y fuertes críticas del entorno (Herman 2005).

$\mathrm{Y}$ así como las familias son con demasiada frecuencia quienes expresan un mandato de subordinación y tolerancia en nombre de las buenas costumbres y el honor de la familia, otras personas del entorno social de estas mujeres pueden colaborar para que ellas tomen conciencia de su situación y reconozcan el agravio. Se trata de relaciones de amistad o vecinales, es decir vínculos de naturaleza horizontal, de mayor simetría y espontaneidad, que les "abren los ojos" a las mujeres (expresión que designa el fin de la naturalidad y normalidad de la violencia). Estos vínculos sociales constituyen una fuente de apoyo pues precisamente desnaturalizan la violencia. Aquí la ausencia de los conflictos de intereses generados por la distribución de recursos escasos, por posiciones de poder generadas en los roles diferenciados al interior de la familia y por expectativas tradicionales de comportamiento, facilita intercambios de solidaridad y ayuda mutuos. También las asociaciones civiles o públicas resultan una fuente de apoyo ya que promueven en primera instancia los derechos de la mujer y posibilitan que la mujer se autorreconozca como víctima del maltrato (Agoff/Herrera/Castro 2007). 
De este modo, es posible ver que existen, al menos, dos elementos de indagación en la génesis de un sentimiento de agravio asociado a la experiencia de violencia, que resultan de gran valor heurístico. Tenemos, por un lado, el problema de la afiliación o de los otros en general, como testigos, cómplices o fuente de apoyo de las víctimas. ${ }^{11}$

Por otro lado, el vocabulario moral y emocional permite también descubrir los límites de las experiencias consideradas como válidas o no completamente reprobables. Expresiones tales como "lo bien portada que debe ser una esposa", "su mujer no se merece que la golpeen, es una buena persona", "pedir permiso al marido", "él debe darme para el gasto", etc., dan cuenta de la infantilización de las mujeres, de su consecuente necesidad de tutelaje y de su posición subordinada al compañero, que abre la vía a cualquier forma de la violencia masculina. El lenguaje moral y emocional refuerza y reproduce el status de subalterno o la condición de sujetos minorizados (Segato 2003), las cuales buscan conmiseración frente a su situación y se sienten avergonzadas de lo que les sucede.

Por el contrario, la indignación en tanto es "un sentimiento con un revestimiento moral que conlleva en sí una cierta idea de restitución" (Silva Santisteban 2008: 90) podría ser indicativo de una cierta transformación de las conciencias en el sentido de una idea de injusticia asociada a la experiencia de violencia.

\section{La eficacia simbólica del derecho}

La universalidad del fenómeno de la violencia de género y en particular de la violencia de pareja se asienta, entre otras cosas, en la primacía de los roles familiares de las mujeres -como hijas, esposas y madres-, por sobre cualquier otro rol social. La contracara de esto resulta la autoridad masculina en todos los campos de decisiones, no solo en el familiar. Es frecuente observar que los maridos reglamentan los modos de vestir de las mujeres, son quienes les otorgan permisos para trabajar o estudiar, deciden si las mujeres pueden frecuentar amistades. Sin embargo, los testimonios recogidos parecen sugerir

11 El rol de los hijos en la decisión de separarse de las mujeres es ambiguo: algunas se separan por ellos, otras permanecen en la familia alegando los mismos motivos. Cierto es que los hijos menores siempre resultan víctimas, junto a sus madres, de la violencia masculina. 
que estamos en una transición cultural con indicios de cambios, y otros de conservación de la ideología de género y familiar. Sorprendentemente las generaciones de mujeres más jóvenes no son tan permeables a los discursos de derechos, como las mayores de 35 años, para quienes las nuevas legislaciones comienzan a resonar de algún modo.

Estas mujeres ven reflejados sus problemas en los discursos públicos sobre los nuevos derechos, aunque de un modo particular: los significados de sentido común asociados a estas nuevas legislaciones están lejos aún de la idea de igualdad entre hombres y mujeres. Las mujeres entrevistadas reconocen en estos discursos su derecho a la integridad física, su "derecho a ser respetadas". Podemos con ello presuponer que esta forma peculiar de apropiarse de un derecho es distinta a la noción de derecho a la igualdad, aún muy ajena a estas mujeres como reclamo.

La movilización de estos derechos como lenguaje de igualdad resulta una tarea pendiente y necesaria si, tal como afirma Smart (1994), este lenguaje puede ser reclamado por todas las personas, con independencia del género o la clase. ${ }^{12}$

Ni la noción de igualdad, ni la de autonomía personal como derechos individuales parecen posibles aún en el universo discursivo y de prácticas de estas mujeres. La noción de justicia en ellas sugiere ante todo una asociación con la dignidad (esto es, como lo opuesto a la experiencia de humillación).

Con todo ello podemos hipotetizar además que la interpretación de sentido común que se hace de estas nuevas legislaciones está lejos todavía de enjuiciar la desigualdad de género, sino que se acerca más a la condena a la violencia explícita (en sus formas variadas de violencia sexual, económica, emocional o física) como medio para obtener o mantener la subordinación de las mujeres. De igual modo que los hombres violentos que recurren a terapia de rehabilitación, ${ }^{13}$

12 Resulta interesante preguntarse si así como la noción liberal de la justicia peca de ingenua en relación al acceso a la justicia y se muestra ciega al género, a la pobreza y a la raza, las víctimas, como contrapartida a esto, tampoco se ven reflejadas en el liberalismo clásico que no las incluye de facto como iguales.

13 Se trata de una investigación en curso sobre las concepciones de masculinidad que privan entre los hombres violentos con sus parejas, que asisten a terapias grupales de rehabilitación. 
difícilmente ponen en duda la relación de dominio-subordinación entre hombres y mujeres, sino que frente a los nuevos discursos en contra de la violencia, cuestionan la violencia como modo de imponer el dominio, pero no el dominio mismo.

A pesar del poder simbólico de las nuevas legislaciones, se observa en la aptitud de desnaturalizar una experiencia de injusticia naturalizada y normalizada por las tradiciones. Esto obedece a que el derecho puede constituirse en un lenguaje que les permite a las mujeres decodificar el significado de la violencia de un modo diferente al conocido: se trata de una experiencia naturalizada que el derecho ahora -en tanto lenguaje legítimo- nombra o designa como delito. Así las mujeres comentan con asombro "dicen que ahora es un delito".

Con esto puede verse la eficacia y legitimidad del derecho -aún en sociedades con escasa confianza en las instituciones- para definir la realidad a través de su poder de nominación, para darle nuevos significados o un nuevo lenguaje a los problemas cotidianos. Las mujeres aprenden a hablar de sus experiencias con otras categorías del lenguaje, significando las cosas de otro modo (Merry 1997).

Así, la fuerza simbólica del derecho radica entre otras cosas en la posibilidad de acabar con el preexistente (y único) horizonte referencial.

Además, es posible observar el impacto simbólico del derecho en el desarrollo de la subjetividad, al devolverles a las mujeres su carácter de sujeto. Los testimonios de las víctimas de violencia reflejan relatos biográficos de sucesos, sin opciones, sin un sujeto en la forma de "un yo" con un proyecto individual de vida. La mujer resulta parte de un grupo indivisible -la familia- y las legislaciones que la protegen de la violencia, en tanto la apelan en su carácter de sujeto de derechos, le hacen actuar con comprensión de sí mismas como individuos con derechos, como individuos con derecho a actuar en su nombre.

Ahora bien, ¿puede ser el derecho y la exigencia de justicia una vía para construir una subjetividad como individualidad? Dado que hasta ahora el ser mujer se vive como digna y merecedora de respeto en su rol de madre-esposa, cabe preguntarse si el derecho puede ser un nuevo espacio de autoidentificación, que posibilite la individuación como subjetividad no atada ni al proyecto familiar exclusivamente ni a la desigualdad, y pueda así garantizar una forma de re- 
conocimiento que sustituya este ideal femenino tradicional de la abnegación. ${ }^{14}$

Dado que el derecho de las mujeres moviliza una concepción de sujeto contraria a la que prevalece en el imaginario y prácticas sociales del sujeto tutelado que debe ser representado, su eficacia simbólica radica también en su capacidad de moldear nuevas identidades de género asociadas a la autonomía y el empoderamiento. No esperar conmiseración o misericordia, sino reparación moral, puede resultar otro indicio del devenir de un sujeto social empoderado por una (nueva) conciencia legal, es decir, un sentido de sí como persona definido por el derecho (Merry 1997).

Se ha enfatizado ya el poder de la ley para, entre otras cosas, definir la identidad personal. No se trata sólo de una cuestión de definición de la personalidad legal (la naturaleza jurídica del sujeto o ciudadano) con propósitos de regulación, sino de aspectos asociados a la vida social en la forma de expectativas, responsabilidades y restricciones (Cotterrell 2004).

\section{Consideraciones finales}

La tensión entre la ley y la costumbre se expresa como una disputa por los modos de interpretar un conflicto social y pone en duda esa comprensión común y naturalizada de las víctimas y de las personas de su entorno, quienes interpretan el fenómeno de la violencia en un lenguaje de virtudes femeninas, es decir, entendiendo la violencia como castigo merecido o en el mejor de los casos, inmerecido, en resumen como una sanción legítima y no en un lenguaje de derechos y de violencia como delito.

Esta tensión entre ley y costumbre se cristaliza en la disputa entre el derecho a la integridad y autonomía de la mujer versus el ideal de la unidad familiar. Esta tensión expresa también la distancia que separa los valores y normas que reinan en el mundo de la vida del ideal normativo del derecho. En el mismo sentido y tal como afirma Fraser (1989) en su crítica a Habermas, la esfera privada del mundo de la vida juega un papel central en la reproducción de la vida simbó-

14 "Los sujetos constituidos identitariamente en referencia a la feminidad se debaten en una dinámica ser-deber ser irremediablemente nociva para la configuración de un yo unitario" (Serret 2001: 148). 
lica y material de la sociedad y las desigualdades políticas y sociales, y por tanto en la reproducción y constitución de las inequidades de género. Así, las posibilidades de la vida no están solo restringidas por imposiciones sistémicas en la forma de colonización del mundo de la vida.

Antes bien, estas diversas esferas o fuentes de reconocimiento son relaciones sociales insustituibles y en tanto ejercen influencias recíprocas, se complementan. En efecto, si tal como sostiene Honneth (2009) la textura o la materia de la justicia social es la garantía de la autonomía personal y esta sólo se alcanza por las diferentes vías intersubjetivas de reconocimiento (de la esfera de las relaciones íntimas, de las relaciones jurídicas y del trabajo), podemos derivar que un reconocimiento jurídico sin una valoración social puede dejar trunco el desarrollo completo de la autonomía personal, ya que las relaciones de reconocimiento son condiciones decisivas de aquella.

Sostiene Honneth que una de estas formas de intersubjetividad práctica está influenciada inmediatamente por la actividad del Estado, donde este interfiere de modo directo en las condiciones de relación de reconocimiento, al modificar la inclusión de los derechos subjetivos, al incluir nuevos grupos sociales o declarar realidades modificadas como circunstancias jurídicamente relevantes. Esta esfera sienta las bases del reconocimiento recíproco de las personas como ciudadanos iguales y libres. En contrapartida, las otras dos esferas de reconocimiento recíproco -las relaciones familiares y el trabajono son muy abiertas a la influencia legal estatal: el Estado de derecho no puede intervenir en una mejora de las condiciones de reconocimiento en las relaciones familiares o sus medios resultan muy limitados para lograr su influencia aquí (Honneth 2009: 364).

Si bien, como afirma este mismo autor, el Estado de derecho por sus competencias regulatorias a través de los derechos protegidos por sanciones puede garantizar el reconocimiento jurídico de los ciudadanos, su poder es limitado si la justicia social no es también conquistada y asegurada por el poder de la sociedad civil. Así diversas agrupaciones civiles pueden constituirse en agencias de realización de justicia al favorecer condiciones de reconocimiento, tal como es el caso de los citados refugios para mujeres víctimas de violencia, o asociaciones civiles que les prestan ayuda. El problema radica en la coexistencia de diferentes principios morales según los cuales se 
orientan las diferentes formas de reconocimiento y que oscilan entre lo tradicional o consuetudinario, en el caso de las relaciones familiares y comunitarias, y lo equitativo e igualitario (es decir, donde los individuos se reconozcan como iguales y libres), del lado de las relaciones jurídicas.

El reconocimiento jurídico, por su parte, presenta otras dificultades o límites ya que difícilmente puede por sí solo desafiar las condiciones estructurales que provocan la desigualdad de género. Dado que el sistema jurídico liberal entiende los problemas sociales como conflictos individuales e intenta solucionarlos en ese nivel, puede sin proponérselo atentar contra la lucha por la igualdad de género que es el problema de fondo. En efecto, si partimos de la idea de que la violencia de pareja es una de las tantas expresiones de la violencia de género, podemos afirmar que la penalización de la violencia de pareja conduce a una privatización de las causas (Pitch 2003). ${ }^{15} \mathrm{Se}$ trata de un problema que en principio es de naturaleza colectiva o, como afirma Howe (1987), es claramente a gender-specific social injury.

Tamar Pitch (2003) lo ejemplifica a través del caso de la movilización por el divorcio y el aborto en Italia. Históricamente esta tuvo como consigna la necesidad de afrontar problemas sociales tales como la liberación del colectivo femenino, más que garantizar libertades individuales. Sin embargo, el funcionamiento de la legislación misma sobre el aborto se apoya en la autodeterminación, la libertad de disponer del propio cuerpo y de la propia vida, que implica el reconocimiento de un poder individual. En este sentido, la ley despolitiza la cuestión del aborto, al trasladarla del plano del interés colectivo y de la comunicación pública al interés individual.

Así, el lenguaje de los derechos sustituye al de la opresión y de la discriminación. Los conflictos crecen impulsados más en nombre de las "víctimas", que de los oprimidos, es decir, por sujetos que comparten no tanto una condición social que determina toda su existencia, sino el haber sufrido ofensas particulares por parte de categorías de sujetos individualizables.

15 En efecto y tal como sostiene Larrauri, es conveniente cambiar el mensaje actual de la legislación de la violencia de género que tiene que ver con la criminalización de un problema social. El objetivo en primer lugar debería ser lograr una mejor protección de las mujeres (Larrauri 2007: 136). 
Dado que la nueva ley de acceso de las mujeres a una vida libre de violencia garantiza libertades individuales, la ausencia de una movilización y sensibilización de la violencia como problema social, puede poner en riesgo la lucha colectiva, dejando el problema a merced de cada individuo y no como ofensa moral y asunto que compete a todo el colectivo femenino.

Se trata de no "dejar de hacer publicas las posibilidades de aspirar a derechos, garantías y protecciones" (Segato 2003: 16) ya que al sostener la movilización es posible enfatizar su eficacia simbólica como instrumento de propaganda y agitación; como forma de incidir "en la moral, las costumbres y el substrato prejuicioso del que emanan las violencias" (Segato 2003: 16).

Precisamente, para que estos derechos surtan efectos requieren ser movilizados e interpretados por la sociedad como tales (Felstiner/ Abel/Sarat 1980-81), esto es, la sociedad debe incorporarlo a su representación del mundo social. Un cambio legislativo sin una amplia y sostenida movilización social puede resultar en detrimento de una apropiación y ejercicio de derechos, como también en una juridificación del problema, dando como resultado un panorama de derechos sin reivindicaciones.

\section{Bibliografía}

Agoff, Carolina/Herrera, Cristina/Castro, Roberto (2007): "The Weakness of Family Ties and their Perpetuating Effects on Gender: A Qualitative Study in Mexico". En: Violence Against Women, 13, pp. 1206-1220.

Boltanski, Luc (2000): El Amor y la Justicia como competencias. Tres ensayos de sociología de la acción. Buenos Aires: Amorrortu.

Bourdieu, Pierre (2000): La dominación masculina. Barcelona: Anagrama.

Cámara de Diputados (2007a): Ley General para la igualdad entre hombres y mujeres. En: <www.diputados.gob.mx/LeyesBiblio/pdf/LGIMH.pdf> (23.05.2011).

- (2007b): Ley federal de Acceso a una vida libre de violencia. En: <www. diputados.gob.mx/LeyesBiblio/doc/LGAMVLV> (23.05.2011).

Chatzifotiou, Sevaste/Dobash, Rebecca (2001): "Seeking Informal Support: Violence against Women in Greece". En: Violence Against Women, 7, pp. 1224-1250.

Cotterrell, Roger (2004): "Law in Culture". En: Ratio Juris, 17, 1, pp. 1-14.

Eisikovitz, Zvi/Winstok, Zeev/Fishman, Gideon (2004): "The First Israeli National Survey on Domestic Violence". En: Violence Against Women, 10, pp. 729-748. 
Felstiner, William L. F./Abel, Richard L./Sarat, Austin (1980-81): "The Emergence and Transformation of Disputes: Naming, Blaming, Claiming". En: Law and Society Review, 15, 3-4, pp. 631-654.

Fraser, Nancy (1989): Unruly Practices. Power, Discourse, and Gender in Contemporary Social Theory. Oxford: Polity.

Frías, Sonia (2010): "Strategies and Help-Seeking Behavior in Law Enforcement Offices Among Mexican Women Experiencing Partner Violence”. (Manuscript submitted to Violence Against Women).

Güezmes, Ana/Palomino, Nancy/Ramos, Miguel (2002): Violencia sexual y física contra las mujeres en Perú. Estudio multicéntrico de la OMS sobre la violencia de pareja y la salud de las mujeres. Lima: OMS/Centro de la Mujer Peruana Flora Tristán/Universidad Peruana Cayetano Heredia.

Hausen, Karin (1990): "Überlegungen zum geschlechtsspezifischen Strukturwandel der Öffentlichkeit". En: Gerhardt, Ute et al. (orgs.): Differenz und Gleichheit: Menschenrechte haben (k)ein Geschlecht. Frankfurt am Main: Helmer, pp. 155161.

Herman, Judith L. (2005): “Justice from the Victim's Perspective". En: Violence Against Women, 11, 5, pp. 571-602.

Honneth, Axel (1997): Kampf um Anerkennung: Zur moralischen Grammatik sozialer Konflikte. Frankfurt am Main: Suhrkamp.

- (2009): "A textura da justiça. Sobre os limites do procedimentalismo contemporaneo". En: Civitas - Revista de Ciências Sociais, 9, 3, pp. 325-368.

Howe, Adrian (1987): “'Social Injury' Revisited: Towards a Feminist Theory of Social Justice". En: International Journal of the Sociology of Law, 15, pp. 423438.

INEGI (Instituto Nacional de Estadísticas y Censos) (2006): Encuesta Nacional sobre la Dinámica de las Relaciones en los Hogares 2006 (ENDIREH). México, D.F.: INEGI.

INSP (Instituto Nacional de Salud Pública)/SSA (Secretaría de Salud) (2003): Encuesta Nacional sobre Violencia contra las Mujeres (ENVIM). Cuernavaca: INSP.

Lagarde, Marcela (1990): Los cautiverios de las mujeres: madresposas, monjas, putas, presas y locas. México, D.F.: UNAM.

Larrauri, Elena (2007): Criminología crítica y violencia de género. Madrid: Trotta.

Margalit, Avishai (1996): The Decent Society. Cambridge: Harvard University Press.

Merry, Sally (1997): “Gender Violence and Legally Engendered Selves”. En: Identities, 2, 1-2, pp. 49-73.

Moore, Barrington (1978): Injustice: the Social Basis of Obedience and Revolt. London: Macmillan.

Nussbaum, Martha (1999): "Women and the Decent Society: The Case of India". En: Folkers, Gerd/Nowotny, Helga/Weiss, Martina (eds.): Sternwarten-Buch: Jahrbuch des Collegium Helveticum II. Zürich: Haffmans, pp. 90-117.

Pitch, Tamar (2003): Un derecho para dos: la construcción jurídica de género, sexo y sexualidad. Madrid: Trotta. 
Schütz, Alfred (1993): La construcción significativa del mundo social. Barcelona: Paidós.

Segato, Rita (2003): "La argamasa jerárquica: violencia moral, reproducción del mundo y la eficacia simbólica del derecho". Brasilia: AGENDE (Ações em Gênero Cidadania e Desenvolvimento).

Serret, Estela (2001): El género y lo simbólico. La constitución imaginaria de la identidad femenina. México, D.F.: UAM-Azcapotzalco.

Silva Santisteban, Rocío (2008): El factor asco. Basurización simbólica y discursos autoritarios en el Perú contemporáneo. Lima: Red para el Desarrollo de las Ciencias Sociales en el Perú.

Sitaraman, Bhavani (1999): "Law as Ideology: Women, Courts and Dowry Deaths in India”. En: International Journal of the Sociology of Law, 27, pp. 287-316.

Smart, Carol (1994): "La mujer en el discurso jurídico". En: Larrauri, Elena (comp.): Mujer, derecho penal y criminología. Madrid: Siglo Veintiuno, pp. 167-177.

Wright, Georg H. von (1979): Explicación y comprensión. Madrid: Alianza.

Wright Mills, Charles (1981): Poder, politica, pueblo. México, D.F.: FCE. 


\section{Stefanie Kron}

\section{¿Legitimidad política por despolitización de la migración? Una reflexión crítica del arreglo institucional de un nuevo régimen regional de migración en Norte y Centroamérica}

En los últimos 20 años la regulación de la migración y el control de fronteras se ha transformado en un campo marcado por una creciente transnacionalización y multilateralización de las respectivas instituciones y políticas. Esto no solo tiene impactos importantes en uno de los núcleos de la soberanía nacional - el de la regulación de la (in)migración y del control de fronteras nacionales. Además se están transformando las maneras de establecer la legitimidad política. En lo referente a la europeización de las políticas migratorias, tales impactos y transformaciones en cuanto a soberanía nacional y legitimidad política están bien analizados ya (Buckel/Wissel 2009; Hess/Kasparek 2010; Papadopoulos/Stephenson/Tsianos 2008; Tomei 2001; Transit Migration Forschungsgruppe 2007). En el caso de las Américas, al contrario, apenas existen investigaciones al respecto (Kron 2009; 2010a; 2010b; 2011). Por lo tanto, en este ensayo analizaré dichos aspectos del proceso de la regionalización y multilateralización de políticas migratorias en Norte y Centroamérica. Tomando la Conferencia Regional de Migraciones (CRM) como ejemplo, pondré énfasis en los discursos y prácticas dominantes a través de los cuales nuevas entidades regionales de regulación de migración establecen legitimidad política, aunque no están legitimados por los procedimientos democráticos.

Mi hipótesis principal es que la CRM forma parte del arreglo institucional de un emergente nuevo régimen regional y post-democrático de migración y de fronteras en Norte y Centroamérica. Este régimen tiende a reformular el complejo fenómeno de la migración en términos de un problema de seguridad pública para toda la región. Este nexo 
seguridad-migración tiene cuatro impactos: primero, legitima la separación de acciones políticas transfronterizas de los debates públicos y de los procedimientos democráticos de decisión a los niveles nacionales e internacionales. Segundo, justifica la creciente influencia de actores intergubernamentales que no disponen de un mandato político o jurídico bien definido i.e. por las Naciones Unidas. Esto es particularmente evidente en el caso de la Organización Internacional de Migraciones (OIM) que es, de hecho, una agencia "privada" de servicios en el campo de manejo de la migración internacional (Geiger/Pécoud 2010). Tercero, resulta en la criminalización de la migración irregular y, cuarto, lleva a la separación de la misma del debate político sobre derechos ciudadanos de poblaciones móviles. ${ }^{1}$

A continuación, precisaré, primero, lo que entiendo por nexo seguridad-migración. Luego esbozaré el contexto político global del génesis de la CRM. La tercera parte del artículo finalmente enfocará el nivel regional y consiste en un análisis de los discursos securitarios producidos por la CRM. ${ }^{2}$

\section{El nexo migración-seguridad}

Los autores de la llamada Escuela de Copenhague han determinado que, desde los años 1980, la tematización y el tratamiento institucional de la migración como un problema de seguridad pública constituye un fenómeno global. En otras palabras: la actual percepción dominante de la migración es la de una amenaza para la sociedad, la democracia y el desarrollo económico. Según los mismos autores este

1 A propósito de delimitar movimientos migratorios transfronterizos y de carácter indocumentado, ilegalizado o clandestino a partir del término criminalizante "ilegal", en el marco de este ensayo se asumirá el concepto de "migración irregular" propuesto por la Global Commission on International Migration (GCIM) (2005), definiendo así inmigraciones, emigraciones y migraciones de tránsito que se realicen fuera de las políticas públicas de regulación de la migración. Las mismas varían de país a país y además son objeto de cambiantes coyunturas políticas y legislativas, así que el estatus y las prácticas de una persona migrante pueden ser legal o ilegal dependiendo del correspondiente contexto en el cual se mueve. Con respecto a datos estadísticos resulta difícil, por la naturaleza indocumentada, estimar el número de personas migrantes irregulares en el mundo. Khalid Koser habla de una cantidad de alrededor de 30 millones migrantes irregulares (Koser 2005: 9).

2 Con Siegfried Jäger (2001) entiendo por "discurso" un conjunto de prácticas sociales interrelacionadas con la percepción y acepción de la realidad social. 
nexo seguridad-migración está organizado alrededor del "crimen organizado" (Wæver 1995; Wæver et al. 1993; Weiner 1992; 1995). Esto significa, en particular, la criminalización de la migración irregular y de las redes de apoyo comercial y no-comercial que la facilitan.

En este contexto es importante mencionar que en el trayecto de las dos décadas pasadas, agencias intergubernamentales como la OIM han contribuido decisivamente a la creación de un lenguaje internacionalmente común, el cual ha reconceptualizado la migración irregular en términos de dos delitos criminales: el de human smuggling (traducido al español como "tráfico ilícito de migrantes") y el de human trafficking (traducido al español como "trata de personas"). El nexo migración-seguridad, por ende, también tiende a representar las múltiples prácticas y estrategias de la migración irregular como un escándalo ilegal y a reducir sus actores más diversos a solo dos figuras discursivas: por un lado, el criminal "traficante de migrantes" o "tratante de personas", quien viola sistemáticamente los derechos humanos de migrantes irregulares; por el otro lado, el/la migrante quien viola la ley y/o ha sido víctima de traficantes o tratantes (Papadopoulos/Stephenson/Tsianos 2008).

Sabine Hess y Vassilis Tsianos, quienes trabajan el tema de la europeización de políticas migratorias, denominan "discurso anti-trafficking" esta estrategia discursiva de criminalizar la migración irregular (Hess/Tsianos 2007: 29). Los autores además destacan que se trata de un discurso sobre migración actualmente dominante y que forma parte del surgimiento de nuevos regímenes de migración y de fronteras al nivel mundial. El discurso anti-trafficking si bien incorpora el discurso de derechos humanos, lo hace solamente en términos de protección de las supuestas víctimas del tráfico de migrantes y de la trata de personas. Ahora bien, el/la migrante irregular nada más aparece como una potencial víctima del crimen organizado.

Según el enfoque constructivista de la Escuela de Copenhague, este nivel discursivo está acompañado por el aumento de medidas transfronterizas para una securitización de la migración. Esto se manifiesta en nuevos modelos legislativos y figuras jurídicas que priorizan la penalización de la migración irregular y de las redes sociales y comerciales que la facilitan, así como en una creciente presencia de 
fuerzas de seguridad no solo en las líneas fronterizas mismas sino también en el interior de los países. ${ }^{3}$

A manera de tesis se puede decir que los debates sobre la conexión entre migración y (in-)seguridad contribuyen a la formación del problema migración-seguridad de manera decisiva. Por eso las discusiones sobre la migración irregular no son simplemente descripciones de una realidad existente, sino más bien las mismas forman parte de esta realidad o incluso la crean.

\section{El nivel global: los Procesos Regionales de Consulta}

Desde los años 1990, la actividad mas importante de la OIM ha consistido en impulsar y luego coordinar la formación de por lo menos 15 denominados Procesos Regionales de Consulta sobre Migración (en inglés: Regional Consultative Processes on Migration - RCPs) en todas partes del mundo (Georgi 2010). ${ }^{4}$ Los Procesos Regionales de Consulta son foros informales que reúnen a representantes de gobiernos y de organizaciones intergubernamentales con el fin de debatir asuntos migratorios a nivel regional y de crear nuevas alianzas que finalmente deberían resultar en nuevos acuerdos bilaterales y multilaterales. En un informe de evaluación del año 2001, elaborado por Amanda Klekowski von Koppenfels, la OIM justifica los Procesos Regionales de Consulta con la necesidad de encontrar

a regional-level response to changes in international migration trends and a growing recognition that the current international migration system, which was developed in another area with other determinants and a completely different balance of power, is no longer appropriate (Klekowski von Koppenfels 2001: 16).

3 Véase i.e. Bigo (2000), Bigo/Guild (2005), Wæver (1995), Wæver et al. (1993), Weiner (1992; 1995) para el caso de Europa; así como i.e. Dunn (1996), Payan (2006), Rochlin (1997), Sandoval (2005), Specht (2008) en lo que concierne a América del Norte.

4 Entre los RCP más consolidados cuentan la Conferencia Regional de Migraciones (CRM o Proceso Puebla) y la South American Conference on Migration (SACM) en las Américas; la Bali Ministerial Conference on People Smuggling, Trafficking in Persons and Related Transnational Crime (Bali Process) y el Manila Process en Asia; el Budapest Process y el Cross Border Cooperation Process (Söderköping Process o CBCP) en Europa; así como el Mediterranean Transit Migration Dialogue (MTM), el Migration Dialogue for West Africa (MIDWA) y el Migration Dialogue for Southern Africa (MIDSA) para el espacio transregional Europa/África (Hansen 2010). 
Así el régimen internacional de migraciones que se formó en los años 1950, enfocaba la protección de refugiados por un lado y los problemas de migrantes laborales por el otro. Para manejar estos asuntos las Naciones Unidas crearon el Alto Comisionado de las Naciones Unidas para Refugiados (ACNUR) y la Organización Internacional de Trabajo (OIT). Los demás asuntos del ámbito de la migración internacional fueron arreglados por medio de acuerdos bilaterales (i.e. los programas bracero entre México y los EE.UU., y los Gastarbeiterprogramme en Europa). Con el término de la guerra fría, según Klekowski von Koppenfels, las tendencias y los patrones de las migraciones internacionales así como la cantidad e importancia de los estados involucrados en la migración internacional habían cambiado significativamente. Aparte de la casi triplicación de personas migrantes en el mundo de 75 millones en 1950 a 214 millones en el año $2010,{ }^{5}$ la OIM constata una traslación de patrones de migraciones unidireccionales (es decir fuga y emigración) hacia transmigraciones, migraciones circulares y migraciones de tránsito. Además se considera la creciente importancia de migraciones intrarregionales y de SurNorte, i.e. de los países latinoamericanos a los EE.UU. o de África a los países miembros de la Unión Europea (UE). Ante este trasfondo la OIM llega a la conclusión de que la migración internacional se ha convertido en un proceso multi-nacional por lo que "national or bilateral approaches to migration management are no longer as applicable as they once were" (Klekowski von Koppenfels 2001: 17).

No obstante, la base más importante de la legitimidad política de los Procesos Regionales de Consulta que nunca han sido legitimados por leyes, elecciones u otros procedimientos democráticos, es la problematización de la migración irregular como una forma potencial de crimen organizado transnacional, es decir como un problema transfronterizo de seguridad pública que habría que manejar o combatir a niveles multilateral y regional. Klekowski von Koppenfels escribe al respecto:

$[T]$ here is now more irregular migration as well as smuggling and trafficking of migrants. Trafficking today is again and again referred to as a growing and changing problem. It appears that at least some trafficking and smuggling is controlled by organized crime, meaning that

5 Véase <www.iom.int/jahia/jahia/about-migration/facts-and-figures/lang/en> (03.06.2011). 
traffickers/smugglers have a wide network upon which they can draw to outwit or avoid law enforcement authorities. While some of the organized trafficking/smuggling groups appear to be very small operations, others are international in scope and are thus able to function effecttively across borders [...]. Logically, then, governments could be more effective in combating trafficking/smuggling were they also to work together on this issue (Klekowski von Koppenfels 2001: 17).

Por consiguiente el tema más importante de la mayoría de los Procesos Regionales consiste en la lucha contra tráfico de migrantes y la trata de personas la cual, por su parte, se justifica no solo con la protección de la seguridad pública, sino también con la protección de los derechos humanos de sus supuestas víctimas. La siguiente cita ilustra esta victimización del y de la migrante como parte de la estrategia de legitimación política:

Combating trafficking is, indeed, one of the main issues discussed at the majority of the regional consultative processes addressing migration and is a topic, more than others, that appears to concern sending and receiving countries equally, largely because of the grave human rights abuses inherent in trafficking and the potential for such abuses in smuggling (Klekowski von Koppenfels 2001: 31).

En la cita se reconstruye, por un lado, al traficante/tratante de personas como un actor privado y extra-legal quien sistemáticamente viola los derechos humanos de migrantes irregulares y, por otro lado, al estado y a entidades transnacionales como los Procesos Regionales de Consulta como actores que luchan contra estos actores no-estatales con el fin de proteger la seguridad de todos incluyendo los derechos humanos de migrantes. El o la migrante como portador/a de derechos ciudadanos, así como la responsabilidad de los estados afectados por la migración transfronteriza de garantizar estos derechos en contextos migratorios, son temas que apenas forman parte de los Procesos Regionales de Consulta.

\section{El nivel regional: el Proceso Puebla}

¿Cómo se manifiesta el discurso anti-trafficking en el caso de la Conferencia Regional de Migraciones (CRM)? La Conferencia que se fundó en 1996 en Puebla, México, forma parte de los primeros Procesos Regionales de Consulta que se crearon. Mejor conocida por Proceso Puebla, la CRM es considerada al mismo tiempo el Proceso Regional más consolidado. Es por eso que tiene carácter de modelo para 
otros Procesos (Hansen 2010; Klekowski von Koppenfels 2001; Thouez/Channac 2005).

El contexto regional para la fundación del Proceso Puebla es el siguiente: desde los años 1980 los movimientos migratorios desde México y del istmo centroamericano hacia los EE.UU. y Canadá están creciendo cada vez más. Así, el número de migrantes en EE.UU. procedentes, especialmente, de El Salvador, Guatemala, Honduras y Nicaragua se triplicó entre 1980 y 1990; se volvió a duplicar hacia el año $2000 \mathrm{y}$ ha continuado creciendo rápidamente en los años $2000 .^{6}$ Desde inicios de los años 1990, los EE.UU. reaccionaron a este fenómeno mediante la adopción de requisitos migratorios, legislación y mecanismos de control fronterizos más estrictos (Dunn 1996; Sandoval Palacios 2005). Sin embargo, estas disposiciones políticas, adoptadas nacionalmente, no tuvieron como resultado el descenso de la inmigración del istmo, sino solamente la ilegalización de gran parte de ella. En el 2003 alrededor de 2,2 millones de personas de origen centroamericano fueron registradas en Estados Unidos (GCIM 2005: 5). No obstante, de acuerdo con algunas estimaciones, entre 4 y 5 millones de personas del istmo residen en EE.UU., la mayoría sin un status legal de residente. ${ }^{7}$

Por supuesto, México es el país de tránsito más importante para los movimientos migratorios irregulares que se dirigen hacia el norte. Sin embargo, desde los años 1990 Centroamérica se ha convertido, asimismo, en un espacio de tránsito cada vez más atractivo, no sólo para los mismos centroamericanos, sino también para migrantes de Suramérica, África, Asia y Europa Oriental. Esto se explica por las políticas más estrictas de inmigración y de control fronterizo de los países de América del Norte, pero también porque hasta fines de los años 1990 casi no había políticas coherentes de inmigración, ni reglas para el otorgamiento de visas en los países centroamericanos. Además, las fronteras terrestres de los estados del istmo estaban muy poco controladas y, por consiguiente, eran más o menos abiertas, por lo cual cualquiera las podía cruzar. Adicionalmente, Costa Rica en

6 Simultáneamente, las remesas monetarias registradas de los migrantes se incrementaron en forma significativa. En el 2007, p.ej., representaban entre el $10 \%$ (Guatemala) y más del 25\% (Honduras) del Producto Interno Bruto (PIB) (Worldbank 2008: 116, 121).

7 Véase: US Census (2002) (<www.factfinder.census.gov/servlet>; 11.01.2011). 
particular se ha convertido en un destino importante de la llamada migración sur-sur, especialmente desde Nicaragua y más recientemente desde Colombia (Rocha 2005; 2006). Los ciudadanos nicaragüenses representan en la actualidad el $76 \%$ de la población inmigrante en Costa Rica, cifra que no incluye los millares de indocumentados que residen permanente o temporalmente en este país (Lee 2010: 11ss.). ${ }^{8}$ Frente a este telón de fondo de creciente migración transfronteriza y de intentos nacionales ampliamente infructuosos de parte de los países norteamericanos para limitar la inmigración, se fundó el Proceso Puebla con el fin de abordar la migración transfronteriza como un asunto regional y multilateral.

El Proceso Puebla está integrado por los siguientes estados con derecho de voto: EE.UU. Unidos y Canadá, sus principales financiadores; México; Belice; Guatemala; Honduras; El Salvador; Nicaragua; Costa Rica; Panamá y República Dominicana. Argentina, Ecuador, Colombia, Jamaica y Perú participan como observadores. La oficina regional de la OIM para México y América Central, localizada en San José, Costa Rica, administra los fondos y coordina las actividades. Una amplia gama de organizaciones intergubernamentales también coopera con el Proceso Puebla, entre ellas, ACNUR, el Programa de Naciones Unidas para el Desarrollo (PNUD), la Comisión Económica para América Latina (CEPAL), el Fondo de Naciones Unidas para la Infancia (UNICEF) y el Fondo de Población de las Naciones Unidas (FPNU). Algunas organizaciones regionales tales como la Comisión Centroamericana de Directores de Migración (CCDM) y el Sistema de Integración Centroamericana (SICA), y también una red de Organizaciones No-gubernamentales (ONGs) regionales y nacionales están representadas como observadores. El diagrama organizacional es completado por una unidad especial denominada "red regional contra el tráfico ilícito y la trata de personas". El Proceso Puebla tiene reuniones anuales a la cual sólo pueden asistir los vice-ministros del interior y de relaciones exteriores de los estados miembros del Proceso y la OIM. Los delegados de los estados observadores y de las organizaciones asociadas tienen acceso a eventos especiales, talleres y seminarios. La presidencia (presidencia Pro-

8 Véase también: Castro Valverde (2002: 5), GCIM (2005: 17). 
Témpore) rota entre los estados miembros (<www.rcmvs.org>; 15.01.2011).

El Proceso Puebla articuló por primera vez una conceptualización de la migración transfronteriza, ampliamente aceptada en ese entonces, como un campo específico y de creciente importancia de las políticas públicas que requería ser abordado a nivel regional y multilateral. Su primera declaración, publicada tras su reunión de fundación en 1996, definió la migración como un fenómeno que potencialmente podía beneficiar a los países de origen y destino, y también como un problema potencial en términos de seguridad y desarrollo que podía afectar tanto a Norte como a Centroamérica. Así, de acuerdo con esa declaración, la migración debía ser "ordenada" mediante intervenciones coordinadas regionalmente (Comunicado Conjunto, I Conferencia Regional sobre Migración, Puebla, 1996, p. 1 y $3)$. Esta declaración también contiene 20 acuerdos básicos. El primero recalca la necesidad de promover el desarrollo y la adopción de un "enfoque integral, objetivo y de largo plazo sobre el fenómeno migratorio, el cual tome en consideración sus razones y sus manifestaciones" (ibíd. p. 1). Sin embargo, en forma aún más explícita que en el caso de otros PCRs,

[t]he Puebla Process emerged due to concern over irregular migration affecting the entire region [...] [T]he Puebla Process was initiated with the firm intention of reducing irregular migration in the North and Central American region (Klekowski von Koppenfels 2001: 34).

De este modo, la mayor parte de los acuerdos subsiguientes mencionan ya medidas concretas para disminuir la migración irregular y para combatir el tráfico ilícito y la trata de personas.

Estas incluyen intercambio de información y datos entre los estados miembros (acuerdo 14), reformas legales que faciliten la penalización del tráfico ilícito de migrantes (15), campañas de información pública sobre contrabando (16), cooperación extensiva en términos de asistencia técnica y desarrollo de capacidades de los recursos humanos con el fin de perfeccionar los sistemas de investigación, manejo de pruebas (17), promoción del intercambio de información, de la cooperación regional en el campo de la asistencia técnica y el desarrollo de competencias de los recursos humanos con el fin de controlar los flujos de migrantes indocumentados extrarregionales (20), y el desarrollo de medidas para combatir la falsificación de documentos de 
viaje. Sólo dos de los acuerdos, en forma poco concreta, se refieren a la facilitación de la migración documentada (13) y a la migración laboral (10). Otros dos acuerdos plantean la necesidad del desarrollo económico y social de los países de donde salen los migrantes (3 y 4). También se pueden señalar tres artículos donde se habla de los derechos básicos de los migrantes irregulares $(5,6$ y 7$)$ y otro que se refiere a la necesidad de armonizar las leyes y las políticas migratorias en el conjunto de la región (12) (ibíd. 1-3).

El primer paso en la consolidación del Proceso Puebla consistió en el desarrollo de un "plan de acción" (Plan of Action), adoptado en la segunda reunión anual celebrada en Panamá en 1997. La OIM jugó y sigue jugando un papel decisivo en el desarrollo y la realización del plan de acción. En efecto, ha generado conocimiento y análisis; ha coordinado actividades y ha organizado talleres para los representantes de los gobiernos (véase RCM 1997). ${ }^{9}$ Por ejemplo, un documento de la OIM sobre el combate de la migración irregular y el tráfico ilícito de migrantes sirvió como una especie de informe técnico y como pauta para el plan de acción. Dicho documento señalaba la migración irregular de los países del istmo, como una amenaza común para todos los países miembros del Proceso Puebla. Aún más, Centroamérica era presentada como un espacio sin gobierno, de movimientos no autorizados e incontrolados. De esta manera, la "necesidad" de intervención en esta subregión era reafirmada:

Central America [...] serves increasingly as a corridor for the irregular movement of persons. Significant numbers of nationals of the Central American countries contribute to the streams of irregular migrants to the north. Furthermore the Central American [...] territories are increasingly used as a transit zone for migrants from outside the region. This increase of irregular movements and smuggling of migrants has caused an increasing [...] understanding that these practices could constitute a threat to national security. The governments increasingly perceive the need for solutions (IOM 1997: 2).

9 El plan de acción fue revisado en el 2009. La nueva versión incluye, además de la gestión migratoria, centrada todavía en migración y fronteras irregulares, dos nuevas categorías de intervención: derechos humanos y desarrollo. No obstante, el área de derechos humanos pone énfasis en la cuestión de las supuestas víctimas del tráfico ilícito y la trata de personas y define a las mujeres y a los niños como grupos especialmente vulnerables (RCM 2009). 
En consecuencia, las acciones contra el tráfico de migrantes y la trata de personas y otras medidas orientadas a reducir la migración irregular ocupan la mayor parte del plan de acción: siete de los doce objetivos se centran en la reducción de la migración irregular y en la erradicación del tráfico ilícito y la trata de personas. Dichos objetivos incluyen el fomento de la cooperación regional, el intercambio de datos y campañas de información pública, "ordenar" las fronteras y mejorar su seguridad, el desarrollo de programas de retorno de los migrantes irregulares y la cooperación técnica con el fin de modernizar los sistemas de información, control y seguridad. Otros objetivos importantes son la armonización de las leyes de migración, la cooperación técnica en el desarrollo de competencias de los funcionarios públicos encargados de cuestiones relacionadas con la migración y la promoción de la cooperación con organizaciones intergubernamentales y con ONGs. En cambio, temas tales como migración, desarrollo y derechos de los migrantes que formaban parte de la declaración de 1996 están ausentes en este plan de acción (véase RCM 1997).

En la reunión anual del Proceso Puebla del año 2000 se acordó concederle una base más operativa y de buscar asistencia por otras organizaciones internacionales y por iniciativas de seguridad nacional para la realización de los proyectos de cooperación regional (Klekowski von Koppenfels 2001: 36).

Hasta la fecha, todos los informes de la OIM sobre los Procesos Regionales de Consulta consideran que el Proceso Puebla ha logrado bastante en lo que se refiere a la prevención de la migración irregular mediante la cooperación regional, mayores controles fronterizos y regulaciones más estrictas. Por ejemplo, el informe más reciente sostiene que el Proceso Puebla ha sido muy exitoso en relación con asuntos de política migratoria en el área del tráfico ilícito y de la trata de personas (Hansen 2010: 27ss.). En efecto, desde su creación y hasta el 2007, todos los estados miembros han introducido reformas en las leyes migratorias o penales con el fin de incluir el tráfico ilícito y la trata de personas como delitos penales y para proteger a sus víctimas.

En relación con los países de Norteamérica, se debe señalar que Canadá reformó su legislación migratoria en el 2002, en ella introdujo la figura legal del tráfico ilícito de personas; en el 2005 la 
ley C-49, la cual define la trata de personas como delito, fue incorporada a su código penal. Estados Unidos adoptó una ley específica para proteger a las víctimas de trata y violencia en el 2000. Su "Ley de Inmigración y Nacionalización" fue reformada en 1995 y nuevamente en el 2005, y desde entonces estableció penas a acciones o intentos para traer o introducir extranjeros no autorizados a EE.UU., transportarlos dentro de EE.UU., dar refugio a extranjeros ilegales, fomentar el ingreso de extranjeros ilegales, o conspirar para cometer estas violaciones, a sabiendas o por omisión irresponsable de su status ilegal. La Ley federal penal de México contiene algunos artículos en relación con la criminalización y la penalización del tráfico (201, 203, 205 y 366) y la Ley general de población define como delictivas acciones relacionadas con la facilitación de la migración irregular. Sin embargo, no fue posible determinar cuándo dichos artículos fueron elaborados y adoptados.

En lo que respecta a América Central, la legislación penal de Costa Rica fue reformada en 1999 y desde entonces incluye una ley contra la explotación sexual de menores (No. 7899). Fue reformada nuevamente en el 2009, y ahora contiene el delito de trata de personas. En El Salvador, Guatemala y Honduras un decreto contra la trata de personas reformó la legislación penal en el 2003 (El Salvador, No. 210) y en el 2005 (Guatemala, No. 14-2005; Honduras No. 234-2005). Desde 2004, existe en Panamá una ley que regula la disposición para prevenir y tipificar delitos contra la integridad y contra la libertad sexual. Además, esta ley modifica artículos específicos del código penal. Mientras que El Salvador, Honduras y Panamá incluyeron el delito de tráfico ilícito de personas dentro de las reformas de su código penal, Costa Rica (2006 y 2010) y Guatemala (1998) agregaron figuras legales a su legislación migratoria para castigar el tráfico ilícito. Nicaragua adoptó una ley específica contra el tráfico ilícito ya en 1996, pero hacia el 2007 aún se encontraba discutiendo un proyecto de ley para tipificar y castigar la trata de personas. Además, la migración irregular por sí misma es criminalizada por medio de ciertos artículos de las leyes de inmigración o de población en los casos de Estados Unidos, El Salvador, Guatemala, México y Nicaragua (véase: Conferencia Regional sobre Migración 2007: 93; <www.rcmvs.org/documentos/investigacion/ pagina_matrices.htm>; 13.01.2011). Además, casi todos los estados 
centroamericanos han establecido o han restringido, cuando ya existían, los requerimientos de visa (<www.rcmvs.org/documentos/ investigacion/visas.htm>; 15.01.2011).

\section{Conclusiones}

Los Procesos Regionales de Consulta en general están caracterizados por interacciones de actores gubernamentales, intergubernamentales y civiles en forma de red. Otro elemento es su alto grado de voluntariedad, informalidad y flexibilidad. Esto quiere decir que los Procesos Regionales son capaces de responder con alta sensibilidad a cambios de patrones y rutas de las migraciones internacionales. Impulsados por actores intergubernamentales como la OIM, los Procesos Regionales son arreglos institucionales vanguardistas con respecto al diseño y la creación de nuevos regímenes de migración y de fronteras a los niveles regionales. No obstante, distinto a las organizaciones de las Naciones Unidas, ni la OIM ni los Procesos Regionales están legitimados por los procedimientos democráticos. Lo que forma su base de legitimidad política es el nexo migración-seguridad lo cual está centrado en el discurso anti-trafficking (Hess/Tsianos 2007). Esto deviene en la criminalización de los múltiples actores y prácticas de la migración irregular, provocando, primero, la omisión del necesario debate sobre derechos ciudadanos en contextos migratorios y, segundo, la creciente presencia transfronteriza de fuerzas policíacas y castrenses en el campo político de la migración. En este sentido se puede hablar de una securitización de la migración a nivel global y de la formación de arreglos institucionales como parte de nuevos regímenes post-democráticos de migración y de fronteras.

El análisis de los discursos y prácticas dominantes del caso específico del Proceso Puebla, por su parte, hace evidente el interés de los EE.UU. de extender la regulación y el control de las inmigraciones hacia México y los países del Istmo Centroamericano. Los EE.UU. aspiran a involucrar a México y a los estados centroamericanos como fronteras externas - o países fronteras (Sandoval Palacios 2005). En otras palabras: lo que se puede observar es una desterritorialización de la soberanía nacional en el ámbito político de la regulación y control de las migraciones internacionales a los países de tránsito al sur de los EE.UU. Es por eso que aún más claramente que otros Pro- 
cesos Regionales de Consulta, el Proceso Puebla legitima su existencia mediante el discurso de una candente amenaza por las migraciones irregulares, y sus facilitadores para la seguridad pública y ciudadana, y para la estabilidad política y económica en toda la región. Por consiguiente, desde su creación en 1996 hasta hoy se trabaja exitosamente en la elaboración y aplicación de un plan de acción que incluía la harmonización de políticas y legislaciones migratorias en todos los países miembros del Proceso Puebla. Para tal fin cuentan el establecimiento de un sistema de información mejorado y la incorporación del tráfico y de la trata de personas como conceptos criminales en las legislaciones de migración así como la estandarización de los requisitos para extranjeros de obtener una visa, lo que en el caso de ciudadanos de la mayoría de los países de África, de Asia, de Sudamérica y de Europa del Este significa graves restricciones, i.e. la supresión de la antigua posibilidad de ingresar fácilmente los países centroamericanos como turista. Otro elemento clave del plan de acción es la cooperación técnica de fuerzas de seguridad en los ámbitos de control de fronteras y de procesamiento penal de tráfico y trata así como en el de expulsión y repatriación de migrantes extra-regionales irregulares. Uno de los objetivos más importantes del Proceso Puebla es, por ende, el garantizar la gobernabilidad de los movimientos migratorios hacia los EE.UU. ya desde los países de origen y de tránsito. De esta manera el nexo seguridad-migración y el discurso anti-trafficking contribuyen a la descontextualización social y despolitización del fenómeno de la migración irregular, ya que se le separa del debate político sobre migrantes indocumentados como agentes y sujetos de derechos ciudadanos y sobre la responsabilidad de los estados afectados por la migración transfronteriza de garantizar estos derechos.

\section{Bibliografía}

Bigo, Didier (2000): "Border Regimes and Security in an Enlarged European Community Police Cooperation with CEEs: Between trust and Obligation”. En: EUI Working Papers RSC 2000/65.

Bigo, Didier/Guild, Elspeth (2005) (eds.): Controlling Frontiers. Free Movement Into and Within Europe. Aldershot: Ashgate. 
Buckel, Sonja/Wissel, Jens (2009): "Entgrenzung der Europäischen Migrationskontrolle - Zur Produktion ex-territorialer Rechtsverhältnisse". En: Brunkhorst, Hauke (ed.): Soziale Welt: Sonderband "Demokratie in der Weltgesellschaft". Baden-Baden: Nomos, pp. 385-405.

Castro Valverde, Carlos (2002): Migración Nicaragüense en Costa Rica: Población, Empleo y Necesidades Básicas Insatisfechas. San José: FLACSO.

Conferencia Regional sobre Migración (2007): Seminario sobre Legislación Migratoria. Compilación de Trabajos (<www.remvs.org/Publicaciones/docs/Seminario \%20Legislaci\%F3n\%20Migratoria-compilaci\%F3n\%20de\%20trabajos.pdf>; 19.01.2011).

Comunicado Conjunto, I Conferencia Regional sobre Migración, Puebla (1996): $<$ www.acnur.org/biblioteca/pdf/3991.pdf > (19.01.2011).

Dunn, Timothy (1996): The Militarization of the U.S.-Mexican Border, 1978-1992. Low Intensity Conflict Doctrine Comes Home. Austin: University of Texas Press.

GCIM (Global Commission on International Migration) (2005): Migration in the Americas. A paper prepared for the Policy Analysis and Research Programme of the Global Commission on International Migration (<www.un.org/esa/ population/meetings/fourthcoord2005/P09_GCIM.pdf $>$; 29.07.2010).

Geiger, Martin/Pécoud, Antoine (2010) (eds.): The Politics of International Migration Management. Houndmills/Basingstoke/Hampshire: Palgrave McMillan.

Georgi, Fabian (2010): "For the Benefit of Some: The International Organization of Migration and its Global Migration Management". En: Geiger, Martin/Pécoud, Antoine (eds.): The Politics of International Migration Management. Houndmills/Basingstoke/Hampshire: Palgrave McMillan, pp. 45-73.

Hansen, Randall (2010): "An Assessment of Principal Regional Consultative Processes on Migration”. En: IOM Migration Research Series No. 38. Genève: IOM.

Hess, Sabine/Kasparek, Bernd (2010) (eds.): Grenzregime: Diskurse, Praktiken, Institutionen in Europa. Berlin: Assoziation A.

Hess, Sabine/Tsianos, Vassilis (2007): "Europeanizing Transnationalism! Provincializing Europe! Konturen eines neuen Grenzregimes". En: Transitmigration Forschungsgruppe (ed.): Turbulente Ränder. Neue Perspektiven auf Migration in Europa. Bielefeld: Transcript, pp. 23-38.

IOM (International Organization for Migration) (1997): “Combatiendo la migración irregular y el tráfico de migrantes. Elementos para una respuesta”, preparado para la Segunda Conferencia Regional sobre Migración, Panamá, 11-14 de marzo 1997 (<www.uhu.es/siis/listados/TABLA\%20WEB.doc>; 19.01.2011).

Jäger, Siegfried (2001): Kritische Diskursanalyse. Eine Einführung. Duisburg: DISS.

Klekowski von Koppenfels, Amanda (2001): "The Role of Regional Consultative Processes in Managing International Migration”. En: IOM Migration Research Series No. 3. Genève: IOM.

Koser, Khalid (2005): Irregular Migration, State Security and Human Security. A Paper Prepared for the Policy Analysis and Research Programme of the Global Commission on International Migration (<www.gcim.org/attachements/ TP5.pdf $>$; 03.11.2010). 
Kron, Stefanie (2009): "Migration und Rebordering in Zentralamerika. Eine Skizze". En: Krämer, Raimund (ed.): Grenzen in den internationalen Beziehungen. Potsdam: Universitätsverlag, pp. 134-149.

- (2010a): “Orderly Migration. Der Puebla-Prozess und die Transnationalisierung der Migrationspolitik in Mittelamerika”. En: Hess, Sabine/Kasparek, Bernd (eds.): Grenzregime: Diskurse, Praktiken, Institutionen in Europa. Berlin: Assoziation A, pp. 73-86.

- (2010b): "Migración irregular y discursos securitarios en Centroamérica: el caso de Costa Rica". En: Encuentro, XLII, 87, pp. 26-37.

- (2011): "Sicherheitsdiskurse im Kontext der Regionalisierung der Migrationspolitik in Mittelamerika: Das Fallbeispiel Costa Rica". En: Burchardt, HansJürgen/Öhlschläger, Rainer/Wehr, Ingrid (eds.): Lateinamerika. Ein unsicherer Kontinent? Baden-Baden: Nomos, pp. 139-161.

Lee, Sang E. (2010): "Development or Despair? The Intentions and Realities of South-South Migration". En: Encuentro, 42, 87, pp. 6-25.

Papadopoulos, Dimitri/Stephenson, Niamh/Tsianos, Vassilis (2008): Escape Routes. Control and Subversion in the 21st Century. London: Pluto Press.

Payan, Tony (2006): The Three U.S.-Mexico Border Wars: Drugs, Immigration and Homeland Security. Westport: Praeger.

RCM (Regional Conference on Migration) (1997): Historical Plan of Action (<www.rcmvs.org/plan_accion.htm>; 19.01.2011).

- (2009): Plan of Action (<www.rcmvs.org/plan_accion.htm>; 19.01.2011).

Rocha, José Luis (2005): Migración internacional en Centroamérica. Mapeo regional de flujos, legislación, políticas públicas, organismos e investigaciones. Managua. UCA/SJM/UNFPA.

- (2006): A Region Torn Apart. The Dynamics of Migration in Central América. I Una región desgarrada. Dinámicas migratorias en Centroamérica. Managua: Servicio Jesuita de apoyo a las migraciones en Centroamérica/Red Nicaragüense de la Sociedad Civil para las migraciones.

Rochlin, Francis L. (1997): Redefining Mexican "Security”. Society, State and Region under NAFTA. London: Lynne Rienner.

Sandoval Palacios, Juan Manuel (2005): "México: País Frontera. La nueva frontera geopolítica regional de América del Norte". En: Sandoval Palacios, Juan Manuel/Álvarez de Flores, Raquel (eds.): Integración latinoamericana, fronteras y migración: los casos de México y Venezuela. México, D.F.: Centro de Estudios de Fronteras y Chicanos/Plaza y Valdéz, pp. 65-100.

Specht, Johannes (2008): "Securitización de la migración y derechos humanos en EE.UU y México: ¿amenaza u oportunidad para una ampliación de la ciudadanía?". En: Potthast, Barbara/Ströbele-Gregor, Juliana/Wollrad, Dörte (eds.): Ciudadania vivida, (in)seguridades e interculturalidad. Buenos Aires: FriedrichEbert-Stiftung/ADLAF/Nueva Sociedad, pp. 300-317.

Thouez, Colleen/Channac, Frédérique (2005): Regional Consultative Processes for Migration: An Evaluation Based on IMP's Work. New York: UNFPA. 
Tomei, Verónica (2001): Europäisierung nationaler Migrationspolitik in Europa. Eine Studie zur Veränderung von Regieren in Europa. Stuttgart: Lucius \& Lucius.

Transit Migration Forschungsgruppe (ed.) (2007): Turbulente Ränder. Neue Perspektiven auf Migration an den Grenzen Europas. Bielefeld: Transcript.

US Census (2002): Statistical Abstract of the United States 2001. The National Data Book. Austin: Hoovers Inc.

Wæver, Ole (1995): “Securitization and Desecuritization”. En: Lipschutz, Ronnie (ed.): On Security. New York: Columbia University Press, pp. 46-86.

Wæver, Ole/Buzan, Barry/Kelstrup, Morten/Lemaitre, Pierre (eds.) (1993): Identity, Migration and the New Security Agenda in Europe. London: Pinter.

Weiner, Myron (1992): The Global Migration Crisis: Challenge to States and to Human Rights. New York: Addison-Wesley Longman.

- (1995): "Security, Stability and International Migration". En: International Security, 17, 3, pp. 91-126.

Worldbank (2008): Migration and Remittances Factbook 2008. Washington: Worldbank.

\section{Páginas Web consultadas}

$<$ www.factfinder.census.gov/servlet> (11.01.2011).

$<$ www.iom.int/jahia/jahia/about-migration/facts-and-figures/lang/en $>(03.06 .2011)$.

$<$ www.remvs.org $>$ (15.01.2011).

$<$ www.rcmvs.org/documentos/investigacion/pagina_matrices.htm $>(13.01 .2011)$.

$<$ www.rcmvs.org/documentos/investigacion/visas.htm> (15.01.2011). 



\section{Markus-Michael Müller}

\section{Citizen Participation and Crime Prevention in Latin America: The Problems Behind the Solution ${ }^{1}$}

A recent flyer distributed by the Mexico City police department, the Secretaria de Seguridad Pública del Distrito Federal (SSPDF), informs local residents about the possibilities and merits of citizen participation in security matters. In addition to providing information about the different activities of the citizen participation program it ends with the following disclaimer:

This program is of public character. It is not conveyed nor promoted by any political party and its resources come from the taxes paid by all taxpayers. It is forbidden to use this program for political and electoral goals, for pecuniary rewards or any other purposes different from those established in the program. Anyone that will make an improper use of the program's resources in the Federal District will be sanctioned according to the respective law and from the responsible authority (SSPDF 2009).

This uneasy and contradictory relationship between citizen participation in security matters and the instrumentalization, or better put, appropriation, of the latter for private or political purposes is at the centre of this article. By drawing on the results of empirical fieldwork in Mexico City, this article takes a closer look at a local community policing program, the Policía de Barrio project, in order to demonstrate that contrary to the expectations of many Latin American policy makers, think tanks, NGOs and a growing number of related scholarly articles and books, community participation in security matters cannot

1 Parts of this contribution appeared in the European Review of Latin American and Caribbean Studies 88 (2010) and are reprinted here by permission. Research for this article was conducted between 2006 and 2009 as a part of the project "Public Security as Governance? Policing in Transitional and Developing Countries", of the Research Center (SFB) 700: "Governance in Areas of Limited Statehood - New Modes of Governance?", funded by the German Research Foundation (DFG) and located at the Freie Universität Berlin. I would like to thank Ruth Stanley for her helpful comments on an earlier version of this paper and Frank Müller and Forrest Kilmnik for their invaluable research assistance. 
be expected to function as a blueprint for improving citizen-police relations and the prevailing (in)security situation in contemporary urban Latin America (on the latter aspect, see IBRD 2008; Koonings/Kruijt 2007; Rotker 2002). By confronting the official claims and objectives of the Policia de Barrio program, together with an analysis of how this community policing program operates in practice, this article argues that despite its claim for improving police-citizen relations and the security situation, the concrete practices of the Policia de Barrio are overdetermined by different socio-political features of the local context, such as clientelism, police corruption, and party politics. These components, therefore, render the contribution of this community policing effort for the sustainable improvement of local accountability, police efficiency and legitimacy unlikely.

This article draws on the following sources to develop its argument: In addition to official documents, NGO reports and available academic literature, it is based on 20 expert interviews with current and former members of the local security apparatus, local residents and NGO members, that were conducted between 2006 and 2009. Based on a semi-structured questionnaire, expert interviews seek to obtain relevant information by interviewing actors who, due to their position and experience within a particular context, can be assumed to possess special knowledge about practices and processes within this social setting. Therefore, they can be described as "experts" (Bogner/Littig/Menz 2005). The interview material was then analyzed with a deductive categorization effort according to the method of qualitative content analysis (Mayring 2008).

The remainder of this paper is organized as follows. I will first offer a brief overview of the community-policing concept that will be discussed in the context of the recent community policing euphoria in Latin America. Next, I will give a brief introduction of the local context together with the relation between the implementation of the Policia de Barrio program and the local democratization process. Following this, I will highlight the main objectives and instruments of the Policia de Barrio program and will identify the important problems with regards to the way the program functions in practice. The concluding section will summarize the main findings of this article and outline directions for future research on this topic. 


\section{Community Policing comes to Latin America}

As a consequence of the current perception of a "metropolization of crime" (Castillo 2008) throughout Latin America, urban policy makers in all major Latin American cities are increasingly looking abroad for solutions to the problems of urban insecurity. This contributes to a growing transnationalization of Latin American urban security governance, conceived as the growing involvement in and impact of external concepts and (frequently non-state) actors, such as international organizations, intergovernmental organizations, donor agencies, security consultants or NGOs, on local policing agendas. One important consequence of this development has been the import of policing strategies and concepts, mostly from Anglo-Saxon countries. The most prominent respective policing importations have been zero tolerance and/or broken windows policing efforts, which have played a part in the hegemony of tolerancia cero (zero tolerance) or mano dura (strong hand) security agendas in many countries in the region (Glebbeek 2010; Dammert/Malone 2006). Whereas these concepts have been widely criticized by academics and civil society organizations for their repressive nature and the human rights violations that frequently accompany their implementation, another imported Anglo-Saxon policing model received a more favorable response: community policing.

In fact, since the 1990s, an increasing number of Latin American countries have opted for a variety of community policing efforts. These efforts focus on enhancing the level of cooperation between local residents and the police at the neighborhood level. Such projects have been promoted and implemented in Argentina, Brazil, Chile, Colombia, Costa Rica, Ecuador, El Salvador, Guatemala, Honduras, Mexico, Peru, Venezuela (Dammert 2004; Dammert/Malone 2006; Eilbaum 2004; Feth 2008; Föhrig/Pomares/Gortari 2006; Frühling 2004; Brogden/Nijhar 2005: 178-185; Sozzo 2005). Although there is still considerable academic debate as to how to define community policing, the following citation captures the official expectations associated with this concept:

Officers and neighborhood residents approach each other as co-equal partners in the design and implementation of programs designed to address local problems. Such "co-production" practices can plausibly lead to greater effectiveness and greater legitimacy: effectiveness be- 
cause the community would be more fully involved; legitimacy because the police would be open to democratic oversight (Herbert 2001: 448).

Therefore, community-policing programs not only promise an improvement of the urban security environment, but also seek to make security governance more democratic, participatory, and accountable. These programs look to increase the local populations' confidence in the police, and to improve police sensitivity to citizens' security concerns.

The increasing attractiveness of community policing for Latin American urban policy makers is related to three interconnected dimensions: First, the hegemony of Anglo-Saxon policing discourses and practices, which seem to have become the global hallmark "of a new crime control establishment that draws upon the new criminologies of everyday life to guide its actions and mould its techniques" (Garland 2001: 17). Second, and closely related, the emergence of an international development discourse with obvious neoliberal undertones - which calls for police reform measures and promotes the principles of ownership, participation, and accountability (Buvinić/Alda/Lamas 2005: 11-13; for an important critique, see Stanley 2006) that has converted community policing into "the current preferred police reform model in international aid and development circles" (Murphy 2007: 243). Finally, in the newly democratized political environment of Latin America, policy makers and police reformers are struggling more or less successfully - and with more or less political commitment - with the heritage of authoritarian rule and "political policing", which, in addition to the problems of frequent and endemic police abuse as well as the participation of police officers in criminal activities and large scale corruption, have seriously undermined confidence in the local police institutions as well as their credibility. These dimensions mutually reinforce each other and have contributed to the emergence of a political consensus among many academics, local NGO activists, and policy makers regarding the usefulness of community policing strategies as the "international best practices", whose adaptation to Latin America is not only perceived as a promising and sustainable security effort, but also as an important contribution to rebuilding trust in the local police forces.

What is frequently ignored is the fact that even with regard to Anglo-Saxon countries that first developed community policing strate- 
gies, the alleged "success" and concrete achievements of such programs still leave open questions and unresolved matters of dispute (Herbert 2006; Stanley 2006; Waddington 1999). Furthermore, the Latin American promoters and practitioners of community policing also tend to ignore critical evaluations concerning the implementation of these programs in other regions of the Global South (Brogden 2002; Lau 2004; Ruteere/Pommerolle 2003). Summarizing much of these criticisms, Mike Brogden and Preeti Nijhar, in their detailed analysis of community policing efforts in the Global South, indicate that community policing is situated in a long and problematic tradition of "exporting used goods from the Western supermarkets of policing and other legal institutions to so-called developing and transitional countries". They further suggest that it is "at best, [an] unproven practice. At worst, it is simply a practice that reinforces existing schisms and inequalities" (Brogden/Nijhar 2005: 161, 229). In a similar direction, and with explicit reference to the equally ignored fact that community policing emerged as a response to a number of genuine US-American urban policing problems, Christopher Murphy recently stated:

Its own Western development, suggests that to be effective COP [Com-
munity oriented Policing] requires mature democratic political gover-
nance, a legitimate, stable and effective police organisation, and a high
level of community stability and consensus. But as most police reform
environments have discredited, corrupt, unsophisticated, often violent
and ineffective police forces and are in unstable, insecure and conflict
ridden communities with undemocratic social and political forms of go-
vernance, its [sic!] not surprising that COP has often failed to be an ef-
fective policing model in such environments (Murphy 2007: 258).

These critical comments have been ignored by most of the current literature that supports and promotes the import of community policing to Latin America. To a certain degree, "bewitched" by an alleged ontological democratic potential of the "community" and the "demonstration effect" of the "new security doxa" (Wacquant 2009) in the guise of community policing, most of the related literature is characterized by an exclusive problem-solving orientation whose principal concern is the promotion of concrete action - for example, the implementation of community policing programs - not an in-depth analysis of the community policing concept itself (Feth 2008). Furthermore, it is not uncommon that respective state authori- 
ties and security agencies themselves evaluate the outcomes of the politics they implement, and only in a very few cases do such publications include the perceptions and experiences of the recipients of community policing projects (Feth/Müller 2009). This, of course, does not imply that these studies are not aware of possible problems and shortcomings of community policing efforts. However, these problems are often perceived as technical problems that can be resolved through more efficient and sustainable implementation procedures (Frühling 2004: 28-36). This primarily technical and problem-solving orientation, as this article highlights and proposes, is an important factor in the shortcomings of the literature advocating large-scale implementation community policing programs in Latin America. These shortcomings exist in the absence of a deeper contextualization of local community policing ideas and practices, in particular with respect to their political appeal - beyond immediate security concerns - for local policy makers, as well as in their lack of sensitivity for the possibility of appropriating community policing resources for personal or political interests. In this regard, already in 2000, Rachel Neild warned

\begin{abstract}
that the clear danger of community policing is that it may be used as a tool for social control or for local caudillos - strongmen or "party bosses" - to maintain their dominance. Models from other contexts must be examined with these questions in mind, and issues of replicability considered carefully, particularly for a Latin American context (Neild 2000: 9).
\end{abstract}

The remaining pages of this article demonstrate that such critical warnings are indeed important components, though in most cases neglected ones, of the way things work in Latin American experiments with community policing.

\title{
2. Community Policing in Mexico City
}

Mexico City has recently been labeled as "a relative newcomer to the community policing philosophy" (LaRose 2006: 286). However, this view has to be corrected. Already in the 1980s, the Moral Renovation Campaign of Mexican president Miguel de la Madrid (19821988) included a project of community-oriented neighborhood policing known as Policía de Barrio. This project, it was hoped, would create new confidence in the police forces by promoting the image 
of the police officer as "everybody's friend" (SEGOB/Presidencia 1988: 69-70). Although the existing documents and literature do not permit an appraisal of the project's success or failure, it seems that the project was eventually disregarded and finally abandoned. It was not until the beginning of the new millennium that there was a restoration of this policing effort with the revival of community policing that occurred in Mexico City, which is closely related to the local democratization process.

Whereas since 1928 the Mexican president directly appointed the Mexico City mayor, in 1997, due to constitutional changes, the local population could, for the first time in 71 years, directly elect their mayor. In this election, the majority of the residents voted for Cuauhtémoc Cárdenas from the Partido de la Revolución Democrática (Party of the Democratic Revolution, PRD). When Cárdenas was elected the mayor of Mexico City, he was expected to improve the local security situation, which the majority of the local politicians and Mexico City residents perceived as having been in a state of constant deterioration since the mid 1990s (César Kala 2000: 222-223; Davis 2006: 65; Pansters/Castillo Berthier 2007: 41). This development was widely interpreted as evidence of the failure of the security policies of the preceding Partido Revolucionario Institucional (PRI) administrations, as well as the deficiencies of their authoritarian, abusive and highly corrupt police apparatus.

Probably the most important factor for this political success was the PRD's discursive commitment to democratization, which placed an important emphasis on citizen participation (Davis/Alvarado 2004: 136). Already during his electoral campaign, Cárdenas promised a more democratic government and a participatory governance model that would differ significantly from the decades of authoritarian politics under the PRI. This focus was clearly expressed in his campaign motto: "Juntos! Gobernaremos la ciudad" (Together! We will govern the city). A cornerstone of this effort was the introduction of the principle of effective citizen participation in local politics. According to this official democratic commitment, the local population would also receive more opportunities to participate in local security matters. This participation, in turn, was expected to contribute to a closer police-citizen relationship, which would result in a more successful fight against crime. 
In this regard, the introduction of a community-policing program by the Cárdenas administration, which was expressed in the creation of the policia comunitaria (community police), served as the ideal strategy to combine these objectives (Davis 2003: 20). Following the official discourse, the police units of the SSPDF assigned to this program were to patrol those neighborhoods with the highest numbers of reported crimes. Through their presence in these areas, it was expected that they would contribute to the establishment of a closer and better relationship between the local population and the police, thereby rebuilding trust and confidence in the police apparatus and enhancing the capacity of the latter to fight against crime.

To accomplish this, the SSP secretary selected the "highest-crime areas" and gave officers a three-month training course to teach them to coexist with the members of the community. Selected patrol cars and police guard stations were painted with the words "Community Police", and that was all that was done (Arroyo Juárez 2007: 430, emphasis added).

Notwithstanding the initial ambitious objectives, the program soon fell by the wayside in the following years. However, due to the still unresolved security and police problems, as well as the related citizen mistrust in the local police forces, this program was reinstituted and renamed a few years later under the PRD government of Andrés Manuel López Obrador (2000-2005). The program, formally established in 2003, was now called Policía de Barrio. In his inaugural speech, then-Police Chief (and current mayor of Mexico City) Marcelo Ebrard stated the centrality of re-establishing a police-citizen relationship that was based on mutual confidence and trust, and considered to be the essential element of local policing. The creation of the PB, modeled after similar international experiments, was to serve this purpose.

[T] he principal instrument for combating crime is this confidence, is the support of the community for the actions of the police, and, on the other hand, the support of the police for the community. We call this program, with this ambitious goal, Policía de Barrio, because this is how the police have operated in Mexico City for a long time, and this is what has been lost for some decades for different reasons. [...] Therefore, we need to overcome this distance. This is the most important effort that we can promote as a security strategy. We can have the best equipment, but if we do not construct this bridge and this mutual support, it will be very difficult to achieve positive results. [...]. This is what the international experiences, be it of Japan, Chile, or Spain with whom we have been 
working, tell us. This is what the oral traditions tell us. We did not undertake a study of this topic in Mexico City, but we recall that in the 1950 s and throughout most of the 1970s, the police had a very high level of support from the community (SSPDF 2003).

As explicitly acknowledged in this speech, the reestablishment of this program was not accompanied by an evaluation of its predecessor or the structural conditions of Mexico City and its police apparatus. Instead, as the passage quoted demonstrates, the decision to implement this program was based on what was heard from the experiences of other countries, as well as on the evocation of an idyllic, golden-age picture of the $1950 \mathrm{~s}$ and $1960 \mathrm{~s},{ }^{2}$ when the population of Mexico City was said to have had confidence in their police forces (Arroyo Júarez 2007: 430). Despite this lack of scientific and professional evaluation, the following years saw the Policia de Barrio program implemented throughout the city.

The main objective of the Policia de Barrio program, according to official statements, can be identified as the (re)establishment of confidence in the local police forces by bringing them into closer contact with the local population, while making them more accountable to the local residents by permitting the latter a voice in the evaluation and planning of police work and strategies. These steps are perceived as essential components of a more efficient strategy in fighting local crime. In 2006, the Policia de Barrio was operating with 1,836 police officers, drawn from the Preventive Police (about $6 \%$ of its active members), which were assigned to 169 patrol areas characterized by high criminal indices in 15 of the 16 boroughs of the Federal District (SSPDF 2006: 225-226).

Since then, the basic police work of the officers assigned to this program has been rather simple. As specified by information provided by members of the local administration of justice and local NGOs, a pair of beat cops, whose presence and patrol turns have to be confirmed by selected residents, is assigned to a certain patrol area (Código Águila). In addition, members of the Policía de Barrio partic-

2 Such golden-age rhetoric frequently accompanies and justifies the implementation of community policing programs. In this regard, Waddington already stressed in 1984 that "'Community Policing' is a romantic delusion, not for the 'world we have lost', but for one we never had. It harks back to a harmonious idyll, where the police were everyone's friend. It was never thus, and it is unlikely that it will ever be" (Waddington 1984: 5). 
ipate in the meetings of the local comités vecinales (neighborhood committees). This participation, in turn, was intended to contribute to the evaluation and reorganization of local police strategies according to the security needs of the communities.

However, although the Policia de Barrio is assigned to a certain area in a respective Mexico City borough, it is important to stress that neither the precinct mayors nor the local programs for crime prevention and citizen participation have direct control over the Policia de Barrio agents, who remain under the central authority of the SSPDF. Before detailing this fact, I will present a closer look at the neighborhood committees and their relationship to public security issues. Correspondingly, it is these institutions that are the principal instruments for citizen participation in local security issues, while also serving as the principal coordination and evaluation mechanisms for the Policia de Barrio (Alvarado et al. 2006: 26).

\section{Community Policing in Practice: Clientelism, Mistrust and Politics}

Owing to the fact that the community policing programs emphasize the crucial role of citizen participation and accountability, and because in the case of the Policia de Barrio the neighborhood committees are the single most important aspect in this regard, it makes sense to take the neighborhood committees as a starting point for addressing the question of how the program works in practice. When we consider the fact that the concrete legal function of the neighborhood committees with regard to their participation in local public security provision are vaguely defined, ${ }^{3}$ this suggests that in the absence of a

3 The role of the neighborhood committees with regard to questions of public security were first established in Article 80 of the Ley de Participación Ciudadana del Distrito Federal (Law of Citizen Participation in the Federal District, LPC) passed in 1999. This article, although in rather vague and imprecise terms, states that the neighborhood committees are responsible for the "verification of public security programs". In 2004, the law was modified and the committees' role in citizen participation was redefined. It is Article 88 of the new law that defines the role of the committees to "emit opinion concerning the public security and administration of justice programs of the territorial coordinations". In addition, Article 92 states that the internal organization of the committees has to include a Coordinación de Seguridad Ciudadana y Prevención del Delito (Coordination for Citizen Security and Crime Prevention). 
clearly defined legal function, their respective activities, as well as the resulting outcomes, depend on the existing local context together with the practices of the committee members. Taking into account the fact that the democratization of the Mexico City politics was not accompanied by the dissolution of political clientelism and paternalism that characterized the politics of the capital under the decades of PRI oneparty rule (Bartra 2007: 64-69; Durand Ponte 2007; Hilgers 2008; Schütze 2005), it should come as no surprise that the activities of the neighborhood committees are also haunted by clientelistic practices (Rodríguez Luna 2007: 244-245; Zermeño/ Gutiérrez Lozano/López Aspeitia 2002: 245-251). The lasting impact of these relations can be easily identified in the realm of policing and the activities of the $\mathrm{Po}$ licia de Barrio. Members of neighborhood committees as well as representatives from the local administration of justice interviewed for this study frequently stressed that in many cases the members of the neighborhood committees tend to "privatize" the Policia de Barrio officers assigned to their neighborhood and use them for private purposes. For example, Antonio, ${ }^{4}$ an ex-director of a local crime prevention program, with respect to his experience with the local neighborhood committees stated:

In reality, there was a lot of corruption going on in the subcommittees [of public security]. Members of the subcommittees had the Policía de Barrio agents practically under their private authority. They converted those police officers into private vigilantes, keeping an eye on their houses, cars, shops etcetera. All of this was highly arbitrary (interview April 2008).

Such behavior is generally tolerated by the local authorities, as it represents a crucial feature of the practices of informal negotiations or gestiones that still stand at the heart of Mexico City politics: in exchange for the delivery of services to local residents, the latter offer political support to people capable of providing these services. However, this relationship is frequently mediated through local brokers or intermediaries. Their power is based on political capital derived from their capacity to mobilize people. This in turn enables them to function as informal spokesmen of local level collective in-

4 As many people interviewed for this article explicitly asked me not to be cited with their names, I decided to use anonymous names for all interviewees as well as fictitious names throughout the text. 
terests and to present these interests to state authorities. This position provides such brokers with a privileged access to state personnel and resources that they can then appropriate, to a certain degree, for their private and political purposes (Hilgers 2008: 137; Müller 2012). The following passage from the interview with Antonio offers an inside view of these practices and their pervasiveness within the context of Mexico City politics:

Yes, this system obviously produces a vice of certain privileged relationships, but this goes on everywhere. There are certain personalities, certain groups, which manage to establish a direct relationship with some public official and, well, this opens the door to a more expedient path. For example, we have a good relationship with Manuel, a local member of congress. When the people asked for more light on one street, well what did we do? We asked the people to send a request to the person responsible for the sector [jefe del sector], the local chief of public security. But this is nothing more than a formality. We picked up the phone, called the person responsible for the sector, whom we know and who is familiar with our relationship with Manuel, and, well: "Listen chief, these people need these things. When can we meet to speak about this with you personally?" And, well, isn't it great that things can be taken care of so easily? What we do, and this is completely within the same logic, is take advantage of a privileged contact in order to solve a concrete problem.

In such a context, the political and legal nature of the neighborhood committees creates ideal circumstances for the concentration of these practices of negotiation, while establishing privileged spaces for the arbitrary appropriation and distribution of public security resources for private and political purposes. Against this background, it is not surprising that when Pamela, a local member of a neighborhood committee in the middle-class neighborhood of Coyoacán, was asked what the police do in order to improve the local security situation, she replied: "Well, of course they'll send me officers, because I have the phone number of the local police chief [jefe del sector]. I call him, they come" (interview September 2007).

Such forms of privileged access to and the private appropriation of public security resources, however, are not exclusively the domain of neighborhood committees in middle-class districts. For example, Rodrigo, a shopkeeper and former member of a neighborhood committee in the marginalized Mexico City borough of Iztapalapa, explained that during the time he was active in the 
neighborhood committee he organized other shopkeepers in his area to collect money to be passed on to the local Policia de Barrio officers to keep an eye on their stores and have "a little bit more surveillance out here" (interview November 2007).

Under such conditions, it is evident that the evaluation of the work of the Policia de Barrio by the neighborhood committees, as well as the resulting police-community relations, may often be based more on the neighborhood committee members' personal interests than on the security concerns of the entire community. In general, local members of the administration of justice and NGO activists remained skeptical, when taking into account the political history and fixed influence of clientelism and local political bossism into broader political structures, if the neighborhood committees could be expected to function as authentic representative bodies of the respective neighborhood as well as efficient institutions for the accountability of the Policia de Barrio. This absence of real accountability mechanisms perpetuates the institutional problems of the local police forces, such as informality or involvement in criminal and corrupt practices (on these topics, see Davis 2006; Martínez de Murguía 1999; Müller 2012), thereby making the expected positive impact on policecommunity relations, as well as the positive contribution to the local security situation, questionable.

However, it is important to stress that the informal privatization of the Policia de Barrio and the resulting fragmentation of their security provision is not limited to the activities of the neighborhood committees. Rather, Policia de Barrio officers can be "appropriated" by a broad variety of actors, ranging from shopkeepers to ordinary citizens. Although, the neighborhood committees undeniably have privileged access to the Policia de Barrio agents, this privilege does not imply exclusivity. In the local context where the majority of police officers opted for employment with law enforcement out of an interest in "making money" (Arteaga Botello/López Rivera 2000), "buying" private protection from the police is a rather common phenomenon (Müller 2012: chapter 3; Pansters/Castillo Berthier 2007: 45; Anozie et al. 2004: 4), and the Policía de Barrio seems to be no exception in this regard. Accordingly, Marcos, a member of a local NGO, explained that in prosperous zones of the Federal District members of the local population would "donate" money to the Policia de 
Barrio officers, who, motivated by these financial incentives, in turn showed a greater and more regular presence in these areas than in more marginalized zones. This suggests that money-driven market logic also negatively affects the quality of the local community policing effort and contribute to a high degree of spatial selectivity and geographical fragmentation (interview March 2006).

The informal appropriation of police officers is not the only problem related to the activities of the Policia de Barrio. Other features include arbitrary and criminal behavior that frequently contribute to widespread negative perceptions of the Policia de Barrio program. For example, Rafa, a shopkeeper in the middle-class neighborhood Colonia del Valle explained that although the Policia de Barrio officers assigned to the zone have a clearly defined patrol area and schedule, in practice, the agents show up whenever they want. Although in theory their patrols have to be individually confirmed after their completion by selected local residents, in practice, he, in his function as such a controller, has been frequently "asked" by the local Policía de Barrio agents to confirm all of their patrols for the entire day at one time. After they received his signature, the agents would not return for the rest of the day to continue with their patrols. These facts, according to this shopkeeper, seriously undermine not only the efficiency but also the credibility of the program (interview September 2006).

A further element that appears to discredit local implementations of the Policia de Barrio program was mentioned in an analysis by the NGO Democracia, Derechos Humanos y Seguridad of neighborhood reactions towards insecurity problems. The authors referred to an incidence in the marginalized Mexico City borough of Iztapalapa, in which the residents mentioned that the local Policia de Barrio agents are involved in extorting local residents and delinquents (Alvarado et al. n.d.: 29). For that reason, a spokesman of a local business organization in the middle-class borough of Coyoacán declared that after having been informed by local authorities about their plans to assign Policía de Barrio units to patrol his residential zone, he as well as other members of the organization vehemently, and successfully, rejected this proposal. This refusal was based on fears that the permanent presence of and monitoring by Policia de Barrio agents would permit the latter to gather sensitive information concerning the daily routines of the residents and, therefore, taking in- 
to account the bad reputation of the local police forces and their frequent connections to organized crime, would represent a serious security risk for them and their families (interview December 2007). However, as the following interview passages demonstrate, members of the lower social classes and marginalized segments of the local population have equally negative views of the Policia de Barrio, albeit for different reasons. For example, Rebecca, a sex worker working in downtown Mexico City, stated:

Preventive Police, Policía de Barrio, Judicial Police, that doesn't make a big difference. Customers are a problem, most of all, when they refuse to pay, but the authorities represent another risk for us. They try to extort us. When you refuse to pay, they take you to the delegación, where they can keep you for 24 hours without any possibility of making a phone call. They tell you that you have been arrested for committing a crime. To achieve a good relationship with the police, you have to give them the money they want and everything else they ask you to. There are a lot of colleagues that had to enter into a sexual relationship with a policeman (interview October 2006).

In addition, Héctor, a resident from the marginalized Mexico City neighborhood of Iztapalapa, mentioned that due to the behavior of Policia de Barrio officers in his neighborhood, local residents perceive them as an aggressive presence in the area. This is highlighted in the following interview:

[There] is a program that they call Policía de Barrio, where you have police officers who walk around and keep an eye on the neighborhood, but in reality they are not very efficient, because when the people here see eight police officers walking around, they perceive this as an aggression. It's not that the Policía de Barrio officers show up and talk colloquial with, let's say an old woman, as friends [cuates]. No, when they come, they are very indifferent to what's going on here. So with this attitude they will never be able to integrate with the community.

You just said that the Policía de Barrio operates here with groups of eight people?

Policía de Barrio... yes, yes.

Well, in other neighborhoods I was told that there are only two police officers on patrol. Here it seems that this is somehow different?

Yes! And they don't show up every day. Sometimes they come once in a week, sometimes every two weeks. Policía de Barrio... Yes... Here are some police posts [módulos de vigilancia] that belong to the citizen participation program. In these posts there's sometimes a Policía de Barrio officer, but this guy locks himself up in his post. So, he is safe, but in 
the street before him, there's no security. There's no security because he is inside his post and doesn't make his patrols. When they finally go on patrol, well then always in a group of many, and the people here have an aggressive view about this (interview September 2007).

However, it seems that such perceptions of mistrust, mentioned by Héctor, are not one-sided but are instead mutual. As Carlos, a local policeman from the same borough, explained, due to the prevailing lack of confidence in the police by the local residents in his patrol area he would prefer not to make his patrols on foot, as required by the Policia de Barrio program, in order to avoid problems with the residents. Instead, he uses a police car for collecting the signatures for the Código Águila (interview March 2008).

Against the background of the aforementioned observations, it is of little surprise that Fernando, an instructor of the Instituto Nacional de Ciencias Penales (National Institute for the Study of Criminal Science), a public agency that offers training for public servants involved in the prosecution and administration of justice, gave the following description of nearly six years of community policing in Mexico City:

The only thing the SSPDF has done was to put more police on the streets. More police presence on the streets of certain neighborhoods. This has nothing to do with approaching the citizens. There is no direct contact with the citizens. All they do is give the policemen a paper with which they go to the store and ask the clerk for a signature, they go the pharmacy and do the same, they go the beauty salon and ask the owner for a signature. This is what the Policía de Barrio is all about for them (interview December 2009).

This outcome, in addition to the abovementioned problems of clientelism and police corruption, which according to the involved interview partners are well known by the respective authorities, raises the question why this program continues to be presented and actively promoted by the local government and the SSPDF as a key strategy for addressing the security demands of the local citizens. Ramón, who works for a local crime prevention program, gave a possible and convincing explanation of this paradox. He explained that the creation of the Policia de Barrio program should not be interpreted as a serious commitment to establishing citizen participation in security issues. Rather, it represents the symbolic intent to demonstrate a political will to improve the local security situation in 
a democratic way, and to express sensitivity to the respective demands of the local civil society by avoiding the transformation of the traditional structure of the local Preventive Police. This permits a kind of illusory decentralization by maintaining central political control over the local police apparatus at a time when local politics are marked by growing inner-party rivalries between the different factions of the PRD (interview July 2007). In a similar vein, Antonio, introduced above, stated:

In the end, there is no interest in converting public security into something more closely related to the community. There is an interest, a necessity, and a decision for control. They [the government of the Federal District] are convinced that this is something necessary, and because of this, they are not interested in participation or even at the very least in dialogue with the community. The police in Mexico are very corrupt, and because of this, I think that there is no will from the government of the Federal District to resolve these problems. This is why they don't want better local control and supervision. With a centralized police structure, the control of the corrupt superiors over their agents in the Federal District is much more efficient (interview April 2008).

In this respect, NGO activists and members from the local administration of justice interviewed for this study indicated that the Policia de Barrio projects reflect a more general development in the realm of local policing, a development which can be described as "symbolic policing". In Mexico City, local authorities increasingly tend to address security problems and critical issues in the local law enforcement agencies without a serious commitment to structural reforms. They are instead concerned with publicly visible and displayable measures, such as the acquisition of new, more fashionable uniforms, new equipment, or the creation of new police units. The increasing attractiveness of such forms of symbolic policing, as the interviews indicated, is closely related to the local democratization process, the pluralization and competition among local and national political actors, as well as the resulting politization of security issues in Mexico City. Leaving aside political conflicts between the local city government (PRD) and the federal government (first PRI, later the Partido Acción Nacional, the National Action Party, PAN), this politization is also reflected inside the governing structure of Mexico City, although being more evident at the level of the boroughs. Here, internal factionalism within the dominant party (PRD) frequently de- 
termines not only the supply and security equipment assigned to specific boroughs, it also impedes a further decentralization of policing faculties and the creation of impartial accountability structures at this administrative level. This is due to the fact that the government of Mexico City prefers a centralized police structure that can more easily facilitate the maintenance, and image, of a certain degree of control over the local public security apparatus. However, in order to demonstrate their commitment to democracy and citizen concerns, which exist in a political conjuncture where security problems rank among the most important political issues in local opinion polls, local politicians tend to create seemingly "innovative" and "progressive" police units and programs (on the historical roots of this pattern of "symbolic policing", see Davis 2012). These programs, however, due to their fixed influence in the prevailing political context, coupled with the absence of serious political will for a structural police reform effort, are in many cases a failure by design. Therefore, such efforts like the Policia de Barrio, "may serve for show as much as for anything else" (Davis/Alvarado 2004: 149).

\section{Conclusion}

The active participation of citizens in the provision of public security through the implementation of community policing programs has become an important urban policing strategy in contemporary Latin America, which is actively promoted by local politicians, NGOs, national and international think tanks, and academics. This support is in large part due to the assumed potential of this "international best practice" to contribute to a more efficient, democratic and accountable policing, as well as to improve citizen-police relations. This article presented a critical analysis of a Mexico City community-policing program: the Policia de Barrio project. By confronting the officially stated goals and objectives of this community policing program, with the community policing practices on "the ground", this article demonstrated that the experiences in Mexico City significantly differ from the widespread positive expectations regarding the democratic potential of community policing programs and their contribution to improving citizen-police relations. 
First, the Mexico City case study demonstrated that the local community policing efforts are overdetermined by established structures of clientelism and police corruption that permit and facilitate the private appropriation/distribution of community policing resources for private purposes. Second, the case study also showed that the program's contribution to an improvement of citizen-police relations is doubtful. Far from finding a harmonious cooperation between police and citizens or contribution to a mutual beneficial coproduction of security, descriptions of illegal and abusive conduct from Policia de Barrio officers were encountered, as well as strong sentiments of mutual mistrust between community policing officers and local residents. Finally, the findings of this article stress the centrality and negative impact of politics. The abovementioned observations suggest that the Policia de Barrio program should most of all be interpreted as an effort of "symbolic policing" aimed at the public. Furthermore, the program can be regarded as a discursive display of an "authentic" commitment to citizen participation and to democratization, without a real political will to confront the structural problems of the local police forces or to enhance police accountability.

Whereas these findings from Mexico City already question the predominant positive evaluation with which the advocates of community policing programs in Latin America promote the introduction of such policing models, there are at least two additional factors that deserve attention. First, it should be recalled that when Rudolph Giuliani was contracted by influential actors of the Mexico City business community in order to develop an export version of his zero tolerance policing approach, ${ }^{5}$ he initiated a report containing 146 recommendations to the authorities - all of which were accepted by the SSPDF - and explicitly referred to the Policia de Barrio program (recommendation 127) as a crucial component for an improvement of the "quality of life" in Mexico City (SSPDF 2003). As Alex Vitale has convincingly argued, the "quality of life" paradigm and the related policing focus on the "recuperation of public spaces", which is a central theme in most other Latin American cities today, are fundamental features of more repressive policing schemes, such as the

5 On Giuliani's activities in Mexico City, see Müller (2009) and Davis (2007). 
initial zero tolerance policing approach advocated in New York City (Vitale 2008). When further recalling that even leading scholars in the field of criminology classify zero tolerance policing as a community policing effort (Johnston/Shearing 2003: chapter 6), then there should be more skepticism about the widely assumed "ontological" emancipative and democratic potential of community policing projects.

Second, it is striking that most of the current research on community policing in Latin America treats the notion of "community" as unproblematic. The fact that the local is not necessarily a privileged place for democratic empowerment is obvious in the case study of Mexico City. This insight receives additional support from a recent study on community policing in Buenos Aires. This study demonstrates not only the selective participation of the local residents, but also stresses that the people participating in these programs frequently have a repressive vision of crime prevention that predominantly focuses on the eviction of homosexuals, prostitutes or adolescents drinking in the streets of their neighborhood. In this respect, the analysis demonstrates that the local community policing initiatives perpetuate existing power relations inside the communities together with the resulting processes of social and spatial exclusion, rather than overcoming such divides (Feth 2008). As Graham Ellison observed, this outcome and the related neglect of innercommunity relations of power by the community policing advocates represents "the most fundamental weakness" of community policing because it

assumes the existence of a relatively homogeneous community with shared values about the role of the police, a functioning civil society and the absence of serious ethnic, class, religious and ideological fissures.

It, therefore, assumes or presupposes a situation that

is simply not the case in many transitional contexts (Ellison 2007: 208).

Against this background, the present paper should be read as a call for empirical studies on community policing efforts in Latin America that are more sensitive to the fixed influence of such policing imports into wider socio-political relations and local "cultures of con- 
trol". In fact, in Latin America, as well as in other regions of the socalled "developing world",

most of the analyses relevant to policing are driven by today's policy requirements, or are rooted in an uncritical liberalism; nuanced theoretical analyses are missing, as are ethnographic studies (Hills 2009: 212).

In order to overcome the resulting shortcomings, future research should try to address these topics by moving beyond the "excessive formalism" (O'Donnell 2006: 287), which haunts most of the related studies and their frequently apolitical and decontextualized treatment of security and policing issues in contemporary Latin American cities.

\section{References}

Alvarado, Arturo/Martínez, Olivia/Torres, Amparo/Urusquieta, M. Ulises (2006): Respuestas Vecinales a la Inseguridad Pública en la Ciudad de México. Woodrow Wilson International Center for Scholars, Latin American Program Special Report, 24-29 (<www.wilsoncenter.org/topics/pubs/LAP_August.pdf>; 22.10.2007).

- (n.d.): Respuestas Vecinales a la Inseguridad Pública en la Ciudad de México. México, D.F.: Democracia, Derechos Humanos y Seguridad, A. C.

Anozie, Valentina/Shinn, Juhie/Skarlatos, Katy/Urzua, Julio (2004): Reducing Incentives for Corruption in the Mexico City Police Force. International Workshop, Public Affairs 869 (<www.lafollette.wisc.edu/publications/workshops/20032004/pa869/2004-MEXICO.pdf>; 12.01.2007).

Arroyo Juárez, M. (2007): "Evaluating the Zero Tolerance Strategy and its Application in Mexico City". In: Cornelius, Wayne/Shirk, David (eds.): Reforming the Administration of Justice in Mexico. Notre Dame: University of Notre Dame Press, pp. 415-438.

Arteaga Botello, Nelson/López Rivera, Adrián (2000): "Everything in This Job is Money: Inside the Mexican Police”. In: World Policy Journal, 17, 3, pp. 61-70.

Bartra, Roger (2007): Fango sobre la democracia. Textos polémicos sobre la transición Mexicana. México, D.F.: Planeta Mexicana.

Bogner, Alexander/Littig, Beate/Menz, Wolfgang (eds.) (2005): Das Experteninterview. Theorie, Methode, Anwendung. Wiesbaden: VS Verlag für Sozialwissenschaften.

Brogden, Mike (2002): "Implementing Community Policing in South Africa: A Failure of History, of Context, and of Theory". In: Liverpool Law Review, 24, pp. 157-218.

Brogden, Mike/Nijhar, Preeti (2005): Community Policing. National and International Models and Approaches. Portland: Willan. 
Buvinić, Mayra/Alda, Erik/Lamas, Jorge (2005): Emphasizing Prevention in Citizen Security. The Inter-American Development Bank's Contribution to Reducing Violence in Latin America and the Caribbean (Best Practices Series). Washington, D.C.: Inter-American Development Bank.

Castillo, José (2008): “After the Explosion”. In: Burdett, Ricky/Sudjic, Deyan (eds.): The Endless City. London: Phaidon, pp. 174-185.

César Kala, Julio (2000): "Fenomenología del Delito: Diagnóstico de la Criminalidad en el Distrito Federal”. In: Diálogo y Debate de Cultura Política, 3, 12, pp. 214228.

Dammert, Lucía (ed.) (2004): Seguridad Ciudadana. Experiencias y Desafios. Valparaíso: FLACSO.

Dammert, Lucía/Malone, Mary Fran T. (2006): "Does It Take a Village? Policing Strategies and Fear of Crime in Latin America". In: Latin American Politics and Society, 48, 4, pp. 27-51.

Davis, Diane E. (2003): "Law Enforcement in Mexico: Not yet under Control". In: NACLA Report on the Americas, 37, 2, pp. 17-24.

- (2006): "Undermining the Rule of Law: Democratisation and the Dark Side of Police Reform in Mexico". In: Latin American Politics and Society, 48, 1, pp. 55-86.

- (2007): "El factor Giuliani: delincuencia, la "cero tolerancia" en el trabajo policiaco y la transformación de la esfera pública en el centro de la ciudad de México". In: Estudios Sociológicos, XXV: 75, pp. 639-668.

- (2012): "Policing and Mexican Regime Change: From Post-Authoritarianism to Populism to Neo-Liberalism". In: Pansters, Wil (ed.): Violence, Coercion, and State-Making in Twentieth-Century Mexico. Stanford: Stanford University Press, pp. 68-90.

Davis, Diane E./Alvarado, Arturo (2004): "Mexico City: The Challenge of Political Transition". In: Chavez, Daniel/Goldfrank, Benjamin (eds.): The Left in the City. Participatory Local Governments in Latin America. London: Latin American Bureau, pp. 135-168.

Durand Ponte, Victor Manuel (2007): "Gobiernos de izquierda y democracia: ciudadanos o clients". In: Bartra, Roger (ed.): Izquierda, Democracia y Crisis Política en México. México, D.F.: Nuevo Horizonte, pp. 151-164.

Eilbaum, Lucía (2004): "La policía 'al servicio de la comunidad': tradición policial y vientos de cambio". In: Tiscornia, Sofía (ed.): Burocracias y violencia. Estudios de antropología juridical. Buenos Aires: Antropofagia, pp. 159-201.

Ellison, Graham (2007): "Fostering a Dependency Culture: The Commodification of Community Policing in a Global Marketplace”. In: Goldsmith, Andrew/Sheptycki, James (eds.): Crafting Transnational Policing. Police Capacity-Building and Global Policing Reform. Oxford: Hart, pp. 203-242.

Feth, Anja (2008): "Viel Lärm um nichts? Kommunale Kriminalprävention in Buenos Aires". In: La Rosa, Sybille de/Höppner, Ulrike/Kötter, Matthias (eds.): Transdisziplinäre Governanceforschung. Gemeinsam hinter den Staat blicken. BadenBaden: Nomos, pp. 230-250. 
Feth, Anja/Müller, Markus-Michael (2009): Security Governance between Failure, Symbolic Legitimation and Informality: Lessons from Latin America's Metropolis. Berlin: Mimeo.

Föhrig, Alberto/Pomares, Julia S./Gortari, Cecilia (2006): “Citizen Security Policy in Argentina: The National Crime Prevention Plan”. In: Tulchin, Joseph S./Ruthenburg, Meg (eds.): Toward a Society under Law. Citizens and their Police in Latin America. Baltimore: Johns Hopkins University Press, pp. 243-260.

Frühling, Hugo (ed.) (2004): Calles más seguras. Estudios de policía comunitaria en América Latina. Washington, D.C.: Inter-American Development Bank.

Garland, David (2001): The Culture of Control. Crime and Social Order in Contemporary Society. Chicago: University of Chicago Press.

Glebbeek, Marie-Louise (2010): "Mano Dura: Fighting Crime, Violence, and Insecurity with an Iron Fist in Central America". In: Kuhns, Joseph B./Knutsson, Johannes (eds.): Police Use of Force: A Global Perspective. Santa Barbara: Praeger, pp. 63-72.

Herbert, Steve (2001): "Policing the Contemporary City: Fixing Broken Windows or Shoring Up Neo-Liberalism". In: Theoretical Criminology, 5, 4, pp. 445-466.

- (2006): Citizens, Cops, and Power: Recognizing the Limits of Community. Chicago: University of Chicago Press.

Hilgers, Tina (2008): "Causes and Consequences of Political Clientelism: Mexico's PRD in Comparative Perspective". In: Latin American Politics and Society, 50, 4, pp. 123-153.

Hills, Alice (2009): Policing Post-Conflict Cities. London: Zed Books.

IBRD (International Bank for Reconstruction and Development) (2008): Urban Crime and Violence in Latin America and the Caribbean. Status Report on Activities. Washington, D.C.: IBRD.

Johnston, Les/Shearing, Clifford (2003): Governing Security. London: Routledge.

Koonings, Kees/Kruijt, Dirk (eds.) (2007): Fractured Cities. Social Exclusion, Urban Violence and Contested Spaces in Latin America. London: Zed Books.

LaRose, Anthony P. (2006): "Individual Values of Mexico's New Centurions: Will Police Recruits Implement Community-Based Changes?". In: Journal of Contemporary Criminal Justice, 22, 4, pp. 286-302.

Lau, Raymond W. K. (2004): "Community Policing in Hong Kong: Transplanting a Questionable Model". In: Criminal Justice, 4, 1, pp. 61-80.

Martínez de Murguía, Beatriz (1999): La Policía en México: ¿Orden social o criminalidad? México, D.F.: Planeta.

Mayring, Philipp (2008): Qualitative Inhaltsanalyse: Grundlage und Techniken. Weinheim: Deutscher Studien Verlag.

Müller, Markus-Michael (2009): “Wenn 'Null Toleranz' und 'Zerbrochene Fensterscheiben' auf Reisen gehen: Globalisierung und die Restrukturierung des historischen Zentrums in Mexiko Stadt”. In: Kriminologisches Journal, 41, 2, pp. 8299 .

- (2012): Public Security in the Negotiated State. Policing in Latin America and Beyond. Basingstoke: Palgrave Macmillan. 
Murphy, Christopher (2007): "The Chart before the Horse: Community Oriented versus Professional Models of International Police Reform". In: Goldsmith, Andrew/Sheptycki, James (eds.): Crafting Transnational Policing. Police CapacityBuilding and Global Policing Reform. Oxford: Hart, pp. 243-262.

Neild, Rachel (2000): Themes and Debates in Public Security Reform. A Manual for Civil Society: Community Policing. Washington, D.C., Washington Office on Latin America.

O’Donnell, Guillermo (2006): “On Informal Institutions, Once Again”. In: Helmke, Gretchen/Levitsky, Steven (eds.): Informal Institutions \& Democracy. Lessons from Latin America. Baltimore: Johns Hopkins University Press, pp. 285-290.

Pansters, Wil/ and Castillo Berthier, Hector (2007): "Mexico City". In: Koonings, Kees/Kruijt, Dirk (eds.): Fractured Cities. Social Exclusion, Urban Violence \& Contested Spaces in Latin America. London: Zed Books, pp. 36-56.

Rodríguez Luna, Ricardo (2007): "La participación de la ciudadanía en la prevención del delito: estudio de caso en la ciudad de México". In: González Placencia, Luis/ Arce Aguilar, José Luis/Álvarez, Metztli (eds.): Aproximaciones empíricas al estudio de la inseguridad. Once estudios en materia de seguridad ciudadana en México. México, D.F.: Porrúa, pp. 225-253.

Rotker, Susan (ed.) (2002): Citizens of Fear. Urban Violence in Latin America. Camden: Rutgers University Press.

Ruteree, Mutuma/Pommerolle, Marie-Emanuelle (2003): "Democratizing Security or Decentralizing Repression? The Ambiguities of Community Policing in Kenya". In: African Affairs, 102/409, pp. 587-604.

SEGOB (Secretaría de Gobernación)/Presidencia de la República (1988): Justicia y Seguridad. Cuadernos de Renovación Moral. México, D.F.

SSPDF (Secretaría de Seguridad Pública del Distrito Federal) (2003): Discurso del Secretario de Seguridad Pública del DF, Marcelo Ebrard Casubon, durante la presentación de la Policía de Barrio en la Plaza de Constitución $(<w w w$. prodigyweb.net.mx/comunicacion0303/htm/dis_20-03-03.htm>; 21.05.2006).

- (2006): Memoria Institucional 2000-2006. México, D.F.

- (2009): Seguridad: A TU ALCANCE. México, D.F.

Schütze, Stephanie (2005): Die andere Seite der Demokratisierung. Die Veränderungen politischer Kultur aus der Perspektive der sozialen Bewegung der Siedlerinnen von Santo Domingo, Mexiko-Stadt. Berlin: Tranvía.

Sozzo, Máximo (2005): "Metamorfosis de los discursos y las prácticas sobre seguridad urbana en la Argentina". In: Dammert, Lucía/Bailey, John (eds.): Seguridad y reforma policial en las Américas. Experiencias y desafios. Buenos Aires: Siglo XXI, pp. 39-57.

Stanley, Ruth (2006): "The Globalisation of 'Democratic' Policing. Community Policing as an Export Model”. In: Costa, Sérgio/Domingues, José Maurício/ Knöbl, Wolfgang/Pereira da Silva, Josué (eds.): The Plurality of Modernity. Decentring Sociology, München: Hampp, pp. 87-98.

Vitale, Alex S. (2008): City of Disorder. How the Quality of Life Campaign Transformed New York Politics. New York: New York University Press. 
Wacquant, Loïc (2009): Punishing the Poor. The Neoliberal Governmentof Social Insecurity. Durham: Duke University Press.

Waddington, Peter A. J. (1984) "Community Policing: A Sceptical Appraisal". In: Norton, Philip (ed.): Law and Order and British Politics. Aldershot: Gower, pp. 84-96.

- (1999): Policing Citizens: Authority and Rights. London: UCL.

Zermeño, Sergio/Gutiérrez Lozano, Saúl/López Aspeitia, Luis Ernesto (2002): "La democracia impertinente: Comités vecinales en una cultura estatal". In: Revista mexicana de Sociología, 64, 1, pp. 231-268. 



\section{Autoras y autores}

María Carolina Agoff: Sociología, Centro Regional de Investigaciones Multidisciplinarias, Universidad Nacional Autónoma de México.

Martín Aldao: Derecho, Universidad de Buenos Aires, Argentina.

Kathya Araujo: Sociología, Universidad Academia de Humanismo Cristiano, Santiago, Chile.

Daniel Bonilla: Derecho, Universidad de los Andes, Bogotá, Colombia.

Marianne Braig: Ciencia Política, Freie Universität Berlin, Alemania.

Hans-Jürgen Burchardt: Ciencia Política, Universität Kassel, Alemania.

Sérgio Costa: Sociología, Freie Universität Berlin, Alemania.

Marco Estrada Saavedra: Sociología, Centro de Estudios Sociológicos, El Colegio de México.

Fabiola Fanti: Derecho y Ciencia Política, Centro Brasileiro de Análise e Planejamento, São Paulo, Brasil.

Carla Gras: Sociología, Consejo Nacional de Investigaciones Científicas y Técnicas y Universidad Nacional General Sarmiento, Argentina.

Jacint Jordana: Ciencia Política y Administración, Universitat Pompeu Fabra, Barcelona, España. 
Stefanie Kron: Sociología, Freie Universität Berlin, Alemania, y, actualmente, Universität Wien, Austria.

Marta Rodriguez de Assis Machado: Derecho, Fundação Getúlio Vargas y Centro Brasileiro de Análise e Planejamento, São Paulo, Brasil.

Markus-Michael Müller: Ciencia Política, Universität Leipzig, Alemania.

Thamy Pogrebinschi: Ciencia Política, Instituto de Estudos Sociais e Políticos, Universidade Estadual do Rio de Janeiro, Brasil.

José Rodrigo Rodriguez: Derecho, Fundação Getúlio Vargas y Centro Brasileiro de Análise e Planejamento, São Paulo, Brasil.

Juliana Ströbele-Gregor: Docente/Profesora, Instituto de Estudios Latinoamericanos, Freie Universität Berlin, Alemania.

Ingrid Wehr: Profesora e investigadora, Arnold Bergstraesser Institut, Universität Freiburg, Alemania.

Jonas Wolff: Senior Research Fellow, Peace Research Institute Frankfurt, Hessische Stiftung Friedens- und Konfliktforschung, Alemania. 

El Instituto Ibero-Americano (IAI) de la Fundación Patrimonio Cultural Prusiano en Berlín dispone de un amplio programa de publicaciones en alemán, español, portugués e inglés que surge de varias fuentes: la investigación realizada en el propio Instituto, los seminarios y simposios llevados a cabo en el IAI, los proyectos de cooperación con instituciones nacionales e internacionales, y trabajos científicos individuales de alta calidad. La „Bibliotheca Ibero-Americana“ es una serie que existe desde el año 1959 y en la que aparecen publicadas monografías y ediciones sobre literatura, cultura e idiomas, economía y política de América Latina, el Caribe, España y Portugal.

\section{Volúmenes anteriores:}

148. Cultura, sociedad y democracia en América Latina. Aportes para un debate interdisciplinario. Klaus Bodemer (coord.), 2012

El libro recoge los resultados de investigaciones puestas en marcha o ya finalizadas en el marco del Programa de Becas de corto plazo para América Latina de los años 20072011, lanzado y financiado por las Fundaciones Alexander von Humboldt y Fritz Thyssen. De acuerdo con la filosofía básica de ambas fundaciones, las contribuciones, escritas en la lengua materna de sus autores (español y portugués), provienen de diferentes disciplinas, cubren una amplia gama de temas y se distribuyen en cuatro bloques: "Actores sociales, democracia y gobernabilidad", "Derecho y estado de derecho", "Cultura y sociedad" y "Ciencia y tecnología".

147. Múltiples identidades Literatura judeo-latinoamericana de los siglos xx y xxi. Verena Dolle (ed.), 2012

El libro reúne colaboraciones de autoras y críticos que investigan, a partir de producciones literarias y culturales, los procesos de negociación y reflexión de las identidades judeo-latinoamericanas en los siglos xx y xxi, sobre todo en el Cono Sur. Se destaca el rol que desempeño y desempeña la cultura judía en sus multifacéticas expresiones en América Latina.

\section{Ideas viajeras y sus objetos: El intercambio científico entre Alemania y} América austral. Gloria B. Chicote / Barbara Göbel (eds.), 2011

Ideas viajeras y sus objetos constituye una contribución a las revisiones sobre los Bicentenarios de las independencias en América Latina desde la perspectiva de la circulación de los saberes y los entrelazamientos entre conocimiento y cultura. Los distintos artículos obedecen a la intención de remarcar el carácter ambiguo y muchas veces conflictivo que tienen en el desarrollo científico las relaciones entre los diferentes ámbitos en los que se efectúan las investigaciones: los centros periféricos constituidos en objetos de estudio y las metrópolis a las que los resultados son dirigidos. A lo largo de este libro se debate acerca de posibles construcciones y localizaciones de archivos en el pasado y en el presente, que adquieren importancia sustancial en los diferentes estratos de formación de las memorias tanto en Alemania como en América austral. 
145. Culturas políticas en la región andina. Christian Büschges / Olaf Kaltmeier / Sebastian Thies (eds.), 2011

La región andina se caracteriza, en el nuevo milenio, por transformaciones radicales de sus culturas políticas. Los movimientos indígenas de Ecuador y Bolivia son paradigmáticos de un proceso de descolonización cultural que rompió con los esquemas poscoloniales de representación política. Junto a ello, se observa una ruptura con las políticas neoliberales que se expresa en una nueva izquierda latinoamericana asociada a nombres como Hugo Chávez, Evo Morales y Rafael Correa. El libro reúne dieciocho contribuciones que analizan dichos cambios en las culturas políticas desde diversas perspectivas académicas. De este modo, Culturas políticas en la región andina constituye un aporte hacia un mayor entendimiento de un espacio político que está en movimiento.

144. „Una estirpe, una lengua y un destino“. Das Sprachideal der Academias de la Lengua Española (1950-1998). Kirsten Süselbeck, 2011

Neben einer umfassenden Definition der Analysekategorie „Sprachideal“, welche in weiteren Studien nutzbar gemacht werden kann, und einem Abriss der Geschichte der Asociación de Academias de la Lengua Española, liefert das Werk anhand der Lektüre der Akten von elf Kongressen der Sprachakademien, die von 1951 bis 1998 abgehalten wurden, eine Beschreibung des akademischen Diskurses der Sprachbewertung in Bezug auf den Umgang mit diatopischer, diastratischer und diachroner Variation, mit der Variation als Folge von Sprachkontakt und mit den als „unkorrekt" geltenden Sprachformen. Gleichzeitig wird erläutert, in welcher Form das Sprachideal als Stütze einer Identitätspolitik fungiert.

143. Escribir después de la dictadura. La producción literaria y cultural en las posdictaduras de Europa e Hispanoamérica. Janett Reinstädler (ed.), 2011

¿Qué efectos tienen las dictaduras en las producciones artísticas? ¿En qué medida la literatura puede ser adecuada para superar un trauma? ¿Qué aportan los textos literarios, el cine, las obras teatrales en sociedades postdictatoriales para la creación de modelos de identidades basadas en la memoria? En este tomo, se plantean estas y otras preguntas más, analizando las condiciones y las formas de las producciones artísticas después de las dictaduras en diferentes países de Europa e Hispanoamérica.

142. La expresión metaperiférica: narrativa ecuatoriana del siglo $X X$. José de la Cuadra, Jorge Icaza y Pablo Palacio. Fernando Nina, 2011

Este libro presenta una visión conjunta de tres importantes escritores ecuatorianos de la primera mitad del siglo XX: José de la Cuadra, Jorge Icaza y Pablo Palacio. Por medio de una lectura inferencial de sus obras se analizan la construcción y composición de un campo escritural hasta ahora poco conocido: la literatura ecuatoriana. En el esquema de tradición y renovación en que se ha venido ubicando a la literatura latinoamericana se introduce ahora la novedosa fórmula de una expresión metaperiférica, que se sustrae a una clasificación en uno de esos dos espacios, que está más allá del centro y de la periferia y que al mismo tiempo mantiene con ambos una relación consustancial. 

141. El viaje y la percepción del otro: viajeros por la Península Ibérica y sus
descripciones (siglos XVIII y XIX). Ricarda Musser (ed.), 2011

A lo largo del siglo XVIII, las actividades relacionadas con los viajes se intensificaron considerablemente en Europa. El desarrollo de la infraestructura en el siglo xix, como la extensión de la red de ferrocarriles y la circulación de buques a vapor, transformó los viajes al extranjero en un fenómeno de masas. El objetivo de la obra es contribuir al conocimiento de las especificidades del viaje en España y Portugal, y analizar, desde el punto de vista de diferentes disciplinas, como la literatura, la historia, la historia del arte y la geografía, la construcción de una imagen de la Península Ibérica en el contexto europeo.

140. Venezuela heute. Politik-Wirtschaft-Kultur. Andreas Boeckh / Friedrich Welsch / Nikolaus Werz (Hrsg.), 2011

In diesem Band wird die komplexe Situation Venezuelas in ihrer Widersprüchlichkeit kontrovers und zugleich mit analytischer Distanz diskutiert. Auf eine landeskundliche Einführung folgen Beiträge zu politischen, ökonomischen und gesellschaftlichen Themen: zur Sozialstruktur, der vom Erdöl dominierten Wirtschaft, dem »Sozialismus des 21. Jahrhunderts« sowie zu Wissenschaft und Kultur, Literatur und Musik. Den Abschluss bilden die Außenpolitik und die deutsch-venezolanischen Beziehungen.

139. Die Erfindung einer Nationalliteratur. Literaturgeschichten Argentiniens und Chiles (1860-1920). Katja Carrillo Zeiter, 2011

Die zum Ende des 19. und zu Beginn des 20. Jahrhunderts erscheinenden argentinischen und chilenischen Literaturgeschichten sind Teil der seit der Unabhängigkeit geführten Debatten um die neue nationale Identität der ehemaligen spanischen Kolonien in Amerika. Die Positionen dieser Debatten reichten von einer völligen Abgrenzung zu Spanien bis zur Verteidigung der kulturellen Einheit des Hispanischen. Die Arbeit geht den diskursiven Strategien nach, die es ermöglichten, eine nationale Literaturgeschichte zu erfinden, die sowohl als unabhängig von der spanischen Tradition verstanden wurde, als auch die eigene nationale Tradition bis in die Kolonialzeit zurückverfolgen konnte.

Más información: http://www.iai.spk-berlin.de/es/publicaciones.html

Ibero-Amerikanisches

Institut

Preußischer Kulturbesitz 